Portland State University

PDXScholar

$1-1-1985$

\title{
Socialization and ideal expectations for the health professional role in the provision of quality terminal care for the urban elderly
}

Margaret B. Neal

Portland State University

Follow this and additional works at: https://pdxscholar.library.pdx.edu/open_access_etds Let us know how access to this document benefits you.

Recommended Citation

Neal, Margaret B., "Socialization and ideal expectations for the health professional role in the provision of quality terminal care for the urban elderly" (1985). Dissertations and Theses. Paper 332.

https://doi.org/10.15760/etd.332

This Dissertation is brought to you for free and open access. It has been accepted for inclusion in Dissertations and Theses by an authorized administrator of PDXScholar. Please contact us if we can make this document more accessible: pdxscholar@pdx.edu. 
SOCIALIZATION AND IDEAL EXPECTATIONS FOR

THE HEALTH PROFESSIONAL ROLE IN THE

PROUISION OF QUALITY TERMINAL CARE

FOR THE URBAN ELDERLY

by

Margaret Eeth Neal

A dissertation submitted in partial fulfillmerit of the requiremerits far the degree of

\author{
DOCTOR OF PHILOSOPHY \\ in \\ URBAN STUDIES
}

Port land State Uriversity

(C) 1985 Margaret Eeth Neal 
TO THE OFFICE OF GRADUATE STUDIES AND RESEARCH:

The members of the Committee approve the dissertatior of Margaret Beth Neal presented November 27, 1985.

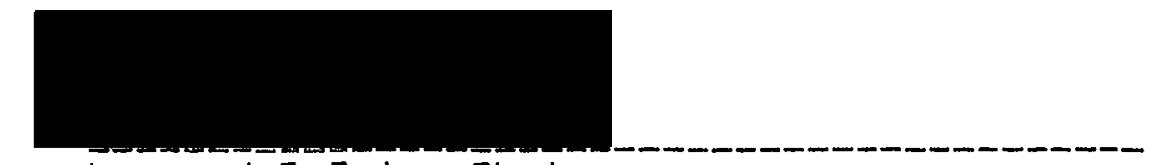

Leorard D Cair, Chairperson

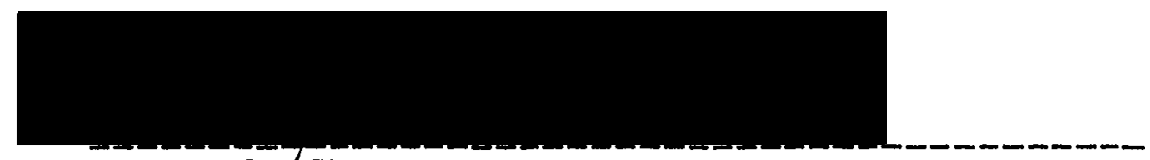

Naricy J.J Chapman

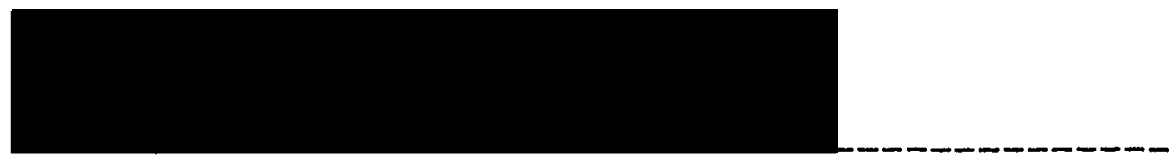

Sheldon M. Edrier

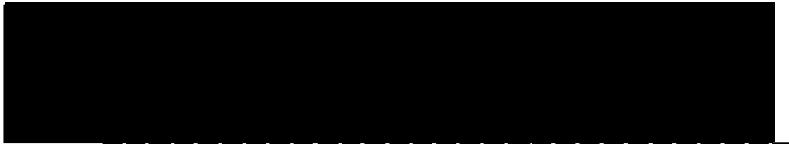

Clyde/R. Pope

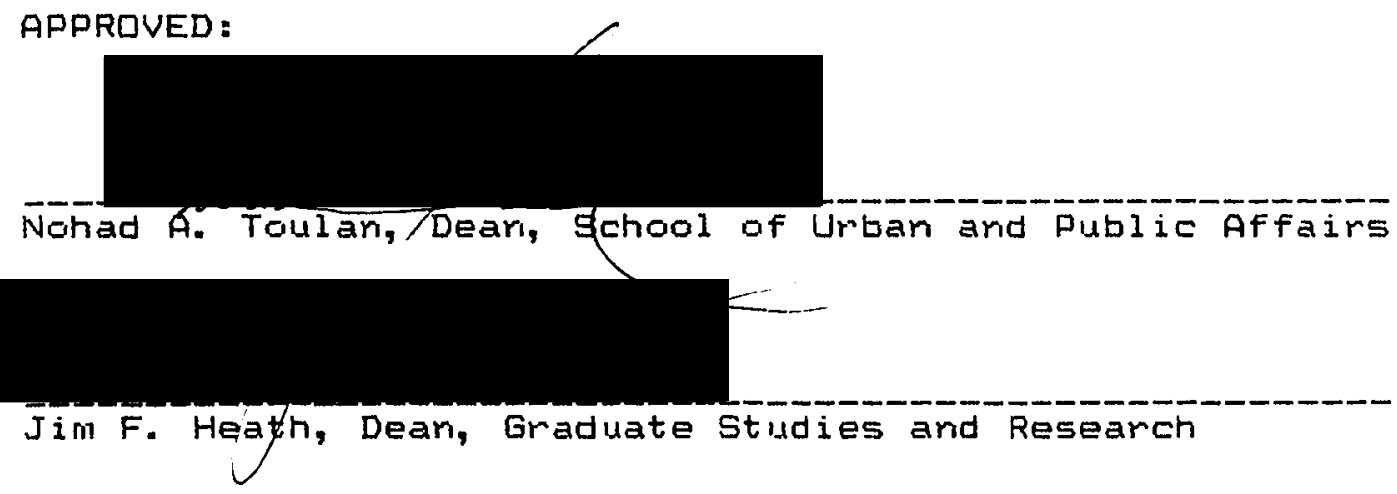


AN AESTRACT OF THE DISSERTATION OF Margaret Eeth Neal for the Dactor of Philosophy in Urban Studies preserited Novernber $27,1985$.

Title: Sccializatior and Ideal Expectations for the Health Professional Role in the Provision of Guality Terririal Care for the Urbar Elderly.

APFROVED EY MEMBERS OF THE DISSERTATION COMMITTEE:

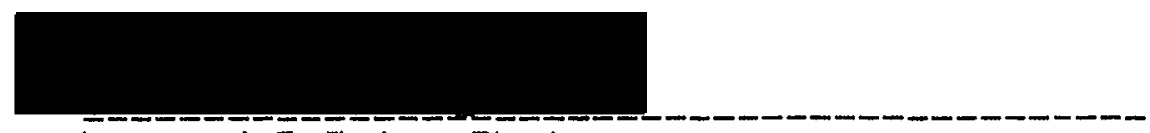

Leonard D Ciain, Chairpersor

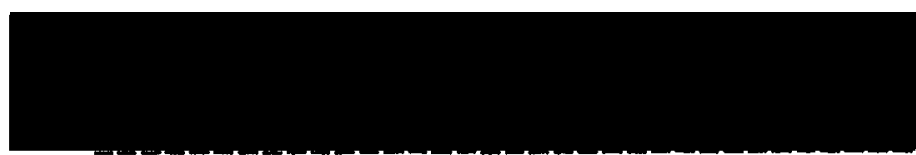

Naricy J.TChapinan

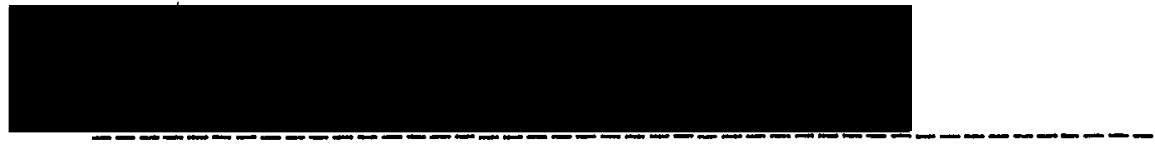

Sheldon M. Edrier

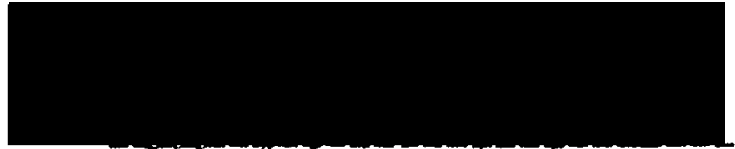

Ciýdefr. Pape

This study irivestigates socializatior ard ideal expectations for the health professional role in the provision of quality terminal care. Guiding the research 
are role theory, sacialization theary, and Talcott Parscins' (1951) pattern variables.

The research was coriducted in three phases. The first phase involved development of an analytical framework elaboratirg upon Parsors' five pattern variables, which were first conceptualized as dimersions describing the ways in which roles could vary. Specific indicators for each of the patterr variables were developed. Typologies characterizing (1) the medical, or corveriticial, madel arid (e) the holistic madel (specifically, the hospice model) far the pravisiar of health care based on these iridicators ther were developed.

Using the analytical framework, the seccird arid third phases consisted of: (1) a content analysis of the physiciar arid rumse socialization literature to determine the role prescriptions learred by these health professionals; ard (E) a content analysis of open-erided iriterviews with a greup $(N=94)$ of terminally ill elderly patierits $\left(r_{1}=17\right)$, family members $\left(r_{1}=38\right)$, arid health professiorials $\left(r_{1}=39\right)$ fram 10 urban health care programs (five conventioral ard five haspicel ta ideritify ideal rale expectatioris for the health professional.

$$
\text { Majar findirigs were that: (1) Parsors' pattern }
$$

variables, with elaboration, can provide a useful framework. for role analysis; (2) physicians and nurses appear to be socialized to a rumber of role prescriptigris corsisterit with 
the medical model, although there is evidence of conflicting sccialization (to both models) for some role prescripticrs; (3) resporiderits' expectations generally were consistent with thise prescribed by the haspice model with same natable exceptians; (4) the mole expectaticns of the three groups of resporiderits were mare corgruent thar was expected, although subgroups" (conventional versus hospice) expectations terided tei differ.

Implications of the firdirgs for: (1) rale aralysis; (2) socialization of health professicinals to minimize rale strain and conflict with patierts ard families; (3) coritinued implementation of converitional and hospice models for the provision af quality termiral care; (4) assessment of the quality of terminal care are explored; arid (5) further research are explored. 
ACKNOWLEDGEMENTS

The completion of my graduate studies, and especially of this dissertation, would have been impossible without the assistance of many people. I wish to express my deep personal gratitude to Dr. Leonard D Cain, chairperson of my doctoral committee, for his guidance, $t$ ime, concern, patierice, arid counsel. Drs. Naricy J. Chapmar, Shelder M. Edner, ard Clyde R. Pope, the members of my committee, also gave gererously of their time, advice, and emotioral support, arid I am very grateful. I owe much to Dr. Jahn E. Oי Brier, who first ericouraged me to attend graduate school, who employed me as a research assistant, and from whom I have learried so much. I also wish to thark Dr. Barbara J. Stewart, yet another of my valued professors, and Drs. Victor Marshall, Jim Paulson and Erian Stipak, for their much-appreciated consultation. Thanks also to Dr. Nohad Taular and to the Maurie Clark Fellowship and the Dan Davis Merit Scholarship funds.

To Drs. Arthur Emlen, Naricy J. Chapman, Berit Irigensoll-Daytor, and all my colleagues and friends at the Regioral Research Institute for Human Services I express my thertes for their emotional and technical support, patience, flexibility, and understanding.

Very special thanks is due Dr. Marie P. Beaudet, who gave me eridless encouragemerit, provided substaritive 
consultation, and gave technical assistance; she is resporsible in large part for my successful completion of this project. Thanks also to Diana White, who read an earlier draft of this manuscript, and to Joan Strong Buell; both were integrally involved in the research from which the data for this dissertation originated, and both have been dear friends. Drs. Mary Sweeney and Mary Burki provided valuable emotional support throughout the project, as did so many of my other friends and even acquaintances; hopefully, they will fargive me far rot mentiaririg tha!a all by rame. To my parerits, Maurice $W$. and Rosemary $c$. Neal, and to David, Erin, and Jamien Leckey, I wish to express my deep love ard appreciation. I dedicate this dissertation to them; their hope, belief, and encouragement have bolstered me throughout its writing. David's technical assistarice with editirg, proofirg, table arid figure design, and chther help at critical jurctures of the project, and his tolerance of mariy personal arid household inconveniences, were critical to my completion of the work.

Finally, to the fatients, family members, and health care providers who so willingly talked with us about their experierices and their ideals, I express my sincere thanks. The original study for which they were interviewed was supported in part by a grant from the Administration on Agirig (Grant No. 90-AR-2063/01). 
TAELE OF CONTENTS

PAGE

ACKNOWLEDGEMENTS . . . . . . . . . . . . . . . . . . . iii

LIST OF TABLES . . . . . . . . . . . . . . . . . . . $x$

LIST OF FIGURES . . . . . . . . . . . . . . . . . . .xViii

CHAPTER

I INTRODUCTION . . . . . . . . . . . . . . . . 1

Statement of the Problem........... . 1

Gverview................... 6

I I REVIEW of THE LiteratuRE . . . . . . . . . 8

Models of Health Care Provision in
Anerica .................... B

Descriptian of Major Models . . . . . $B$

Paradigms of the Dactor-Patient

Relatiorship Within the Medical and

the Holistic Madels . . . . . . . . 13

The Context for Charge between Models. - 24

Summary .. . . . . . . . . . . . . 31

Care of the Dyirg in America Taday. . . . 33

Needs of the Terminaliy Ill . . . . . 33

Needs of the Family of the

Criticisms of Converiticinal Care for

the Termirally Ill... . . . . . . 39

The Hospice Model as an Alternative . . 43

Questiaris and Coricerns about Hospice Care... . . . . . . . . . 52

Surnmary . . . . . . . . . . . . 61 
Definition and Assessment of

Quality Care.............. 6a

Definirg "Quality Care". . . . . . . . 62

Approaches for Assessing the

Qulality of Care... . . . . . . 69

Summary ................. TE

II CONCEPTUAL TOOLS . . . . . . . . . . . . . . 81

Role Theary . . . . . . . . . . . . . 81

The Coricept of Role........... $8 z$

Perspectives in Role Theory ...... . 83

Role Prescriptioris or Expectations . - . 88

Qther Role Thearetic Concepts . . . . . 89

The Role af the Professional. . . . . 92

The Role of the Patient. . . . . . . . . 94

The Rale of the Health Professicnal : . 97

Summary ................ 98

Issues in Socialization Theory ard Research. 98

Definition of Socialization . . . . 100

Who are the Socializirig Agents and

What is their Relative Importance

in the Process of Sacialization . . 103

Is the Scicializee ar Active Participant

or a Passive Recipierit in the

Process?............. 109

Does the Attitudiral Learring that

Dccurs Represent Charige or

Maturation in the Socializee? . . 110

What is the Status of the Socializee

Durirg the Socializatior Process? - 117

What are the Dutcomes of Socialization

arid How Eriduring are They?. . . . . 117

Sumarny ................. 119

IV DESCRIPTION OF THE RESEARCH . . . . . . . . 120

Coriceptual Framework . . . . . . . . . . 120

Research Questigns arid Hypotheses . . . . 129 
vii

Research Questions . . . . . . . . 129

Research Hypatheses . . . . . . . . 130

$\checkmark$ RESEARCH DESIGN AND METHODS . . . . . . . . 13E

Phase 1: Developmerit of the

Analytical Model. . . . . . . . . 13

Phase Z: Identification of Role

Expectatioris Learried through

Professional and Workplace

Socializatior . . . . . . . . . 137

Ideritification of the Literature . - 137

Analysis of the Literature... . . 139

Phase 3: Ideritificatior of Patierits', Families" and Health Professicirals" Role Expectatioris for the Provider of Termirial Care. . . . . . . . . 14E

Selection and Profile of Participating Programs arid Responderits . . . . . . . 143

Description of the Interview Schedules ............ . $15 \epsilon$

Content Analysis of the Interview Data . . . . . . . . . . . 159 Quality and Limitatians af the Iriterview Data. . . . . . . 1EE

VI ANALYTICAL MODEL . . . . . . . . . . . . . 17E:

VI I RESULTS . . . . . . . . . . . . . . . . . . 198

Research Question 1........... 198

Affectivity Variable: Indicator 1A: Affective Involvement . . 200

Diffuseness Variable: Iridicatcirs:

ZA: Scope of Care. . . . . . . 207

2E: Urit of Care ........ E15

ZC: Availability of the Health Professiciral. . . 218

Particularism Variable: Indicator

3A: Care Approach . . . . . . 2e1

Ascription Variable: Iridicators:

4A: Treatmerit Goal . . . . . . 225

4E: Pain Control Practices . . 234 
viii

4C: Patient Involvemerit . . . 236

4D: Family Invalvement . . . 244

4E: Voluriteer Irivolvement . . . 24B

4F: Criteria for Evaluating

the Health Frofessional. . 249

5A: Motivation ........ 253

SB: Interprofessional

Communication ...... 2060

5C: Interprofessiorial

Decision-Making..... . 263

Summary . . . . . . . . . . . .

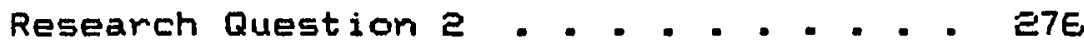

1A: Affective Invalvement . . . . 276

2A: Scope of Care.......... . $28 E$

2B: Unit of Care . . . . . . . . . 292

EC: Availability of the

Health Professional. . . . . 305

3A: Care Approach . . . . . . . 317

4A: Treatmerit Goal . . . . . . . 322

4B: Pain Control Practices . . . $33 E$

4C: Patient Irivolvement . . . . . . 348

4D: Family Involvemerit . . . . . 365

4E: Volunteer Involvement . . . . 380

4F: Criteria for Evaluating

the Health Professiorial . . . 384

SA: Motivation ... . . . . . 391

5B: Interprofessional

Communication .. . . . . . 400

5C: Iriterprofessional

Decision-Making. . . . 406

5D: Professional-Patient

Continuity . . . . . . . . . 415

Summary .. . . . . . . . . . . 421

Research Question 3.......... 441

1A: Affective Involvement . . . . 441

2A: Scope of Care... . . . . . . 443

2B: Unit of Care . . . . . . . . . 444

eC: Availability af the

Health Professional . . . . 445

3A: Care Approach . . . . . . . 447

4A: Treatment Goal . . . . . . 447

4B: Pain Control Practices . . . 449

4C: Patient Involvement . . . . . 450

4D: Family Irivolvement . . . . . . 45e

4E: Volunteer Involvement..... 453 


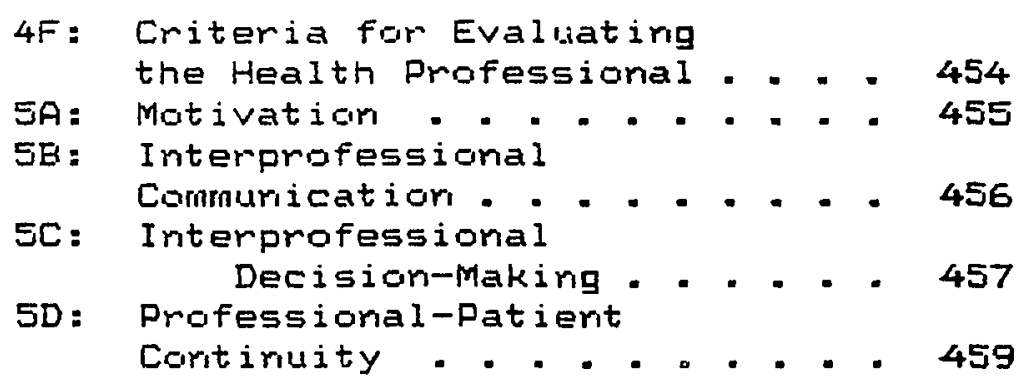

VIII SUMMARY, DISCUSSION, AND IMPLICATIUNS . . . . . . . . . . . . . 460

Limitations of the Research . . . . 460

Summany arid Discussion of Major

Findings.............. 46E

Research Questican 1... . . . . 462

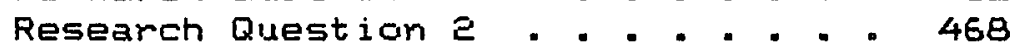

Research Questign 3 . . . . . . . 488

Evaluation of the Utility of

Parscins' Patterr Variables. . . 49こ

Recommendations for Future Research . . $49 \Xi$

Coritributicirs of the Present Study. . . 499

BIBLIOGRAPHY . . . . . . . . . . . . . . . . . . . . 5O2

APPENDICES . . . . . . . . . . . . . . . . . . 519

A: Resporident Selection Plan and Respondent

Profiles.............. . 519

B: Iriterview Schedules . . . . . . . . . . . 530 
I Summary of Advantages and Limitations of the Methods of Quality of Care Assessment . . . 77

I I Description of Prograns Participating in the Study $(N=10)$. . . . . . . . . . . . 147

II The Medical Model Versus the Hospice Model: Categorization by Parsons' Pattern Variables... . . . . . . . . . . 179

IV Arialytical Madel: Indicators of Parsons'

Pattern Variables as They Pertain to Role Expectations for the Professianal Provider of Termirial Care. . . . . . . 181

$\checkmark$ Results of Review of Literature Concerning

Professional Socialization far the Role of Physician--Affectivity Variable, Iridicator 1A: Affective Involvement . . 202

UI Results of Review of Literature Concerning Professional Socialization for the Role of Nurse--Affectivity Variable, Indicator 1A: Affective Involvemerit . . . . . . . . 205 
VII Results of Review of Literature Concerning Prafessioral Socialization for the Role of Physician--Diffuseness Variable, Indicator 2A: Scope of Care... . . 208

VIII Results of Review of Literature Concerning Professicrial Sacialization for the Role of Nurse--Diffuseness Variable, Indicator 2A: Scope of Care . . . . . 212

IX Results of Review of Literature Concerning Professional Socialization for the Role af Physician-Diffuseness Variable, Indicator 2B: Unit of Care... . . . 216

$X$ Results of Review of Literature Concerning

Professicnal Socialization for the Role of Nurse--Diffuseness Variable, Indicator 2B: Urit of Care... . . . 217

$X I$ Results of Review of Literature Concerning Professioral Socialization for the Role of Physician--Diffuseness Variable, Indicator 2c: Availability of The Physician.............. . e19 
xii

XI Results of Review of Literature Concerring Professional Socialization for the Role of Nurse--Diffuseness Variable, Indicator 2C: Availability of the Nurse . . . . . 220

XII Results of Review of Literature Concerning Professional Socialization for the Role of Physician--Particularism Variable, Iridicator 3A: Care Approach . . . . . 22Z XIV Results of Review of Literature Corcenning Professional Socialization for the Role of Nurse--Particularism Variable, Indicator 3A: Care Approach . . . . . 224

XV Results of Review of Literature Concerning Professional Socialization for the Role of Physician--Ascription Variable, Indicator 4A: Treatment Goal . . . . . 227 XVI Results of Review of Literature Concerring Professional Socialization for the Role of Nurse--Ascription Variable, Indicator 4A: Treatment Goal....... 231

XVII Results of Review of Literature Cancerring Professional Socialization for the Role of Physician--Ascription Variable, Indicator 4B: Pain Contral Practices.. - 235 
XVIII Results of Review of Literature Coricennirig Professional Socialization for the Role of Nurse--Ascription Variable, Iridicator 4B: Pain Control Practices. . 235 XIX Results of Review of Literature Concerning Professional Socialization for the Role of Physician--Ascription Variable, Indicator 4C: Patient Irvolvement . . . 237

XX Results of Review of Literature Concerring Professional Socialization for the Role of Nurse--Ascriptian Variable, Indicator 4C: Patient Involvement . . . 24Ë

XXI Results of Review of Literature Coricerring Professianal Socialization for the Role of Physician-Ascription Variable, Indicator 4D: Family Involvement..... 24E

XXII Results of Review of Literature Concerning Professional Sacialization for the Role of Nurse--Ascription Variable, Indicator 4D: Family Involvement. . . . 247

XXIII Results of Review of Literature Cancerning Professional Socialization for the Role of Physician-Ascription Variable, Indicator 4F: Criteria for Evaluation . . 251 
XXIV Results of Review of Literature Concerning

Professional Socialization for the Role

of Nurse--Ascription Variable,

Iridicator 4F: Criteria for Evaluation . . 254

XXV Results of Review of Literature Concerning

Professional Socialization for the Role of

Physieian--Collectivity Driertatian Variable,

Indicator 5A: Motivation....... esE

XXVI Results of Review of Literature Concerning

Professioral Socialization for the Role of

Nurse--Col lectivity Orientation Variable,

Indicator 5A: Motivation......... 258

XXVII Results of Review of Literature Concerning

Professional Socialization for the Role of

Physiciar--Collectivity Oriertation Variable,

Indicator 5B: Interprofessional

Communication .. . . . . . . . . . . 261

XXVIII Results of Review of Literature Concerring

Professianal Socialization for the Role of

Nurse--Collectivity Orientation Variable,

Iridicator SB: Interprofessional

Communication.............. . $26 \varepsilon$ 
XXIX Results of Review of Literature Concerning Professional Socialization for the Role of Physiciari--Collectivity Orientation Variable, Indicator 5C: Interprofessional Decision-Making... . . . . . . . . . 26'

XXX Results of Review of Literature Concerning Professional Socialization for the Role of Nurse--Collectivity Orientation Variable, Indicator 5C: Interprofessiaral Decision-Making. . . . . . . . . . . . $26 \epsilon$

XXXI Descriptiors of Socialization for the Role of Physician: Indicators Mentioned by Each Saurce Reviewed. . . . . . . . . . . . . eEg

XXXII Descriptions of Socialization for the Role of Nurse: Indicators Mentianed by Each Source Reviewed.. . . . . . . . . . . . 271

XXXIII Words and Themes Comprising Each of the Four

Categories of Indicator 1A: Affective Involvemerit . . . . . . . . . . . . . 279

XXXIV Indicator 1A: Affective Involvement

Sumnary of Responses by Respondent Group . EB1

$X X X V$ Indicator $2 A:$ Scope of Care--Summary of

Resparises by Responderit Group . . . . . - 287

XXXVI Indicator 2B: Unit of Care--Surnmary of

Responses by Respondent Group . . . . . . E96 
XXXVII Indicator EC: Availability of Care--Summary

of Responses by Respondent Group . . . . 306

XXXVIII Indicator 3A: Care Approach--Summary of

Responses by Responderit Group... . . . . 318

XXXIX Indicator 4A: Treatment Goal--Summary of

Responses by Responderit Group . . . . . . . $3 £ 4$

$\mathrm{XL}$ Iridicator 4B: Pain Control Practices

Sumrnary of Resporises by Responderit Group - 338

XLI Indicator 4C: Patierit Involvement--Summary

of Responses by Resporiderit Group . . . . 351

XLII Indicator 4D: Family Involvement--Summary

of Resporises by Resporident Group . . . . 368

XLIII Indicator 4E: Volunteer Involvement

Sumrnary of Responses by Respondent Group. - 382

XLIV Indicator 4F: Criteria for Evaluation

Sumnary of Resporises by Respondent Group - 386

XLV Indicator 5A: Motivation of Health

Professiana1--Summary of Resporises by

Respondent Group . . . . . . . . . . . 39E

XLVI Indicator 5B: Interprofessional

Communication--Summary of Responses

by Responderit Group . . . . . . . . . 401 
xvii

XLVII Indicator 5C: Interprofessional Decision-

Making--Summary of Responses by

Respondent Group .. . . . . . . . 408

XLVIII Iridicator 5D: Professional-Patient

Cantinuity--Summary of Responses by

Responderit Graup . . . . . . . . . 416 


\section{LIST OF FIGURES}

FIGURE

PAGE

1. Conceptual Framework . . . . . . . . . . 121

2. Parsoris' Pattern Variables . . . . . . . 174 


\section{CHAPTER I}

INTRODUCTION

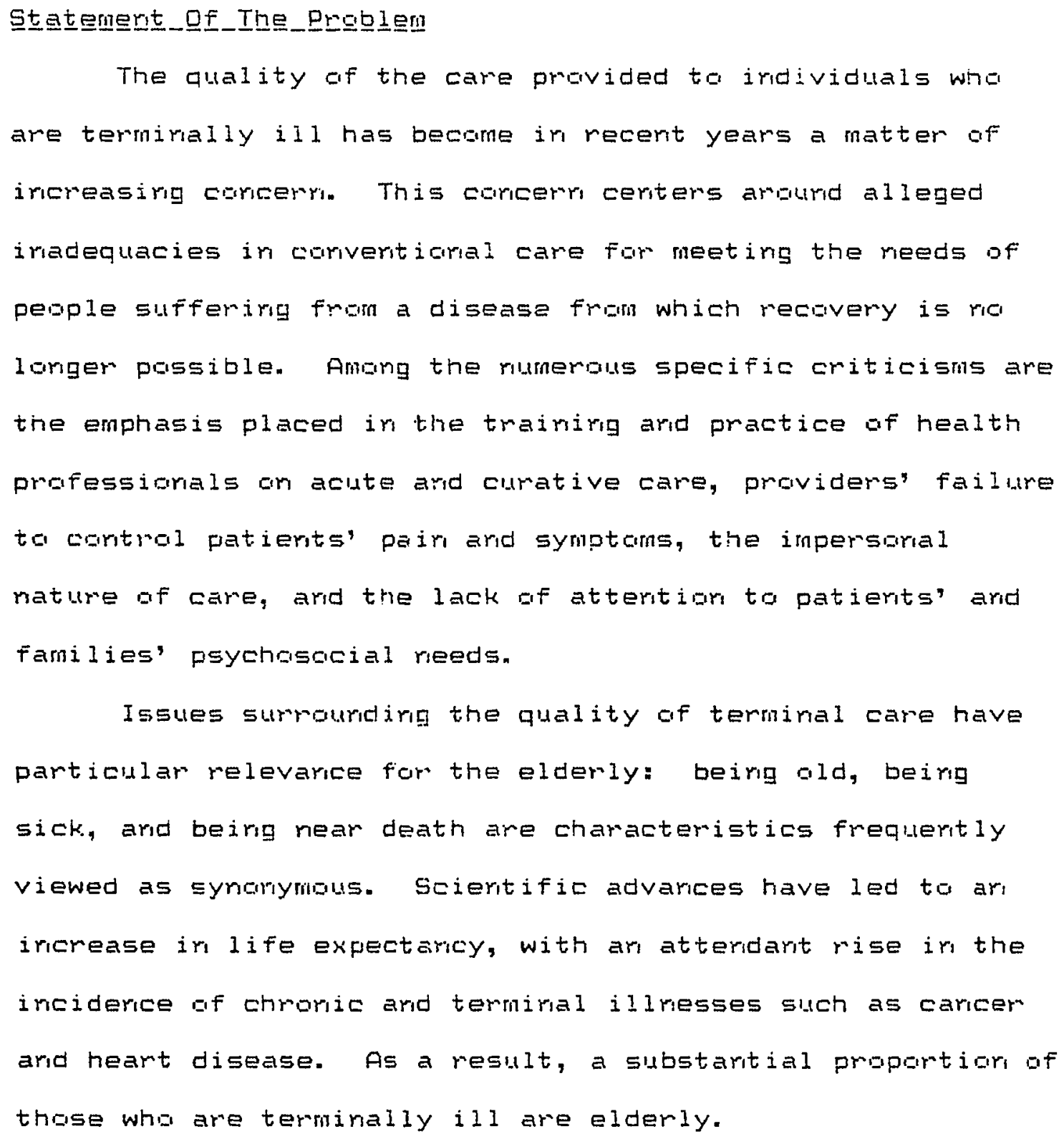


The provisigr of quality termiral care is esseritially ar urbar problem. Durs is an urbar sciciety. With specializatigr and advances ir technology have come the hospital and ather medical facilities for the delivery of health care services. Whereas in the past in mural America, peaple usually died at hame, in taday's umbar settirg death cecurs primarily in these specialized, urbar health care iristitutioris.

Ir resparse ta perceived deficiericies ir care af the termirally ill, an altemrative caricept of termiral care has beer proposed: the hospice philasgphy af care. With the proliferation of hospice proponerits, the issue of the efficacy af this model of care as ar alternative ta canveritiaral care for the terminally ill takes or ircreasirg sigrificarice. Federal arid state govermments already have implemented rules ard regulatiors geverring licersure and reimbursement of the burgeoririg number af haspice programs throughout the country.

Yet, ever among hospice supporters, the proliferaticir of haspice programs has giver, rise to a mumber gf circerns arid questigris regardirg the viability of the haspice coricept in America. Can hospice meet the rieeds of the dyirig, arid huw well car it meet these reeds? How acceptable is the haspice coricept to consumers arid providers of care? Hospice care was corceived and developed ir Eritain; car hospice principles be implemented ard feasibly administered in the 
U.S.? Car hospice become integrated irig the traditigral health care system? If so, car its iritegrity be preserved? As the rumber of naspices iricreases, and as the shortage of key healtn persorirel such as rumses coritimus, car cumperit training programs prodice professianals with the characteristics ard qualificatiars recessary ta pravide naspice care?

The priblem addressed in this research is the adequacy af the sacializatiar of physiciars ard nurses for the provisiar of quality termiral care, as "quality" is defired by carsumers ard providers alike. Specifically, the romative rale prescriptigris of twis groups of health professionals, physiciars arid rurses, as comveyed through professioral arid workplace socializatigr, are ideritified ard analyaed with emploasis on the corventidral ard the hospice racidels af care. These role prescriptidris ther are compared with the expectatiors for the ideal provider of teminal care that are held by a group (N=94) af terminaliy ill patierits $\left(r_{1}=17\right)$, family members af teminally ill patients (ri=38), ard health professigrals wha themselves provide termiral care $(n=39)$. The ultimate aim af the research is ta ideritify ways in which the quality of terminal care may be impraved.

This research is appraached from a perspective that is primarily stmuctural-functioral. The theoretical framewcirk. 
guiding the research is derived from role theary, specifically as it relates to socialization for professignal roles. Parsars' (1951) pattern variables of role expectatiors are operaticralized arid used to classify, first, the varigus romative role expectations to which physiciars and rurses are socialized arid, second, the expectatiors for the ideal provider of teminal care held by the patients, family members and curreritly practicing health professiarals who were interviewed.

The research is both basic ard applied in rature. It coritributes to krigwledge about the rature of the health provider role with respect to the provisiar af teminial care, examining the definition of a "professional:" Ar, aralytical framewark comprised of indicatars of expectations for the health professianal role is develaped, operatiorializirg and elaborating upin Parsors' patterr variable framework. This research tests the acequacy of the patterr variables for role aralysis, particularly for (a) differertiating between the rale of the health professiaral urider the medical madel af care and this role under the halistic model, (b) differentiating between two professicral roles (physiciars and nurses), ard (c) differertiatirg anorig the role expectations of the occuparts of variaus roies withir the role set lpatierits, family members, ard health professignals. 
The finairgs of the research have a rumber if practical implicatiars. The specific iridicatars af rale expectatioris develaped based ar Parsaris" patterri variables pravide a braad framework fram which ta view the rale expectatiors assaciated with the health professioral's rale ir the pravisian af terminal care. This framewark car be used in the develapmert af irstruneritatiar for assessing the quality of termiral care ard, followirg further refiriemerit, for recruiting ard selectirg healtin professigrals for the provisign of quality terminal care.

The illumiration af corsistericies and incarsistercies ir professigral arid workplace socializatior af physiciars arid nurses enables the idertification of sources of rale strair such as incorisisterit patterrirg of the pattern variables or socializatiar of professiarals to both madels af care. Areas where modificatiaris in edbcaticar may be called for ta minimize these inconsistencies car ther be determiried.

The findirgs from the companison of patients, family members', and health professicmals" perceptions of attitudes ard behaviars of health professiarals that coritribute ta the provision of quality temiral care pairt ta amenas af poteritial coriflict amorg these groups and also have implicatiars bato for role theary and for sacializatior theory. The research, themefore, has implications both for 


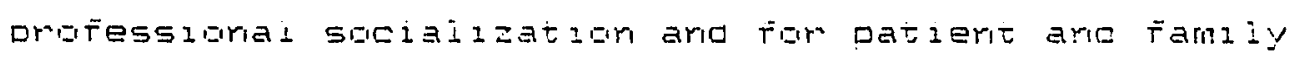
edicatirim.

Firally, the firdirgs From tine comparisor dí patierits", families", ard praviders" cescriptiars af tineir ideal provider af termiral care with the principies of care embodiad in the medical ard the nijistic models aid in ascentaining the desimagility ard larg-tern viability gf tinese two mogeis for the provisigr af quality temmiral care.

\section{므브느르트}

The rernairibig chapters af the dissertatibri further intracuce the tapic, review relevart literature, describe the methadalogy used for implemeritirg the research, detail the findirgs, ard discuss the implicatiars of the findings. Chapter II reviews tinree areas af pertirerit 1 iterature. Iroluded are the litematures describirg (1) the models af health care provisigrir America, (E) the state af the art relative to care of the dying ir Anerica, and (3) the defiritigr ard assessmert af quaitity care.

Chapter II Gutlimes the carceptual touls used ir the reseamch ard iricludes ar Gverview of issues ir the cariceptualiaation of role and role theory ard socializatiar theory. Chapter IV applies the carceptual täls discussed ir the previnus chapter ir its descriptiar af the research. Ir. particular, the cariceptual framework uriderlyirg tine study is preserited, arid the specific research questiurs are detailed. 
Chapter $v$ altitiries the researoh desigh ard metingds. This research was comdicted ard is described ir three pinases. The first phase irvalved the developmerit of ari aralytical micel, based ar Parsors' patterr variables, far use in classifying the role expectatiors af health professigrals. Ir the secarid phase, a systematic review af literature was camoucted for the purpose of identifying the role prescriptiars ard expectatiars to which physiciars ard rurses iri trajuirig are professigrally socialized. The strategy emplayed far ideritifyirg the mole prescriptions arid expectatiors to which physiciars ard rumses are sacialized is described here. The third phase carsisted of rearalysis of data gathered in the earlier explaratary study described abive. These data were used to determire patierits', families', arid health providers, rale expectatiors far the provider af quality temmimal care. The pricedures far selecting resporderits, the iriterview schedules used, ard the quality ard Iimitatiors af the data ame discussed.

Chapter VI preserits the aralytical model developed ir the first phase af the research, as described ir chapter $V$. Chapter VII details the results af the study, using the arialytical madel. Ir this chapter, each af the research questiars is dealt with separately. The final chapter, Chapter VIII, summarizes the firdirgs and discusses their the Greticai ard practical implications. 


\section{CHAPTER I I}

\section{REVIEW OF THE LITERATURE}

Three literatures relevarit to this dissertation will be reviewed here: (1) Iiterature coricernirig the models of health care provision ir. America taday; (2) 1 iterature regardirg the care of the dyirg in America taday; arid (3) literature relating to the definition and assessmerit of the quality of health care.

MODELS OF HEALTH CARE PROVISION IN AMERICA TODAY

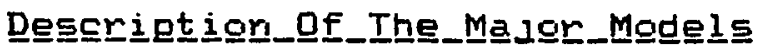

$$
\text { Hardy (1978) states that there is ro one prevailing }
$$
paradigm, or madel, that is used by health professionals. Two mode15, however, appear to dorninate Americar health care: the medical model ard the holistic model. These two competing models are described in this section.

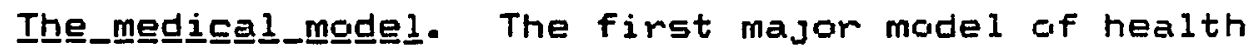
care provisior in America has been variously referred to as the "medical interverition pattern," the "disease model," or" the "biomedical model" (Freidson, 1970a); the "classical hospital care model" (Wessen, 1966, cited in Roserithal et al., 1980); the "medical teaching model" (Coornbs arid Pawers, 1975); arid the "traditional pattern" (Gemain, 1980). This 


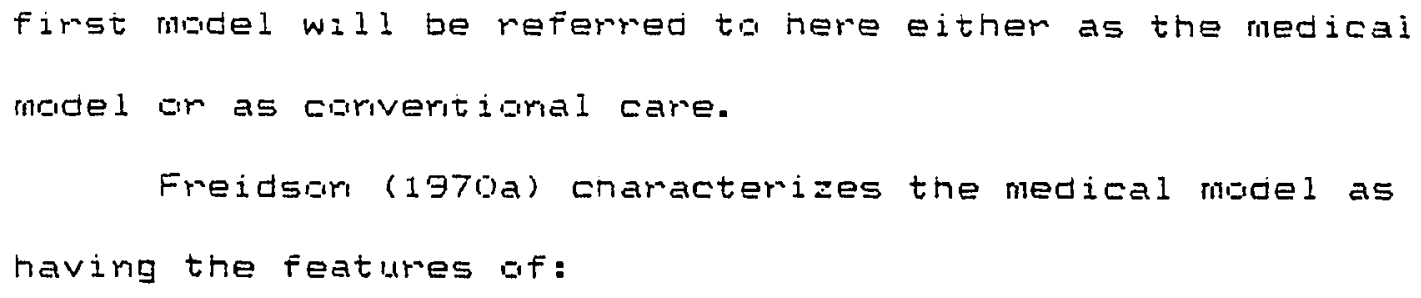




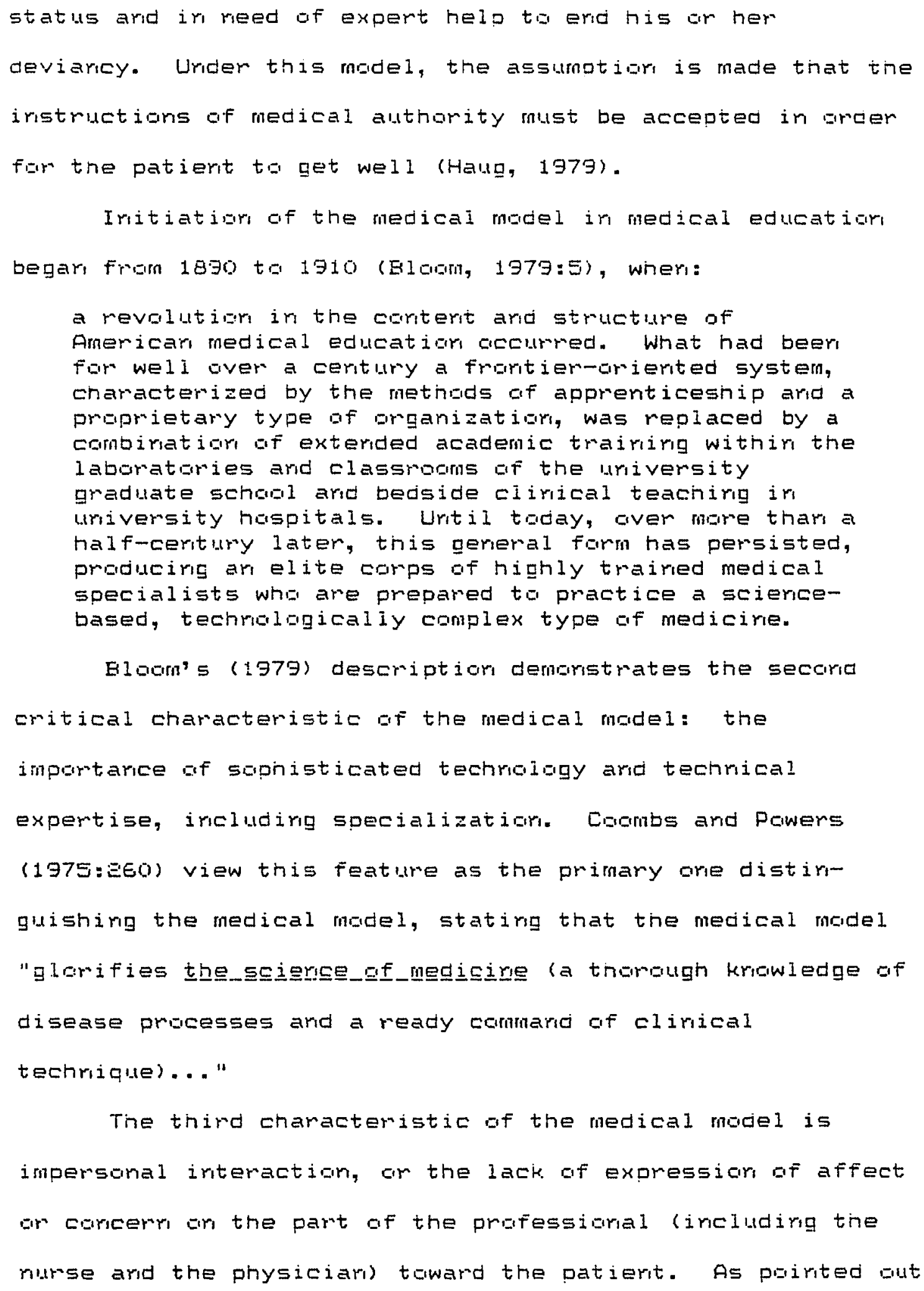




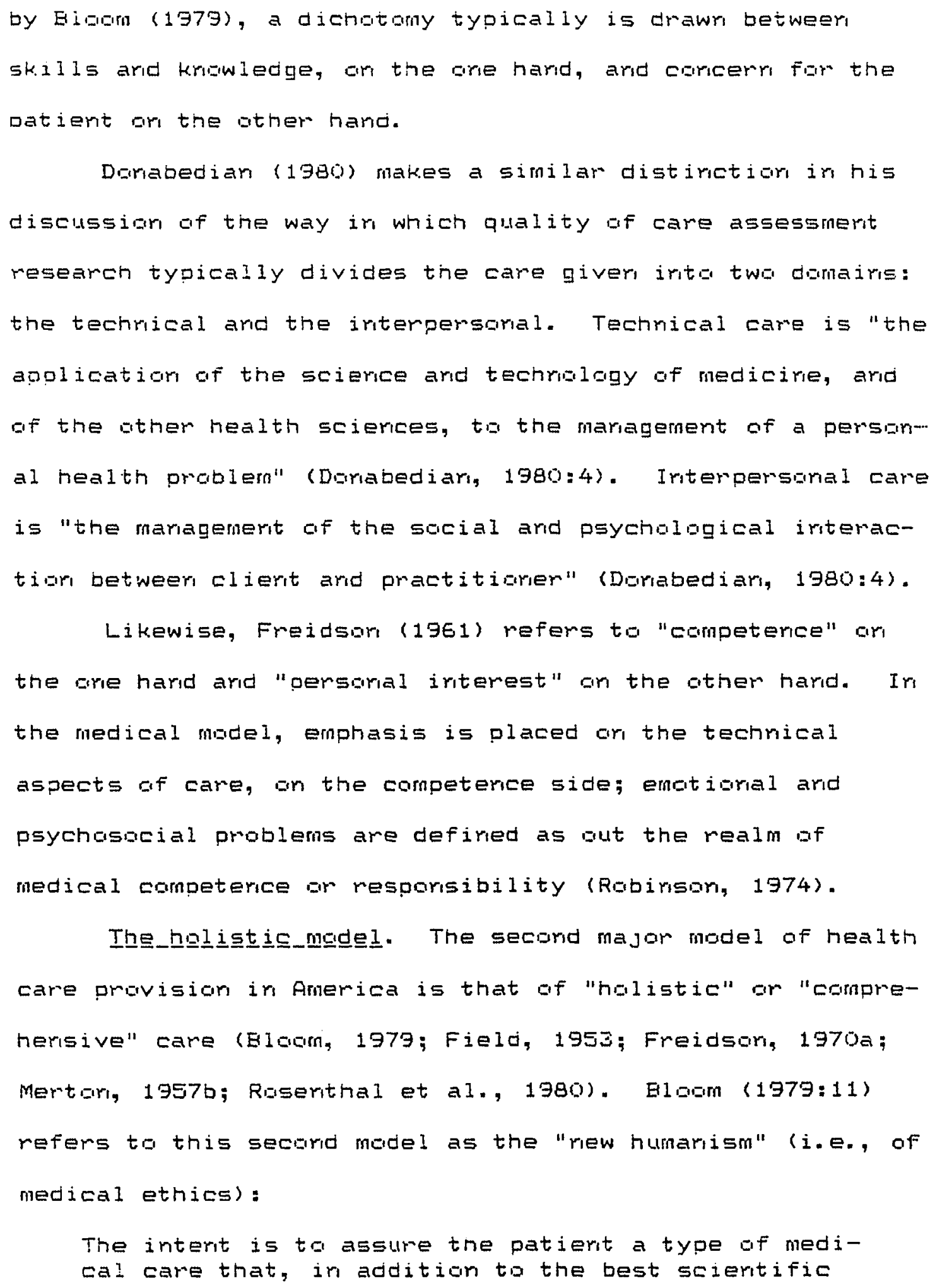


techniques, would iriciude coricerr about the enitibral and social factors in the oatiert's iliness.

Furthemore, according to Freidsor (1970a:134), this model mairitairs "the view that ailmerts snould rut be maraged discretely, separately from each otmer by individual specia?ists."

Fielo (1953) is are proporert af this madel ar anilasophy of "total medical care" and its concept of "patierits as people." She (Field, 1953) advocates a broadered corrcegt of iliness, particulamiy prolunged illness, as both a medical arid a social problern. Also, she advises an emphasis br the iritrinsic wortn of the patient as a persom, with interest ceritered rut merely an the disease process, but ar the patient as a persor and on his or her sicial background as well.

In describing tinis comcept af compmenersive, or halistic, medical care, Field (1953) antlines the reed far: (1) atteritior to the social and emational factors; (a) care of the family as a unit af treatment; (3) mehabilitation as a part of total medical care (includirg self care and sheltered workshops); ard (4) iriclusion of sacial service (specifically, the establishmert af a social service departmert) as a part oí tatal medical care. With regard to the secord feature (iriclusigr of the fanily in the care), Field (1953:E19) asserts, "Experience has demorstmated that 
the iliness of ane member bf the family has its repercussigris gr the eritire group, affectirig their health ard well being." Rehabilitatigr (the thimd feature) nas a role in the pravisiar af temiral care irsofar as renabilitatiar therapy is aimed at promotirg quality af iffe. Mertar (1957b) also has described tnis halistic madel af heaith care provisigr. In his review ef the histary gf medical edicaticr, he rutes the recert advarices in psychasomatic medicire ard the "remewed emphasis, withir medicime, upar the caricept af ithe patient as a whale persar. i" (Mertar, 19570:25). Ar advacate af this "social medicire," Merton (1957) cites mary pinysiciaris who feel as he does.

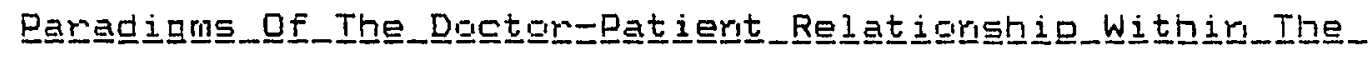

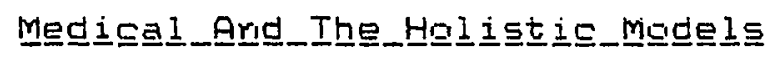

There are several paradigms of the dactora-patiert relatiorship that fit gererally withir either the medical madel ar the halistic modei af health care pravisiar. These paradigms facus cin two related features which differertiate the medical and the holistic models af care: (1) physiciar autharity ard patient participatiar, arid ( particularly physiciar disclasure of the diagrasis and progrisis.

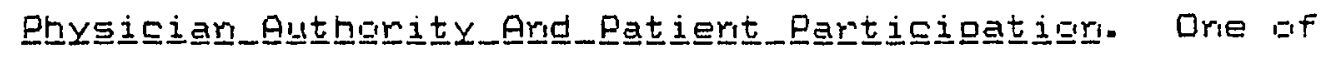
the principal differences between the medical and the 
hilistic model carcerrs the amourit af altharity the physician nas. Ir the medicai model, as ruted above, the patierit is expected to defer to the ohysiciar's authority ard expertise. In the holistic model, the patiert participates ir his ar her gwn care ard is irvalved in treatment decisigrs. Several authars have described midels gf "the dactar-patiert relatigrship" which address tine extert of physiciar autharity in this relatiorsinip.

Particulariy illustrative ard saliert is Talcott

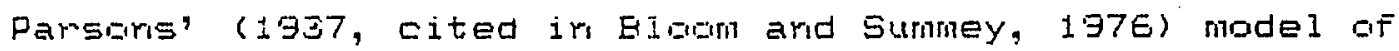
the dactom-patiert relatibrsipip as a sacial system.

Parsins" madel iricludes the followirig premises, as described by EIrim and Sumney (1976:

1. The problem af health is intimately irvalved in

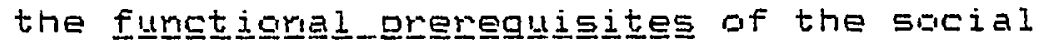
system. Ton low a gerieral level af health, tor high ar inciderice of illress, is dysfurgetigrabl.

ت. Sickress ard health are, because of their

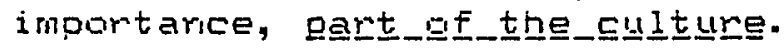

3. Health care is a $5 g$ gi ween a helping agerit ard a persar rieeding help.

4. The social roles of the health care relatiorship are a patterried sectar af culture ard are tius

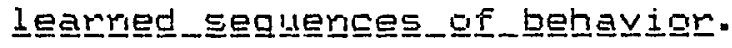

Quating Parsare (1951), BIgorn arid Summey (197E: ت4) poirit out that the premise af the Parsariam madel af the dactorpatient system is ore af furctional specificity: "Moderm medicire is angariaed abult the application of sciertific krigwledge to the problems of illress and health and to the cartrol Gf disaase." 
Derived fram these premises are Parsans" ideai types Gf sick arid professigral roles (ElGGm arid Summey, 1976 ). The sick. role is cinaracterized as an irvoluritary, temparary form cif uridesimable ard dismugtive social deviarce, wnich "must be coritmolled ta preverit abuses by persons wha gaim peychalggical rewards as a result gí the legitimized deperidericy of illmess" (Elgign and Summey, 1976:ZZ). The iridividual who cocupies the sick rale nas certair goligatiars: "ta be mativated ta get well;" "to seek tecnnically campetert helo;" arid "ta trust tne dactar; ar, to accept tne competemce gap (the asymmetry of the relationship)" (EIobu ard Summey, 1976: 04 , citirg Parsars, 1951). The accuparit at the sick rale has privileges as well, irciudirg exemption from "perfarmance of romal social obligatiars" and from "resparsibility for ore's owr state" (Elodm and Summey, 1976:24, eitirg Parsars, 19511.

The dactar, wha cocupies the professiaral role, is obligated to "act far" the welfare af the patierit;" to "be guided by the rules of professigral behaviarg" to "apply high degree of achieved skili ard kngwledge ta priblems git illness;" arid to "be cbjective ard emotigriaily detached" (BIorm arid Summey, 1976:E4, citirg Parsoris, 1951). The privileges of the professiaral role include: "access to physical and persirial iritimacy" (i.e., ir exariraticur of the patient"s body); "autsnumy;" arid "professigral diminarice" (Blown and Sumrey, $1976: 24$, citirg Parsars, 1951 ). 


$$
\text { Saasz ard Hailerider (195E) exterded the Parsariar }
$$

madel by agsitirg a tinree-fald typalagy af tine dactar-

Datiert melatiorship which irogrparated the inpilcatigms for" this relatiarsing of varigus types G $\bar{r}$ illress. Tinis typaiggy includes: (1) activity-passivity; (E) guidaricecagperatigr; and (3) mutual participatior. The first two af these types are essentialiy symorymulus with the medical model. The third parallels the holistic model. Szasz ard Hollender's (1956:586) first type af dactarpatiert relatiarsmip (activity-passivity) is "the aldest coriceptual model." Here, the physician daes somethirg tg the patierit. Saasz ard Halierien (195G) state that this made1's ariertatiar amigirated im arid is apprapriate far treatment of emergencies. This type "gratifies physicians" needs far mastery ard cortmibutes ta feelirgs af superiurity... it requires that the physiciar disideritify with the patiert as a persgri" (Saasz ard Hollender, 195E).

The secard type (guidarce-couperation) is that winich Szasz and Hollender (1956:586) assert "urderlies nuch of medical practice." This type of relatigrship is emplayed ir rom-emergercy situatigrs. While the patiert is acutely ill, he ar" she "is corscious ard has feelings ard aspiratioms bf his or her awr." The patiert seeks the physiciar"s help, is willirg to conperate, ard trarsfers piwer to the physiciar due ta the physiciar"s krowledge af medicire. Ir this type of melatiarship, the patierit is expected ta lagk up ta, 


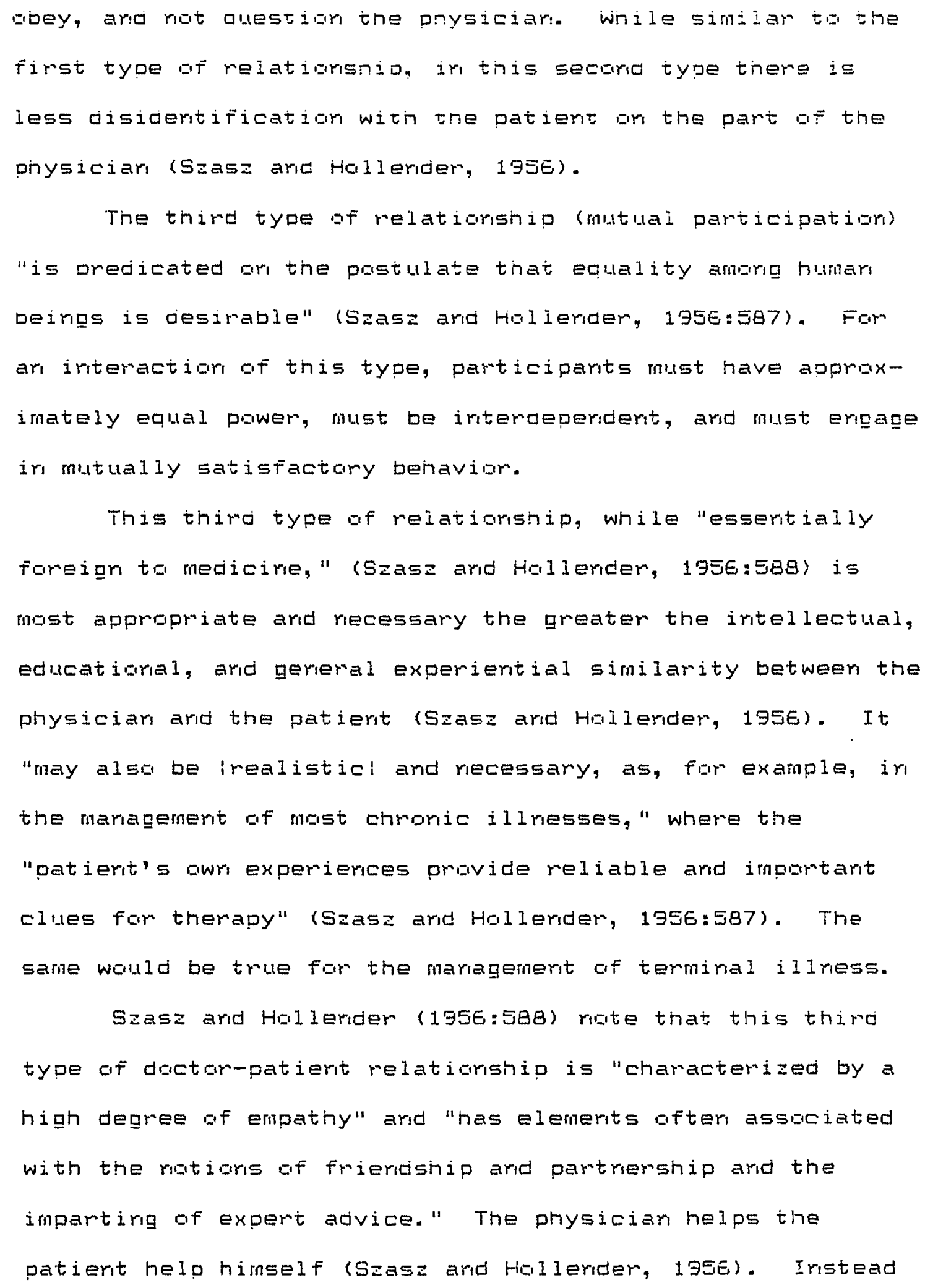


at demiving satisfactigr from dower aver somegre else, the physiciar's satistactibrs stem fram "nore abstract, 1 ass

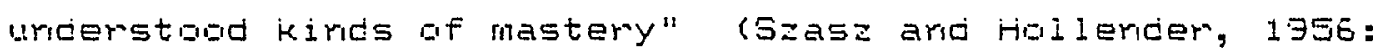
588). SaAs: ard Hallerider (195E) poirit Gut ticat the physiciar must urderog a process bif charge as he br she strives te alter the patierit's state if the patierit's emergent reeds are to be campiemerted. Qtherwise, the physiciar "foists upar the patient the same rale cir helpless uassivity from which he (allegedly) tried ta mescue him im tine first place" (SEasz ard Hollerder, 195E: 588). Szasz arid Hallender (195E) argue that eaci af tine three types af therapeutic relatiarshjps is appropriate urider certain circumstarces. Wher there is a charge, such as ir the patiert's symptoms or ir the way he or she wisines to relate to the physiciar, they state that the physiciar must charge. In the situation of a patierit with a disease tinat has progressed ta beccme iricurable, it may be inferred that the physiciar, in his ar her powerlessress ta cure, must change his or her attitude.

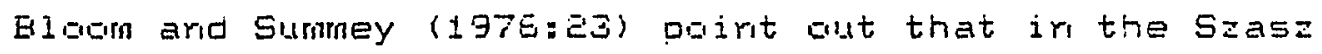
and Hoilerder typalogy, as in the Parsariar midel, "depersderice-irdepemderice is the behaviaral quality which is mast sigrificant." The exterit of physiciam diminarice, or patient passivity or deperderce, mequired in this rale was pisited to depend an the rature of the patiert"s iliress. Szasz ard Hollender's typolagy of the doctar-patiert melatigrsinip has 


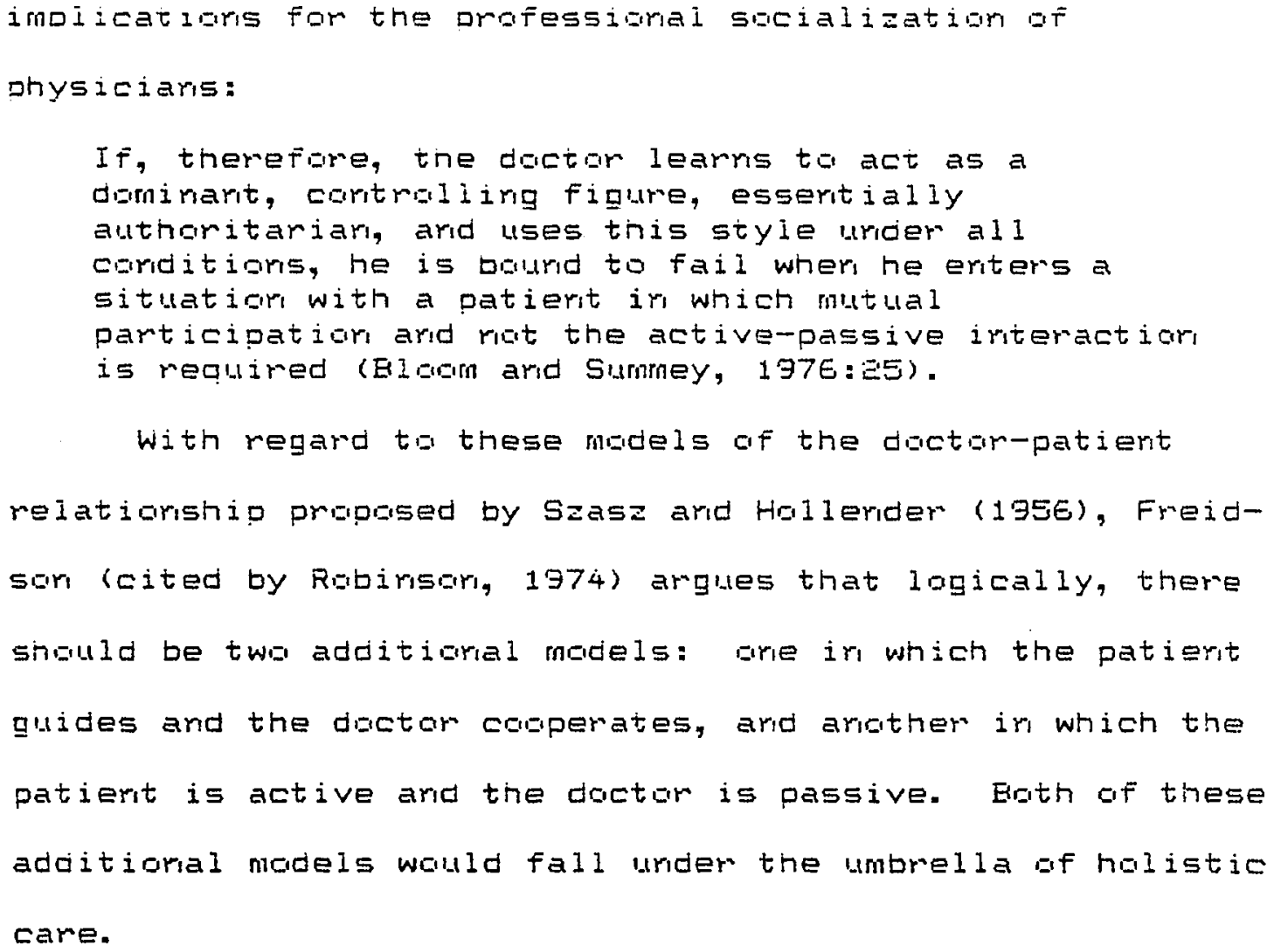


Hallg (1979) asserts that this "authority model" gf tine acictor-patiert relatiariship iromeasingly has been challeriged sirice the mid-1960's. The urwillirgress to accept professigral authority without question or the part of clierits nas beer characterized as "carsumerism" (Reeder, 1972 , cited ir Haug, 1979). Accardirg to Haug (1979), eviderice af this tremd toward iromeased corsumerism is foumd in tine demard for acciurtability ard corsumer quality assessmerit (Reeder, 197:'), the varigus self care mavemerits (Levir et al., 1976), arid the populamity af da-it-yourself bouks lsehremt arid Eiseriberg, 1976) (all cited iri Hasg, 1979).

Ta test the questiar ar whether the elderly, tar, are chailenging physiciar authomity, Haug (1979) conducted ar iriterview survey af 640 maridomly sampled persors im a midwestern state. She fourd that the 153 respariderits aged 60 arid Gver were more I ikely to accept physiciar autharity, both ir terms of attitudes ard benaviars, thar were yourger" graups ses\% af the youriger groups, compared to grily $8 \%$ af the persaris aged 60 or older had high scares or a measire of willirgress to challerge physiciar authority). Haug (1979: 859) cuncludes:

Because future ciharts af the elderly are likely ta be better educated arid tius more medically krowled geable, arid carry aver current teridericies rejectirg authority, it is suggested that physiciars will reed to exercise their powers af persuasiar, ard deperid less or their traditiaral autharity ir ericauriters witn patierits. 
Veatch arid Tai (1980) also rigte the "new" marai momms af (1) Datiert abtarigry ard (E) patierit self-determiratior, ar at least corsent to medical treatment, arid argue that there is a perceatible shift taward these rams. The staridard for disciasure based ch the conserisus gif are's colleagues has beer gradually abaridgried, they assert, ir. favor of the "reasirable persir stariard," ir which the physician is required to disclese what a reasurable persor would fird relevart for makirg a decisigr to participate ir tine therapy (Veatch ard Tai, 1980).

Ehys Commurication by the physiciar with the patiert, ar with the patient and the family, is ore way in which the exterit of the physician's autharity ard of the patient's participation ir the care may be marifest. The followirig paragmaphs describe some of the literature with regard to this area. In a study specifically of physiciars' prefererces for revealing or not revealing diagnosis of a fatal illress to patierts ard their fanilies, Hamar (1971) posits two distinct models. The first, the "psychiatric (semi-Freudiar) madel," parallels the medical model. This psychiatrin model is derived from Wahl's work (1965, cited in Harmar, 1971) ard addresses whetenener ta tell, and how_much ta tell, patients ard their families.

The assumptions of this "psychiatric" madel are that: (1) fear, denial, and repressign of deatin are ratural, and 


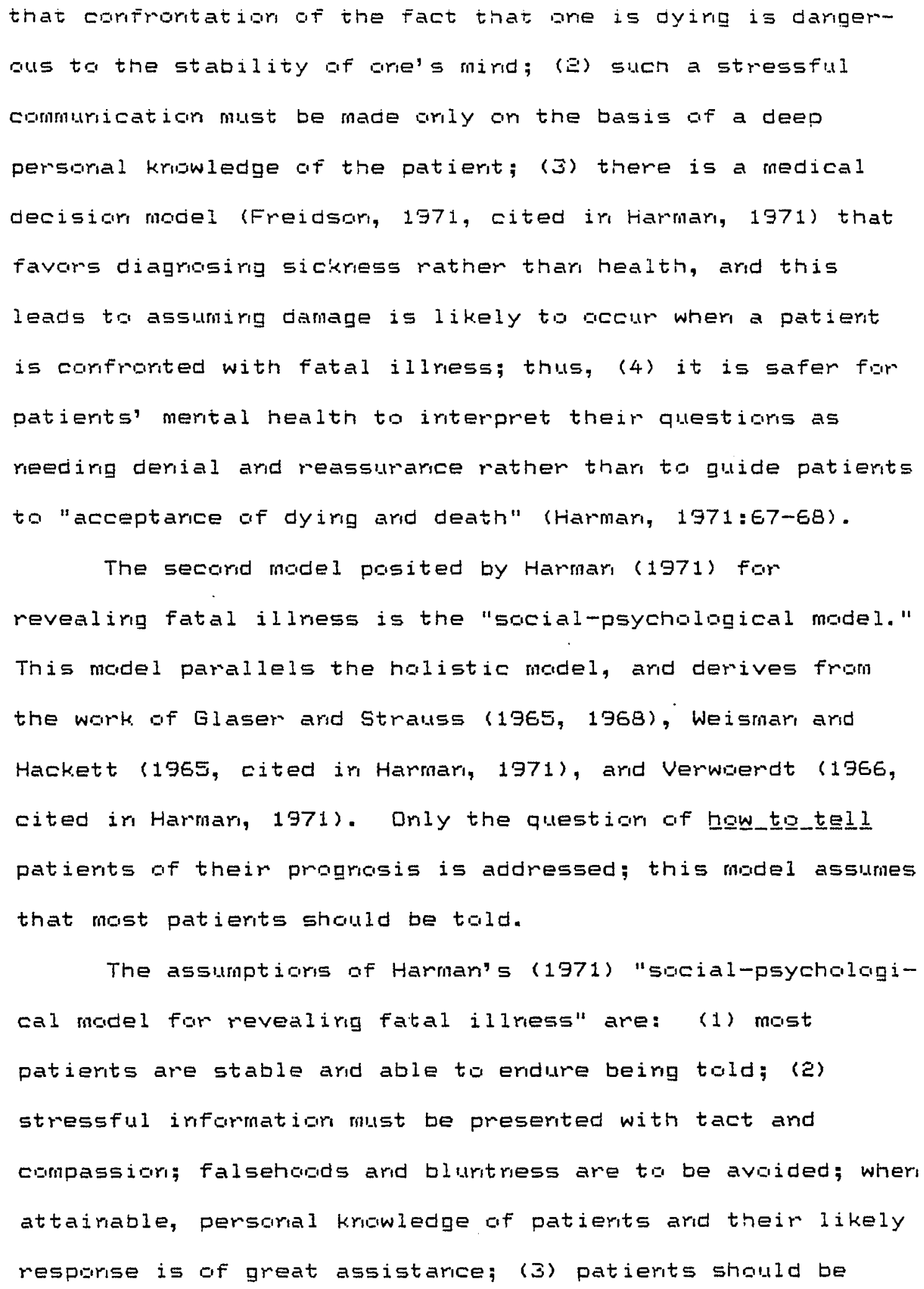




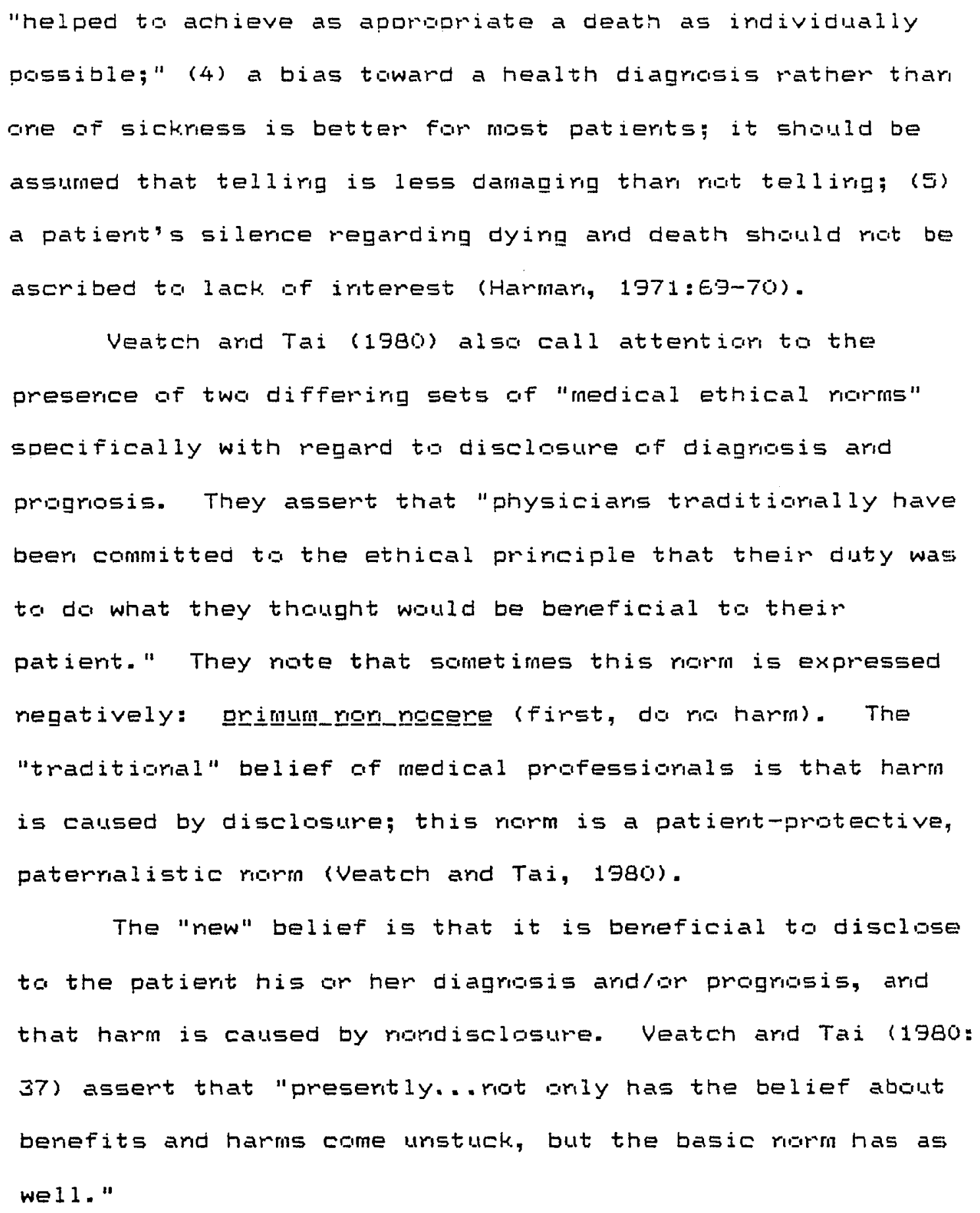




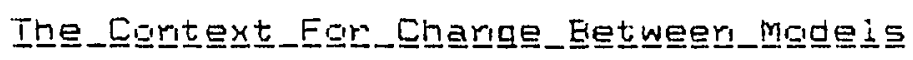

Fram the above descriptians af the medical ard the holistic models for health care provisigr and the varigus specific submrdels, a sense af cyclical movement between the two madels is discerred. Reserithal et al. (1980) describe the "traditiaral haspital patterr" ard say that aver the past few decades this madel has beer underging charge toward cre af comprehersive, ar holistic, care.

Field (1953) pairis alut, hawever, that the corcept of the patient as a whale persar is rat "rew;" that a sick orgari carrigt be separated from the persari to whom it belorgs is attested by the age-old adage that "the part car never be well uriless tine whale is well." Nar is the carcept of the iriterrelatiorship betweer physical and emotioral states riew:

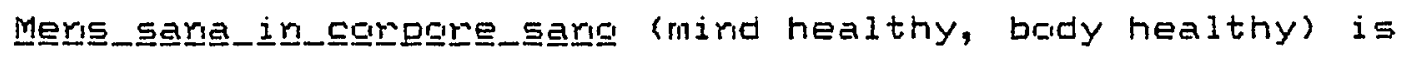
possibly alder thar the Romar Empire (Field, 1953). Mertari (1957: 25 ) alsg argues that "the lineage af this idea is, of course, arcierit-Jahr Lacke, Fraricis Weld Peabridy..." (Merton, 1957::5). Ir ather wirds, the caricept af the holistic madel af care proeded that of the medical model, ard row there is some eviderice af a return, at least thegretically, ta this halistic madel af care. What, then, initially caused the idea of holistic, or comprehersive cane to fall from favar? Accardirg to Elgarn (1979:5), a key role was played by the famius Flexrer 
Report, which irdicted the perro quality ef medical educatior in the early 1900 "s. This report braugit about a "revalutian" ir medical education (EIcur, 1979). Priar to this time, a "frortier-arierited," mor-scierice-based, ard techrologicaliy simple system existed. A rew madel af medical educatior, the medical model, evolved ir mesprirse. The effect of this rew educatigral model was a dramatic increase in medical specializatior (Blacm, 1979).

Accomparying this irchease in specialiation was a dehumarizatior of medicine (Elocm, 1979). Furthermbre, a charige ir the rature of the domiriarit or paradigm diseases also accurmed (Veatch ard Tai, 1980). Prich to the 1960's, "the paradigm disease was the aggressive, acute irfectior," ard the expected outcomes were either rapid death or cure (Veatch and Tai, 1980:41). "As long as the midel was acute illress with a passive, perhaps uricoriscicus, patiert, the authoritarian, rather patenralistic physiciar was undenstardable" (Veatch ard Tai, 1980:41). Hawever: by the 1960'5, with techrological developments such as hemodialysis; heart trarsplart; sırgery, radiaticir, arid chembtinerapy for malignaricies; ard perfectiar of the respirator, the infectiaus diseases and the diseases af infaricy were al 1 but elimirated (Veatch and Tai, 1980). "Chronic disease sudderly became the scacially domirarit or paradigm disease" (Veatch ard Tais $1980: 41)$ 
with this shift ir paradign disease came a different type af patierit: Gre who is ill arid debilitated Grily irtemittently, and who is mucn more capable af participatirg ir his ar her awr care (Veatch ard Tai, 1980). Robinsar $(1974)$, tac, paints ta the distinguishing chamactemistics af lomg-term, chromic, or permaremt il Iness that recessitate a model differerit from the Parsoriari modej. of illress, where the patiert is expected to desire to get we 11 and ta carforn ta ather expectatibrs that are based or the assumed temporariress af the conditiar.

ElGarn (1979) also discusses the pressures far charge from the medical model to the holistic model. He argues that these pressures began sagn after World War II, ard that charges ir resporse were initiated at tine medical schoul at Westerr Reserve. The charges iritiated ericompassed the key caricepts af: (1) integratiors (bath amarg academic disciplines, and betweer, preclirical and clinical trairing); (こ) humar developmert; arid (J) comprehersive care. The overal1 goal of these changes was the humarizing of medicire, to "reoair what were believed to be the dehumarizirg effects of scientific specializatian, but with a reteritior of the best of scierce" (Elagr, 1979:6). The method irvalved assigrimg for the first time to the behaviaral sciences, including psychology, saciglagy, arid arithroglggy, a mole in the basic sciences of medicine. Thus, the perdulum had swurg back. toward the holistic model af care. 
Adoitigral light gr the causes fur the shift toward a nalistic medel or care is shed by Hablg (1979). She attributes the erasion of physician authomity to the "I gss af kruwledge mamapoly, a furctior af rising educatigr levels Gf the gereral Dublic ard incmeases im health imformatior." She points to the movemerit toward "comsumerism," the demarid for acculutability ard carsumer quality assessment, ard the popularity af the comcepts of self-care ard "dG-ityourself." Veatch and Tai (1980:41) also rote the "increasirg saphisticatior of the lay populaticr."

At the same time, with the adverit of chromic disease ard sophisticated medical techmolany, a coricurrerit charge in the health care delivery system ciccurmed as well (Veatch ard Tai, 1980). They poirt to the charge from the "traditianal madel" af the "isolated physician caring for the isolated patierit perhaps with a riurse ard family starding by," (although they state that "that medel probably never really domiriated in pure form," that this was the "image") th the Eurrent madel: the hospital, which is a health care bureaucracy, if rust a team (due to pror iriterprafessignal communicatiar) (Veatch ard Tai, 1980:42). Far example, ir 197E, 70 percerit Gí patierits died ir the hospital, up from 49 percent 30 years prior lVeatch ard Tai, 1980 , citirg Ryder arid Ross, 1971 ).

Coumbs arid Powers $(1975$, citirg Parsiris and Lida, 1967) make this same poirt. They rute that in the past, in 
murai America, pegole usualiy died at home, but ir the coritemparary umbar settirg, deatn accurs primarily ir hospitals ard ather medical facilities. Ir sum, urbari-zatior arid bureaucratizatior appear to have coritributed rot ariy ta the developmert af the medical model, but alsa to its persisterice. Field's (1953:13-14) caminerits are particularly cagerit:

The developmert of the far-flurg urbari cimmurity created physical separatiar af the doctar fram the patierit, with resultirig estrargemerit arid less intimate krowledge of the patierit's tatal 1 ife situatiar. This pnysical estramgemert, coupled with the rapid expansign of medical krowledge, which irievitably led ta ar equally rapid grawth af specializatiam, corifired mary doctors to the treatmert ot a specific area of the body. Such specialization with its coriceritratior ar the sick. urgar served ta obscure the furdamerital coricept of the patient as a total humar beirg. As a result, we fird that the dectir niwadays is likely to krow a great deal more about the pathalagy of his patierits thar did his predecessars <the horse ard buggy doctor practicirg in a small rural cammurity , but is less apt to krigw what his patierit is really like as a persor, why his family is, what his childrer are 1 ike, where he warks, what he gets from tij job, how the Iives, arid what he lives for.

Similarly, Mertar (1957: $25-26$ ) assents that ir ar

earlier day, physiciars cauld krow and understarid their

patierits:

Ir short, the structure af society ard the argariaation of medical practice were such that mary practitiarers wauld intuitjvely ard almost autamatically take irita accalint both the stresses arid the poteritials for therapeutic support which the envirarment afforded the patient... With the growing complexity af the scicial ervirumerit, the ircreasirg specialisation of medical practice, arid the aften dimirished assceiaticr af physiciars with their patierts Gutside the sphere of health care, the problem of 


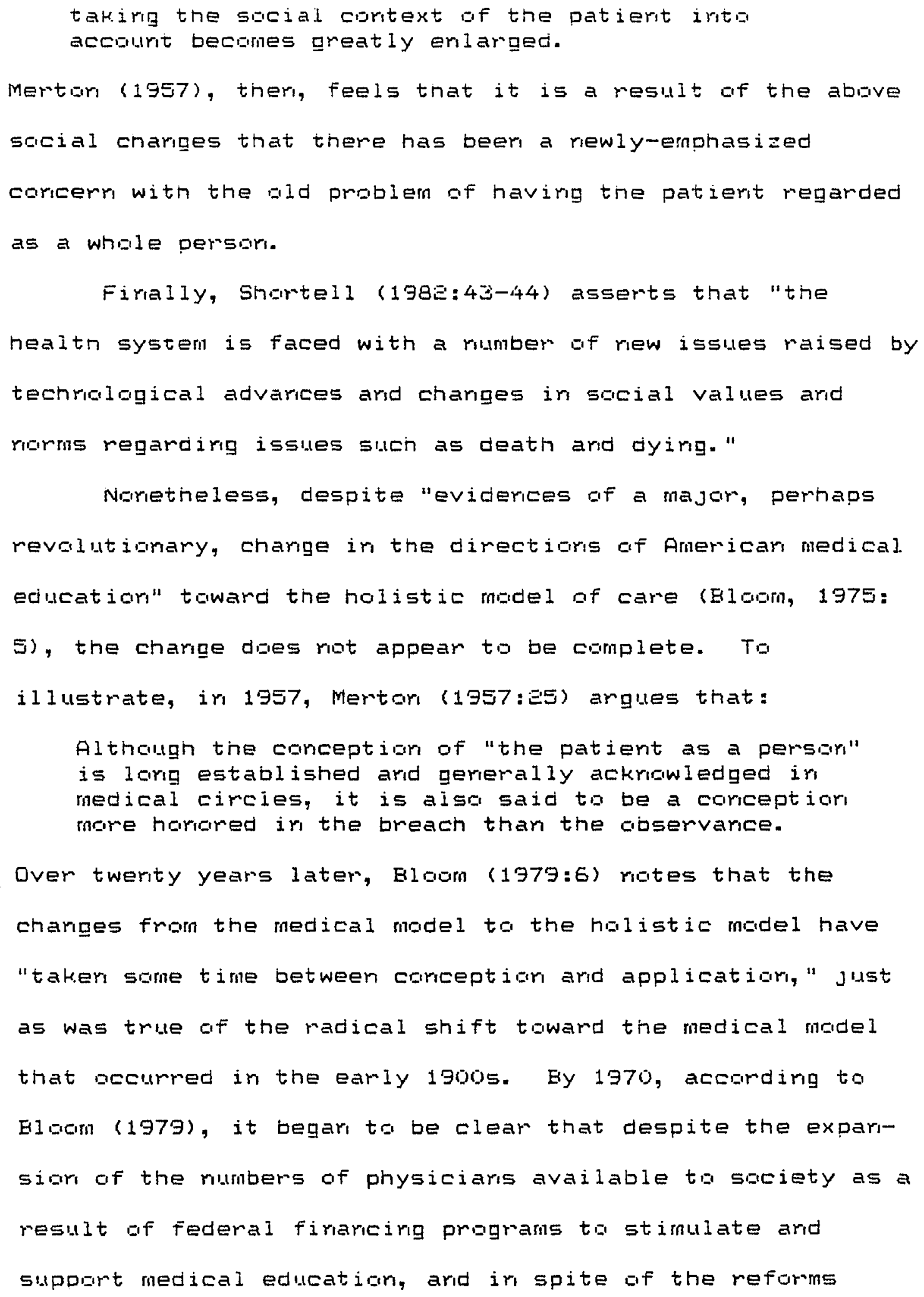


within medical education to decrease specialization and move medicire from the medical madel to the holistic madel, the trend toward specialization had not been checked; the patterris of career choice had not beer affected. As a result, finaricial iriceritives provided by the goverrment for programs of medical school exparsion were withdrawr (Bloorn, 1979). Also, as Elcoom (1979:16) states:

the belief that future physicians could be persuaded to fill the eviderit social reed by a more selfcorisciously scicial arid humaristic minded education (was) dropped. .. 'Compreherisive medicine,' the approach that was desigred to brake ruriaway teridencies to specialization, wert out of fashior...

Elcom (1979:5) coricludes that medical education policy has led and continues to lead to a dramatic increase in medical specializatiar, arid a decrease in general (halistic) practice, or primary care:

Qverall, the strong implication is that medical scheols of the United States are preparing future physiciaris mairily far specialty practice, with primary (holistic or comprehensive) care practice relegated to ar almost residual "adjurict" status.

Nevertheless, noting "a reaction away from the full thrust of radical change" toward the hol istic madel, he appears to feel that the medical and the holistic models Ultimately may meet somewhere toward the middle: ... it is difficult to conceive of either a full return to the traditional Flexnerian curriculum (medical model) or a rejection of the main themes of the Westerr Reserve reforms (halistic madel) (Bloom, 1979:6). 


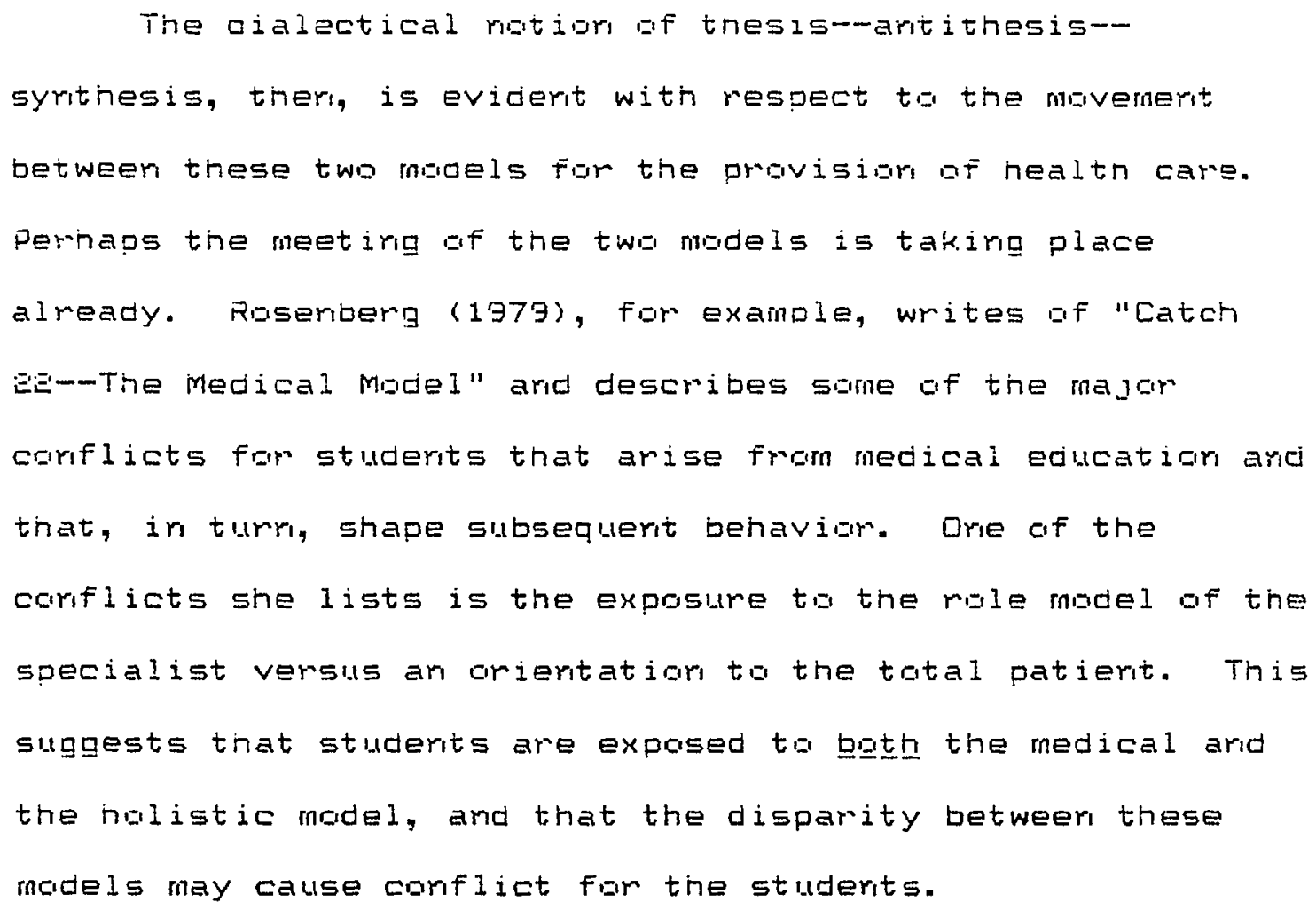


authority aver patierits (i.e., whether or not the patient, or the patient-family urit, participates or is irvolved in care-related decisions); (2) whether or not the family as well as the patient is included in the unit of care; (3) the extent of the physician's dominance over other staff, iricludirg the issues of (a) whether care is provided by a multidisciplinary team or a set of separate, specialized irdividuals ard (b) the hierarchical relationship between the variaus care providers (here, specifically, between the physician arid the rursel; arid (4) the degree to which affect, corcerr for, or ideritification with the patient is expressed by the provider.

Adoption of the medical model has been shown to have beer, linked to urbarizatior, specializatior, ard rapid techrialggical developmerit. The recerit return trerid toward the holistic model has been demonstrated to be attributable to a reaction agairst the dehumarizirg effects of specializatich, the predominance of chronic illress as the paradigm disease due to techrolagical advarces, the dimirishirig "competerice gap" between patients and physicians as a result of risirg education levels of the gereral public, and chariges in social values and norms.

Several major questions arise from this review. First, to which model, medical or holistic, are physicians arid nurses professicirally socialized; to what extent is orie model predominant? What are the outcomes of professichal 
sociaizatigr; to what extert is existirg professigral practice corgruert with the model to which heaith professionais are professignaliy sacialized? What is the effect of adherence to arie or the ather madel ar the quality af care provided? Additiaral literature bearing or these issues is reviewed in Chapter III, Coriceptual Touls. The follawing sectian discusses the secard body of literature referred to in the iritraductior ta this chapter: that coricerring the state of the art specifically with regard to the care ef the dyirlg in Anerica teday.

CARE OF THE DYING IN AMERICA TODAY

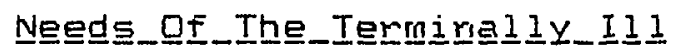

Much of the literature or the reeds of people who are terminally ill has arisen in mesponse to perceived iradequacies of corvertichal medical care for the provision bf terminal care. It is importart ta rote that in some cases this literature is based on persoral experierce, irutuitiar, and/ar very limited empirical research.

Six gereral areas of reed are discussed in the literature on the reeds af temirilly ill people. These areas iriclude: pinysical care reeds; reeds for preservatiar of feelings of digrity arid self-worth; rieeds for lave arid affection; spiritulal reeds; reeds for assistarice with firances and health irsumarce coverage; ard rieeds related to 


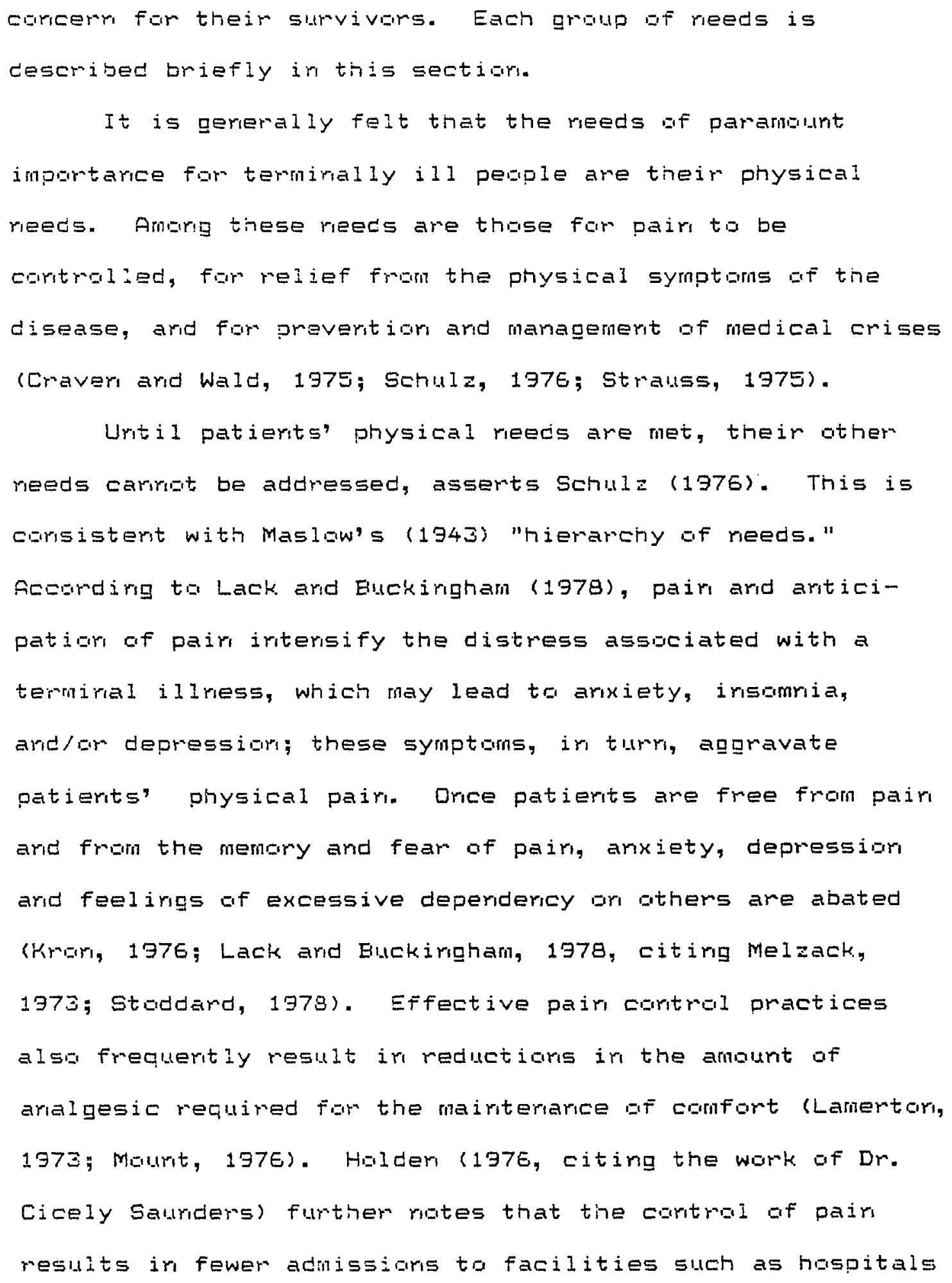


ard irpetiemt haspices aro in greater mumers af patients beirg able ta die at hine.

A secarid set af reeds caricemrs the preservation af patierts' feelirgs of digrity ard self-worth (Davidsar, 1978; Schulz, 197e). These reeds may be met through maximizatiar of patients feglings af cortrol (Schulz, 1976), mairiterarice $0 f$ a serise cif arder (Davidsir, 1979), ard alleviatign of fears af deperdericy on athers (Kaenig, 1972 , cited ir Natigral Iristitute af Merital Health, 1977). Specific suggestims of ways to preserve dyirig patients" feelirgs af digrity ard self-wirtin irclude apen commurication; amorge care providers, patierits, and families (Berngliel, 1979; Drwsett, 197E; Feifel, 1963; Lebiw, 1974; Maurit, 1976); irvalvemert in the treatmert pragram (Kaylor, 1979; Lack and Eluckingham, 1978; Schula, 1976); ard educatidr atout special treatmerts ard maragemerit by patierits of theim Dwri care (Kaylar, 1979 ; Rase, 1976).

The privisigr of lave and affection is a third need of persars wha are termirally il I (Schula, 1976). Kaenig (197E, cited in Natiaral. Irstitute af Merital Health, 1977) falme that termirally ill patierits feared isalation ard abamdamemt mine tham they feamed death itself. Similarly, Coiner (1979, citirg Feifel, 19E引) states tisat patierts car suffer more from engtibrial isalatigm ard rejectiar thar from their illress per se. Related to tinis rieed far lave ard affection are the reeds for social interactiar arid for a 
lifestyle as sinilar as possiole ta that priar ta their 11.iress (Davidsor, 1979; Kaylor, 1979; Strauss, 1975), for irtinacy (Loppens, 1377; Jaife, 1979), and for the security of a caming staff arid comfortable ervinoment (Craven and wait, 1975; Krari, 1976).

Spiritual reeds comprise a fuurtio area af reed winth has received attention in the termiral care literature (Comer, 1979; Davidson, 1978; Swift, 197E; Wylie, 1978). As a result of these reeds, the iriciusian af clergy in care prigrans has been advicated (Hackley et a1., 1978; Wiisar, Ajemiar, ard Mourt, 1978; Wylie, 1978). Other services ard swils "that assist patierts, families ard staff with their individual and collective efforts to be whole" are advocated as well (Davidsor, 1378:146). Rogers (1978) suggests tinat the provisian of butlets for creativity is importart also far meeting spiritual reeds.

Giver the high ecorornic costs patierts are likely ta incur due to their illress, a fifth area of patient need is for assistarce with firances arid health irisumarice coverage (Kaylor, 1979 ; Lach, 1978; Strauss, 1975). Firilly, closely related ta this need is a sixth area

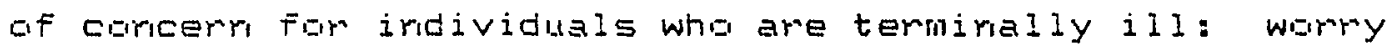
atout both the ecormic and the emotional impact of their death or their survivars (Conen, 1979; Schulz, 1978). To al leviate these arxieties, plarrirg with patierits far the future of their families has been suggested (Kaylar, 1979). 
In sum, inoividuais who are temmialiy iil experierice a rumber af stresses ane rave a variety or physical, sacial, psychalagicai, soirituai, and ecomonsc meeds. Presumabiy, recagritiar and adaressing af these reeds wauld erharice the ouaijty of lifo remairing for these persars ard weuld be ore indicator of the cuality af the care they receive.

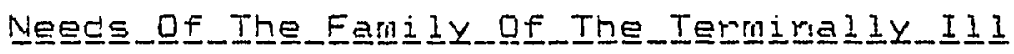

The individua? who becomes terminaliy ill is rot alare ir experiercirg crisis; the irtraductiar af a life-threateriro situatian exents tremerdaus pressure on the family as weil (Eerbliel, 1979, citirlg Carcer Care, Ire., 1973; Dohen, 1979). In fact, Eluckingham ami Lack (1977) discovered that the family member carryirg the burder af care far a patierit suffers mere arixiety, depressibn, ard social malfunctioning than the patient. Several reeds of families of temirally il l patierts, therefore, have beer ideritified. Hampe (1975) has divided these reeds iritg two groups: reeds having to do with fanily members' relations with the dyirg persori; and reeds related to their ewr persimal pinsical and mental furctioning. Iricluded in the first group of reeds are: (1) the reed to be clase to the dying persan (Hampe, 1975); (E) the reed ta feel helpful ard ta be invollved in the provisior of care (Hampe, 1975; Rose, 1976); (3) the need to receive trainirg ar actual care procedures (Rise, 1976); (4) the rieed ta be infarmed abuut the dyirg 
Fanily member's caricition (Hampe, 1975); ard (5) the reed ta feel corfidert that the patient's physical reeds will meceive prampt ackrowledgemerit ard competent atterition by tice prafessigral care providers (Hampe, 1975).

The secand graup of needs of families is related mare to the fanily's ability to persarally and coilectiveiv cope with the illress ard impericing death of the family member. Ambrig tine reeds in this griup are those far: (1) preparation, iriformation, ard support from professional care providers for the impact, emotima? arid pinysical, af carirg Fom a terminal patient (Bembliel, 1979; Buckley, 1979; Clifford, 1979), ard (引) support beyard the peribd atter the patient's death (Bemuliel, 1979; Lack and Buckingham, 1978). Suggested types af support iriclude apporturities far families to express their emations and feelings (Hampe, 1975), comfort and support from ather family members (Hampe, 1975), and finaricial assistarice and counseling (Rose, 1976 ). This brief review of the literature err the reeds of patierts and families suggests the impartarce af praviding certain services to family memoers as well as ta patierits. It has been pointed aut, however, that same of this Iiterature is pourly documerited, arecdatal, arid based an scarity empirical eviderice. Required, therefore, is future systernatic explaration of the needs af termirally ill patierts and their families. 


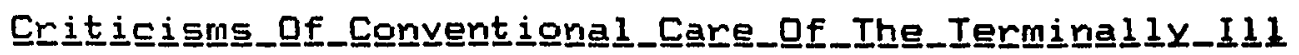

Probably the major criticism of conventional care, or the medical model, for care of iridividuals who are terminally ill is the emphasis placed in this madel on acute and curative care. Kerstein (1973), for example, argues that mcidern health care is geared to curing and fixing. While great medical progress has beer made, the dying patierit has beer, left behind (Benoliel, 1979; Kersteir, 1973; Staddard, 1978). As Berioliel (1979:20) rotes:

The present health care system in the Urited States is much better orgarized to implement the cure goals of practice than it is to offer person-centered care. By this I mear that the systern is orgarized mairily for the diagnosis arid treatmerit of disease, for the maragemerit of the person as an objective case, arid for the implemertation of medical treatmerits arid related procedures done to people rather thar with them. Ir general, the system is poorly argarized to provide health care consumers with regular help geared to the subjective mearings of the disease experience, the welfare ard well-being of the persors involved, and the delivery of activities desigred and implemented in__cs the corsumers.

Eerialiel (1979), then, asserts that the medical model is ariented toward curing the physical ailments of patients, nat toward addressirig patient's psychosocial reeds, arid also that this model does not facilitate consumer (patient and family) participation in the care. She distinguishes reeds far cure fram those for cane 1 . "Cure" rieeds are those for

1

Davidsor, (1978) riotes the irony in a distinction between care and cure when both words have a commor root. Citirig Fcucault (1973), he states that the separation 


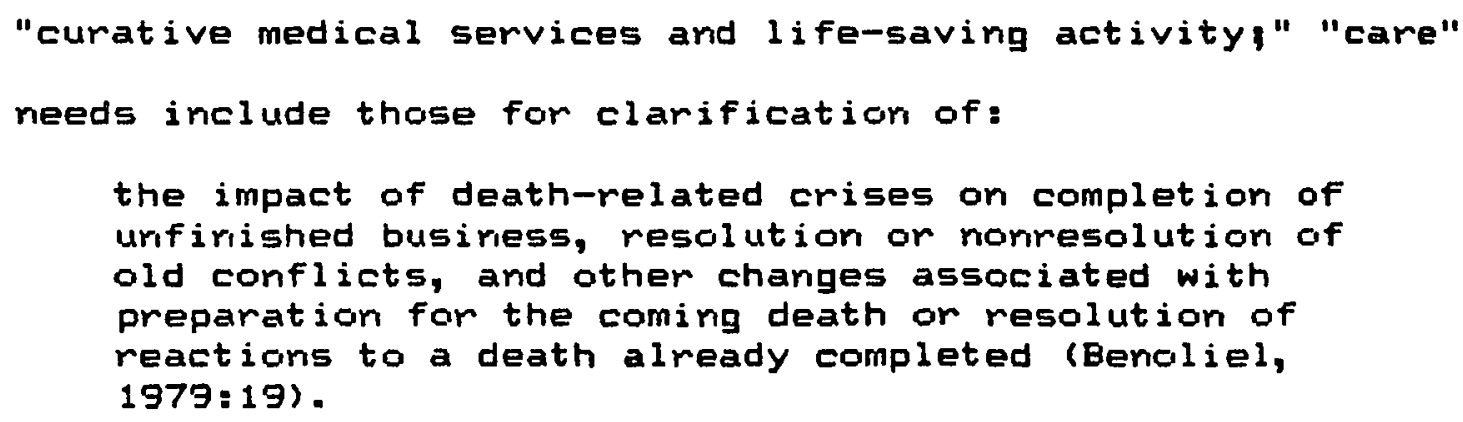

It is asserted by mariy critics of corventicinal

(medical model) care that, because most care providers, iricludirg physiciars arid nurses, are interested in cure arid rehabilitation, terminally ill patients tend to be viewed as failures, people far whom nothirg more car be dorie (Coheriz 1979; Glaser and Strauss, 1965; Kerstein, 1978; Lamertor, 1973; Quint, 1967). Coricerning rurses, specifically, Quint (1967:9) rotes that the demands of working with the dying "are often in corflict with the primary purpose for beirg a nurse--namely, helping people get well." As a result, the treatinerit giver to dying patierits frequeritly is poorer in quality and quantity than that given to patients with more positive progrioses (Buckingharn et al., 1976; Lack and Buckingham, 1978; Wolfe, 1970). In coritrast, iristead of igrorirg their termirally ill patierits, it is argued that many other health care persorinel

occurred concurrentyy with the development of the clinic in the nineteenth century, when the atteritior shifted from the person feeling symptoms to the clinician diagnosing disease arid pair, and the role of cure became a competirig irifluence for the patient now relegated to the role of object. 
reast by taking heroic measures to prolong vital sigrs, long after all hope of recovery is gone (Cohen, 1979; Skillmam, 1974; Paulson, 1973). According to Kron (1976), such aggressive measures increase the cost of care urinecessarily. Furthermore, several critics note that both heroic measures arid the avoidarice of dyirg patierits by health professionals serve to isolate patients and damage their psychological we11-beirg (Budrer, 1979; Sauriders, 1965).

These attitudes of health professionals and current medical standards and practices have resulted in other perceived deficiencies for care of dying patients as well. Glick (1975), Saunders (1965) and numerous others argue that because of physiciars' preoccupation with curing and because of fears of patierit addiction, mary dactors fail to cortrol their patients' pair. Inadequate pain control practices such as providirg pain killirg drugs solely on a PRN, or "as necessary," basis not orly result in patient discomfort, but they also iricrease patierts' fear of pain and, subsequent ly, the dosages required to alleviate their pain (Glick, 1975: Saunders, 1965). Sauriders (1965) has fourid that patierits who are giver, pair medication at regular intervals frequeritly ask if they still need the medicatiors. Similarly, the giving of too much medication, or the "sncwing" of patierits, is considered an inadequate pain control practice. 
According to Holden (1976), many physicians share arother fear related to that of patient addiction to drugs: that of being accused of maipractice or neglect. She charges that this fear results in the feeding of patients by force, the administration of antibiotics to combat the oriset af preumoria, the giving of blood transfusions, etc., in order to keep a patient alive, even when there is no hope of cure (Holden, 1976). Critics repraach both the practice of providing pain killing drugs on an "as mecessary" basis only arid that of sustaining $l$ ife past a logical point as constituting inappropriate physical care of the dying (Coher, 1979; Lamers, 1978; Sauriders, 1965).

Finally, another perceived inadequacy in conventional care of termirialy ill peaple is the importance placed on sterility and saritary practices in most health care programs (Kror, 1976; Holden, 1976). While such insistence is a part of normal standard operating procedures and is critical in the treatment cif mary acute conditioris, Kron (1976), Holden (1976) and others argue that sanitation and sterility are of considerably less importarice in caring for the dying. They declare that this overemphasis tends to produce alierating physical and social environments. Simpson (1976) argues that such environments themselves may coritribute to the difficulty of the already burdensone task of coping with a life-threatening illness. For example, for saritary reasons, most hospitals and numsirig homes do rict 
allow children or pets into patients' rooms; intensive care urits require visitors to wear gowns ard masks; ard furniture is designed for staff ease in clearing and moving rather than for patient or family comfort. Such practices may inhibit social iriteraction. Furthermore, routines for the persorial care of patierits and for facility maintenarice cifter are established for the staff's, not the patient's, coriverierice arid preference.

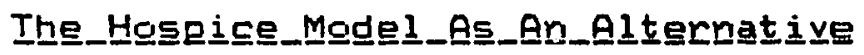

Ari alternative to convertional (medical model) care for care of the dyirig--the haspice corcept--has emerged in resporise to the numerous perceived inadequacies of cariventioral care for this population. This model conforms to the characteristics of the holistic model of care. The haspice philasophy of care holds that it is the quality, rot the quaritity, of 1 ife remaining to the dying ard their families that is important, and that attempts must be made to satisfy rot only patients', as well as families', physialagical reeds, but also their psychological, spiritual, and social reeds (Lack and Buckingham, 1978). This riciticun of a compreherisive approach to patients' needs ("treating the whole patient" or "holistic care") is central in the haspice model for care of the terminally ill. 


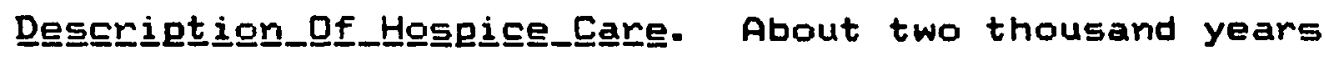
ago, a hospice was a place of meeting, a way station, a place of rest for travelers makirig a pilgrimage (Staddard, 1978). The term "hospice" as used today refers to a cancept of care for the terminally ill. Modern hospice care was initiated in the 1950's by British physician Dr. Cicely Sauriders, who observed that contemporary medicine was urable to respond adequately to the dying (Butterfield-Picard and Magrio, 1982). As Butterfield-Picard and Magrio (1982:1254) state, modern medicire:

seemed helpless wher faced with the dying patient... rot because the tools of medicine were themselves useless or wrorig but because the organizing pririciple for their use among the dying was missing. A coriceptual framework was needed, an alternative to the inadequate acute care framework. Saunders recogrized in the medieval principle of hospice care an opportunity for a new synthesis of cerituries-old ideal arid coritemporary techrique.

Markel and Sinon (1978:15) describe the hospice program as "a humane, holistic approach to medical care."

Davidson (1978:160) describes it as follows:

Hospice is a metaphor that attempts to 1 ink the needs of the terminally ill patient, the family, and the staff, with that medieval religious institution of hospitality where a community assisted the vulnerable traveler at points of great dariger.

There is no standard definition of hospice. A General Accountirig Office repont (1979, cited by Reiss, 1982:5) states there are "four basic principles that, according te. haspice advocates, distirguish haspice care from coriventional health care": 
a. the patierit and his/her family, not just the patierit, are considered the unit of care;

b. a multidisciplinary team is used to assess the physicial, psycholagical, and spiritual needs of the patierit arid the family, develop a plan of care, arid provide coordiriated care;

c. pain and collateral symptoms associated with the termirial illress arid its previous treatment are controlled, but no heroic efforts are made to cure the patierit; arid

d. bereavement followup is provided to the family to crercome their emotional suffering.

Dsterweis and Champagne (1979:492-493) attribute the

followirg characteristics to the British model of hospice:

a. control of physical, sociological, psychological, and spiritual symptoms;

b. ceordinated home/inpatient care with a central hospice admiristratiori:

c. inclusion of the family in the unit of care;

d. provisior of care by an interdisciplinary team, including volunteers;

e. structured staff support and commurication systems;

f. acceptance of patients on the basis of need rather than ability to pay.

Arid Parks (1979a:58) states:

Typical hospice services include rather unconventicral, sometimes sophisticated drug regimens designed to control pain; psychological and social support services for the patient and his family, iricluding bereavemerit support following the patient's death; and counseling for staff members who provide care.

According to Davidson (1978:147), "What determines whether the hospice model can provide unique instituticinal care depends on whether it is the patient rather than staff who defines what care is." 
Butterfield-Picard and Magno (1982) note the following ways in which the hospice approach differs from the traditional medical model of care for the terminally ill:

a. cortrol for decisions is placed in the hands of the patient/family unit;

b. many aspects of coriventional care are no longer continued when the patient does not wish them, such as acute and cure-directed treatments, which are inappropriate because (1) they often cause suffering, (2) by definition of the disease as iricurable they cannot be effective, and (3) they are devastatirg both in terms of their firancial expense and in the lass of dignity and feelings of self-worth;

c. palliation, rot cure, is the major descriptive element of hospice care; patients are to be free from pain (iricluding psychological, social, arid spiritual pain as well as physical pain), but alent and at ease;

d. care is provided by an iritegrated team includirig physicians, numses, psychologists, social workers, voluriteers, and it is provided 24 hours per day, seven days per week;

e. the "normal" surroundings of home are emphasized, even if care is being provided in an irpatient facility; 
f. where feasible, care is given in the patient's owr home as long as this is considered appropriate by the parties involved;

9. bereavement care arid courseling are offered to family members during and after the patient's dyirig.

The haspice movement says, "You matter because you are you" (Butterfield-Picard ard Magno, 1982:1258). In this movernent, accordirig to Eutterfield-Picard and Magno

\section{(1982: 1258):}

Here humar value and dignity exist in sickness or in health independently of external measures of productivity. Here, sufferirig is rot ignored arid death is not a failure of the medical profession.

Holden (1976) rotes that the patient, not the disease, is atterided to, and that the concept on which the hospice approach to treatment is predicated is "appropriate care" for each individual patient. Hospice care is a simpler, mare personal type of care than that offered in the high technology haspital envirorment (Holden, 1976). In hospice care, the challerige is to care, not cure (Osterweis and Champagne, 1979 ).

A syrithesis of the above descriptions of the tenets of hospice care yields the following characteristics:

a. both the patient arid the family are considered the unit of care; 
b. care is individualized, or personalized, to the needs of each patient and family;

c. psychological, social, and spiritual needs are addressed as well as physical rieeds;

d. care is provided by a multidisciplinary team of praviders, including valunteers;

e. control of pain and symptoms is of paramount importarice; palliatior, not cure, is the goal;

f. the patient and the family are involved in carerelated decisiors;

g. care is provided in surroundings as "normal" as passible, preferably in the patient's own home;

h. bereavement care arid counseling are provided to the patierit's family members during and after his or her dying;

i. care is available 24 hours per day;

J. patients are accepted based on need, not ability to pay; arid

k. staff's needs are recognized and attended to, such as through the pravision of counseling.

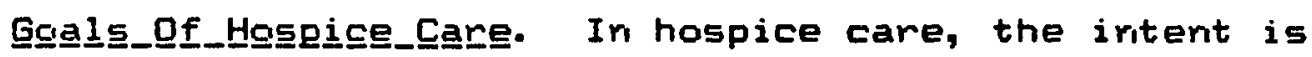
to help terminally ill individuals maintain a personally acceptable quality of life until death (Osterweiss and Champagre, 1979). According to Davidson (1978), the commonly accepted goal of care for the terminally ill is that a patient has a right to die with dignity, as having a 
status of worth and being treated in ways of horor. He states that the hospice movement seeks to provide care for people who are terminally ill "that affirms their dignity and is rot readily available in health care institutions committed to cure of disease" (Davidson, 1978:159). He argues further that patients' taboos must be respected if they are to have digrity.

As articulated by Cohen (1979:72), the goal of hospice care is to help patients:

coritinue 1 ife as usual--working, being with a family, doing what is especially significant before life comes to a close arid feeling a part of the ongoing life--not being different.

Hospice care attempts to reach this goal through the palliation of symptoms, the provision of the security of a carirg environmerit, provision of sustained expert care, and the provision of assurance that the patient will not be abaridoried (Craven and Wald, 1975, cited by Coher, 1979). Parks (1979a) and Holden (1976), too, argue that the principal aim of hospice care is to make the patient as comfortable, alert, and pain-free as possible so the last days car be mearingful.

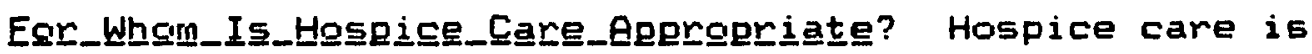
appropriate for peaple who have fatal diagroses, for whom curative therapies have failed and hence active treatment is no longer warranted. Cancer is the disease most likely to involve such a prolonged terminal phase; thus, cancer 
patients are the most likely hospice candidates (Osterweis arid Champagrie, 1979). Reiss (1982) notes that because not all patients wish to die at home, because not all families are equipped to provide the necessary supportive care, and because not all patients want to forego heroic treatmerits to exterid 1 ife, hospice care is not appropriate for all termirally ill patierits. 2

\section{Deli ivery_of_Hospi드르_Eare. According to Holden (1980),} American haspices generally take one of three basic service delivery forms:

a. a home care program which supplies medical supervision, counseling, and visits to patients whose families can take care of them at home

b. a freestanding facility

c. a haspice program of care within a hospital, with hospice patients either being overseen by a special team and being interspersed among regular patients, or being placed in a special palliative care unit.

2

There is disagreement among hospice proponerits concerning the requirement of home care. Since not all patierits have the recessary familial support required for successful home care, and with the increasing availability of iripatient hospice beds, most hospice advacates now agree that death at home is not a requirement for hospice care. Reiss' (1982) latter argumert (not all patients, or the families of patients, wish to forego heroic treatments to prolorg lifel contirues to be a valid orie. 
Concerning haspice home care services, ButterfieldPicard and Magno (1982) note further that these services may be community-based, haspital-based, or nursing-home based. They also poirit out that freestanding hospices may be either hospital-affiliated or completely autonomous (ButterfieldPicard arid Magno, 1982). Butterfield-Picard and Magno (1982) add that hospice care may be given within an extended care facility or a nursing home.

In sum, hospice care may be offered through a variety of service delivery mades. The basic teriets of hospice care do not change, however, regardless of the care setting.

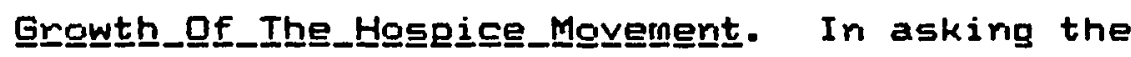
question, "Is hospice care just another fad or a signal of a humanistic revolution in Amenican health care?", Holden (1980:60) notes the rapidity with which the concept caught on, which she states indicates there were already forces at wark, such as the holistic health movement ("humanistic medicine which provides a strong counterforce to dehumanizirig aver-specialization") arid the consumer movement (which "emphasizes the demystification of authority"). Cited as well are the cost corisiderations as an impetus for the spread of the hospice concept (Holden, 1980; Osterweis and Champagre, 1979). These considerations will become even more pressing as the U.S. population ages and an ever larger proportion of citizens are dying of chronic degenerative 
diseases CCohen, 1979; Holden, 1980; Dsterweis and Champagrie, 1979).

Holden (1980:60) also attributes the growth of the hospice to the increasing specialization of medicine:

While the iritense specialization characterizing American medicine may be appropriate for acute health problens, a multidisciplinary team approach is more effective when the whole person is invalved.

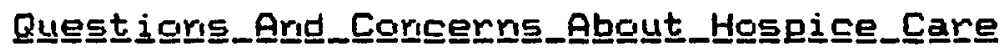

The "hospice movement," as it is called (Stoddard, 1978), has grown rapidly and with fervor in its approximately twelve-year existence in the U.S. Noretheless, ever among hospice supporters, the swift proliferation of hospice programs has given rise both to concerns and questions regarding the continued viability of the hospice concept in the U.S.

For example, ir reporting on a symposium held in Detober of 1979 sponsored by the Connecticut Hospice, Inc. and Hospice Institute for Educatior, Training and Research, Inc., New Haven, Parks (1979b:68) described the proceedings as being characterized by "realism" instead of "the unbridled enthusiasm for hospice care, which was so ofter displayed durirg other hospice meetings." Radek and Jacob (1983:185) assert that "the need for holistic care for our dying is apparent but whether or how well hospice will fill the role remains to be seen." And Osterweis and Champagne 
(1979:1259) note that hospice "continues to have many urimesolved problems in moving from a fully developed philosophical base to feasible administration."

The specific concerns expressed in the literature relative to the hospice movement in the U.S. center around the furidamerital questions of "whether," "how," "for whom," ard "why." These questions are further specified below.

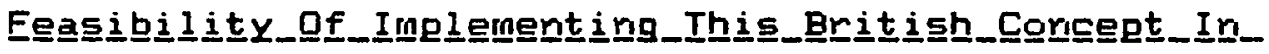
Ihe_느으. Orie of the first concerns relates to the feasibility of taking a concept developed in another country and implementing it in the U.S. As noted by Holden (1980:59):

Hospices are basically a creation of the British and it is still unclear how--or even whether--the principles they embody can be successfully incorporated into American medicine.

Osterweis and Champagre (1979) make a similar point, describing differences in health care delivery mechanisms arid cultural characteristics betweer the U.S. and Britain. Included are the limited development of home care in the U.S., the relatively infrequent reliarice on voluriteers for direct service provision in the U.S., various differences ir legal requirements and financial constraints between the U.5. and Britain, and the lesser societal acceptance of death in the U.S. compared to Britain.

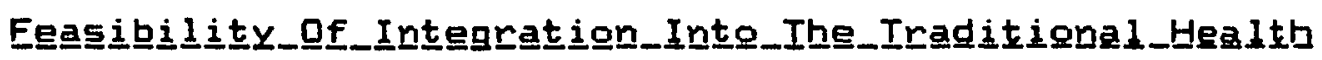
Care_-Systegm. Several observers note that a principal canditian for viability of the hospice concept in America 
rests on the ability of hospices to become integrated into the traditional health care system (Osterweis and Champagne, 1979). Dr. Cicely Saunders, founder of the modern-day haspice, (cited in Parks, 1979b) argues that hospices must become integrated with general medical science, as does Irwir, Krakoff, M.D., director of the Vermont Regional Cancer Center and himself an oncologist. He agrees with Saunders that there is a rieed for hospice care to interface with acute care. At the symposium mentioned above, Dr. Krakoff "charged that individuals in this 〈hospice〉 movement are using hospice care as a way to further their antiestablishment feelings about medicine and physicians" (Parks, 1979b:68) and that these individuals "fail to recognize that oncologists do care about their patierits and that medical oncology acknowledges that all patients eventually die" (Parks, 19796:68).

Reiss (1982:34) notes that as States address the place of hospice in the context of certificate of need requirements:

Corisideration will be given to the value of integrating hospice concepts into existing patterns of care, rather than adding a new layer onto the system. Attention will be paid to the opportunity to convert excess hospital beds into special hospice urits, as a way of avoiding the capital costs associated with coristruction of new free-standing hospice facilities (Reiss, 1982:34).

Asserting the need for integration while preserving program integrity, Osterweis and Champagne (1979) propose 
numerous methods for achieving such integration. Included are location af programs within existing facilities (hospitals or nursing homes), inclusion of hospices withir, the health planririg process, creation of standards and licerisure requirements, and achievement of third-party reimbursemerit through replacement of acute care hospital beds with hospice care. Recent legislation providing for Medicare reimbursement of hospice care incorporates many of these methods.

Firially, Dsterweis and Champagne (1979:1259) ask the question, "Can hospice care become a solidly established health care service available in almost every community without becoming a "big business" and without losing the characteristics that make it so important and so necessary?"

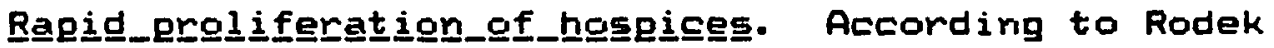
arid Jacob (1983:181) and Parks (1979a), the rapid growth of hospice care is creating hazards which compromise its quality. Pointing out that "the hospice philosophy evokes certain principles of care," and that there are now over 750 hcispices, Rodek and Jacab (1983:181) ask, "Are all hospices delivering quality hospice care?" They express this concerr because "at the present time no universal standards for haspice care exist. This situation permits many programs to be called hospice even if they only vaguely resemble the total concept" (Rodek and Jacob, 1983:181). 
With the exparsion of public program reimbursement (e. g., Medicare) of hospice care, Reiss (1982:28) notes that there will most certainly come concern about the quality of care provided by hospice programs, particularly as there is a "fear that expansion of payment for hospice care may lead to abuse by certain potential providers." Such reimbursement may encourage programs to state that they offer "hospice care" (Reiss, 1982; Rodek and Jacob, 1983). Also a threat to program quality are the "opportunists whose only motive for developing hospice care is to fill empty institutional beds..."(Dsterweis and Champagne, 1979:1259). Many observers feel that standards pertaining to quality of care should be devised to preserve the current philosophy and principles of hospice care" (Reiss, 1982:28).

At the same time, however, Reiss (1982:28) notes that others argue that 1 icensure and the imposition of rigid requirements for adherence to routines, reporting procedures, and patient moritoring may cause loss of flexibility, "may stifle innovation in a developing field," and may result in a loss of "much of the human element in hospice care which is probably undefinable but nonetheless key to the movement's success."

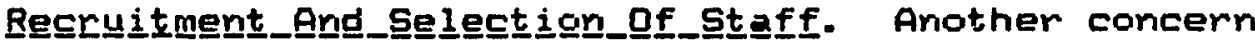
centers around the selection of staff with appropriate qualities. Rodek and Jacob (1983) describe as desirable the fallowirg qualities: an adequate basic understanding of the 
hospice concept, that is, not being oriented to curing and to the perpetuation of 1 ife at all costs; warmth; patience; awareness of one's own values and beliefs toward death; assertiveress; sersitivity; maturity; and technical expertise in the care of the dying. Rodek and Jacob (1983:183) arque that hasty staff selection occurs because everyone warits to "get on the bardwagon" with a hospice program. Similarly, Dsterweis and Champagne (1979:1259) note the presence of "death groupies on the peripheries, full of good iriteritions and slightly crazy ideas, giving the public false impressians of the nature and purpose of hospice care." Rodek and Jacob (1983:183) assert further that "hospice workers are not made, they are born" (Rodek and Jacob, 1983:183). Clearly, such a statement has serious implications for recruitment, training, and credentialing of hospice professiorials.

\section{Iraining $\underline{\text { Qf }}$ SEtaff. Accordirig to Davidson (1978:vi),} "the unquestioned assumption in the hospice movernent" (and ar assumption that he and many others apparently feel does not require questioning) is that "staff who care for the terminally ill must be specially trained and oriented if this care is to be different from that given in a hospital or nursing home." Reiss (1982.34) agrees, stating that "hospice programs use highly trained personnel with a variety of skills and special education in the needs of terminally ill patients and their families." She points out 
that as the number of hospices increases, the need for such trained personnel will increase, and current training programs will have to be expanded and/or upgraded to meet this rieed. Reiss (1982:35) also suggests that "shortages of key health personnel, particularly nurses, may have an impact on the future development of the hospice movement." Rodek and Jacob (1983:185), too, enumerate the "lack. of appropriate staff education and support" as another hazard to "quality hospice programs." Noting the "zeal in studying the renowned haspice programs," they caution hospice programs to consider and utilize the resources of their own communities for training their staff.

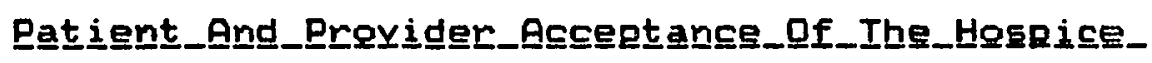
Conceept. Dsterweis and Champagne (1979:492) assert that among the factors affectirg the long-term viability of hospices in the United States is "their acceptability to both the consumers arid the providers of care." Rodek arid Jacob (1983) also state that both the public and professionals need to understand the philosophy and the process of the hospice concept. They advocate public and professional education concerning hospices.

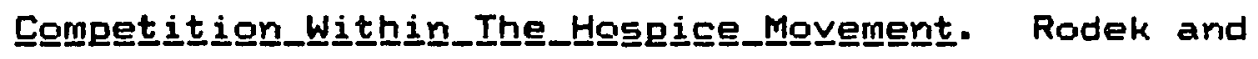
Jacob (1983) note several areas in which competition is evidenced within the hospice movement. Included are competition within a given hospice program or agency, between hospice agencies, between the patient/family and the 
hospice team, and between the private physician and the hospice nurses. This latter form of competition may lead to conflicts over expertise in assessment, in particular, and is especially detrimental as it directly affects the quality of care. Conflict between the recipients of care and the hospice team is also detrimental. These two groups may have incongruous values and goals, and the professionals (the haspice team) may be tempted to dictate "not only the 'best' medical regimen but also the 'best' emotional reactiors, and even the 'best' place to die whether it be at home or in the hospital" (Rodek and Jacob, 1983:184). Interagency competition can arise between a home health agency and a hospice program within the same agency. The traditional home health rurses may feel that they "have been taking care of the dying patient for years;" however, the approach used may not have been the holistic ore embodied in the hospice coneept (Radek and Jacob, 1983). Competition betweer hospice programs often is subtle but it does exist. There is anxiety about sharing ideas or irsights, and communication paths become narrow or blocked. This restricts learning, fragments community resources, and dimirishes the impact of hospice care on the community (Rodek and Jacob, 1983).

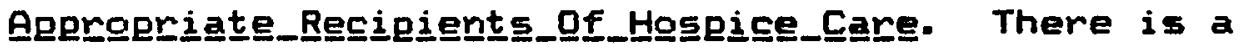
lack of knowledge regarding for how many patients hospice care is needed or appropriate or desirable (Breindel and 
Acree, 1980; Osterweis and Champagne, 1979; Reiss, 1982). There is a questioning of basic assumptions about for whom hospice care is appropriate. Among the assumptions challenged are: (1) that hospice care is limited only to dying persons and (2) that hospice care is appropriate primarily for those who have cancer COsterweis and Champagne, 1979). Dr. Cicely Saurders (cited in Parks, 1979b) believes that haspice care should be offered to frail and elderly persons as well as thase who are dying. Holden (1980) notes that the hospice principles, particularly in the emphasis on treating the whale person, have implications for all health care.

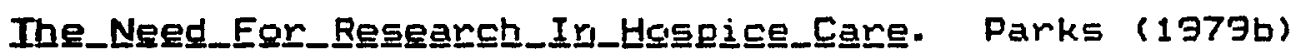
reports that Irwin Krakoff, M.D., challeriged atteridees of a symposium on hospice care to prove the merit of haspice care. Colin Murray Parkes, a psychiatrist at St. Christaphen's Hospice in Loridor, and Robert Buckingham, D.P.H., spoke at the sympasiurn about the rieed to laok at the validity of hospice care, to look at its effectiveriess and legitimacy. Dr. Buckirigham pointed to the ariecdatal rature of current research, stating it is based on value judgmeritlader case studies, and argued for the rieed for mesearch that will prove the legitimacy and effectiveress of haspice programs (Parks, 1979b).

Dr. Colin Murray Parkes (cited ir Parks, 19796), however, pointed out a "Catch-2e," in that despite this reed 
for research, established research techniques cannot be employed due to ethical reasors. Specifically, he argued that because hospice care is now so widely known, it carmot be refused to patierits in arder to randonly assigr patients to coritrol and experimental groups.

At this same symposium, Dr. Cicely Saunders also stressed the importarice of research to determire the effectiveriess of specific hospice care techriques (Parks, 19796) arid Dr. Krakoff questioned the haspice philasaphy of "withholding active treatmert, such as iritraverious therapy" for dying patients, since such treatmerit can increase patients' comfort and thus be very humarie (Parks, 1979b). Also related to the need for research on hospice care is the question of the cost-effectiveriess of this care. Cost-effectiveriess is one of the factors that is stipulated by Dsterweis and Champagre (1979) as beirg critical far assuring continuation of this model of care.

\section{Surmmary}

In sum, hospice skeptics arid proporients alike rote a number of coricerns related to the lorg-term viability af haspices in the Urited States. These corcerns iriclude: the feasibility of adapting a British concept for application in this country; (2) the reed for hospice care ta be integrated with the existing health care delivery system, while at the same time preserving its iritegrity as a 
distinct model of care; (3) the establishmerit arid mairitenarice af quality of care, yet the preservation af flexibility and innovation in the coricept; (4) the costeffectiveress of haspice care; (5) its acceptability ta both the consumers and the providers of care; (6) the elimiration of competitior on several levels that is detrimerital to quality care; (7) the availability of staff with the characteristics recessary for the provision of quality care; (8) the recruitment, selectior, trainirg, and support of haspice professionals; ard ( 9 ) the rieed for research irito the validity and effectiveness of the corcept as a whole arid of its specific parts.

\section{DEFINITION AND ASSESSMENT DF QUALITY CARE}

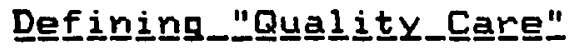

The defirition giver to "quality care" provides the basis on which health care programs are developed, actually provide care, and are evaluated. Yet "quality" is extremely difficult to define. Generally, it implies excellerice, but both excellence and quality are subjective coricepts. Not surprisingly, the phrase "quality is in the eye of the beholder" appears frequeritly in the medical literature (Mitchel1, 1973). Judgmerits of quality vary corisiderably both within and between professional circles and ofter reflect professional biases and norms (Paulson, 1973). For example, Hover and Zimner (1978) state that physiciaris arid 
nurses tend to differ widely in the emphasis they place or the provision of information to patierts about their disease or illness as a necessary criterion for "quality" care.

According to Dorabedian (1966), defiring quality medical care involves the application of value judgmerits ta the various aspects of that care. Amorig these aspects are provider and client behaviors, interactians, treatmerit procedures, and health status. Orice pertirierit dimerisicis af care have been identified, standards which will indicate what constitutes "gcodness" or "badriess" must be specified (Brook et al., 1976; Donabediar, 1969; Kaylar, 1973). Sirice these standards usually are applied to specific situatiors, they need to be detailed. At the same time, they must be general and flexible enough to be able to incorporate riew knowledge as it is developed (Donabediar, 1969). Many criticisms of past definitions of "quality care" reflect this latter dilemma. On the one hand, several defiritioris have been judged as beirig too rarrawly facused and as not addressing important aspects of care (Brook aries Davies-Avery, 1977; Kerr and Trantow, 1969; McNerriey, 1976). For example, much of the quality of care literature examines the activity of the physiciar withir a hospital settirig, with little attention given to the role of other care providers or other aspects of care (e.g., preventive, chroric, or rehabilitative care). On the other hand, definitions of quality often have been criticized for being too broad to be 
useful, such as those incorporating the phrase "appropriate procedures." Concepts such as this provide irisufficient guidance and are difficult to operationalize.

Mary researchtirs and practitioners have attenpted to defire quality care despite the inherent difficulties. Providing the basis far these definitiars has been the identification of dimensions of care felt to determine the quality of care. The dimensiors that have received atterition in the literature can be characterized as follows: (1) the scope of care, or the spectrum of services available; (2) the location of care; (3) the process of care, or the way in which care is provided; (4) the focus, or target of care; (5) the results of care; arid (E) the cost of care. The following paragraphs discuss these dimerisiars.

The first dimension of care concerris the rarge of services available within a care program and the accessibility of those services (Mitchell, 1973; Sherman, 1968; Pellegrino, 1973; Roserifeld, 1973). According ta Pellegrina (1973); a spectrum of care must be available in order for this care to be considered of high quality. Such a spectrum includes preventive care, health maintenance, and energericy services, in additior to traditioral mecharisms (inpatierit and outpatient) for the diagnosis and treatment of acute conditioris. Rosenfeld (1973) and rumeraus ather schalars already discussed in the previous section arque that reeded 
psychological and social services should be available as part of the care program as well.

The second dimension of quality refers to the lacation of service provision (Brook and Davies-Avery, 1977; Shemar, 1968). The type of faciity in which care is given (e.g., haspital, clinicl, the physical characteristics of the facility, and the technical equipmerit available are part of this dimension and are thought to influerce providers' ability to provide quality care.

A thind dimerisior of quality care, arid the ore most often discussed in the quality of care literature, coricerns the way care is actually provided, with focus on the diagnosis and management of common disorders (Pellegriro, 1973). Dre aspect of this dimension of quality is the appropriateriess of treatmerit based on professional judgmerits and/or accepted standards of practice (Brook and Davies-Avery, 1977; Mitchel1, 1973; Myers and Graham, 1973; Pellegrino, 1973; Rosenfeld, 1973). The competence of those providirig care, their professional ethics and etiquette, arid the continuity of care are other factors within this dimerision which are incorporated into some definitions of quality (Sherman, 1968; Roserifeld, 1973; Paulsor, 1973).

A focus on the patient in the care process is a fourth dimension often seen as vital for care to be of high quality. Kerr and Trantow (1969), for example, base their definition of quality care on the ability of the systern ta 
respond to patient needs. Sherman (1968) feels similarly; he argues that responsiveriess of the system and its ability to focus on individuals are important correlates of quality. Pellegrino (1973) states that services must be humariely administered in order for care to be of high quality. The results, or outcomes, of care are a fifth dimension used to define quality care that appears in the literature. Qutcome criteria are generaliy patierit-cirierited and include such factors as acceptability of or satisfactior with care, the patierit's degree of knowledge relative to his or her diagnosis, compliance with treatment reginens, and self-care capacity (Hover and Zimmer, 1978; Mitchel1, 1973; Myers and Graham, 1973; Rosenfeld, 1973). McClure (1973) uses a more elaborate definition that incorporates assessmerit of the exterit to which outcomes which could have beer, medically avoided are minimized aver time.

The sixth and final dimersior of quality that has appeared in definitiors of quality care corcerris the cost of care. Specifically, some authors argue that the extent to which services are efficient and affordable is influeritial in determining the quality of care arid, therefore, should be iricluded in definitions of quality Mitchell, 1973; Myers and Graham, 1973; Pellegrino, 1973).

In sum, it is clear that "quality care" is a complex, multifaceted concept. The specific criteria of quality care that are delineated above are by no mearis exhaustive of 
those employed by scholars in this field; the wide range of dimerisions of care that are considered important, however, is evident.

Empiriiㅗㄹㅡ-Regsearach. Donabedian (1980:35) poirits cut that there has been little empirical research that has dealt directly with the subject of the definition of quality care. There is, however, a great deal of work that touches on the subject. He then proceeds to review relevant aspects of selected studies. His review is the most comprehensive orie found. A few of these studies are highlighted here in this section; attention is focused, though, on Dorabedian's summaries of the state of the art.

Most of the empirical research conducted in this area has centered around individuals' (clients', providers' or both) opinions about the attributes of providers, with inferences drawn regarding the "ingredients of goodness" ir, the care they give. Typically, the care given is divided into two domains: the techrical and the interpersorial. Techrical care is "the applicatior of the scierice arid technology of medicine, and of the other health scierces, to the maragement of a personal health problem" (Donabedian, 1980: 4). Interpersonal care is "the maragement of the social and psychological interaction between clierit and practiticrer" (Donabedian, 1980:4).

Coser (1956, 1962) found, for example, in her studies of clients' views, that the ideas patients had of a gocd 
doctor could be classified into these two categories. Scrnewhat more than half of the patients interviewed saw a good doctor as one who provided kindness, love, and security, while the others focused on the doctor's "scientific and professional competence." Freidson (1961) had similar findings, but he made the point that "in reality, people wanted both "persorial interest" and "competence," and that "while the two attributes... were distinguishable properties and could be discussed separately, patients insisted that ore could rot exist without the other" (Dorabedian, 1980:38 quoting Freidsor, 1961).

Practitioners, in contrast, "tend to define quality not in general terms, but by specifying in detail the clinical activities of patiert care, focusing almost exclusively on technical management," according to Donabedian (1980:48-49).

A few studies have expressly compared clierits' arid providers' views of the quality of care. Some of these studies found the views to be similar, while others discovered differences in the relative importance attributed to particular aspects of care accordirig to the resporiderit's role (Donabedian, 1980:71). 


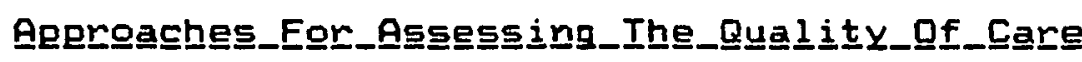

Once the critical components of care have been identified and standards for quality have been defined, ways in which to evaluate the quality of the care given must be determined. Such evaluation is important for measuring the extent to which the health care systern achieves its goals and for indicatirig areas which need improvemerit. Yet the measurement of quality has always been orie of the mast difficult activities to uridertake in the health field.

Orie of the foremost scholars, and probably the principal scholar, in the area of definition arid assessmerit of quality care is Avedis Donabedian. Donabedian (1966, 1969, 1978, 1980) lists three major approaches to evaluating the quality of care: assessment of the structure of care, assessment of the process of care, and assessmerit of the outcome of care. As Brook et al. (1976) note, these three approaches are defined somewhat imprecisely; some measures may be labeled and categorized as variables of more than one approach. However, the conceptual distinction is impartarit to maintain, as each approach focuses generaliy on quality ir a way different from the other two approaches. This riext section briefly describes each of these approaches, their strengths, and their weakresses.

The_struucture_Ageroach. The appraisal of structural variables is one of the most common appraaches to assessing 
the quality of care. This approach focuses on evaluating the adequacy of the orgarization, the training and qualifications of the staff, the physical facilities, ard the rules arid policies governing professional work (Roserifeld, 1973). Doriabedian (1978:13) defines the approach as encompassing assessmerit of "the materials and social instrumeritalities that are used to provide care."

The premise of the structure approach is that quality

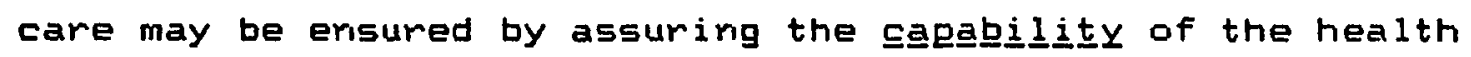
care system to provide good medical and health care. Ar, assumption is made, for example, that well-trairied professionals in well-equipped facilities will automatically provide good care for their patierts. There is, however, relatively little empirical evidence to support this contention. In addition, according to Dorabedian (1969), most researchers concede that the appraisal of structural variables is too indirect to provide a defiritive method af assessing care quality. A firal criticisn of this appraach is that the structural aspects of care change slawly arid generally are not considered to be useful tools for cont inuous surveillance of care to moritor or assure quality.

Ihe_Procegss_Agergaach. The second approach to appraising the quality of care involves an examination of the process of providing care, usually focusing or diagriasis arid treatment procedures. Evaluations utilizing this approach are directed toward determining the exterit to which health 
professionals adhere to accepted standards of practice (Rosenfeld, 1973). The assumption in this approach is that procedures based upon accepted standards of practice are related to the outcomes of the care and are useful in mairitaining or promoting health (Donabedian, 1969). Staridards of good practice are established by recogrized leaders in the profession and involve the ideritification of optimal care procedures against which other professionals examirie their wark.

Both implicit and explicit criteria may be utilized to assess procedural aspects of care. Implicit criteria for quality care are those which are based an nornative staridards, or the conventional wisdom of a number of physiciars or other trairied persorirel. Because judgments are made cir a case-by-case basis as to whether correct procedures have been followed, the use of implicit criteria has beer criticized as being time-consuming, costly, ard urireliable (Donabediar, 1978).

Explicit methods of evaluation are based upor previously established criteria that specifically state correct procedures. Actual practice is then compared with these criteria. Advantages associated with the use of explicit criteria include the reduction of professioral bias, the practicality of implementing these criteria, ard the ability to replicate results (Payre, 1968). At the same time, a reliance on explicit criteria makes it difficult to address 
adequately individual variability. In additior, explicit criteria for assessing the quality of care are difficult to develop, and there is considerable doubt surrounding the utility and validity of some of the explicit criteria arid standards which have been used (Donabedian, 1978). Finally, it has been argued that reliance or predetermined criteria may stifle innovation and may lead to over-utilization of tests and procedures which, in turn, is likely to result in unnecessary costs (MoNerney, 1976).

While resolution of the debate between the relative merits of implicit versus explicit criteria may rot be forthcoming, Donabedian (1978) has propased a solution for facilitating the use of the process approach for assessirig the quality of care. This solution is to combine both sets of criteria into a two-stage approach. First, explicit criteria are developed and applied to all individual cases. Then, those cases which do not meet the explicit standards or for which application of explicit criteria is irapprapriate are identified ard subjected to critical review by peers, who determine implicitly whether or not the procedures used were adequate under the circumstances. Despite this suggestion, mary researchers questicir the wisdom of examining process variables at all. A major criticism is that orce a certain procedure has been ideritified as being an important component of quality care, other aspects of care have terided to be overlooked or neglected 
(McAuliffe, 1979). To illustrate, when treatment procedures are examined, little is dorie concurreritly to determirie whether or not the condition being treated was correctly diagnosed in the first place. Similarly, a focus exclusively on physician behaviors leaves unknown the impact of other health professionals on the care process.

In addition to the substantive issues concerring the use of the process approach to quality of care assessment, there are methodological problems assaciated with its use. The primary difficulty is that medical records gererally are heavily relied upon as a source of data. Fessel (1972) and others report that these records are often iricomplete arid inaccurate and that the iriformation contained therein is typically unrelated to outcome. A related criticism is that what actually may be assessed is the quality of the recording rather than the process of care (Donabedian, 1978). In addition to the questionable reliability and validity of using medical records, their examination requires sifting through large amourts of irrelevant information; it is, therefore, quite unwieldy. To alleviate this particular problem, abstracts of medical records frequeritly are utilized (Natiorial Academy of Sciences, 1974; Roserifeld, 1973). The standardization of recording formats and the isolation of key criteria for examinatiar could be of assistance in this regard as well (McAuliffe, 1979). 
The second principal method for obtaining processrelated data is through direct observatior. As might be expected, criticisms of this method abound also. Among these criticisms are the potential for observer bias, the tendency for those being observed to behave in a sacially desirable fashion, and the difficulty of observirg certain important aspects of care (Rosenfeld, 1973).

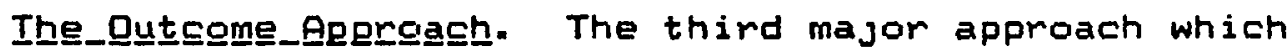
has been used to appraise the quality of care irvalves the study of the outcomes or results of the care provided. Theoretically, an individual's health status is affected (although not necessarily determined) by the treatmert received. Therefore, advocates of the outcome appraach propose that the quality of care provided be determiried by examining the various charges in health status. Many researchers submit that, in fact, quality of care can be assessed ultimately only through the examination of these end results or outcomes Llembcke, 1977; National Academy of Scierices, 1974; Shapiro, 1967; Williamsar, 1970). Variables included by those utilizing this approach encompass patient mortality, morbidity, mobility ard other furctional abilities, amelioration of discomfort and disability, satisfaction or dissatisfaction with care received, patierit compliance, and loss of time from work (McAuliffe, 1979; Payne, 1968; Rosenfeld, 1973; Starfield, 1974). 
In general, advocates of the use of outcome criteria to determine the quality of care provided feel that outcomes reflect the overall adequacy of the process used by health care providers. This method also emphasizes the importarice of the health and well-being of the client, which leads ta a broader and more comprehensive coricept of health care.

At the same $t$ ime, there are a number of problems associated with the use of outcome measures. First, it is not always easy to determine what is a satisfactory or urisatisfactory outcome. Secord, it is often difficult to determine precisely what effect the practitioner or treatment procedure has had on the patient. Rosenfeld (1973), for example, notes that medical care is only one of several factors influencing outcome. MeNerrey (1976), too, suggests that medical care has relatively little influence compared to envirormental, societal, genetic, and life style factors. Even more serious is the angument that outcome ard quality of care are not riecessarily correlated. McAuliffe (1979) points out that good medical practice does not necessarily result in a positive outcome nor are people always adversely affected by poor care. In addition, he arid others suggest that there is a plethora of methodalogical problems surrounding the use of outcome measures, iricluding the absence of followup procedures and the lack of empirical validation procedures. Finally, in the case of termi rial. care, death is the immirient outcome. Clearly, outcome 
measures other than improved or mairitained health are necessary in this situation.

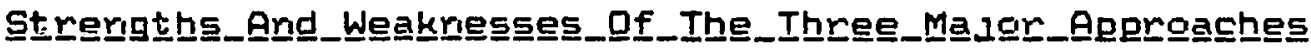

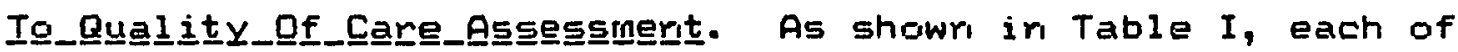
the three major approaches utilized in the past for assessing the quality of care has both advartages and disadvaritages. To address the shortcomirgs of these individual appraaches, arguments have been made for combining the three (Block, 1975; Donabedian, 1978; Naticrial Acadeny af Sciences, 1974; Payne and Lyons, 1969; Pellegrino, 1973 ). For example, Pellegrino (1973) coriterids that the major task. for those involved in the evaluation of health care should be to determine the linkage between process and cutcome. Similarly, Doriabedian (1978) and Block (1975) advacate the use of methods of assessing quality of care which combirie process and outcome measures. They, along with others, conterid that accurate and meanirgful assessments of care which will contribute to improving quality of care require this combination of approaches.

\section{Summaxy}

In this section of the Review of the Literature, the three major approaches to assessmerit of the quality of health care have been outlined and their strerigths and weakresses noted. The structure approach facuses an evaluating the adequacy of the orgarization, the training 
TABLE I

SUMMARY OF ADVANTAGES AND LIMITATIONS OF THE METHOUS OF QUALTTY CARE ASSESSMENT

Approach

Structure

Process

Outcome
Eocus

- Capability of orgarization/ program to provide care

- Determined through examination of staff credentials, physical facilities, and rules and policies

\section{- Adequacy and appropriateness of procedures followed in car delivery based upon standards and practices}

- Determined through application of implicit or explicit

criteriai usually involves use

of medical records

- The results of care; the change in Health status following treatraent

- Determined through examination of patients' satisfaction with care, physical status, functonal capacity
Linaitations

- Little evidence to link structure to quality care

Limited focus

- Little evidence to link process to outcome

- Limited focus (e.g., no critical examination of original dagnosis; often focus only on care provided by physician)

- Data sources often unrellable

Difficult to determine what is satisfactory outcome

- Difficult to control for confounding factors

- Outcome and quality care may not always be correlated

- Absence of adequate follow-up procedures

\section{Advantages}

- Data readily available

- Helps to maintain minima standards

- Spectflc procedures for improving care and upgrading standards may be identified

\footnotetext{
Incourages broader and more zomprehensive concept of health care

\section{- Reflects overall adequacy}

of the care process
} 
and qualifications of the medical staff, the physical facilities, and the rules and policies governing professional work (Rosenfeld, 1973). The premise is that quality care may be ensured by assuring the capability of the health care system to provide good care.

The process approach involves an examination of the care process, using implicit or explicit criteria for determinirg the extent to which health professionals adhere to accepted standards of practice (Rosenfeld, 1973).

The outcome approach involves the study of the results of the care provided, usually by examining charges in the patient's health status or satisfaction with care.

The present study has benefited by taking note of the weakriesses of the structure, process, and outcome approaches when applied separately arid heeds the advice that these approaches should be combined. Drawing from the structure approach, the assumption is made that the training of the staff (specifically, the role expectatiors to which health professionals are socialized) will have at least some impact on the quality of care received by the patient. Alsa examined are the individual characteristics of providers that terminally ill patients, family members, arid health professionals feel contribute to professionals' ability to provide quality terminal care.

In keeping with the process approach to quality of care assessment, the patients, families, and health 
professionals interviewed were asked to describe behaviors of health professionals that they particularly liked or felt contributed the the provision of "quality" terminal care, and those which they disliked or felt impeded the provision of "quality" terminal care.

The outcome apprcach variable of satisfaction with care is incorporated into the framework, albeit indirectiy. Those elements which would contribute to patient and fanily satisfaction with care, at least with regard to providerrelated aspects of care, can be inferred from the expectations for the health professional role of those patierits and families who were interviewed. Similarly, the role expectations of the sample of health professionals themselves irivolved in the provision of terminal care car point to the attributes and behaviors on their part that would contribute to their satisfaction with the care.

This research also responds to several concerns and criticisms of previous research that are expressed by Danabedian (1980:36-67):

There is an averabundarice of more or less fanciful opinions, among them my own, about what quality means or what it should mean. I wish there were as much attention given to studying how clients, practitioners, administrators, ar,d policy makers define quality when asked to do so, arid what definitions can be inferred from their actual behavior...

People are seldom asked to say what they thirik the quality of medical care mears. The question is put indirectly. What is a good doctor, nurse, or 
clinic? What is a bad one? What does the respondent like arid dislike about his doctor, nurse, clinic, and 50 on? From these opiniors about the attributes of providers inferences must be drawn about the ingredients of "goodness" in the care they give. In order to make the task simpler, the respondent is often given a list of attributes arid asked to rank all these or to select some. Wher this is done, the questioner's view of the bouridaries and content of the concept of quality may be imposed on the respondent. Mareover, the resporiderit's answers are influericed by his interpretaticir of the language in which the choices are presented. Finally, studies of this kind ofter deal with particular populations in special situations. When this is the case, it is not clear how generally applicable the findings are.

The research to be described here addresses the first part of this wish, soliciting the opinians of a sample of patients, family members and health professiorials with regard to their definitions of quality terminal care. Resporidents' views also are obtaired iridirectly through questions about health professionals' attributes and behaviors that are liked. These questions, however, are operi-ended questions that permit responderits to use theirowr words, without constraint from the interviewer's biases. This work, like that of its antecederits, is: targeted toward a special type of care; its applicability is, therefore, limited. Nonetheless, this study represerits a preliminary step toward assessmerit of the quality of terminal care, an area largely unexplored to date. 


\title{
CHAPTER I I I
}

\section{CONCEPTUAL TOOLS}

\begin{abstract}
The purpose of this chapter is to describe the canceptual tools that have guided the framing of the research problem ard the approach to its solution. First, role theary arid role theoretic concepts are reviewed. Next, soms of the critical issues in socialization theory ard research are detailed.
\end{abstract}

ROLE THEORY

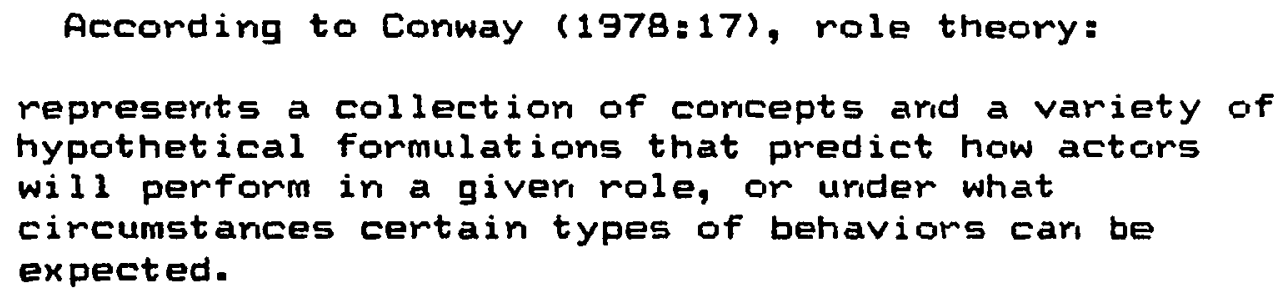

Turrer (1974:161) notes that role theory is built around an analogy drawn between the players on a stage and the actors in society; role theorists view the sacial world as "a network of interrelated positions, or statuses, within which individuals enact roles." For each positior, there are expectations about how iricumberits of rales are to behave. Role expectations are derived from: (a) the "script" (the norms that specify how individuals ought ta 
behave); (b) other "players" (the demarids of the other players in the interaction situation); and (c) the "audience" (the "reference group that circumscribes the behavior of actors in various statuses") (Turner, $1974: 162)$

Role theory is not a well articulated and unified theory (Turner, 1974). Stryker (1959, quated in Heiss, $1968: 3)$ argues that:

There is considerable confusion arid controversy regarding the nature and bouridaries of role theary... there are even some who would deny its very existence as a distinct entity... however... most saciologists seem to ackrowledge that there is a distinctive theory, though ore would be hard pressed to get complete agreement as to exactly what is encompassed by the term.

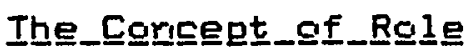

Origirally used in theater, the word "rale" refers to a part played in a drama. The word began to appear ir social science literature in the 1920's (Conway, 1978, citing Thomas and Biddle, 1966).

The concept of role has been defiried variously by numerous sociologists. According to Biddle and Thomas (1966), a role is a set of prescriptions definirig what the behavior of a pasition member should be. Thorriton and Nardi (1975:8781) state that a role is a "set of expectatioris impinging on an incumbent of a social position." Shortell (1982:27) defines the concept of role as a set of "collectively held expectations which defire appropriate 
behavior for persons in a given social position." Coonbs (1978:14) states simply that a role is "that which a persor in a given status is expected to do." Heiss (1968:3) defines role as a set of "prescriptioris for interpersonal behavior which are associated with particular, scicially recognized, categories of persons." Hardy (1978) notes that the concept of role is useful for linking individuals and saciety.

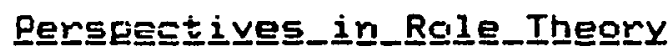

Sociological theory is domiriated by three differerit perspectives, two of which historically have treated the concept af rale. Qne cause for the confusior cancerning role theory may be the existerice of these distirict perspectives. These three perspectives are structuralfunctionalism, symbolic iriteractionism, arid coriflict theory.

The principal social theary guiding this aralysis af the health professional role in the provision of quality terminal care is structural functional theory. Structuralfunctionalism views society as a biological system with: (1) bourided, self-regulating subsystems, capable of maintaining equilibrium; (2) basic society reeds that, like bodily needs, must be met; and (3) parts and structures which serve specific key functions for survival and equilibrium (Shortell, 1982:29 citing Maykovich, 1980). As 
nated by Shortell (1982:29, citing Levine, 1977), the structural-furctional appraach is helpful in corceivirg the health care system, as it "helps to draw attention to haw behaviom is influenced by values and beliefs, arid not solely by physical or psychological symptoms."

Symbolic interactionism, urilike structuralfurctionalism, views behavior not merely as a furction of adherence to normative standards, but as a direct result of the individual's interpretation of the situation, that is, the meaning attached to the interaction (Shortell, 1982).

Conflict theory focuses on conflict, deviance, and change (Shortell, 1982). For example, iristead of viewirig the doctor-patient relationship as one of asymmetric equilibrium ir which patients are willingly subardirate, as does the functiorialist Parsons, conflict theorists such as Freidson assert that patients' and doctors' interests clash (Shortell, 1982). The conflict perspective also is useful for the study of professioral behavior within health care organizations and competition between professional groups arid organizations for scarce resources (Shortell, 1982).

The structural tradition and the symbolic interactiar tradition are evident in the two contrasting perspectives in role theory. These two perspectives are outlined briefly below.

Structural_functional_role_thegry. Structural role theory has been distinguished from structural-furctioral 
theory by Heiss ( 1968 ), who states that stmuctural role

theory:

car be viewed as that segmerit of structural-
functionalism that operates on a micro-level of
aralysis rather than on a macro-level.. it shares
the iriterests and basic postulates of structural-
furictional theory but it focuses on a small urit,
the mole, rather than on a larger unit such as the
group, iristitution, or society (Heiss, $1968: 25-26)$.
As described by Hurley (1978:37, citirg Turner, 1962),

the structural-functional medel of role specifies:

that the individual enacts the prescribed set of expectations appropriate to individuals in relevarit ather statuses, coriforms to others' expectatioris, and receives in return some indicatiors of approval.

Heiss (1968:28) points out that the distirictive concerns of structural-furictioral role theorists are their iriterest in the coritent, orgarizatior (structure) arid functiors of social statuses arid roles. The structuralfurctionalist view postulates that role behaviars are learried early in life, perfected through practice in schouls and early adulthood, performed on the occasioris called for by the society, arid then passed on ta others. In this view, role behavior itself is fairly static, consisting of a rehearsed set of performarices (Frarik, 1974:246). The rale occupant is seen as a passive recipierit arid eriactor of cultural norms and contents.

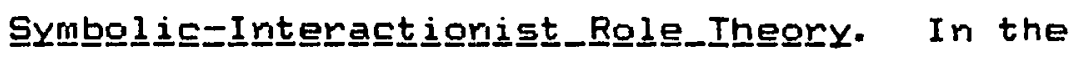
cortrasting Meadian, or social interactionist, view of role theory, the principle of role reciprocity is emphasized, in 
which the individual devises $h$ is role performance on the basis af the role that he imputes to the other" (Hurley, 1978, citing Heiss, 1976). This symbolic interactionist view mairtains that iridividuals are coristantly in the process of constructing roles as they interact with others, arid that people adjust their behavior according to how they perceive others interpreting it (Frarik, 1974:246).

Heiss (1968:5), taking the irteractionist view, states that the basic postulate of role theory is that:

Social interaction is required for the development of the characteristics which make a Homs sapieris into a social being... All the basic human characteristics require social iriteractior at a symbolic level to develop; biological maturatior aro self instruction are not enough (Heiss, 1968:5). Social interaction provides a persor with a self, with role-prescriptions, etc., and these are, in turr, required for social life. A circular arid cumulative process is postulated.

Citing Mead (1947), Shuval (1975b:414) states that the socializee responds selectively to the expectatichs of significant others and interralizes the role they defirie for him. Robinsori, 1974:18), also adheres to the symbolic interactionist perspective:

It is urithelpful to seek for the correct script far scmeone who occupies a particular social positior or to expect there to be universal or even widespread agreement about the way the rale should be played.

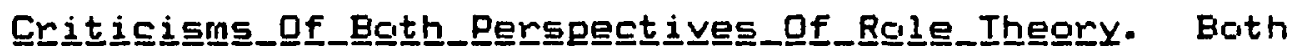
the structural-furictionalist view arid the symbolic iriteractionist view of role theory have been criticized. Among the major criticisms of the structural-furicticral 
approach to role theory are that: (1) it ignores the determiriative corisequerices of role enactments for changes or alteratiors in the social structure; (2) that it doesn't iridicate when, where, or how processes are to occur it simply says what processes must accur); arid (3) it does not recagrize reciprocity anorig status networks, expectatiors, the self, role-playing capacities, and role behavior. It is principally a classificatory corcepti its main thrust is how specific social cortexts determine variations in individual coriduct. It does rot accourit for the variety af patterns of sacial orgarizations (Turner, 1974). The principal, arid very seriaus, criticism af symbalic irteractionist rale theory is that it has little predictive ability ('rumrer, 1974).

Ir the coritext of role theary, ther, the primary distiriction between the structural-furictionalist and the symbalic iriteractiorist perspectives appears to be that in one (structural-functionalist) roles are viewed as beirig scripted, while in the ather (symbolic iriteractionist) they are viewed as being regotiated, with there being no such thirg as the correct script.

Accordirg to Heiss ( 1968$)$, role thearists da share two basic assumptions: (1) that roles are learned in the process of social iriteraction and (E) that when people interact with others, they see thernselves and these others as accuparits of particular statuses. The expectatiars 


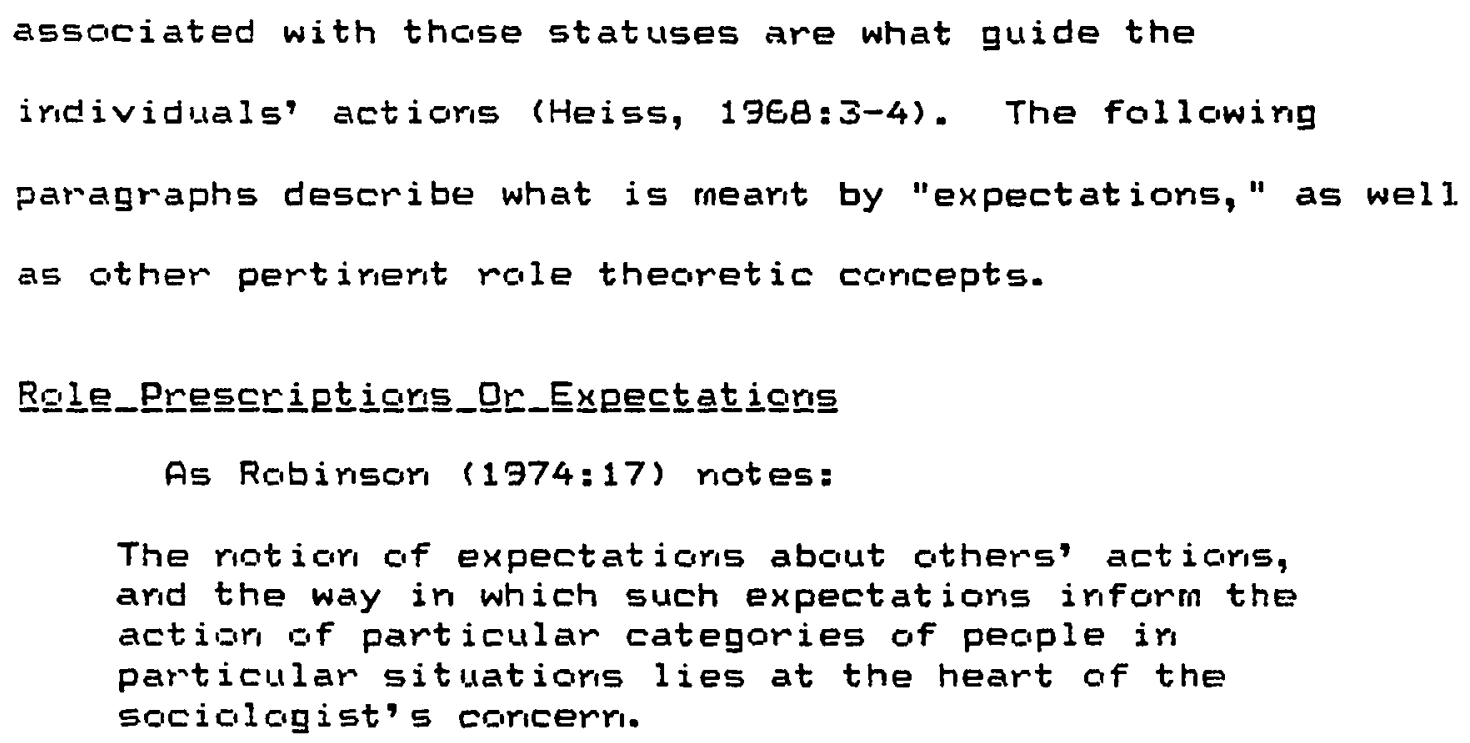

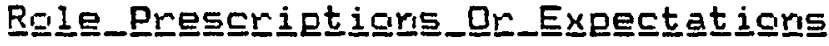

As Rabinsori (1974:17) notes:

The roticorl of expectatioris about others' actioris, arid the way in which such expectations inform the actiar of particular categories of peaple ir particular situatiors 1 ies at the heart of the socialagist's coricerr.

Orie framewark for viewirig the expectatioris assaciated with a particular role is that provided by Parsars' (1951) patterr variables of role expectatior. This framework is described in detail in Chapter VI, Aralytical Model.

Rale prescriptioris and role behaviars are learred

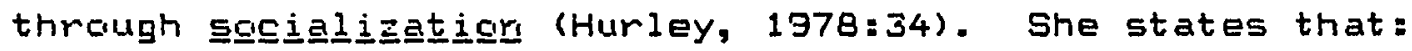

Role prescriptions for the cccupart of a particular status nat orily explicitly specify how that individual is to behave, but implicitly specify as well the behaviors of persons in related positions toward the coccuparit of that particular status (Hurley, 1978:35, quoting Brim, 1957:345-347).

$$
\text { Sources of role expectatioris ipiclude the societal }
$$

riarms present in a culture or sub-culture arid the iridividuals with whorn one interacts. According to Thorritari arid Nardi (1975), most mole behavior is prescribed and expected by cthers.

Rale expectatiors may be behavioral, attitudinal, ar cognitive in conterit (Thornton and Nardi, 1975). They may 
be covert or overt; they can be described in terms of the degree of coriserisus coricerririg them, both withhir a source, and 므트weeㅡㄹ two sources. Corisensus/dissensus may be actual or suppased (Thorritor arid Nardi, 1975).

Thorntor, and Nardi (1975) state that there are three passible reactions to role expectations: (1) social adjustmerit, where there is adequate meetirig of role expectatiors and performarice, (2) psychological adjustmert, where cangruity is achieved between the individual's desires arid rieeds arid the role, arid (3) adaptatior, which accurs if the role is irterralized ard assimilated so the person arid the role are, in a sense, iriseparable. This third reaction is possible orly if the first two reactiors are accomplished. Wher, there are coriflicts among expectations,

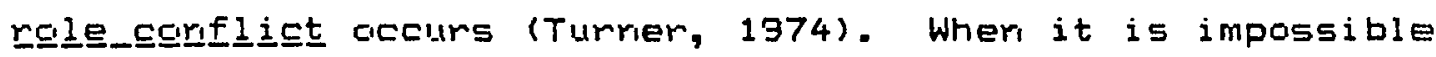

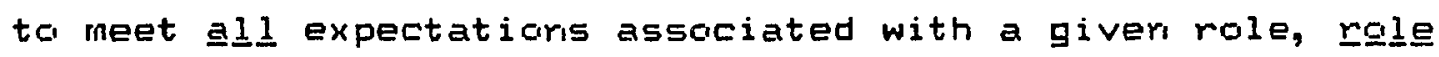
strrai ir may result (Turrier, 1974).

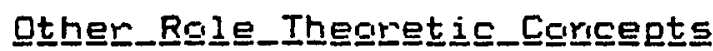

Other concepts with respect to role theary also are important to delireate and define here. These iriclude "rorms," "role set," arid "status" or "positior."

Nórms. Hardy (1978:3) defines a norm as a concept that origirates ir the concept of role arid that "refers to a set of rules or standards guiding behaviar." Gardor (1966:32) defiries norms as patterried on commorily-held 
behavior expectatiors, or as learned responses, held in carnmon by members of a social group.

Relle_eset. As defiried by Merton 11957a, cited in Huritirgtar, 1957:181), role set is "the complex af rale relationships which persons have by virtue of occupying a particular status." As Eecker et al. (1961:47) argue, "to understand the behavior of ariy one category of people in the argarizatior, we must see them in their relatiors with ather persors with whom they come in contact." They state further" that each group "has its awr perspective arn the problems that arise out of their mutual iriteraction" (Becker et al.,

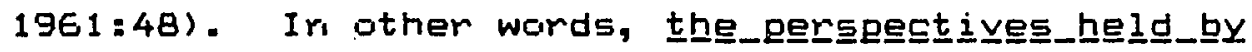

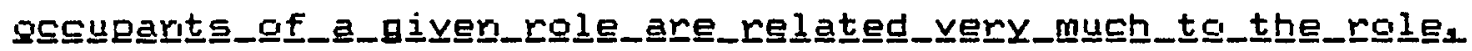

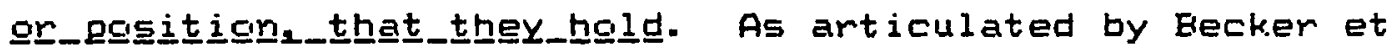
al. (1961), medical students, as occuparits of a positicr cor role:

have the rights arid privileges, the duties and obligations, associated with that position. Because they all eccupy the same irstitutional position, they tend to face the same kirids of problems, and these are probleins which arise out of the character of the position... The opportunities and disabilities of the studerit rale are decisive in shapirig the perspectives students hold.

To further illustrate this corcept of role set, Alexy's (1981-82) research is useful. In studying the perceptiaris of wand atmosphere on an oricology unit, Alexy (1981-8E) found that patients, family members, and staff perceived the ward atmosphere differertly. He coricluded 
that each of these groups lpatients, family members, and staff) "assuned diverse roles on the Urit which pravided them with access to varying amourts of information about the relaticriship, treatment program, arid systems mairitenance dimensiars of the environment" (Alexy, 1981-8E:334). Freidson (1961) also poirits out that members of the role set will have varying expectations of each other. He argues that this explains the coriflict that appears in the dcctar-patient relationship. Freidson (1961) criticizes Mertar's coricept of role set, however, due to its iriability to allow us to assess the importarice of each perspective ir exacerbatirg or reducirg conflict. He notes that an expectation has no irfluence in itself (Freidsor, 1961).

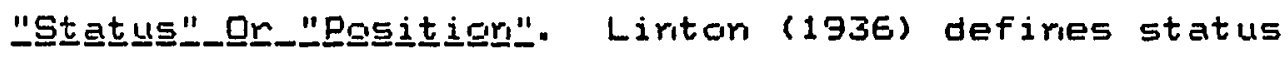
as a positich in a particular pattern of recipracal behavior. Coombs $(1978: 14)$ states that status is "a social position that is set in the structure of a group before a given individual comes along to occupy it." Status may be defiried an another level, as well, as representirig an individual's position with relation to the total society. Mare recerit thearists have used the term "pasition" rather than "status." Williams (1960) suggests that there are three major elements which make up a position. These are: (1) role, or functional content of the position, (2) status, or moral evaluation of the positian, ard (3) sacial power, or anount of influence carried by the positior. 
Accarding to Williams (1960), position (or status) and role are inseparable. Ore carrict perfarm a rale without accupying a social position.

The_Rgle_므_The_Prafess

Prior to discussing expectations associated with the role of the professional, it will be useful to delirieate what is mearit by a "professior" arid a "professional."

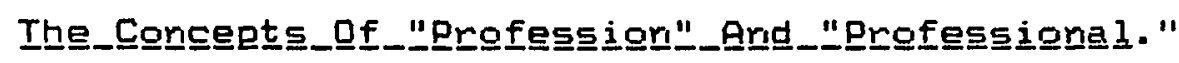

Goode (1960, quated from Robinson, 1974:93) derives ter

characteristics of "professions." These include:

1. The profession determines its own standards of education arid trainirg.

2. The studerit professional goes through a more far-reachirg adult socialization experierice thar the learner in other occupations.

3. Prafessiciral practice is ofter legaliy recogrized by some form of 1 icerisure.

4. Licerisirig arid admissicir boards are manred by members of the profession.

5. Mast legislation coricerried with the profession is shaped by that profession.

6. The ciccupaticir gairis iri iricome, power and prestige rarking and can demand higher calibre studerits.

7. The practiticher is relatively free of lay evaluation arid control.

8. The riorms of practice enforced by the professich are more stringent than legal controls.

9. Mernbers are more strorgly ideritified and affiliated with the profession than are members of ather accupatiors with theirs.

10. The profession is more likely to be a terminal accupatior. Members do not care to leave it, arid a higher proportion are certain that if they had to do it over again they would again choose that type of work.

Freidson (1970a) extracts from Goode's formulation the one characteristic distinguishing a profession from ar 
occupatian: the might to coritral its own wark. Robinson (1974) coriderises Gcoode's derivations and adds this point made by Freidson to arrive at a three-part definition of a professiarial: (1) orie who has had prolonged trainirg, (2) ore who has a collectivity or service orientation, and (3) crie who has the right to caritrol his or her owr work. Jacox (1974) uses these same three points in herdefirition of a professioral arid points aut that cocupations are corsidered more or less professional to the degree that they passess these three major characteristics. She adds:

Because of the esateric nature of the knowledge held 〈by a prafessian), anly members of the professior are recognized as competerit to defire what tasks and practices are necessary arid safe" (Jacox, 1374:4).

Becker et al. (1961:5), in their study of medical studert socializatior, defire people as practicing a profession when they "apply knowledge and skill ir perfarmirig services for other meri, for argarizatioris, or for society at large, arid when those services are accepted on trust (or at least in the short ruri)."

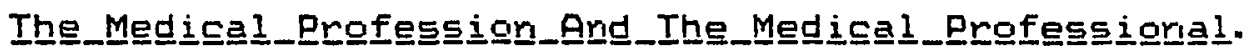
Mertan's (1957:71) definition specifically of the profession of medicire provides further elueidation:

The profession of medicine, like other accupations, has its own romative subculture, a body of shared and transmitted ideas, values and standards toward which members of the profession are expected to orient their behavior. The norms and standards define techrically and morally allowable patterns of behavior, indicating what is prescribed, preferred, permitted, or proseribed. The subculture, ther, refers to more thar habitual behavior; its norms 
cadify the values of the profession. This extends even to the details of lariguage judged appropriate by the profession; like other occupations, medicine has its own distirictive vocabulary, arid like the vocabularies of other occupations, this one is ofter described derisively as jargon by outsiders arid described appreciatively as technical terminology by irsiders. The medical subculture covers a wide range--from matters of language to matters of relatioris to patierits, colleagues, and the conmurity--and it is the function of the medical school to trarisnit this subculture to successive generations of neophytes.

As Parsoris (1951) states, the role of the physician belorigs to the general class of "professional" roles, a subclass of the larger group of accupational roles. He ther gees an to apply his pattern variable framework for viewing role expectatiors to this role af the physiciar, as will be detailed in Chapter VI, Analytical Model.

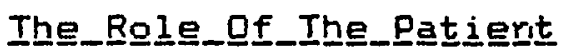

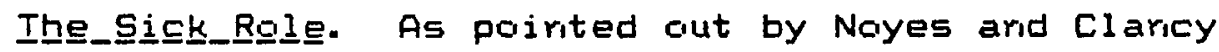
(1977), the sick role, or the social role accompanyirig illness, was first described by parsons (1951). This rale, like other roles, is a "constellation of expectatiors irvolving both rights and duties" (Noyes and Clancy, 1977: 41). The rights of a persor accupying the sick rale iriclude: (1) exemption from the duties of his or her nommal social role; and (2) the right to be cared for; since the person is not to be blamed for being sick, "members of saciety become obligated to him" (Noyes arid Clancy, 1377: 
41). These nembers are primarily the individual's family arid his or her physiciar (Noyes arid Clancy, 1977).

The duties of the person in the sick role also are twofald: (1) to wish to get well, sirice society regards illness as an uridesirable state; and (2) to obtain competent help ir arder to get well ard to cooperate with the treatmerit prescribed (Noyes and Claricy, 1977).

The sick role is ari irvoluntary, temporary form of undesirable and dismuptive social deviance which is conferred by the physiciar in his or her diagnosis of illness (Bloam and Summey, 1976). Bloom and Summey (1976:23) mote that the sick role is are which "must be contralled to prevent abuses by persoris who gain psychological rewards as a result of the legitimized deperidency of illress."

The_dying_role. Only in the past few years have refererices to the "dying role" appeared in the literature. Like the sick rale, the dying role is time limited. Iristead of ternirating in the restaration of health, though, the dying role ends in death (Noyes and Clancy, 1977). Both the sick role ard the dyirig role are conferred by the physician (Noyes and Claricy, 1977). The obligations and rights of persons in the dying role differ, however, from thase of persons in the sick role.

Dccuparits of the dying rale are expected, or obligated: (1) to retain their "will to live;" (2) to make arrarigemerits for the orderly transfer of their property arid 
authority; (3) to avail thenselves of the necessary supports arid to cooperate with caregivers; (4) to decrease their deperiderice upan the physician, since "society reserves the physiciar's rale for the mare important restorative function arid, in so doirg, jealously guards against iriroads upori the physician's time arid energy;" (5) to accept any lass of freedom arid privileges imposed by caregivers, ard cooperate with the rules arid routines of caregivers; and (6) to mairitain as much iridependerice as passible. While deperidency in persaris in the sick role is ericouraged, persoris in the dyirig role are expected to rely upon themselves to a greater degree so as to avoid imposirig an urirecessary burden on the caretakirig system (Noyes and clancy, 1977).

The rights of persoris in the dying rale iriclude:

permarerit exemptian from the responsibilities and cornmitmerits af their previous "well" social roles, and the right to gradually disengage from the social system; (2) the right to be taken care of; and (3) the right to continuirig respect, status arid dignity (Nayes arid Clancy, 1977). Dsmorid arid Seigler (1976, cited in Mullaly arid Osmorid, 1979) arid Williams (1982) also have differentiated between the "sick role" arid the "dying role." All three of these researchers, as well as Noyes arid Clancy (1977) note that recerit years have coritinued to see the assignmerit of dyirig persons to the sick role. They argue that such assignment is iriappropriate. Mullaly and Osmond (1979:411) assert: 
Dactors and rurses are responsible for recognizing these differerices between the sick arid the dying rolel, arid far insuring a proper transition from the sick rale, where every effort must be made to save the ill person's life, to the dying role, where the gaal is rot to save 1 ife but to insure a relatively painless and timely death.

Mullaly and Dsmord (1979:411) argue that "history

shaws that for centuries these roles were clearly defined

arid these skills practiced effectively." Williams (198::8)

coricurs:

Historically, the care of persoris who could rot be cured has always been a part of the : le of health professiorals--ir particular, of physiciaris arid rurses. Orily within the twentieth century has it became possible for the curative enphasis to become domirarit in medicine.

Ta substaritiate this clain, Williams cites Feifel (1977)

arid Kastenbaum (1977). Williams (1982:8) goes on to rote

the regative implications of "derial of a legitimate professional role related to the dying," iricludirig the

viewirg of every death as a treatmerit failure, with

consequences of burnout, isolation and neglect of patients, intrastaff conflict, and patierit-staff conflict.

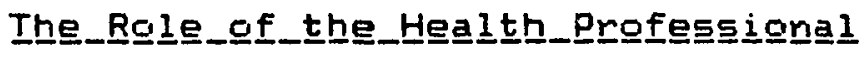

Williams (1982) notes that physicians arid nurses have camporients to their professional roles that are reciprocal to the sick role and to the dying role. The "therapeutic," or curative, role is reciprocal to the sick role and is "that role associated with active medical treatment and aimed at the restoration of the patient to health" 
(Williams, 1982:9). The "supportive" role is "that set of role behaviors aimed at caring for the patient, supporting iridependent functioning, arid easing pain and discomfont" (Williams, 138E:9).

\section{Summangy}

This section has reviewed a number of caricepts with respect to roles, role expectations, and role theory. As discussed ir the followirg sectior, the pracesses of socialization through which these role prescriptions and expectaticris are acquired is the subject of carsiderable disagreemert. Relevant issues in socialization theory and research are presented.

\section{ISSUES IN SOCIALIZATION THEORY AND RESEARCH}

The literature pertaining to socializatior theory and research is fragmerited arid roncumulative (Levirisori, 19E7). Drie explanation for this may be that, as noted by Hurley (1978), the area knawr as "socializatior" has emerged from three different traditions: sociology, anthropology, arid psycholagy. As a result, there is ro arie general theory af socialization (Levinsor, 1967; Hurley, 1978). Nor, as might be expected, is there consensus with regard to haw to defirie the term "socialization." In addition to the question of the defirition of "socializatior," there are a rumber of majar theoretical issues differentiating the sociologists, 
anthropologists, and psychologists who are concerned with the process of socializatior. These issues, as summarized by Hurley (1978:30, citing Goslin, 1969), include:

the relative importarice of early as opposed to later experiences on socialization outcomes; the relative enphasis attached to individual rieeds, motives, arid drives as opposed to envirormental determinarits of behavior; the relative importarice attached to process as oppcised to content in predicting the outcomes of sacial behavior; the emphasis placed upon the unique aspects of the socialization experierice as apposed ta its common properties; and, firaliy, the focus upon the processes promotirig coriformity to societal romm as opposed to the caldses of deviations from these behavioral rorms.

Further distirguishirg psychologists from socialagists are "differences in views regarding the characteristics of the learrer arid the learring process and differerices in the coriceptualization of socialization as an active or passive process" (Hurley, 1978:30).

This section provides ar overview of certain issues related to socialization from a sociological perspective that have relevarice for this study, iricluding:

\author{
1. What is "socialization?" \\ 2. How does socializatior occur? That is, who are \\ the socializers or socialization agents, and what \\ is their relative importarice? \\ 3. Is the socializee an active participant or a \\ passive recipient in the socialization process?
}


4. Does the attitudinal learring that occurs represent change or maturation in the individual?

5. What is the status of the socializee during the socialization process?

6. What are the outcomes of socialization and how eriduring are they?

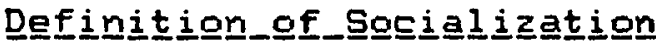

Socialization has been defired differently by various saciologists. The definitions of Merton (1957a) and Jette (1974) are most useful for the purposes of the present study.

$$
\text { Merton (1957a:40-41) defines socialization as: }
$$

the process through which individuals are inducted irito their culture. It involves the acquisitior of attitudes and values, of skills and behavior patterris makirig up social roles established in the social structure.

Jette (1974:272) defires socialization as:

the process whereby individuals learn and iriternalize the attitudes, values, and behaviors appropriate to persons functioning as social beirigs arid resporisive, participating members of their society. Socialization ensures that the individial will develop an identity, ar self, arid also the motivations and requisite krowledge to perform adequately in the social roles he is called upor to eriact thraughout his lifetime.

Jette (1974) goes on to state that, once recogrized, the societal and cultural patterns of socialization help to explain corsensus in role definitions ard behaviors, 
attitudes, and values abserved in the majority of individual mernbers of a society.

As summarized by Elkin \& Handel (1972:29-32, cited in Hurley, 1978:32), the goals of socializatior, from the scicietal perspective:

focus primarily on the attainment of some form of competence that the society accepts as appropriate for adult performance, as well as an iriternalized commitment to continuing responsible participatior, in society.

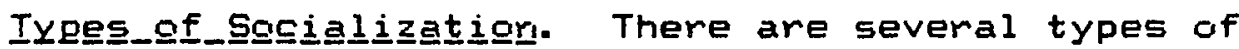
sccialization, includirg child socialization, adult sacialization, role socialization, occupational socialization, professioral socializatior, developmental socialization, and resocialization. In the present study, the focus is or adult role sacialization, and specifically, professional socialization.

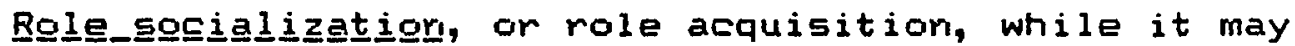
not ericompass the whole of socialization, is a very important aspect of adult socialization (Bloom, 1979). Role socialization is "the acquisition of the habits, beliefs, attitudes, and motives which enable a person to perform satisfactorily the roles expected of him in his society" (Bloom, 1979:39, quating Brim and Wheeler, 1966:53).

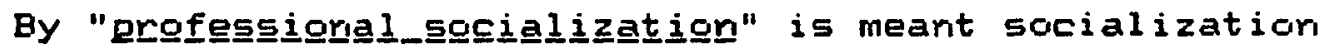
into a professichal role. Professional socializatior is a form of occupational socialization, which, in turn, is a particular type of role socializatior. 
The professional socialization of physicians, in particular, has received considerable atterition from sociologists interested in occupational socialization. Mertor (1957) points out that this is due to the fact that the medical profession commands the greatest amourit of prestige ir American society, arid that other professional ofter loak to the profession of medicine as a model. This atterition is reflected in the remainer of this review of the professiarial socialization literature.

Shuval (1975b:413) defires professional socialization as a process accurring "over a period of years during which cardidates gradualiy learr the values, attitudes, and rormative behaviors of the professional group in which they are seeking to acquire membership." She rotes that professiorial socializatior may be viewed as a special form of adult scicializatior. Firally, Jacox (1974) poirits out that the formal beginning of professional socialization is admission ta a professional school.

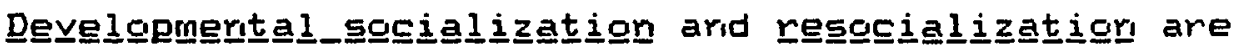
two final types of socialization. Examples of developmental systems include schools and universities. Resocialization systems are those that attempt to correct deficiencies in earlier socialization, such as prisors and mental hospitals (Bloom, 1979). While developmerital socialization is of primary interest in the current research, the possibility of a need for resacialization also will be considered. 
The following sections devote attention to specific issues in socialization theory and research as they relate

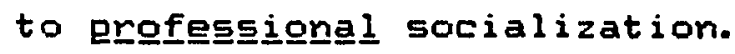

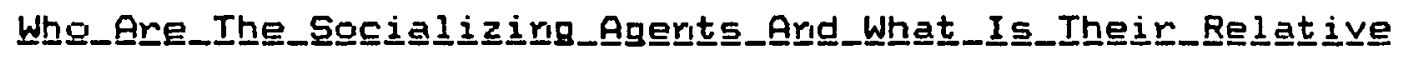

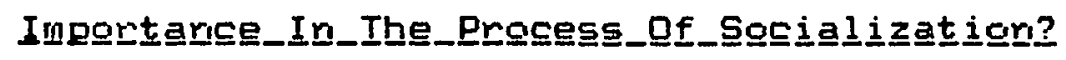

The basic dilemma raised in this questian, as it relates to professional socialization, centers around the importarice of the educational institution in the process of socialization. With regard to the professional sacialization of physiciars and nurses, the question is whether the socializing agents are the medical school and the rursing school exclusively.

Lurie (1981) points out that there are three major scaciological approaches to professioral socializatior. These include: (1) the Mertonian school, in which educatior, arid trairing are seen as the primary determirarits of professional socialization; (2) the Becker-freidson school, in which the effect af situatiorial factors in the work setting is considered; and (3) the Light (1980) school, in which professional socialization is viewed as an interactive pracess chaice among role models on the basis of persorial compatibility. The present study incorporates the first two views; while the contribution of personality to professional socialization is recognized, this issue is rot directly addressed (see Chapter IV, Conceptual Framework). 
The view that the medical school is the sole socializirg agert for the physician's role is advarced in the classic work by Merton et al. (1957), Theeㅗtug른

Phyㅗㅗ도르. Merton (1957b:76-77) states that medical schools "have the double furction of transmitting to studerts the cogritive standards of knowledge and skills ard the maral staridards of values arid norms." The function of medical schools, Merton (1957:7) asserts, is:

to transmit the culture of medicine arid to advance that culture... to shape the novice into the effective practitioner cif medicine, provide him with a professional identity so he comes to think, act, arid feel like a physiciar.

Becker et al. (1961), however, take another view.

They argue in their classic study, Boys_ir. Whinitge, that both the medical schocil arid the collective character of students (medical school culture) irifluerice physiciaris in trainirig, but the role of the medical school is of low influence.

Coombs (1978:16) asserts that:

In saciological terms, the medical school is a formal sacializirg onganization whase mission is to process medical aspinarits so that they can furictior effectively arid confidently in their new status as physicians.

He also argues, however, that informal sources (e. 9. , classmates, friends) as well as formal sources (i.e., the school) are irvolved in the process. In a similar veir, Brim (1976) assents that socializing agents can be formal or informal. 
Alternatively, Jette (1974:272-273) takes the view of socializirig agerits primarily as informal sources, declaring that the socialization process "emerges in the context of mutual interaction with others in interpersonal relationships." Bloom (1979), too, questions the importance of the school (formal institution) in the socialization process. Citirig studies by Jacob (1957) and Barton (1959) of college student attitudes, Bloom (1979:28) notes that "there is indeed a doubt whether, at the higher educational level, schools have any significant influence at all or student values." He goes on to state:

Much has beer taken for granted about the relationship between the medical school and the profession it serves, but there has been comparatively little study of this relationship. Although "socializatior for the professiorial role" has been conceived of as the major theoretical problem, the coriceritration of data collection has been ir the medical school. The relevarice of the firidirigs of such research for behaz added) in the physician"s role has been largely a matter of assumptior.

Traditionally, the medical school has been closely tied to its parent profession. In taking the Hippccratic cath, still used for the ritual entry irito the profession, the new medical school graduate swears "tc teach...this art... by precept, lecture, and every other mode of instruction... (to) impart kricwledge of the art of (his)... own sons and thase of... 〈his〉 teachers, ard to disciples... according ta the laws of medicine." By this symbalic act, the point of formal entry into the profession is rooted in a strong tradition that to practice is also to teach (Bloom, 1979:32).

Bloon's (1979) caveat with respect to the unkrown nature of the link between professional socialization to the role arid actual behavior in the role is importarit to 
note. Narretheless, Bloom (1979:32) argues that given the cortinued use of the Hippecratic oath, "the assumption that the faculty of the medical school still represerits, broadly speaking, the prevailing norms of the medical profession seems justified." At the same time, poiriting out the advent of new professional medical roles such as the full-time faculty physiciar arid the normedical professicinals who now have teaching, research, and patient care responsibilities in the medical school, he questions the feasibility of assumirlg that the medical school is the one legitimate socializing agent of the profession (Bloom, 1979). Furthermore, arguirg that by definitior, scaialization produces "an internalized set of behavioral guides," Bloom (1979:36) maises the possibility that these guides "may or may not be appropriate for the operatirig behavioral requirements of the situation for which it is preparatory." He asserts that the issue of predominant socializing agerits remairis to be answered:

Is the medical school a separate institution, the settirg mairily for its own distirictive culture and experience? Or is the medical school the direct representative of the medical profession, a socializing agency with a major function in preparing the total physician in attitudes and values as well as in the skills and knowledge necessary for his or her professional role?

A firial perspective is revealed in a survey by Blumenfield, Levy, and Kaufman (1979) specifically of attitudes of 
medical students toward communication with patients. These researchers found no statistically significarit differerices between different classes or between residents in different years of training. They canclude: "These attitudes are not altered by formal education or clinical experierce" (Elumenfield, Levy and Kaufmar, 1979:307).

Questions and findings along similar lines are found in the literature corcerning the professional socialization of rurses. Gliebe (1977), Myers (1982), arid Strauss (1968) al 1 poirit to the disparity between what a nurse must kriow in the work setting, (as well as what beliefs, attitudes, and behaviors she or he learns at work) arid what is taught at school.

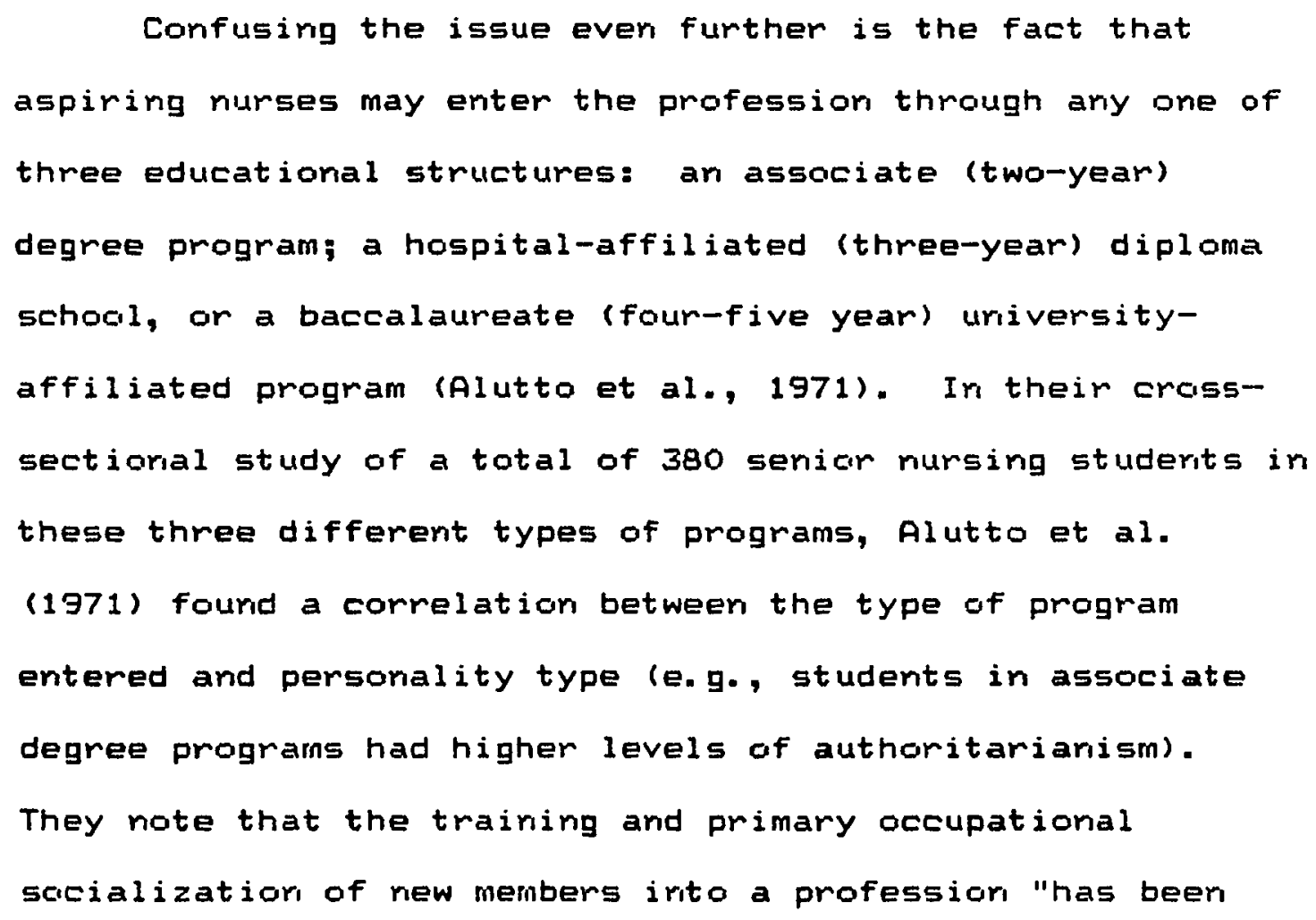


assumed to be relatively constant and meliable" and, similariy, that "it has perhaps been natural to assume that members of any given professional society are relatively hamcgeneous in terms of skills and values" (Alutto et al., 1971:140). Their research was designed to test empirically this set of assumptions for the nursing profession. Given the differences in personality found, Aluttc et al. (1971) coriclude that "homogerieity of the socialization of the rursing profession may be neither desirable nor passible, if the assumption is made that the minimum professiorial knowledge of incoming professianals is relatively equal. The variatiors allow for assimilation of individuals with different personality characteristics. Gliebe (1977) points aut that the effectiveriess of professional socialization is determined by the degree of corisensus or the part of the school's faculty. Quint (1967) also observes differences in teacher perspectives ard the effect of these differences on studerit attitudes. Arid Jacox (1974) notes that expectations regarding a profession begin to develop lorig before prafessional socialization (formal eciucation) begins; these expectations can influerice the effectiveriess of professioral socialization. The socializing agents posited by Jacox (1974) to contribute to professiorial socialization of the student iriclude the faculty, the clinical settings, the patients, other 
studerits, members of ather disciplines, and the larger commurity of which the school is a part.

In the present study, the focus is on the faculty and the clirical settirig (the "school experience" of physicians and nurses in training) as well as the workplace. The patential for self-selection of personality types inta professions, while important to keep in mind, is not directly examiried. This latter possibility has implications both for the training and the recruitment of health professicirials. For example, Searle (1981) notes that physicians learn an obsessive-compulsive role as part of their prafessional socialization ard as a reaction to their work situations. She further argues, however, that a physician's "persorality type may predispose him to accept role demands: Type $A$ personalities are particularly susceptible" (Searle, 1981:185).

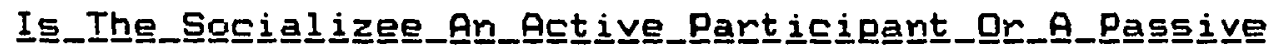

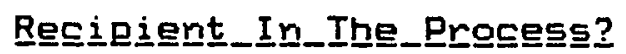

Dne of the issues that most clearly distinguishes positions on socialization is that of whether the persor, being socialized (the socializee) is seer as ar active participart or a passive recipient in his or her socialization. The view of the socializee as a passive recipient of cultural norms and contents sees the effects of scicializens as being unidirectional. The view of the 
socializee as active sees socialization as a reciprocal process in which the socializee and the socializer are mutually influenced. This latter view has become iricreasingly papular (Hurley, 1978).

The dilemma in this question, once again, can be attributed to the issue of whether a structuralfunctionalist or a symbolic interactionist perspective is taker. Adhererits of the structural-functionalist view see the sacializee as passive, while symbolic interactionists see the socializee as active (Hurley, 1978).

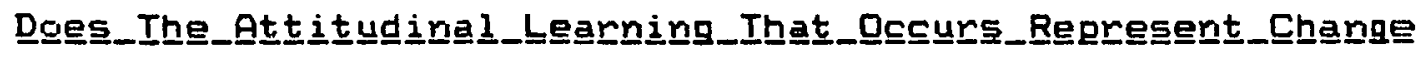

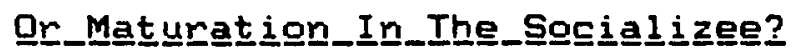

Early research into socialization for the role of physiciar, found that changhges occur in students' attitudes while they are in medical school. Eror's study of cynicismhumanitarianism (1955, cited by Bloom, 1979), for example, found increasing cynicism amorg medical students as they progressed through school arid decreasing cyricism amorig law students arid nurses. (Bloom (1979) cautions readers, however, that the attitudes held by law students at the outset of their studies gereraliy are quite differert fram those of beginning medical students, with law students cynical and medical studerits humaritariar). Lasagra (1968), too, found changes that occur in medical school, including a decrease in idealism, increased cyricism, arid iricreased 
emotional detachmerit. The findings of Gordon and Mensh (1962, cited in Bloan, 1979:30) in their comparison of freshmen and seniors corroborate those of Eron and Lasagna. Gordon and Merish (1962, cited in Blacm, 1979:30) coricluded that their study:

corifims the findings of other investigators that from the first year on, being benevolerit, ir the serise of wariting to help other people, beccimes decreasingly impartant to the medical studerit.

Eloom (1979:30), hawever, questioris whether these arid similar findings are "a valid indication of the medical schools' functioning in some way to make cyrics of idealists, and therefore to dehumarize the approach of future physicians toward their patients." He rotes, for example, that Becker and Geer (1958, cited in Bloom, 1979) assert that medical students, like athers their age, simply become more realistic. This charge toward realisn was iriterpreted by Becker and Geer as a furictiorial learriirig process, since "for a doctor, this growth teward realism is especially necessary if ore is to be effective as a physician" (Bloom, 1979:30). Bloom (1973) also rotes that Fax (1957) speaks of a developmerital process, but instead ef viewing this charge of attitude as a correction of raive stereotypes, she sees it as a "patterned experierice built into medical educational situations that produce attitudes specifically fitted to the doctor's role" (Blocm, 1979:31). 
Support for the view of the socialization process as a developmental, or maturational, one also comes from the work. of (1) Thornton and Nardi (1975), two sociolagists working in the area of role socialization generally, and (2) Coumbs and Powers (1975), who have examined the process of sacialization for the physician's mole specifically as it pertains to death and dying.

Thorntor, and Nardi (1975) suggest that there are four stages of role acquisition, begirning with articipation and followed by formal, informal, arid persorial stages. In the ariticipatory stage, those aspiring group membership begir to adopt group values, idealizing what the role should irivalve rather than what it does involve; a role is broadly defired, iricomplete and ambiguous. They state that future adjustmerit to a role may depend upon the degree of accuracy of what is coriveyed and perceived about the role at this stage.

In the formal stage, the individual shifts from viewing a positior, ar rale, from the autside to seeirg it from the inside as a member of a role set. In this stage, role expectations and requiremerits are clearly defiried, ofter, in formal, written terms. These expectatiors are also idealized and tend to refer to expected behaviar, krowledge and skill. Attitudinal elements may be preserit, but usually they are not emphasized. Examples include professioral standards and norms. The instrumental purposes of the role are emphasized, and there is a fairly high degree of 
coriserisus corcerning appropriate behavior and the skilis ard knowledge riecessary for role performance (Thornton and Nardi, 1975).

In the informal stage, Thorriton and Nardi (1975) suggest that informal features of the role arise arid are transmitted through the interactican of individuals, especially colleagues. Personal expectatioris of the role may be ir oppasition to formally expressed ares, so there usually is role dissensus. In this stage, individuals begin shaping the role to themselves.

The persoral stage is described by Tharritor ard Nardi (1975) as a time of relative role corsensus, where the iridividual is able to influence others' expectations of him/her. This stage is viewed as the most importarit in terms of adjustment to the role. While this persciral stage is rot necessary for role performance, it is important for adjustmerit to the role arid satisfaction with ore's positicr. Coombs and Powers (1975) speak similarly of a developmertal role socialization process whereby physiciarisin-training specifically master the complexities of the clinical role pertaining to death ard dying. Their thesis is that medical practitioners evolve through five fairly predictable, but not inevitable, developmental stages. The first stage, according to Coombs and Powers (1975), is the preprofessional stage. In this stage, the student still has the laymar's attitude ard persorally 
identifies with the dyirg patient. The studerit has ar idealized view of the doctor role: "the doctor as a bulwark against death and suffering" (Coombs and Powers, 1975:253) arid "the physiciar, like the proverbial couritry doctor, should be warm and compassionate" CCoombs and Powers, 1975:254).

The second stage which Caombs and Powers (1975) fourd medical students to go through was that of "desersitizirg death symbals." They fourd that studerits have repressed anxieties and use a number of coping mechanisms, including humor, overwark, arid adoptirig a "detached scientific attitude" (Coambs arid Powers, 1975:257). Accarding ta Caombs arid Powers (1975:257), students Iearr "the expected professional response" which is "a calm, objective rationality arid a full coritrol of emotion" in preparaticar for encounters they will have with living patierits.

The third stage is "objectifying and combating death" (Coombs and Powers, 1975). Students develap a protective shield to reduce the enotional impact when a patient dies. The principal method used in this depersonalizirlg is to objectify death, to deny the subjective features:

The clinician learns to view dyirg patients rot as peaple with feelings, but as medical eritities, specimens, or objects of scieritific iriterest... the old scientific fragmeritalization method... heavy demands are routinely made upon medical trairiees to be exhaustively thorough ir trying to keep people al ive and well... Not urit il every life-saving attempt has been exhausted do they let up. In the hospital setting, such extraordinary efforts to revive the 
patierit and prolong 1 ife are routine (Coombs and Powers, 1975: 259).

Coambs and Powers (1975) note further that in the clinical pathology conferences ("death rounds"), poor clinical performarice and methods which could have prevented death are discussed, but there is no forum for the giving of praise far a job well dore. The assumption is made that "death is preventable and is not supposed to happen to good physicians" (Coombs and Powers, 1975:260). Death is viewed as the enemy, as a failure, ard the clinician's reputation arid self esteem are at stake (Coambs and Powers, 1975). The fourth stage posited by Coombs and Powers (1975) is "questioning the medical model." Physiciars enter this stage "when they can no longer escape the absurd extremes to which efforts are sometimes taker to keep patierits alive" (p. 261). Physicians at this stage see these extremes as "iricampatible with gaod medical practice" arid come to realize that "it is unrealistic to expect a cure for everybody" (Coombs and Powers, 1975:263).

The fifth stage, "dealing with personal feelings," is a stage of self examination (Ccombs and Powers, 1975). Coombs and Powers (1975:263) note that the physicians they interviewed were "having a horrible time dealirig with death and dying on a personal and professional level," yet everyarie knows that the goad doctor is supposed to be calm, with his own feelings under control-someone on whom the family car rely for steady support, insight and understanding. The doctor who 
feels anxiety or fear in the face of death must carefully conceal these emotiors.

The physicians at this stage "fault their mentors for giving them such little help with the subjective aspects of death" (Coombs and Powers, 1975:266).

In summary, the firidings and assertions with regard to this issue of whether the attitudinal learring that occurs during professional socialization represents a charge or maturation in the socializee are contradictory. Whether (1) attitudes charge as a result of the professional socialization process, (that is, whether commitmerit occurs, involving "a persoral attachmerit to certain activities arid goals ... (providing)... a basis for consistency arid stability in individual behavior in different situations") (Levinsor, 1967 :258, citing Becker, 1964); (2) changes are temporary situatioral adjustments; or (3) the socializee simply matures remains unresolved.

This issue appears to be linked to that of the relative importance of the formal educational institution im the professional socialization process. A related issue concerns when this process occurs. The work of Thornton and Nardi (1975) and Coombs and Powers (1975) seens to suggest a developmental process occurring beyorgd the years of medical school. It seems plausible, however, that the development pasited by these researchers could be sped up by effectirig changes in the educational process (e.g., by providing 
students with opportunities for dealing with the subjective aspects of being a physiciar, as suggested by Coumbs and P(wers, 1975).

What

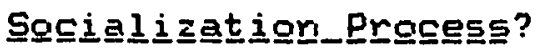

There are two predominarit and contrastirig views with regard to the status of the socializee during the professional scicialization process. These views are enunciated in terms of the professional socialization of physiciars by Becker et al. (1961) or the ane harid arid Mertan et al. (1957) on the other. The perspective of Becker et al. (1961) is of the socializee as a subordinate, or a "bay." Merton's (1957b) and Huntingtor's (1957) position is that sacializees comprise a "little society," as Blocin (1979) states, and that as students move through medical school they tend to develop ari image of themselves as dactors rather than as merely students (Huntington, 1957).

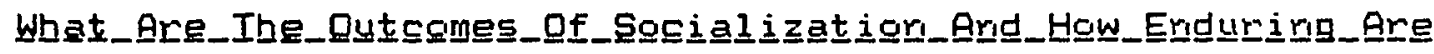
Iney?

According to Levirison (1967:258):

Perhaps the central question of socialization theory... (is) What kirids of relatively enduririg, professionally relevarit changes, if any, do studerits undergo under various socializing coriditions (ecological, cultural, structural, processual, and the like)?

This question is related to that corcernirg whether attitudinal changes undergone by socializees truly represerit 
changes in commitment that can be attributed to their

prafessioral socialization, whether they are simply a

furiction of maturation, or whether they occur as a result of

situational adjustinent (e.g., to the medical school).

Levinson (1967:258) asserts that:

Socialization theory does irivalve the premise that the most sigrificant changes wrought in the student are the relatively enduring ones, and that they will exert an appreciable influence or his further professional developmerit even though they may also be modified in the process. In other words, the scicializing experience brings abcut changes in certain personal characteristics; these affect the student's subsequerit career arid are in turn affected by it. Socialization research thus deals with the interplay of envirorimental coritexts arid relatively enduring yet changeable personality structures.

Ir sum, Levinson (1967) argues that changes that are rigt enduring are out of the purview of socialization theary ard research.

Caombs (1978) rotes two divergerit approaches eviderit in previous studies of the professional socialization cif physicians: (1) longitudinal designs to trace charges in studerit attitudes through the course of medical training (e.g., Eron, 1955, 1958), and (2) detailed case studies of the socializing institutions (e.g., by Becker et al., 1961) arid their sociccultural milieu. Studies of this latter type, however, tell more about studerits' adaptation to the medical school culture than about enduring changes undergcre by students (Coombs, 1978; Levinsor, 1967). Given this, Levinson (1967) asserts that the Kansas group (Eecker et 
al., 1961) "cannot systematically pursue" what he has termed perhaps the ceritral question in socialization research, that of the enduring outcomes of socialization.

Entwined with this question is that of coriformity to the normative role to which the professional is socialized. Waitzkin arid Waterman (1976, citing Freidsor, 1970) argue that it cannot be assumed that concrete behavior reflects the norms to which the professional has been scicialized. As noted earlier, Elrom (1979:32) makes a similar poirit, asserting that while the conceritration of data collection regarding socialization for the professional role has beer ir the medical school, the "relevance of the firidirgs of such research for behavior in the physician's role has beer largely a matter of assumptior."

Summanary

This section has provided an overview of some of the concepts and issues within socialization theary that have relevarice for the present study. The conceptual tools described in this chapter have guided the develapment of and are incorporated irito the conceptual framework for the research. This framework arid the specific research questions addressed in the present study are preserited in the next chapter. 


\section{CHAPTER IV}

\section{DESCRIPTION OF THE RESEARCH}

In this chapter are presented the conceptual framework. that guided this research and the specific research questions and hypotheses that are exarnined.

\section{CONCEPTUAL FRAMEWORK}

The purpose of this conceptual framework is threefold: to designate the areas af inquiry of this research, to clarify the interrelationships of these areas, and to specify the theoretical assumptions underlying the present study. Figure 1 depicts this framework. Each of the varicus areas, or variables, has been enclosed by a box which is lettered. In the narrative that follows, the letter of the box is given, as well as the narne of the variable being described. As shown in Figure 1, the two priricipal outcomes of iriterest, or dependent variables, are the normative (ideal) expectations for the health professional role in the provision of quality terminal care (Box $F$ in the figure), ard the long-term viability of hospice care in the U.S. (Box G). A number of factors are conceptualized as affecting these 


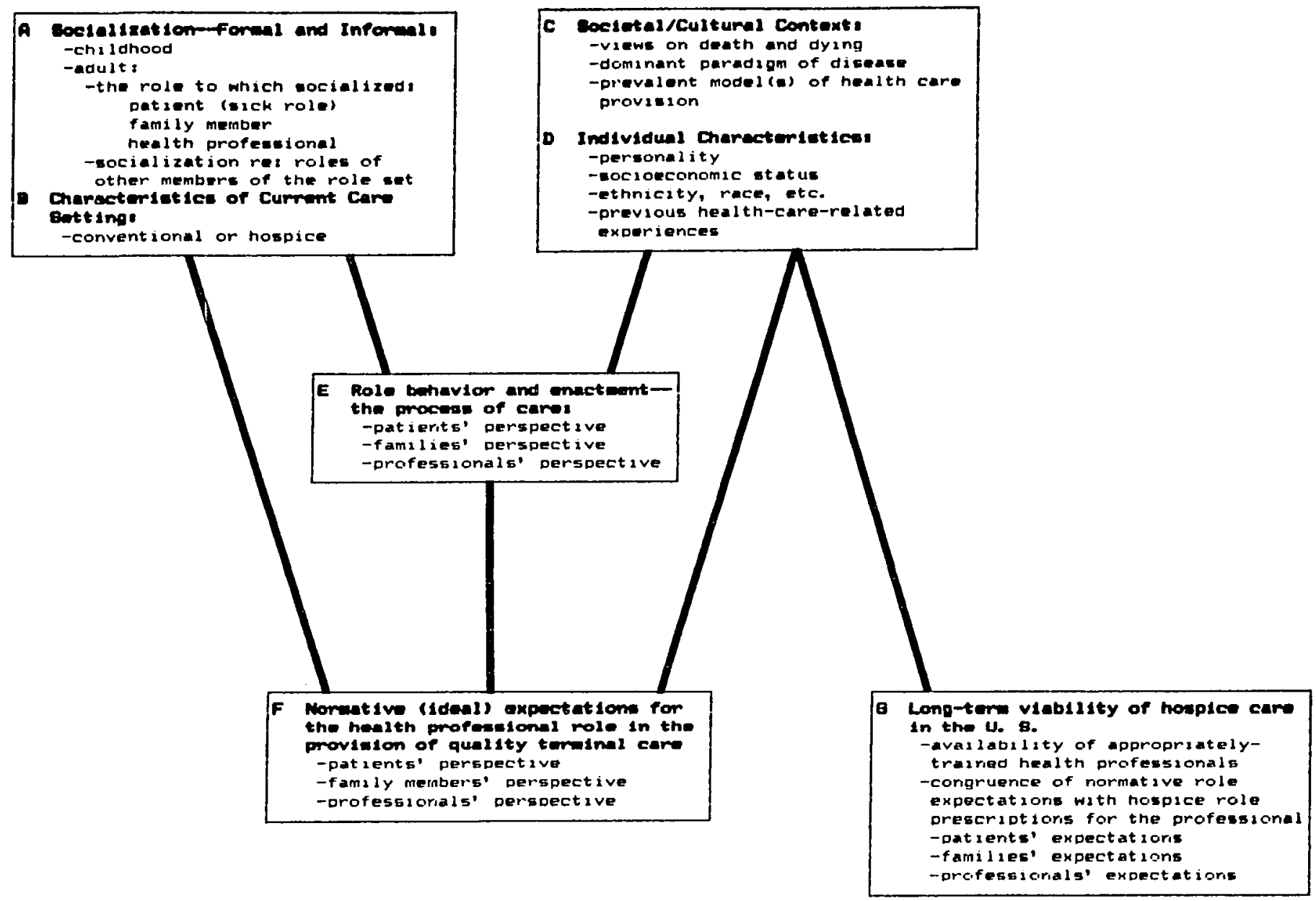

Eipure_1. Conceptual framewark. 
normative role expectations arid, ultimately, the viability of hospice care in the U.S. 1

Factors related to the societal/cultural context (A) are conceptualized as a major determinarit of individuals' role expectations for the ideal provider of terminal care. Among these factors are sacietal views on death and dying. As poirted out earlier, aurs has been termed a "deathdenying scaiety." Death derial may be expected to predispose future professionals toward avoidance of dying patients. Patients and families may be predisposed toward denial of impending death and toward failure to prepare for this eventuality. Such behaviors arid attitudes on the part of each group have consequerices for the professiarialpatient, or professional-patient/fanily relationship, particularly in the areas of conmurication and patiert/ family participation in the care.

Another social/cultural coritext variable is the paradigm of disease that is domirant. Whether the paradign disease is acute or chronic is seen as likely to affect, through sacialization processes, the role expectations for the provider of terminal care. Another such factor is the

1

With regard to this last outcome, it should be pointed out that several factors not included here also figure in the feasibility of hospice care, such as the cost of care, but these are beyond the scope of the present st udy. 
model(s) of health care provision that currently is prevalent (i.e., medical or holistic).

Socialization, both formal and informal (C), then, is the next factor conceptualized as affecting role expectations for the ideal provider of terminal care. of particular importance in this research is adult role socialization, in which individuals learn the expectations associated with a given role, such as the role of the patient, the role of the family member, or, of primary iriterest here, the role of the professional health provider. In addition, the expectatiors associated with other members of the role set are learred. The patierit, his or her family members, and the professionals involved in the patient's care comprise the role_set in this research. As will be recalled, this coricept, developed by Mertan (1957a, cited in Huntingtor, 1957:181), refers to "the complex of rale relationships which persons have by virtue of cccupyirig a particular status." Each of the groups in the role set has its owr perspective. Expectations for the role occupied as well as expectations for the other members of the role set are learned through socialization processes.

Individual predispasing characteristics (D) are viewed as a thind set of factors affecting role expectatiors for the ideal provider of terminal care. These characteristics irclude the individual's persanality, sacioeconomic status, ethnicity, race, and other demographic characteristics, as 
well as previous experience with health care professiorials and settings

The type of care that is currently being received or provided (conventional or hospice) (B) is a fourth factor seen as likely to influerce the expectations for the ideal provider of terminal care. As described momentarily, a tentative hypothesis is advariced that the expectations of patients, fanilies, and providers in conventional care programs are likely to be more similar to the corveritioral (medical) model of health care than are those of patierits, families, and providers in hospice care.

In addition to affecting directly the role expectations held for the ideal provider of termiral care, all of the above factors are seen as affecting role behavior, or the way in which the role is enacted by the individual (E) in the process of giving or receiving care. Role behavior itself, particularly that of the other members of the role set, also directly affects role expectatiors.

Firally, the above-described factors all iridirectly affect the long-term viability of hospice care in the U.S. (G). In addition, three factors are seen as directly impacting the future of hospice care: socialization (C), and particularly the role prescriptions to which health professionals currently are socialized (F) and the societal/cultural coritext (D). 
The conceptual framework employed in this research car be summarized, then, as follows: (1) the dominant scicial/cultural context is reflected in social and cultural norms coricerring roles and role expectatians; these norms are transmitted through socialization processes; (2) cambinations of roles form role sets, or groupirigs of rales that intersect; persors who occupy different roles have different perspectives concerning problems ard situations by virtue of their contrasting, although complementary, roles; (3) behavior is goverried by normative expectations, but not exclusively; individual predispositions and characteristics coritribute to behavior as well; (4) the dominant scicial/ cultural context, socialization processes, the particular role occupied, individual predispositiors and characteristics, ard the characteristics of the care settirg in which care is being received or provided are all factors that coritribute directly to role behavior and to the normative expectations held for the role of provider of termiral care; these factors contribute indirectly to the viability of hospice care in the $U$. S. with regard to the availability ef professionals capable of providing hospice care, arid the acceptability of hospice care to consumers arid providers alike.

The conceptual framework described above has guided this research and melds aspects of all three of the domiriant sociological perspectives that have been detailed in Chapter 
III, Conceptual Tools: the stmuctural-functiorial, the symbolic interactionist, and the conflict perspectives. Rather than choosing a "partisar" approach, elements of each have been selected in order to lend the greatest amount of understanding to the research problem at hand. Emphasis is given to the structural-functional viewpoint, however, as it affords a logical first step in assessirig the role ra structural-functional concept) of the health professiaral in the provision of terminal care.

The framework employed is corisisterit with that developed by Bloom (1963, cited in Bloom and Summey, 1976), which has as its central concept the social system. Bloon's model is an extension primarily of the work of Parsons (1937, 1951, 1968), Szasz and Hollender (1956), Spiegel (1954), Kluckhohn (1950, 1958) and Bales (1950) (all cited in Bloon and Summey, 1976). The esseritial premise of this and all models of the social system is that "social relationships have a pattern based on learred cultural expectations and maintained by the functional homeostatic processes inherent in all systems" (Bloom and summey, $1976: 31)$.

Bloom's (1963, cited in Bloom and Summey, 1976) madel contains the roles of the doctor (A) and the patient (B) and the two important elements of this relatiorship-- $(x)$ "the personalities of the participants, upon which the 'rapport' is dependent" (Bloom and Suramey, 1976:2E) (an 
expressive transaction), arid (Y) "the skill of the physiciar as a 'medical scieritist'" (Bloom and Summey, 1976:26) (ari iristrumental transaction). "Social forces," including the medical profession for the physician and the fanily for the patient, figure into this model sirce they affect how the roies $A$ and $E$ are interpreted. Additional "subcultural reference groups" encompassing factors such as "class, race, religion, and ethnicity, which furction in particular cases as the significant sources of value-oriertation for either or both the doctor and his patient" (Bloon ard Summey, 1976:29), also are included. Firially, as these scicial forces and subcultural reference groups are based in the dominant culture, all of the above elements in Bloom's (1963) model are circumscribed by "the domirart sociocultural matrix" (Bloom and Summey, 1976:30).

In the present research, the role is the unit of analysis. In particular, this research focuses on the expectations for cone role in the patient-farnily-health professional role set: those for the health professianal ard the role of the physician and the nurse, in particular. The concept of the role-set, however, is utilized in that the expectatiors of patients and families are examiried, as well as those of health professionals themselves with regard to the role of the health professional in the provision of terminal care. The conflict perspective is enjoined in the assumption that by virtue of the role occupied, role 
occupants' perspectives, values, attitudes, and expectations are likely to vary and to be at odds with one another.

The conceptual framework for this research reflects the cortributions of both formal and informal socialization agents and processes in the transmittal of rormative expectations for roles. A broad definition of professional socialization is employed, encompassing not simply what is taught formally, but also that which is corveyed through commision or amission by formal sources, as well as through iriformal interaction, such as with fellow studerits. The impact of individuals' personalities is recognized but rot assessed directly, except as emerges in the writings of scholars who have described the values, orientations, and motivations to which physicians ard nurses are socialized.

Taken into account in this conceptual framework, then, are mariy of Freidson's (1961, 1965, cited in Bloom and Summey, 1976) eriticisms of Parsons' model of the social systern. As summarized by Bloom and Summey (1976), these criticisms include:

1. The Parsonian model views the doctor-patient relationship from the perspective only of the physician, ignoring the expectations of the other members of the roleset, including the patient's family, the nurses, and other persons significant in the treatment process. 
2. Expectations are presented by Parsons as the primary influence on behavior, yet expectations actually are orily "ideal" standards.

3. Expectations have no influence in themselves; orly the position of the person halding then can influence their beirig met.

4. Parsaris" functional model igrores "the necessity of conflict in human relationships," yet, Freidsan argues that "conflict exists because each party, the professiorial and the patient, seeks to gain his own terms from the other" (Bloom and Surmey, 1976:31).

The following are the specific research questions that are examined in this study.

\section{RESEARCH QUESTIONS AND HYPOTHESES}

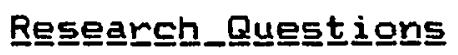

The questions investigated in this research are:

1. What are the normative role expectations to which (a) physicians and (b) nurses are socialized, as described in the literature? With which model for the provisior, of health care, medical or holistic, are these role expectations most congruent?

2. What are the role expectations held by a group af terminally ill patients, family members of teminally il people, and health professionals currerity providing terminal care for the "good" or "ideal" 
provider of terminal care? With which model for the provision of health care, medical (conventional) or holistic (hospice), are these role expectations most congruent and how do patierits', families', arid health professionals' role expectatiors for the ideal provider of terminal care compare?

3. How do the role expectations of patients, families, and currently practicing professionals for the physician and nurse provider of terminal care compare with the role expectations to which physiciars arid rurses in training have been socialized?

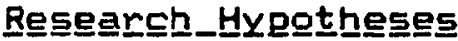

The research hypotheses are:

$\mathrm{H}_{1}$ The nommative role expectations to which physicians arid rurses are socialized, as described in the literature, will parallel those delineated by Parsors as characterizing the professional role. These expectations typify those prescribed by the medical model of health care provisior.

He The role expectations for the ideal provider of terminal care held by resporiderits (terminally ill patierits, family members of terminally ill people, and currently practicing health professionals) will be most congruent overall with those prescribed by the holistic (specifically, the hospice) madel of care. 
$\mathrm{H}_{3}$ The expectations of patients, families, and health professionals for the "good" or "ideal" provider of terminal care will differ from one another.

$\mathrm{H}_{4}$ The role expectatiors for the ideal provider of terminal care will be affected by the type of program (conventional or hospice) in which the patient, fanily member, or health professiorial is curreritly receiving or giving care. The expectations of individuals in conventional prograns will be mast corgruerit with those prescribed by the medical model. 


\section{CHAPTER $V$}

\section{RESEARCH DESIGN AND METHODS}

Now that the problem focused upon in this research has been described and other relevarit work in the field has been reviewed, specification of the research design and the procedures used in this project is appropriate. The research was conducted in three phases. The first phase irivolved the development of the analytical model to be used in the reseanch. In the second phase, a systematic review of 1 iterature was corducted for the purpose of ideritifying the role prescriptions and expectations to which physicians ard rurses in training are prafessionally socialized. The third phase consisted of analysis of data gathered in an earlier exploratory study that was desigried to identify important factors related to the provisior of quality ffrom the poirt of view of patierits, families, and health professionals) terminal care for the elderly. These data were used to determine the role expectatiors held by these three groups for the provider of terminal care.

Within this chapter are described the procedures used in each of thege three phases, including those to develop the analytical model, to identify in the literature the role expectations to which physicians and nurses ir trairing are 
socialized, to select and interview respondents for the earlier exploratory study, and to analyze the data. Also contained are a profile of the study respondents, a description of the iristruments used, and a discussion of the quality and the linitations of the data gathered in this earlier study.

PHASE 1: DEVELOPMENT OF THE ANALYTICAL MODEL

In order to characterize: (1) the role expectations to which physiciars and rurses in trainirig are professionalIy sacialized, as these are described in the literature, and (2) the role expectations for providers of terminal care that are held by a group of people themselves terminally ill, family members of terminally ill peaple, arid professionals actively involved in the provision of terminal care, ari arialytical model was needed. A search of the literature for such a model was initiated, and Parsons' (1951:66) "systern of types of passible pattern variables of rale definition" was discovered. This pattern variable framewark. carsists of five concept-pairs, or polar alternatives, of adjectives for describing particular role expectations. These concept-pairs are: affective neutrality-affectivity; specificity-diffuseness; universalism-particularism; achievement-ascription; and self-orientation--collectivity orientation. These pattern variables are explaired in detail in Chapter VI, Analytical Madel. 
Both an asset and a liability of Parsons' pattern variable framework is its gerieral riature. The pattern variables were developed by Parsons (1951) to be used at the individual, cultural, and societal levels of analysis. Specifically, Parsons (1951) argued that these patterr variables could be used to categorize decisions made by individual actors (the modes of orientation in persorality systems), the value patterns of culture, and the nornative requirements in social systems (the rommative denarids or rales).

The broad applicability of Parsons' patterr variables in a variety of contexts, however, creates a difficulty in defining and operationalizing these variables. To aid in their definition and operationalization for the present study, the writings of interpreters of Parsons' wark as well as the writings of Parsons himself were examined and the various explications and previous uses of the pattern variables were examined.

Most of the research in which the pattern variables had been used was prospective and involved asking participarts to respond directly either (1) to questions designed as specific indices of the pattern variables, (see, for example, Williams' 1959 exploratory study of friendship and social values in a suburban commurity) or (2) to hypothetical situations constructed to reflect the alternatives of the pattern variables. (as in Parks' 1967 
work attempting to tie together personality and social role by means of the pattern variables). Most useful for the purposes of this research were the definitions employed of the pattern variables.

Next, the literature pertaining to the two key paradigms for the provision of health care in the U.S., the medical model, and the holistic model (and ir this case, specifically the hospice model, which is a holistic madel) was scrutinized. Particular attention was paid to areas in which the role expectations prescribed by one model appeared to conflict with thase prescribed by the ather. The two models were examined in order to identify both general and specific, explicit arid implicit rale expectatiors for the health care professional as prescribed within each model. The original intent was to use Parsons' pattern variables, exclusively, to characterize these role expectations. It becane clear, however, that not enough descriptive detail was afforded by the pattern variables themselves; the pattern variables needed to be operatiaralized.

As a result, based on the descriptions found in the literature pertaining to these two models, a list of conterit areas, or themes, that appeared to encompass the various role prescriptions for the health professional was formulated. This list of themes, referred to here as "indicators," was modeled after Parsons" pattern variables; that is, each indicator was developed to be comprised of the two opposite 
poles of a concept, to be framed in terms of two polar alternatives. In most cases, these poles represented the opposing positions of the medical model versus the hospice medel with respect to the concept tapped by a giveri role expectation. Following development of this list of "indicators," the interviews with terminally ill patients, family members arid profesisional care providers were studied in a preliminary fashion in an attempt to ideritify ary additional relevent coritent areas or themes, arid the list was madified as required.

The last step was to place each indicator urider the purview of ore of Parsons' pattern variables. This procedure was a somewhat difficult one because of the ambiquity arid overlap within the patterr variables. It was, therefore, an admittedly arbitrary process. Given orie af the purposes of this research, however, that is, to explore the utility of the pattern variables as a means of describing the various dimensions of role prescriptiors for a "good" provider of terminal care, this categorization was both necessary and legitimate. It represerits a restatement and elaboration, or operatioralizatior, of the pattern variables. As discussed in the final chapter, future research to deternine the validity of these indicators for each pattern variable should be conducted. Such research should involve performance of a factor analysis on resporises of a representative sample to a series of questions or 
hypothetical situations depicting each indicator developed in this study.

The analytical model develaped is preserited in Chapter VI.

PHASE Z: IDENTIFICATION OF ROLE EXPECTATIONS LEARNED THROUGH PROFESSIONAL AND WORKPLACE SOCIALIZATION

The secorid phase of the research irivolved identification of the role prescriptions and expectations learned through professioral workplace sacialization by physiciaris and rurses. Ir order to do this, a systematic review of pertinent literature was coriducted.

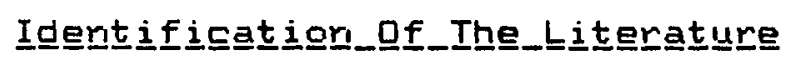

Relevant books and journal articles were identified in three ways: (1) through examination of the Psychalagical Abstracts, the Sociological Abstracts, and the Social Science Citation Index, (2) through the use of computer searches by key words, and (3) through the application of a "snowball" technique, involving scanning all sources cited in each book/article reviewed and noting, obtaining arid reviewing those appearing to be relevant.

The examination of the Psychological Abstracts, the Socialogical Abstracts, and the Social Science Citation Index served to identify specific readings of interest. 
More important, however, was its function to guide the selection of key words to be used in the computer searches. Four sets of computer searches were conducted through the Portlarid State University Library in November cif 1983 using Bibliographic Retrieval Services, Inc. (BRS). Two different data bases were searched: NCMH and HLTH. Ore search of the NCMH data base queried the base for titles or abstracts containing the words "pattern" or "patterns" and "parsors" in their titles or abstracts. A second seamch, this time of the HLTH data base, was conducted using the words "professional socializatior" arid "socialization" and "physician" or "physicians" or "rurse" or "nurses") or ("student" or "students") and ("nedical" or "rursirg")>. 1

A third search of the HLTH data base was made using the words ("terminal care" or "terminal illress") and ("role" or "roles") and ("perceive" or "perception" or "perceptions") and: (1) ("patient" or "patients" or "client" or "clierts" or "family" or "families"); (巳) ("medical" or "medicine" or "nursing" or "health care"); (3) ("physician" or "physicians" or "nurse" or "nurses"); (4) (""student" or "students") and ("medical" or "nursing")).

1

Parentheses surrouriding groups of words deriote all the various words that the computer was instructed to search

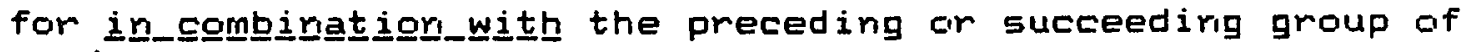
words. 
A fourth search of the HLTH data base was conducted using the words ("terminal care" or "terminal illness") and ("professional" or "professionals" or "professionalism" or "socializaticn" or "professional sacialization") ard: (1) ("rnedical" or "medicine" or "rursing" or "health care"); (2) ("physiciar" or "physiciars" or "nurse" or "nurses") or ("studerit" or "students") and ("medical" or "nursing")). Priritouts of the titles arid abstracts of the books arid articles identifed were acquired ard read. An attempt then was made to obtain copies of thase origirial sources appearirg to be most pertinerit arid to read these in their eritirety. Detailed rotes regarding statements and findings related to specific role expectatiors to which physicians or nurses ir trairing are professionally sacialized were taker to enable subsequent analysis in temms of the analytical madel based an Parsons' pattern Variables, as described above and iri Chapter VI.

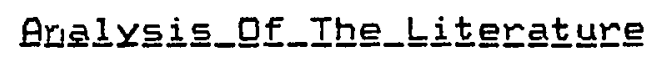

The techrique employed in analyzing both the literature and the interview data (these data are described in the rext sectiaril was content analysis. Broadly defined, coritent analysis is "a multipurpose research method developed specifically for investigating a broad spectrum of problems in which the content of communication serves as the basis of iriference" (Holsti, et al., 1968:597). Mare 
specifically, it is a technique for classifying recording urits (e.g., words, seriterices, themes, paragraphs, entire dacuments, open-ended responses to interview questions) inta categories con the basis of the judgments of orie or more analysts.

Briefly, the steps irivalved in performing a cariterit arialysis of data are:

1. Selection of categories or classification schemes irito which the dacuments or responses, or portions thereaf (called conterit urits) are to be placed;

2. designation of the size of the urits to be caded (e.g., word, theme, sentence, paragraph, etc.);

3. determiration of the system of enumeration (e.g., appearance, frequericy, or interisity of the attribute);

4. coding of the data; that is, the systematic trarisformation ard aggregation of raw data iritc. urits, so as to permit precise description af the conterit.

The virtue of coritent analysis is that it allows the researcher to describe systematically the attributes of the message, or resporise. It "guards against distortion by selective perception" (Bowers, 1979:292), as all relevant data (i.e., both in support of and arguing against research hypotheses) are included. 
With regard to the third and fourth steps described above, cartent analysis is viewed as a quarititative techrique. There is disagreement, however, as to the meaning of the term "quarititative." Holsti, et al. (1968) note that while some definitions equate "quantitative" with "numerical," gthers are less restrictive arid include studies in which findings are reparted in terms such as "more," "less," ar "iricreasing."

Arialyses usirig exact frequericy courits as their system af erumeraticir are a particular pairit of coriterition. The case for such arialyses is powerful, especially the argumerit that such analyses enable conclusions to be stated with more precisior. Conversely, some researchers take the position that the equation of content analysis with exact frequency tabulatiar leads to uridue emphasis beirig placed or precisior at the cost of problem sigrificance. Especially in problems of applied social science, inferences drawn on the basis of simple appeararice or nonappearance of attributes in messages (sometimes called "qualitative" content aralysis) may be more sigrificant than those based on freggueㅡㄷㅗ of appeararice. This argument is especially valid when a linear relatioriship carriot be assumed between frequericy and importarice of attributes (Holsti, et al., 1968).

Given the purpases of this research, the data urit felt to be most meaningful was the theneme. For the same reason, the system of enumeration chosen was the agegarariceㅡ 
cif particular themes in a given document or respondent's iriterview. The classificaticin scheme for the documents (arid the interview responses) is that defined in the aralytical framewark develciped as part of the research, as discussed in the early part of this chapter and described in detail in Chapter UI. Trat is, the themes, or variables, choseri for aralysis are those contained within the analytical model, which is based or Parsors' patterr variables of role defiritiar.

It is the "qualitative" form cif conterit analysis, theri, that is used here. It should be noted, though, that the label "qualitative" is somewhat misleadirg, sirice data caded in terms of appearance of attributes may be (arid is) preserited rumerically. For example, the percentage cif items (e.s., articles, books, interview responses) in which a theme appears may be giver, (Holsti, et al., 1968).

\section{PHASE 3: IDENTIFICATION OF PATIENTS', FAMILIES', AND HEALTH PROFESSIONALS' ROLE EXPECTATIONS FOR THE PROUIDER OF TERMINAL CARE}

The interview data for this research were gathered through an earlier exploratory study that was desigred to identify important issues and factors related to the provision of quality terminal care for the elderly. In this study, personal interviews were conducted with iridividuals having intimate knowledge of the area of terminal came and 
comprising the role set (Merton, 1957a), that is, representirig the various perspectives from which care can be experienced: terminally ill people, family members of terminaliy ill persoris, bereaved family members, and professioral health care providers. The following sectiors: describe the pracedures used to select programs and resperidents to be interviewed, (2) profile the programs and the responderits, (3) describe the interview schedules used, arid (4) detail the data analysis procedures.

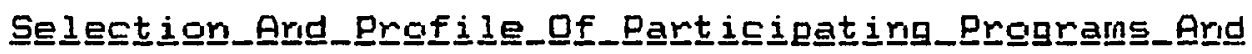

\section{Resgengderits.}

Given the exploratory rature of the earlier study, it was important to obtain the views of persors representing the varicus approaches to termiral care and the erivironments in which terminal care is given. Therefare, a two-step responderit selection desigr was required. First, programs providing terminal care were selected and second, patients, families, arid staff within each program were ideritified for participation in the study. Appendix $A$ contains ar overview of the respondent selection plan.

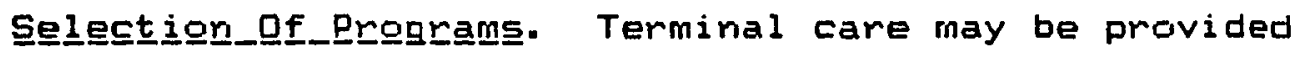
or an inpatient basis (e.g., ir a hospital or rursing home) or in the patient's own home. In addition, this care may be either "conventional" or "hospice" care, as discussed in Chapter II, Review of the Literature. 


\begin{abstract}
"Coriventional" care is that based on the medical madel; that is, primary atterition is given to patierits" medical needs, arid care is ariented toward aggressive treatnerit, with the principal aim beirig exterision of the patient's life. Generally, in conventional care, the emphasis is or irpatient care, and when care is given at
\end{abstract} home, the home care providers, usually nurses, are staff members of an autorionous argarization. In "hospice" care, the holistic model of care is followed, whereby patierits' psychalogical, social, spiritual, arid ather reeds, as well as their physical reeds are addressed. Care is provided by a multidisciplinary team, and an attempt is made to provide as much care as possible in patients' owm hornes. Arother feature is that patients' families' reeds also are addressed. Hospice care may be given within a hospital, rursirg home, or as part of an already existirig horne care program. This care may also be provided through a separate program in which orly hospice care (irpatient arid/ar home care) is offered.

Therefore, to represerit the various termiral care approaches and envirements, respandents from 10 different prograns were iricluded in the study. Due to budgetary cansiderations, where possible, programs in the Portlarid, Oregor, area were selected. These programs were selected purposively on the basis of the researchers' knowledge of the programs providing teminal care in the local commurity 
as well as that of lacal informarts specializing in the area of ternirial care who were corisulted.

In making the program selections, as well as later in the course of the iriterviews, it became clear that in practice the distinction between "hospice" and "conventicirial" programs is nat always clear-cut. Some programs claimirg to provide hospice care fell short of this goal in terms of meeting a 1 l of the characteristics of hospice prograns, detailed in Chapter II, that are widely accepted arid corsisterit with the National Hospice Organization staridards. Ancther program was reluctarit to desigriate itself as a hospice because of its lacation within a haspital arid because the patients it served were scattered throughout the hospital. While this model far hospice care is row accepted, at the time of the study there existed a decidedly "purist" haspice factior that considered orly autariomous hospice programs as "true" hospices. If a progran possessed, at least on paper, all or nearly all of the characteristics of a hospice program as detailed in Chapter II, it was desigrated a "hospice-like" program. Prgfilie_Qf_Ihe_Prggrams. of the 10 programs ultimately selected, five were "hospice-like" arid five were "converitional." Nine of the 10 programs were in Portlarid. Orie, a freestanding hospice, of which there was rone in Portland, was located in arother Western state. Three haspitals (two of which were "hospice-like"), four nursing 
homes (ane "haspice-like"), two hame care programs (one "hospice-like"), arid ore autoromous haspice facility were iricluded in the study. Table 2 briefly describes each program. Apperidix A provides detailed irifarmatian coricerring each program.

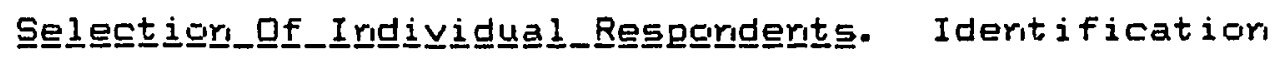
of the study participants comprised the secorid step in the selection pracess. The study design called for the interviewing af ter peaple (two terminally ill patients, two family members of teminally patients, two family members of patierits who had receritly died ireferred to here as "bereaved fanily members"), three health professionals (referred to as "staff" or "staff members"), arid the administrator or super-visorl ir each of the 10 pragrams. of the 100 praposed interviews, 94 were completed.

The admiristrator or supervisor of each program was first interviewed. He or she then desigrated three staff persoris heavily involved in the care of patierits having late stage disease, preferably of different disciplines, such as a nurse, a physiciar, and a social service provider. 
TABLE I I

DESCRIPTION OF PROGRAMS PARTICIPATING IN THE STUDY $(N=10)$

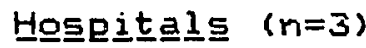

1. A teaching hospital selected to represerit a traditichal iripatierit approach to terminal care

E. A private rour-profit hospital with a well-established "hospice-like" pregram for caricer patierits

3. A private nori-profit hospital with a very recently established "hospice" irpatierit unit

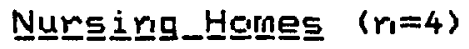

4. A proprietary skilled nursing facility represeritirg a coriveriticial appraach to patient care

5. A run-prafit rursing home with skilled and iritermediate care beds, specializirig in rehabilitation, sponsored by a fraterrial orgarizatior, representing a coriventiorial approach to care (although plaririrg for a hospice urit had beguri)

E. A non-profit nursing home with religious affiliation and beth skilled and iritermediate care patierits, representirig a corveritional appraach to care (but corsidering specializing ir terninal care)

7. A rori-profit skilled arid intermediate care facility with religigus affiliation, providing "hospice-like" services (arid plaririrg for a designated hospice urit)

$$
\text { Hgine_Carne_Programs }\left(r_{1}=2\right)
$$

8. A "hospice" home care program under the auspice of a large rori-profit, Urited Way-funded, full service home health agericy

3. A sinall ron-profit full service home health agericy represeritirg a conventional approach to home care

$$
\text { Autgorgangus_Hosgíge }\left(r_{1}=1\right)
$$

10. Ari autcirimous, free-standing haspice progran offering bath iripatierit and home hospice care (located outside the Portlarid, Oregori, area as no such program had beeri established localiy) 
The administrator or a staff person designated by him or her then ideritified two temminally ill patients meeting the following criteria, which were modified from those used by Hintor, (1979):

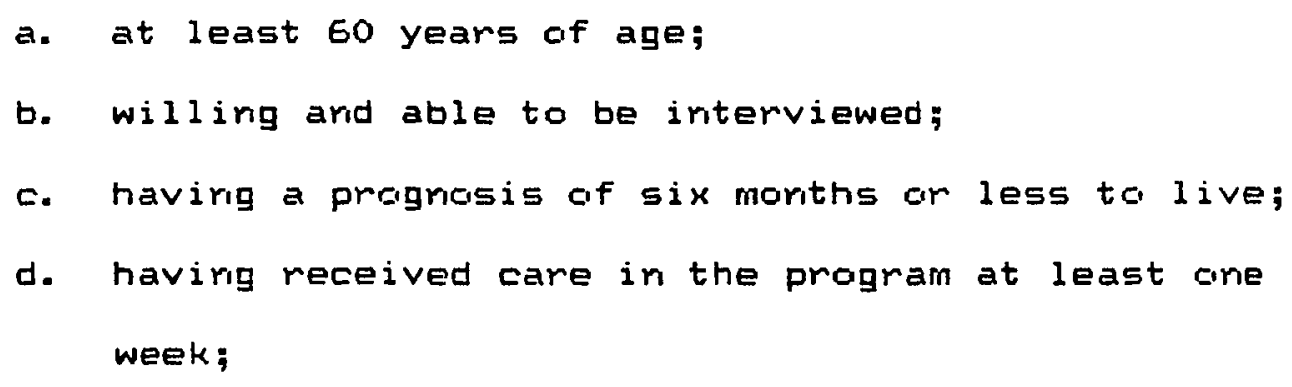

The firial criterior was that ore patierit was to be crie for whom staff felt care "was going wel1," and the ather was ta be crie for whom care was "not goirig so well" for some reasor. This criterion was applied to maximize the rarge of perspectives arid capinions that patierits would bring to bear cri the rature of "quality" termiral care.

Similarly, two family members of older (age 60 or over) terminally ill patients being cared for in the program were ideritified by the admiristrator or staff persoris. Family members could be related to the patients interviewed or they could be fanily members of patierits not interviewed. The stipulation made was that they should be first arder family nembers or menbers who were close to the patient.

Finally, two family members whose loved ones had died withir the last six months (bereaved fainily members) were identified arid interviewed. 
For bath the bereaved family members and the fanily members af patierits currently il1, the selectior criterior af "care going or having gone well"/"care not going or not havirig gorie so well" was applied. That is, ore family ar bereaved family member was to be ore for whom the patient's care was goirig or had gone well, arid the other was to be one for wham the patient's care was not goirig or had not gane sa We11.

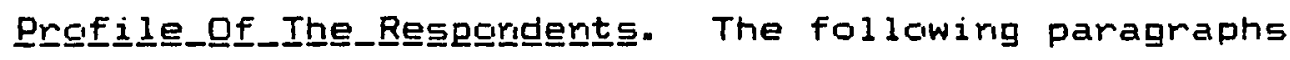
profile the characteristics of the resporiderits by group. Appendix $A$ contains additichal detail.

Patiㅡ믄. A total of 17 of the proposed 20 patierits (two in each of the 10 prograns) were interviewed. In ane program, no patients were irterviewed because the program's start-up date was delayed and because no patients meetirig the study criteria had been served by the clase of the irterviewirg periad of the project. In another program, which was quite small, only one patierit could be iriterviewed. Orily three of the patients who were served in this program while iriterviews were being corducted met the study criteria, and the rumsing supervisor reported that two of thase declined to participate when she approached them. Nire of the 17 patients interviewed were women and eight were men. Ages ranged from 57 to 86 , with 75 as the median age. Although the man who was 57 did not fit the age criterion for the study, he was included because (1) he and 
the ather patierit interviewed in that site were the only two patierits who were cotherwise eligible to participate, and (E) mare important, he expressed enthusiasm for the study and a desire ta be iriterviewed wher he learned about the study.

Fifteer of the 17 patierts had a primary diagrosis of cancer. Orie patient was diagrosed with amyotrophic lateral sclerosis, ard arother had experienced a severe cardiovascular accidert (CVA) arid had a very limited progrosis. The time sirice the diagnasis or since the first episode of il Iriess rariged fram three weeks to over seven years. Five people reported being ill far are year or less, five athers had beer ill ore and a half to two years prior to the iriterview, arid the remainirg seven from three to seven and orie-half years.

Ir most cases, the iridividual's progrosis was "guarded," "uricertair," or "unclear," reflectirig providers" reluctarice to estimate specific amounts of time left to live. At least three patients had outlived their original progrioses, two by over a year; orie man was especially delighted about "surprising the experts." Mast patierits krew about their disease and stated to the interviewer that they were "living on borrowed time" or "couldn't expect to survive this too long." Orie person did not know her prognosis, ore either did not know or did not wish to speak of 
it, arid one had been told, according to staff, yet denied it. $\Xi$

Most of the patients with whon the researchers spoke had been cared for in a variety of settings. Of the eight people who were iriterviewed in the haspital or their homes, arily orie had ever been a patient in a riursing home. In coritrast, resporiderits iriterviewed in nursing homes gerierally reparted several episodes of hospitalization as well as home care.

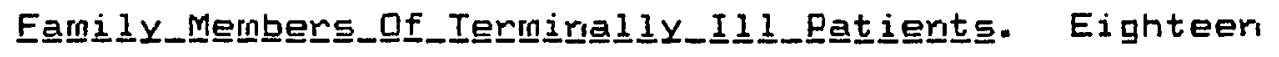
fanily members of patierits who were currenertely teminally ill were interviewed far the study. It should be noted again that the family members iriterviewed were rot recessarily thase of patierits who were interviewed.

There was arily arie patierit and orie family member available to be interviewed from one home care program, and in the pregram which was quite new, no patierits arid, cerrsequeritly, no family members, fit the study criteria. In one of the rursirig homes, staff erithusiastically reconmerided a third family member in addition to the two called for in the responderit selection plan. This persor was interviewed both

$\overline{2}$

As roted earlier, awareriess of the progriosis was not a criterion for participation. Patierits and families were iriterviewed "for research irito caring for people with a serious illness," as the research team did not want to rist. divulging previously urikrown or deried informaticri, arid because such awareness was not central to the purpose of the study. 
in arder to comperisate for the lower rumber of family

members from the other programs and because the staff member al ready had coritacted the family, and they were very much iriterested in takirig part. The staff person also indicated that this family had preserited a problem for the staff in the past ard, therefore, fit the criteria of a family member where care had not gore well.

The group of farnily members interviewed contained 15 wemer and three men who ranged in age from 30 to over 80. Iricluded were a nephew, a riece, a sister, seven wives, six daughters, arid two husbarids. In 13 cases, their ill relative was also irterviewed for the study. In three of the five remaining cases, iriterviews were conducted with the family menbers in ariticipation that their ill relatives would be iriterviewed as well, but the patients subsequeritly became too ill to be interviewed. The fourth family member was iriterviewed in place of the wife of ane of the patients because the patierit had requested that she not be iriterviewed. In the fifth case, a patient having no family was iriterviewed, so a farily member of arother patierit (who was too ill to be interviewed) was asked to participate.

The temirally il relatives of the family menber respondents ranged in age from 57 to 84 . Of the two whose ill relatives were urider the age of 60 arid 50 did not meet study criteria, the reason for iricluding one, and thus his family member, is described in the profile of the patients 
interviewed. The second was a family member of a patient 58 years of age; this iridividual was included at the program staff's insisterice because of their reported difficulty in ideritifyirg responderits who met all criteria.

Fifteen of the responderits' relatives had some form of cancer, two had suffered strokes, and one had anyotrophic lateral sclerosis. Length of illness or time sirice diagrosis rariged from five and one-half moriths to six years. The furictional status of the patierits about whom family members spake varied. Two patierits, while quite seriausly i11, were ambulatory arid apparently were continuing mary of their romal activities. Four of the patients were very close to death at the time their family members were iriterviewed; cone marı died anly hours after his wife's interview.

The degree of irvolvemerit of family members in the patient's care varied as well, although most of the family nembers interviewed seened to provide corsiderable support. The least involved was a man who visited his uricle every week and took care of his finarices. This man was the patient's closest relative. Some of the other family members interviewed had came from out of state ta be with their ill relatives in their last days. of those who were spouses of terminally ill peciple, all were or had been heavily involved in providing care at home. Many were themselves ir poor health. The role for several of the 
daughters appeared to be that of advocate and irifommationgatherer. Orie daughter had quit her job to take over her father's busiriess.

Twerity beㅌ트르르 family members (two in each of the 10 preigrams) were interviewed. These family members included daughters, husbards, wives, one cousin, ore daughter-in-law, arid cine brather. The respondents rariged in age from their late eOs to 86 years of age. Seventeen of the eO farnily members, terminally ill relatives had had some form of carcer, including carcer of the color, breast, or lumg, leukemia, arid multiple myeloma. Orie mar had had cirrhosis of the liver arid two womer had had a severe stroke. Many had beeri ill for several years before they died, but some far arily a few weeks. The median length of the relative's illriess was 20 moriths; the mear lerigth was abiut 30 moriths. Most of the family members had been bereaved for just orie cir twa moriths, although one person had beer bereaved for orily 10 days, and arother for nearly two years. The recollectiors of this latter respariderit remairied quite vivid, arid the program staff had felt that her interview wold make a strorg coritribution to the study.

All of the bereaved family members had beer, very heavily irivolved in the care of the relative who had died. With two exceptiors, all had cared for their relatives at horne at some point during the course of the persan's illress. One, a brather, had not, but he had visited his 
sister daily, both when she was in her own home and when she was in the haspital. Arother resporident's sister had cared for their ill mother in her home, with the responderit providirg cither types of support. This resporiderit was orie of the several of the respondents who had played the rale of advocate for the terminaliy ill patients, which irvolved gathering informatior, seeking explarations, arid spending nights in the haspital or numsing home witn the patierit to make sure that they received the necessary services.

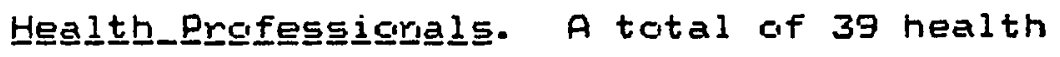
professiorals, Sreferred to variously as "staff," "care providers," "health professionals," or "professional care givers" throughout this document), iricludirg the administrators or supervisors of the 10 programs, were iriterviewed far the study. In are site, only three providens were interviewed since the fourth became ill and urable ta participate.

of the 10 admiristrators ar supervisors iriterviewed, seven had training in a field in addition to that of administration: five were numses, cre was a social worker, arid one was a physician. In ore program, administrative resporsibility for the program was shared by two individuals. The person who was most involved in day-to-day supervisicun was designated as the administrator for the purposes of the study. 


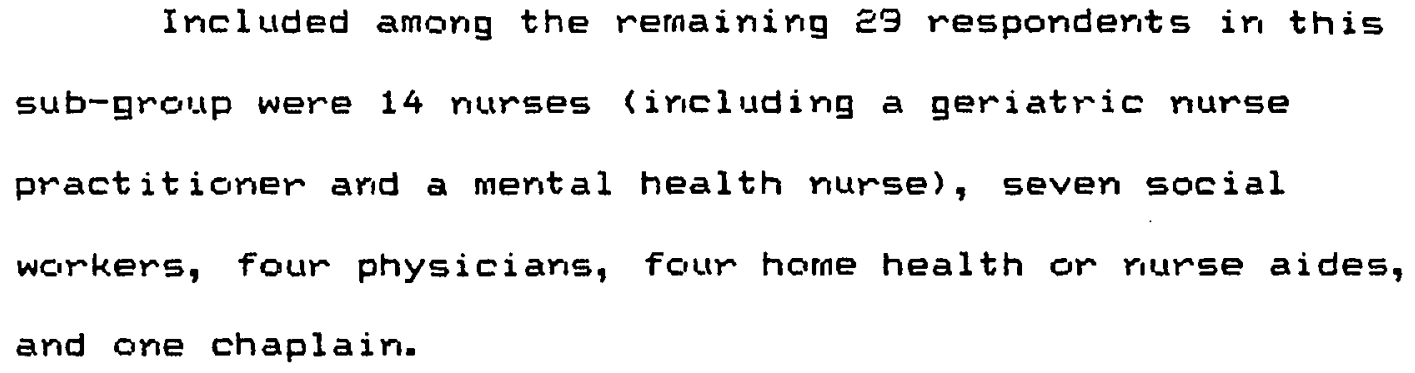

The lerigth of time the health professiarials interviewed had been workirg in their currrerit positions rariged from orie morith to 23 years. The median lerigth of time was orie year.

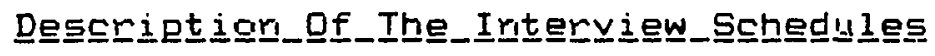

The instrumerts developed for use in this earlier study were desigried to elicit the views of the respondent groups concerring issues surrouridirg the defiritior, provision, and assurance of quality terminal care. Guiding their developmerit was a preliminary conceptual model, with the desigri based or a review of relevarit literature. This madel caritairied those elements asserted ir the litera-ture as factors affecting or iridicating the quality of care. The iriterit was to structure the interviews so that the importarit dimensions of quality terminal care, from the perspective of all pertirierit groups, would be ideritified and explicated. With this goal in mird, while standardized for each responderit graup, questicirs were operi-erided to promote free expression of experierices, thoughts, and coricerris. The iriterviews were coriducted face-to-face, both because of the 


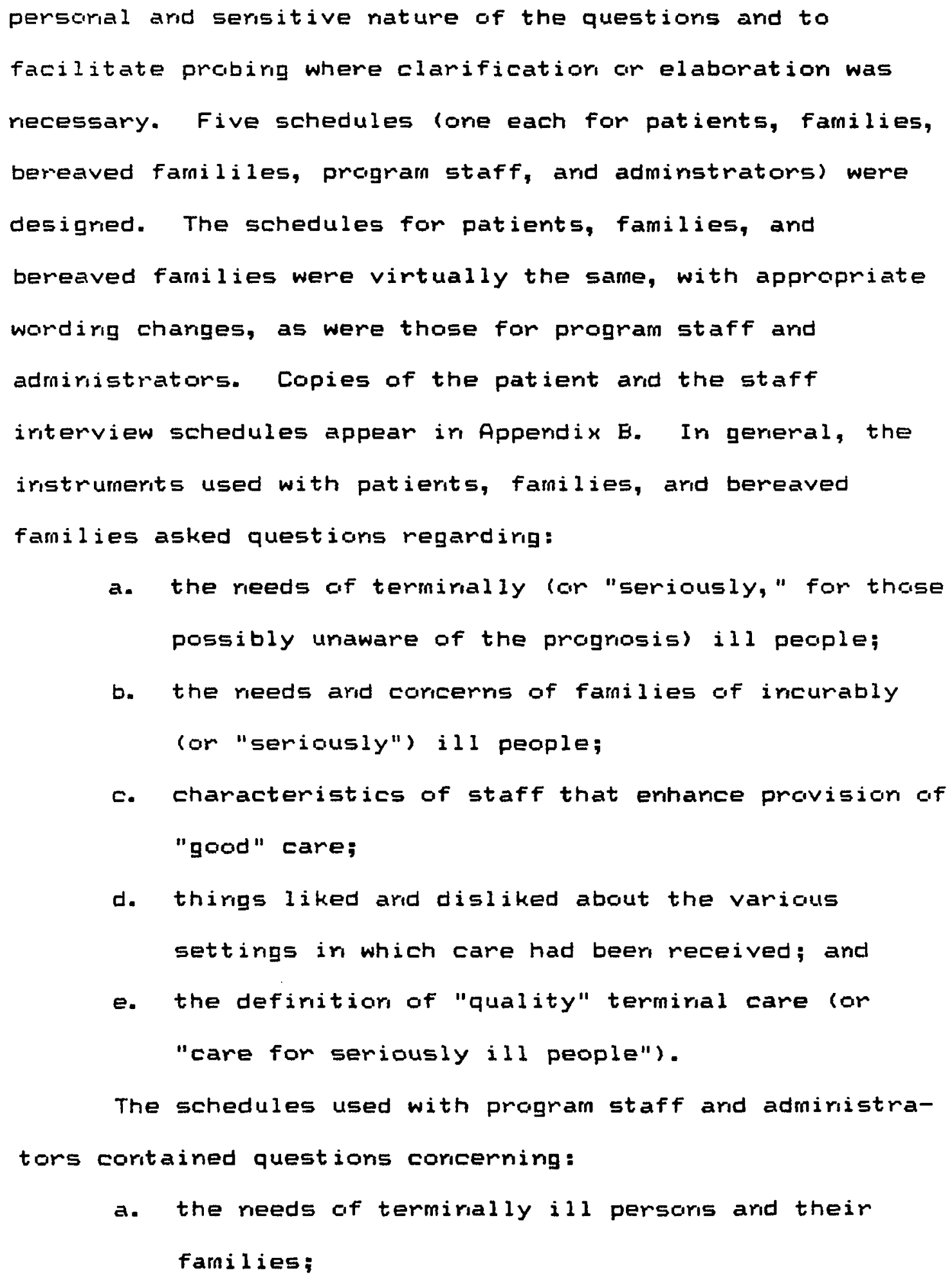


b. characteristics of staff that entance provision of "good" care;

c. factors (e.g., policies and practices) hindering and facilitating provision of "good" care;

d. the definitior of "quality" terminal care;

e. recommendations for assuring provision of "quality" terminal care;

f. indicators of "quality" terminal care; and

9. (for adriristrators only) characteristics of the program in general and of service recipients.

Questicirs af a general riature regarding these issue areas were asked as well as some employing a version of the critical iriciderit techrique. This latter methad invalved asking staff to think of three specific cases in which care had gorie well, arid then three ir which care had not gone as well as they would have hoped, and to describe the circumstances in each of those six cases. Similarly, patierits arid families were asked to recall three care providers they had especially liked and three they had rot liked. Ore example of general questioning came rear the clase of the interview, when all responderits were asked to describe what they thought "good care for people who are seriously ill corsists of" Cor "tiermiraliy ill", for providers and thase patients and families aware of the prognosis). 


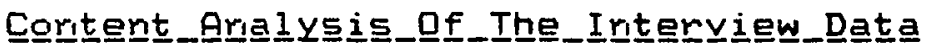

The techrique emplayed in analyzing the interview data was a form of content arialysis. Traditionally, applications of coritent analysis have not invalved the direct questioning or abservirg of people. Iristead, already existirig written material is examined (Kerlinger, 1973). Increasingly, hawever, this techrique has been applied to data, or messages, generated in the research process, such as resporises to aperi-ended questioris in survey research. In fact, the coding of open-ended questionmaimes may be considered to fall under the mubric of both coritent arialysis and survey research; some researchers use the terms "content arialysis" arid "cciding" iriterchangeably (Holsti, et al., 1968). As noted in the discussion of the analysis of the literature on the socialization of physiciars and rumses, content analysis allaws systematic description of the message, or response, and elimirates distortion caused by selective perception. As Holsti, et al. (1968:603) observe, this is especially importarit in research such as that reported on here:

To analyze... operi-ended questionnaires, the social scientist often requires information of a subtlety or complexity which renders casual scrutiriy inadequate, even if undertaken by a skilled and sensitive reader.

Given the purposes of this research, the data urit felt to be most meaningful was the theme. The system of 
enumeration chosen was the ageearanance of particular themes in a given document or respondent's interview. As a result of the open-ended rature of the questioris, an attempt had to be made in analyzing the data so as not to weight the resporises of some participarits more than others due to their loquaciousness. This attempt took the form of analyzing the data by appeararice or rorappeararice of a given theme rather than an exact frequency tabulation.

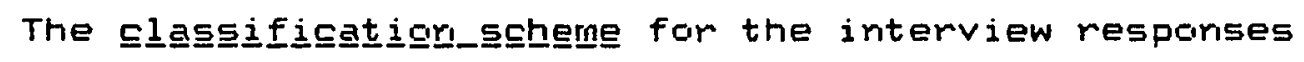
(as well as for the socialization literature) was that defiried in the analytical framework developed as part of the research, as discussed in the early part of this chapter and described in detail in Chapter VI. That is, the themes, or variables, chosen for aralysis are those contairied withir the analytical madel, which is based on Parsons' pattern variables of role definition.

Ir sum, a thematic analysis of the views of the three groups of respondents (patients, families, and health professiorals) with regard to the characteristics arid behaviors they felt a provider of quality termirial care should possess arid exhibit was conducted. As described ir the preceding section, Descrigtion Schhedulules, a rumber of questions pertirient to the research problem were asked in these operi-ended, structured interviews with terminally ill patients, family members, and health professiorals currently providing termiral care. 
Instead of selecting for arialysis only certain questions asked in the iriterviews, hawever, a decision was made to read all interviews in their entirety, arid to note and code al 1 commerits relevarit to the research problem. These comments were recorded as to their position with regard to each of the pattern variables as operationalized in the analytical model (see Chapter VI).

The decision to analyze the interviews ir their eritirety was made for two reasons: (1) because cif the appeararice of commerits relevant to resporidents' role expectations for the provider of quality terminal care throughout the iriterviews, arid not just in response to particular questions, and (2) because of a desire an the part of the researcher rat to take interviewees' comments out of context. As a result of the freedom of response al lowed through the cpen-ended resporise format, interviewees accasiorally would answer a question priar to its being asked. To avaid the boredom and impatience which would result from asking responderits to repeat themselves later in the iriterview, these out-af-sequence resporises were rioted by the iriterviewer and the question was nat asked except wheri clarification or elaboration was felt to be recessary or desirable. The reverse of this situation occurred as well: irterviewees frequently remembered things that they should have mentioned earlier, or a thought came to mind and they wished to express it then, regardless of its relevarice at 
that time. Also, sometimes the response given to one question was actualiy much more pertinerit to another. After all responderits' relevant comments were coded, they were aggregated by resporident group: patients, families (including families whose relatives were living at the $t$ ine af the interview as well as those whase relatives had died within six months prior to the interview), and health professionals fthe administrators arid the program staff were conbined to form one group).

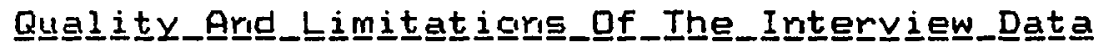

The interview data brought to bear on the questions posed in this study are exceedingly rich in detail and breadth, providing the perspectives of proyiders actively involved in the provision of terminal care as well as thase of termirally ill patients and family members af gravely ill or recently deceased patierits. The quality and the limitations of the data gererated in this study are related to the (1) respordent selectior, (2) instrumentation and data callectior, and (3) analytical procedures used. Specifically, caution is required in interpreting the findings and generalizing from them due to the non-rardon nature of the respondent selection process, the use only of verbal self reports of the resporidents arid the lack of behavioral ciata, and the open-ended format of the instruments. 


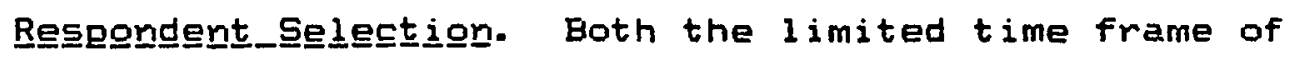
the study and cost considerations precluded the use of raridom selection procedures either for programs or for individual respondents (patients, fanilies, and providers). Random selection of patients and families was not feasible because of the relatively short time frame within which iriterviews were to be conducted and the small number of patients in a program at any give time likely to fit the study criteria. Random selection of family members who had been recently bereaved was deemed too time consuming. The represeritativeriess of the respondents interviewed, therefore, carnot be assured.

The responderit selection procedures chosen, however, did attempt to maximize the likelihood of identifying a range of individuals with a wide variety of perspectives caricernirg the provision of quality care for terminally ill older people. Professionals of various disciplines who were irivolved in the provision of termiral care (physiciaris, nurses, aides, social workers, and clergyl as well as patients and families (some who had had relatively positive and others who had had negative care-related experiences), were to be interviewed. Furthermare, inclusion of the "care had gone well/care had not gone well" criterion was felt to be a more useful and practical approach to obtaining views of "quality" terminal care which would be based both on 
positive and negative experiences than a random selection procedure.

Nonetheless, there was a possible bias taward persors least likely to be critical of care in a given program, iri that resporiderits were to be identified by the pregram administrators because of their krowledge of the staff persons most involved in providing temminal care arid of the patients and families who would meet the criteria. For the most part, though, havirg the administrator er their designee select the resporidents did rot seem to result ir orily favarable comments about the care; providers arid recipierits of care (patients and families) alike seemed quite cardid and willing to relate shortcomings as well as positive aspects of care. There were cases in which e르느 of the two patierits, family members with ill relatives, arid farnily members whose relative had recently died of a terminal illness seemed to be perscris whose care-related experiences appeared, or the whole, relatively pasitive, Gr, conversely, negative. Rather thar being ar iriteritional disregand of the study criterior of orie resporiderit for wiom care had gorie well arid one for whom care had ricit gore se we11, more ofter this deviatian seemed to have ciccurred because of an atternpt to satisfy the other criteria. Ever, thase were not rigidly adhered to, with the most obviaus example being the identification of patierts or family members of patierits younger than 60 years of age, 
particularly in programs which provided care to a very small nurnber of terminally ill patients.

Another problem with having respordents selected and apprcached initially by the progran admiristrator or staff is that the exact rumber of persoris who were corisidered but riwt approached for some reasori, or who were appraached but who refused to participate, is unknowr. The selectors did not indicate difficulties in obtaining agreenerits to be interviewed once individuals were asked, but again, those who might have refused may not have been approached. Ir a few cases, we were referred to potential resporidents without their havirg been apprised of the study; these perscirs were a bit apprehensive at the outset, especially about sigring the form indicating their informed consent to participate in the research.

It should also be pointed cut that, as would be expected in research in which very ill people are to be interviewed, some interviews which had been arranged with patients had to be rescheduled or another patient selected because the first became unable to resporid due to a serious deterioration in condition or, in a few cases, death. Most of the patierits who were interviewed ar whase care was described by a family member had a primary diagrosis of cancer. Ir that the desigration "temmirally ill" usually is applied to victims of cancer, hawever, and mast prograns being developed specifically ta serve the 
"terminally ill" are targeted toward persors having carcer, this is rot viewed as a 1 initation of the study. No special efforts were made to maximize demagraphic differences among respondents arid no sciciaecaramic data were gathered formaliy for ary of the responderit groups; however, a fainly broad range of firancial statuses, levels of education, and occupations seemed to be represented anong the participants. With the excepticin of some respondents who were Jewish, however, no members of ethric or racial mimorities were interviewed. Thus, the results with respect to the role expectations held for health professicinals providing termirial care may be somewhat culture-bound.

Two final respondent selection issues should be roted. First, the data were gathered with the quality af temirial care given priricipally to the elderly (persoris age 60 arid olderl in mirid. This is not viewed as a serious Iinitaticir, however, as the greatest proportion of deaths ir the U.S. (approximately four-fifths) are of persoris over the age cif 65 (Halper, 1979). Second, only programs providing terminal. care in urbar areas were included. Again, as the bulk of health care, especially specialized health care, is provided in urban settings, this is not viewed as a 1 initation of the Etudy.

In gerieral, the persons with whom we spoke were very open and willing to describe their experiences and feelirigs about the various care settings and providers. Most of the 


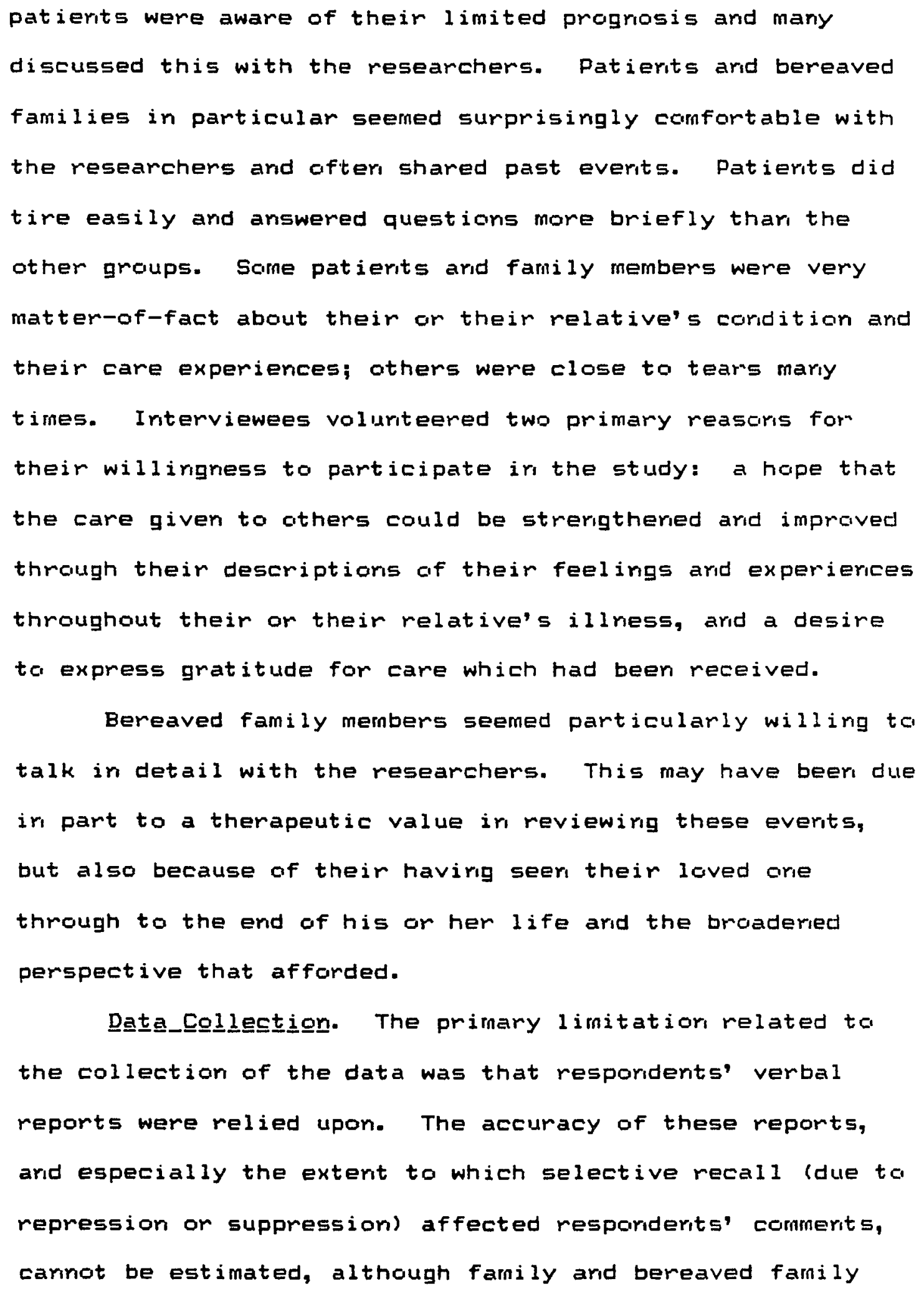


members, accounts of the various experiences with care they or their relative had had usually were quite vivid arid appeared to be fairly compreherisive.

Some professiorials commerited that they wished they could have had more time to consider their responses; for these persaris, a mail questiorraire might have beeri more suitable. A loss of completeriess and clarity, as well as a lower rumber of resporises, inight have resulted, however, had the questionnaire been mailed. Also, the value of persorial commurication and presence in the care setting carrot be overstated in research of this type.

The use of the open-ended question format geriemaliy seemed to be appreciated by all respondents, although some people did remark that certain questicirs were "hard." This farmat was $v$ iewed by the research team as that most appropriate ard useful given the exploratory rature of the study, but it did pose some prablems both in terms af conductirig the iriterview itself (questiors were scinetimes answered before they were asked) and in arialyzing the data, as discussed below.

Firialy, the instrument did contain a "checklist" which listed various statements carcerning the provision of care to seriously ill people and asked respondents to rate how much each item "mattered." Unfortunately, the checklist as a whole proved to have a number of deficiencies. First, it was too long. Second, it was biased taward the hospice 
model of care; that is, all items contaimed wording carsistent with haspice principles. Third, it asked respondents to indicate the importance of each item lhow much each mattered), which was a somewhat corifusirig format. Should such a checklist be used in the future, it could be much improved through decreasing the number of items, wording some statemerts to be consistent with the medical model orientation to health care, arid asking responderits to indicate the extent to which they agreeg with each statement. Fourth, certain iters, or statements, posed problems in that they coritained words that were iriterpreted differeritly by the various respondents, such as ore which referred ta "services."

Despite the deficiericies of the checklist, it did serve to elicit some interesting and enlightering comments. Therefore, a decision was made to use in the analysis orily those pertirient explanatory remarks made in resporise to the item or the checklist, ngt the ratings of importarice assigned by mespondents to the various items.

Datta_Analy $\underline{\text { șis. }}$. The primary difficulty associated with open-ended questioning is the reliability of the analysis. As detailed previously, the analytic method chaser for the purposes of this study was content arialysis. Iri cartent analysis, the reliability of a study is a function of both the judge(s) or coder(s) and the categories irito which data must be classifed. Affectirig the reliability of the 
cader(s) is the type of units desigriated to be coded. When these urits are "ratural," (e.g., a word or a paragraph), few problems arise; when the units are themes, as in this study, codirg is more difficult because of the lack of physical guides to distinguish one urit, ar theme, from ariother.

The secorid step in content analysis, arid the secorid area in which reliability can be problematic, is the decisian concerring the category irita which the urit is ta be placed. As Holsti, et al. (1968:658), poirit aut:

Reliability of classificatior is largely a furcticir of category definition and the types arid rumbers of discriminations to be made... fime discrimiraticis between categories ofter result in a high inciderice of disagreement. After pretestirig, the irivestigatar may aggregate such categories, but this appraach is applicable orly if the fine distinctions are rict of major theoretical sigrificarice.

They go ori to say that, paradoxically, "As categories ard units of analysis become more complex, they are likely te. become both more useful arid less reliable" (Holsti, etal., $1968: 660)$

The validity of the data also should be discussed here. Holsti, et al. (1968) state that normally, if the data serve as a direct answer to the research questior, as is the case at least partially in this research, rather thar as indicators of characteristics to be inferred, ard if the purpose of the research is a purely descriptive one, coritent, or face, validity is sufficient. Conterit validity 
usually is established through the informed judgment of the irvestigator. In that the firdings appear to be plausible and in keeping with what might have expected, they are felt to have coritent validity.

Summary. Ir sum, there are certain drawbacks in the methodological procedures used in this study, including the fairly small number of cases $(N=94)$, the respondents riat having been selected rardomly, a few iristarices in which the selection criteria were not rigidly adhered to, the use of self-report rather than behavioral data, and the use of open-ended questions and the performarice of conterit aralysis. At the same time, the research was exploratory in nature, and the design employed yielded data very rich in detail, from persans receiving or giving terminal care ir a rarige of urban programs. It is felt that the data are exceedingly rich arid provide a reasoriably compreherisive view of the types of role expectations held by patients, families, and health professiorals for the ideal provider of quality terminal care. 


\section{CHAPTER VI}

ANALYTICAL MODEL

The analytical model developed as part of this research is derived from and comprised of Parsoris' (1951) pattern variables, which were first referred to in Chapter II and then discussed briefly in the first section of Chapter V, Research Design arid Methods, Phaaㅡ르르

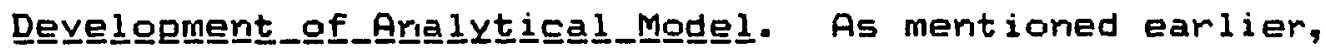
these pattern variables offer a framework for viewirg the role expectations associated with the health professional rale in the provision of quality terminal care. A description of the pattern variables is preserited below. Ar elaboration of the analytical model developed for this research theri follows.

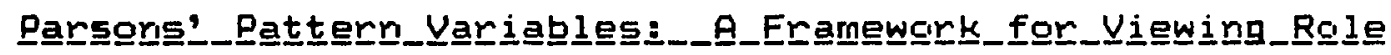

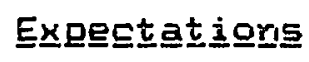

One framework for viewirig the expectations assaciated with a role is that developed by Parsons (1951). His "system of types of possible patterr variables af role definition" (Parsons, 1951:66) consists of five coriceptpairs or polar alternatives. The five corcept-pairs are: 
(1) affective neutrality--affectivity; (2) specificity-diffuseness; (3) universalism--particularism; (4) achievement-orientation--ascription--orientation; and (5) callectivity-arientation-self-orientation. (See Figure e.)

Parsons views the pattern variables as beirg interrelated and not as simply constituting a list. He states that the concept-pairs revolve about ari axis which has two poles: motivational orientation and cultural (value) orientation. Two of the patterr variables (universal ism-particularism and achievemerit-ascriptiori) are of particular relevarice to the value-orientation pole; two are of particular relevance to the motivational-orientation pole (specificity-diffuseress ard reutrality-affectivity); and the fifth is "neutral" between then collective-self orieritation) (Parsors, 1951:102). There are 32 possible combinations of polar values of the five variables. These variables enable categorization of the normative demands on roles.

Turner's (1974:36) description of Parsoris's pattern variables and their meaning is a particularly clear ore and is reproduced below:

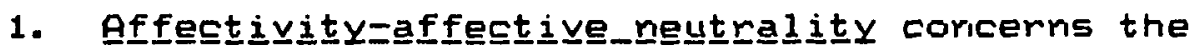
amourit of emotion or affect that is appropriate in a given interaction situation. Should a great deal or little affect be expressed?

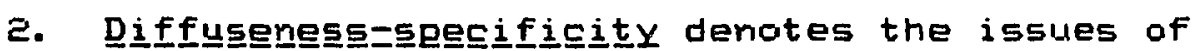
how far-reaching obligations in an interaction 
Neutrality vs.
Affectivity

Specificity vs.

Universalising vs.

Achievemerit vs.

Collective vs. Self Orieritatior

Eigure_e. Parsons' pattern variables.

$\stackrel{5}{5}$ 
situation are to be. Should the obligations be narrow and specific or should they be extensive and diffuse?

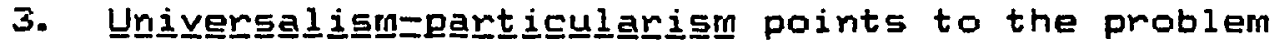
of whether evaluation and judgmerit of others in an interaction situation is to employ staridardized and agreed-upor criteria or subjective stardards. Should evaluation be performed in terms of objective, universalistic criteria or in terms of more subjective, particularistic standards?

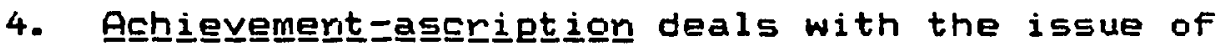
how to assess an actor, whether in terms of performance or on the basis of inborn qualities, such as sex, age, race, and family status. Should an actor treat another on the basis of achievements or aseriptive qualities that are urrelated to performance?

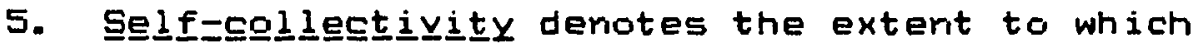
action is to be orierited to self-interest and individual goals or to group iriterests and gaals. Should an actor consider his personal or self-related goals over those of the group or larger collectivity in which he is involved?

Parsons (1951) has applied his pattern variable

framework to the role of the physiciar. As he states, this

role belongs to the genemal class of "professional" roles, a

sub-class of the larger group of accupatianal roles:

As an occupational rale it is institutionalized about the technical content of the function which is given a high degree of primacy relative ta other status-determinarits. It is thus inevitable both that incumbency of the role should be achieved and that performance criteria by standards of techrical competence should be prominerit...

In common with the predominant patterns of occupational roles generally in our society it is therefore in addition to its incorparation of achievement values, universalistic, furicticnally specific, arid affectively neutral. Urilike the role of the businessmar, however, it is collectivityorierited not self-oriented... 
There is ar intrinsic connection between achieved statuses and the requirements of $h$ igh technical competence, as well as universalism arid cornpeterice...

High technical competerice also implies specificity of furiction. Such intensive devotion to expertness in matters of health arid disease precludes comparable expertness in other fields (Parsons, $1951: 434-435)$.

With regard specifically to the pattern variable affectivity-neutrality, he asserts that:

The physician is expected to treat an objective problem in objective, scientifically justifiable terms. For example whether he likes or dislikes the particular patiert as a persor is supposed to be impelevant, as indeed it is to most purely cbjective problems of how to hardle a particular disease (Parsons, 1951:435).

Concerning the physiciar's collectivity orieritatior,

Parsons (1951:435) notes:

The "ideology" of the profession lays great emphasis on the obligation of the physician to put the "welfare of the patient" above his persorial interests, and regards "commercialism" as the most serious and insidious evil with which it has to contend... The "profit motive" is supposed ta be drastically excluded from the medical world.

In sum, the role of the professional, which includes the role of physiciar and that of nurse, is, accordirig to Parsons and in terms of the pattern variables, characterized by affective neutrality, specificity, universalism, achievement, and collectivity orientation.

For the purposes of this research, these pattern variables have been operationalized through the identification of one or more "indicators" of each of the five pattern variables, as described in the first section of 


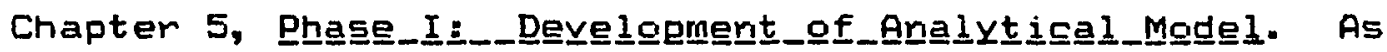
roted earlier, these indicators were developed through a review of the literature describing the medical and the hospice models of care. Parsors' (1951) application of the pattern variables to the role of the physician, as an example of the general class of professionals, which is a sub-class of the larger groups of occupational roles, resulted in the characterization of the role of the physician as affectively neutral, specific, uriversalistic, achievement-oriented, and collectivity orierited. It is this last quality that, Parsons (1951) asserts, differeritiates the professional from other occupatioral roles.

Descriptions of the rale prescriptions and expectations for the professioral within the medical medel parallel Parsons' characterization of the medical practitioner (or, in general, the professioral) role; that is, the role of the professional in the medical model is affectively neutral, specific, universalistic, achievement oriented, and collectivity oriented.

The professional role within the hospice model of care can be seen to differ dramatically in pattern variable terms from that within the medical model. Based on the principles of hospice care as described in Chapter 2 , the hospice professional role would have tendencies toward the following characteristics in pattern variable terminology: affectivity, diffuseness, particularism, ascriptior, 
orientation, and collective orientation. In other words, the professianals within the two models appear to differ in all aspects of their roles except in their collective orieritation, which is the one characteristic that Parsoris argued differentiated professionals from other occupational roles.

Table III depicts the role dimensions, or the poles of each pattern variable, as prescribed by (1) the medical madel, arid (2) the hospice model. Again, it should be remembered that parsons sees the patterr variable alternatives as polar concepts denating extreme points af variatiari alorg a continuum. It is appropriate, therefore, to speak of a role with expectations having tendencies toward affective neutrality, universalism, specificity, achievement, ar collective orieritatiori, for example. As explairied by Parks (1967), the role expectations prescribe the morms of choosing certain pattern variable alterratives, that is, of choosing these alternatives in a significant propomtion of the situations ericountered ir that role. This characterization of the role of the hospice professional, especially, however, may be too simple. A more accurate description requires elaboration and modi-fication of Parsons' pattern variable framework. Specifically, "indicators" in which the pattern variables are operationalized to have particular mearirig in this research problem are required. 
THE MEDICAL MODEL VERSUS THE HOSPICE MODEL: CATEGORIZATION BY PARSONS'

PATTERN VARIABLES

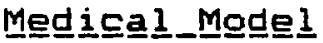

Affective Neutrality

Uriversalism

Specificity

Achievemerit

Collective Orientation

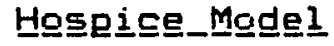

Affectivity

Particularism

Diffuseness

Ascription

Collective Orientation

In additian, within this elaborated framework, bath polar extremes of one of the pattern variables may be viewed as descriptive of the role expectations of the hospice professional. This variable is achievement-ascriptior. In hospice care, there is a clear role for lay people, including the patierit and the family, who participate by virtue of their ascribegd role or status, and voluriteers, who may or may rot have exterisive professioral training. At the same time, the haspice physician or nurse is crederitialed ard has achhiev를 his or her role through specialized education and training. Furthernore, this professional is expected to achieve a goal: comfort and enhanced quality of life for the patient. This goal, while different from the goal of 
the professional providing care within the medical model (life prolongatiori), is, noretheless, a goal requiring sophisticated technical skill; as such, it may be viewed as represeriting an achievemerit orientation.

On the next several pages, the analytical model which was developed as part of this research is preserted. The model is presented first in tabular form in Table IV. Table IV depicts: (1) each of Parsons" pattern variables (rumbered and in capital letters); (e) the simplified rame used ta refer to this patterr variable (in pareritheses); (3) the name of the indicator developed (numbered and lettered); and (4) the two opposite poles of the indicator (left=1, right= 2). Generally, for both the pattern variable alternatives arid their indicators, pole 1 represerits the role prescription for the doctor or nurse under the medical madel (arid also those alternatives stipulated by Parsoris as thase indicating the role expectations for the "professional" role). Pole 2 represents the role prescription urider the hospice model. Exceptions to this are roted by ar asterist. arid are explained in detail in the following rarrative description of each iridicator, which follows Table IV. Ir, this description, each of Parsons' (1951) patterr variables is listed, followed by a description of the operational indicators, or variables, developed as a part of the preserit study specifically for definition of the role of the health prafessional in the provision of terminal care. 
TABLE IV

ANALYTICAL MODEL: INDICATORS OF PARSONS' PATTERN VARIABLES

AS THEY PERTAIN TO ROLE EXPECTATIONS FOR THE PROFESSIONAL PROUIDER OF TERMINAL CARE

1. AFFECTIVE NEUTRALITY---AFFECTIVITY

(Referred To As Affectivity Variable)

1A: Affective Involvement:

1. Neutral Affect/No Emoticnal Involvement

2. Positive Affect/Moderate Emotional Involvement.

z. SPECIFICITY-DIFFUSENESS

(Referred To As Diffuseress Variable)

EA: Scope of Care

1. Provision of Physical Care

2. Provision of Holistic Care

EE: Unit of Care

1. Patient Is Uritt of Care

2. Patierit And Family Are Unit of Care

ZC: Availability of Care

1. Limited Availability

2. Unlimited Availability

3. UNIVERSALISM--PARTICULARI SM

(Referred To As Particularism Variable)

3A: Care Approach

1. Generalized Care

2. Individualized Care

4. ACHIEVEMENT-ORIENTATION--ASCRIPTION ORIENTATION

(Referred To As Ascription Variable)

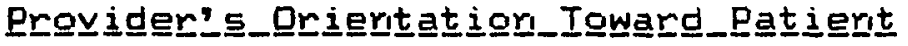

4A: Goal of Care

1. Goal Is Life Prolongation

2. Goal Is Comfort, Quality of Life*

(Cont i nued) 
TABLE IV, Continued

4B: Pain Cortrol Practices

1. Drugs Given As Needed (Intermittent ly)

2. Drugs Given At Regular Intervals

4C: Patient Irivolvement

1. Patient Not Involved

2 Patient Is Involved

4D: Family Involvement

1. Family Not Involved

2. Family Is invalved

4E: Volunteer Involvement

1. Volunteers Not Involved

2. Volunteers Involved

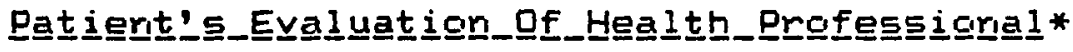

4F: Criteria For Evaluating Health Professiorial*

1. Performance Criteria Used

2. Ascribed Characteristics Used

5. SELF-ORIENTATION--COLLECTIVITY ORIENTATION**

(Referred To As Collectivity Variable)

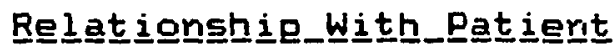

5A: Motivation of Health Professional

1. Professional's Welfare First

2. Patient's Welfare First

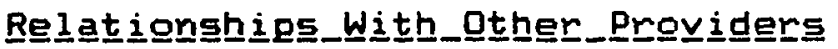

5E: Interprofessional Commuricatior, Collaboration

1. Separate Professionals, Minimal Communicatior

e. Professionals Communicate, Collaborate As

Team

5C: Interprofessional Decision-Making

1. Hiemarchical Decision-Making And

Relationships

2. Egalitarian Decision-Making And Relationships

* Indicates left-hand pole (pole 1) may represent the role

of the health professional under the hospice model, instead

of the medical model

* Indicates both models' role prescriptions may be righthand pole (pole e). 


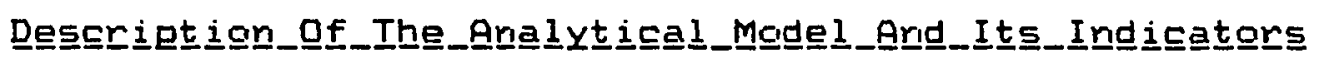

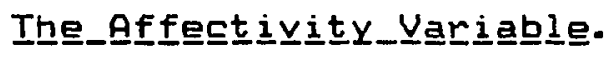

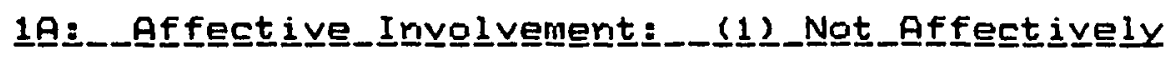

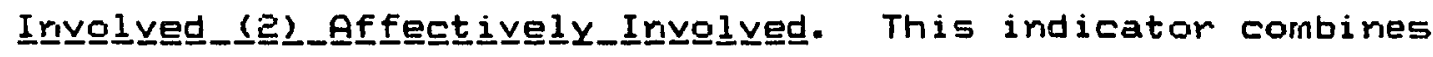

Parsons' (1951) Affectivity pattern variable and Williams'

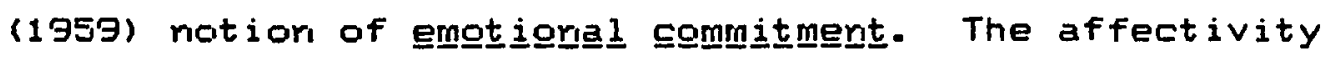

pattern variable concerris the exterit to which it is

appropriate for the physician or nurse to express enotion or

affect in his or her role, such as in interaction with the

patient or family (Turner, 1974). Ariother way of

conceptualizirig this is offered by 01 ser (1978), who states

that actors who are affective attend to their own and to

others' feelings, and the interaction is on a persciral

basis. The iriteraction between actors who are affectively

neutral is or ari impersonal basis.

Williams (1959) states that the affectivity pattern

variable represents a role expectation as to the exeress

of affect. He argues that neither this pattern variable ror-

any of the other four covers the aspect of affectivie

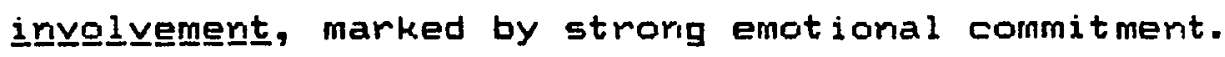

It should be noted that Parsons himself later added an

additional pattern variable to his original scheme:

instrumental-expressive (Parsons, 1953, "Same Commerits ar

the State of the General Theory of Actior," American

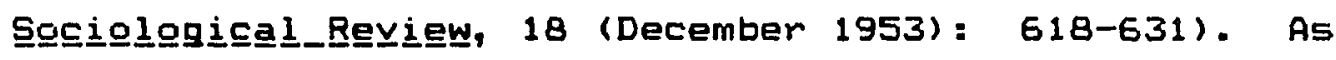

01 sen (1978:83) writes, this pattern variable describes: 


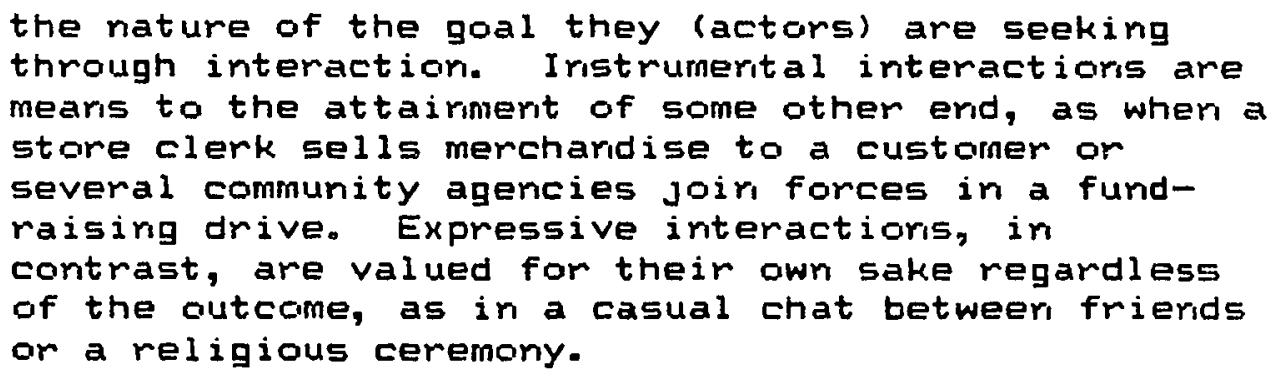

Williams' (1959) notion of emotioral commitment could conceivably be considered within this instrumentalexpressive variable, but Parsors himself, iri his later writings, seems to have abandoned the concept as canstitutirg a patterr variable. Iristead, he employed it in his broader "theory of actior" framework (see, for example, Parsons, 1950, "Pattern Variables Revisited: A Resporise to

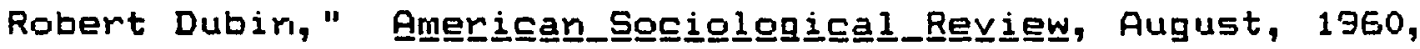
$25,4,467-483)$. Furthermore, no empirical applications of the pattern variable framework which used this sixth variable could be found.

In the opinion of this author, the corcepts "expression of affect" and "emotioral involvement" do not represent separate dimensions of role expectatiors, requiring, in esserice, a sixth pattern variable. Rather, they represent a continuum of affect. For the purposes af the present research, therefore, the two concepts of affectivity and emotional involvement were combined. Also important to note is the fact that while Parsciris' pattern variable framewark generally consists of a left and a right pole which are diametrically opposed to orie arictier, 
this particular indicator, even as coriceived by Parsors, differs from that model. The affectivity pattern variable has as its left pole (pole 1) not negative affect but reutrality. This deviation is easily uriderstood both ir this context of expectatioris for the health professiorial role as well as expectations for other roles. Logically, negative affect probably would be undesirable on the part of a professional or nonprofessional.

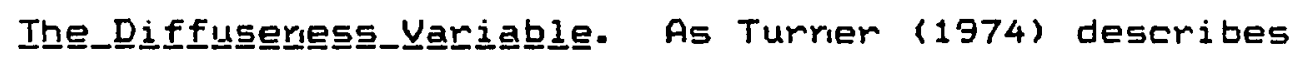
it, the specificity-diffuseress pattern variable concerris the issue of whether obligations in the interaction situation should be narrow arid specific or exterisive arid diffuse. Three indicators of specificity-diffuseress were identified as relevarit expectations associated with the role of the professianal provider of terninal care.

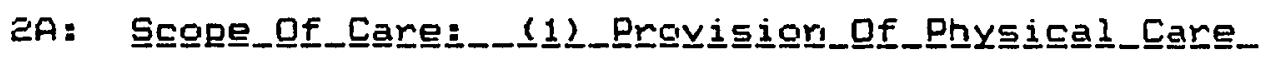

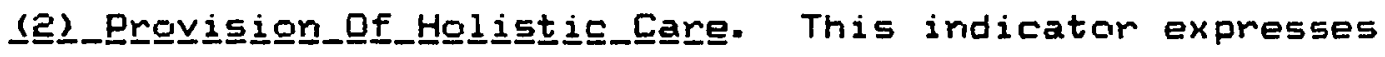
whether the provider attends only to the patient's physical care needs or whether he/she attends to the broader emotional, psychasacial, and spiritual needs of the patierit as well as the physical needs.

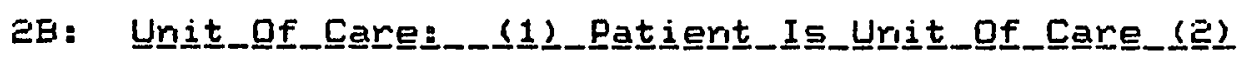
Patiennt/Farnily_Is_브느_of_Care. Determined here is whether the provider gives care just to the patient or whether the needs of the patient's family also are addressed. 


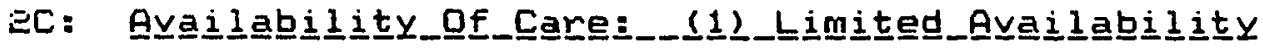

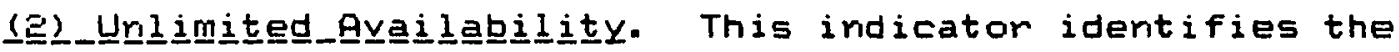
exterit to which the provider is available and accessible to the patient. While most physicians can be reached by telephone, the degree of difficulty and the rapidity with which this is accomplished can vary considerably arid coritribute to a perception either of accessibility or iraccessibility. Iricluded in this category is the expectation coricerring how much checking or or visitirig of the patient is done (whether the patient is in ari irstitutional settirg such as a hospital, rursirg home, or inpatierit hospice, or at home with the aid of a hame health program) arid how often the patient is seen by the primary provider (usually the physician).

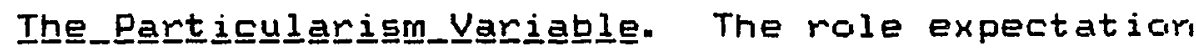
which is "universal" is generalized, where ego (the actor) has no particular relationship with alter (the object) (Parsoris, 1951). 0lser (1978) differertiates the poles of this pattern variable in terms of whether the interaction follows a standard patterr (universal orientatior) or is unique to that specific situation (particular orieritaticn). In other words, this pattern variable examines the degree of reflection of existing norms and practices; if standard norms and practices exist and are followed, regardlesss of the object's specific situation (needs, individuality) this is a universalistic orientatior. Generalized, or stardard, 
care (universalistic orientation) is the rorm for

professional behavior (Parsons, 1951).

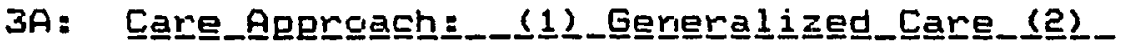

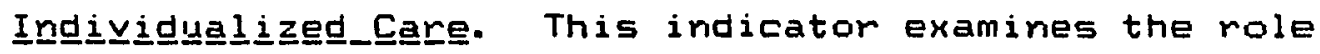
expectation with respect to whether the treatmerit given to one patient is expected to be essentially the same as that given to all patients (generalized care) or whether the expectation is that the care be tailored to meet the various particular reeds of each patient (individuelized care).

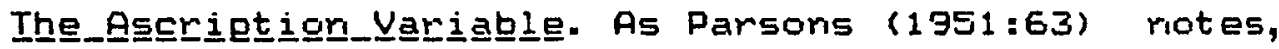
three of the pattern variables caffective reutralityaffectivity, self- collectivity oriented, and universalistic-particularisticl refer "to ego as actor," ir. this case, the physiciar or rurse provider of termiral care. One (specificity- diffuseness) specifies the "scope of ega's 'interest' in the object," arid the fifth (achievernentascription orientation) describes the "characteristics of social abjects thernselves, that is, from ego's poirit of view of the alter in the complementary role-orientation structure or to ego himself as an object" (Parsons, 1951:65 and 63). In other words, this pattern variable concerns not anly the physician's or nurse's view of the patient, but also the patient's view of the physician or nurse.

Turner (1974:36) points out that the achievemeritascription pattern variable deals with the issue of how ar, object (the health professional, here) is_tto_be_assegs 
that is, in terms of (1) his or her performance or (2) on the basis of inborr qualities. Mayhew (1968) ard Parsons himself (1951) would probably take exception to the adjective "irborr." Parsons defires ascription in terms of what the object is, iricludirg being "a physician" (Parsors,; 1951:64). They argue that this pattern variable refers to classification of the treatment of other actors (like universalism-particularism): when the other is treated eritirely with reference to his or her fixed positigri in ar established social structure, li.e., being a doctar ar a runse) or wher he or she is categorized in terms af his or her qualities, this is ar ascription orientation. As Parsoris (1951:64) puts it:

The major focus of a particular role-expectatiori... may be what the object is in this serise, e.g., that he is ego's father, that he is a physiciar, or that he is cover six feet tall... This (quality) may be the criterion for differentiation of treatment and af expectatiors of his behavior.

Alternatively, an orientation that focuses on the actor's performarice (past, preserit, or future), that is,

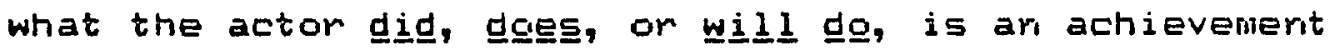
orientation (Mayhew, 1968). Expectations are orierited ta the actor's effectiveness on success in achievirg particular goals or performances (Parsons, 1951).

In sum, the "actor" or "object" in this situation may be eiㅡher ego (physician, nurse) or alter (patient) (Parsons, 1951:64). An achievement (or performance) 
orientation can refer to the performance either of the physician ar the nurse, or of the patient or the patient and the family. Similarly, an ascription for personal qualities or characteristics) orientation can refer to the characteristics of either ego or alter.

Arid herein 1 ies one source of confusion with regard to this pattern variable. The role expectation may be examined from the perspective of the physician or rurse focusing on the patient, ar from the perspective of the patient focusing or the physician or the rumse. The difference betweer the twis perspectives, then, is whether the focus is or alter, the other (the patient) and how he or she is to be treated, or or ego, the role iricumberit, (the physician or nurse) arid how he or she is evaluated.

The simplest way to defire and operatioralize this pattern variable, arid the most consistert with the facus of the other pattern variables, is in terms of how the physician or rumse is expected to treat the other actars ir the interacticir (the patiert, the family, voluriteers). The first five indicators of the achievement-ascription patterr variable demoristrate this perspective. The sixth and last iridicator demonstrates the secorid perspective, how the physician or rumse is evaluated by the patient. 


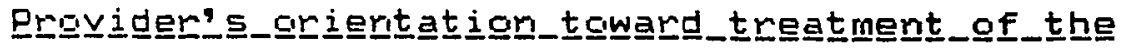

르트르르른

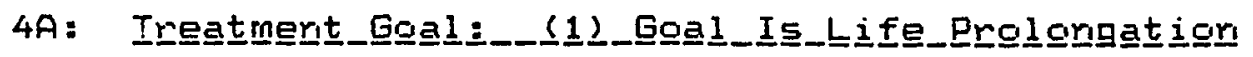

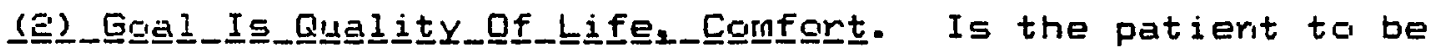
treated with a goal of life prolongation in mind, or with the patient's confort and quality of life in mind? These differerit goals can be lacked at as represeriting the two apposite poles of this pattern variable, or simply as differerit aspects or possibilities withir ore pole. Ar argumert is made here for viewirg them as two apposite poles.

Treatmerit cif a patierit as though it is possible that he or she could or should, with proper treatment, live through the illness implies ar agchievengent_orieritatig toward the patient on the part of the provider. The expectation is that the patient will perform, will resperid to treatmerit, arid at least maintain the current level of health, if rot get better. The treatmerit is aggressive arid cure-amierited, and the goal is life prolargatiar.

Treatmerit of a patierit with ar eye taward Iife quality rather than life prolorgation implies an acceptarice of the disease as a termiral ore, arid as a quality, or attribute, of the patient. The patient who is terminally ill will rot, by definition, regain his or her health. Rather than expecting the patient to do so (achievement orieritatiori), the termiral illriess comes to be seen as ari 
attribute of that patierit, and the provider is expected to treat the patient on this basis. This implies an ascribed orieritatior. At the same time, this terminal status is not viewed with an attitude of there being "rathirig mare to do." What is ta be dore, the treatment goal, simply is different: comfort arid quality cif life.

It could be argued, then, that ir both the hospice arid the medical model, the professional role is achievemeritarierited, that one differerice betweer the expectations for this role in the two madels is simply the existence of differerit goals. However, because the bas difference in treatmerit goals is the patient's quality, or ascribed status, of being terminally ill, depiction of the haspice madel's prescriptian for the role of the provider of

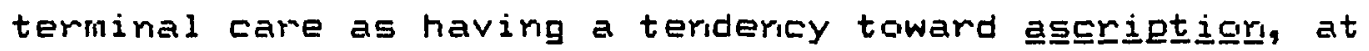
least in this indicator, seems most accurate.

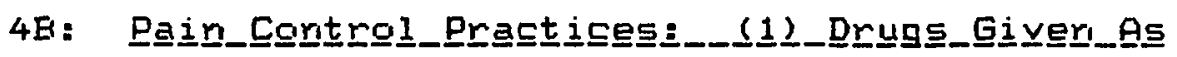

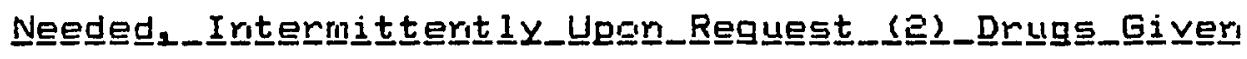

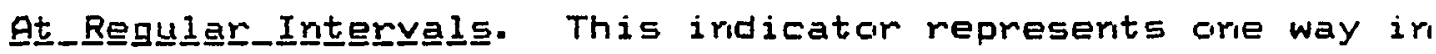
which the provider's treatment orientation (Iife prolorgation versus quality of lifel is manifest. Because of the number of references to pain medicatior practices, both in the literature on care of the dyirg arid in the irterviews with patients, families, arid providers, this was included as a separate indicator. 
Pair medicaticr may be given on an as needed basis, that is, as is felt recessary by the nurse or as requested by the patierit (pole 1, medical model). Alterratively, it may be giver regularly, such as every four hours (pole $Z$, haspice madel). Providers subscribing to the medical medel far care afteri feel the latter practice leads ta rarcatic addiction and are meluctarit to give pair medicatior or this basis. These providers gerierally are concerned with prolcrging their patierit's life (Indicator 4A: Treatment Gaal). Dther providers (i.e., hospice prafessiarials), guided by their treatmert of the patient's termiral illress as ari ascribed quality arid their coricerr for the patierit"s comfort arid quality of life, administer pain medicatior regularly sa as to coritral the patient's pairi adequately, erablirig him or her to furction as nommally as passible arid eriharicirg the patierit's quality cif life.

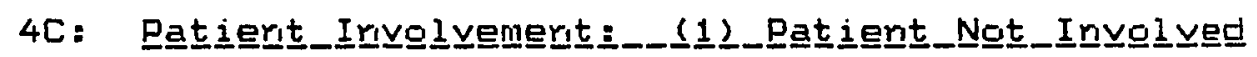

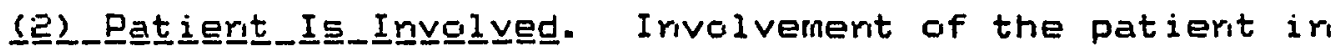
care-related decisiors implies treatmerit of the patierit from an ascribed orientation, as the patient is irivolved rot as a result of his or her competerice or performarice as a previder of health care but irstead, because of his or her ascribed status as a patierit, arid as orie directly affected by this care.

The cpposite pole, no involvemerit of the patierit ir care-related decisions, implies an achievemert orientation. 
The professiarial provider "krows best," and it is in the patierit's best iriterest to let that provider administer all treatmerits he or she believes to be effective and to make al 1 care-related decisioris.

Ar importarit factor eriablirg arid indicating patierit participation on nonparticipation in the care is carnmuricatior. Is the patierit iriformed, for example, of his or her progriosis and af the provider's treatment plans?

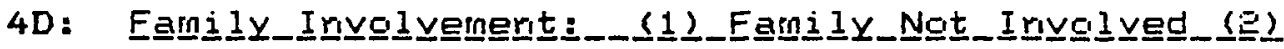

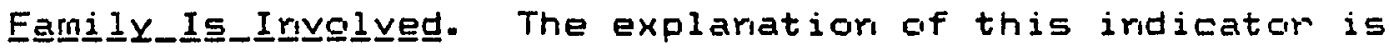
the same as that for the above irdicator of patierit participation or non-participatior in the care.

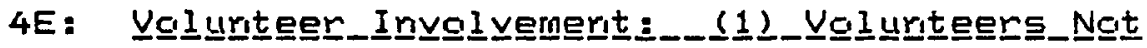

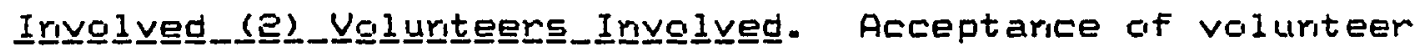
irivolvemerit in the care implies an ascriptiori-corierited role expectation. Volunteers may or may not have professional trainirig, but are involved because cif some perscrial attribute such as desire to help. Nonacceptance or nonutilization of volurteers ir the care implies an achievement orientation: no one but the health professicinal is seer as capable or qualified to provide this care.

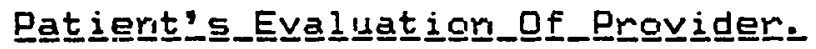

As detailed earlier in this subsection describirg the iridicators of this patterr variable, achievemert-ascriptior, the second perspective within this pattern variable is that of the patient and how he or she evaluates the provider. 


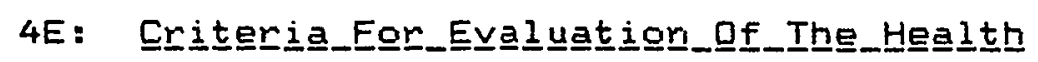

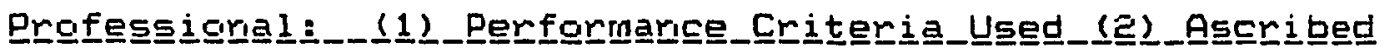

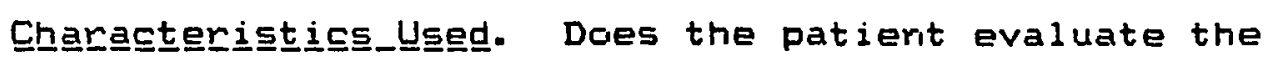
provider in terms of the provider's perfommance (achievemerit orientation) or in terms of his characteristics or qualities (ascribed orieritation)? That is, are the providers evaluated as "competent," "good," or "knowing what they' re doing," (achievenent arientation) or are they evaluated ar the basis of personal characteristics or status, such as beirg the dactor ("he's the doctor"), beirig "male," "female," or "physically strong" (ascription orientatiari)? As discussed earlier, the sick role, in which the patient is expected to accept and comply without question ta the health professional's orders ard decisions, is the corollary of the professional role in the medical model. It would seem that, as a result of this unquestioned compliance, evaluation by the patient of the professioral ir the medical model would be ascribed, based on who the health professional is, the characteristics of the health prafessiarial. Alterriatively, the hospice model would appear to prescribe an achievement orientation: the health professioral being evaluated by the patient in terns of the professional's performance, not simply his or her position as a doctor or rurse. In sum, the poles or this indicator seen to be reversed for the medical and the hospice models 
with regard to the role expectations prescribed for the health professicrial.

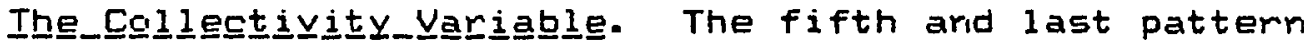
variable corcerris the permissibility of the actor's:

pursuing any interests "private" to himself as distinguished from those shared with the other members of the collectivity in which he plays a role... A role, ther, may defire certairi areas of pursuit of private interests as legitimate, and ir cither areas obligate the actor to pursuit of the common interests of the collectivity. The primacy of the former alterrative may be called "selforieritation," that of the latter, "collectivityorieritatior" (Parsoris, 1951:60).

With regard to the problem of role expectatiors for the provider of quality temirial care, there are two aspects of this pattern variable. The first corcerns the provider's relatiorship with the patient. The secord relates to the relatiorship of the provider with other providers.

This patterr variable represents a somewhat differerit level af arialysis, and it has frequently been drapped in empinical research concernirg the pattern variables (e. g., Williams, 1960). It is useful here, though, as the distinction seems possible, ever though both models are sometimes on the same pole.

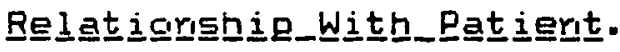

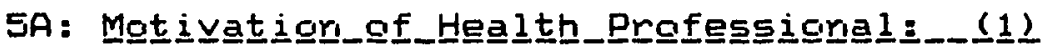

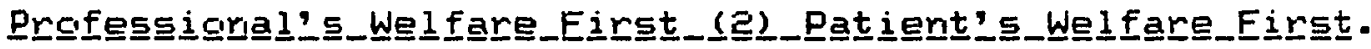
This is the iridicator in which the norms of both the medical model arid the hospice model appear to prescribe that 
professiorials have a collective orientatior. Thus, both madels fall on the collective-orierited pole. It may be, however, that the medical madel is less collective- oriented thar the haspice model.

Providers who are corcerned primarily with their patierits' welfare, who are dedicated to serving their patierits, have a collectivity, or service, orientatior. Thase who corsider their own self interests before thase of their patierits have a self orieritation (e.g., those who are members of the profession for profit matives, or simply because "it is a job").

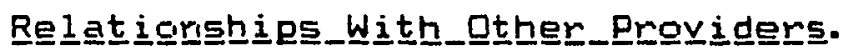

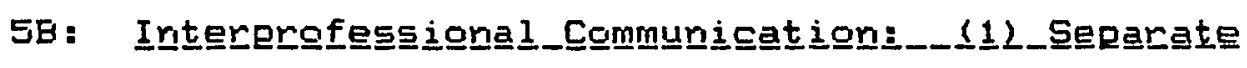

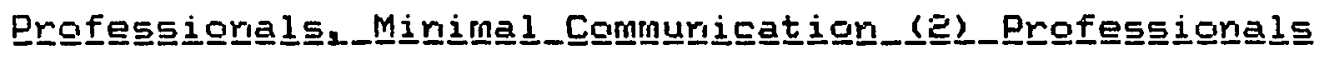

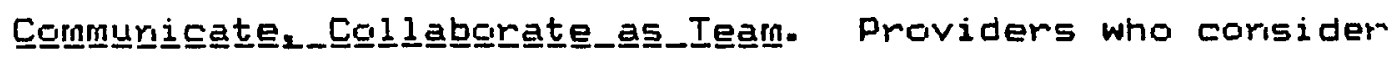
themselves as part of a team and who communicate with other providers involved in their patient's care are collectivityarierited. Providers who are separate, individual practitioners who do nat consider themselves as part of a care-giving team and who do not communicate with other providers who may be irivolved in the patient's care may be corisidered to be self-oriented.

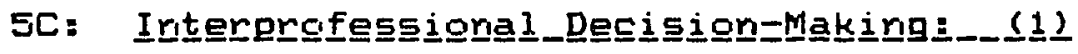

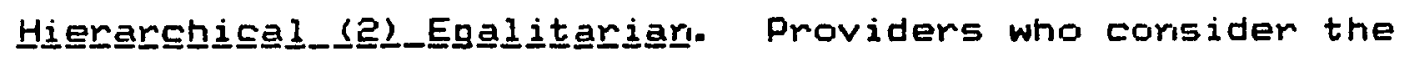
iriput of all team members equally demorstrate a collectivity orientation. Those who observe a hierarchical chain of 
commarid arid communicaticin amorg providers may be said to be se If-orierited.

Suㅡ므므로

This chapter has described the analytical model that was develaped for use in this research. This madel, ar, elaboraticir or ciperatioralizaticir, of Parsoris' (1951) patterr variables of role definition, was created for two purposes. First, it was to be used in classifying the role expectations to which physiciars and nurses, specifically, are socialized, as these are described ir the literature. Secorid, it was to be employed as the scheme for categorizing the role expectations held by a sample of terminally ill patients, family members, arid professional providers af termirial care who were interviewed in an earlier exploratory study of the definition of quality termiral care. Ir the followirg chapter, the firdirgs of the research are preserited using this aralytical model. 


\section{CHAPTER VII}

\section{RESULTS}

In this chapter are presented the firidirigs of the study. The three research questiors are addressed separately and in sequence in three major sections. Providing the structure for the analysis are the iridicators developed for the purposes of this research. As detailed ir Chapter VI, Analytical Model, these iridicators were derived from and elaborate on Parsons' (1951) patterri variable framework for the analysis af role expectatioris.

RESEARCH QUESTION 1: WHAT ROLE EXPECTATIONS ARE LEARNED BY PHYSICIANS AND NURSES THROUGH PROFESSIONAL AND WORKPLACE SOCIALIZATION, AND WITH WHICH MODEL FOR THE PROVISION OF HEALTH CARE, MEDICAL OR HOLISTIC, ARE THEY MOST CONGRUENT?

This question was addressed through a thematic coriterit analysis of literature in the area of socialization for the role of physician or nurse. The specific methods used for identifying the literature are detailed in Chapter $V$, Research Design and Methods. Particular attention was paid to literature focusing on the role expectatioris to which 
physicians and nurses are socialized with respect to care of the dying.

As described above, providirig the structure far this thematic content analysis of the literature are the indicators of role expectations that were developed as part of this study. The role expectations which are learried and held, first by physiciars, ther by numses, as these are reported in the literature, are preserited with respect ta each indicator.

To aid in the summarizing of the role expectatiors noted by the various sources reviewed, two tables, ore describing the role expectations reported to be learred and/or held by physicians, and one describing the role expectatioris reported to be learred and/or held by rurses, have been prepared for each indicator. Included on each table are four columns: (a) the author(s) and the date of the publication; and descriptions of (b) any normative rale expectations reported to be learned through professicirial socialization; (c) any role expectatiors said to be learred and/or held by the physician or rurse in the workplace; arid (d) the ideal role expectations in this domain from the perspective of the author (s).

Dne additional piece of iriformation is ircluded ir each of the last three colurns. As explairied in earlier chapters describing Parsons' pattern variables and the analytical model developed for this study, each iridicator is 
comprised of two poles. Orie pole, generally the left pole (or the "1" in this case), represents the rormative expectation consistent with the medical model of care. The other pole, generally the right pole (or the "2"), represents the role expectation consistent with the holistic model of care. In each of the last three columns $(b, c$, arid d), theri, a number represeritirig the pole of the expectatian described by each particular source is included. A key to the meaning of each number ("1" or "2") is at the head of each table. The presence of both numbers ("1-e") in a column means the source indicated a conflict in this rale expectatior. The absence of an entry in a columr mearis the source did not directly address that topic. Explaratory notes under the numbers are included where sources made particularly interesting poirits.

Finally, two master tables, orie relevarit to socialization for the physician role (Table $X X X I$ ), the other to socialization for the nurse role (Table $X X X I I$ ), were prepared. These tables 1 ist all of the sources reviewed down the left side of the page and each of the iridicators across the top of the page. "X' $s$ " indicate which sources addressed which indicators. These tables are useful as overviews and are discussed in the summary of this sectior.

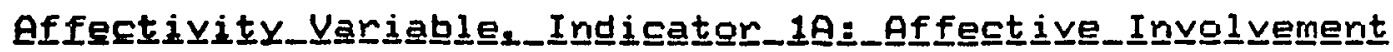

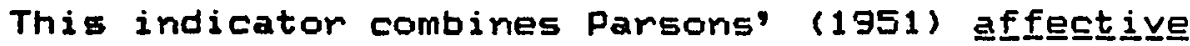

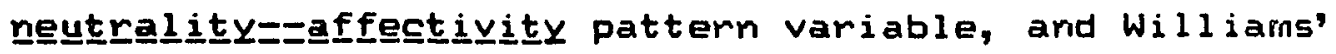


(1959) notion of emotignal_commitment, which was discussed in Chapter VI, Analytical Model. Upon examination both of the literature reviewed and of the resporises of the patients, family members, and health professionals interviewed (Research Question 2), it became clear that these two concepts are closely intertwined empirically. It seems that affect as it is expressed often corveys the degree to which the health professional is emotiarially or personally involved with the patient or the patient arid the family.

This indicator, ther, examines the literature with respect to the role expectations far the degree of affective, or personal, involvenent on the part of the health professional toward the patient or the patierit and the family. Neutral affect and no personal invalvemert exemplify the medical model position (pole 1) on this indicator. The right pole (pole e) is positive attenticr to the interpersonal relationship with the patient ard at least some persorial involvemerit and represents the hal istic approach.

Exxpeㄷtattigris_Eor_The_Role_of_Physiciaㅁ. As showr or Table $W$, the sources reviewed consistently pointed out that physicians in their professional socialization receive little instruction in interpersonal relatiors with patients and in fact learn to be emotionally detached (pole 1). Workplace ("actual practice") socialization is similar. 
TABSE V

RESLLIS OF REVIEW OF LITERATURE CONCERNING PROFESSIONAL

SOCIALIZATION FOR THE ROLE OF PHYSICIAN

AFFECTIVITY VARIABAE, INDICATOR IA:

AFFECTIVE INVOLVEAENT

\begin{tabular}{|c|c|c|c|}
\hline & $\begin{array}{l}1 \text { = Neutral Affect/ } \\
\text { No Personal Involvenent }\end{array}$ & $\begin{array}{l}2=\text { Positive Affect/ } \\
\text { Personal Involvesent }\end{array}$ & \\
\hline Author (5), Date & $\begin{array}{l}\text { Professional } \\
\text { Socialization Process }\end{array}$ & $\begin{array}{l}\text { Actual } \\
\text { Practice }\end{array}$ & $\begin{array}{c}\text { Ideal } \\
\text { Practice }\end{array}$ \\
\hline
\end{tabular}

Becker et al. (1961)

Bloos (1979)

Coombs (1978)

Cocmbs \& Powers (1975)

\section{1}

Taught value of impersonal

way of vizwing events.

1

Exphasis is placed on cognitive aspects of performance.

1

Relatively small anount of forwal instruction is devoted to interpersonal aspects of patient welfare; students are moved from initial idealism to detached concern; develop protective shieid, suppression.

1

Medical teaching nodel glonifies science of aedicine at expense of art of medicine; not taught to relate warniy, weaningfully. Students start with layman's attitude (2), evolve to (1): "salw, objective rationality and full control of motion." Taught to be analytical, non-emotional. "The educational processes wich foster expathy compassion are not clearly visible."
1

1

Spares the professional the anxiety, discomfort the lay perspective suggests, esp. in death.

\section{2}

Physician needs interpersonal skills, esp. the ability to comsunicate (cites research).

\section{2}

Fully roumded physician is sorely needed BUT emotional detachment is necessary, no watter how sympathetic clinician way be. At the same tive, long range suppression is not always healthy.
$1-2$

Physicians are at differen developmental stages.

\section{2}

Must treat patient and farily with "gentlentess and sympathy:" patients need "warm sensitivity and understanding concern". BUT, cannot take personally; wust retain composure, not sob over favorite patient; not a doctor, then. 
TABLE V, Continued

Lasagna (1968)

Levinson $\{1967\}$

Lief \& Fox (1963)

(1979)

Rosenberg (1979)

Schuiz \& Aderman (1976)

Scurry et al. (1979)

Searle (1981)

1

As medical skills improve, social skills often atrophy due to total immersion in aedicine,
3

Decrease in emotionality is disturbing. siudents becone increasingly

emotionally detached.

Citing others, arques

students becoue emotionaliy detacined.

Students in medical school are trying to find a balance of detachment and concern. presented; arques for theory of conflicting denands placed on students. Asserts growth in cynicisn and apathy results.
1

Doctors resort to styles of interaction characterized by detached concern.

$1-2$

Their research indicates

"wowen physicians way

form better relationships with dying patients"
1
1

To become enotionally invoived could be haraful.
2

1-2

This might have "implications for the vulnerability of the female house officer to feelings of sadness other etions when the patient dies."

2

Patients want doctors who talk to them. 
Sources were less clearly in agreement in terms of their ideals. Some were disturbed by the lack of emotionality on the part of physicians, while others advocated this due to the "harmful effects" such emotionality car have. Many strongly advocated increased positive attention to the iriterpensonal aspects of care, arguirg that it is essential that physicians be "wel1-rounded" and relate warmly and humarly with their patients. They cautioned, noretheless, that physicians should not become enotionally involved.

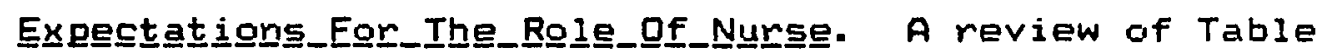
VI reveals a great deal of anbiguity in the role expectations to which nurses are socialized with respect tc their interpersonal relationship with patients. Ir gereral, according to these sources, nurses appear to learn some basic communication skills, but also to develop professicmal distance (poles 1-2). Some disengage from dying patierits due to a fear of overirvolvement (pole 1); others do riot but later suffer stress (pole 2). The gerieral consensus was that nurses should possess good interpersonal skilis and should be "authentic interpersonally," but they should rot become "overinvalved." 
TABLE UI

RESLITS OF REVIEW OF LITERATURE CONCERNING PROFESSIONAL

SOCIALIZATION FOR BHE ROLE OF WURSE

AFFECTIVITY VARIABLE, INDICATCR IA:

AFFECTIVE INOLLEMENT

\begin{tabular}{|c|c|c|}
\hline Ruthor (s), Date & $\begin{array}{c}1 \text { = Neutral Affect/ } \\
\text { No Personal Involvenent } \\
\text { Professional } \\
\text { Socialization Process }\end{array}$ & $\begin{array}{c}2=\text { Jositive Affect } \\
\text { Personal Involvement } \\
\text { Actual } \\
\text { Practice }\end{array}$ \\
\hline Eersain (1980) & ' & $\begin{array}{l}1-2 \\
\text { The ceath of a patient is } \\
\text { one of the sost emotion- } \\
\text { ailly devasting problems } \\
\text { faced by nurses, even when } \\
\text { the "appropriate level of } \\
\text { professional distance for } \\
\text { sound clinical judgment } \\
\text { has been maintained." }\end{array}$ \\
\hline Myers (1982) & & $\begin{array}{l}\qquad 1-2 \\
\text { Found in her case study } \\
\text { that some nurses initiated } \\
\text { condolences upon the } \\
\text { death of a patient; others } \\
\text { did not; some avoid, } \\
\text { use euphemisms. }\end{array}$ \\
\hline
\end{tabular}

Quint (1967)

1

\section{2}

Assignment to a dying patient has trewendous emational impact.
Ideal

Practice
Little attention is given to interactional problems associated with dying, or to comunication skills. Trainees learn to miniaize tive spent with dying patients, to change the subject, to wake menspecific cowents, to refer questions to an authority. The conversational aspects of nursing are presented in general rather than specific terms. Trainees learn cotsposure \& self control are highly valued \& learn to talk to patients in "professiona: manner."

\section{$1-2$}

Give of themselves, share, listen, receive, respond with husan authenticity; BUT still acknowledge the defenses of professional caregivers.

\section{$1-2$}

A broader base in beinavioral science content is needed. Interaction with dying patients is critical, BUT becoming personally imvolved with the dying patient is not good. 
TABLE VI, Continued

Rosentinal et al. (1980)

Ross (1978)

Thrush et al.

(1979)

Vachon (1978)

Williams (1982)

$$
1-2
$$

$1-2$

A biguity found in nursing school: nurses are taught to be cheerfui, reassuring, but at the same time, they develop a definition of professional behavior which includes dignity, distance.
The aporopriate extent of enotional involvement is ambiguous in school $b$ on the job.
Competence in interpersonal skills is essential for achieving an uncerstanding of the patient. BUT nurses snouid not becose over involved.
Because of a fear of overinvoivement, nurses may disengage, withdraw from patierit.

1

There is direct avoidance 8 ainimizing of interpersonal contacts with the terminally ill.

2

Because of various motivations for working with the dying, notes that some staff become overinvolved, overidentify with patients.

1

2

$1-2$ involvement.

The death of a patient arouses psychological trausa; often the response is isolation, neglect of dying patients.

The ideal is the nurse who "dares to care."

Notes stress of over- 


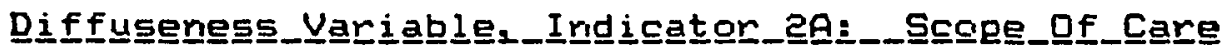

This indicator examines sources' assessment of the role expectations to which health professionals are socialized with respect to the scope of care to be given. "Scope of care" refers to whether only the physical care needs of patients (pole 1) or patients' psychosocial needs as well as their physical needs (pole e) are addressed. This latter option is termed "holistic care," and is consistent with the hospice model of termiral care. The former, "physical care," represents the medical model approach to health care.

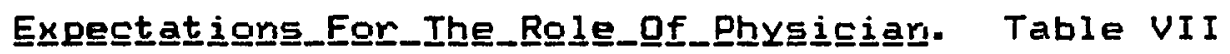
summarizes the findings of the analysis of the literature on this issue. With the exception of two sources fran the late 1950's (who note that physicians are, or were ther, being socialized to provide comprehensive, or holistic, care) and one current source who asserts students are exposed to both approaches, all others state that there is nearly exclusive attention to the physical aspects of care, both in their professional socialization and in actual practice (pole 1). Even one of those two sources (Fox, 1957) noted that while comprehensive care was being taught, many students felt "social problems" were beyond the scope of the doctor's work.

There was similar consensus, with one exception, that physicians should, ideally, attend to patients' psychosocial 
TABLE VI!

RESHLTS OF REVIEW OF LITEZRTURE CONCERNING PRCFESSIONGL

SOCIRLIZATION FOR THE ROLE OF PHYSICIAN

DIFFUSENESS VARIABLE, INDICATOR $3 A$ :

SCOPE OF CARE

$1=$ Physical Care Only 2 = Psychosocial Care Also

Professional Actual Ideal

Autnor(s), Date Socialization Process Practice Practice

Becker et al. (1961)

Bicon (1979)

Coombs (1978)

Coombs \& Powers (1975)

Field (1953)
1

Patients should be "really"

sick, not psychosomatically.
$1-2$

Discusses the "new huranism of nedica! ethics. At the same time, notes that the bulk of the physician performance literature focuses on technical, not interpersonal, processes.

1

Training is diseasecentered.

\section{1}

Exotions, feelings of patients often overlooked.

\section{2}

Must deal openly with subjective features of medical care: the enotions, feelings of patients, fanilies.

\section{2}

-The clinician learns to view dying patients not as people with feelings, but as medical entities, specimens, or objects of scientific interest... the old scientific fragmentalization wathod."
Professional socialization

should include concern about ewotional, social factors in patient's illness; should teach such skills, knowledge.
1-2 2

Concentration is on the Emphasis should be on the sick organ. intrinsic worth of the patient as a person, not just as a disease; notes this concept is not new; possibly is older than Roman Empire. (Continued) 
TABLE VII, Continued

Fox (1957) 2

School teaches conorehensive care, but iany students feel solution of "social problems" is beyond the scope of the doctor's work.

Harman (1971) 1

2

Few respondents had any education for the socialpsychological care of dying patients.

Recomnends discussion groups re: probleas of social-psych. care of dying patients be held for medical students.

Lasagna (1968)

1

2

Orientation in nedical school is to the medical probles, not the patient.

Merton (1957b)

2 1

There is a renewed emphasis on the patient as a wole person.

This renewed emphasis on the patient is "a conception sore honored in the breach than the observance."

Need new curriculum that is patient-oriented from the beginning.

Arques for "social nedicine" and cites wany physicians who feel sinilarly.

General medical practice \& psychotherapy are not corpatible. Argues against courses in death \& dying: students may not WANi knowledge in the psychotherapeutic area; there may not to enouch time; may not be consistent with contemp. practice of medicine.

Robinson (1974)

1

Sowe doctors feel

emotional, psychological, social problems are out of the sphere of medical competence. 
TABLE VII, Cont snued

Rosenuerg (1979)

There is conflicting sociali-

zation; there is exposure

to the role of specialist

AND an orientation to the

total patient.

Salber (1975)

Doctors are trained in
clinical rather than

social aspects of aedicine.

1

(1975)

Searle (1981)

1

Doctors are socialized to

total imersion in redi-

cire, medical problens.
1

2

Need to learn the patient's life circunastances in order to treat effectively; these infiuerice seeking of care, presentation of symptons, acceptance of medical assessment \& intervention.

?

Medical schools need to focus on socialpsychological aspects of dying to eliminate avoidance behavior.

\section{2}

Patients seem to want a doctor wo has time to listen to their problems, talk to them.

2

Prevalent lack of concern New philosophy calis for for patients' psychologi- awareness of patients' cal state; there is iso- psychological needs. lation and abandonwent. 
needs as well as their physical needs (pole 2). The exception, Mullaly \& Osmond (1979), argued that such attention is not appropriate: that students may not want krowledge in the "psychotherapeutic" area, there is likely not enough time, and that attention to psychological needs may not be consistent with the contemporary practice of medicine.

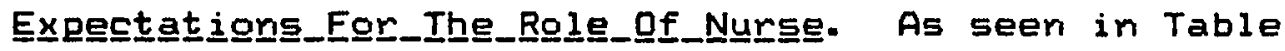
VIII, only one source (Lurie, 1981) argued definitively that nurses are socialized to provide psychological support to patients (pole 2 ), while one source asserted they defiritely are not socialized to address patients' psychological reeds (pole 1). The remaining several athers noted ambiguity arid conflict in nurses' professional socialization, poirtirug out deficiences in actual trainirg and continued separation, rather than integration, of behavioral and biological camponerits of care. Mast agreed that in the work settirg, provision of physical care supersedes the givirg of psychosocial care (pole 1). The ideal af all sources was inclusion of the psychosocial dimensions of care within the realm of nursing care (pole 2 ). 
TABLE VIII

RESLLTS OF REYIEN OF LITERATURE CCNCERNING PRLFESSIONAL

SOCIALIZATION FOR THE RCLE OF WWLSE

DIFFJSENESS VARIABLE, INDICATOR ZA:

SCOPE CF CARE

1 = Physical Care Only 2 = Psychosocial Care Also

\begin{tabular}{|c|c|c|c|}
\hline Author (5), Date & $\begin{array}{c}\text { Professional } \\
\text { Socialization Process }\end{array}$ & $\begin{array}{l}\text { Actual } \\
\text { Practice }\end{array}$ & $\begin{array}{l}\text { Ideal } \\
\text { Practice }\end{array}$ \\
\hline Germain (1980) & $\begin{array}{l}\text { N-2 } \\
\text { Nurse educators prior to } \\
1969 \text { (influence of Kubler- } \\
\text { Ross) attempted to expard } \\
\text { the physical focus of care } \\
\text { of the dying to a more } \\
\text { holistic patient and } \\
\text { family focus. While the } \\
\text { nursing literature is } \\
\text { reolete with references to } \\
\text { Kubler-Ross, training is } \\
\text { inadequate. }\end{array}$ & $\begin{array}{l}\qquad 1 \\
\text { What holistis knowiedge } \\
\text { is learned is only } \\
\text { infrequently translated } \\
\text { into practice. }\end{array}$ & 2 \\
\hline
\end{tabular}

Krant (1978)

2

2

Nurses usually have wore Physical and psychoskills in relating to the logical factors go hand physical and often psycho- in hand. logical relief of suffering.

Lurie (1991) 2

1

Nurses are socialized to Citing work of several give psychological support authors, states that to patients. nurses terd to respond to patients' talk of dying with avoidance behaviors.

Myers (1982)

$1-2$

Resocialization toward the social rather than the medical model for nurses is being scrutinized.
2

Social as well as medical aspects of death and dying must be respected. 
TABLE VIII, Continued

Quint (1967)

\begin{abstract}
$1-2$
During the 50's there was grewing esponasis on psychological nursing care, but a general silerice about cying. Nurses are taught to care for patient's body, not to interact. Also, not al] curricula emprasize psychological asuects. The directive to provide psych. care is vague, subject to different interpretations and mettiods of implementatior.
\end{abstract}

Rosenthal et al. (1980)

Schulz \& Aderman 1

$$
1-2
$$

Giving emotional support (talking, listening) is given high priority in professional training; at the same time, there is continued influence of the biomedical model, with its exphasis on physiologic resconses. Most nursing textbooks separate biological \& behavioral conponents of care; also, behavioral components usually are associated with psychiatric nursing.

\section{1}

The provision of emotional support is given low priority in the job setting.
Technical (pnysical) activities take precedence. Social \& psych. aspects of patient care are not explicitly built into hospitals' accountability systems.

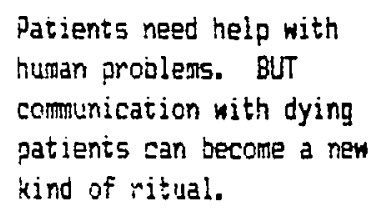


TABLE VIII, Continued

Simpson (1976)

Tnrush et al. (1979)
1

Nursing education tends

to support the purely

"biological-tectinical

approach to patient care;

psychosocial aspects

of death \& dying are relatively negiected.
1

Little attention is given to the patient's enotional needs.

\section{1}

Nurses sometines resor:

to avoidance behaviorsthis obscures the psycho-

social aspects of care.
2

Nurses shouid have an awareness of psychological neeors.

2

Death \& dying have

psychosocial dimensions. 


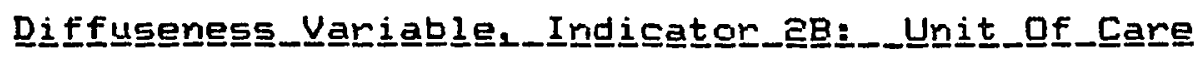

Examined here are sources' views corcerning what urit of care--solely the patient (pole 1), or the family as well as the patient (pole 2) physiciars and nurses are socialized to address. Specifically of interest is whether or not ary mention was made of the expectation that health professionals address the needs of the familly in addition to those of the patient.

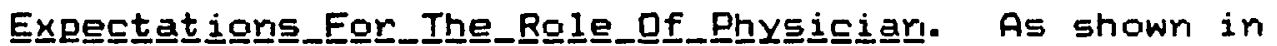
Table IX, only five sources addressed this issue, arid orily one source referred to families and their needs in the context of physicians' professioral socializatior. This source stated that students are not prepared to meet the needs of families. All sources agreed that families' needs generally are not addressed by the physician (pole 1), but that the focus of treatment should, ideally, be the family unit (pole 2 ).

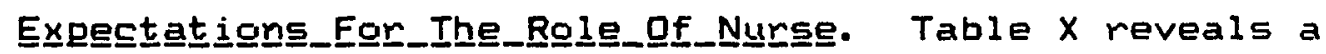
similar lack of attention to this role expectation for nurses by the sources examined. One source stated that the patient and the family are the clierits (pole e). Another asserted that the needs of fanilies frequently are overlooked (pole 1). Others noted that the family focus is orily sometimes apparent (poles 1-2). All implied that such a focus is desirable (pole 2 ). 
TABLE IX

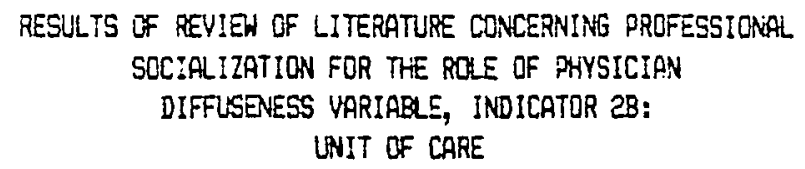

\begin{tabular}{|c|c|}
\hline Author (s), Date & $\begin{array}{c}1 \text { = Patient Only } \\
\text { Professional } \\
\text { Socialization Process }\end{array}$ \\
\hline Coomos (1978) & \\
\hline $\begin{array}{l}\text { Coombs \& Powers } \\
\text { (1975) }\end{array}$ & $\begin{array}{l}1 \\
\text { "The developmental person- } \\
\text { ality changes which result } \\
\text { frcm gedical socialization } \\
\text {... are not comicive to pre- } \\
\text { paring the doctor enotionally } \\
\text { so that he can meet the needs } \\
\text { of dying patients and their } \\
\text { families in the depersonalized } \\
\text { hospital setting." }\end{array}$ \\
\hline
\end{tabular}

Field (1953)

Exotions, feelings of

Actual

Ideal

Practice

Practice

patients \& their

fanilies are often overlooked.

\section{1}

2

2

2

Krant (1978)

Rosenberg (1979)

1

2

There is a need for focus on the family as the unit of treatment; experience has demonstrated that illmass of one member has repercussions on entire group.

1 Citing others, notes needs of patient's spouse often are not met.

1

Medical politics \& hostility dominate over the needs of patients \&

families.
2

There is a need to help the fanily. 
TABiE $x$

RESLLTS OF REVIEN OF LITERATURE CONCERNING PROFESSIONAL

SCCIALIZATION FOR THE ROLS OF NURSE

DIFFUSENESS VARIABLE, INDICATCR 2B:

UNIT OF CARE

Author(5), Date

$1=$ Patient Only

$2=$ Patient and Family

Professional

Actual

Ideal

Socialization Process

Practice

Practice

Germain (1980)

$1-2$

Prior to 1969 and the

influence of Kubler-Ross,

there was some evidence

in the literature of a

patient \& fanily focus.

Now nursing literature is

replete with references to

Kuoler-Ross, but there is

a lack of acequate training.

Hrant (1978)

Argues that hospital Families should be

policy may fail to reet assistec, as well as

the needs of patients' the patients.

5pouses; fanilies'

needs frequentiy are

overlooked.

Ayers (1982)

$1-2$

Found in her case study

that sone nurses talked

to the fanily (bereaved)

and some did not.

Rosenthal et al. (1980)

2

Both the patient \& the

fanily are cilents. 


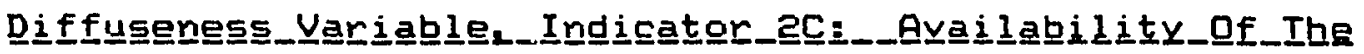

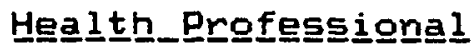

This indicator identifies sources' perspectives of the role expectations concerning the availability and accessibility of health professionals to the patient or the family, in terms of time and physical presence.

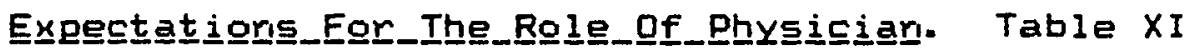

surnmarizes the findings of the analysis of the literature. Mast of the relevant comments made by sources addressed the issue of avoidance by physicians of patients who are dying. All indicated that either during their professional sacialization or in the workplace, dying patierits frequeritly are avoided (pole 1). Dre source noted that medical students learr about "the preciausness of time" as a result of theip professional socialization experiences. Two sources offered their ideals that dying patients rict be avaided ifole 2).

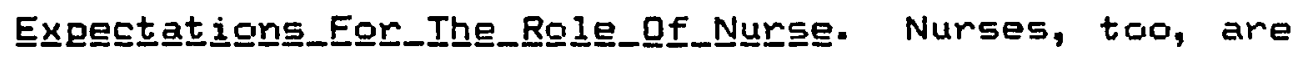
seen by the nursing socialization sources as avoidirg dying patients, as shown on Tablè XII. One source addressed the issue of 24-hour availability, noting that while nurses maintain continuous coverage, their schedules are more rigid than those of physicians; therefore, they tend to be less available. The ideal role expectation was stated overtly by only one source; this ideal was for non-avoidance ( 2 ). 
TABLE XI

PESULTS OF REVIEW OF LITERATURE CONCERNING PROFESSTONAL

SOCIALIZATICN FOR THE ROLE OF PHYSICIAN

DIFFUSENESS VARIABLE, INDICATOR ZC:

AVAILABILITY OF THE PHYSICIAN

1 = Limited Availability $2=$ UnI inited Avallability

$\begin{array}{ccc}\text { Professional } & \text { Actual } & \text { Ideal } \\ \text { Practice } & \text { Practice }\end{array}$

Author (s), Date

Coombs \& Powers

(1975)

Harman (1971)

Through the socialization process, medical students beconte concerned about the preciousness of time.

Schulz \& Aderman (1976)

Scurry et al. (1979)
1

Until doctors reach Stage

5 lof the developorental

stages of coping with

deathl, avoidance is

often used as a coping

technique.

1

Found considerable avoidance of dying patients by medical students.

\section{1}$$
\text { (n) }
$$

a

Dying patients should not be avoided. 
TABLE XII

RESLRTS OF REVIEN OF LITERRTURE CONCERNIHG PROFESSIONAL

SOCIALIZATION FOR THE ROLE GF NURSE

DIFFUSENESS VARIABLE, INDICATOR 2C:

AVAILABILITY OF THE ANPSE

1 = Limited Availability $2=$ Uniimited Availability

$\begin{array}{lccc} & \text { Professional } & \text { Actual } & \text { Ideal } \\ \text { Ruthor (5), Date } & \text { Socialization Process } & \text { Practice } & \text { Practice }\end{array}$

Lurie (1981)

1

Citing several authors, states that nurses tend to respond to patients' talk of dying with avoidance behaviors.

Hyers (1982)

$1-2$

Nurses in general maintain

continuous coverage, but nurses' work schedules are far wore texporally rigid than doctors'.

Ross (1978)

1

Nurses sonetimes disengage, withdraw fron dying patients due to fear of over involvement.

Schulz \& Aderman

(1976)

Thrush et al.

(1979)

Hilliams (1982)

\section{1}

Nurses sometimes avoid dying patients.

1

There is direct avoidance 8 nininization of interpersonal contacts with dying patients by nurses.

1

There often is isolation \& neglect of dying patients by nurses due to their inability to deal with death. 


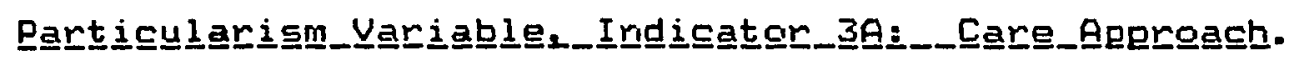

As described in Chapter VI, Analytical Model, this indicator examines whether the role expectation to which health professionals are socialized is for care to be generally or individually oriented; that is, whether, the treatment given to a patient by a health professioral is to be essentially the same as that giver to all patients (pole 1, generalized care) or tailared to meet the particular needs of each patient (pole 2 , individualized care).

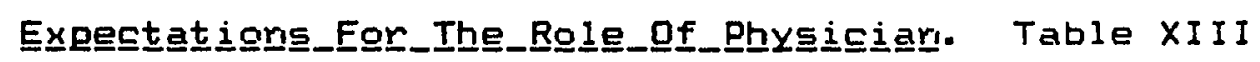
summarizes the findings of the analysis of the literature as they relate to this indicator. Orily ore of the sources indicated that the approach to which physiciaris are socialized is the individually oriented approach fFreidson, 1970a). All others asserted that professioral socializaticir imparts a generalized approach to studerits, whereby studerits become disease-ceritered and dehumanized in their appraach (pole 1). Those sources who stated their ideal expectatior advocated the individualized approach (pole 2 ).

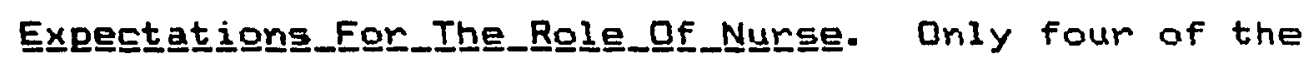
sources examined commented with regard to role expectations for the appropriate care approach, as shown on Table XIV. The one making reference to the professional socialization of nurses on this issue (Rosenthal et al., 1980) noted that students learn to replicate the known approach for dealing 
RESULTS OF REVIEH OF LITERATLUE CONCERNING PRCFESSIONAL

SOCYRLIZATION FOR THE ROLE OF PHYSICIAN

PARTICILARISM VARIABLE, INDICATOR 3A:

CARE APPROACH

\begin{tabular}{|c|c|c|c|}
\hline Author (5), Date & $\begin{array}{c}1 \text { = Generalized Care } \\
\text { Professional } \\
\text { Socialization Process }\end{array}$ & $\begin{array}{c}\hat{c}=\text { Individualized Care } \\
\text { Actual } \\
\text { Practice }\end{array}$ & $\begin{array}{c}\text { Ideal } \\
\text { Practice }\end{array}$ \\
\hline $\begin{array}{l}\text { Blumenfield et al. } \\
\text { (1979) }\end{array}$ & $\begin{array}{l}1 \\
\text { Students surveyed ex- } \\
\text { oressed little uncertainty } \\
\text { \& made broad generali- } \\
\text { zations to dying patients, } \\
\text { specifically re: whether } \\
\text { patients should be told } \\
\text { about their terminal } \\
\text { illness. }\end{array}$ & & $\begin{array}{l}2 \\
\text { Each patient should be } \\
\text { evaluated on an indi- } \\
\text { vidual basis. }\end{array}$ \\
\hline Coombs (1978) & $\begin{array}{l}1 \\
\text { Medical students learn } \\
\text { to depersonalize the } \\
\text { patient. }\end{array}$ & & 2 \\
\hline $\begin{array}{l}\text { Coombs \& Powers } \\
(1975)\end{array}$ & $\begin{array}{l}\text { Students learn deparson- } \\
\text { alizing tectriques to } \\
\text { cope with the death of } \\
\text { patients; the pritary one } \\
\text { learned is to deny the } \\
\text { subjective features, view } \\
\text { patients as entitijes, } \\
\text { speciuens, objects of } \\
\text { scientific interest, } \\
\text { not as persons with feelings. }\end{array}$ & & 2 \\
\hline Freidson (1970a) & $\begin{array}{l}\text { "Cinical experience" is } \\
\text { one of the two basic } \\
\text { values of the medical } \\
\text { orofession. }\end{array}$ & $\begin{array}{l}2 \\
\text { Decisions are based on } \\
\text { the uniqueness } \& \text { uncer- } \\
\text { tainty of each case. }\end{array}$ & \\
\hline
\end{tabular}


TABLE XIII, Continued

Harwan (1971)

During medical school,

trainees become disease-

centered \& relatively

dehusanized in their

patient-care attitudes.

1

"Professors tend to... reduce

everything to fundamental

chemical and physical cellular

processes, unaware of the

sterility of this ambition."
2

In medical education, stress individualization of care, but also educate re: typical dying trajectories 50 students learn generalities on wich individualization is based; teaci skilis needed for finding the nost appropriate death for a patient.

2

"The doctor must respect

sinultameously the

general \& the individual."
Rosenthal et al. (1980)
1

Cite other authors who note that decisions are based on typologies of patients and their conditions rather than on viewing each patient as a unique individua!. 
TABEE XIV

RESULTS OF REVIEW OF LITERATURE CONCERNING PRCFESSIONAL

SOCIOLIZATION FOR THE ROLE OF NURSE

PARTICULARISY VARIABLE, INDICATOR JA:

CARE APPRCACH

\begin{tabular}{|c|c|c|}
\hline & 1 = Gereralized Care & $2=$ Individualized Care \\
\hline Author (5), Date & $\begin{array}{c}\text { Professional } \\
\text { Socialization Process }\end{array}$ & $\begin{array}{l}\text { Actual } \\
\text { Practice }\end{array}$ \\
\hline
\end{tabular}

Quint (1967)

1

Rough handling of the

patient (depersonaiized

treativent of his/her

bodyl is one way used

to cope with the dying

patient.

Rosenthal et al. (1980)

$1-2$

While nurses' training \& philosophy urge then to treat each patient as an individual rather than a "case," students learn to replicate the known approach for dealing with problexs, to categorize patients according to presenting problexs; many instructors are not coufortable dealing with uncertainty.
Simpson (1976)

Thrush et al. (1979)

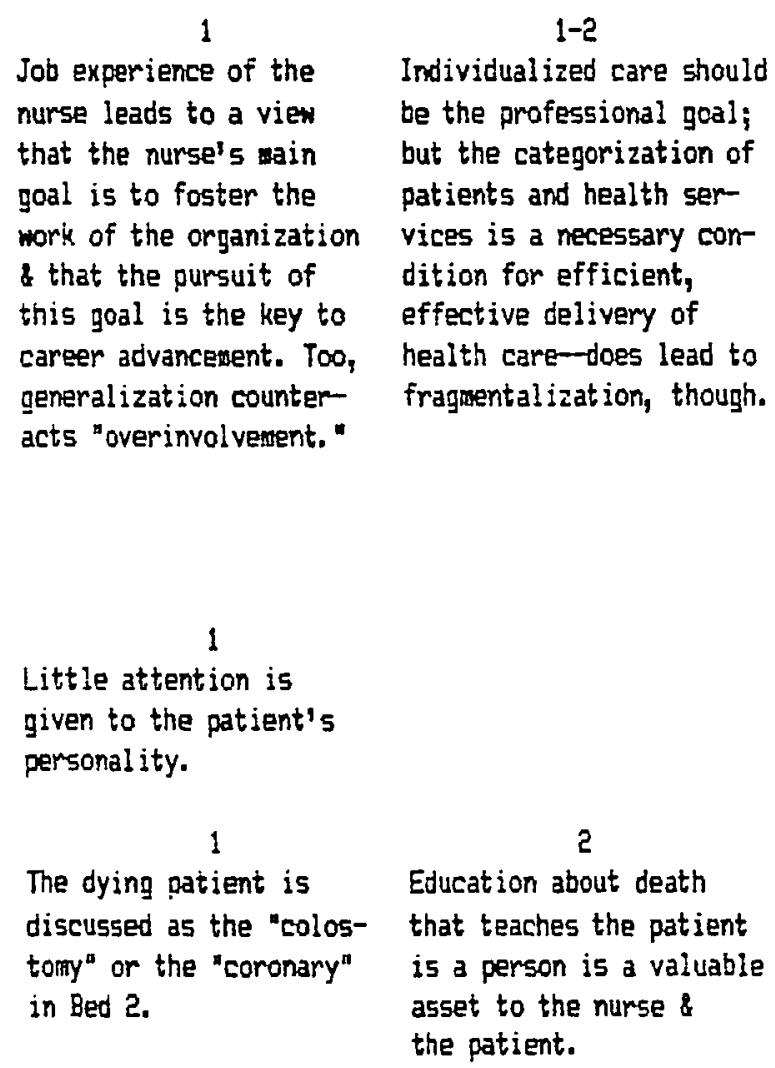

1

Little attention is given to the patient's personal ity.

1

The dying patient is discussed as the "colostony" or the "coronary" in Bed 2.

\section{2}

Education about death that teaches the patient is a person is a valuable asset to the nurse \& the patient. 
with problems and to categorize patients according to their presenting physical problem (pole 1), despite the training they receive indicating that nursing's philosophy is to treat each patient as an individual (pole 2). Each of the four sources reported that in actual practice, the generalized, depersonalized approach predominates (pole 1). of the two sources stipulating their ideals, both cast their votes for the individualized approach, although Rosenthal et al. (1980) were ambivalent, pointing out that categarizatior, of patients is necessary for efficierit, effective delivery of health care.

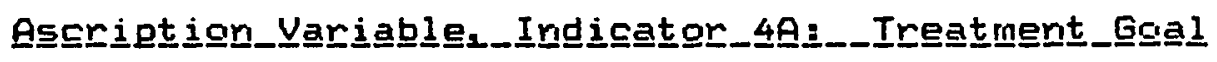

Examined in this iridicator are the expectations concerring the goal of the treatment received by the terminally ill patient: whether the patierit is to be treated with (pole 1) a goal of life prolorgation or (pole 2) a goal of the patient's quality and comfort of remaining life in mind. At issue is whether health professionals are socialized to meet a goal requiring that all attempts to treat (cure) the patient right up to the very end be made (pole 1), or to shift the goal to one of confort and quality of life for the patient who is terminally ill (pole 2 ).

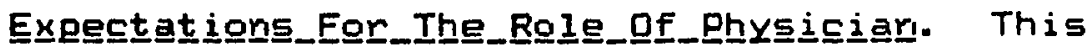
indicator received more attention than any of the others by the sources consulted in this analysis of the physician 
sacialization literature. Two themes relevant to socialization with respect to the goal of care are evident. First, as revealed in Table $X V$, in general, sources assert that physicians are cure-oriented, are socialized to a highly technological approach to medicine, ard are taught ta used their techrical skills to prolong life, as death is seen as the antithesis of good medical practice (pole 1 ). Second, the lack of formal education of physicians concerning death and treatment of dyirig patients is poirited out (pole 1).

There appears to be a conflict in role expectatioris as enacted in actual practice. Some sources report that physicians rely on the criterion of "quality of life" to aid them in their decisions concerning treatment, and/or the philosophy that no extraordinary measures should be taken with the terminally ill (pole e). Other sources assert that physicians gererally continue to adhere to the position that death should be avoided at all costs (pole 1).

There is a similar conflict in the ideals of the sources examined: some assert that the physiciar's goal should be to prolong life, while others argue that patierits should not be kept alive solely for the purpose of prolonging their lives: that quality of life is the primary consideration. Most sources would seem to agree that useless treatments should be avoided and patients' symptams should be relieved, the ambiguity lays in the definitior of 
TABLE XV

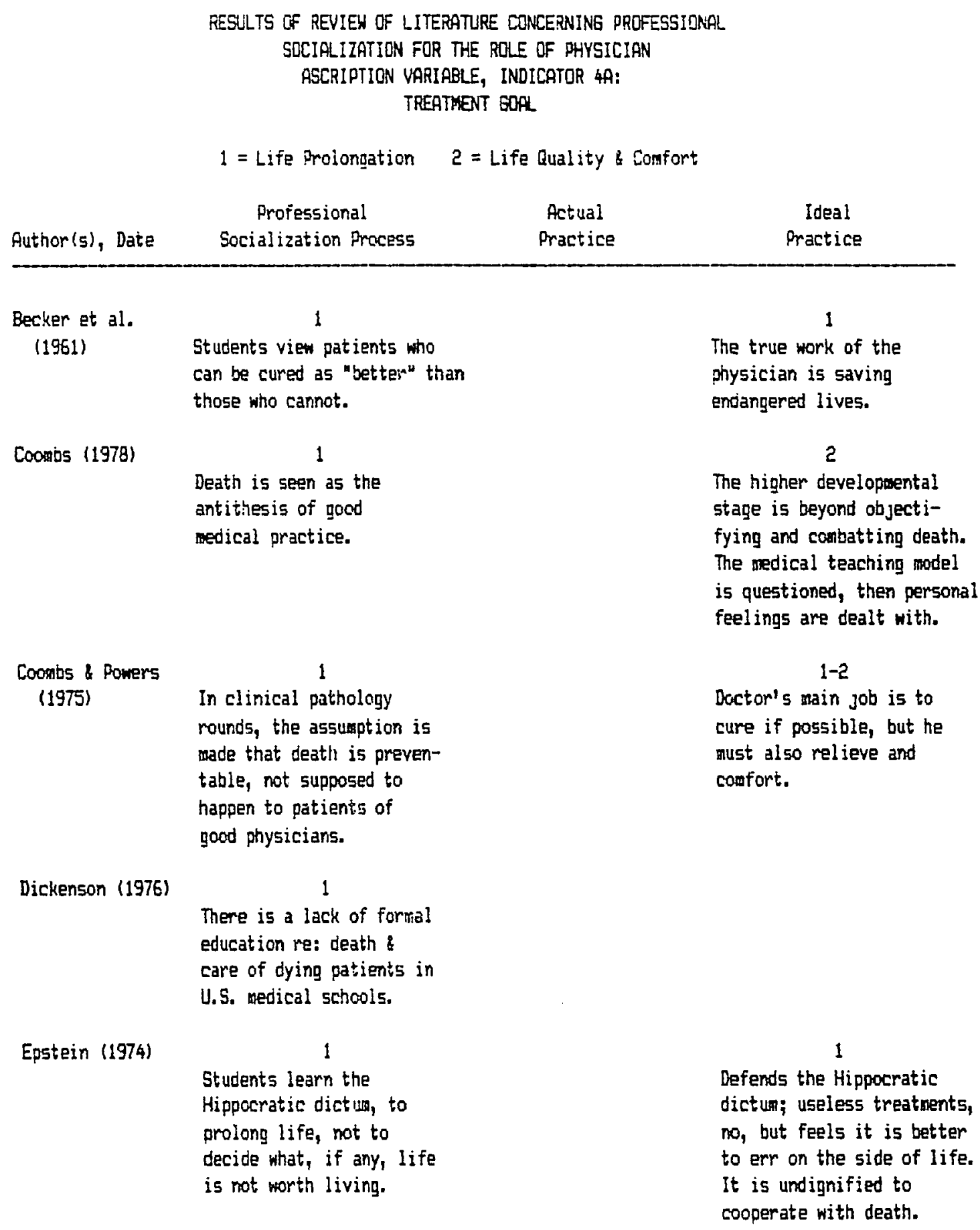

(Continued) 
TABLE XV, Continued

Kanoti (1975)

The "rilitant concept" opposes death at all costs. Ethicists them selves do not agree re: distinction between extraordinary \& ordinary means.
Lasagna (1968)

Morison (1974)

Mullaly a Osmond (1979)

Schram et al. (1978)
$1-2$

What is "extraordinary" is debated; estiwates of patient's future quality of life are sonetines used. Cultural nomes will not allow sanction of euthanasia.

1

Cite others who arque that dying persons are being treated in the sick role.

$1-2$

Note recent court decisions

have rejected "quality of life" as valid criterion, yet Scurry et al. (1979) found this factor ranked most important by house officers in their decisions to use the "no code" designation.
2

Physician judgments wust respect life, but not necessarily prolong it.
The irternist in training is taught nore about dramatic acute illnesses than problens of chronic disease, $\&$ is given no preparation for problems connected with death.

Lack of formal education in U.S. medical schools re: death \& care of the dying. 
TABLI XV, Cont inued

Schulz \& Aderman (1976)

Scurry et al. (1979)

Searie (1981)

Simpson (1976)

Veatch \& Taj

(1980)

Willians (1982)
1

Arque that research shows dying patient is considered a deviant, and that death is associated with disappointment \& failure by physicians, who cope by avoiding death.

$1-2$

Their research shows that wile house staff admit discomfort with dying patients, they say they do not avoid dying patients. Authors note incompatibility of responses.
Physicians are socialized to a highly technological approach to medical practice; may lead to over-diagnosis, over-treatment.

Error of omission is learned to be greater than error of comission, so do everything possible for patient.
1

The role of the physician recedes to that of the nurse in terminal care.
$1-2$

Extension of life remains first priority, but remission of symptons also a major goal.
2

In the $1960^{\prime} \mathrm{s}$, chronic disease suddenly became the socially dominant disease; prior, it was aggressive, acute infection.
Agree strongly with "no code" designation.

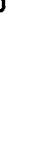


"useless" and in the timing of the physician's transition ta treating patients within the dying, as opposed to the sick, role.

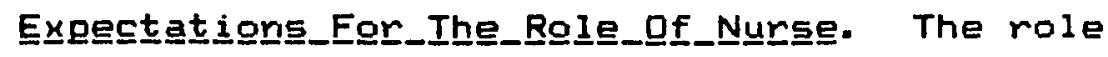
expectations concerning the appropriate goal of care for nurses appear to be in even greater corflict than those for physiciars. Table XVI show that several sources argue that the domain of nursing is related to "care" functions, which include an emphasis an patients' physical arid psychological comfort (pole 2). At the same time, nurses are reported to be highly influenced by the treatment orientatior af physicians and to place a high value on recovery (pole 1 ). Some sources note the lack of adequate education for nurses in death and dying (pole 1). All sources agree that the ideal goal for care of the terminally ill should be the provision of comfort. While relating more to Indicator $5 \mathrm{C}$, Interprofessional Decision-Making, an interesting thread running through the work of several sources should be pointed out here, as well, as it frequerity surfaced in the context of expectatiors with regard to the goal of care. This thread was a belief that in the care of the termirally ill, the role of the nurse should become domiriarit over that of the physician. 
TABLEXVI

RESLL IS OF REVIEN OF LITERATURE CONCERNING PROFESSIONAL

SOCIALIZATION FOR THE ROLE OF NURSE

ASCRIPTICN VARIABLE, INDICATOR AA:

TREATMENT SOAL

$1=$ Life Prolongation $2=$ Life Quality \& Comfort

Professional Actual idea!

Author(s), Date Socialization Process Practice Practice

Germain (1980)

2

2

Asserts that the primary

aip of nursing is "care."

Krant (1976)

2

5

More input by nurses is More input by nurses is provided in late-stane mecessary in late-stage disease. disease.

Lurie (1981) 2

$1-2$

One of tine central values

comon to all nursing is the enphasis on "care" Tinere are conflicts between nursing \& medicine re: "core," "care," \& functions (which include necessary nursing procedures as well as the provision of psychologica! support, health counseling, and aducation) as opposed to being physicians' subordinates \& performance of aaintenance or "core" functions.

Myers (1982)

$1-2$

Found in her case study that nurses proferred to spend time with neonates who were getting better rather than worse; yet their goal was Jay-today comfort. 
TABLS XVI, Contunued

Quint (1967)

Rosenthal et al. (1980)

Sispson (1976)

Thrush et al. (1979)

Veatch \& Tai (1980)
1

Littie attention 15 given

to oreparing nurses to

cope with problems assoc:-

ated with dying; nurses are

prepared to take care of

only the body. Textbocks

snow corcery mainly for

life-saving or tectnical

matters re: death, such

as sody preparation. High

value is attached to

recovery. Also, preparation

for death is not standardized.

$1-2$

$1-2$

Nurses are socialized to celieve that physicians "cure" \& deal with complicated medical problems; nurse practitioners "care" for all patients \& "cure" simple problens. Nurses delegate to others "core" functions-keeping track of medications, etc.

\section{2}

2

In terminal care, the physician's role recedes, $\&$ the nurse's rale takes its place.

\section{1}

The preservation of life

is the foremost goal of the medical professions.

2

The nurse is seen as providing "care," the physician as providing "cure."
2

Care and comfort are needed.
2

2

(Continued) 
TABLE XVI, Continued

\begin{tabular}{|c|c|c|c|}
\hline Williams (1982) & $\begin{array}{l}\qquad 1-2 \\
\text { Nursing theorists see } \\
\text { domain of nursing as re- } \\
\text { lated to "care:" yet } \\
\text { wille there is increasing } \\
\text { discussion of death, the } \\
\text { average nurse still is } \\
\text { unpredared to assist } \\
\text { patients who are dying. }\end{array}$ & $\begin{array}{l}1 \\
\text { Only recently has the } \\
\text { curative emphasis becone } \\
\text { possible \& doainant. By } \\
\text { inclination or socializa- } \\
\text { tion within the hospital } \\
\text { system, most nurses } \\
\text { identify with the treat- } \\
\text { ment-oriented philosophy } \\
\text { of the physician: dying } \\
\text { patients violate norms by } \\
\text { their failure to respond \& } \\
\text { by their eventual death. } \\
\text { Death is yiewed as a treat- } \\
\text { ment failure. This resu!ts } \\
\text { in burrout, isolation, \& } \\
\text { neglect of patients, intra- } \\
\text { staff conflict, \& patient- } \\
\text { staff conflict. }\end{array}$ & $\begin{array}{l}\text { The dowain of nursing } \\
\text { is care \& support. The } \\
\text { A supportive role is } \\
\text { appropriate for the care } \\
\text { of the dying. }\end{array}$ \\
\hline
\end{tabular}




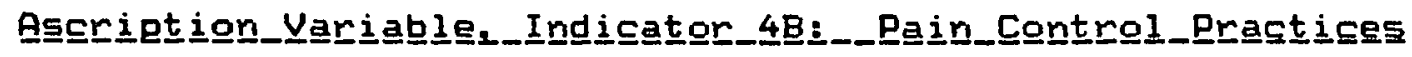

Role expectations with respect to pain control

practices to be followed by health professionals in the care of terminally ill people are examined in this section. As discussed in Chapter VI, Analytical Model, expectations concerning appropriate pain and symptom control may be either that pain and symptoms should be controlled orily as they arise and are experienced by the patierit (pole 1), or that pain and symptoms should be eliminated if possible, generally through the administration of medication at regular intervals so they are not experienced (pole 2 ). This latter view is consistent with the treatmerit gaal of quality of 1 ife. The former perspective is related to the treatment goal of prolonging 1 ife and the potential adverse effects connected with regular administration of medicatior.

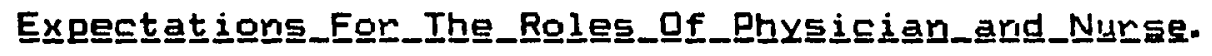
As seen in Tables XVII and XVIII, only ore of the sciurces analyzed (Krant, 1978) addressed this indicator. He commented both on the role of the physician and the nurse, arguing that physicians receive inadequate education in pain and symptom control (pole 1), arid that murses gererally have better skills in this area (pole 2). From his perspective, pain and symptom control through the administration at regular intervals of medication is ideal (pole 2), as this enables the patient to be comfortable and to be able to plar. and communicate with family members. 
TABEE XVII

RESULTS OF REVIEN OF IITERATURE CONCERNING PRCFESSIONAL SOCIALIZATION FOR THE ROLE OF PHYSICIAN ASCRIDTION VARIABLE, INDICATOR $4 B$ : PAIN CONTRQL PRRCTICES

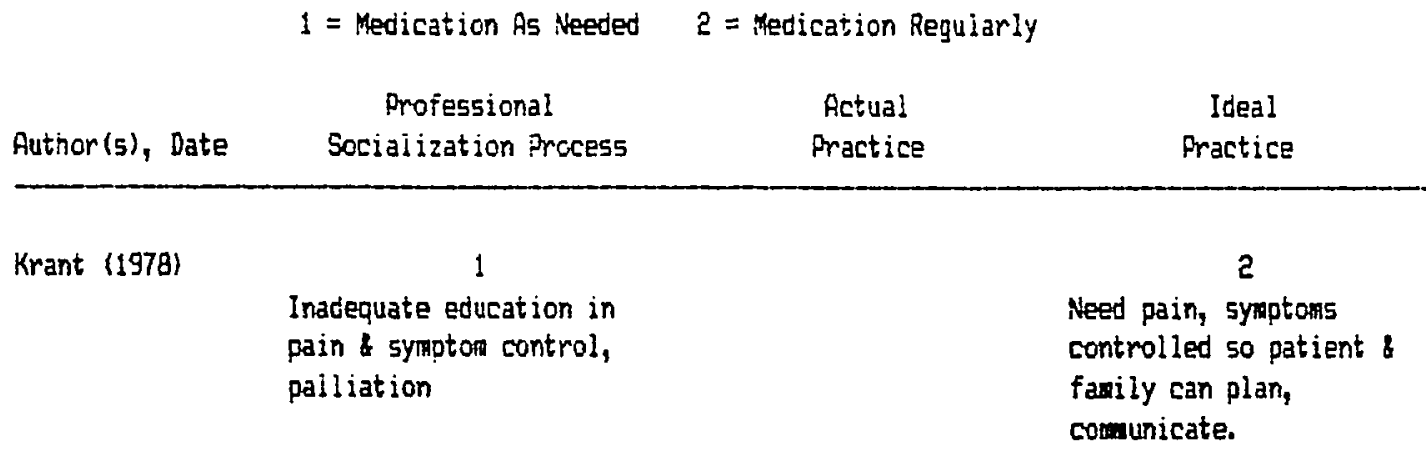

TABLE XVIII

RESULTS LF REVIEW OF LITERATURE CONCERNING PRDFESSIONAL SOCIALIZATION FOR THE ROLE OF NURSE ASCRIPTION YARIABLE, INDICATOR 48 ; PAIN CONTREA- PRACTICES

$1=$ Medication As Needed 2 = Medication Regularly

Author (5), Date

Professional

Actual

Ideal

Socialization Process

Practice Practice

Krant (1976)

2

Nurses usually have nore skills in relating to physical and psychological relief of symptows.

\author{
2 \\ Pain \& sympton control \\ is essential.
}




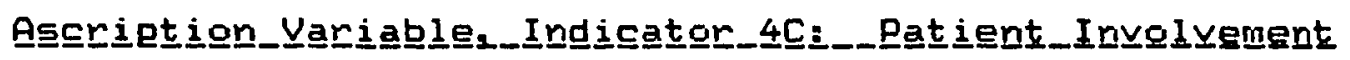

Role expectations to which health professionals are socialized with respect to involvement of patients in treatment-related decisions are examiried here. An achievement orientation is implied by an expectation for no involvement of patients in treatment-related decisions cpole 1); this orieritation sees the professionals as "knawing best," due to their specialized training. Involvement of patients (pole e) implies an ascription oriertation, since patients are involved not as a result of their competerice or performance as providers of health care, but instead, because of their ascribed status as patients, and as those directly affected by the care they receive.

As noted in Chapter VI, certain conditions serve as enabling factors for patient involvemert, or participation, in care-related decisions. Farticularly, informatior about the patient's diagrosis and prognosis, treatmerit optioris arid resources, as well as a willingness on the part of the health professional to allow patients some say or input irita treatment-related decisions are likely to be required. Both of these enabling factors are visible in the relevart statements made in the literature consulted.

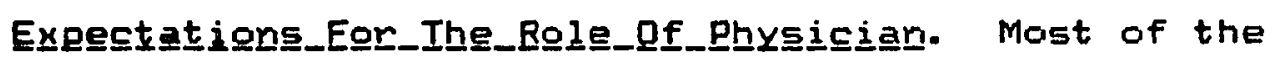
sources making statements relevant to this indicator commented on the provision of information to patierits, as described in Table XIX. Of the two sources who discussed 
TABAE XIX

RESULTS OF REUIEW OF LITERATURE CONCERNING PRCFESSICNAL

SOCIALIZATION FOR THE ROLE DF PHYSICIAN

ASCRIPTION VARIABLE, INDICATOR 4C:

PATIENT INVOLVEMENT

$1=$ Patient Not Involved 2 = Patient is Involved

\begin{tabular}{|c|c|c|c|}
\hline Author(s), Date & $\begin{array}{c}\text { Professional } \\
\text { Socialization Process }\end{array}$ & $\begin{array}{l}\text { Actual } \\
\text { Practice }\end{array}$ & $\begin{array}{l}\text { Ideal } \\
\text { Practice }\end{array}$ \\
\hline
\end{tabular}

Becker et al. (1961)

Beverly (1976)

\section{Blumenfield}

et al. (1979)

\section{1}

Students learn that

patients should be

cooperative, submissive.
1

Asserts that the general consensus anong physicians is that the whole truth should not be told.
2

Found socialization had

no effect-students same as house staff: patients should be told of their terninal illness. Ruthors note this represents a change froe the 1970's.

Freidson (1970a)
1

Each doctor has ultivate responsibility for his om patient; this is one of two basic values of the medical profession: "medical responsibility." This affects willingness to involve patients in decisions.
2

Patients want to know, 50 physicians should comunicate information using a tentative approach.

$1-2$

"The patient must be viewed as a distinct individual who is dealing with an extrexely isportant life event." Student should look beyond own needs and "what say seen to be the cultural thewes of today."

(Continued) 
TRBLE XIX, Continued

Harman (1971)

Haug (1579)

Krant (1978)

Lasagna (1968)

Rosenbern (1979)

There are conflicts in

socia!:ization; stucents

learn soth that tiley need to

te leaders and to work with

a team and that they need to be authority figures.
$1-2$

Notes challenges to physician authority are occurring las evidenced by seif-care and right to information movements) except by older people.

1

Asserts physicians are more likely to tell nales than femaies of their terminal illness.

1

States various studies indicate 70-90\% of doc tors do not inform patients they are facing a terminal illness.

Aisc, the image of doctor as Father, omiscient iaads to belief that docfor is not to be disobeyed.
Patients should be helped to reach death in the way they desire. They need information for this to occur.

2

Since self-care is inevitable, public needs training on appropriate utilization 8 limits of self-care.

\section{2}

Acknowledgement \& conmunication are very important for "easeful death" of the patient.

\section{2}

Studies indicate that 7789\% of patients would wish to be told if they were dying. Scili:z \& Aderman
(:376)
1

Arnue that in many cases, coctors do not revea! the nature of the terninal

i.iness to their patients.
$1-2$

The physician needs to be able to decide which decisions one must make \& wich must be left to the patient and the family.

\section{2}

Patients desire and need information.

(Continued) 
TABLE X:X, Contirued

Scurry at a:. (1979)

Searie (1981)

Szasz \& Hollender (4956)

Veatch \& Tai

(1980)
$1-2$

Found $25 \%$ of house officers responded that they thought it "essential to tell a dying patient of his prognosis, only $57 \%$ believed they did not avoid telling a patient directiy that he is dying." Such resporses are not entirely compatisle; indicate likely unconscious avoisance of patierits.

1

Due to oosessive-conpulsive role of physician to te thorough, complete, \& the strong sense of responsibility felt, physicians are not inclined towerd patient participation in decision-making.

\section{1}

Posit several nodels of the doctor-patient relationship, with nost crmmon one being physician guidance, patient cooperation.

$1-2$

Assert there is a change occurring: was "do no harm," (paternalism, therapeutic privilege); now it is patient autonory se!f-determiriation (protruth cultural mood).

Q150, :ay population is incrossingly sophisticated.
Disclosure is ideal.

2

Patients want wore responsibility for their health care, want someone who is candid about the limits of his knowledge and that of $i$ cine in general.

\section{2}

Imply preferred model is mutual participation, esp. where patient is terminal, as physican does not know what's best, cannot cure. 
the provision of information in the context of professional sacialization, one (Blumenfield et al., 1979) reported that students felt patients should be told of their terminal illness (pole 2), while the other source (Harman, 1971) found that physicians were not learning to inform patients (pole 1).

Those sources discussing the actual practice of physicians indicated, with one exception, that physicians do not reveal the terminal nature of patients' il lriess to theim patients (pole 1). Scurry et al. (1979) found that over four-fifths of the house officers they surveyed viewed the provision of information as essential to patients; however, only just over half believed that they did not avoid telling patients they are dying.

The sources which addressed this issue of provision of information generally felt that, ideally, patients should be told if they are dying. Blumenfield et al. (1979), however, caution that the physician should examine the case of each individual patient; not al I patients should be told. Several sources approached the subject of patierit involvement in more general terms, particularly as it related to the norm of "medical responsibility." In general, earlier (publication dates prior to 1979) sources indicated that it ig this norm to which physiciars are socialized (pole 1), they argue that physicians are socialized to believe that the patient's welfare is the 
physician's responsibility; therefore, the physician should make the treatment decisions and patients should be cooperative arid submissive. Most newer sources 11979 and more recent) note the cultural changes currently taking place, such as the consumer rights and the self-help movements (pole 2), and the increasing challenges to physician authority. Especially important for the present research, however, is Haug's (1979) finding that older people are much less likely to question their physiciar, and/or to wish to participate in their own care.

Exceptions were Searle (1981), who points out the obsessive-compulsive role to which physicians are socialized arid their reluctance to allow patient participation in decision-making, and Rosenberg (1979), who asserts that physicians in training receive contradictory messages (poles $1-2$ ) with respect to who, physician or patient and family, should make treatment decisions. Rosenberg (1979) indicates that the ideal is a situation in which the physician decides which decisions should be made by whom. All other sources feel iricreased patient involvement is desirable and/or inevitable, ard the ideal role expectation is for the physician to facilitate appropriate decision-making.

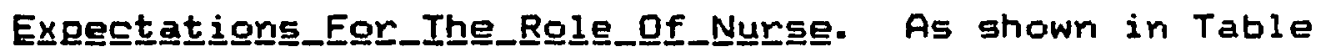
$x X$, the sources in the literature examined point out that while some attention is devoted to the concept of "involving 
TABLS XX

RESULTS OF REVIEW CF LITERATLAE CONCERNING PROFESSIONAL

SOCIALIZATICN FOR THE ROLE OF NURSE

ASCRIPTION VARIABLE, INDICATOR AC:

PATIENT INYOLVEMENT

$1=$ Patient Not Involved 2 = Patient Is Involved

Professional

Actual

Ideal

Futior (5), Date Socialization Process Practice Practice

Duint (1967)

1

2

Patients who cooperate are oreferred. Patients often are not informed of their prognosis.

Open awareness is ideal; however, author seens to assume it is the doctor's responsibility to provide this inforwation.

Rosenthal et al. (1980)

Schulz \& Aderman (1976)
$1-2$

"Involve the patient" is a phrase bandied about in the literature, education \& practice without exploration of its meaning or implication.
$1-2$

The basis of professional authority is being eroded as patients become better educated; yet patients who are perceived as demanding, moncompliant are "probien" patients, may be isolated. Uncertainty and loss of control are trreatening to health professionals, including nurses.

Re: the provision of information: traditionally the resporisibility of the physician, but his failure to provide nakes nurse's manayement of the patient more difficult.

1

Nurses tend to avoid the subject of death.
1

Ideally, from the nurse's perspective, the patient snould follow eagerly and exactly the therapeutic progran, be pieasant, uncomplaining, and $f i t$ into the hospital routine.
2

The patient reeds \& wants to know.

(Cont inued) 
if는 PY, SOnt:Y:EE

Veatch \& Tai $(\leq 90)$

Hilliams (1982)
$1-2$

The nurse looks more favorably to disclosure, but traditionally has

feit obliged to say the matter should be discussed with the pnysician; now there is more active patient involvement.

\section{1}

There is a faicure to share accurate information with the patient.
2

Information should be shared so the patient can fulfill the dying role, whereby the patient is no longer dependent on medical authority, is wore independent \& autonomous. 
the patient," little concrete training in implementation methods is provided (pole 1-2). Also, the loss of cantrol inherent when patients participate in decision making is threatening to nurses and other health professionals. With respect to the provision of information specifically concerning the nature of the patient's iliness and prognosis, there appears to be consersus that nurses do not provide such information (pole 1). Rasenthal et al. (1980) note that the provision of information traditionally has been the responsibility of the physiciar. All but one source feel that patient involvement and the provision of information to patients to facilitate involvemert (pole 2 ) is ideal. Rosenthal et al. (1980) preserit the nurses' ideal as being one in which the patient is cooperative, pleasant, and uncomplainirig (pole 1).

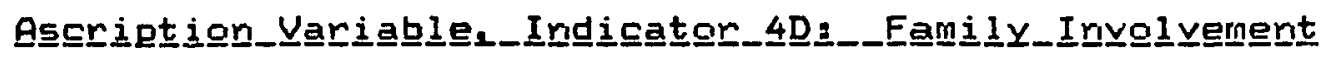

This section examines sources' reports of expectaticris to which health professionals are socialized with respect tci invalvement of families. Just as invalvement of patients in their own care and in care-related decisions implies ar ascription orientation on the part of the health professional, so does involvement of the patients, families (pole 2). Expectations that health professionals not involve patients" families, that the professionals "krow best," are achievement-oriented (pole 1). 


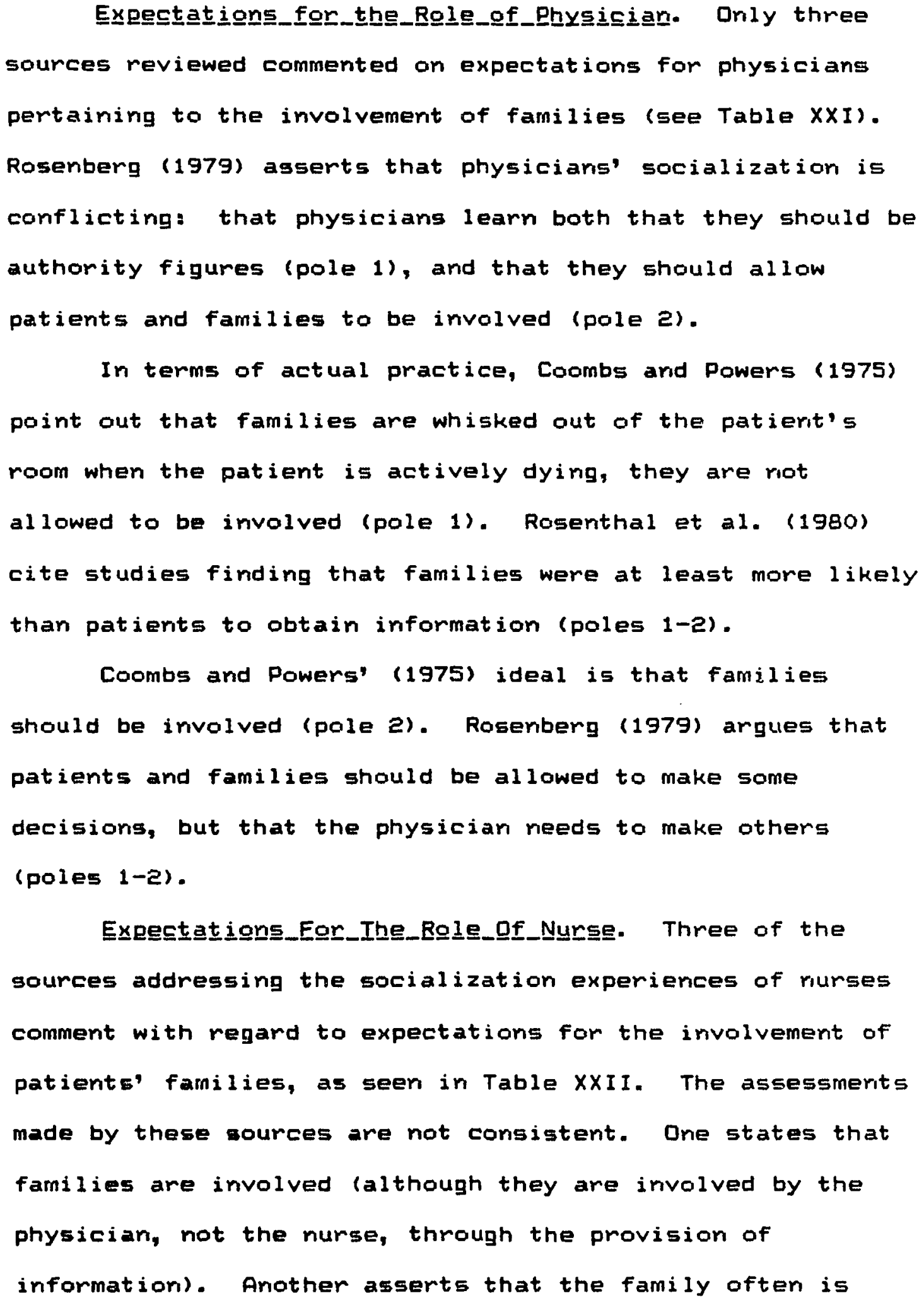

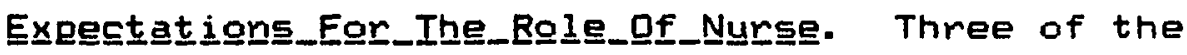
sources addressing the socialization experiences of rurses comment with regand to expectations for the involvement of patients' families, as seen in Table XXII. The assessmerits made by these sources are not consistent. One states that families are involved lalthough they are involved by the physician, not the nurse, through the provision of information). Another asserts that the family often is 
TABLE XX:

TESULTS GF REVIEN OF LITERATURE CENLERNIVG FRCFESSICNAL

SCCIALIZATION FUR THE ROLE CF MTYYSICIAN

ASCRIPTIGN VARIABLE, INDICATISA AD:

FAMILY INVOLUEAENT

\begin{tabular}{|c|c|c|c|}
\hline Author(5), Date & $\begin{array}{l}1 \text { = Family lot Involved } \\
\text { Professional } \\
\text { Socialization Irocass }\end{array}$ & $\begin{array}{c}2=\text { Family ls Involved } \\
\text { Actual } \\
\text { Practice }\end{array}$ & $\begin{array}{c}\text { Ideal } \\
\text { Practice }\end{array}$ \\
\hline $\begin{array}{l}\text { Coonts \& Powers } \\
\text { (1975) }\end{array}$ & & $\begin{array}{l}1 \\
\text { Family is not allowed to } \\
\text { be present during final } \\
\text { moments of patient's life. }\end{array}$ & 2 \\
\hline Rosenterg (1979) & $\begin{array}{l}\qquad 1-2 \\
\text { Conflicting socialization: } \\
\text { be authority figure vs. be } \\
\text { tean player with patients } \\
\text { and families. }\end{array}$ & & $\begin{array}{l}1-2 \\
\text { Physician aust decide } \\
\text { decisions physician shouid } \\
\text { make \& which ones sust be } \\
\text { left to the patient o the } \\
\text { family. }\end{array}$ \\
\hline $\begin{array}{l}\text { Rosenthal et al. } \\
\text { (1380) }\end{array}$ & & $\begin{array}{l}\qquad 1-2 \\
\text { Cite studies showing } \\
\text { families are nore likely } \\
\text { to obtain information than } \\
\text { patients. }\end{array}$ & \\
\hline
\end{tabular}


TASL XX::

RESULTS OF REVIEN OF LITERATURE CONCERNING PRCFESSIONAL

SOC:ALZZAT:ON FOR THE ROLE OF NURSE

ASCRIPTICN UARIABLE, INDICATOR 4D:

FAMI!Y SNVLLVEXENT

$1=$ Fanily Not Invoived $2=$ Family Is Involved

Professions!

Actual

Ideal

Aution (s), Data

Sociailization Process

Practice

Practice

Myers (:982)

\section{2}

Found in case study that parents were involved in ciscussion of treatirent options; howeyer, medical dostors initiated discussions.

Rosentinal et al. (1980)

Talcot-Porsonby

(1973)
$1-2$

The phrase "involve the fani iy" is prevalent in the literature, education \& practice, yet its meaning and iuplications are not explored.
$1-2$

The conventional strategy is to maintain control over fanilies; there is struggle, cor flict between nurses and families. When the patient is dying, though, visiting rules often are relaxed. Conferring the role of patient upon the faraily is more common than conferring that of worker.

The provision of inforinaticn is traditionally the responsbility of the prysician.

1

Modern medicine oiten excludes the fanily.
$1-2$

Farilites can be a probiem; the patient's domestic problems may follow hilu. While fanily involvement is consistent with nursing philosophy (which enphasizes the importance of patient' 5 support systems), it threatens numses' authority \& autonoty. At the sase time, it can cut down on nurses' work, let thew spend less time, not get enotionally involved, although with terainal patients, the nurse who delegates may feel quilty.

2

The fanily should be kept fully informed. Everything should be explained, including the nursing

care $b$ how the family can help. Family should be encouraged but not forced to become involved. 
excluded. A third notes that visiting rules frequently are relaxed for families of dying patients, but that families generally are not included as workers, helpers, or team members, and that any information provided to them usually is given by the physician.

Talcot-Porisonby (1973) argues that, ideally, families should be kept fully informed and advised as to how they car help (pole e). Interestingly, this author cautions that families should not be forcegd to becone involved. Rosenthal et al. (1980) appear to have mixed feelings concerring their ideal expectations for family involvement. They point out that families can be a problem, particularly in situations in which the patient and the family do not have a positive relationship. At the same time, families can aid in reducing nurses' work and decreasing the possibility of nurses' becoming emotionally involved with the dying patient.

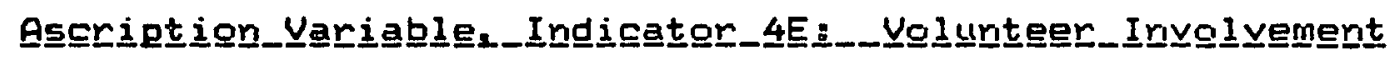 \\ None of the sources arialyzed made mention of role \\ expectations learned through socialization by either \\ physicians or nurses that addressed involvemerit of \\ volunteers in the care of dying patients.
}




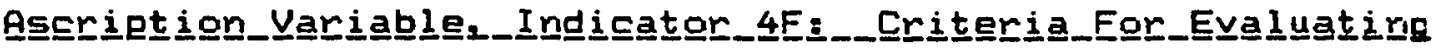

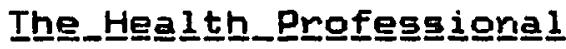

As noted in Chapter VI, Analytical Model, this last indicator of the achievement-orientation--ascription

orientation pattern variable differs in perspective from the previous six. Instead of ascertaining how the health professional is expected to treat or evaluate the patient or other members of the role set, this indicator examines the expectation concerning how the patient and other members of the role set evaluate or assess the health professional. Under scrutiny in this irdicator is whether the rale expectation to which the health professional is socialized is that the professional be evaluated in terms of (pole 1) his or her effectiveness, competerice, skills and capacities (pole 1, performance orientation) or his or her sex, age, intelligence, physical characteristics, or group membership (e.g., M.D., R.N.) (pole 2 , ascriptive or ascribed orientation).

In Chapter VI, Analytical Model, it was stated that in the medical model, since the patient is expected to comply unquestioningly with the health professional, evaluation of the professional likely would be ascribed, based primarily on the health professional's position as a doctor or a nurse, or on other personal ascriptive characteristics. Alternatively, in the hospice model, since the patient is expected to take a more active role in his or her care, it 
was posited that the health professional would likely be evaluated on the basis of performance capacity, not simply position as a doctor or nurse or other ascriptive characteristics, such as sex or age. In this indicator, then, the poles descriptive of the medical and the holistical models are reyerssed.

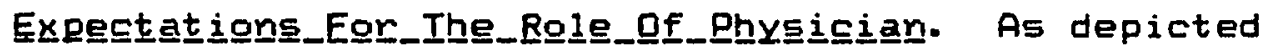
in Table XXIII, there was no consensus with regard to whether physicians are socialized to expect to evaluate themselves or to be evaluated by patierits on the basis of ascriptive qualities or their performance. A considerable number of the sources noted that physicians are reluctant to criticize each other's performance (pole 2 ), that physicians are viewed as amniscient by virtue of their positioris as physicians (pole 2), and that physicians learn the need to protect this image and to rever make a mistake. At the same time, some sources note that physiciaris are aware of instances of incompetent performance (pole 1), they learn to be self-critical (pole 1), and they are socialized to high standards and an obsessive-compulsive workstyle (pole 1). Notable anong sources' ideals are the cornents of Fox (1957), who points out that doctors who do not present themselves as all-knowing evoke criticism and alarm on the part of patients, and those of Searle (1981), who argues the opposite position: that patients want doctors who are selfcritical. The lack of agreement among sources appears to be 
TABLE XXIII

RESLLIS IF REVISN OF LITERATURE CONCERNING PRGFESSIUNAL SOCYALIZATION FOR THE ROLE GF DHYSICIAN

ASC.IDTION VARIABLE, INDICATOR QF:

CRITERIA FOR EVALLATISN

$1=$ Acrievenent Criteria $2=$ Ascriation Criteria

Protessional

Actual

Ideal

Author (s), Date

Socialjzazion Process

Practice

Practice

Cucous (1979)

1

Yecisai students say good

doctors aust be techni-

ca: ¿y competent.

$F_{0 K}(1957)$

Harnian (1971)

Lasagna (1968)

\author{
Mullaly : Osmond \\ (1979)
}

Robinson (1974)
2

Students are socialized

to be "savant."

2

Trainees are reluctant

to make negative judgments

of colieagues' professional conduet.

\section{2}

Medical students are unquestionably superior, intellectually, to the "average man."

1
2

The doctor is regarded as an expert.
2

The doctor wust act like a savant; otherwise, evokes criticism \& alarm.

1
The image of the doctor is one of father, diety, priest, omniscient, yet the doctor "knows how fallible he often is. "
1-2

Doctors need sufficient natural sensitivity \& espathy.

\section{$1-2$}

Any practitioner is assumed qualified to perfora any ordinary duties, but the work of each is also seen as a creation of his personality and experience. Kerit is evaluated bases on both formal training \& experience. 
TABLE XXIII, Continued

\begin{tabular}{|c|c|c|c|}
\hline Rosenioerg (1979) & $\begin{array}{l}\qquad 1-2 \\
\text { Learn the need to protect } \\
\text { the inage of aedicine, of } \\
\text { colleagues (2) yet know } \\
\text { of instances of incompe- } \\
\text { tence (1); leam the need } \\
\text { to be self eritical (1) } \\
\text { versus the need never to } \\
\text { inake a mistade (2). }\end{array}$ & $\begin{array}{l}1 \\
\text { Medical politics \& } \\
\text { hostility cominate over } \\
\text { the neecs of patients } \\
\text { families. }\end{array}$ & \\
\hline Searle (1981) & 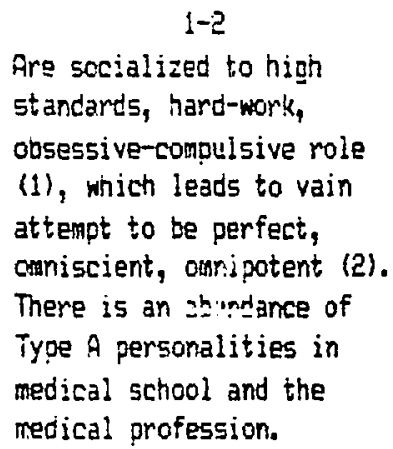 & & $\begin{array}{l}1 \\
\text { Patients want doctors } \\
\text { wo are candid about the } \\
\text { limits of their knowledge. }\end{array}$ \\
\hline
\end{tabular}




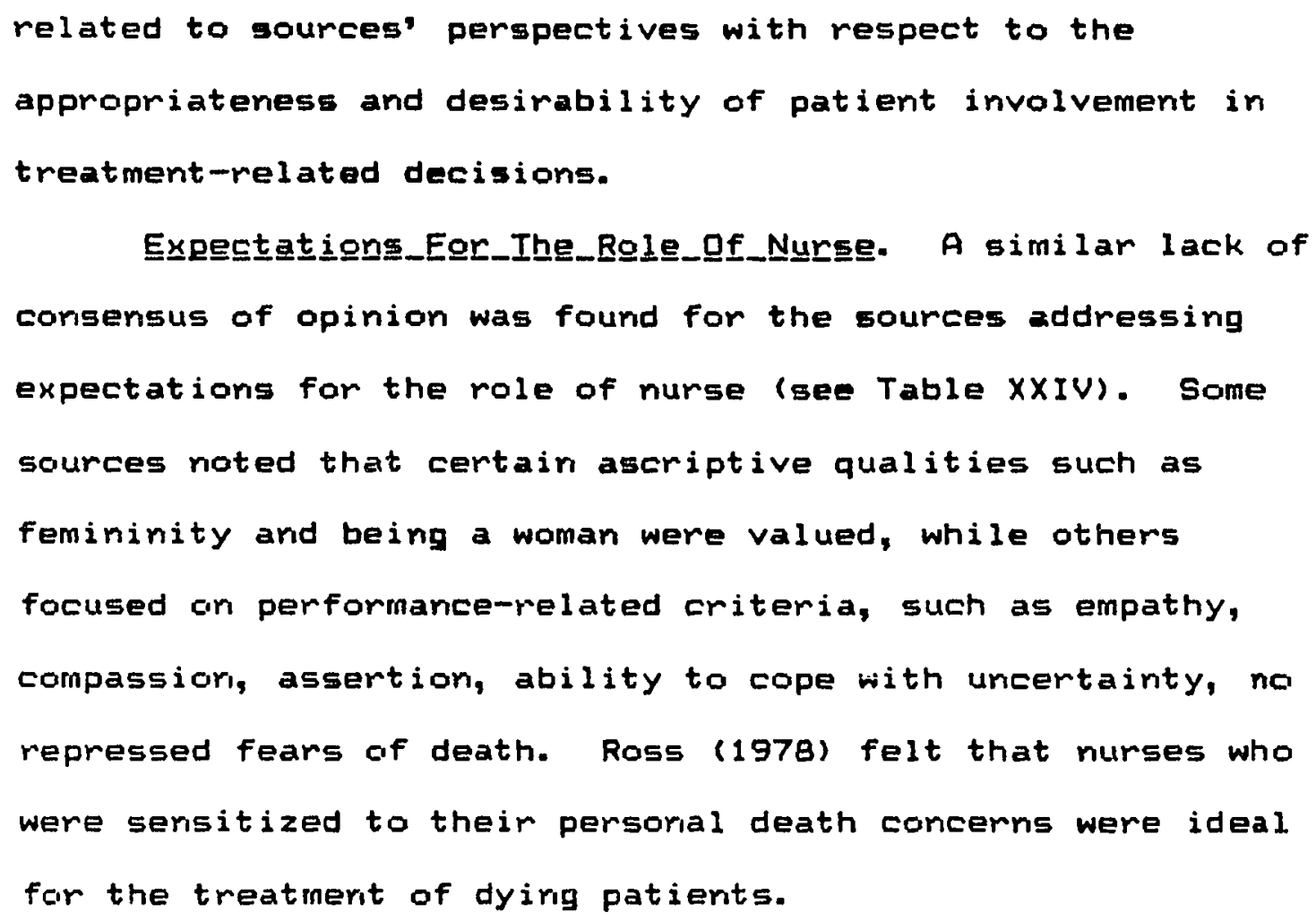


TABLE XXIV

RESLLIS OF REVIEN OF LITERRTURE CONCERNING PROFESSIONAL

SOCIALIZATION FOR THE ROLE OF NURSE

ASCRIPTICN VARIABLE, INDICATOR 4F:

CRITERIA FOR EVALLLATICN

$1=$ Acnievenent Criteria $2=$ Ascription Criteria

\begin{tabular}{lccc} 
& Professiorial & Actual & Ideal \\
Author(5), Date & Scciaization Process & Practice & Practice \\
\hline
\end{tabular}

Jacox $\langle 1974\rangle$

2

2

Sorte nursing instructors

There is a predominance

Luris (198:)

Myers (:9a2) explicitly tell their

students that their

femininity is an ispur

tant asset to be used

when relating to physicians.

1

Pre-socialization:

describes the importance

of selecting the right

candidate with the right

characteristics, including

empathy, compassion,

assertion, less bureau-

cratic, nore psychosocial,

yetter able to cope with

uncertainty.

2

1

The school-based iceal is that the nurse does not sake a mistake, responis clearly. of women in the ranks.

\section{Observes that nurses do wake mistakes, do not always respond clearly and quickly.}

Quint (1967)

1

The avoidance of errors in practice is taught as extremely important, and is related to comcerns of personal negligence.

Ross (1978)

1

Found some nurses were sensitized to death, some had repressed personal fears of death.
1

Nurses sensitized to their personal death concerns are helpful in the treatment of dying patients. 


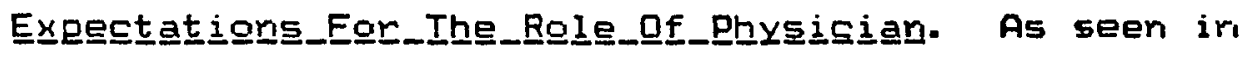
Table XXV, in general, most sources seem to feel that scicialization is to the service orientation (pole 2), but pressures related to the rieed to protect colleagues arid ter gain and protect position also are learred (pole 1). As expected, several sources expound the ideal of the service orientatior (pole 2, patiert's welfare first). Two sources, however, (Searle, 1981 and Coombs, 1978) argue that orie impartarit method for serving the patient irvolves meeting the needs of the phyㅗㅡ트름 first (pole 1), including needs to talk about subjective feelings arid to be enotionally and physically fit.

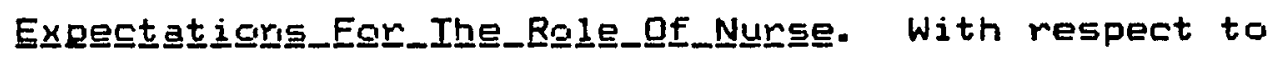
the socialization of rurses, a change in the role expectations to which nurses are socialized appears to be underway. Motives other than a humanistic calling to sacrifice oreself for the sick (pole 2 ) are becoming acceptable, including personal fulfillment and social status (pole 1), as described in Table XXVI.

The ideals of the sources rarige from the expected service ideal (pole e) to implementation of various strategies to protect the rurse from stress (pole 1, although again, this is seen as having benefits for patients arid fanilies, as well as the nursel ta a mixed ideal, whereby both a wish to meet patients' needs and a desire for personal fulfillment are seen as acceptable (poles 1-2). 
TABLE XXV

RESLLTS OF REVIEN OF LITERATURE CONCERNING PRCFESS:DNAL

SCCIALIZATYON FOR THE ROLE OF PHYSICIAN

COLLECTIVITY ORIENTATION VARIABLE, INDICATCR 5A: MDTIVATION

$$
1=\text { Provicer's Wel fare } 2 \text { = Datient's Welfare }
$$

Firs:

First

\begin{tabular}{ll} 
Aution(5), Date & $\begin{array}{c}\text { Professional } \\
\text { Socialization Precess }\end{array}$ \\
\hline & $\begin{array}{l}\text { Medical students state } \\
\text { that a good doctor must } \\
\text { be dedicated to the } \\
\text { patient's welfare. }\end{array}$
\end{tabular}

Harnan (1971)

Robinson (1974)

Rosenberg (1979)

\section{1}

Reports that seniors were less patient-centered than fresimen and intern/resident sampies. Also notes that trainees are roluctant to make negative judgments of co!leagues' professiona! conduct; this rould be an infraction of the conserr sualiy defined ethics of physicians.

\section{2}

A service orientation is ipherent in the definition of a professional.

$$
1-2
$$

Students learn the need to protect the inage of wedicine \& colleagues but are aware of instances of incompeternce. Also learn the need to be seif-critical, yet at the sane tine, to never make a wistake.
Actual Ideal Practice Practice 
- $A B E \equiv X X$, Continuec

Sean': (1781)

Shuval (1975a)

Veatch \& Tai (1980)
2

Socialization is to the "service ideal."
1

Actual commitment is to the occupational role of physician.

$1-2$

The physician needs to be attuned to his/her ann welfare (decrease use of drugs, alconol; improve marital relations; get more sleepl to best be able to serve the patient.

1

Cites vested interests, territorial competition anong disciplines \& their dorains.

\section{2}

Refer to Parsons (1951) collectivity orientation " and note two changes: patient welfare has expanded to include patient autonumy, and the "collectivity" has changed to incluoie several professional roles. 
TAELE XXVI

RESULTS GF REVIEW GF LITERATURE CONCERNING PROFESSIONAL SOCIPLIIATION FOR THE ROLE OF NURSE

COLLECTIVITY URIENTATION VARIABLE, INDICATQR 5A: ROTIVATION

1 = Drovider's Welfare 2 = Patient's Welfare

First First

\begin{tabular}{|c|c|c|c|}
\hline Author (s), Date & $\begin{array}{c}\text { Professional } \\
\text { Socialization Frocess }\end{array}$ & $\begin{array}{l}\text { Actual } \\
\text { Practice }\end{array}$ & $\begin{array}{c}\text { Ideal } \\
\text { Practice }\end{array}$ \\
\hline
\end{tabular}

Alutto et al. (1971)

Eermain (1980)

Jacox (1974)

Myers (1982)

\section{$\hat{2}$}

Found no difference in orientation among nursing students in three educational structures lassociate, diploma, baccalaureate); all had a service orientation.
$1-2$

Cites Vachon's (1978) reasons for wanting to work witi dying patients, only one of which is a sense of humanitarian calling. States that ideal nursing performance is impeded by professionalbureaucratic role demands.

2
Are socialized to have a wilizngress to serve others.

$$
1-2
$$

The old nurse values said nurses follow a calling to care for the sick \& poor through sacrifice of self for others. Energing nurse values say nurses select a social status and follaw gersonal goals

first and respond to a high, sacrificial calling last. 
TAELE XXVI, Sontinued

Quint (1967)

A hich value is olaced on protecting self from

regligent performance.
Rosenthal et al. (1980)

Vachon (1978) $i-2$

Nurses want to alleviate suffering and to participate in the process of caring for or curing the sick, but professionalbureaucratic role demanos ingede idea! nursing performance.

$$
1-2
$$

Describes possible notivations of staff for caring for dying patients, including accidents or convenience; cesire to do the "in" thing; intel lectual appeal or desire to gain contral over pair or illness; religious or humanistic "cailing;" previous urresolved grief; suspicion one wight develop the disease.
$1-2$

Other reasons for doing a good job of caring for the dying, as well as service orientaicion, are acceptable, including personal worthwileness \& fulfill went.

2

The ideal is the humanitarian, or service concept/ orientation of nursing.

\section{1}

Because of these various motivations, unexpected stress can be encountered 1 pose problews for patients, other staff, families. Advocates recognition that staff have needs, motivations, \& stress $t$ urges that staff develop insight into own needs; waintain balance between work : outside life; quard against too great a need to be needed la tean approach is cruciall; maintain support systea at work \& outside; have ongoing support of counselor, therapist. 


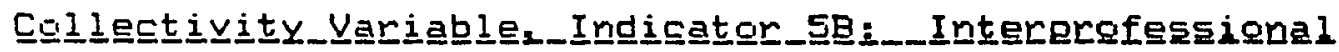

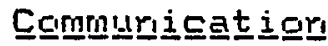

Examined in this indicator is the role expectation

with respect to the need for health professionals to: spole 1) furictiar separately, individually; or (pole e) coordinate their efforts, to communicate, to work together, and/or to be a "team." Health professionals who coordinate their efforts and are supportive of one another are viewed as being collectivity orierited. Health professionals who furiction separately and independently are seen as self arierited.

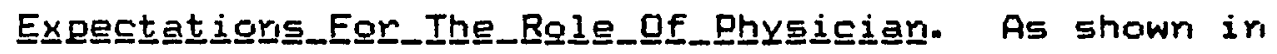
Table XXVII, orily three of the sources reviewed specified haw physiciars are socialized with respect to this issue. Raseriberg (1979) motes that physiciaris receive corflictirg messages (poles 1-2) in their professional socialization, iricludirg those to be an autharity figure, but also to work with a tean. This author asserts that in practice, however, the tendericy is to "go it alorie" (pole 1). Each of the other sources, as well, point out competition and poor cornmurication anong professionals in actual practice (pole 1).

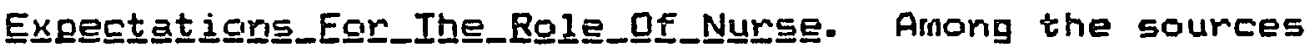
discussing socialization for the role of nurse lsee Table XXVIII) there was a general consensus that while nurses may receive some trainirig ir haw to work with certain ather 
TFELE XXVI:

RESULTS OF REVIEN OF LITERATURE CONCERNING DROFESSICNAL

SOCIALIZATION FOR THE ROLE OF PHYSICIAN COLIECTIVITY ORIENTATION VARIABLE, INDICATCR EB: INTERPROFESSIONAL

COMMUNICATION

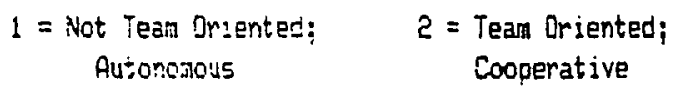

Professional

Rctual

Ideal

Autinor (5), Date

Socialization Process

Practice

Practice

Rosertere (1979)

$1-2$

1

Conflicting socialization: Tendency is to "go it

be a leader, be responsible, alone."

work with a team, be an

authority figure.

Shuval (1975a)

1

Notes competition between

disciplines \& their

donains.

Veatch \& Tai

(1980)

1

What is dominant now is the hospital, rather than the isolated physician. The hospital, if not a team, is at least a health care bureaucracy. Cowunication within the staff is often less than ideal. 
TABLE RYVIT:

RESLLTS OF REVIEN OF LITEGRTURE CONCERNING PRCFESSIONAL

SOCHRIIZOTICN FOR THE ROLE OF NURSE

COLLECTIVITY ORIENTATION VARIABLE,

INDICATCR JB: INTERPGCFESSIOHALL

CEMALINICATICN

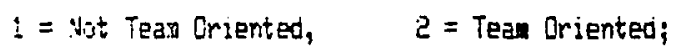

Jacox $(! 974)$

Lurie (1981\}

Quint (1967)

$1-2$

Students are not taught

to work effectively with physicians. They do

learn, though, to use

clergy; referral to a

minister can take the

pressure off the nursing staff.

Rosenthal et al. (1980)

Hilliams (1982)

$$
\text { 1-2 }
$$

Nurses raay learn to be tean-oriented, but they are not 5killed at regotiating with other heel th professionais.
1

Cites others who note troblems of teamwork : interpersonal contrunication.

1

Cites work of others who found probleas of poor inter-professional cormunication.

There are comunication probiems between physicians and nurses; these sten directly from alefenale noms.

$1-2$ $1-2$

The nurse needs to learn how to work in a lead professional \& interprofessional teams, but also have the ability, authority to nelue decisions independently, autononously, as well as in collaboration.
Conflict in cure vs. care philosophy leads to intrastaff conflict. 
professionals such as clergy, they are not skilled at negatiatirg with ather health professionals (Quint, 1967; Rosenthal et al., 1980). In additior, there are problems ir the workplace of pcior inter-professional cormunication arid cooperation (pole 1 ).

The ideal expectation is for the nurse to be a capable team member, communicating and collaborating with the other professicirals irivolved (pole 2). Roserithal et al. (1980) feel that the rurse should have the ability and authority ta make decisions indeperidently and autoromously, as well as in collaboration (poles 1-2).

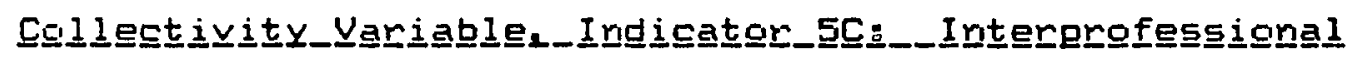

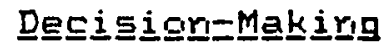

Clasely interrelated with Iridicator 58 (Interprofessichal Communicationl is this indicator of the role expectations corcerring the status relationship between health professionals. Examined is the question of whether the decision-makirig structure is hierarchical, with one professional making the decisions (pole 1) or egalitarian, with all disciplines havirg equal input in decisions fpole 2). This indicator looks at those sources that deal specifically with this question of decision-making and authority.

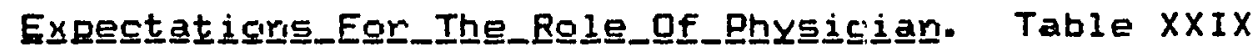
shows that faur sources make commerits in this area 
TPBLE XXIX

RESULTS OF REVIEN OF LITERATURE CONCERNING PROFESSIONAL

SOCIALIZATION FCR THE ROLE OF PHYSICIAN

COLLECTIVITY DRIENTATION VARIABLE,

INDICATCR 5C: INTERPROFESSIOW L

DECISIONA AKING

\begin{tabular}{|c|c|c|c|}
\hline Author (5), Date & $\begin{array}{c}1 \text { = Hierarshica: } \\
\text { Profossional } \\
\text { Socialization Process }\end{array}$ & $\begin{aligned} &= \text { Egalitar } \\
& \text { Retual } \\
& \text { Practice }\end{aligned}$ & $\begin{array}{c}\text { Ideal } \\
\text { Practice }\end{array}$ \\
\hline Rodirison (1974) & & 1 & $\begin{array}{l}1 \\
\text { The activities of other } \\
\text { occupations who work in } \\
\text { relation to health } \& \text { ill- } \\
\text { ness are derived frow } \\
\text { those of the medical pro- } \\
\text { fession. Even if the } \\
\text { medical professional does } \\
\text { not perforn these acti- } \\
\text { vities, he or she does } \\
\text { control \& have final res- } \\
\text { pensibility for then. }\end{array}$ \\
\hline
\end{tabular}

Rosenterg (1979)

$1-2$

Conflicting socialization:

medical students learn

to be leaders, be respon-

sibie, yet at the same

time, to be tean menters \&

to check everything with

a superion.

Shuval (1975a)

1

There are status differentials among health

professionals.
2

These differences shouid be attenuated to enable collaboration as a team.

Veatch \& Tai (1980)

$1-2$

Traditionally, the doctor-

nurse relationship has been

hierarchical (doctor higher).

Increasingly, nurses are

developing a sphere of

role autonony \& respon-

sibility. 
coricerning the socialization, professional and workplace, of physiciaris. Three note traditional status differentials (pole 1), especially between doctors and nurses, and the fourth reports that physiciars receive conflicting messages in training with respect to whether they are to be the leader and be responsible, or whether they are just orie member of a team (poles 1-2). Two sources express ideals, ore of whorn (Rotinson, 1974) accepts as a given the higher status of the physician and believes this hierarchy is appropriate (pole 1), while the other asserts that team collaboration (pole e) is the ideal approach.

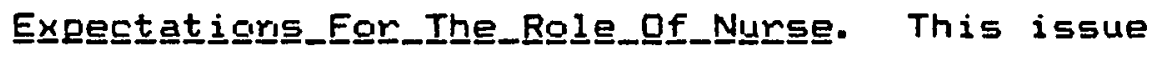
appears to be quite a salient one with respect to the role of the nurse. As seen in Table $x X x$, the majority of the sources commerit on this issue of iritemprofessional decisionmaking. Most of these sources assert that nurses are scacialized to hold expectations for hierarchical decisiormaking (pole 1). Two opposite forms of hierarchical structure are described, however: one in which the physician is at the pinnacle making decisions, the other ir, which the rurse holds this position of autonomy and authority. Some sources argue that nurses are socialized tc obey physiciars, and that nursing is subordinated to medicine; others argue that nurses learn autonomous decision-making skills in their professioral socialization, and that particularly in the care of terminally ill 
TABDE XXX

RESLLTS GF REYIEN DF :TTERATUSE CCALERNING PROFESSIONGL

SCEC:AL:ZATICN FOR THE ROLE OF NHARSE

CCLLECTIVITY ARIENTATION VARIABLE,

INDICATOR SC: INTERPROFESSIONAL

DECISIDA-MAKING

\begin{tabular}{|c|c|c|c|}
\hline & $1=$ Higrarchical & $=$ Egalitaria & \\
\hline Author(s), Date & $\begin{array}{c}\text { Professiona! } \\
\text { Socialization Process }\end{array}$ & $\begin{array}{l}\text { Actual } \\
\text { Practice }\end{array}$ & $\begin{array}{l}\text { Ideal } \\
\text { Practice }\end{array}$ \\
\hline
\end{tabular}

Alutito et ais. (1971)

Freithofer \&

Feiton (1976)

Germain (1980)

Gliebe (1977)

Krant (1976)
1

Found a predisposition

to autionitarianis 5,

greatest akong nurses

in associate degree pro-

grans, then diploma, then

baccalaureate.
1

Found hierarchical relationships in their exploratory research (physician first).
1

Arque the nurse, due to the amount of contact with the patient \& fanily, is in a sost favorable position to assist individuals cope with death $\&$ dying.

Socialization iaparts autononous decisionmaking skills.

1

Autonony, independence, \& flexibility are learnat.

1

Nurses are socializes to be "obedient," not auto" momous, not to exercise professional judgment.

\section{1}

Autonony, independence, $\$$ willingness to take risks are ideal.

1

In late stage disease, nurses have more input.
1

More input by nurses is necessary in late stage disease.

(Continued) 
TABLE XXX, Continued

Lurie (1981)

$$
1-2
$$

There are colleagial relations between nurses \& physicians, yet hierarchical relationshios between nurses (who are on top) \& other heaith care workers.

Myers (1982)

Quint (1967)

Rosenthal et al. (1980)

Simpsor (1976)

Wessell (1979)
1

Nurses are socialized to

see the nurse as a leader.
1

The physician is perpet- Nurses need to break old uated as being in the sole authority position.

1

Nursing is subordinated to medicine-a fewaledominated one to a maledoninated one; the roots of this are in sexista (cites several sources). The physician is at the pinnacle; the nurse is expected to support physician's decisions [E. g., re: provision of information).

In terminal care, the role of the physician recedes, shifts to the nurse.

\section{1}

The nurse presently plays The nurse should docua ajor role in the management \& execution of care of the terminally ill at home. established patterns of dealing with physicians; need to do nore than just carry out doctors' orders.

\section{2}

The professional sociailzation of nurses wight be improved to develop a cadre of nurses who are more assertive than is at present customary, \& wore skilled in negotiating with other health professionals in a team setting.

\section{1}

Nurses should have the predowinant role in the provision of terminal care.

1 ment \& expand this role. 
patierits, actually have more input than physicians. All sciurces argue that ideally, nurses should at least be equal members of the health professional team (pole 2), and several sources assert that nurses should play the dominant role in the provision of care to the dying (pole 1).

Suromaㅡy

Tables $X X X I$ and $X X X I$ depict the indicators addressed by each of the sources reviewed with regard to expectations which each asserts are learned arid held by physicians and nurses, respectively. These tables are useful for pointing out the types of role expectatioris to which the most atterition was devoted in the literature reviewed. Indicators receiving the greatest amount of attention in the literature on socialization of physicians included: 4A (Treatment Goal), 2A (Scope of Care), 4C (Patient Irivalvement), and $1 A$ (Affective Involvemert). Those meritioried most aften anong the sources reviewed in the literature or socialization of nurses included: 5C (Interprofessional Decision-making), 4A (Treatment Goal), eA (Scape of Care), and $1 A$ (Affective Involvement), in that order. If prevalence of appearance in the literature car be assumed to indicate salierice, this analysis reveals considerable cormonality of focus on particular issues in socialization for these two health professional roles. Not mentiored in either of the socialization literatures was the 
TABLE IIII

DESCRIPTIOHS OF SOCIN 1IATIOOW FOR IHE ROLE OF PHYSICIAN:

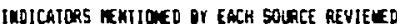

IWOICAIOSISI MENTIOWED

\begin{tabular}{|c|c|c|c|c|c|c|c|c|c|c|c|c|c|c|c|}
\hline \multirow[b]{2}{*}{ DUTHOF IS! AVE DATI } & \multicolumn{2}{|c|}{ AAFFECIUIIY: } & \multicolumn{2}{|c|}{ DIFFuSERESS } & \multicolumn{2}{|c|}{ : PAKTICUCARISA: } & \multirow[b]{2}{*}{ A } & \multirow[b]{2}{*}{48} & \multicolumn{2}{|c|}{ ASCAIPIION } & \multirow[b]{2}{*}{$4 t$} & \multirow{2}{*}{$\begin{array}{r}5 \\
4\end{array}$} & \multirow{2}{*}{\multicolumn{2}{|c|}{${ }_{5 k}^{\text {Calecrivity }}$}} & \multirow[b]{2}{*}{ st } \\
\hline & $!$ & 1a! & $2 \mathrm{~h}$ & $2 \mathrm{E}$ & $x:$ & $3 A !$ & & & $4 c$ & 40 & & & & & \\
\hline & : & : & & & i & i & & & & & & $:$ & & & \\
\hline \multirow{2}{*}{$\begin{array}{l}\text { Decter. Geer. Hohtes. I } \\
\text { Strauss } 118611\end{array}$} & $:$ & 1: & $x$ & & $!$ & $!$ & 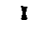 & & $x$ & & & : & & & \\
\hline & $:$ & $\vdots$ & & & $\vdots$ & $!$ & & & & & & $!$ & & & \\
\hline \multirow{2}{*}{ Dever Ir (1979) } & $:$ & $\vdots$ & & & $\vdots$ & $\vdots$ & & & & & & ! & & & \\
\hline & : & $:$ & & & : & $\vdots$ & & & t & & & $\vdots$ & & & \\
\hline \multirow[t]{2}{*}{ Bloon (11989) } & $!$ & t: & 1 & & : & $:$ & & & & & & : & & & \\
\hline & $!$ & : & & & ! & $\therefore$ & & & & & & $\vdots$ & & & \\
\hline \multirow{2}{*}{$\begin{array}{l}\text { Blusetivield. Lerv. } 1 \\
\text { Koufean (1979) }\end{array}$} & $:$ & $\vdots$ & & & $\vdots$ & $\mathbf{I} !$ & & & $\mathrm{I}$ & & & $\vdots$ & & & \\
\hline & $:$ & : & & & : & : & & & & & & : & & & \\
\hline \multirow[t]{2}{*}{ Cootbs (1978) } & : & $1:$ & $x$ & I & ! & 11 & 1 & & & & & 11 & $x$ & & \\
\hline & : & $\therefore$ & & & $\vdots$ & : & & & & & & $!$ & & & \\
\hline Cosobis \& Foners 119753 & $\vdots$ & $\begin{array}{l}1 \\
\vdots\end{array}$ & 1 & $x$ & : & $x !$ & $\mathrm{I}$ & & & 1 & & $\vdots$ & & & \\
\hline \multirow{2}{*}{ Dickenson (1976) } & $:$ & $:$ & & & : & $:$ & $\mathrm{t}$ & & & & & : & & & \\
\hline & $:$ & $:$ & & & $:$ & : & & & & & & $:$ & & & \\
\hline \multirow[t]{2}{*}{ Eostein (1974) } & $\vdots$ & $i$ & & & $\vdots$ & $\vdots$ & 1 & & & & & $\vdots$ & & & \\
\hline & $\vdots$ & $\vdots$ & & & $\vdots$ & $!$ & & & & & & $\vdots$ & & & \\
\hline Fieid (1953) & ; & $\vdots$ & 1 & 1 & $\vdots$ & $:$ & & & & & & $:$ & & & \\
\hline for $(1957)$ & : & $:$ & $x$ & & $:$ & $:$ & & & & & & 1: & & & \\
\hline \multirow{2}{*}{ Freidson $1197\left(0_{3}\right)$} & 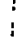 & $\vdots$ & & & $\vdots$ & $\vdots:$ & & & $\mathrm{x}$ & & & $\vdots$ & & & \\
\hline & : & $\vdots$ & & & : & : & & & & & & : & & & \\
\hline \multirow{2}{*}{ Hicts 119701} & $:$ & $!$ & & & $:$ & $!$ & & & & & & $:$ & & & \\
\hline & $i$ & $\vdots$ & & & $i$ & : & & & & & & $!$ & & & \\
\hline Hat aen (1971) & : & : & $\mathrm{I}$ & & 1: & 1: & & & $\mathrm{x}$ & & & 1: & $x$ & & \\
\hline & $\vdots$ & $\vdots$ & & & $:$ & $!$ & & & & & & ! & & & \\
\hline Havo (19979) & $!$ & $!$ & & & $:$ & $\vdots$ & & & $x$ & & & $\vdots$ & & & \\
\hline & $:$ & $:$ & & & $:$ & $i$ & & & & & & $i$ & & & \\
\hline Kenoti (1975) & $!$ & $!$ & & & $:$ & $:$ & $y$ & & & & & $:$ & & & \\
\hline Krant $(1978)$ & $\vdots$ & $\vdots$ & & 1 & $\vdots$ & 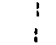 & & I & 1 & & & $\vdots$ & & & \\
\hline & $\vdots$ & $\vdots$ & & & : & : & & & & & & : & & & \\
\hline Lawona 119881 & $:$ & 1: & $\mathrm{I}$ & & : & I: & 1 & & 1 & & & 1: & & & \\
\hline & $:$ & : & & & : & $:$ & & & & & & $:$ & & & \\
\hline Levinson $(1967)$ & $!$ & 1: & & & $!$ & $!$ & & & & & & $\vdots$ & & & \\
\hline Lief \& Fox (1963) & $\vdots$ & $x !$ & & & $\vdots$ & $\vdots$ & & & & & & $\vdots$ & & & \\
\hline & & & & & & : & & & & & & $:$ & & & \\
\hline
\end{tabular}


TRBiE IIXi. Coatinued

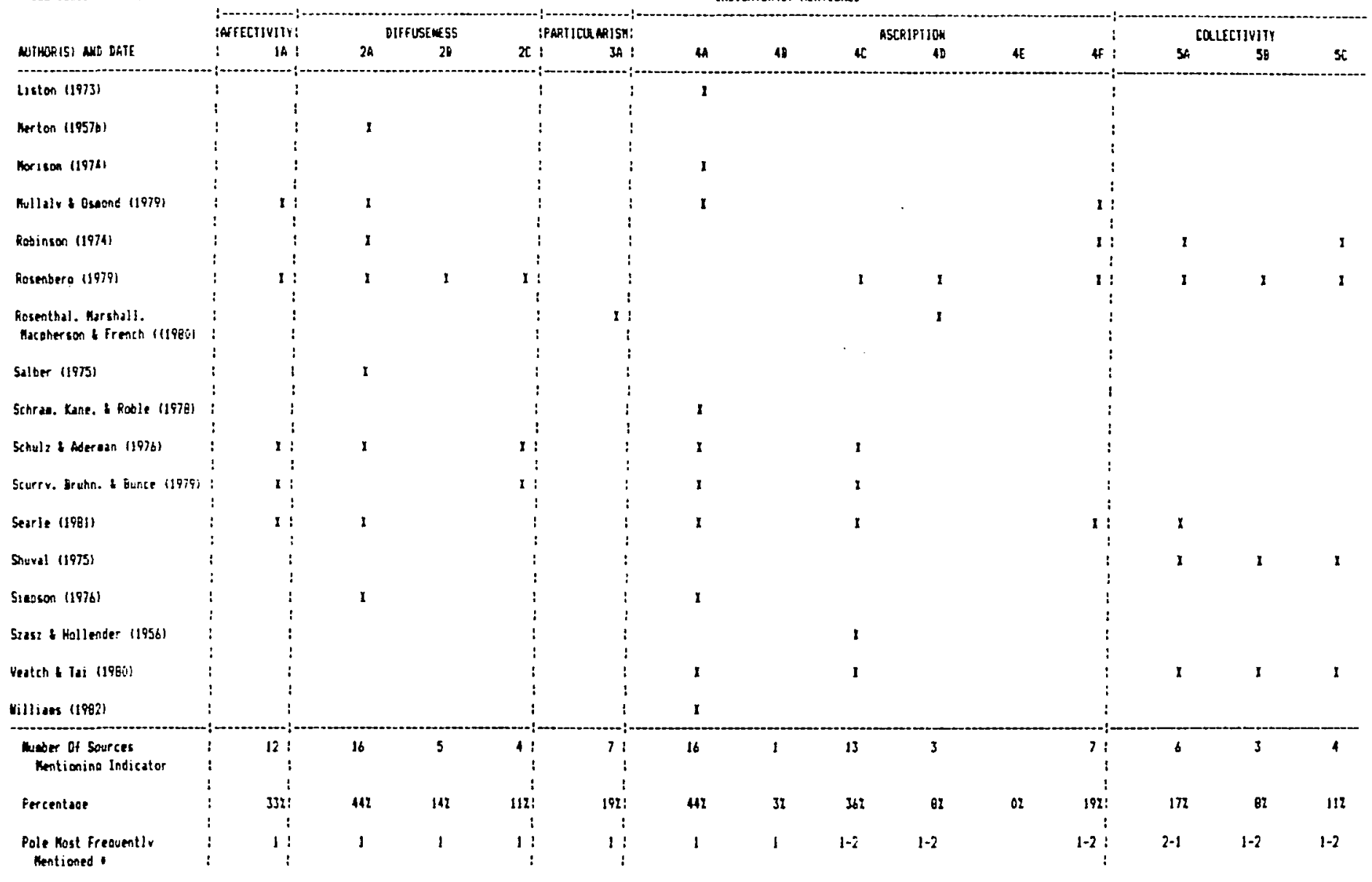

- Pole 1 a aedical codel nor antive role expectations

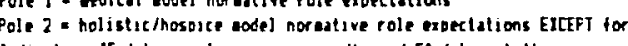

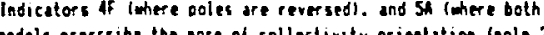




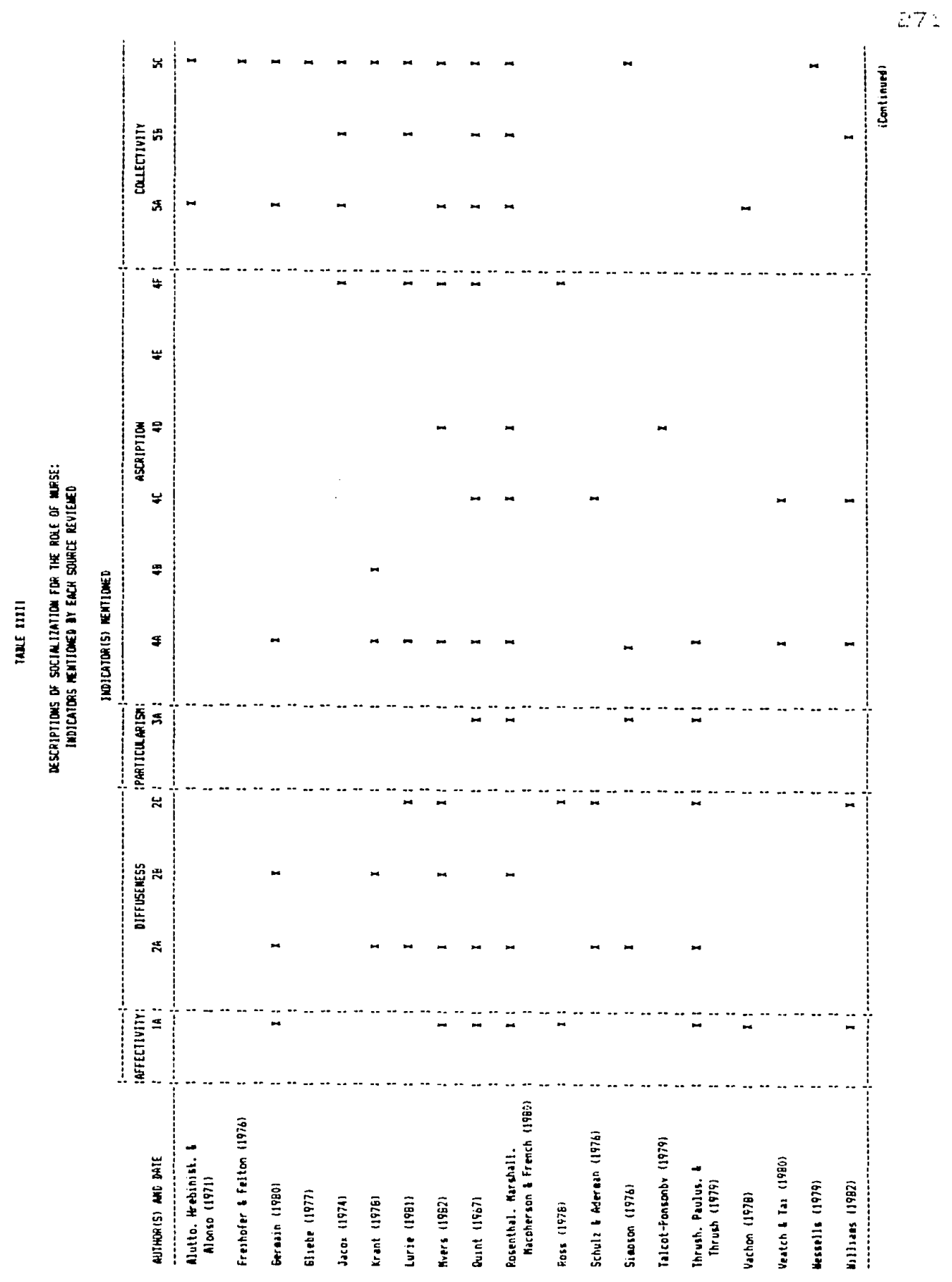


TABLE MIII. Continued

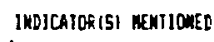

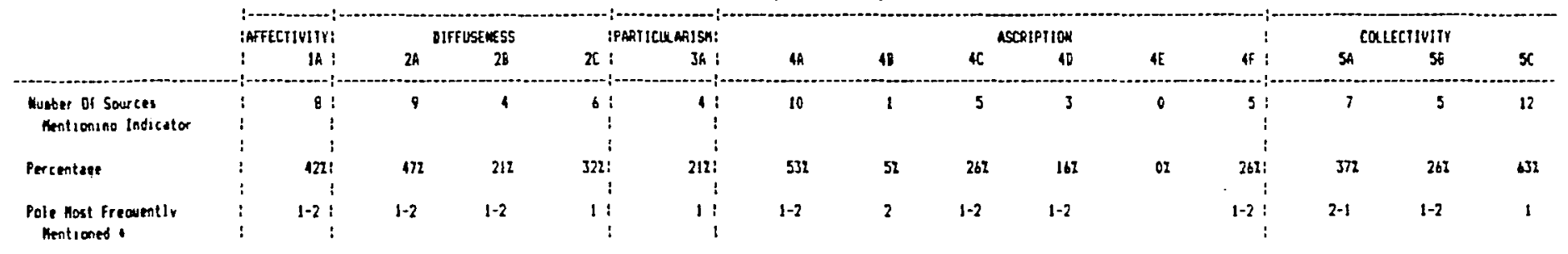

- Pole 1 = ectical sodel noraative role esoertations

Pole 2 = holistic/hossice dodel nor attive role expectutions EBCEFT for

Inticators ff latere soles arte reversed. and SA lathere both 
issue af volunteer invalvement in the care (4F). Noteworthy also is the lack of attention to the issues of pain control practices (4B) and family involvement (4D).

Tables $X X X I$ and $X X X I I$ also cortain a row specifying, for each indicator, which pole, 1 or 2 , best represents the reports of the majority of the sources reviewed with regard to the specific role expectations that the physician or nurse is socialized to hold. It should be recalled that pole 1 is assaciated with the medical model of health care provision and pole 2 with the holistic madel, with the exception of Iridicators 4F (Criteria for Evaluation of the Health Professional), in which the poles are reversed, and 5A (Motivation of the Health Professional), in which pole $a$ represents the narns of both models.

As depicted in Table $X X X I$, this analysis of the literature on socialization for the role of ghysician reveals that, as hypothesized, the role expectations which are learried and held by physicians gererally appear to be congruert with the norms of the medical madel. At the same time, there appear to be some issues with respect to which socialization for the role of physician is (a) conflicting ard/ar (b) seems to be moving toward the norms associated with the holistic model. These issues include patient and family involvement $(4 C$ ars $(D)$, criteria of evaluation of the health professional (4F), intemprofessional communication (SB), and interprofessional decisior-making (SC). 
With respect to professional and workplace lactual practice) scicialization for the role of nursse (see Table $X X X I I)$, there was very little consensus concerning the role expectaticris to which nurses are socialized. The field of nursirg appears to be in quite a state of flux; based on this analysis of the literature, nurses appear to receive a corsiderable number of conflicting messages with respect ta the role expectations which they are expected to hold.

These conflicting messages came both from withing rurses' professional socialization and betwㅡ를 their professional and their workplace socialization. The areas in which conflicting messages derive from within nurses, professiarial socialization with respect to expectations for affective invalvemerit (Indicator 1A), the appropriate scope of care (2A), the appropriate unit of care (2B), the appropriate care approach $(3 A)$, and desirable interprofessicral communication skills (SB). Nurses' professional scicialization appears to conflict with nomms arid values held in the workplace with regard to issues including: the goal of care (4A), where, as co-workers with physicians, nurses are influenced by those norms associated with the medical madel; arid, where professional and bureaucratic demands surface, the areas of patient and family involvement (4C and 4D) (the nurse's job is easier without such involvement); and motivation (SA) (as noted by Myers, 1982, emerging nurse values are that rurses follow personal goals first and 
service arientation second). Particularly interesting is the apparerit emphasis in both the professional and workplace scicialization of nurses on hierarchical decision-making (pole 1, Iridicator 5C), with either the physician or the rumse serving in the daminant role. In sum, based on the literature reviewed, the role expectatiors learned and held by physicians appear to be gerierally corgument with the medical model of health care provisian, althaugh there is some evidence of conflict and charge in these expectations. With respect to the role expectations learned and held by nurses, it is very difficult ta categarize these as belonging to either the medical model or the holistic model; the values and role expectatiars of nurses appear to be in a state of considerable change and flux.

Cautich is required in generalizing from these findirgs, however, as much of the literature that was reviewed corisisted of essays and assentians based on the authors' personal experiences and observations and/or their iriterpretation of the work of other scholars. There is a need for systematic enpirical study of the current sacialization experiences of physiciars and nurses.

In addition, several years of literature were covered. Mary of the mare recent sources seemed to reflect some movement toward the holistic model, at least in certain areas of role expectations. 
RESEARCH QUESTION 2: WHAT ARE THE ROLE EXPECTATIONS HELD EY A SAMPLE OF TERMINALLY ILL PATIENTS, FAMILY MEMBERS OF TERMINALLY ILL PATIENTS, AND HEALTH PROFESSIONALS FOR THE PROVIDER OF QUALITY TERMINAL CARE, AND WITH WHICH MODEL FOR THE PROUISION OF HEALTH CARE, MEDICAL OR HOLISTIC, ARE THESE EXPECTATIONS MOST CONGRUENT?

The findings with respect to each of the fifteer iridicators are reparted in this sectich. A summary is included at the end of the section.

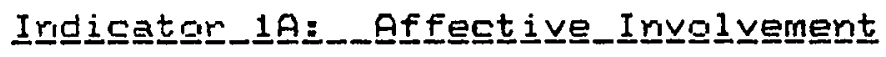

Eased ar ar empirical analysis of the comments of respondents relevant to this dimension, a dichotomous, leftright pale categorization scheme, "no, the health professional should not be affectively involved"/"yes, the health professicrial should be affectively invalved," was determined to be simplistic and not as descriptive of the data as these data merited. A continuum represented by four "Ievels" of affective involvemerit seemed more appropriate. As noted earlier, this variable has as its left pole not regative affect but neutrality. In fact, respondents did describe attitudes and behaviors representing negative affect which they viewed unfavgrably, such as health professionals who were "uncaring," "callous," or "discourteaus." To minimize the corifusion which would likely result from having descriptors viewed favorably and 
urifavorably, the attitudes and behaviors which were viewed regatively were reversed to their positive form, such as "caring," "sensitive," and "courteous," and classified accarding to the scheme developed.

The four levels of affect were derived through:

reading all commerits of resporidents that concerned the affective relatiorship between the health professional and the patiert or patient/family; (2) developirg a preliminary categorization scheme based on this reading; (3) classifying resporises according to this scheme; (4) reading the responses that had been grauped within each categary to assess the degree to which they "fit" together; (5) consulting Webster's Collegiate Thesaurus to determine symarym groupings; (G) discussing the categories with colleagues; (7) refining the categories; and (8) repeating this process varicus times. The scheme described below represerits that ultimately settled upon.

The first category (A) is one which contains responses indicating "neutral" affect, in which the health professicmal is courtecus, polite, and respectful, but reveals little, if any, of him/herself. Duties are performed responsibly, but routinely; there is ro evidence of emotional involvemerit.

The secorid category (B) is one in which the health professional is pleasart, congenial, cheerful, and projects 
some personality. The health professional stili is not emotionally irivolved, or cinly minimally so.

The third category (C) is one in which the health professiaral is warm, kird, caring, compassionate, and iriterested. He or she is, or seems to be, personally irvolved, although rict iritimately or completely.

The fourth category (D) is one in which the health professiciral treats the patient as he or she would treat a family member: as sameone very special, with love, with 100 percent ematiarial irivolvemerit, with deep concern and intimacy. Table $X X X I I I$ contains examples of the types of resporses classified within each of the four categories. 
TABLE $X X X I I I$

WORDS AND THEMES COMPRISING EACH OF THE FOUR CATEGO RIES OF INDICATDR 1A: AFFECTIVE INVOLVEMENT

A. Affect:- Neuthra 1

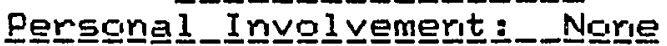

courtecus, polite, civil, respectful, norijudgmental, treats patient with dignity.

NOT demeaning.

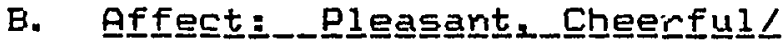

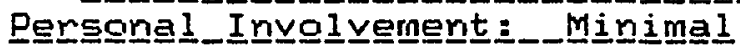

frierdly, saying hella, congerial, pleasarit, charming, sweet, nice, good-natured, with a relaxed attitude, calm, mellow, informal, cheerful, convivial, lighthearted, good bedside manner, projectirg personality, outgoing, interesting, positive attitude, happy, always smiling, teasing, joking, serise of humor, laughing. NOT cross, dreary, dull.

C. Affect:

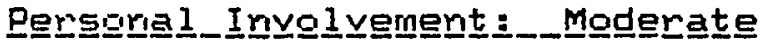

warm, warn persoriality, considerate, cornpassionate, kind, humar, humanmess, thoughtful, thoughtfulness, empathy, empathic, sympathy, sympathetic, understanding, concerred, showing concern, being people rather than professionals, relating humarily, shamirg how they as staff feel, showing emotion, allowing patient to be human, acting like they like the patient, soft-spoken, patient, patience, hugging, affectionate, touching, talking--showing they care, someone with feeling, havirig a heart. NDT callous, indifferent, cold, abrupt, distant, reserved, professional, all business, impersonal, iriconsiderate, impatient, rough.

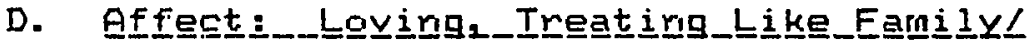

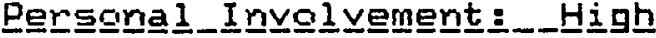

Loving, treating patient like part of their family, like a mother, father, sister; emotionally involved, personally attached, very close, very personal. 
Table XXXIV contains a summary of respondents' responses. It should be rioted that because respondents gave multiple responses, the $n^{\prime} s$ and percentages do not total properly. As shawr on Table XXXIV, all but two of the 17 patients in the sample volunteered comments in the course of their interviews that were pertirierit to this indicator. This indicator, then, with responses from $88 \%$ of the patierits, was crie of the most frequently mentianed by patients. Similarly, all but one of the family members (97\%) made some relevarit comment, as did all but four (three in corvertional programs, ore in a haspice program), or $90 x$, of the health professiarials.

The patients in corventicinal prograns as well as those in hospice programs mentioned category $B$ ipleasant and cheerful) most often, followed by category $c$ (warm arid caring). Family members in each of the types of programs meritioried category $C$ most frequently, and then category $B$. A few patients mentiored category D lloving, emotionally invalved) as did several of the fanily members. More families than patients also mentioned the desirability of being courteous, polite, and respectful (category $A$ ). Somewhat higher numbers of families in conventional programs meritioned each of the categories of affective irvolvemerit than did families ir hospice programs.

The responses of health professionals in conventional programs and as well as those in hospice programs varied 


\section{IAELE $X \times X I V$}

INDICATOR 1A: AFFECTIVE INUOLVEMENI

SUMMARY OF RESFONSES

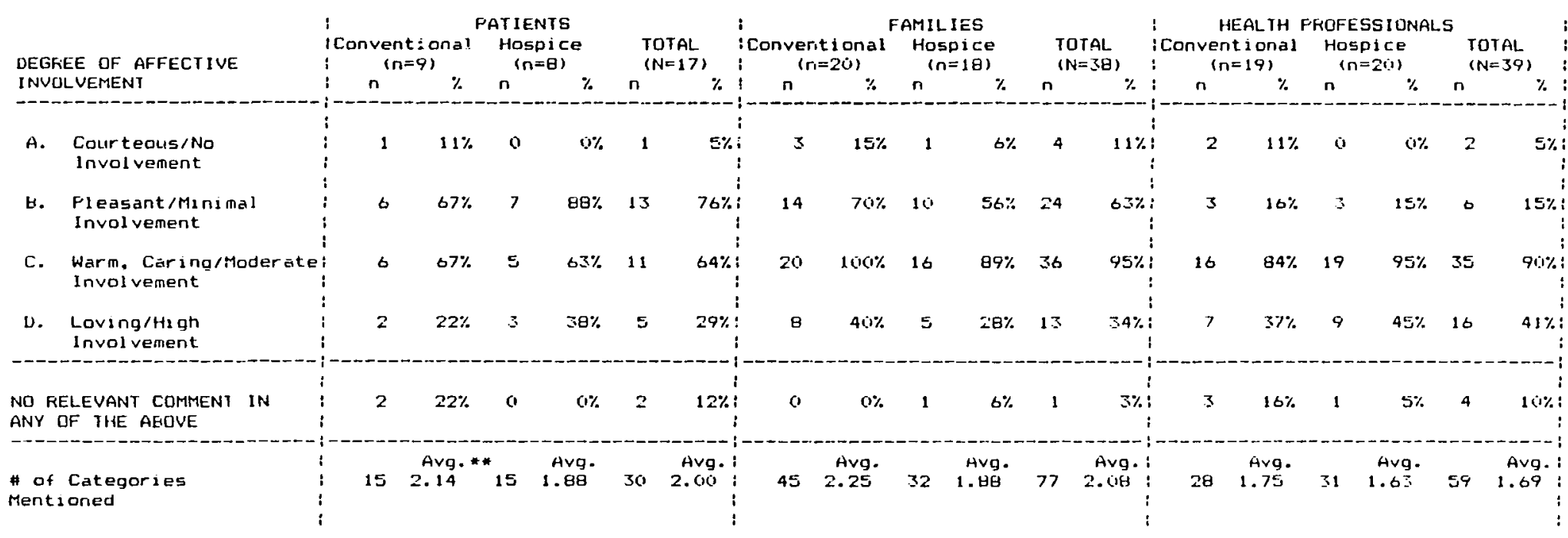

* Responses do not always sum to $n, N$, or $100 \%$ due to multiple responses.

* Average 15 based on " of categories mentioned divided by

$n$ - " of respondents who made no relevant comment. 
from those of patients and families. The categories mentianed most frequently by both sets of health professianals were $C$, followed by category $D$, although two more haspice staff thar converitiona? staff mentioned this latter category. Also, two conventional staff noted the desirability of professionals with category $A$ attitudes and behaviors (being courteous, respectful, and polite) compared to rone of the hospice staff.

In addition to roting the categories mentioned most frequently by each groijp, however, it is important to point out that comments were made by some patients, family members, and health professionals concerning instances in which one or more of the four categories could not be endarsed by them. That is, each of the categories of affective irvolvemert has its drawbacks or risks as well as its beretits.

In Category $A$, for example, foum family members iridicated that health professionals who were courteous and polite, and who "Just did what's necessary," seemed distant; these health professionals were not deemed satisfactory or desimable as providers of temminal care. In other words, health professionals whose attitudes and behaviors were classified in Categary $A$ were not adequate, as far as these family members were corcerred. For these family members, health professionals who were "warm" (Category C) were desired. It is noteworthy that each of these family 
members, relatives was being, or had beeri, cared for in hospice programs.

With respect to Categary B, three family members (two hospice, one conventional) felt that health professionals scmetimes could be tog cheerful ard overly optimistic. Similarly, twa family members (both of hospice programs) noted that professiorals could be too bubbly, too talkative, or kid around too much--that some patients do not like this.

The arly cautionamy nate with respect to category $c$ was offered by one health professional and one family member, both of whom iridicated 1 imits to the desirability of health professionals" sharing information about themselves arid their lives with the patient. The health professiorial pointed out that while personal sharing of one's self and Iife with the patiert cir the patient and the family was desirable, the health professional must take care not tci burrogen the patient arid the family; that is, the health professianal should nat share tog much. The family member cormmerited that health professionals should rot be "full of their own problems."

Category D received the greatest number of cautionamy comments. These comments centered around the dangers of the health professichal's becoming too irivolved and toc close to the patient. Two family members and seven health professionals made comments of this nature. One of the 
family members, a daughter, was concerned that a nurse was becaming tog clase to her father, speriding her time off with him. The daughter seened to feel that this was not prafessional.

The other family member noted that health professionals should not become too involved with their patients because then they themselves will get sick. This comment, as did mast of the comments of health professionals thernselves, related to the danger of "burnout" due to the emational trauma that accompanies overinvolvement and/ar overidentification with the patierit. overideritificatiar was meritioned as a risk particularly with patients who were young.

Qther relevarit comments of health professionals addressed (a) the difficulty of remaining objective in=1, carveritianal) arid (b) the concern that there is only so much time, and if the health professional becomes emotionally involved with a patierit, the time spent with the other patients is likely to be diminished (n=2). This latter caricerri reflects the "universalistic" treatment norm of the medical model of care, and indeed, the two individuals who meritioried it worked in two of the converitianal programs in the sample.

In sum, patierits' expectations centered around professionals being pleasant arid cheerful and being warm and carirg. Families' expectations, too, concentrated in these 
two categories, but the pattern of response was different: the desirability of beirg warm and caring was mentiored more ofter than was being pleasant and cheerful. In addition, a greater perceritage of families meritioned the desirability of professionals who would treat patients as though they were fanily members, who would give them lave, and who would get emotionally involved. Families, expectations, then, were for somewhat more affect arid encitional involvement than were patients'. Health professionals' expectations for professiarials in the role af provider of terminal care were for even greater emotional involvement. The average number of categories mertioned by families was highest of the three groups, followed by patients arid then by health professichals. Expectations by subgroup (conventional compared to hospice) did not appear to differ significantly. Firially, it shculd be remembered that each of the categories of affective involvement has its drawbacks or risks as well as its benefits, as poinited out by some patients, family members, and health professionals. 


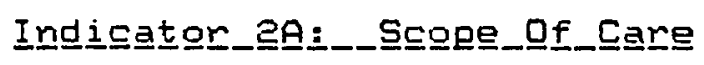

This iridicator represents responderits' views with

respect to the scope of care which they expect to be giver ideally by health professiorals who are providirig terminal care. "Scape of care" refers to whether only the physicial care reeds af patients or patients' psychosocial needs as well as their physical needs are addressed. This latter option is termed "holistic" care, and is consistent with the hospice model for the provision of terminal care. The former, "physical" care, represents the medical model approach to health care.

The data analyzed with respect to this indicator cansisted of relevant responses volunteered throughout the course of the interviews with responderits, including any explanatory remarks made in response to one of the checklist items (item c), in which respondents were asked how much they felt it mattered that "Doctors and nurses sit, talk and listen, as well as attend to patients' physical needs." For reasons explairied earlier (see Chapter $V$, Research Design and Methods, Phase III, Content Analysis of the Interviews), only comments mespondents volunteered were analyzed; the ratings assigried were not. Table $X X X V$ summarizes the responses of respondents as they related to this indicator. It should be roted that within the category of "holistic" care were included a few responses that addressed 


\section{IAELE $X \times X Y$}

INDICATOR 2A: SCOFE OF CARE

SUMMARY OF FESFONSES

\begin{tabular}{|c|c|c|c|c|c|c|c|c|c|c|c|c|c|c|c|c|c|c|}
\hline \multirow[b]{3}{*}{ SCOFE OF CAKE } & \multicolumn{6}{|c|}{ PATIENTS } & \multicolumn{6}{|c|}{ FAMILIES } & \multicolumn{6}{|c|}{ HEALTH FROFESS IONALS } \\
\hline & Conven & $\begin{array}{l}\text { onal } \\
\text { 9) }\end{array}$ & Hos & & & & Conven & $\begin{array}{l}\text { onal } \\
\text { (j) }\end{array}$ & $\begin{array}{l}\text { Hos } \\
\text { in }\end{array}$ & & & & iConver & $\begin{array}{l}\text { ional } \\
191\end{array}$ & $\begin{aligned} \text { Hos } \\
\text { in }\end{aligned}$ & $\begin{array}{ll}\text { ace } \\
2(1)\end{array}$ & & $\begin{array}{l}A L \\
\text { 39) }\end{array}$ \\
\hline & $n$ & $\%$ & $n$ & $\%$ & $n$ & $\%$ & $n$ & $\%$ & $n$ & $\%$ & $n$ & $\%$ & $n$ & $\%$ & n & $\%$ & n & $\%$ \\
\hline Physical Care Oniy & 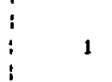 & $11 \%$ & 2 & $25 \%$ & 3 & $18 \%$ & 3 & $15 \%$ & $\Xi$ & $17 \%$ & 6 & $10 \%$ & 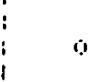 & $0 \%$ & $a$ & $\omega \%$ & a & \%\%: \\
\hline Holistic Care (Both) & 5 & $56 \%$ & 3 & $33 \%$ & 8 & $47 \%$ & 17 & $85 \%$ & 14 & $78 \%$ & 31 & $82 \%:$ & 19 & $100 \%$ & 20 & $100 \%$ & 39 & $1010 \% !$ \\
\hline $\begin{array}{l}\text { No Fielevant Volunteered } \\
\text { Comment }\end{array}$ & $\vdots$ & $33 \%$ & 3 & $36 \%$ & 6 & $35 \%$ & 0 & $\omega \%$ & 1 & $6 \%$ & 1 & 3\%: & 0 & $6 \%$ & a & $\omega \%$ & $\therefore$ & $\%$ \\
\hline
\end{tabular}

- Fercentages may not sum to $160 \%$ due to rounding error. 
the psychosocial aspects of care only. These comments were relatively rare, though (patients: $n=2$ (both hospice); families: $r_{1}=3$ (two conventional, one hospice); health professiorals: $n=e$ (both corvertional).

It should also be pointed out that spiritual needs of patierits, while theoretically a part of the concept of "holistic care," were not ircluded in this analysis unless the resporiderit specified that these needs could or should be met, or were met, by the health professional. Comments that focused on visits that were made, or ideally would be made, by rabbis, ministers, or other clergy were nat classified here. Given this study's focus on the role of the health professional, and specifically the role of the physiciar ar rumse provider of terminal care, it was not felt appropriate to include conments related to provision of spiritual support by other than a health professional.

Tumning now to the data presented in Table $x \times x V$, several results are notewarthy. First is the relative lack of relevant comments made by patients; only $65 \%$ commented compared to $97 \%$ of the families and to $100 \%$ of the health professionals. Second, excluding from the analysis all resporiderits who did not make relevant comments, it is clear that patients were somewhat more likely to comment only on physical care needs $(27 \%)$ than were families $(16 \%)$ or health professionals $(0 \%)$. 
The amount of missing data for patients combined with this result could indicate the greater salierice for patierts of their physical needs ard/ar patients" lack of awareness of the possibility af getting their non-physical reeds met by the health professioral. One patient commented, for example, "The rumses are worderful--they atterid to all your 〈physical〉 needs: they feed you, they clear your bed, and they give you your pills if you're ir pair. What else is there to say?" It is clear from the commerits of several of thase who meriticied physical care reeds orly, however, that there is "physical care" ard then there is "physical care;" specifically, these mespariderits ricited the rieed far physical care withh_comp르트음, physical care that is dorie gently. Orie patierit reported, for example, that "some toss you arourd like a piece of wogd.. The treatmerit I gat this marririg was rough..."

Orie patierit whase commerit was classified as advacatirg a holistic approach explaired that he felt it was very impartarit for docters arid rurses to talk with patierits:

It helps you out a lot, the doctors arid nurses bath. Especially if the doctgr sits dawn and talks to you a few minutes; that gives you quite a bit af relief, you know. You feel like you' re clase to him, you know.

Arother patient felt that health professionals could not be exeeㅡ를 to meet patierits, psychoscicial rieeds, but this would by rice in ari ideal serise: "Dh, we can't expect them to do that--they have too much to do; it's appreciated if 
they do. Orice in awhile, they stop in if they have time..."

Cornmor withir the responses of families, as well as some of the patients whose comments wame classified as advocating a holistic approach, was the emphasis on "encouragement" of patients, the belief that health professionals should "ericcurage" the patierit.

A thind interesting result is the fact that literally al 1 health professiorials roted that the provisior of holistic care for teminally ill patients is ideal. What should be poirted out, though, is that holistic care appears definitely to be only an ideㅡㄹㅡ, not an accomplished fact. Comments by several health prafessiorals iricluded statemerits noting that rumsing is orierited to the provisiom of physical care and is task-oriented, that murses are not trained to talk to patierits, and that there is a reed for health professionals to leam that physical care is rict the mist important thing: that physical care is importarit for comfort, but there is a need to recogrize patierits' social, emotional, and spiritual needs.

Fourth, the data summarized in Table $X X X V$ reveal that there appears to be little relatiunship between the type of program (corventional or haspice) the respariderit represerits and whether he or she is more ar less likely to rote the need for health professionals to address psychasocial rieeds as well as physical needs of teminally ill patients. 
Finaliy, a nate is necessary concerring thase responderits who made commerits which were classified as indicatirig an expectation for holistic care but which focused not or beth physical and psychesocial care reeds of patients, but grily cir psychoscicial care reeds. The patients arid families who made such commerits were rot experiencing physical pair or other physical symptoms which could have been controlled. As ore family member roted, her mother did nat at that $t$ ime need physical care: she needed someone to talk to. This fanily member was frustrated that this need alone could not be met: "I understand that in 〈home care program, you car't have dust a scicial service person unless there's also rumsing care going or, and I don't think that's faim; she doesn't neeed nursing care at this point." This comment appears to illustrate that this resporiderit (a) drew a clear division in role responsibilities between nurses and social workers, arid (b) had a lack of expectation, or uriderstariding, that nurses as well as social workers can meet patients, psychasocial reeds. This same respariderit, however, noted that the numses in the hospital had special trairing in meeting scme of the family's needs, such as thase for enotional support arid for information. Two health professionals, both in coriveritiorial programs, also noted arily psychosocial needs. It seems likely that these persons assumed patients" physical needs would be met, but warited to facus attention on the psychosocial needs of patients. 


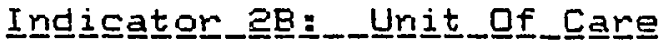

The data with respect to this indicator were analyzed at two levels. The first level examined patients', family members", and health professionals' interviews ta determine who respondents felt should constitute the unit of care: salely the patierit (left pole, or pole 1), or the family as well as the patient (right pole, or pole 2 ); that is, whether or not any mention was made of the desirability (in an ideal or actual serisel for health professionals to address ariy of the needs of the family in addition to those of the patient. The second level of analysis examined the particular types of farnily menbers' needs that were mentioned. The categories of needs were determined empirically through scrutiry of the relevarit individual responses.

The rationale for emplaying the second level of analysis derived from a curiosity about the results from the first level of analysis, particularly with regard to the health professianals' respanses. As will be described belaw, nearly all health professicmals espoused the desirability of treating the family as the unit of care (e.g., "dealirg with families," or "meeting families" reeds, too"). The responses of health professibrals working in haspice programs versus those of prafessianals warking in conventioral programs, however, appeared to differ considerably ir detail. 
The data for this indicator were those received in direct response to a particular question about the reeds of families ("Wriat would you tell a group of medical and mursirig studerits about the reeds of the family of people who are very sick?") as well as other comments volunteered throughout the course of resporiderits' iriterviews. Orie item of the checklist administered at the close cif the iriterview pertairied ta this issue as well. This item asked respondents to iridicate how much it mattemed ta them that "services be previded for families as well as for patieris." Unfortunately, the term "services" cinfused a rumber af mesporidents, especially patients and families. "Semvices" appeared to conmote firancial aid or assistarice, far example, to some lay people, who ther qualified their answer, saying such services should be provided "orly if necessary," ar "only if they" re down and out." Orily those explanatory remarks to this checklist item that clearly pertained to ar expectatiar that families' needs either be met or not be met by the health professional were classified here.

Resporiderits wha 1 isted needs of families that they felt health professionals had met or should have met were classified as indicating the family as the urit of care. Respondents who specified that orily the patient's rieeds should be attended to were courited as iridicating the patierit as the unit. Respondents who made no relevart commerits 


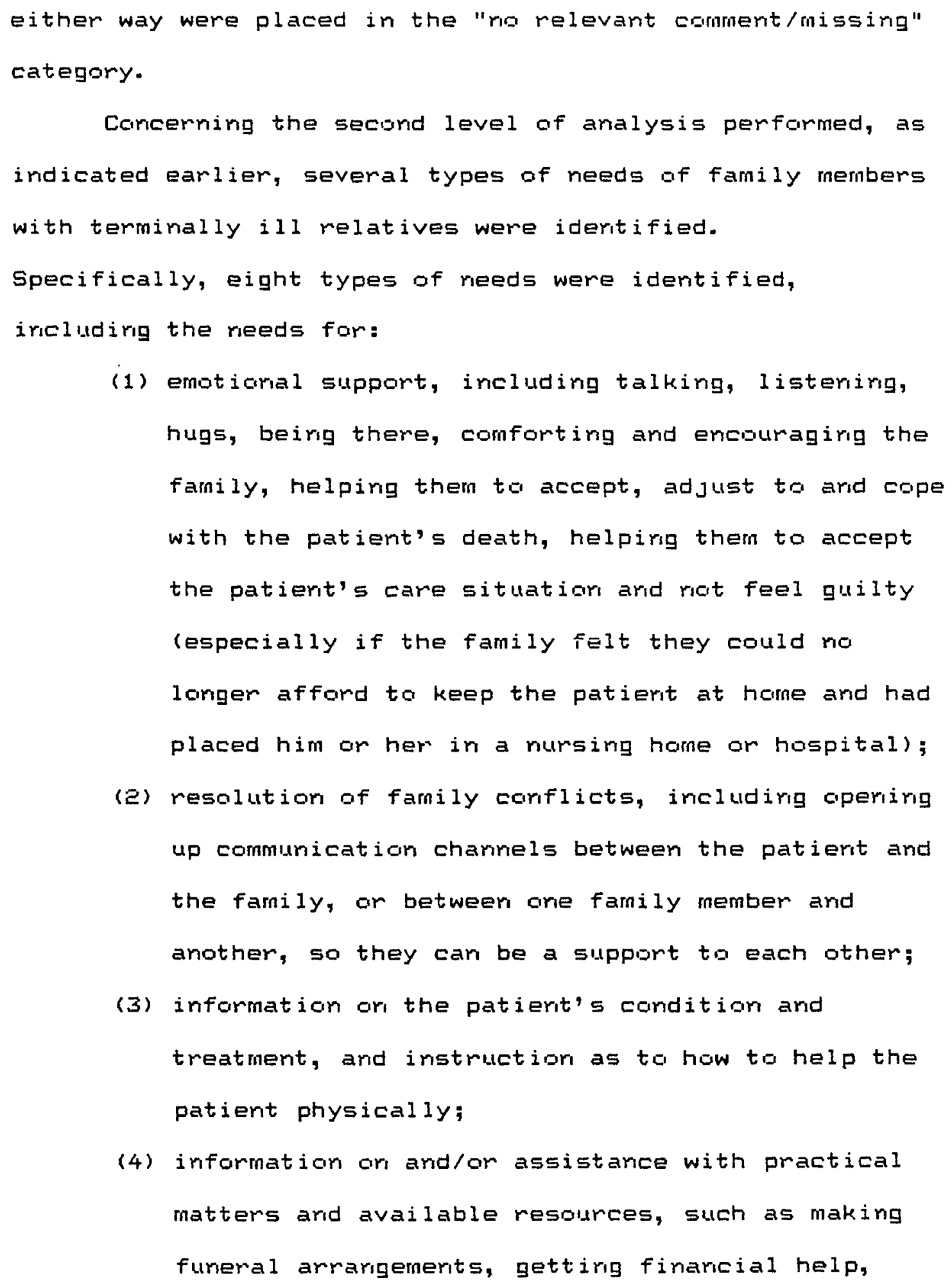

(4) information on and/or assistance with practical matters arid available resources, such as making funeral arrargemerits, gettirig finaricial help, 
getting needed equipment, helping the family make decisions;

(5) ackrowledgement of the family's presence, showing of some interest in and concern for the family;

(6) respite care, mest, a break, ta take time far themselves to assure optimal physical furctioning;

(7) bereavement care, followup support (after the patient has died);

(8) general "help" (and other commerits too general to classify, such as "the family is included," "the family is treated," "the farnily is as important as the patient").

The followirg paragrapts report the results by responderit group: patients, families, arid health professiorials. Table XXXVI preserits the results ir tabular form.

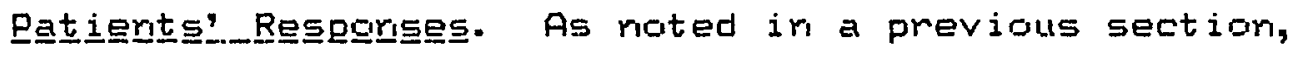
mary of the patients interviewed as part of this study were in the very final stages of their illress ard were extremely weak. As a result, same questicirs were not asked. Among the questions typically mot asked when patients were tiring were this one about the reeds of fanilies arid the several items comprising the checklist. Of the rire patierits in converitional programs, eight had missirg data for this indicator: three patierits were not asked this question, 
1AELE $X X X Y 1$

INDICATOR 2E: UNIT OF CARE

SUMMAFY OF RESPONSES

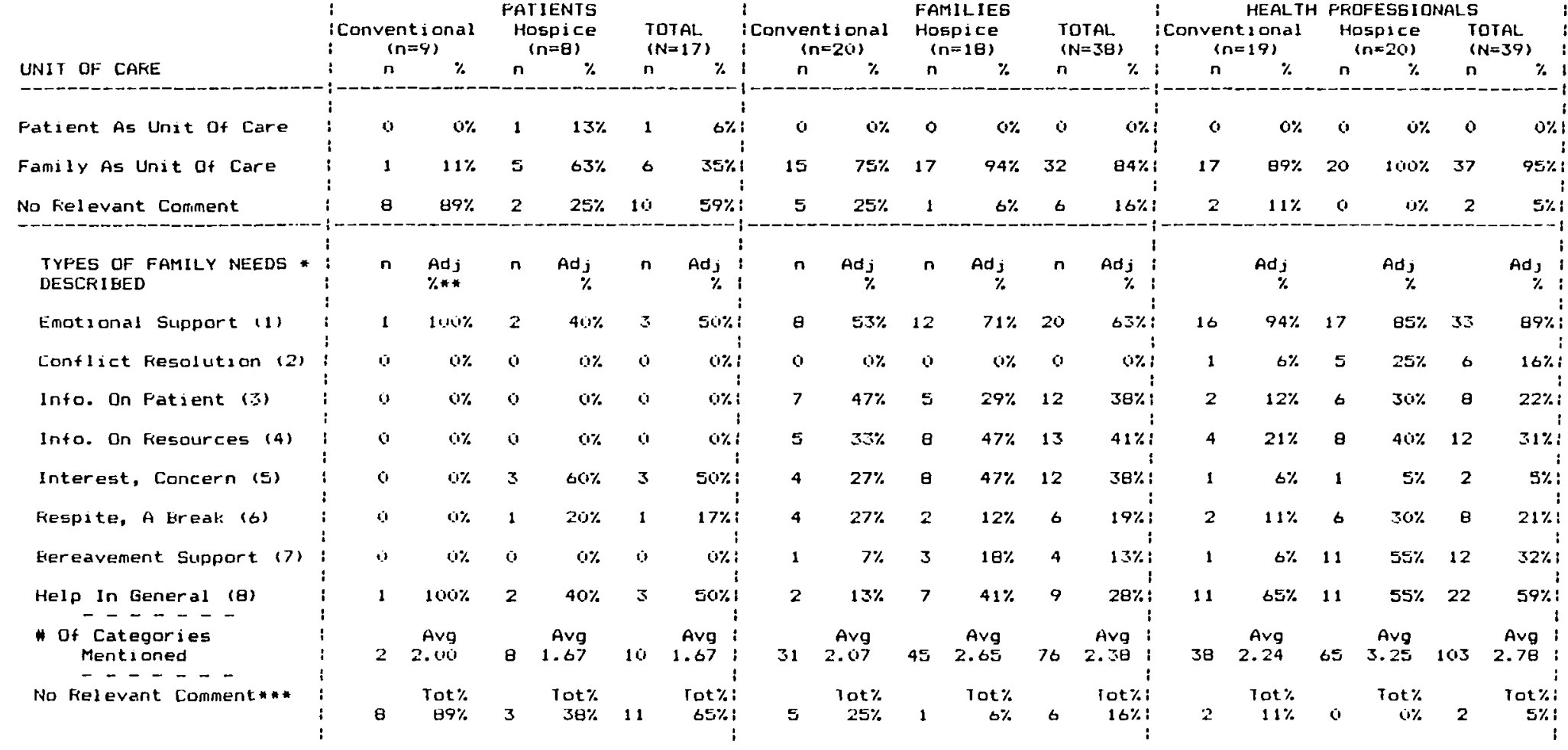

(Cont i nued) 
TABLE $\times X X V 1$. Contznued

\begin{abstract}
- Vescribed here are the types of needs of families mentioned by those respribed here are the types of hels of fant the patient should respondents who indicated the family, not just the patient should be summarized here, then, equals Line 2 under VOLUNTEERED RESFONSES, "Family As Unit of Care." The numbers do not sum to the number in Line 2, however, due to multiple responses by respondents.

* "Adj \%" refers to the adjusted percentage; that is, the ratio of the number of people who mentioned this need to the total number of persons who indicated the family was the desirable unit of care. For example, three out of the six patients $(50 \%)$ who indicated the family isties. anilies.
\end{abstract}

*** Included here are the persons who vol unteered no relevant comments as well as those who indicated the patient is the dessrable unit of care. 
four did not appear to urderstand it, arid ore resporided, "I dan't know." The one patient who both resporided to the question and who seemed to understard it said, "They reed help for themselves and friendship." In the secorid level of analysis, this response was classified in categories $B$, "enotional suppart" and 1, "general help".

Five of the eight patients ir hospice programs either indicated in the course of their interviews that they felt some attention should be paid by health professicrals to the reeds of fanily members or listed one or more ways ir which the staff had helped their family, which they appreciated. A sixth patient discussed firaricial coricemrs he had for himself and his wife (a response nat classified here, as it did not relate to the role of the health professional), and a seventh patient did not understarid the question. The eighth patient noted that his kids were "grown up and married," and that he felt there was not much that could be dorie for the family by the health professionals. This patient's response was classified as indicating the patient orily as the urit of care.

Five haspice patients, then, perceived the family as the desirable unit of care, while one patient felt health professionals could be of little assistance to fanilies. Of the five who noted types of family needs, two described families" needs for enotional support laategory 1: the staff should "make sure they make themselves available to 
take and communicate with the fanily"; health professignals should "go to visit or call the family arid talk to thern"). Three made comments that indicated the family's need for interest arid coricerr for them to be shown (category 5: ".. showing you have sympathy for the family," "place yourself there;" "the service they have here where they take my wife back to her apartment after she visits me is a woriderful thirig... and they get her coffee while she's here"). One patient suggested that staff "give family help for the care of cries that are sick" (category $E$ : respite), and two made comments about general rieeds for help seategary 8: "I' in very concerred that my wife has proper care because she has many needs;" and "Ask what you can do to help the family").

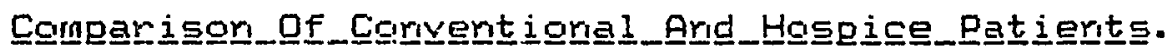
Giver the large quantity of missing data for patients in converitiomal settings, it is not reasonable to compare the resporises relevant to this iridicator of patients in canventianal programs with those of patients in hospice prograns.

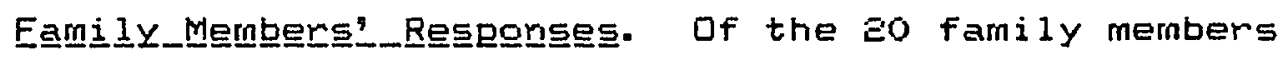
of patients who were or had been in convertional settirus, 15 (75\%) indicated ways in which they as family members had beer helped or could have been helped by the staff lcoded as "family as urit of care"). 
Among these 15 fanily members, the type of fanily need mentioned most frequently was that for enoticial support and ericouragemert (53\%), illustrated by the following resporse:

When they came, they not orly visited with him arid tended to his medical rieeds and requirements, but they visited me on a friendly basis. It was just woriderful to have them to talk to.

This need was closely followed by that for information and irstruction regardirg patient care (47\%): "Explain ta them what is happening to their loved one... explain what kind of a night he's had... explain frightering everits so they are no more frightening than necessary;" "Give suggestions to fanily as to how they can help." The reed far iriterest in and coricern for the family, arid for uriderstariding was meritianed by $27 \%$ of the family members in carveriticual settings: "Be understanding of the family; know it's a termibly hard thing;" "Be interested in the fanily, recogrize them; include them and treat them like they would want to be treated if the positions were reversed." Five family menbers (33\%) meritioned the reed for infornation or resources or for assistance with practical matters, ard four family members (27\%) meritioned families' reed for a break or respite, or help in caring for the patient, such as this family member:

The last day, or the day before, he werit to the haspital, I looked so exhausted that the home nursing girls suggested that scmenre corre out arid get him ready to go... it was a big help because I was getting pretty dowr, physicaliy ard meritally. 
The average number of categories of reed meritioned anong the 15 families was 2.07.

Severiteer of the 18 fanily members of patierits in hospice programs indicated some type of reed of the family that was or could have beer met by the health prafessibrals (classified as "family as unit of care"). The remaining resporidert made no relevarit comment.

The most common categaries of reed mertioned by these 17 family nembers included thase for emstioral support $(71 \%)$, information on resources and practical assistarice $(47 \%)$, for understanding af arid interest in the family $(47 \%$ ) ("The family really reeds help; it's hard for some of the people there (staff) working with (the patierit) to uriderstand what the family is going through; a lat has happeried to us"), for "help" in gereral (41\%) ("They always assured me that if there was any way they could help me, they would"), arid for information on the patierit (29\%). While menticned by only twa family members of patients in hospice programs, core person had a particularly wrenching comment about the reed for respite for the caregiving family member: "I feel because of my father's illness, my mother died, at age 46. She had not been a sickly person; she was a victim as much as my father. Somebody should have stepped iri." The average number of categories mentioned was 2.65.

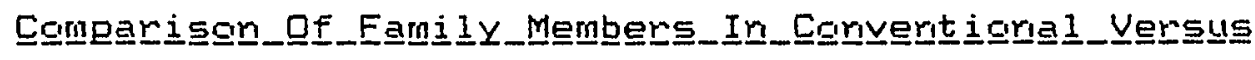
HaSgi드_Prganams. Mare hospice family members made commerits 


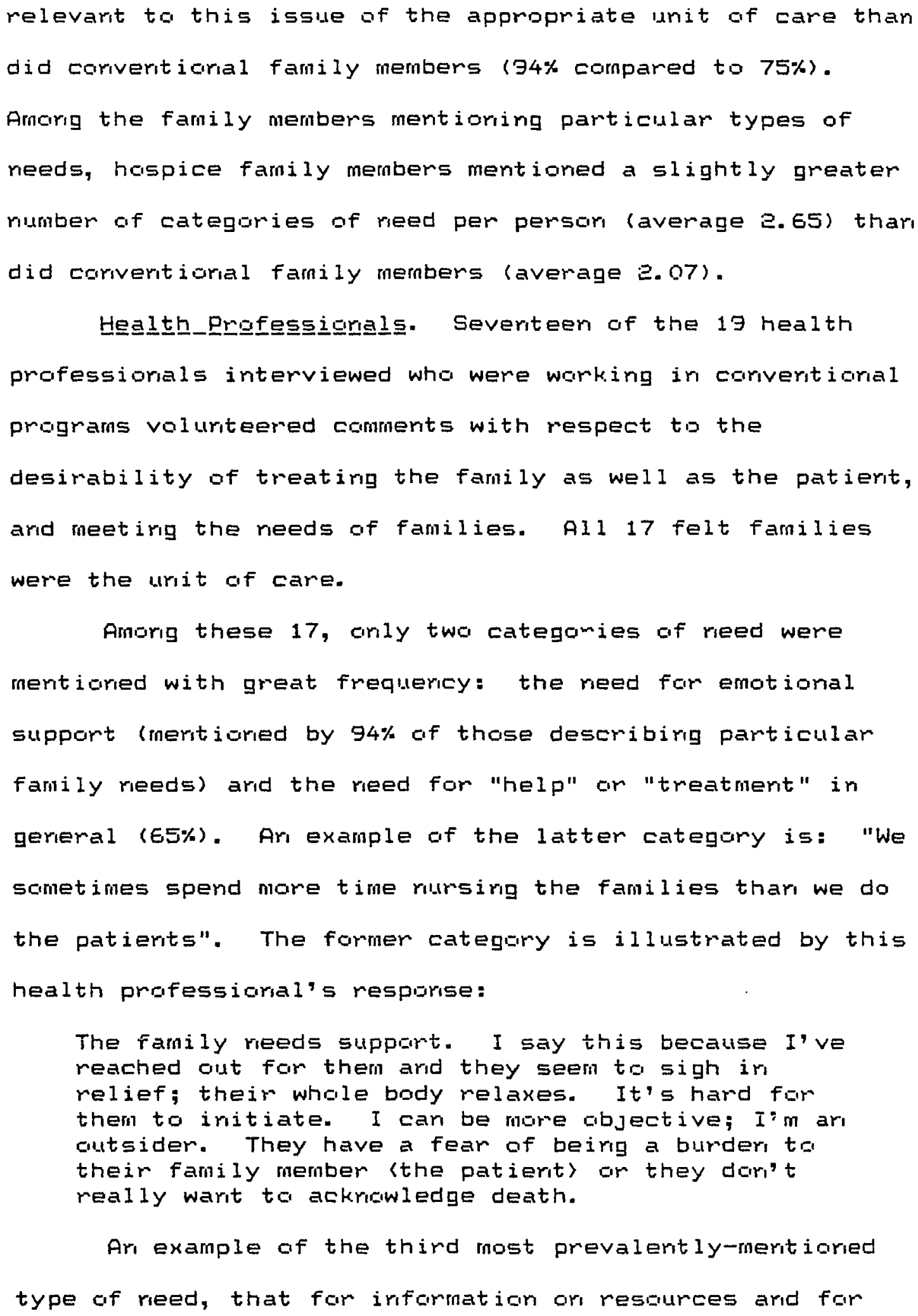


practical assistance (e1\%), cane from a physiciar, who noted that fanilies reed iriformation about what to do with the body arid how to make fureral preparations:

It's very easy to avoid the probler, because they're not going to aske for that informatior, arid if you dor't voluriteer it, everybady will go away... It's rot that it wor"t work out; it will, ultimately. But it could work aut better, and be a better experience if somecire would voluriteer this information.. The level of informatior is 50 pour that they dor't even kriaw what questioris to ask, and unless you tell them absut this, they warlt ask...

The average rumber of categories of rieed meritioned was 2. 24.

All (roeo) of the health professiorals workirig ir hospice programs voluriteered comments that indicated the importance for quality terminal care af treatirg the family as the unit of care, that is, of addressing families' as well as patients' reeds. Anorig the most frequeritly mentioned categomies of reed by hospice professionals, as was true for professicuals ir converitioral programs, were those for emotional support (85\%) and for "help" in general (55\%). Several ather categories of reed, tad, hawever, received a number of meritiors, including those reeds of fainilies for bereavenert services ard follobup erter the death of their relative (55\%); the reed for iriformation about available resources ard assistarce with practical matters $(40 \%)$; the need for information about the patierit"s corrditiar $(30 \%)$, ard the reed for respite $(30 \%)$. The 
average rubber of categaries of reed mentibred by hospice staff was $3 . \Xi 5$.

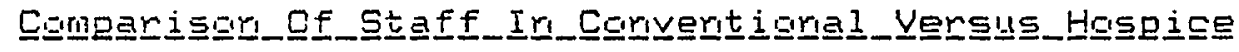
Prograns. All af the prifessiarals in both types af programs, corveritional ard hospice, seemed to feel that the family was the appropriate urit of care when the patient is temminally ill. Professigmals in hospice programs, however, seened to have a greater depth of understandirg af families af teminally ill patients ard their reeds, ar at least to attribute mare reeds to farnilies; these professiarals meritioned a 1 arger rumber of categamies of family reed an average (3. 25 compared to 2.12 ). 


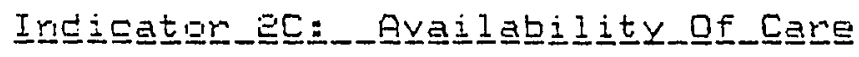

This indicator idertifies respordents' ideal

expectatiors corcerrirg the availability arod accessibility

of health professionals to the patient or the family. 1

Table XXXVII summanizes the findings of the iriterviews with patients, family members and health professianals. The top portiar of this table idertifies the rumber af persars in each group who made ary relevant comment, advocating in the ideal serse either limited availabilty or urilinited availability. The bottom portion looks at thase commerts which iridicated immediate availability was the resporiderit's ideal ard classifies then as to type of response. Some clarification is required with respect to the pole called "Care Not So Available" in the Table. This pole refers to expectatiors that availability of care by health professianals be limited. As might be expected, very few responderits actually advocated linited availability of health professionals. In fact, as showr in Table XXXVII, the commerits of arily two resporiderits were classified as indicating such a prefererice. Both of these responderits were, somewhat surpmisingly, family members. Orie woman

\section{1}

Several resporiderits commerited on availability cif came im conjuction with the cost of care or the patient's and/or family's ability ta pay far the care. Sirce this issue is more a system issue than a role socialization issue, however, these connerits were rot included in this arialysis. Merition is made of the firidirg, however, in Chapter VIII, Summary, Discussicur, ard Implicaticus. 
TAELE $x \times x V 11$

INDICATOF 2C: AVAILAEILITY OF CARE

SUMMARY OF RESPONSES
BY RESPONDENT GRSUP

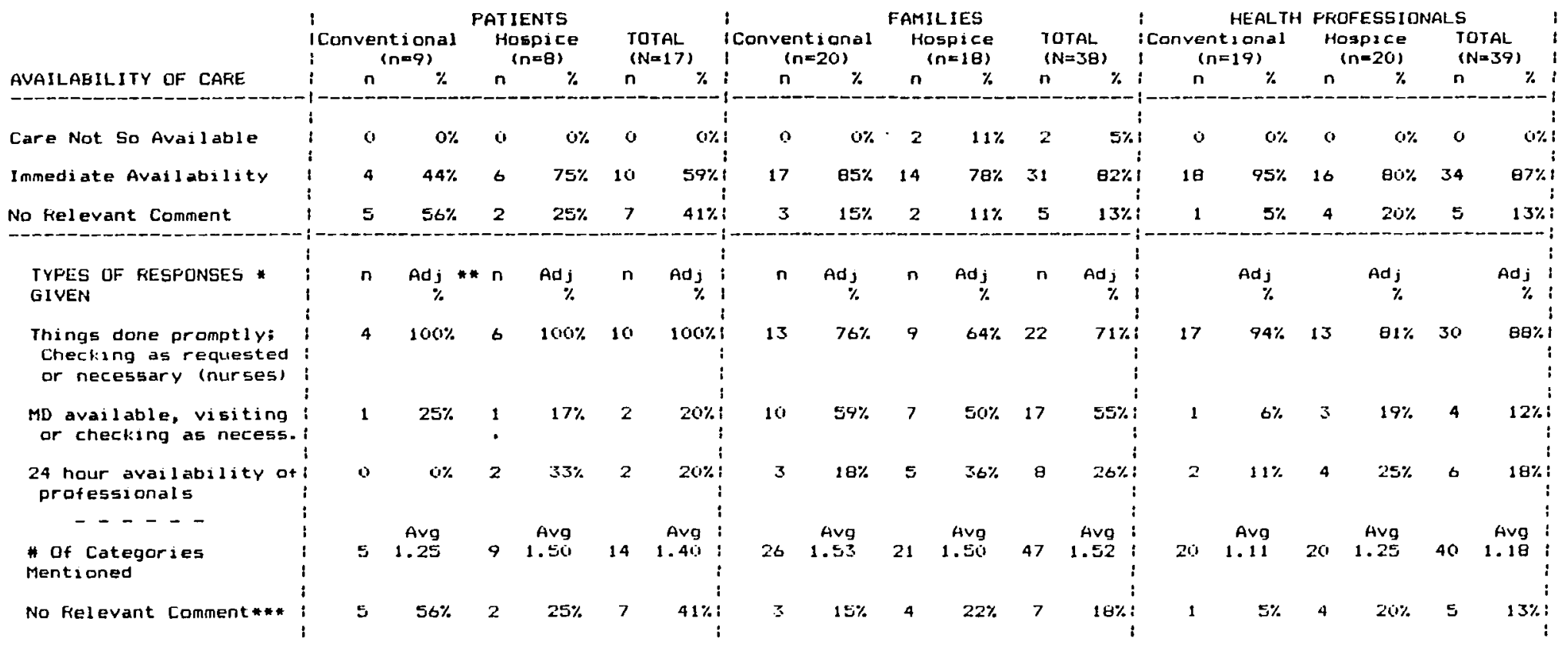

* Described here are the types of responses given by respondents who expected prompt avalability of care. The numbers do not sum

* "Adj \%" refers to the adjusted percentage; that 15 , the ratio of the number of people who gave this response to the total number of

persons who expected, idealiy, prompt avallability of care.

** Included here are the persons who volunteered Nu relevant comments as well as those who UID NOT expect prompt care avallability. 
statad that she felt the home heasth rurses had come tog Gfter. The ather womar meported that her husband had wanted to hold thegretical scientific discussigrs with his hime health rurse, arid that the nurse simply did not have $t$ ime for this, rur did this wornar seer ta feel that the nurse Shguld have time fir this, ever ideally. As will be seen ir the followirg paragraphs, other respinderits, trib, made comments ackriwledgirg and even sympathesizing with nurses" or physicians' actual lack of time, but their ideg 1 appeamed ta be that the health professianal be more available to thera.

Abiut EO\% af all patierits iriterviewed cammerited abaut health professiamals" availability ta them. All but $13 \%$ of the family members arid health professionals made relevarit cammerits. This aspect of care, ther, appears ta be a particularly saliert crie.

To obtair a better picture of what types of commerts were made that irdicated a prefererice for health professiarials wha were immediately available, a subclassification scheme was developed based or an empirical arialysis of the data. Those comments made by resporiderits who felt that, ideally, health professionals should be immediately available were cif three types: thase indicated that (1) health prifessigrals (rubres ard aides) should check regularly arid ofter ar patierits, and they shauld mesprird aridlir do tasks promptly wher called or requested; 
(E) the patient should be visited and checked or regularly arod after specifically by his or her (ar any) physician; and (3) health professiorials should be available ard accessible, in persar ar by telephorie, 24 hours a day.

The category mentiared most frequertiy by all three resporiderit groups was the first; each of the four patierits who made relevant comments gave a mesponse of this type, as did rearly all gif the health professiamals and abuut three quarters of the family members. Ore patient Eormerited, for example: "There's nothirg worse than to be in pain waiㅡ틈ㅁ I have to go up there (to the nurses' statiaris to get arythirg... This buszer doesn't help. I get better service at night;" "They"re right there--anything I reed, I get;" "They should wait on you when you warit the bedpan;" and "A lot of things you can't get dore right now." This last patient was reluctart to complair, though: "Why should I be the big cheese? They've got a lot of other patierits around here."

Family members" commerts included: "They should come as soon as they can wher he rings the bell;" "It's neglect-she sits or the bedpan for 45 minutes; this is ridiculaus. She can leave the light on: no response;" "LQuality care is) availability of prompt help; somebody to arswer that Iight;" and "If she warted a drirk of water, she'd have to wait ar hour." Additigral, larger and more revealirg commerts are the followirg: 
Wher patierts ring the buszer, it should rut remain urariswered for 10 to 15 mirutes... I recognize the pour hospitals ard rumsing homes have their hands full tryirg to staff theim places, but rometheless, somehow there must be a solution to that;

There were times when I'd go, arid I dar't thirk aryore had been in to check or her. Her eyes were secreting, her face hadr't beer washed. That could have beer better. They could have checked her more... Sumetimes they were very short-staffed, but you can't expect a great deal. There are rot much better circunstances. Turrever is high, and they're urderpaid; competent help is hard to find.

At (hospital) she wash't lagked after close... It's just that everyday care that she got wasn't up to par, I dor't thirk.... they didr't loak after her quite as clige as they did here 〈hospice).

They were all so rushed; she was rot the conly patierit.. . The ruluses dor't have time to take care of their patients more because they have to make these awful reports... they have ta sit down sometimes for half an hour, ar hour, an hour arid a half just to write out some type of reparit.

This same mar also commerited:

They used to drop in at times. Well, they wouldn't if we were there...they didr't particularly worry because they kriew if ariythirig was going wrorig, we would call them. But I'm assuming that if we wouldri"t have beer there, haw ofter would they go?... Sametimes wher you have a case like that, if someare is there, fire, but if ric orie is there, haw lorig would that persar be in that predicament befure somecure cane in to lowk arid see if there was arythirg wrorg?

Aruther fanily member was similanly coricerried: "Mather may be reglected at times because of the family's being here-wher they're short-harded, rot coming in to check her as often."

What is strikirig about the commerits of the fanily members is their reflection of the regative experiences the 
responderits have encountered. In fact, most of the comments were regative, albeit some were also sympathetic to the plight of the nursing staff. There also were some positive commerits, such as these: "Every time we would go there (hospital), they were just caming in or going out of the rawm; we just felt they were really taking good care af him;" and "The murses would geever say they were too busy." The comments of health professionals that were classifed in this category focused on the amount of time that health professiarials had to adequately penform patient care tasks and, in some cases, to talk to their patierits. (These latter types of comments were alsa classified in Indicator 2A, Scope of Care--physical orly, or psychosacial also.) Health professionals' comments, as did patients' and families, frequerit ly indicated a great amourit of disparity between the ideal ard the real, on actual situation. Frequent merition was made of the 1 ack of an adequate number of staff. Another factor contributing to the often lessthar-desimable amourit of time health professiarals had to spend with patients was, as noted by the family member above, paperwork and docunertion. A thind factor was discomfort with terminally il and/ar elderly patients. Examples of health professionals' cormerits with respect to this subcategory are:

Termirially il 1 patients need more time, more care... Certain things have to be done in a day, and 
you car't foresee everything... It makes a person feel unimportant if you have to look at your watch... And families get armoyed with mursing staff for beirg sa busy and corveying this to the patient.

The terminally ill have such a fear of isolations abandonment; it is critical that we be there, caring, holdirg their harids, whatever.

Unfortunately, tine is a problem. Getting through treatmerit comes first; then you car talk if you have time.

Beirg so shemtharided; you try to give a bath to 12 pecple in a day... Yesterday I had six patients, and we did se much. I felt so good; I went home with

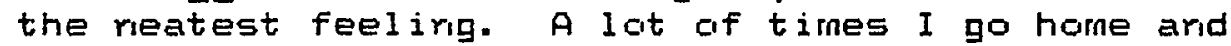
cry because I can't get the wark done.

Farever the staffirg office will tell you that "Hey, you have 20 patients, you get this many rumses." Arid forever, I will say, "Hey, we have cancer patierits; we need more rurses, you know. We don't have patierits that are up arid out af bed walking down the hallways, you krow. These patients are much sicker, arid they mequire emoticrial time, arid it's difficult to convince people that, you knows we actually sperd time sitting doiwn talking to people. And it's difficult (for the staffing office) to see that that is relevant or feasible.

Befare we started the hospice team, we'd do some psychalagical and enaticiral support, but we didr't have much time. Dur hospice nurses make about three $v i s i t s$ per day; the regular rurses make about five a day.

I firaliy feel for the first time since I got out of rumsing school that I'm giving the type of care that I was traired to, because in nursing schocil you have to do such a small patient load that you're almost there coristaritly with them... Ori the other units I've beer spread so thin that you just give what you are able to give--and that's just the basics. 
Scmetimes you don't have enough nurses, like if two patients are dying at orice... arid you haven't been able to be as supportive as you would have liked to have been.

Additicral relevarit remarks made were: "Barriers to good care are time and money; we don't have enough staff now; if we had more moriey we cauld hire more people;" I wish we could decrease the amourit of paperwork for staff, but this is rot realistic because we have to document it if we're going to be paid for it;" "I do wish our visits khome health> could be larger-they average ore hour... I wish there was some way we could legitimately do it;" and "Wher you're urderstaffed, you carrot give a patient proper care. . Quality is caring for what the reeds are righht_wher theyey_neegd_it_-that time element."

Finally, the follawing commerts addressing avaidance behaviars of health professionals toward the dying ard the old were made: "Sometimes we feel discomfort lwith terminally ill patients) and will go in quickly and not take extra time;" "In a hospital, I have worked with people who couldn't face dying patierts, who avoided gaing in the raom;" and the following two resporises:

In some settings, old people are ignored. I know a dactor who will make ar order for vital sigrs every two hours so the patient will get seen every two hours; atherwise they won't.

The dying patient terids to be shurined away a little bit, because either the staff or the fanily is not able to cope with that. And I think here we tend te be more atturied to that arid hopefully are there more ofter with the patient. 
Turning to the second subcategary of availability, physician availability and checking, as shown in Table XXXVII, two patients, both in numsing homes, gave this type af resporise. Orie roted, "Na dactar has seen me here; the nurse was supposed to contact him; nothing's come of that." The other said, "The dactor comes very seldom; there's nothing he can do."

Among fanily members, the availability and accessibility of the patient's physician was a large area of coricerr. Some of their comments include: "The physiciar. was very attentive while he was in the hospital; when he came here 〈rumsing home), the doctor hardly came to see him at all, and that frustrated him a bit;" "Dur own doctor has atterided to her needs wher called upon;" "Both his physician and his surgeons called on him often;" "Dr. -_._ was very accommodating; he came by the house several times; he lived clase by;" "Dr. ... said he would visit at the rursirg home, but later he said no, he doesn't visit rursing hames;" "Dur doctor cames once every few weeks; there shauld be a medical staff here to keep a weekly check on (patierit);" "I don't think she would have got preumoria if she'd been watched over by her doctor;" "(Patient) had a reaction in the middle of the night, ard Dr. _-_- came right away;" and

Since the discharge froin the hospital, we haver't seen him (doctor)... I feel like we've been left darglirg. I feel reseritful that he hasn't been more 
helpful...His office is right across the parking lat.

The (home health) rurse and I took turns calling this hematologist. She was the first to call, and the recepticinist said he'd come cut. Then he called and said there was no way he could come out to the east side, and that wher he agreed to come cut he didr't realize where she lived... He dropped it completely... Qur criginal interrist came out or his lurich hour, and he toak care of (patient), and he was very cornforting.

I had to call him 〈doctor for twa arid a half days, and he finally got back to me. I respect that his practice probably is sizeable, but I wish there could be ore person who could sit dawn arid answer cur questions for us--a doctor; that's the doctor's type duty.

arily foum health professionals, three in hospice programs and ore in a conventional program, gave a response within this subcategary. The health professional from the conventional program noted a case in which care had gone badly because "the patient didn't have a doctor whe had followed his care." The commerts of professionals representing hospice programs were: "Mary staff and physicians feel nothing more car be dome, and so they spend less time; we dor't do this;" "Unforturiately, we have no staff physicians here;" "We may have trouble getting physicians to memain imvolved."

Around-the-clack availability of care, the third subcategory of availability, was important to two patients, both in hospice programs. As ore patient said, "The nurses there stood by me day and right." 
The family members commented: "There's constant staff--in the hospital, she car get the best help as saon as she reeds it;" "Here 〈hospital〉, if he has any problem at al I, he krows he's gat prafessicral help immediately;" "The (home health) numse told us we could call her arytime, day or right, Saturdays ar Suridays, or anytime during the week... We finally did call her or New Year's Eve...;" "No ratter what time, day ar night, they're on call--that's pretty woriderful;" "Mirn was irsecure after being at the hospital for four weeks and then to go home without a nurse right there at your finger." This fanily member ultimately took her mother back to the hospital, where her nother relaxed immediately.

Six health professiorials (two corventional, four hospice) mentioned 24-hour availability of care as an ideal expectation. Examples of their comments include: "We're not operating 24-hour call--we haven't fourd it necessary; but we do have ari arisweririg service around the clack;" "What gives patients the nost secumity is krowing they car call 24 hours a day;" "Twenty-four hour call is one of the best things available, because when something happers at home, there's always someone the family can call who knows the persori; they know the numse will come, right or day." In sum, it appears that patierits, families, arid health professionals alike hold the ideal expectation that health professionals mespond to patierits promptly wher called, 
check patierits frequently, and otherwise spend time with patierits. The actual situatior, however, appears to be one where health professionals often are rushed arid unable to sperd adequate time taking care of theim patients. Some families feel their presence means health professionals do not check cir the patient as much as they might otherwise. Teminally ill patients are reported to take more of the health professional's time, due to their increased physical care reeds and to their emotional care needs. Visits by the physiciar, especially wher, the patient is at home or in a nursirg hame, but sometimes when in a hospital, remain impartart, despite the patient's terminal status, especially as reparted by family members. Arid twenty-four hour availability is regarded highly by fanily members and patierits, particularly where the patient is being cared for at hame. 


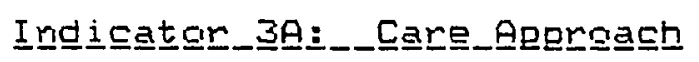

As described in Chapter VI, Analytical Madel, this indicator examines whether the ideal expectation is for care to be gerierally or individually oriented. That is, under scrutiny is whether the ideal role expectatian is that the treatment given to a patiert by a health professional should be (1) esseritially the same as that given to all patients (generalized care) or (e) tailored to meet the particular needs of each patient (individualized care)? Table XXXVIII surnmarizes the resporses of respondents as they relate to this indicator.

As shown in Table XXXVIII, orily orie respondent indicated an expectation for generalized care, for basically the same care or treatment to be received by all terminally ill patierits. This persor, herself a patient, stated, "They"ve got a lot of cther patients arourid here; why should I be the big cheese?" All other respondents, regardless of program, either expressed an expectation for individualized care or made no relevant response. Respondents in hospice programs were just as likely as thase in conventional programs to make no relevarit comment.

That only ore respondent expected gerieralized care is not surprising; it would have been much more so had a number of respondents voluriteered such a comment. Iriteresting, however, is the result that the majority of patients in both converitional and hospice settirigs $(67 \%$ and $63 \%$, 
TAELE XXXVIII

INDICATOR 3A: CARE AFPFOACH

SUMMARY OF RESPONSES

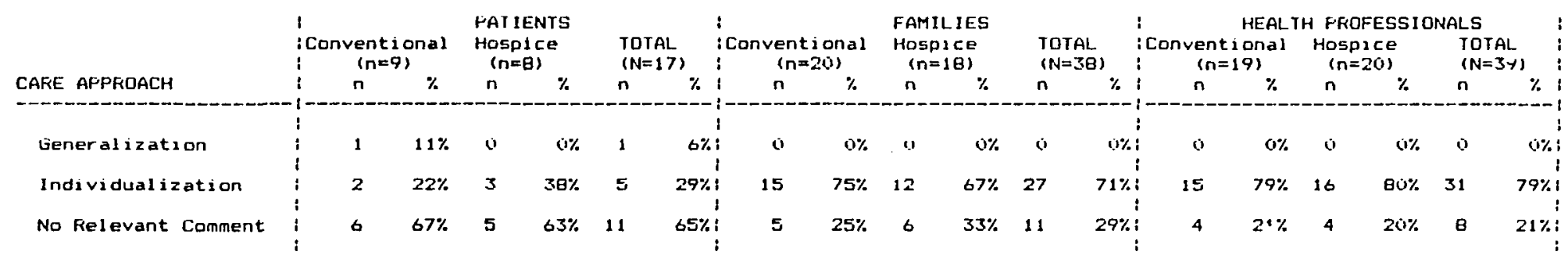

* Fercentages may not sum to $100 \%$ due to rounding error. 
respectively) volunteered no relevant comment. In contrast, less than a thind each of the family members and the health professionals made no relevant comment. Perhaps other patierits feel as the patient above: that they cannot, or should rot, expect ary treatment other than what is given ta. patierits such as they in general. Alternatively, perhaps their expectation, whatever it is, is being met, and as a result, they reglected to mentian it. This possibility seems unlikely, hawever, given patients' resporises pertaining to otfer of the indicators, ir which they mentioned bath attributes of health professionals they particularly liked ard disliked.

It should be noted that some of the resporses classified as indicating ar expectation or prefererce for individualization of care also were classified as one of the categories in Indicator 1A, Interpersoral Relaticuship, or Affective Involvement. The following comments by patients, far example, were corisidered as descriptive of bath indicators: "Personal atterition is the most importarit" (individualization of care ard categary $c$ of Iridicator 1A) and "They all seen to take a personal interest in you" (individualization of care ard category $c$ of Irdicator $1 A$ ). Examples of responses of family members in corventional prograns that were classified here as represerting ari expectation or preference for i-iuividualization of care are: the health professiomal should "get to krow the persari" 
"they seem to have giver her care a great deal af thaught";

"the ares who take her bliridress inte accourt;" "Just havirg someane to call yiu by your first rame, make you feel 1 ike a desired persor;" "deal with a pernsar"s hardicap ar disability;" "adapting to that irdividual"s particular reeds;" "being roticed and spoker to is importarit;" arid finally:

Sizirg up the patient as to krow what he realiy needs ard warits. Some peaple are gruff. You have to decide, "Does he wart me to bark back ar wait or him hand and foot?" Mary people like to push buttoris arid be waited cin hard arid fort. It's important to pay atterition to those crming out of surgery. If riat, they thirik they"re gettirig snubbed. Say "hi" ever if they dan"t rieed it. Tweek their tcies. Tell then they" re haridsome, arid they know goad arid well they're riot. It makes then feel gavd far someare to pay atteritiar...

Comments from family members in hospice programs iricluded: "We all have differert reeds, so if you get approximately a little bit like it, yiu shauld feel. satisfied, and that"s what we do;" "Each cre beirig made ta feel that they are special;" "They didn't learn his rame after three moriths;" "Ariticipating their reeds--that"s it!;" "Talk more to the patient as ar iridividual, as a orieor-cire persari, riat as a rumber cir the dabr."

Examples of relevant resporses of health professiorals ir converitioral settirigs ame: "Be able ta see the digrity, the individuality of the persor, see the person inside, rot be put off by their physical state;" "Be able to mead people; treat the patierit as a persiri, riat just as a 


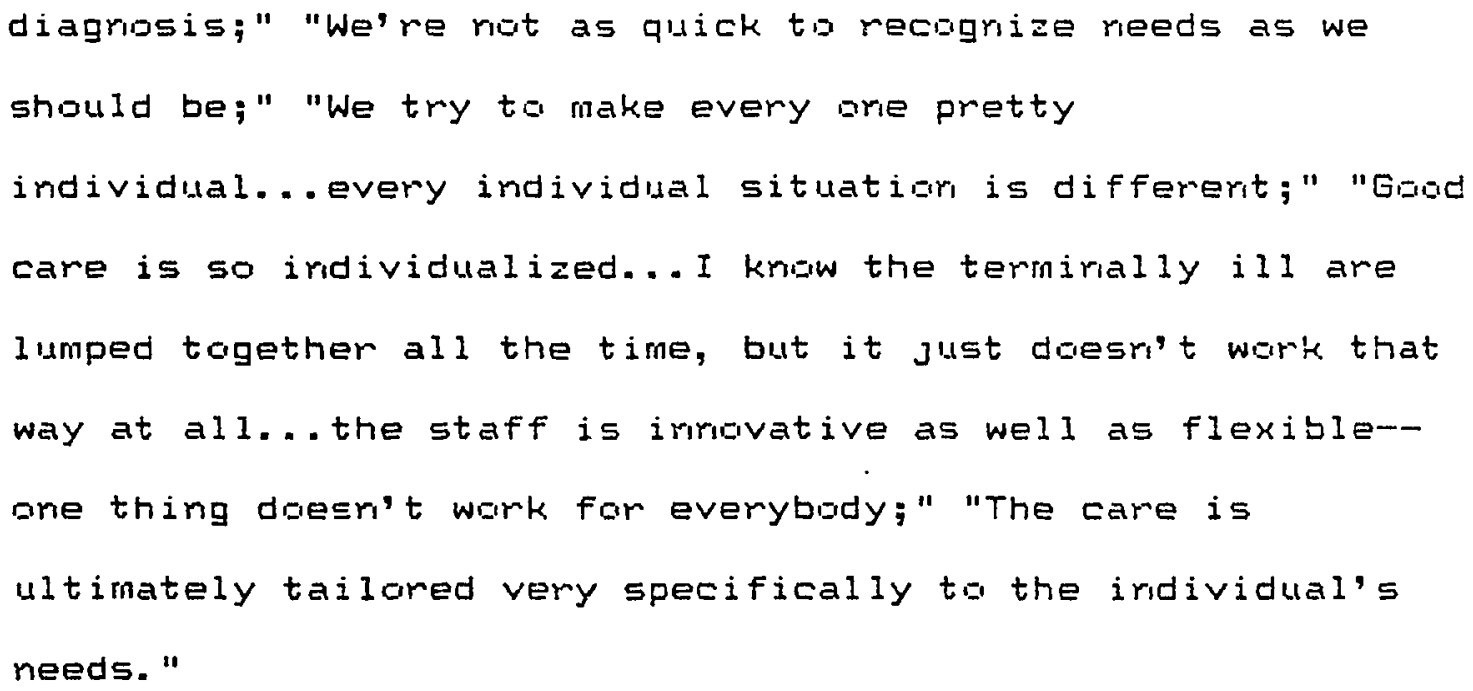

Examples of melevart responses of health professiarials in hospice programs are: "Qur goals ceriter ariurd what's impartant ir that persפgn's care--that might iriclude pain cantral, dealing with their anxiety ar fears, dealirg with the family;" "Really gond staff are in ture with urspoken reeds... 〈they〉 recagnize changes, see somethimg reeds to be done and do it;" "They should have an ear that's beer tumed to pick up little cues that the patient or family car give them;" "Make them a human being, an irdividual;" "The staff is willing to put together an individualized package;" "Get to know people, their strengths; mobilize thase strengths;" "Quality cere is turing irto, assessirg the situation, meeting patierts where they are;" "We did cur best ta make her feel special;" "(Quality care is) real examining of individuals as individuals... In acute care, you treat the disease rather than the person." 


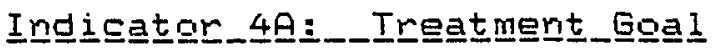

\section{Examined in this indicator are the expectatians} carcerning the goal of the treatment received by the terminally ill patient: whether the patient is to be treated with (1) a goal of life prolongation in mind or (2) the patient's quality ard camfort of remaining life in mind. Should the focus of treatmerit be to make all attempts to treat (cure) the patierit right up to the very end, or should the aim of treatmerit shift to comfort ard quality af life for the patient? The medical model approach has as its goal Iife prolangation; the hospice approach adheres to a goal af comfort and quality of remaining $l$ ife.

A review of the resporses of the patients, family members, and health professiorals who were interviewed, revealed that a decision would have to be made with respect what to do with responses iridicating that ance it was clear that a patient "was temiral," there was "rothing mome that could be done." That is, some respondents acknowledged that cure was rot possible, but did not switch the treatment gaal to one of provisiar of comfort and life quality. Irstead, they stated simply that "rathing mare could be dare." Upori reflectiar, this option af "doing nathing" seemed to the researcher to be a direct result of the treatmert goal af Iife prolongation: wher it becomes clear that the goal will not be accomplished, no rew goal is adopted, there is no charge of omiertation; the gaal (and ofter, the patient) is 
simply abardaned. Such respirises, ther, were categorized as indicatirg a treatmert goal of life prolorgatior.

Table $X X X I X$ depicts the firdirigs from the responses of the patients, family members, ard health professiorals who were interviewed. Qver three-quarters of the patierts indicated how they felt with regard to this issue, which is fairly high in comparisor with the rate af resporise ta other of the variables (indicators) urder study. Eighty-four percent of the families ard all but three (about $92 \%$ ) of the health professionals made some comment relevarit to this issue of the appropriate treatmert goal.

As showr on Table $X X X I X$, five patients in converitional programs felt the treatmerit goal should be life prolongation; they continued to hope for a cure, or at least for improvement. One patient roted, for example, that she wanted to "get her feet walking" arid "get better." Aribther felt that a good doctor is "ore who gets a cure," and although he recognized that he had not been cured, he seemed to continue to hope. Arother patiert said, "They've been doing all kirids of things for me, all kinds of treatment." One patient stated, "I guess all I can say is it's a rouf over my head and a place to exist ir... I guess there's nothing more they can do for me." Orily one patierit in a converitianal program ackrowledged arid seemed to suppart a treatmerit goal of comfort: "They try to keep me comfortable." 
IAHLE $X \times X 1 \times$

INDICATOR 4A: TREATMENT GUAL

SUMMAFY OF RESFONSES

\begin{tabular}{|c|c|c|c|c|c|c|c|c|c|c|c|c|c|c|c|c|c|c|}
\hline \multirow[b]{2}{*}{ TREATMENT GOAL } & \multicolumn{2}{|c|}{ 'Conventional } & \multicolumn{2}{|c|}{$\begin{array}{c}\text { PATIENIS } \\
\text { HOSpice } \\
(n=\theta)\end{array}$} & \multicolumn{2}{|c|}{$\begin{array}{l}\text { TOTAL } \\
(N=17)\end{array}$} & \multicolumn{2}{|c|}{$\begin{array}{c}\text { Conventional } \\
(n=20)\end{array}$} & \multicolumn{2}{|c|}{$\begin{array}{l}\text { FAMILIES } \\
\text { Hospice } \\
(n=1 B)\end{array}$} & \multicolumn{2}{|c|}{$\begin{array}{l}\text { TOTAL } \\
(N=3 \theta)\end{array}$} & \multicolumn{2}{|c|}{$\begin{array}{c}\text { HEALTH } \\
\text { Conventional } \\
:(n=19)\end{array}$} & \multicolumn{3}{|c|}{$\begin{array}{l}\text { FFOFESSIONALS } \\
\text { HOSpICe }\end{array}$} & $\begin{array}{l}\text { LS } \\
\text { TotAL } \\
(N=39)\end{array}$ \\
\hline & $i n$ & $\%$ & $n$ & $\%$ & $n$ & $\%$ & $i n$ & $\%$ & $n$ & $\%$ & $n$ & $\%$ & $i n$ & $\%$ & $n$ & $\%$ & $n$ & $x$ \\
\hline fe Prolongation & 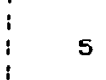 & $56 \%$ & 3 & $38 \%$ & $\theta$ & $47 \%$ & 8 & $40 \%$ & 5 & $28 \%$ & 13 & $34 \%$ & $\because$ & $11 \%$ & 0 & $\%$ & 2 & J \\
\hline Life Quality and Comfort & 1 & $11 \%$ & 3 & $38 \%$ & 4 & $24 \%$ & 10 & $50 \%$ & 9 & $50 \%$ & 19 & $50 \%:$ & 14 & $74 \%$ & 20 & $100 \%$ & 34 & $67 \% i$ \\
\hline No Kelevant Comment & 3 & $33 \%$ & 2 & $25 \%$ & 5 & $29 \%$ & 2 & $10 \%$ & 4 & $22 \%$ & 6 & & $:$ & $16 \%$ & 0 & $\%$ & 3 & \\
\hline
\end{tabular}

* Fercentages do not always sum to $100 \%$ due to rounding error. 
Of the $\Xi i x$ patierits in haspice programs who made a relevart commert, three advacated a gal of aggressive treatment and Iife prolorgation: "They"re doing everything they cari my wife keeps sayirg she has a feelirg that I'm going to get over all of this;" "It"s very easy to give up, arid mast people do, but they shouldn't;" "I still hape far a cure; they have kept me alive for five years... If they car go to the moin, they ought to be able to cure caricer... My main goal in life row is to walk." This last series af statemerits was made by a patierit wha told the iriterviewer that the doctor was corsidering severing the rerve ta the patierit's leg, but since this might make walkirg impossible, the patient couldr't decide if it was worth it. For this patient, ther, pair cortrol might eridarger, not aid, quality of 1 ife.

The cother three patierits ir hospice programs felt that a goal of life quality arid comfort was most appropriate. Orie of these patierits reported that the dactors "talked rice" after his operatian ard corvinced him to have radiatior therapy. He tried cre treatmerit, faurd it tod painful, and said, "No, I warit to die..." He coritirued, "I don't like very much the way they tried to get me irita that... It looked to me like I was a guirea pig, ar experimerit far them--I was 82 years ald." The secorid patierit knew and accepted that she had caricer; she had beem told she had "more thar arie or twa moriths" to live, however. 
She contirued to receive therapy on her arri so that she could stay as indeperdent as possible. The third patierit, who already had Iived much loriger than the health professiorals had believed she would live, rated that the scicial worker at the hospice "talked to me about what was recessary for me to be comfortable. . You have to accept it, and just wait far the day to come wher you are at the erid. I think I'm prepared; I hoge I am."

As showr on Table $X X X I X$, proportigrately more families of patients in corvertional programs than families of patients in hospice programs held life prolongation and coritimued active treatment as their expectation for the treatmert gaal. Responses classified here included those who noted their preference for health professionals who "didr"t give up," who encouraged the patierit to keep tryirg various types of therapies, and/ar who were trying to make the patient better, which sometimes ircluded forcing him or her to eat or orink. Examples of comments made include: "No one's given up or here... I thirk they' re out to help as much as the patient wants help;" "They should give the patierit encouragemerit to go ahead ard try something else;" "The medical profession says they have gome as far with her as they car, that she's terminal, it's a matter af time; it's a question of making her comfortable... I keep telling her not to take anybody's word for it, that she should fight it through;" "They should keep trying, not to say it's no 
use. . Maybe tomornow they' 11 discaver something that will help thern... Look what chematherapy did for him--it gave him a whole year when the doctor didn't think he could take it more than four moriths." This same wornari werit on to say, "They should try to keep the pain down, stap the tumar from griwirig." In sum, canfort reeds were recogrized, as well; the emphasis seemed to be on continuing to treat and hoping for a cure, however. Anction family member rated that core doctor did not treat the patient, saying, "You know you"re not goirg to live," and that "from then on he got worse." A different family member also felt that "if encouraged, <the patierit) might not have given up so much." Many of those families who advocated the alternative treatment goal of enharicing quality of 1 ife ard confort for those who are terminally ill similarly did rot want health professionals to "give up." At the same time, they did rot wart the health professianal to give the patient or the farnily undue hope; their primary coricern at that poirt was the patient's comfort. Several families also commented on the transfer of the patient cut of the hospital after a determination is made that the patient is terminal. The geremal feeling was that this either should be dorie with much iricreased sensitivity or not at all. Exemplary commerits included: "We warit 〈the patierit〉 to be comfortable; that"s why we have her here; we can't da that at home... But you should give them all the ericouragenerit, 
hope you car, because sometimes there are miracles;" "Her quality of Iife is not gord; (stili) they shauld give you the idea that she's rot crossed off;" "They should keep them comfortable, stable, but as far as prolorging their lives, that's foolish... On the other hand, we haver't just given up, either;" "They did everyting they could ta keep him comfortable; they made it easy for him to slip away...they didr't prolarig it."

Dre family member felt her father's physiciar had beer "serigusly remiss" in not telling her father the impact the surgery would have, that it would mear that he willd be ir a rursing home far the rest of his life. She felt that her father "was talked irito the surgery with rio regard for quality of life... He had been ready to die." Arother family member also described a situatian in which she felt

coritinued treatment had been inappropriate:

The nursing home contirued to give (chemotherapy) to him, and they would not stop on oum instructions; sa we called Dr. -... ard asked him to order it stopped, arid he wouldr't do it.. . They would force him to get up arid tie him into a wheelchair, ther, they would leave him sit for an hour and a half at a time... Dr. -... kept ordering that he be up twice a day, one hour each. Arid we felt that at that time it was ridiculous. Also, they wanted to take him irito physical therapy ther.

Dne woman, reported that upon learning that her husbarid"s death was imminerit:

I asked Dr. _-_- that if death was immiment why was he still giving trarisfusians. He said that in curder to stop them he would reed pemmissiar fram <the 


\begin{abstract}
patiert>. I said, "How can he tell you?" He was in no condition to do that. So I told him about (the patient's> uncle. The uricle who had raised (the patierit> had been sick. We all prayed for him to live. 〈The patient) flew up to see him. He had changed so much, suffered so much that (patierit) said at that time, "Dor"t pray for me to Iive." Ser they stopped the trarisfusioris. They said they would make him as comfortable as they could.

Yet another family menber said succirctly:

To me, the paramourt issue is the comfort of the patierit; therapy should rot be forced... My wife arid I were agreed that the orily thing we could do was to rnake her life as pleasarit arid comfortable as was humarly possible, and that was cur eritire aim. PT became absolutely useless, arid it was given up.

This same man was one of those who complaired about the Ltilization review process, whereby patients who rio lorger require skilled nursing care are discharged from care:

Ther finally came the big deal which is traumatic for the patient arid the fanily. I can see the riecessity of it, but there ought to br: a better way to handle it. It gets to the point where the socalled utilization review board at the hospital makes an assessmert that this is a far as the hospital can go, so you've got to get her out. Ther the family must find a place to provide adequate care.

As shawn on Table $X X X I X$, all but two of the health professionals who made a relevarit comment subscribed to the ideal treatment goal of comfort arid quality of life for the termirilly ill patiert. Furthermare, all but three health professiorals (and these three were in corveritianal programs) did address this issue in their interviews. This apparent uriformity of respanse is misleadirg, however. While the goal of comfort was widely espoused, there seemed
\end{abstract}


ta be wide variatiar amang professiorals with respect ta the tinging of the switch from active treatmerit to comfont ard palliation (coritrol of symptoms). Gererally, professiorals in comventignal programs talked of making comfort the goal wher the patiert was actively dyimg, that is, dyirg withir the rext few to several days. Professiarals ir hospice programs mare after talked ir terms of marths rather thar days.

Of the two professigrals whase expectatiars were classified as indicating a treatmerit goal Gf life prolargaticir, crie (a physiciar) said:

That is a point we're adamarit about-termiral illress does riot imply any kind of charige ir care for a patient... other than perhaps to improve it, such as taking pairs to make death ard dying as comfintable as possible.

He werit or to say that treatmerit cortinued, hawever. The ather professional, a numse, said approvingly, "The dactors usualiy don't give up 'til very late."

Resparises relevarit ta this iridicater that were made by health professionals whose ideal expectations were for a treatmerit gaal of comfor ard quality of life pointed arice agair to differences betweer, ideal expectatiors ard actual situatiars ard experierices. Particularly impartarit for this study is the finding that several professiorals themselves admitted ta havirg difficulty acceptirg tine death of a patient, or asserted that ather professigrals with whom they warked had such a difficulty: 
I get angry arid frustrated, particularly with ore patient, knowirg that he was terminal arid really liking that patient and rot being able to help him tor much other than to make him comfortabie, arid that was real hard for me... You know, it's hard for a nurse to, rot exactly give up or a patient, but to actually accept it with a patient that they're termiral ard that you can't just do everythirig for thern.

Two rumses rioted:

Physiciaris, orice they krow you care, they adrit to problems dealing with death... Nursing is finaliy coming arourid, doesr't see so much as defeat--we feel our goal is death with digrity.

As lorig as cure is anticipated, everyore is willirg to wark very hard. As sogri as the patierit is rot salvageable, it becomes very difficult. It's unconscious-attention is less, the staff firids it difficult to go sperid $t$ ime.

A nurse in an administrative position pointed out that ir

her program,

The marnwritten cade is do rot resuscitate. Sorne doctors will write, "Do Nat Resuscitate" (or the patierit's chart>. Dur dactars will not becuase they believe that people (ruluses, aides, etc.) will say, "All right, they're goma die so let's quit takirlg care of them" I as a nurse, and the rumses on this floor believe, "Hoy, let's dor't write them off; let's provide comfort, and let's provide palliatior..."

Ariother rurse noted that "physiciars" are a barrier to quality care; "They feel very threatered by the fact they dor't feel in coritmol... Mary set unrealistic goals, estimates about time left to 1 ive."

Furthermore, several professiorals argued that patients ard/or families, as well, often are reluctarit to give up active treatment: "Scrne doctors never quit 
treating, ard some patients rever give up." Angther health professiorial stated:

That's ore of the differences in Arnerican medicine versus the British. We' re not always able to distirguish... It isn't just the fault of the medical people; it's the American system. Americans wart to be treated uritil the very end... I dor't see any patierits refusing ariother round of treatmerit. If they aren't offered it, they ask for it. So that's just orie of the problens.

The resporises of many of the patierits arid families iriterviewed, as meported above, bear this out. In addition, arie health professiaral rated that patients hate to disappoirt their doctar: "The patient feels bad for letting the doctor down and rot getting well."

Also lamented was the difficulty in knowirg the appropriate time to charge the treatmerit goal from arie of active therapy ta core of palliatior, illustrated by this ccrnment: "With this mar, we rever kriew when we were being realistic, such as whether PT 〈physical therapy) was helping or pushirg him beyord his capabilities." The fact that methods for erisuring "comfort" may be at variarice with one arigther was ruted as well.

Dre professioral made several of the above poirts herself in describirg three of her cases, ore in which a patient ard her husbard "fully expected a miracle from God." This rurse wordered, "What will this do to his religion?" Arother case was are in which "comfort would have had more pribrity if we'd realized she was so close ta death." In 
the thind case, the patient had had three bouts of priedmoria, and "cauld have beer let slip away; but you car"t assume that's what they wart--ir this case, her husbarid has to feel everything humanly possible was done, otherwise he must carmy a treneridus burden gf guilt." This same professiaral felt that "Yau Maㅡㄹ ta feed patients; I do rot feel yad car keep patierts comfortable who are starving ta death. Give them ar IV, mimimal fluw, to keep them hydrated ard comfurtable, rict to keep theri alive."

Two persars rigt in hispice programs commented specifically or the rature of haspice came. Ore said, "The hospice ward is a rew ward we'me usirg, but it's a very gld form of care." The ather asserted, "Everyorie"s sayirig they" re givirug hospice care right raw; they' re giving egretigrs of haspice care, but riot complete, Gverall care."

The follawing additigral commerits ame illustrative cif those made by professignals whose responses were classified as iridicating ar ideal expectation for the treatmert goal cif comfort ard quality of 1 ife:

With the seribusiy ill, treatmerit remairs aggressive, emotiarial suppart secondary; ever the experierice uf pain cones secaridary to treatment ir serigus illress. With the termirally ill, pain coritrol is our primary corsideratiom.

Our goal is to keep peiple as irideperiderit and comfirtable as possible, at home.. There have beer many medical advarices to keep them mame comfontable... The quality of life left should be as goud as you car possibly make it; sametimes that's brimgirig a puppy to the dowr. 


\begin{abstract}
he bught rot ta press to hard, try ta hard, in my airo, to cartirue ar ard ar ir terms of treatmerit ir somebudy wha has late stage disease, compared to soneare wha has a much better type of progrosis.

"Fir peaple wha are dyirg, basically, you bend the rules;" "Therapy is used as riecessary for coinfort;" "We felt the patierit was termiral ard the dictor didn't agree... The reammeridation that we serid the patierit to the haspital 〈fram the rursing hame) didr"t seem apprapriate;" "With the termirally ill, the focus of came is to keep them camfartable, free af pain ard discamfort, and deal with them with the expectatigr that they will coritirue ta get worse;" "The goal is to facilitate the patient and the family coping with livirg uritil tie patierit dies, to promate comfort measures and adequate medical supervisior;" "With the temmirally ill, we dar"t push them... Eut ir this one case, I thirk it was medical mismaragemerit; the physician's attitude was that she's old, she's dying;" "Our geral is to assist the person to mairtain the things that make their life worth Iivirg ard to reaijze ard mirimize things that make their Iife miserable;" "If you don't address comfort needs, it's almast silly to address anythirg else." "Ore barmier is physiciars' rot accepting their patient's treatment is rot workirg, tio patierit's carcer is rot goirg to mesporid, that plaris for symptom control rather thar timor control must pervade." At the same time as describirg his goal arid that af the program as to provide comfart, a physician described
\end{abstract}


the case bf "a lady wha louked like she was dying, but or a quick exam, I faund simple treatmerits, like clearing up a moluth irfectiar, treatirg her crifusior, depressiar, that I thaugh walld imprave her life by days; ruw it's six maritins, and she was able to go hame." He seemed to be saying that hape shiuld rut be giver up. 


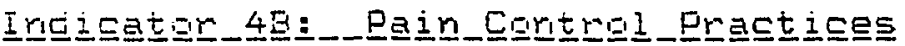

Role expectations with respect to pain coritrol practices to be followed by health professiarals in the care of terminally ill people are examired in this sectior. Expectatiors corcerring pain cortrol practices that are iricicative of the medical madel are those far pain medicatich to be giver or ar "as reeded" basis, that is, as is felt necessary by the health professional or as requested by tine patient. Those holding expectatiars of this type are thase likely to be caricerred about narcotic addiction. Expectatiars carsistert with the haspice model are for pair to be cantrolled, generally through the administration of pair medicatigr at regular time iritervals. Persors holding this latter type of expectation are primarily corcermed with the confort and quality of life of the patient, and feel that given the limited life expectancy of the patient, addictiar is rat an appropmiate concern.

Anong the comments classified heme were those that were viluriteered by resporiderits when respondirig to a checklist item (item $h$ ) that asked then to rate how much it mattered that "pain medication is giver on a regular basis without patierts asking for it." As noted in Chapter $V$, the rating scale on this checklist of several items often did not seen to differentiate responderits very well. Also, several responderits appeared to have difficulty urderstarding the scale. Certain items, too, posed 
problems; tnis are ar pain cortmal is angrig thase items that proved probsematic. The major difficulty, easy ta spot ir retraspect, is that mist respondents were careful to note that medicatiors should be given culy when pair was a probleri, arily wher sich medications were truly necessary. As ruted by some heaitin professiarals, pairis a problem in Grily 50-60\% of teminiml caricer patierits. Furthemome, all resporiderits may rot have giver similar meanirg to the phrase "regular basis."

Ir light of these difficulties, grily the commerits cif resporiderits wha valuriteered additiaral remarks either in resparse to ariather questiar ar ir explaratian af their ratirig cur the checklist item were arialyzed here, thereby prividirg a coritext for their resporse. Norietheless, the reader should use caution in iriterpreting the results.

Table XL coritains a summary of the respanses of the persars interviewed. Qver twa-thirds of the patierits made a canmerit regardirg their preferences corcerrirg pair egritrol practices. Ninety percent of the health professionals and $84 \%$ af the family members addressed this issue ir the course of their interviews.

Loukirig just at thase patierits who made a relevarit commerit, we see that the expectatiors of patients in corvertigral ard haspice programs alike were fairly everily divided betweer the twi appraaches to pain cantrol. Abiut 55\% af the patierits had expectatiars for pair ta be 
TAGLE XL

INDICATOF 4E: PAIN CONTROL FRACTICES SUMMARY OF RESFONSES
BY RESPONDENT GROUF

\begin{tabular}{|c|c|c|c|c|c|c|c|c|c|c|c|c|c|c|c|c|c|c|}
\hline \multirow[b]{2}{*}{ FAIN CONTROL PRACTICES } & \multicolumn{2}{|c|}{$\begin{array}{l}\text { iConventional } \\
\vdots \quad(n=8)\end{array}$} & \multicolumn{2}{|c|}{$\begin{array}{c}\text { FATIENTS } \\
\text { Hospice } \\
(n=\theta)\end{array}$} & \multicolumn{2}{|c|}{$\begin{array}{l}\text { TOTAL } \\
(N=17)\end{array}$} & \multicolumn{2}{|c|}{ 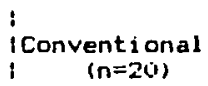 } & \multicolumn{2}{|c|}{$\begin{array}{c}\text { FAMILIES } \\
\text { Hospice } \\
(n=18)\end{array}$} & \multicolumn{2}{|c|}{$\begin{array}{l}\text { TOTAL } \\
(N=38)\end{array}$} & \multicolumn{2}{|c|}{$\begin{array}{c}\text { HEALTH } \\
\vdots \text { Conventional } \\
\vdots(n=19)\end{array}$} & \multicolumn{2}{|c|}{$\begin{array}{l}\text { PROFESSIONA } \\
\text { Hospice } \\
(n=2(i)\end{array}$} & \multicolumn{2}{|c|}{$\begin{array}{l}\text { LS } \\
\text { TDTAL } \\
(N=39)\end{array}$} \\
\hline & $\mathbf{n}$ & $\%$ & $n$ & $\%$ & $n$ & $\%:$ & $\mathbf{n}$ & $\%$ & n & $\%$ & $n$ & $\%:$ & $: \quad n$ & $\%$ & $n$ & $\%$ & $n$ & $\%:$ \\
\hline $\begin{array}{l}\text { Fasn Medication Given On } \\
\text { As Needed Basis Only } \\
\text { (Intermittent) }\end{array}$ & $\begin{array}{l}1 \\
\vdots \\
\vdots\end{array}$ & $33 \%$ & 3 & $38 \%$ & 6 & 35\% & 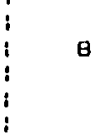 & $40 \%$ & 8 & $44 \%$ & 16 & 42\% & $:$ & $37 \%$ & 1 & $5 \%$ & $\mathbf{\theta}$ & \\
\hline $\begin{array}{l}\text { Fäin Medication Given On } \\
\text { Regular Hasis (e.g.. } \\
\text { Every four Hours) }\end{array}$ & 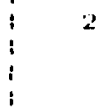 & $22 \%$ & 3 & $38 \%$ & 5 & $\begin{array}{r}29 \%: \\
\vdots \\
\vdots\end{array}$ & $\vdots$ & $45 \%$ & 7 & $39 \%$ & 16 & & 10 & $53 \%$ & 17 & $85 \%$ & 27 & \\
\hline No Kelevant Comment & $i$ & $44 \%$ & 2 & $25 \%$ & 6 & $35 \% !$ & 3 & $15 \%$ & 3 & $17 \%$ & 6 & $16 \% !$ & 2 & $11 \%$ & 2 & $10 \%$ & 4 & \\
\hline
\end{tabular}

- Percentages may not sum to $100 \%$ due to rounding error. 
cortrolled through "as needed," iriternitterit administration af drugs; $45 \%$ preferred regular administration of drugs wnen this was deemed necessary.

The fanily members who made relevarit comments were everily split between the two pain control practices. Whether resporiderits represeritad a corveriticial program or a hospice program made ru differerice. Healti professianals in convertiorial programs were more likely to prefer the pain control practice of providing nedication only or ar irtemitterit, as reeded (PRN) basis thar were the hospice professionals, although the majority heid ideal expectatigrs for regular administratiar. of thase in corveritional programs who resporided, $41 \%$ prefermed that paim medications be admiristered PRN, compared to $6 \%$ of the haspice professianals who resparded. Combining both groups, $77 \%$ af all health professianals who resporided indicated a prefererce that pair medications be admiristered megularly.

Perhaps of nore interest than the preferred appraach to pain cortrol are the varibus additioral related themes addressed by resporiderits in their commerits. Amarg these themes were:

1. the poteritial for patierits or their family members to be reluctart for the patient to take pain medication, ofter due either to a fear of addictior or to a fear that if 
tog much medication is taker it will become imeffective later or (a fear of the patient's becoming "immune");

2. the belief that the patient should not be averinedicated ar "srowed" (except in the case of ane murse, who felt that "snowing" was acceptable; she just wanted patierits to be free of pairl and that medications should be very carefully monitored;

3. the belief by some patierits arid families that whatever practice was recommended by the doctor was that which should be followed;

4. the assertior that the patient's prefererices with regard to pain cortrol practices should be considered;

5. the existerice of differerit types af pairi; arid

6. the resistarice encountered by many patients, family members, and health professigrals en the part of (ather) health professianals in giving appropriate pair medicaticun, whether "appropriate" was corssidered to be regular admiristration or PRN administration.

The following resporises are illustrative of the various themes.

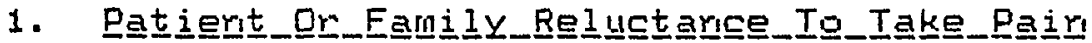
Meㅡ므드르므모. Three patients made commerits relevarit here. Orie, in a corveritional program stated: "I'm not afraid ta take medicatior... (but) I'm trying to keep away from it." Arother, also in a corveriticiral program, advised cithers: "Stay away from the reedle as long as you can; you dori't 
wart to build up tolerarice; you may want that needle later or." The third, in a hospice program, said, "They warited to give me pain medicine regularly, but if I have no pain, I dor"t take any medicire." (As discussed earlier, hospice proporents argue that in cases where there is pain, arid pain medication is administered regularly, the patient ofter comes to believe that he ar she no larger has pain.).

Family members who made comments of this rature iricluded sever in corveritional programs and five in hospice programs. While several family members were concerred about addictior, athers were rot. Some of the remarks made by those in corventioral programs, which represent these opposite points of view, were: "In 'patient's〉 case, he's asking for it tog ofter, and sooner or later they have to limit ar ar he' 11 be living on it completely;" (an irteresting twist, this person advocated regular admiristmatian to alleviate this problem); "I dor't urderstand the thinking that says you can have morphine shots as they reed them, or something like that, and who cares whether they're going to be addicted; that seems so wrarg I car't fathorn their thinkirg;" "My mother would never ask for pain shots;" "He didn't ask for his medication; I had to keep track;" "I dan't care if the patient is to the pairt where they use medication as a crutch; if it makes them feel better, they should have the privilege of using that crutch." 
Fanily members in haspice programs commented: "You shouldri't take argything uriless you have to;" "They get so that they lack forward to it;" "I don't, ard she didn't, want to take it unless needed;" "I heard the nurses say 'Let's try to hold off, I so patients wouldn't become immure;" "I dan't like the idea of becoming addicted." Drily five health professichals cone converitional, four hospicel made comments relevant to this issue of addictiar: "Try to alleviate pain not with medicatior, if mursing procedures can al leviate it... Too much medication leads to addictiar;" "Sometimes a patierit abuses some of her medicire, but if you have patients that have previously done this, they dor't charge just because they are terminally il1;" "A lot of people are willing to live with a lot of pain, and they" re rot willing to look at an alternative to that; it's real hard to convince them."

Arid firally, this comment by a physician:

One of the real problems is that very often people with severe pair who are going to live over a year, people dor't want to treat their pain for fear of addicticu, in cther words, dependence... Pecple with diseases like carcer are esseritially not taking the drug far ary high; they' re rot like street addicts, ard there's na reascirs to withhold drugs. They all worry about anyorie gairig over a year, but still, in al1, they have a might to pain contmol. And thereiri lies crie of cur biggest problems with some physiciars we've had, and ever patierits themselves: they really were so hurg up on this they refused to give good pain control...

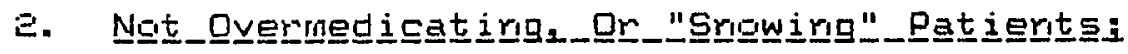

Merietgririg.Then. Three patients (two in conventional 


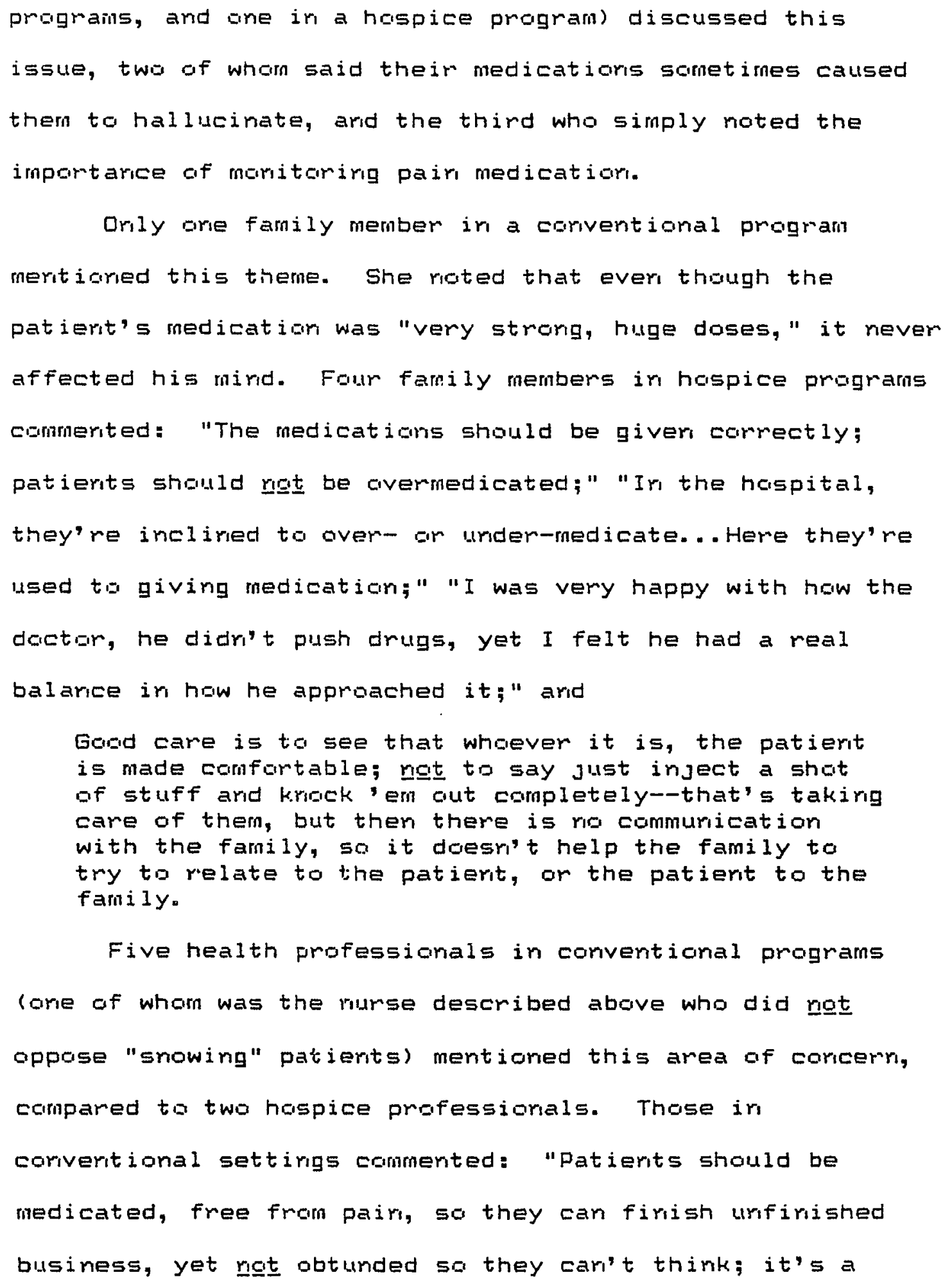

Five health professianals in conventianal programs lore of wham was the rurse described above who did ragt oppose "snowing" patients) mentioned this area af coricerr, cempared to two haspice prafessiorials. Those ir corveritional settirigs commented: "Patients should be medicated, free from pair, so they can firish urifirished business, yet rat obtunded sa they car't think; it's a 
delicate balance;" "You should carefully avoid overmedication;" "We cauldr"t marage this patient's pain; we "snowed" the patient; I dan't krow why it couldn't be caritralled;" "Alertriess must be mairitairied for optimal time." The hospice professionals said: "We push a lat of medicatior--rot so people are "srowed;" it's just... se pair is just, can_be, pretty much ron-existerit;" "Gaod care is havirg patients who are comfortable and alert."

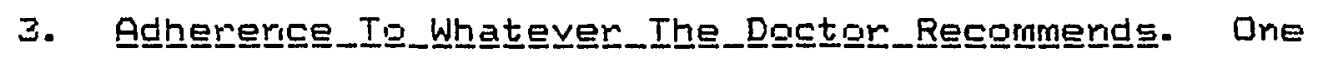
patient (conventional) and three family members (two canvertianal, one hospicel made a point of stating that the patient's doctor should deternine what pain control practice is to be implemerited. The cpinions of these iridividuals were at vamiarice with those who noted instarices in which they felt health professionals had acted inappropriately with regard to pain control (theme 5 ).

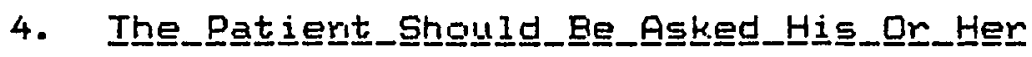

Preferencens. Two patients (ane conventional, one hospice), six family members (three conventional, three hospice), and five health professionals cone conventional, four carventicnal) made a statemerit indicating the patient's preferences with respect to pain control should be ascertairied and taken irito accourit.

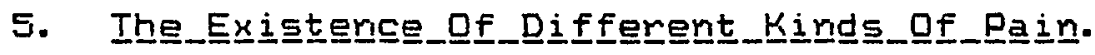
Mentioned by only one health professional (from a hospice program), this theme seems warthy of roting due to its 
urusual rature. This respordent talked af the existence of rot just physical pair, but also spiritual pair. He said:

Some patients, due ta some spiritual ar other dimerisior, may feel they deserye to experierice some af that pair. Sometimes that's so strorg that to rerider pain cantrol is inapprapriate.

He werit gr to describe a situation in which a wamar's body positior had iridicated severe pain, so a nurse, of her bwr voliticir, gave her medication. The rext marnirg, the womar was very angry arid warited to know, "Who deried to me making peace with my God?" He gave cther examples, as well, of patients who appeared to be in physical pair, but for whom the treatmerit was ireffective because their pair was rut physical.

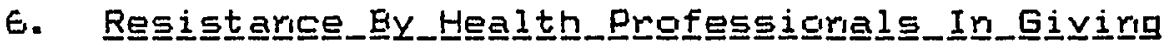

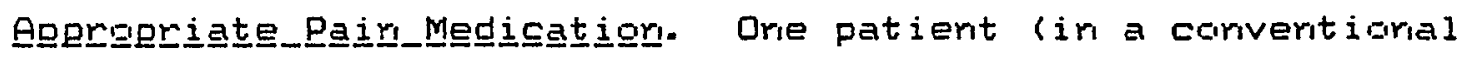
pragrams reparted:

They're pretty callous about pair here... At right, I get medications every four hours. During the day, I have to fight far it... The ideal would be if I could get medication within five minutes of ringing the be11. Right riow, they reglect me so much I'd like to get it every four haurs an the hour--I could deperid an that.

\section{Six family members (thmee corventibral, three hospice)} described instarices in which health professionals had beer. resistarit to givirg pair medicatior ir the way in which the

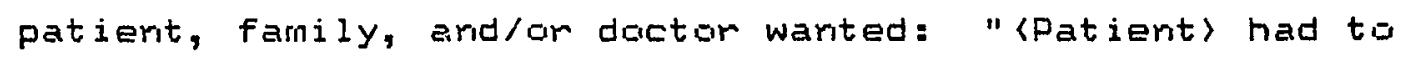
beg for pair pills; they didr't seem to thirk it was 


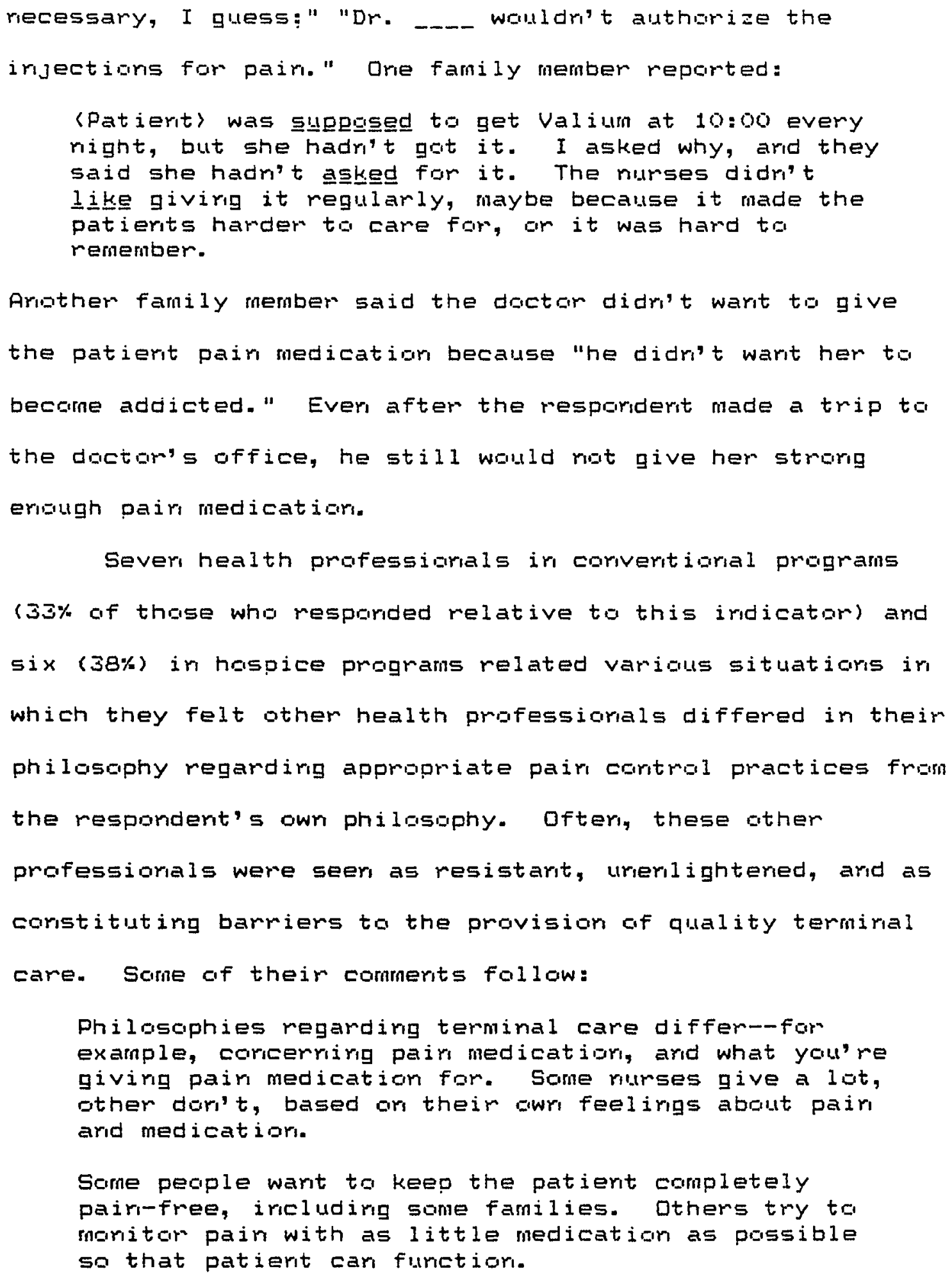


Some murses withhold rinedicatibu simply because they dori't urderstarid the dyirg process... There is a rieed for retraining of rurses; usually you can do this or a gre-tci-gre basis.

These shorter commerits also were pertimerit: "Sometimes we have trulbie getting physicians to give pain orders;" "Wher we warted to get strorger pain meds for her because she was havirg quite a bit of pain, the dactar wauldr't order things for her;" "This patierit warited to die pairi-free, arid morally some rurses felt that wasn't right."

Commerits made by hospice prafessiarals included that of a resporiderit who related how a patient's dactor had refused to believe she had paim, ard had diagrused her as having a lot of psychosomatic illresses. Arother person said, "There's a lat of igromance about pain control in other professionals." Firally, the fullowing two quotes from differerit resporiderits are illustrative:

We have such a problem getting dactars ta agree to give adequate pain medication in scme cases... If we exterid the defirition of "terminal" or "late stage carcer" to rire to twelve moriths, pecple will be happier with that; we'll do a better job treatirig our patients arid corrtrollirg their symptorus.

There are a lat of rurses that aren't confortable givirg large doses of medicire. This causes problems sometimes because the rurse won't give it, and the fanily says, "But you promised you'd keep her carnfortable!" 


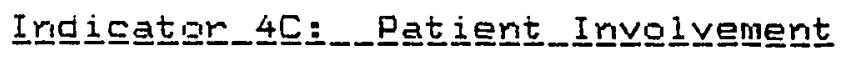

Examined here are expectations for the health professicirial rale with respect to invalvemerit of patients in care-related decisions. An achievement orientation is implied by the expectation of no irivalvement of patients in care-related decisichs; this arientation sees the professiorals as "krowirg best," due to their specialized training. Irivolvement of patients implies an ascription oriertatior, sirice patients are involved rot as a result of their competence or performance as providers of health care, but irstead, because of their ascribed status as patierits, and as those directly affected by the care they receive.

As riated in Chapter VI, Aralytical Madel, certain coriditiors serve as enablirg factors for involvement, or participatior, ir care-related decisiors. Particularly, patients likely will need to be informed of their diagnasis and prognosis and also will require irformation coricerring treatment options and available resources. Arother candition for irvalvenent carcerrs the health professionals' operiness to such involvement, that is, ta allowing patierits some say, or input, into these decisioris arid/ar respectirig their wishes. The link between these conditions is best il lustrated by the comment of orie of the health professionals interviewed: "The dying patient must have the say ever his own dying; he must have as much information as needed to deal with this." 


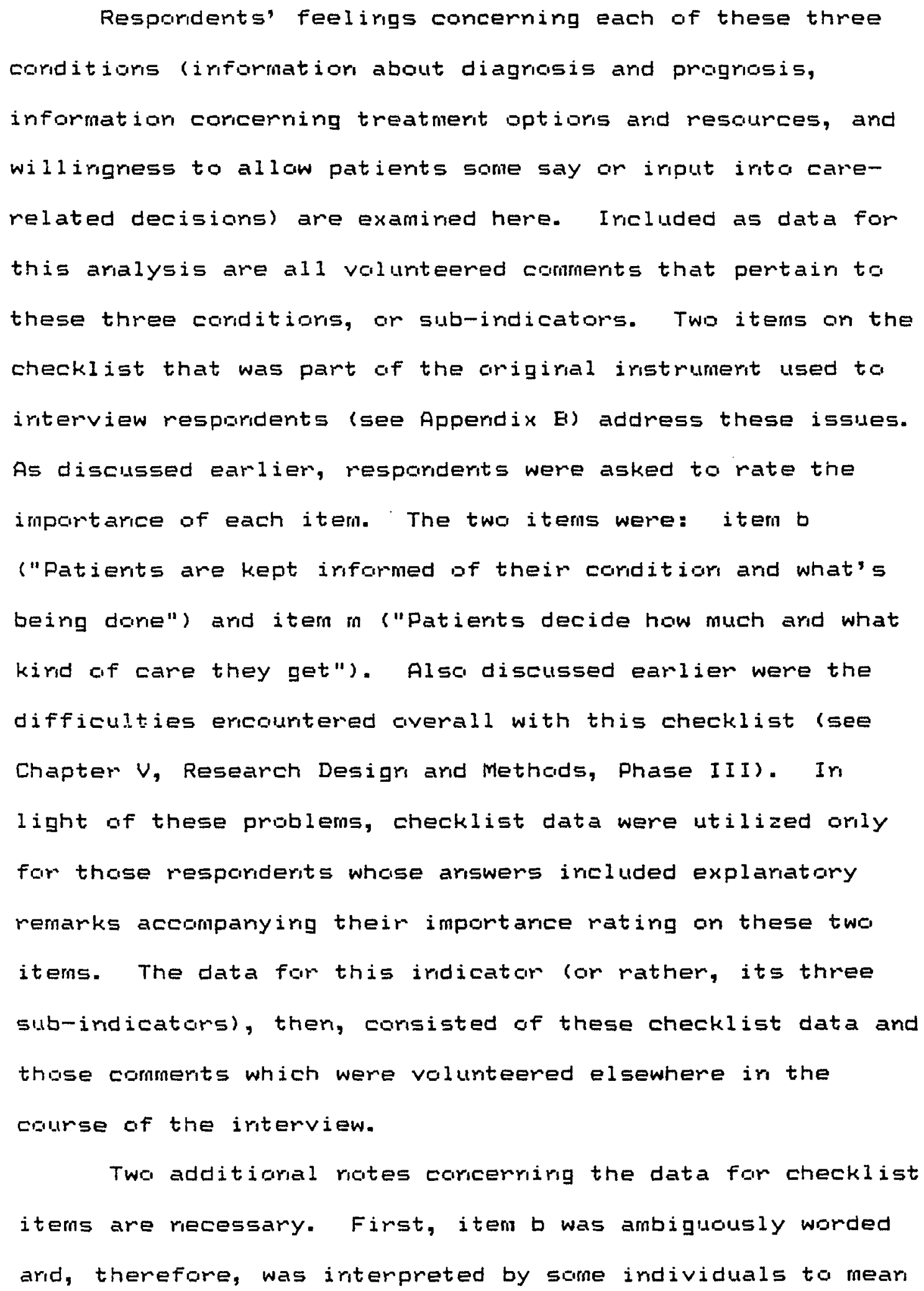




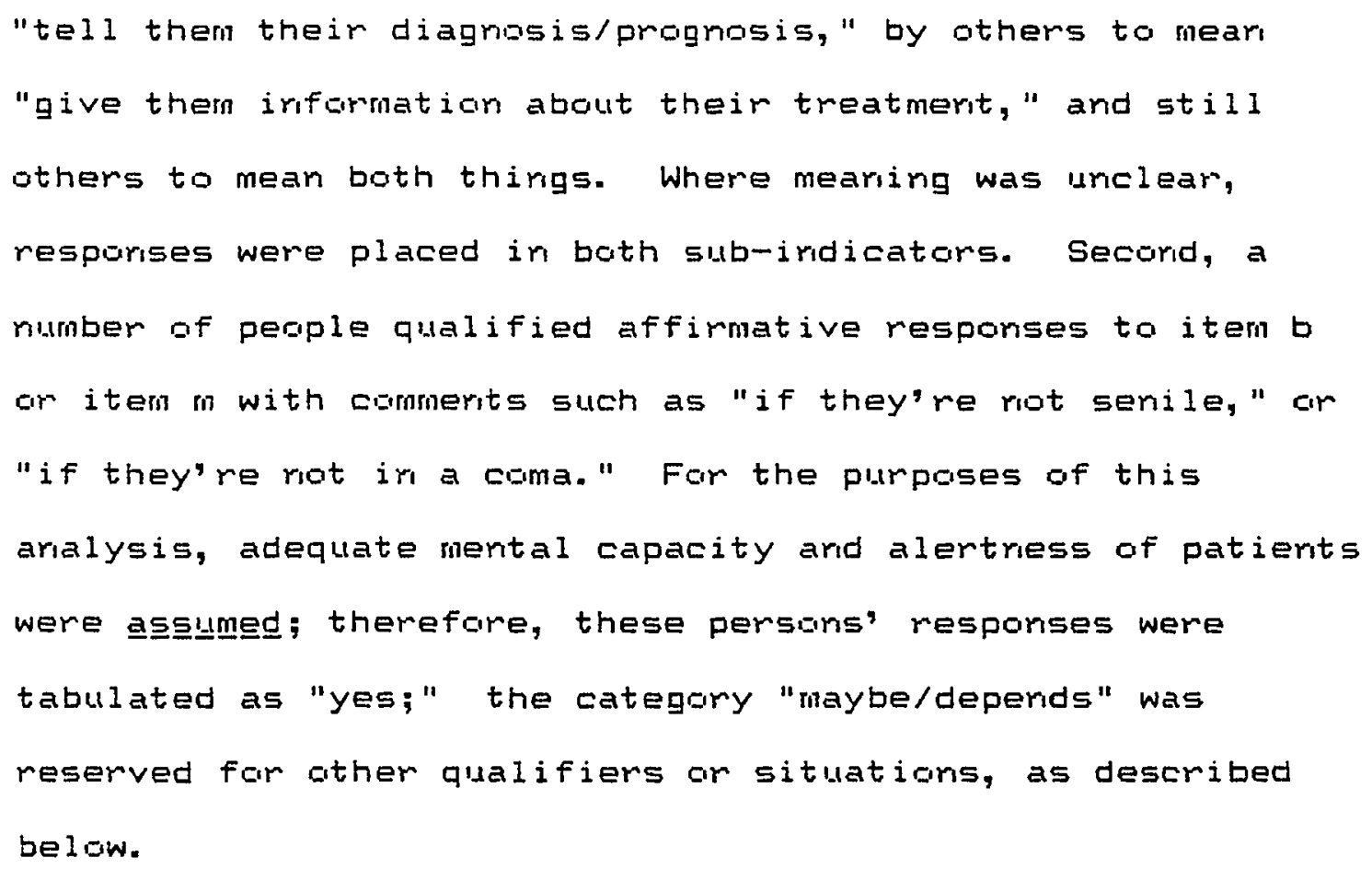


IAHLE XLI

INDICATOK AC: PATIENI INUULVEMENI

SUMTIAFY OF RESPONSES

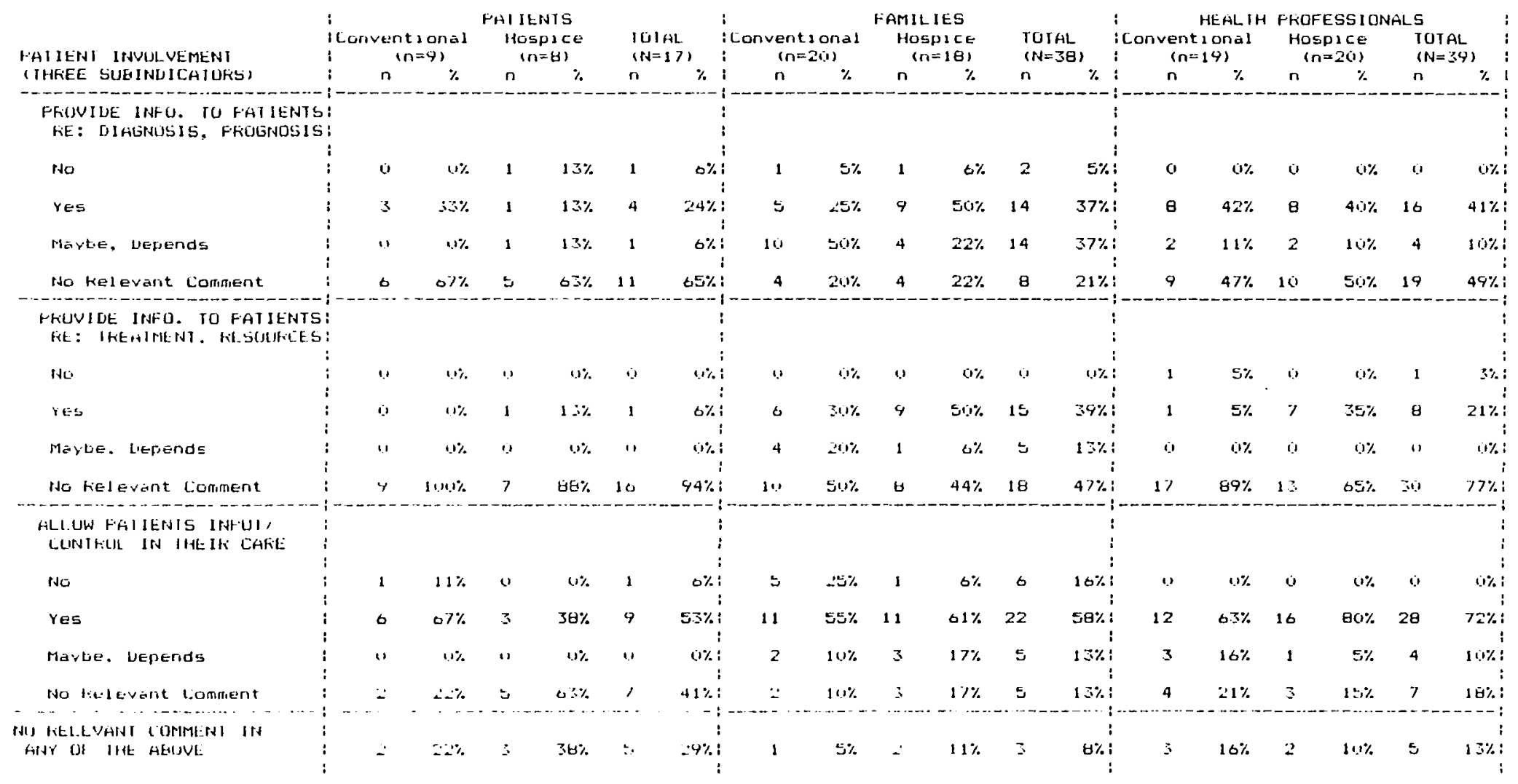

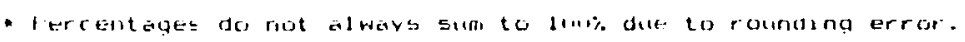


another. To facilitate comparisor between these groups, the perceritages reported in the text that follows are adjusted to iriclude only thase respondents who voluriteered a relevant commert (i.e., thase whase comments were classified as "no," "yes," or "deperids/maybe").

Arnorig the patierts who were interviewed, three patients in each type of program (corventional and hospice) resporided. The patients beirg cared for in converitioral programs all felt that patients should be told their diagnosis and prograsis. The three patients in hospice programs were divided among the resporse categaries, with orie indicatirig "yes," are "ro," and orie, "depends."

Of the resporderts of both patient groups hospice and corveritiaral) combired, $67 \%$ felt that patients should be infarmed af their diagrasis and prognosis. As one of these patients ruted, "It's a lot better krowing; if you dor't know the trutin, haw are yous going to cope?" One patient (17\%) preferred rot to kriaw: "Dor't tell a patient how long he has to live... We'l I go wher aur time cames... When the dactor told me I had two months to live, it upset me and my whale fanily." The last patient (17\%) felt that genergl $1 y$ it was a gond idea to tell patients, but not all patients. He gave an example of a neighbor of his who had "quit" upon firding out he had caricer.

The pattern af resparse for responding fanily members differed for those in conventichal programs compared to 
those in hospice programs. While ore person in each subgroup felt that patierits should rat be made aware of their progrosis, $31 \%$ of the family members in conventional programs iridicated the patient sheuㅡㄹㅡ be told, compared to E2\% of those in hospice programs; $63 \%$ of those in corveritional programs qualified their resporises, compared ta $31 \%$ of the hospice family members. These resporidents felt that patierits' desire ta know or mot krow, and/or their probable resporse to the rews, giver their enotional makeup, should be taken irito accourt. Some respondents specified that the dactor should teli the family and let the family decide if the patiert shauld be told.

The combired percentages far family member respondents (corvertioral and hospice) are: $7 \%$ indicating that patients should mot be told, $47 \%$ that they should be told, and $47 \%$ that it deperids on the individual.

Of the two responderits who argued patients should not be made aware of their diagnosis and prognosis, the one in the corventignal program stated, "I don't believe in that tew much... I thirk it puts a worry on their minds, and it slbws down their process of gettirg better, if there is any charce of getting better." The family member in the hospice program roted that, at the same time, false hope should rot be giver, either.

Examples af commerits made by thase who felt that patients shguld be told, both about their diagnosis and 
prograsis arid abaut treatmerits (the secand sub-indicatar)

fallow. The resprise quated first also indicates that

patients shauld have some imput and cantrol (the third sub-

iridicatar) ir their care.

Everybady has a right to kriow that they are going to die sa that they car do those things that they must do befare they die... If I'm dying arid I dan't know it, I could cumse everybady to hell and back again. Why? Eecause yiu're rict givirig me the privilege of makirig that decisior about what my 1 ife or death shauld be, what I must da or mustn't da. It should be my choice... I believe everybady should have the right ta chagse what they wart prigr to their death.

At 〈haspital〉, we didri't know tar much what was gaing or. I was surprised how much the doctor tald us at 〈another haspital〉. He told me arid her both; that's the way it should be.

Patierits absalutely should be tald, but doctor's darit. Doctors are not arily smart medical men, but they are masters of the Erglish lariguge; they can give you mare gobbledygauk ta caver up a situatior thar you car absomb, without sayirg anything.

Peaple wili came in ard talk with her in gereralities, rot realiy telling her what's ahead, how she's dairg.. She's not gotten one doctor to sit dowr with her at 〈hospital〉 and say, "This is what"s gaing an," "This is what we may or may not be able to predict," or "Do you have any questicins?"

The pattern of respanse did not differ much betweer

health professigrals ir converitioral programs arod those ir

hospice programs. Nine of the health professionals who resporided felt defiritely that patients shauld ngt be told their progrosis, and anly four (twa coriveritional, twe hospice) iridicated that there were situatigrs (other than merital ircapacity) ir which patierits should rot be told 
(e.9., if they did not wish to krow). This left $80 \%$ of those in converitioral programs and of those in hospice programs saying patients shonulㅡㅁ be made aware of their prognosis. The combined perceritages for both sub-groups weres ox "rio," Box "yes," and $20 x$ "maybe/depends."

Examples of professionals" comments include: "You must tell people if they are terminally ill; people have a right to know;" "If a patient isn't aware of his prognosis, the staff car't talk with them, help them deal with their huge fear;" "The patient kept asking, but no one wanted to say that her death was fairly immirient;" "Sometimes dactars arer"t totally horest with patients;" and the comment by a rurse:

People often are not very well-informed by their physician. The physician should be the one who's informirg them, keepirg them up to date, tellirg them what their status is medically. Often it's hard for us if they aren't well-informed.

Two physicians responded: "One barrier <to the provision of quality terninal cares is that patients must accept that they're dying, and if the doctor isn't going to admit it, the patient wor"t be told;" and

It's very rame that we don't tell a diagnosis... We usually always let people krow their prognosis. People ask the question, they get an answer. And we dor't believe iri holding back. I think that beirig able to do that is very satisfying.

In sum, the ideal expectation of all three groups generally appears to be that patients should be made aware of their disease and their prognosis, at least for patients 
wha wish ta krow and/or are judged to be emotionally stable enough to hardle such informatior.

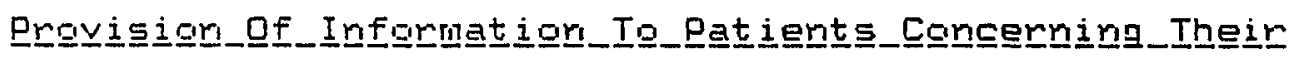

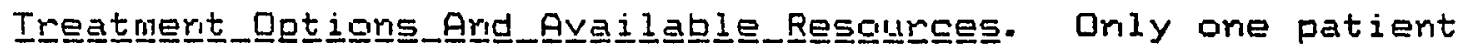
(6\%) gave a resporse that was categorized here; over half of the family members interviewed made a relevant comment, however. Only about one quarter of the health professionals commerited ori this issue. Substaritially more health professiorals in hospice programs (35\%) than in conventional programs (10\%) gave a relevarit resporise.

Among those persins who did comment, only one, a health professibral, felt that this type of irformation should rigt be provided. This person gave an example of a case in which the provision of information about the treatment the patient was receiving would rot have beer "fair." The patierit "didn't have the backgrourd to understand."

The majority of the remairing responderts who commented felt that information about resoumces amd/or treatmert aptiors gergually should be provided (again, as lang as the patient was mat mentaliy incapacitated). A few family members, especially those ir corverticnal programs, remarked that it deperded on the patierit and what they warited to kriaw.

The patient stipulated that iriformation should be giver that was "uriderstamdable." The resporses quoted in 


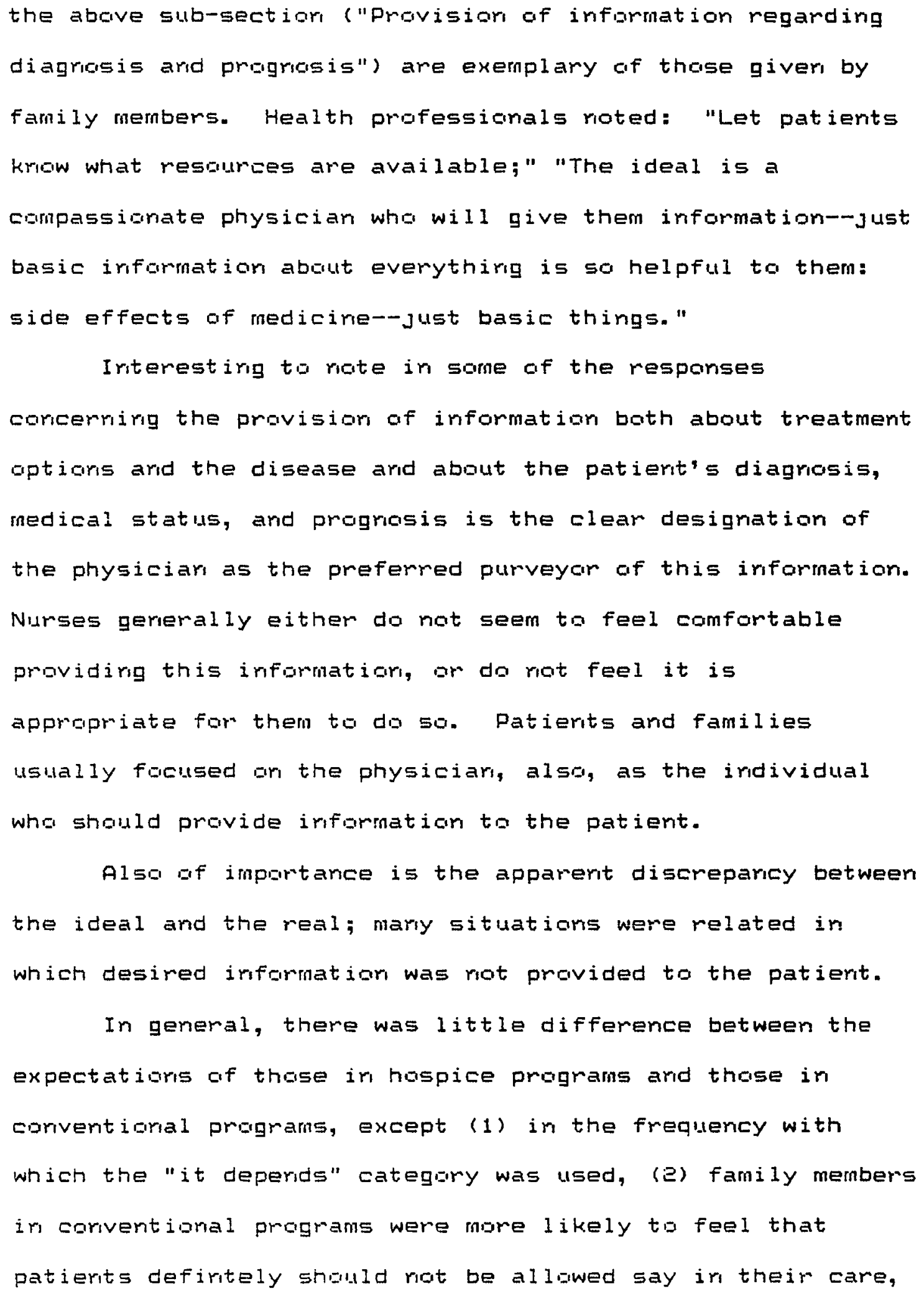


and ( 3 ) hospice professiarials were mare likely to mention expectaticirs that the health professicnal should provide information about treatment options and rescurce availability. Of the three groups (patients, families, and health professionals), more families responded than any ather group.

\section{Qgenness_Ig_Patierit_Ingut_CoritrgI_In_The_Care. Prior} to examining the resporises relevant to this indicater, note should be made of the categories of response for this sub-indicator. Specifically, the "maybe" category was developed for classifying the comments of thase respondents who gave conflicting informatigru in the course of their interviews regarding their views. Examples are given bel aw.

Mare individuals in aI three groups valunteered comments pertaining to this sib-indicator than to either of the ather two. About E0\% af the patients, $87 \%$ of the families, ard ge\% of the health professionals made a relevart commert. Fewer patients ir hospice programs remarked on this issue than did patients in comvertional programs.

Al I but are of the patients who resparded indicated that they felt patients should be allowed at least same say in their care. The patiert who felt otherwise said "The nurses and rurses aides Hrow what they' re doing." The bther patients" cemmerits imcluded those of a man who lifed the 
fact that he was allowed to "sleep practically as lorig as I want and stay up as long as I warit to," but he did not appreciate being told when to take his bath. This man also related an incident where he asked his doctor to alterriate his medications so that he "wouldn't build up a tolerarce." The dactor agreed to do this, and the patierit was pleased. The remaining patients in conventianal prograns expressed their dissatisfactior with "nurses" who were "too bossy," "Overbearing and sassy," or who "wouldr"t give water eriemas" despite the patient's wishes, and with health professichals in general who "force things on you all the time; I dori't like to be forced to do arythirg" (e.g., eat, dririk).

The comments of the patients in hospice programs centered around the administraticir cif medicatior. Ore patient noted that "doctors dan't believe you" if you tell them about ill effects of particular medications. Ancther said, "Well, if you're in pain, it's impartant to get help-usually I ask for pain killer for my arm." The third asserted:

The patient should have the say. You krow your illness; you know when it's hurting you worse thar other times. Now, sornetimes it's hard to convirice a nurse or doctor that maybe you are hurting a whole lot worse thar they thirik you are.

All but five family members in the sample (two in canventional programs and three in hospice prograns, or 13x), made a comment relevant to this issue of patient iriput and control. Five family members in corveritional programs, 
compared to orily ane in a hospice program indicated that the patiert should ricit have such iriput arid cortrol. Typical commerits included: "That would be impossible... some demand mome thar they rieed;" "I thirk the doctar ard rurse krow better than the patierit;" "I dar"t thirik they" re capable; that's what the dactor is far;" "No, that should be dore by doctors." All af these cornents were in resporise to checkilist itern $\mathrm{m}$.

The majority of family members felt that patierts should have at least some imput into their care ard carerelated decisions. Anorig these resporidents was a family member who roted that her relative did rut want iritravenous feedirg and rasagastric tubes, and that the doctar finally agreed to stap this treatmert; this was "hard for the family, but it's what (the patient> wanted." The expenierce af arother resporderit was the apposite, hawever; despite the patient's amd the family's wishes to have chemotherapy stopped, the doctar refused. Aruther resporident felt her mather would have received more attertion if she had taken a larger role in her care: "It's the squeaky wheel that gets the attertion and Mother didr't squeak. She didn't ask for arything--she didn't wart to bother." Two gther responderits agreed: "Mather rever cimplained, you had to askㅐ her; evor thor, she seldom complained; it might have helped if she had;" "The problem is some patients are rot rea? assertive to saying; I'd like to see a patiert advacate." 
Qther peaple roted, however, that patients had to be careful not to complair tog much sa as to avaid alienatirg care providers: "If youl don't conperate with 〈program〉 they cut you ciff, ard she was in rig position to be cut off." This same fanily member reported that the doctor had promised the patient that he would rat take her to a rursimg home, yet the next momning ar ambularce had come and taken her to ore. Dre family member asserted that the patierit should have therapy "arily if the patierit feels like it; if, ricit it should rigt be forced." Other comments included: "They respected his feelings:" "The decisiam process should be the patierit's;" "Some, but rot al1, the say should be the patiert" 5;" "Patierts shiuld have 100\% say."

As noted abave, the third respirise categary, "Maybe," was developed for those respondents who gave coriflictirig imformatior in their interview. Geremaliy, the carflict in infarmatibr came wher resporiderits had related iriciderits gr mace statemerts that implied that they felt patients shauld have at least some say ir their care, yet whi resparided to item m by sayirig, far example, "That should be determiried by the physiciar, the haspital, the nursimg hame--as ruch as the patierit rieeds." This statemerit was made by the man qugted abive in sub-indicatar 1, whis asserted sa vehemertity patierits" right to krow if they ame tomaimaliy ili, ard ta "chagse what they wart pribr ta their deat-. " Such 
conflictirg information may have arisen from difficulties

experiericed in irterpreting tine checklist item rn.

The health professionals" comments which were classified ir this "maybe" category were were similar to those of the families. That is, they resporided to item in saying that they felt it was rot particulamly importarit for patients to decide how much and what kind of care they get, yet they made statenerits earlier in their iriterviews that indicated that they felt patients should have at least some say ir care-related commerits. The resporises of four health professignals sthree in convertioral programs, and one in a hospice programl were af this mature. Ore professiaral in a hospital (comvertianal), for example, made the followirg stat enents:

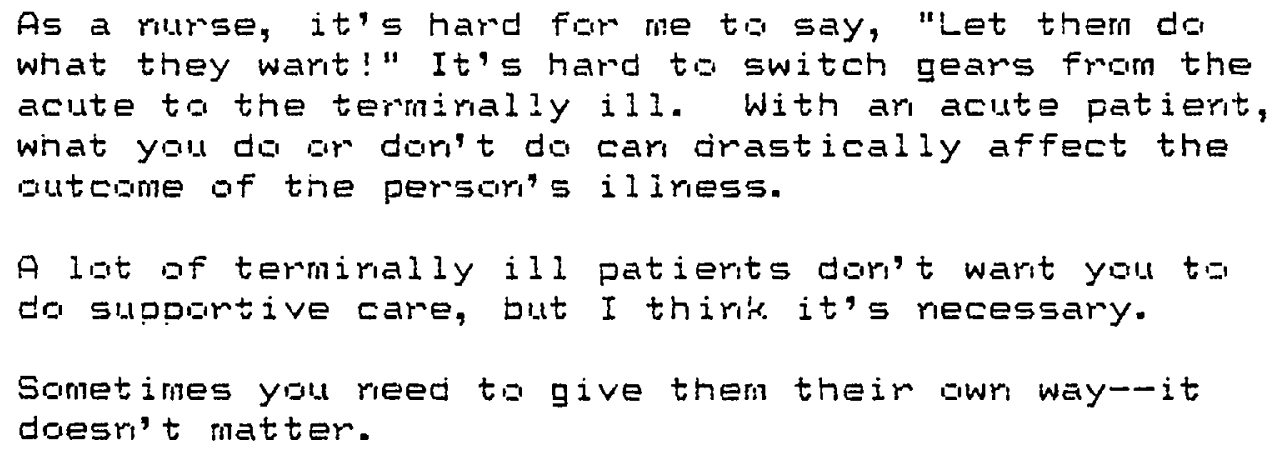

Examples af the respinses of health professiorials wha indicated patierits shgulㅡㅇㅢ defiritely have some say in their care are: "With the termirialy ill, we' re more coricerred abiut what they warit to do, what theney feel tinay reed;" "Caregivers have a tendericy to take cortril, yet patierits reed to be mairitairimg cemtrol ard reed to be irvoived in 


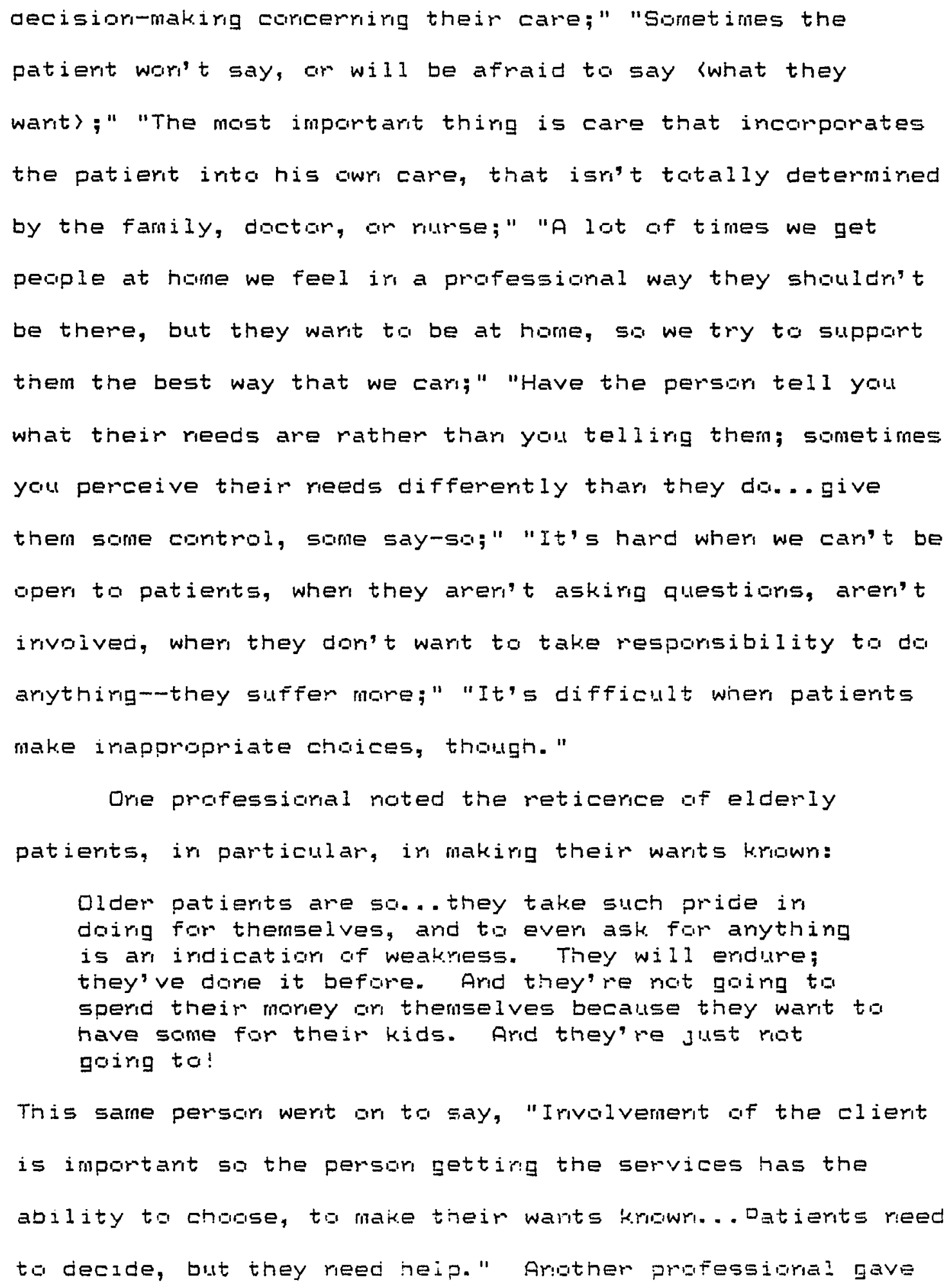




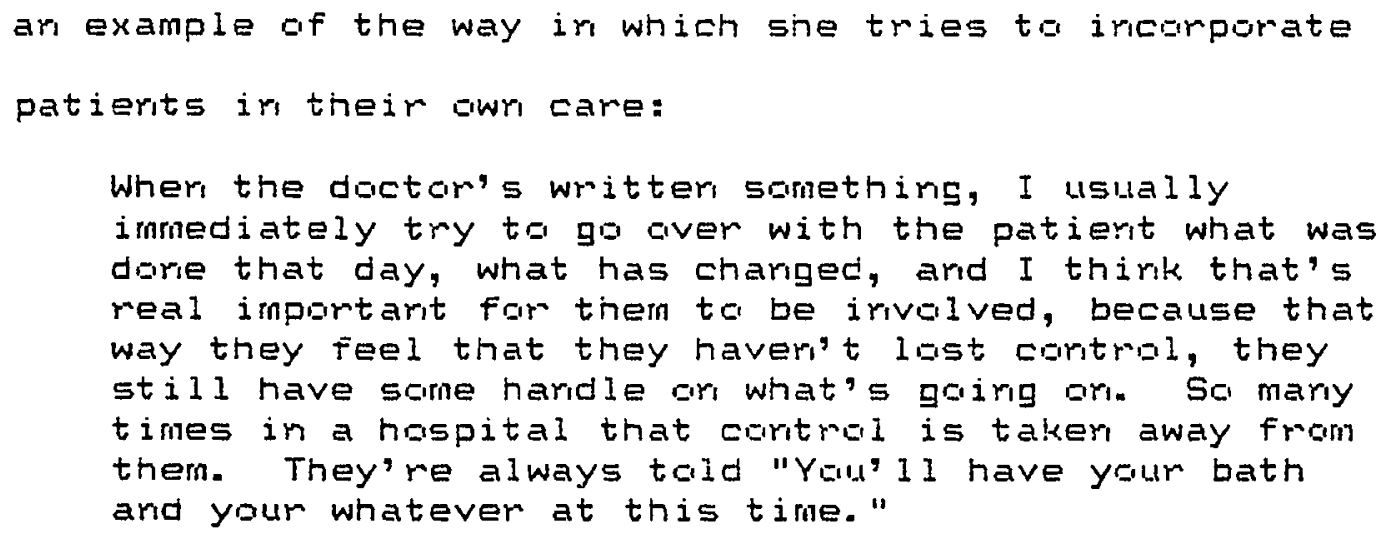




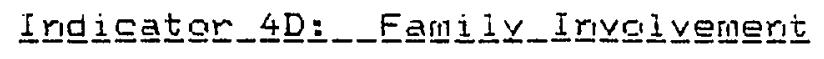

This section examines respanderits" expectations of the health professigral with respect to involvemert of families. Just as irvolvement of patients in their cown care ard ir came-related decisigris implies ar ascription arientatian ari the part of the health professiamal, so does irivalvemerit of the patients, families. Expectatiars that health professiarals rot irvolve patients, families, that the professiarals "krow best," are achievement-crierited.

As was the case in Indicator 4D, Patiert Irvalvement, relevant commerits made by responderits in tine coumse of their interviews, as well as data from two checklist items "e" arid "i") were iricluded in the aralysis, if resporiderits made a remark explaining their response to the item (see previous sectior, "Irdicator 4D" and Chapter $V$, Research Desigr and Metinads, Phase I I for an expiaration af this decisiond. The twa checklist items asked mesporderits how important it was that: "patients" families have a say in the patients" care;" ard "patients" families help care for the patient." "Help," ir this latter iteri, was interpreted variously by resporiderits to mear help with tine physical care df the patiert, help through servirg as ar advicate for the patiert, or help with care just by beirg with the patient, visiting isin br her, and providirg engtiaral support. 


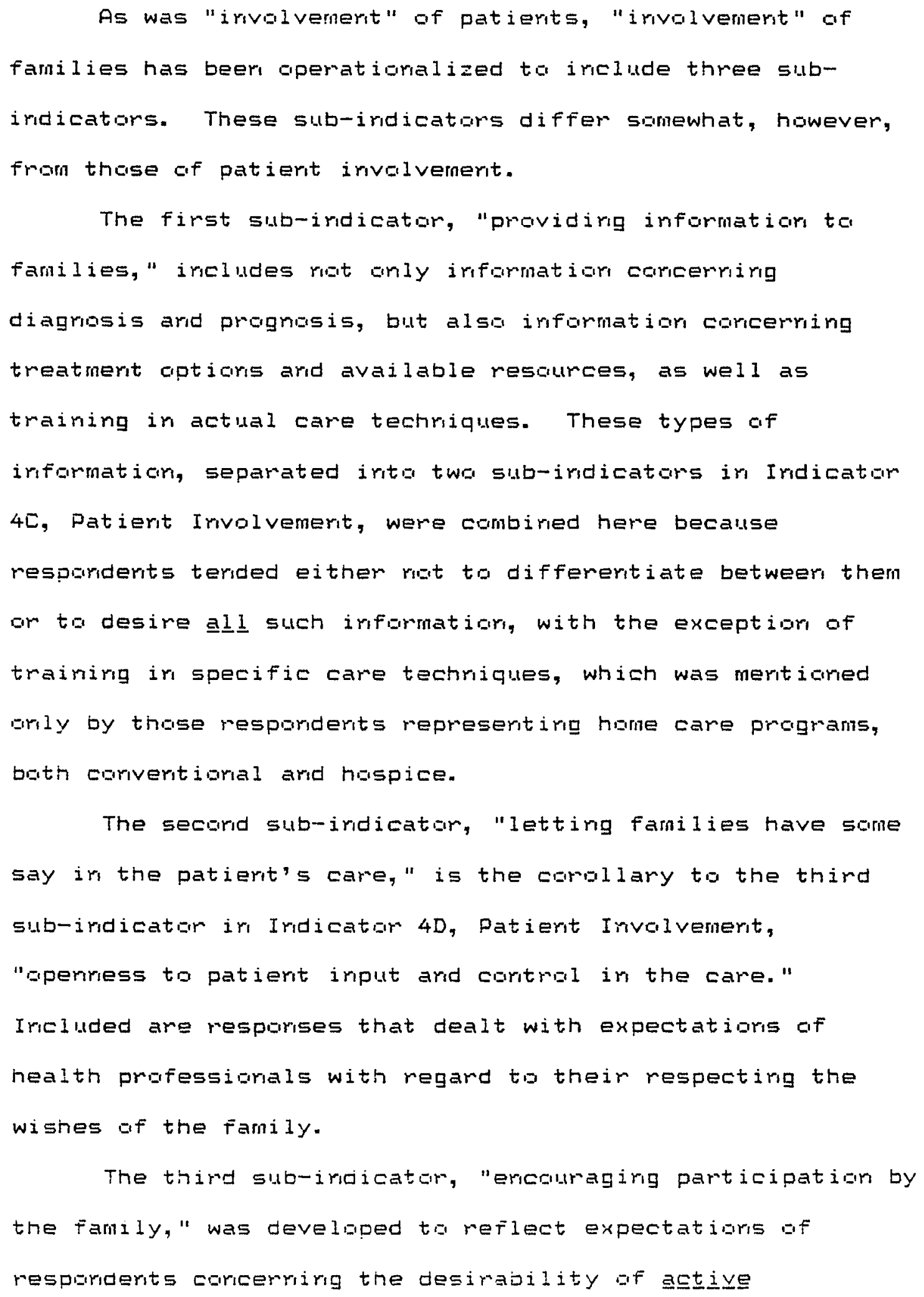




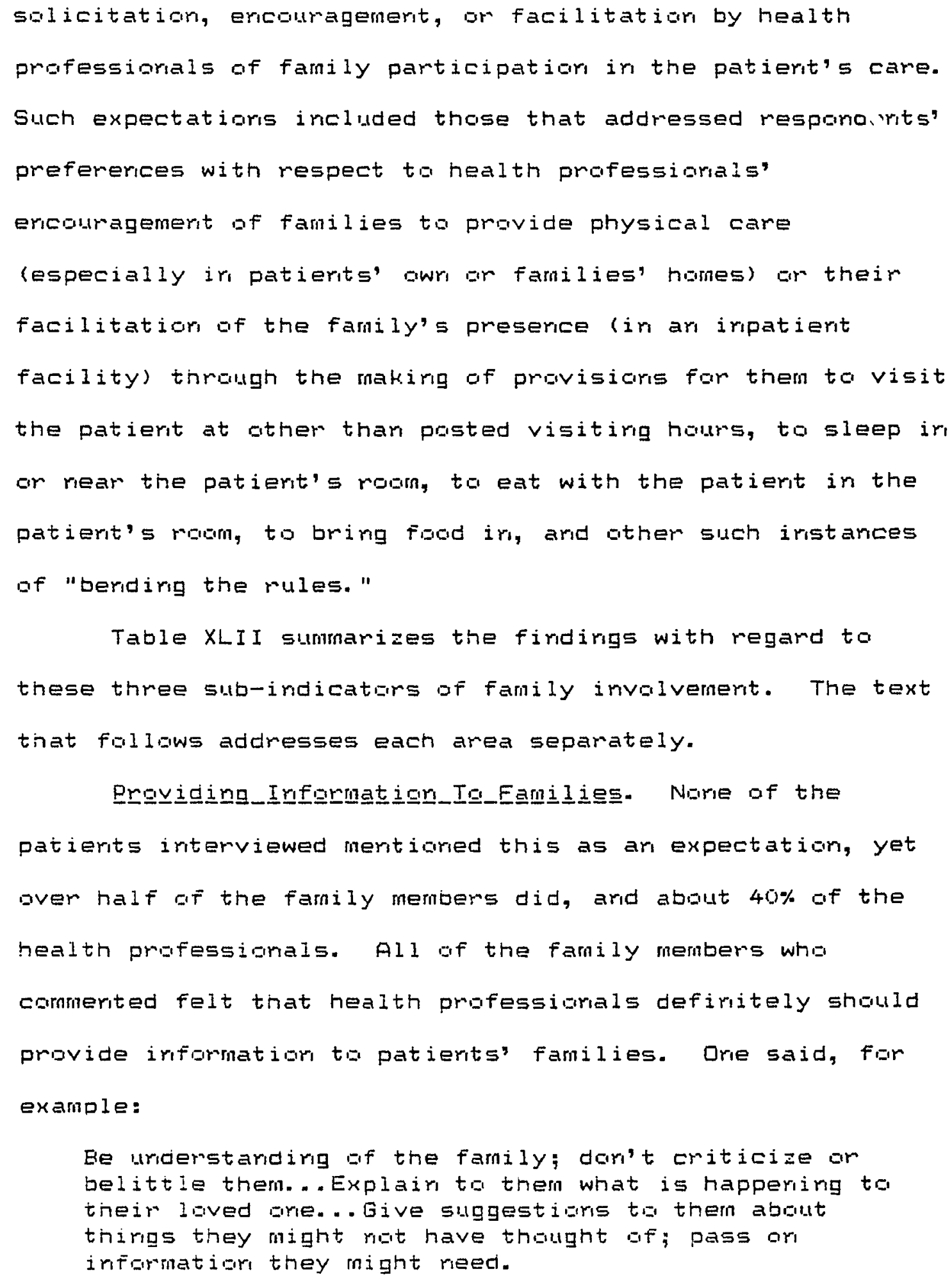


IABLE XL1]

INDICATOF 4D: FAMILY INVOLVEMENT

SUMMARY OF REEPDNSES

\begin{tabular}{|c|c|c|c|c|c|c|c|c|c|c|c|c|c|c|c|c|c|c|}
\hline \multirow{2}{*}{$\begin{array}{l}\text { FAMILY INUOLVEMENT } \\
\text { (THREE SUEINDICATORS) }\end{array}$} & \multicolumn{2}{|c|}{$\begin{array}{l}\text { iConventional } \\
\text { i }(n=9)\end{array}$} & \multicolumn{2}{|c|}{$\begin{array}{l}\text { PATIENTS } \\
\text { Hospice } \\
\text { (n=8) }\end{array}$} & \multicolumn{2}{|c|}{$\underset{(N=17)}{\text { TOTAL }}$} & \multicolumn{2}{|c|}{$\begin{array}{l}\text { iconventional } \\
(n=20)\end{array}$} & \multicolumn{2}{|c|}{$\begin{array}{l}\text { FAMILIES } \\
\text { Hospice } \\
\text { (n=18) }\end{array}$} & \multicolumn{2}{|c|}{$\begin{array}{l}\text { TOTAL } \\
\text { (N=3B) }\end{array}$} & \multicolumn{2}{|c|}{$\begin{array}{l}\text { HEALIH } \\
\text { iconventional } \\
\text { Cons } \\
(n=19)\end{array}$} & \multicolumn{2}{|c|}{$\begin{array}{l}\text { PFOFESSION } \\
\text { Hospyce } \\
(n=20)\end{array}$} & \multicolumn{2}{|c|}{$\begin{array}{l}\text { AL.S } \\
\text { TOTAL } \\
\text { (N=39) }\end{array}$} \\
\hline & 1 & $x$ & $n$ & $x$ & $n$ & $\% 1$ & $n$ & $\%$ & $n$ & $x$ & $n$ & $\begin{array}{ll}x 1 \\
\end{array}$ & $n$ & $\%$ & $n$ & $x$ & $n$ & \\
\hline $\begin{array}{l}\text { PFOVIDING INFORMATION } \\
\text { TO FAMILY }\end{array}$ & $i$ & & & & & $\vdots$ & & & & & & i & & & & & & \\
\hline No & 0 & $\dot{u} \%$ & 0 & $0 \%$ & 0 & or! ! & 0 & $\%$ & o & $\mathbf{0 \%}$ & 0 & $0 \% !$ & 2 & $11 \%$ & 0 & $\mathbf{0 \%}$ & 2 & $5 \% !$ \\
\hline Yes & 0 & $4 \%$ & 0 & $0 \%$ & 0 & $0 \% !$ & 10 & $50 \%$ & 11 & $61 \%$ & 21 & & 7 & $37 \%$ & 7 & $35 \%$ & 14 & $36 \times:$ \\
\hline Marbe, Depends & $\vdots$ & $0 \%$ & 0 & $0 \%$ & 0 & $\alpha \%$ & 0 & $0 \%$ & 0 & o\% & 0 & $0 \%:$ & 0 & $\alpha \%$ & 0 & $\%$ & $\dot{0}$ & $0 \times !$ \\
\hline No Relevant Comment & 9 & $100 \%$ & 8 & $100 x$ & 17 & $100 \% 1$ & 10 & $50 \%$ & 7 & $39 \%$ & 17 & $45 \%:$ & 10 & $53 \%$ & 13 & $65 \%$ & 23 & $59 \% 1$ \\
\hline $\begin{array}{l}\text { LETTING FAMILY HAVE SA } \\
\text { IN FATIENT'S CARE }\end{array}$ & 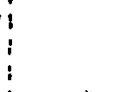 & & & & & $\vdots$ & & & & & & $i$ & & & & & & \\
\hline No & $i$ & $0 \%$ & 0 & $6 \%$ & 0 & $0 \%:$ & 2 & $10 \%$ & 2 & $11 \%$ & 4 & $11 \%$ & 2 & $11 \%$ & 0 & $1 \%$ & 2 & $5 \% 1$ \\
\hline Yes & 2 & $22 \%$ & 1 & $13 \%$ & 3 & 18\%: & 6 & $30 \%$ & 10 & $56 \%$ & 16 & $42 \% !$ & 6 & $32 \%$ & 10 & $50 \%$ & 16 & $41 \times !$ \\
\hline Maybe, Depends & $a$ & $\omega \%$ & 2 & $25 \%$ & 2 & $12 \% !$ & 3 & $15 \%$ & 1 & $6 \%$ & 4 & $11 \% !$ & 1 & $5 \%$ & 0 & $0 \%$ & 1 & $3 \% !$ \\
\hline No Felevant Comment & 7 & $78 \%$ & 5 & $63 \%$ & 12 & $71 \%:$ & 9 & $45 \%$ & 5 & $28 \%$ & 14 & $37 \%$ & 10 & $53 \%$ & 10 & $50 \%$ & $2 u$ & $51 \% i$ \\
\hline $\begin{array}{l}\text { ENCOUFAGING FAMILY } \\
\text { SUPFOFT OF PATIENT }\end{array}$ & 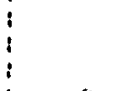 & & & & & $i$ & & & & & & 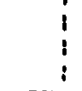 & & & & & & : \\
\hline No & 0 & $4 \%$ & 0 & $0 \%$ & 0 & $\% !$ & 3 & $15 \%$ & 0 & $0 \%$ & 3 & $\theta \%:$ & 2 & $11 \%$ & 0 & (i) & 2 & $5 \% !$ \\
\hline Yes & 1 & $11 \%$ & 2 & $25 \%$ & 3 & $18 \% i$ & 6 & $30 \%$ & 7 & $39 \%$ & 13 & $34 \% !$ & 12 & $63 x$ & 9 & $45 \%$ & 21 & $54 \% !$ \\
\hline Maybe, Depends & 0 & $\omega \%$ & 0 & $0 \%$ & 0 & $0 \% !$ & 1 & $5 \%$ & 1 & $6 \%$ & 2 & $5 \% !$ & 1 & $5 \%$ & 1 & $5 \%$ & 2 & $5 \% 1$ \\
\hline No Kelevant Comment & $\theta$ & 89\% & 6 & $75 \%$ & 14 & $82 \%:$ & 10 & $50 \%$ & 10 & $56 \%$ & 20 & $53 \% i$ & 4 & $21 \%$ & 10 & $50 \%$ & 14 & $36 \% 1$ \\
\hline $\begin{array}{l}\text { NO RELEVANT COMMENI IN } \\
\text { ANY OF THE AHOVE }\end{array}$ & 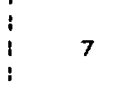 & $78 \%$ & 4 & $50 \%$ & 11 & $65 \% !$ & 3 & $15 \%$ & 2 & $11 \%$ & 5 & $13 \%:$ & 1 & $5 \%$ & 3 & $15 \%$ & 4 & $10 \times i$ \\
\hline
\end{tabular}

* Percentages do not always sum to $100 \%$ due to rounding error. 
Arother family member noted, "They sometimes talk ir

larguage youl dar't uriderstarid; they get put gut wher you ask

for something to be repeated." This same persor, as did a

few ether family members, felt that "Some thirigs should be

told ta family first." Also illustrative of several

persars, commerits were thase by this family member:

Mome than ore persari meeds ta hear what might be

dorie ta help a persan... I remember my mather

commented, "I ari sa glad you were there because I

can't remember what he told me was ahead for me"... I

dor"t warit ta take advaritage af their time or

uririecessarily tie them up. I feel we really have

the right ta ariswers, arid I woryt push and take

advaritage, but I'm goirg to harg arburd uritil an

ariswer cames... I wish there were bre persori, a

doctom, wha cauld sit dawn ard ariswer cur questions

for us.

Additioral commerts by family members iricluded:

I'd call a couple af rice rurses who would give me iriformation or platelets, white colurit, arid hemoglobin--realiy give me irismmatiar. Then I mari across some wha wouldn't give me the time af day. I'd wait uritil they were iff shift.

They"re 〈murses\} willirig to talk to me, rot embarrassed if I ask them questigns. The fanily shauld be told exactly what the situatian is so that they krow how ta deal with it. Of course, some people car't hardle somethirg like that, but I thirk anybody who's trairing ta go irito it cari tel 1 wher they car be tuld and wher they shouldrit be.

This persor alsi deseribed a situatian in which she had rot

beer giver valuable irifommatiors:

At 〈hospital), mobody could tell me where I could get... equipmerit that I'd rieed at home. Arid the rurses didn't mention' $t$ il $I$ brought it up what was available in the way of home help. 
The majarity of the health professigrals interviewed also viewed the health professiaral as having a respinsibility to provide information to fanilies. Some of their comments were: "The family reeds horesty from the doctar and the staff;" "Let families know what resources are available;" "Make then aware of agencies that car help."

Two health professigrals, however, felt that the provision of information to families was rot particularly important, or at least they did not like having to do this, ard saw it as interfering with theim ability ta do theim work. These twa professibrals, bath in the same iripatient facility, resented having to explain what they were doing with the patiert, and why they were doing it (e.g., when they put the patient an the commode, or when they did particular medical treatmerits). As are said, "Ore of the biggest barriers is when families come; it's hard when farilies are standirg there and watchirg you--you have to explair."

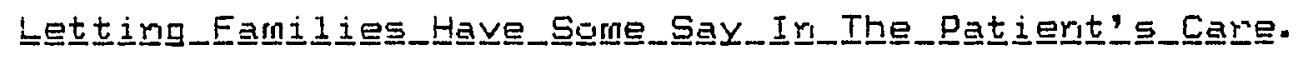
Families themselves, again, were much mare likely ta commerit with respect to this issue of "say," or iriput irito the patient"s care, and especially families in hospice programs, thar either health professiarals ar patierits. Of thase patients who did mespind, al 1 favored at least some family say, although a few issued cautiorary rutes, such as that by a mar who stated that orly are family member should have 
such irput because of the poteritial for conflict, and the plea by arother male patient that families rot treat the patient like a child; this had happered in his case, and he felt it was "dencralizing."

Amorng the fanilies who resporided, the majority $(67 \%)$

felt that families should have irput irta the patient's

care. Ore waman believed this, yet reparted:

The rurses would get so snappish--just irritable at me for butting in. I've gatter so weary--it's like dealing with children who you tell to clear up their roam; you get imritable that they' re rut doing what they should do.

Arsther had had a very positive experierice:

People were very oper and horest with me--all the doctors, al t the nurses. The suggestiors I had were listened to and acted or... At ro time did anybody teli me what to do. They gave me choices and everutuaily I made the decisiaris, ard I appreciate that... My mom had some problems with her pain medication. Dr. _.. gave her a drug, ard she had a very bad resporise which the doctar didr't see. Arid 50 I werit to the nurses, and I told theri. Somebody could have said ta me, you kruw, "Lady, let us do the job." Arid they didr't do that. They chariged the medication... They were just mare than couperative.

A ruluber of these family members, however, did qualify their statemerits, being careful to rote that the patiert's wishes snould have priarity, or that orly the imrediate fanily (e.g, spouse) should be irvolved in grder to avoid corrfusiar.

A fow bi the family members who made melevant comments expressed ambivaience ("mayoeideperids"), gererally seeming to feel that the family snould have at least some imput but 


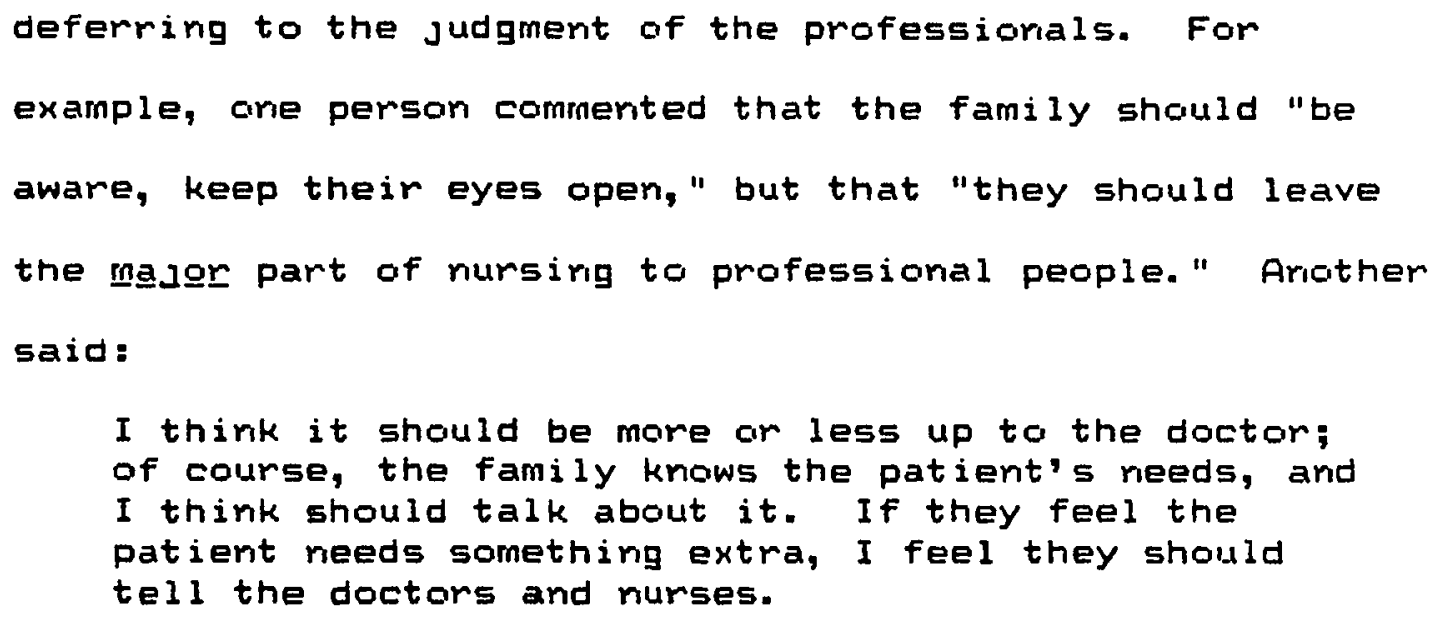

Four family members, (two in corventional programs, two in hospice programs) felt much more strongly that families should ngt have say, as illustrated by these commerits:

It should be between the patient and the doctor. The family shouldn't have anything to say if the patient is meritally alert; this gets the patient mixed up. People tell other people what to do too much."

I was invited to one of those meetings sof the health professional team), arid I just was turred off. I didn't wankt to be resporisible for some of the thirgs that were going on at the time.

About half of the health professionals made comments that were relevant to this issue of family input in the patient's care. All of those in hospice programs who meritioned this issue favored family iriput. Most of thase in converitional programs did, as well, although a few qualified their remarks, stating the patient's wishes should be considered first, or that the family should have say "except when it's bad for the patient." Dre persar, whase response 
was tabulated as a "maybe," stated, "Families need to be corisulted, dealt with, even before they enter the facility." She felt this was an important strategy for keeping them from being too demanding:

Families have a tendency to want a temminally ill patient to have more care. Sometimes we get accused of not caring for them enough. They forget that they have placed their family member here... The farily is the biggest barrier; they are everly protective, expect a lot more, warit everything to be done to just perfection."

The two health professionals who felt it better that families not have say in the patient's care stated: "Families don't understand some of the physical care that"s done--they think we're trying to kill them;" and "Mary times they don't understand what is necessary." The first af these health professionals continued, "If the family comes ir and picks all the time, then you don't want that patient."

Those who felt that the family shgulㅁ have some say, that theeir wishes should be respected, commented: "We provide services at a level the fanily can accept;" "We try to maximize the choices for the patient and the family; they have all 1 the say;" "In this case, we had family confarences; the whole fanily got together, rallied around her... As problems came up we were able to find solutions as a tealam;" and finally:

Families need to feel involved, have a say in what's happening. They don't necessarily have to help with daily care. They must feel that the nursing staff 
is receptive to their suggestions, won't override their wishes.

Despite the gerieral conserisus that the health professional should listen to the families' suggestiors and respect their wishes, a majarity of the health professionals who made relevant comments reported situations in which they felt this say was not in the patierit's best interest, or made the job of the health professional especially difficult. Particularly problematic, as hirited at above, are those families who are "critical," "urrealistic," "overprotective," "picky," "fault-firiding," and/or who "mistrust" or "undermine" the health professiorials. Families who are cooperative ard with whom "gaod communication" or a "good relationship" has beer established, who are "involved with the staff as a team," and/or who are satisfied with the care their relative had received were much appreciated.

A few fanily members themselves noted that fanilies could sometimes be overly demanding, critical, ar interfering. Some advocated "developing rapport" with the health professionals, "The family reeds to get to know the aides and nurses, too, so there's rapport between then").

Drie family nember stated:

Sometimes, the question should be, "What can the family do to be a better team member?" It has to be approached as a two-way situation. I was there iong emough to develop tremendous respect; I was there a lot, all three shifts. The fanily must be cogrizarit

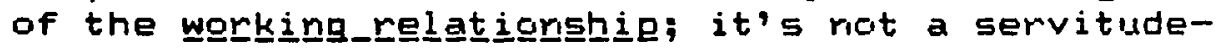
type situation. 


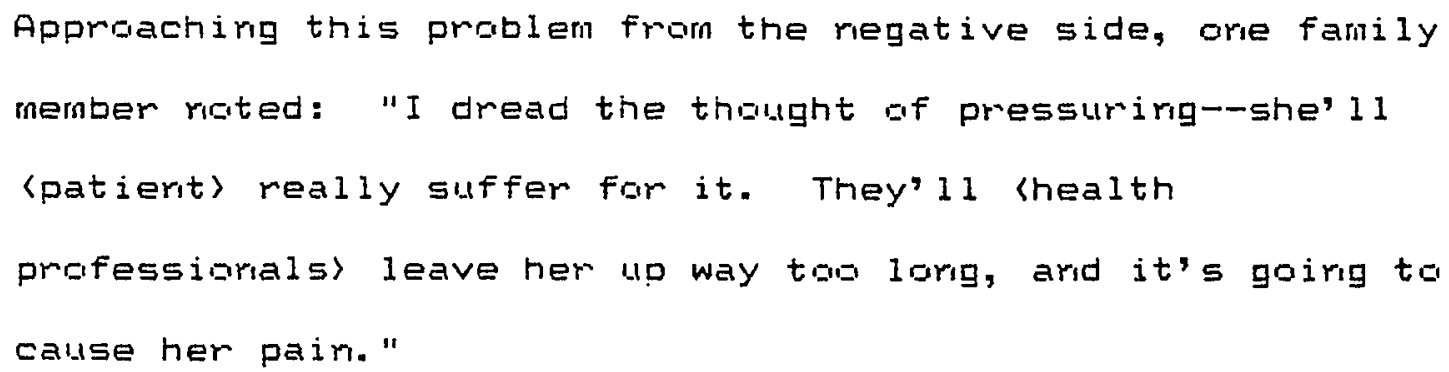


for the patierit, either in the physical care ar in providirg enatiaral support. The majority of the family members in camveritigral progmams wha addressed this issue felt similarly. Examples af commerits made iriclude: "The administrator and the head rurse are very gond about making us feel welcome as a family--they always smile wher we came in;" "They let the whole family go ir, grarichildren go iri--best medicire that he had;" arid the followirg larger commerits:

\begin{abstract}
When she 〈patierit) was first wheeled ir there, cine of the head murses said, "We just love to have farilies take ar irterest ir these patierits. There's mothirig that pleases us mire." Well, I discovered this was purely lip service. I scori fourd gut they meserited my being there as much as I was. They irsisted or calling a big corifererice between the head rurse ard our preacher arid myself ta meach ari understaridirg. I had to bend ori same thimgs and they compramised or some other things.

I slept ar the sifa ir the lourge because I would rot leave him; they didn't mind. They were most couperative... Orie ruluse everi found ar empty suite.. We had all gur family coming down to give blogd, arid we rieeded that extma roam. My husbard liked having his children there.
\end{abstract}

Ir the hospital they' re sa professigral', ir the serise that they"d say, "Well, yau gatta get sut of here naw." well, here we could stay, except ir. extreme cases, I ike they"d say "Wel1, we have to charge her arid." But it wasr"t the brush off. Far irstarce, if you die in tine hospital, well, that's tine first thirg they tell you: "Get aut." That's not how it was here.. This is a way fir a family ta reriew whatever they had as a family.

The last respindent also commerited an the idea gf beirg able ta nelp ir the patiert"s physical care: "There's a strarige maraitity taday--suing: so the irstitutiar is reluctarit to 
let you help." A few family members tald of how they had been allowed to brirg in fand far their ill relative.

A somewhat sumprising firding was that some family members were either ambivalerit abillt health professiarials" ericouragirg them to panticipate in their relative's care or were ragt in favor of this. Resognderits who made memarks of this rature gererally were those whi felt umable ta care for their relative at home. In a few cases, such mespondents had been made by healtin professiarals to feel guilty far rict carirg far their ill relative ir their cr the patierit's name, such as the follgwirg two persars:

Qne persor at 〈program〉 said I didr't warit him hame. I said that had hurt me. Of gourse I warted him home; my dactor said I cgllldgrt take care of him.

I felt like I gugnt to do al I this care, but felt at the same time that I collldgrit, and ta near the professiorals say I shiglulld really made me feel bad.

Aiso cortributiro to some ambivalerice abiut being ericumaged to participate in the patient's care by the health prifessigrals was the feeling or the part of a few farily nembers that the preserice af the family might actually be detractirg from the quality af care received by the patient, because rurses werp less likely ta check gri the patient. This theme was noted in Indicator $\Xi A$, Availability of Care, as weil.

The majority gf the health professigmals who respurided held ideal expectatiors that families should be eroburaged by nealth professigrals to barticipate in the patiert's 
care. Two professigrals did rat feel this way, though. One was the same persor who was reluctant to allaw families to have say in the patiert's care, ard who clearly felt that fanilies more ofter thar mot coritributed regatively to health professiomals' ability to provide quality care. The other perscir felt that a fanily"s coritinulal preserice "kept the patierit from adjusting ta us."

A few other health professiorals were ambivalent due to their awareness of just how difficult, physically and enctiorally, the provisicur of care was on family caregivers, especialiy glder caregivers. Family nembers themselves noted this fact as well. Nearly without exception, the farnily members who were providing care at home for their ill relative, or who had dore this at ore time in the relative's illness, stressed the physical and emotibral strain this caused them, arid, in mary cases, their own immediate families, such as their children and husband.

Qre health professignal who did support the idea of encouraging fanily members to participate in the care of the patiert felt a simularebus responsibility to help families, especially wives, rget to feel guilty if this care gat to be too muci for them, ard rot to feel that they had to do it al 1 themselves. She tried to reassume them that "rogone warks E44 hours a day."

Other healtin professigmals' commerits focused ar efforts that snould be made: to provice accommodatiors for 


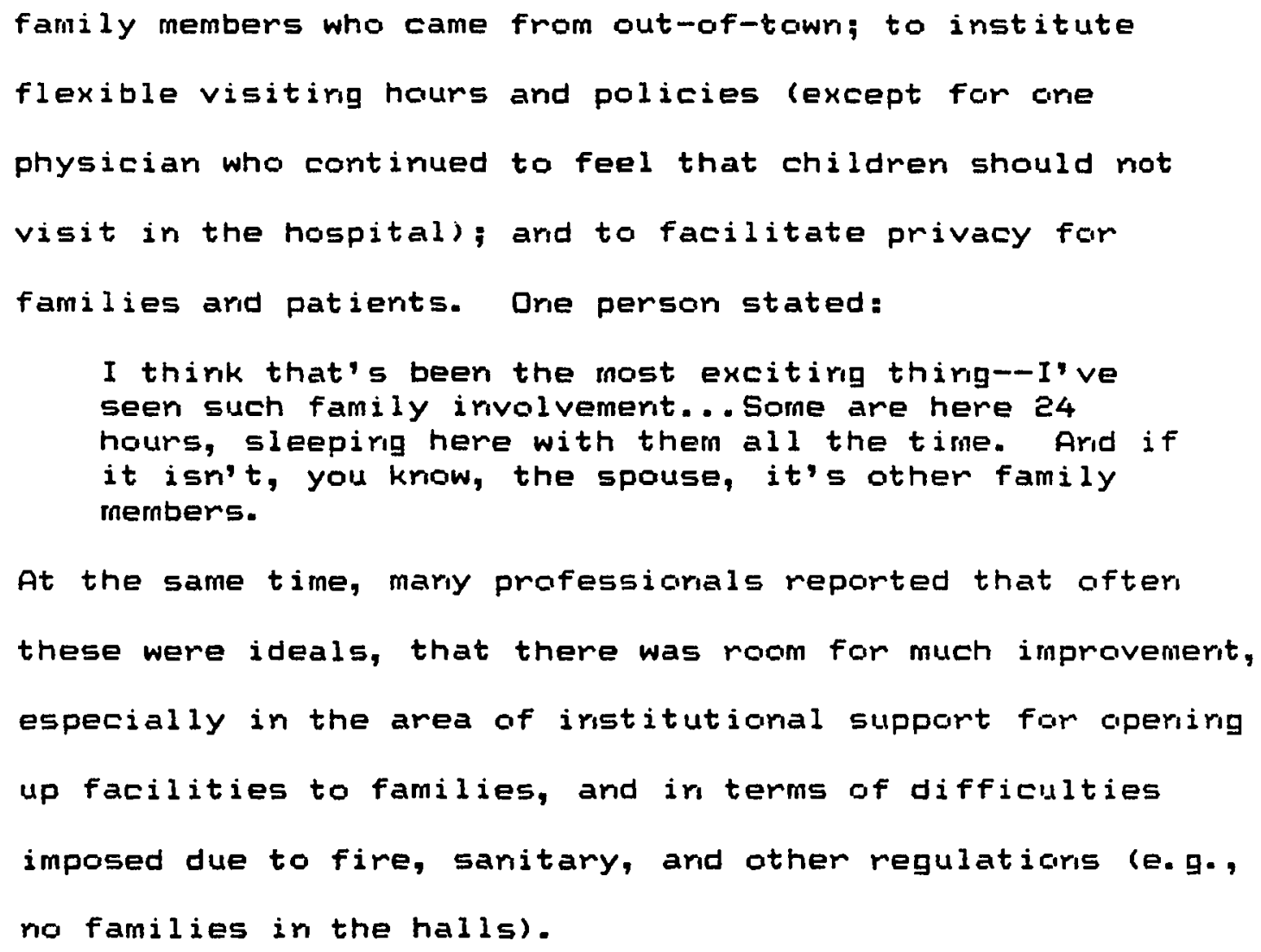




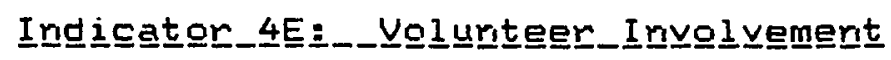

Examined here are respondents' expectations concerning health professionals' involvement of voluriteers in the care of patients. As was arqued in Chapter VI, Analytical Model, willirgress to use voluriteers represerts an ascription oriertation (pole 2 ). This is because such volunteers geremally are lay people with ro fommal trainirig in medicine or nursing; they are involved as a result of some personal attribute, such as desire ta help. Ari achievernerit orientation is implied through an urwillingness to use valuriteers; health professiorals with this oriertaticir see no orie but the health professional as capable on qualified to provide care (pole 1).

The data for patients, families, and mast health professianals that pertair to this indicator corsist completely af comments volunteered in the course af respanderits" iriterviews; ro direct questiar about valuriteers was asked. The health professicinals who were iriterviewed as the administrators of their respective programs are the excepticr. They were asked: "Are volunteers used here? If so, what are their functions? What are the training, experience, or ather requiremerits for valuriteers?" It should be clarified that expectations concerning the use orily of volurteers directly affiliated with a program, or a desire to have volunteers affiliated with a pragram, were exam irsed. 
Table XLIII surnmarizes the responses of respondents with respect to whether or rot their ideal expectation is that health professionals include voluriteers in the care of the patierit. Orily one patierit arid four fanily members meritioned the use of volunteers; all of these responderits were from hospice programs. The patient remarked simply that she liked the volunteers, that they were "very, very rice." Three of the family members reported types of assistance they or their ill relative had received from program voluriteers, including a voluriteer who stayed with the patierit on two occasiors while the family member coriducted persorial busiriess, a voluriteer who stayed with the patierit crie right per week sa that the family member could Qg ta chumch lboth of these family menbers were carirg for their ill relative at home), arid a volunteer from the hespital who gave the patierit "a lot of pleasure." This last voluriteer "was there quite a bit; she even made visits out here wher she 〈patierit) was at home." The fourth family member did riot describe specific tasks that were performed by the volunteers in the program where his wife had been cared for; he simply stated that the volunteers had beer appreciated arid that "they rieed mere voluriteers."

In addition to the health professicinals (adniristrators) who were asked specifically about their use of voluriteers, four health professionals, all in converitional programs, made a commert in the course of their interviews 
IABLE XLIII

INDICATOF AE: VOLUNTEEF INUDLVEMENT

SUMMARY OF RESPONSES
BY RESPONDENT GROUP .

\begin{tabular}{|c|c|c|c|c|c|c|c|c|c|c|c|c|c|c|c|c|c|c|c|}
\hline & \multirow[t]{2}{*}{ ic } & \multicolumn{2}{|c|}{$\begin{array}{c}\text { onventional } \\
(n=9)\end{array}$} & \multicolumn{2}{|c|}{$\begin{array}{c}\text { PATIENTS } \\
\text { HOSpice } \\
\text { (nDB) }\end{array}$} & \multicolumn{2}{|c|}{$\begin{array}{l}\text { TOTAL } \\
(N=17)\end{array}$} & \multicolumn{2}{|c|}{$\begin{array}{l}\text { Conventional } \\
(n=20)\end{array}$} & \multicolumn{2}{|c|}{$\begin{array}{c}\text { FAMILIES } \\
\text { Hospice } \\
(n=1 \theta)\end{array}$} & \multicolumn{2}{|c|}{$\begin{array}{l}\text { TOTAL } \\
(N=38)\end{array}$} & \multicolumn{2}{|c|}{$\begin{array}{c}\text { HEALTH } \\
\text { iConventional } \\
(n=19)\end{array}$} & \multicolumn{2}{|c|}{$\begin{array}{l}\text { PFOFESSIONA } \\
\text { Hospice } \\
(n=20)\end{array}$} & \multicolumn{2}{|c|}{$\begin{array}{l}\text { ALs } \\
\text { TorAL } \\
(N=39)\end{array}$} \\
\hline VOLUNTEER INUOLVEMENT & & $\mathbf{n}$ & $\%$ & $n$ & $\%$ & $n$ & $* i$ & in & $\%$ & n & $\%$ & $n$ & $\% 1$ & $1 \quad n$ & $\%$ & $n$ & $\%$ & $n$ & $\% 1$ \\
\hline & 1 & & & & & & i & & & & & & & : & & & & & \\
\hline No & 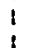 & 0 & $0 \%$ & 0 & $a \%$ & 0 & $0 \%:$ & i & $0 \%$ & 0 & $0 \%$ & a & $0 \%$ & 1 & $5 \%$ & 0 & $0 \%$ & 1 & \\
\hline Yes & $i$ & 0 & $\omega \%$ & 1 & $13 \%$ & 1 & $6 \% 1$ & 0 & $0 \%$ & 4 & $22 \%$ & 4 & $11 \%$ & 9 & $47 \%$ & $\mathbf{5}$ & $25 \%$ & 14 & $36 \%:$ \\
\hline No Relevant Comment & $\begin{array}{l}1 \\
1 \\
1\end{array}$ & 9 & $100 \%$ & 7 & $88 \%$ & 16 & $94 \% !$ & 20 & $100 \%$ & 14 & $78 \%$ & 34 & 89\%:! & 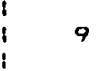 & $47 \%$ & 15 & $75 \%$ & 24 & 4 \\
\hline
\end{tabular}

* Fercentages do not always total $100 \%$ due to rounding error. 
that irdiceted their Feelirgs with respect to the use of valiriteers. Twa Gf these resparderits rubed with favar that their programs used voluriteers; buth of the athers could see a role for voluriteers arid wished that their program would use them.

Of the ter administratans, all five of the haspice administraturs said valuriteers were used in their programs (although bire said the prograin was rite well courdirated), compared to arily two af the five conventianal programs. of the pemairing tinree acmiristraturs, ore was carsiderirg begirrirg ta use valurteers, a secand used ar existirg valurteer service througin aruther agericy, and the thimd said her agericy did rut use valinteers, and would rot use them. Apparemtly this was due ta resistarce ar the part af athers in the prigram.

while haspice prograns ciearly appeared ta use voluriteers mare corsisterity ir the care ef their patients, it shauld be ruted that these voluriteers cariut be arrsidered to be ertirely "lay" valunteers. Faur gaf the five hasjice programs specified varialls types ard houms of trainirg undergarie by volurteers, as weli as carefui screemirg procedures tiat were ir place. This trainirig was seer as esseritial mot arly Tor the valuriteers to pravide

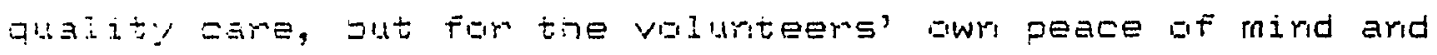
their ganfart in beirg with termiraily ili pegole. 


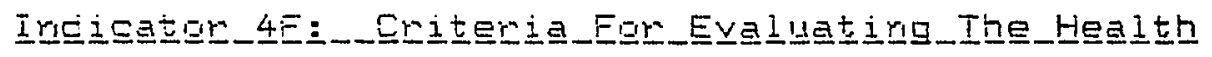

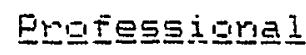

As ruted ir Chapter VI, Arialytical Madel, this last irdicator af the achievemert--ascriptian-arientatibr patterr variable differs ir perspective from the previgus six. Imstead of ascentairing the role expectatiar with respect to haw the healtin prafessiaral is expected ta treat cir evaluate the patierit or ather members af the rale set, this indicator examires the expectatiar caricerrirg how the patient and ather members of the role set evaluate ar assess the healti professigral. Specifically at issue is hgw the health professibrai is to be assessed: (1) or the basis of his or her" effectiveress, competerice, skilis arid capacities (performance capacity), or (E) an the basis af his or her səx, age, inteiligerce, physical characteristics, or group menterstip (e.g., M. D., R.N.) (aseriptive qualities). In Cinapter VI, Aralytical Madel, it was stated that ir the medical modej, simce the patiemt is expected to comply urigestigrimgly with the health professiomal, evaluatiar af the professignal umder this madel likely would be ascribed, basec primarily gr the health professigrai"s prsitior as a cactir ar a murse, ar br ather personal ascriptive charactaristiss. Alterratively, in the haspice model, sirice the patiert is expected ta take a mane active rale in his or

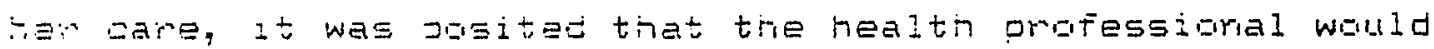

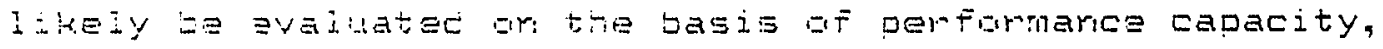




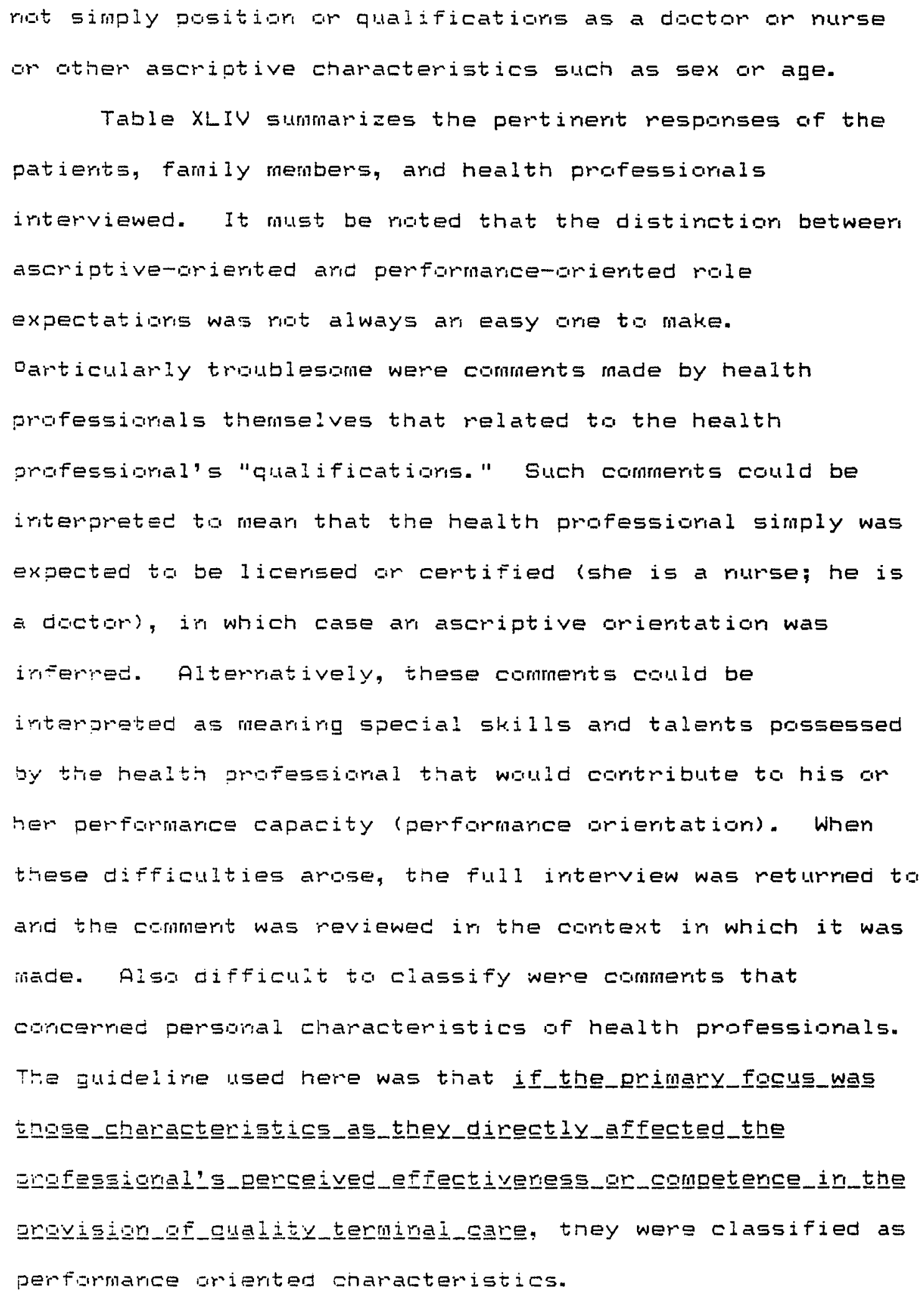


IAELE XLIV

INDICATOR 4F: CRITERIA FOF EVALUATION SUMMARY OF RESPONSES
BY RESPONDENT GRQUF.

\begin{tabular}{|c|c|c|c|c|c|c|c|c|c|c|c|c|c|c|c|c|c|c|}
\hline \multirow{2}{*}{$\begin{array}{l}\text { CFITERIA FOR } \\
\text { EVALUATION }\end{array}$} & \multicolumn{2}{|c|}{$\begin{array}{l}\text { Conventional } \\
(n+9)\end{array}$} & \multicolumn{2}{|c|}{$\begin{array}{c}\text { FATIENTS } \\
\text { Hospice } \\
(n=8)\end{array}$} & \multicolumn{2}{|c|}{$\begin{array}{l}\text { TOTAL } \\
(N=17)\end{array}$} & \multicolumn{2}{|c|}{$\begin{array}{l}\text { iConventional } \\
(n=20)\end{array}$} & \multicolumn{2}{|c|}{$\begin{array}{c}\text { FAMILIES } \\
\text { Hospice } \\
(n=18)\end{array}$} & \multicolumn{2}{|c|}{$\begin{array}{l}\text { TOTAL } \\
(N=3 B)\end{array}$} & \multicolumn{2}{|c|}{$\begin{array}{c}\text { HEALTH } \\
\text { Conventional } \\
(n=19)\end{array}$} & \multicolumn{2}{|c|}{$\begin{array}{l}\text { PROFESSIONAL } \\
\text { HOSp ice } \\
(n=20)\end{array}$} & \multirow{2}{*}{\multicolumn{2}{|c|}{$\begin{array}{l}\text { LS } \\
\text { TOTAL } \\
(N=39)\end{array}$}} \\
\hline & $1 n$ & $\%$ & $\mathbf{n}$ & & n & $\%$ & $\mathbf{n}$ & & $\mathbf{n}$ & $\%$ & n & $\%$ & $n$ & $\boldsymbol{x}$ & $n$ & $\%$ & & \\
\hline Performance, Comp & 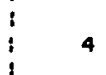 & $44 \%$ & 6 & $75 \%$ & 10 & $2 \times !$ & 16 & $80 \%$ & 16 & $69 \%$ & 32 & B4\%! & 16 & $34 \%$ & 20 & $100 \%$ & 36 & \\
\hline Ascriptive Qualities & $i$ & $22 \%$ & 2 & $25 \%$ & 4 & $24 \% !$ & 10 & $50 \%$ & 2 & $11 \%$ & 12 & $32 \% !$ & 1 & $5 \%$ & 7 & $35 x$ & 8 & \\
\hline No Relevant Comment & $!$ & $44 \%$ & 1 & $13 \%$ & $\mathbf{5}$ & $29 \% 1$ & 2 & $10 \%$ & 2 & $11 \%$ & 4 & $11 \%:$ & 3 & $16 \%$ & 0 & ox & 3 & 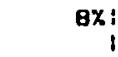 \\
\hline
\end{tabular}

* N's do not sum properly and percentages do not total $100 \%$ due to multiple responses. 


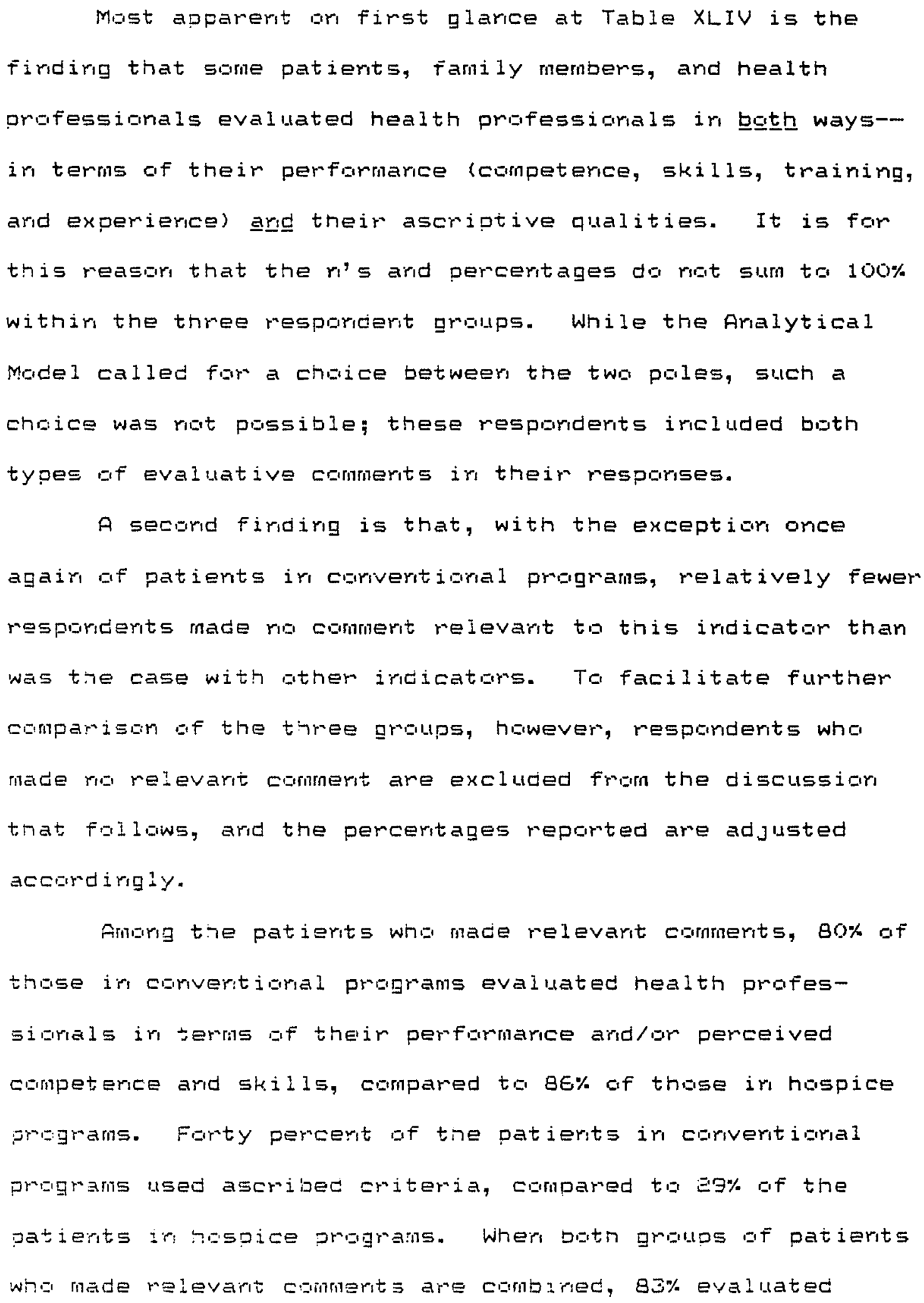


health professigrals ir tems of penformarce criteria, ard $33 \%$ evaluated them usirg ascribed oriteria.

Performarice-smierited comments by patients included: "She krüws what she"s dibrg;" "My dGctors are gugd, all but Grie;" "The rurses are gabd" "They take worderful care of youl her"e;" "Sime people have a kriack. for" beirg a rurse, arid same dim"t." Twa patients described dictors who had misdiagrised theim disease, and twi athers cammented or havirg received eithem "gage" ar "pror" surgical Gperatioris.

Twg patierits who made ascriptive-ariented remarks ficused ar the gerider af the health professional. Ore stated he didr't kruw his doctars well because "It's hard for" ne tio get to knisw mer, myseif." The ather said, "I dar't thirle a mar makes a very grod munse." The asomiptive quality uf physical strergth ar the part af a nurse was valued positively by a patierit, arid arigher patierit felt it was a boust to have "youmg pegple interested--it gives you egirage."

Amarg fanily members in cinveritigrial programs who made relevarit comments, $89 \%$ meritiored achievemerit (performarice) grierted criterie, ard $56 \%$ mertiored ascriptive-grierited criteria. Iriterestingly, ambrg the hospice fanilies, all ino made resevarit cammeris had perfirmarice-grierited mole expectatiars; ariy i3\% had ascmiptive arierited male expectatiars. Combinire the family groups yieided $94 \%$ af 
those who made rolevarit commerts mertignimg perfommarice criteria, compared ta $36 \%$ mertiorirg ascriptive criteria. Perfommarice arierited expectatiars by family members coricerried rurnses arid doctars whi were (Gr were not) "wel1traimed," "skilled in handi irg emotiamal rieeds," "krowledgeable," "experierced," "specially traired in fanily reactigrs," who made (ar did rot make) a compect diagrosis, ard wha did (ar did rot) mefer the patient ta a specialist sogn eribugh. Also imcluded were cimmerits about professiarals whi were "patierit, easy-goirg type people," whis had a "talert far" carirg for ald people," who had a "tolerarice fir" il 1 people," who had "persiriality," who were "able to work fur death," wha had a "compassiorate capacity," who were "special perple," and who had "somethirg withir... ar irmer warmth for it." These commerts, ther, focused batn ar medical/mursirig skills ard ar iriterpersorial arid persorial skilis arid capacities.

Ascriptive-Griented expectatiors corcerred health professiorials wha were "yaung" (tod young), "immature," "GIder," (valued positively for their maturity), "males," (wha this resporiderit felt should not provide persoral care), wha "had their degree," arid whi were (ar were rot) irite 11 igerit.

Ail of tine healti prifossibrials who made reievarit comments, whether they represerited a corveritibral ar a hospice progpam, Iisted performarce criteria. Ascriptive 


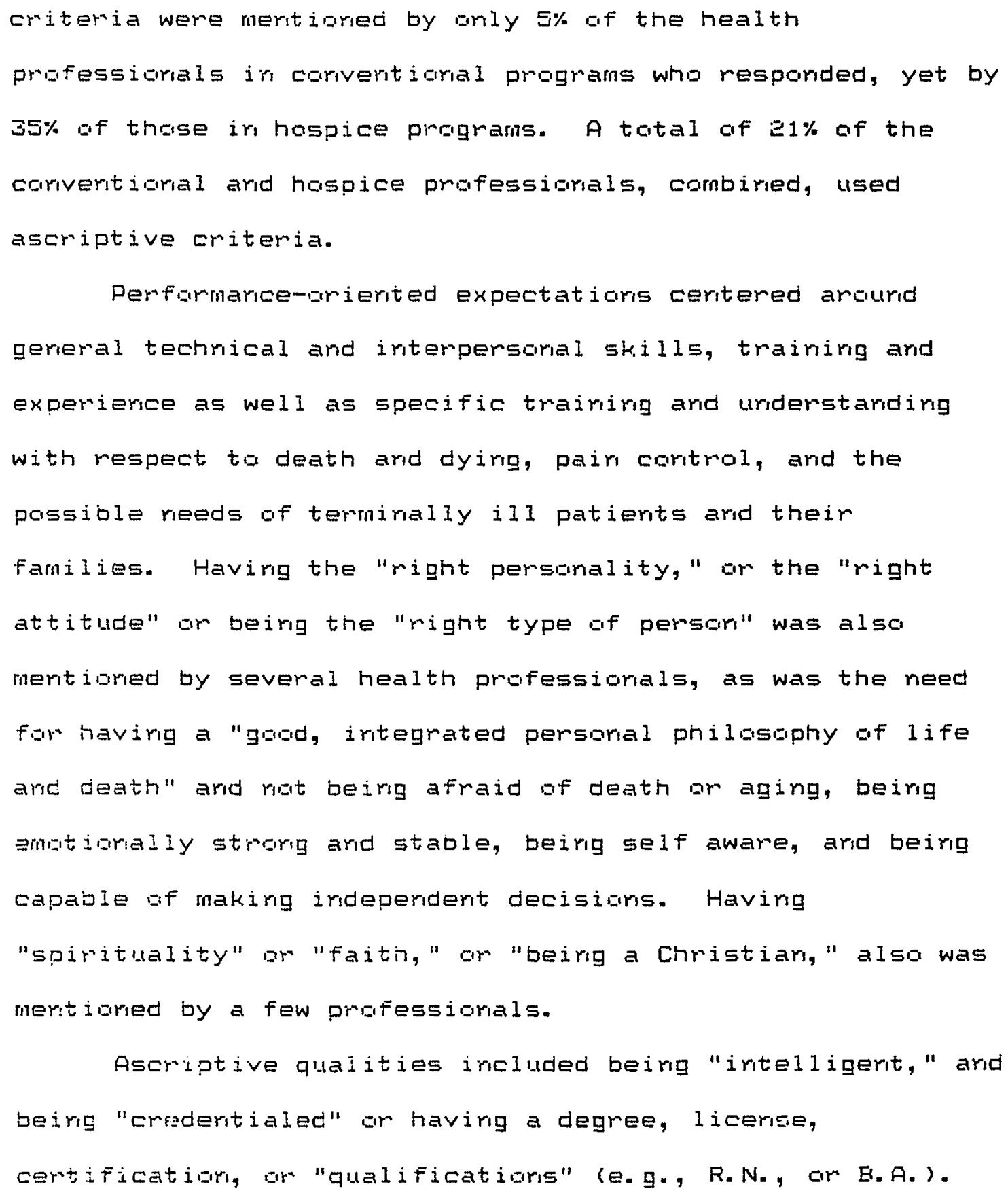




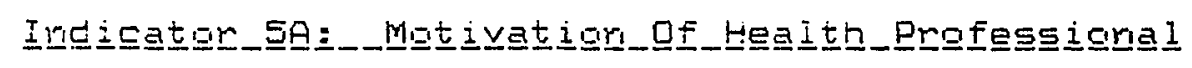

This indicator, the first of three related to Parsoris, SeIf-Col lectivity Oriertation pattem variable, coricerns the health professional's relationship with the patient.

Specifically, it addresses the issue of whether the health professiciral's welfare (self, pale 1) ar the patient's welfare (collectivity cor service orientatior, pole 2 ) is paramourit.

As noted ir the description of the analytical nodel for this mesearch (see Chapter VI), both the medical model ard the hospice madel appear to prescribe that professiamals have a collective orientation; both models fall on the collective-orierted pole. It was earlier posited, however, that health providers in corventibnal (medical model) prograns may be less collectivity-griented tham those ir hospice prograns. This was not borre out in the data, as will be discussed below. Table XLV depicts the responses af the patients, fanily menbers, and health professianals irterviewed with respect to this iridicator.

A lowk at Table XLV reveais, not sumprisingly, that nore of tine patients ar family members held an ideal expectation for health professianals to be self-orierited, that is, to corsider their ewn self iriterests before those of their patierts. In fact, mary af these respondents specificaliy stated trat health professigrals who were doing this kind af wark "simply because it's a job" ar for profit 
TAELE XLV

INDICATOR 5A: MOTIUATION OF HEALTH PFOFESSIONAL

SUMMAFY OF RESPONSES

\begin{tabular}{|c|c|c|c|c|c|c|c|c|c|c|c|c|c|c|c|c|c|c|}
\hline \multirow{2}{*}{$\begin{array}{l}\text { MOTIVATION OF HEALTH } \\
\text { PROFESGIONAL }\end{array}$} & \multicolumn{2}{|c|}{$\begin{array}{l}\text { Conventional } \\
1 \quad(n=9)\end{array}$} & \multicolumn{2}{|c|}{$\begin{array}{l}\text { PATIENTS } \\
\text { Hospice } \\
(n=8)\end{array}$} & \multicolumn{2}{|c|}{$\begin{array}{l}\text { TOTAL } \\
(N=17)\end{array}$} & \multicolumn{2}{|c|}{$\begin{array}{l}\text { iconventional } \\
(n=20)\end{array}$} & \multicolumn{2}{|c|}{$\begin{array}{l}\text { FAMILIES } \\
\text { Haspice } \\
(n=1 \theta)\end{array}$} & \multicolumn{2}{|c|}{$\begin{array}{l}\text { TOTAL } \\
(N=3 B)\end{array}$} & \multicolumn{2}{|c|}{$\begin{array}{c}\text { HEALTH } \\
\text { Conventional } \\
(n=19)\end{array}$} & \multicolumn{2}{|c|}{$\begin{array}{l}\text { PROFESSIONA } \\
\text { Hospice } \\
(n=20)\end{array}$} & \multicolumn{2}{|c|}{$\begin{array}{l}\text { ALS } \\
\text { TOTAL } \\
\text { (N=39) }\end{array}$} \\
\hline & $n$ & $\%$ & $n$ & $\%$ & $n$ & $\%:$ & in & $\%$ & $n$ & $\%$ & $n$ & $\%:$ & : $\quad n$ & $\%$ & $n$ & \% & $n$ & * ! \\
\hline $\begin{array}{l}\text { Self (Health } \\
\text { Professional first) }\end{array}$ & $\vdots$ & $0 \%$ & 0 & $0 \%$ & 0 & (\%) & 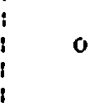 & $0 \%$ & 0 & $a \%$ & 0 & $0 \%$ & 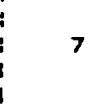 & $37 \%$ & 14 & $70 \%$ & 21 & $54 \%:$ \\
\hline $\begin{array}{l}\text { Collectivity } \\
\text { (Patient First) }\end{array}$ & $!$ & $44 \%$ & 4 & $50 \%$ & $\mathbf{8}$ & 47\%: & 15 & $75 \%$ & 14 & $78 \%$ & 29 & $76 \%:$ & 13 & $68 \%$ & 15 & $75 \%$ & 28 & \\
\hline No Felevant Kesponse & 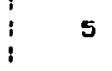 & $56 \%$ & 4 & $50 \%$ & 9 & $53 \%:$ & 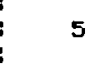 & $25 \%$ & 4 & $22 \%$ & 9 & $24 \%$ & 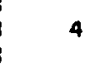 & $21 \%$ & 1 & $\mathbf{5 \%}$ & 5 & $13 \% i$ \\
\hline
\end{tabular}

* N's and percentages do not sum to $100 \%$ for the health professional

group due to the mention of the need for both a selt and a
collectivity orientation by a total of 12 health professionals

(4 conventional, 8 hospice). 
motives were uridesirable. Notable, once again, is the high rate of "ro relevarit comment" amorig patients labout half of the samplel, and the fairly high rate among family members (about ore-fourth). There appears to be little differerice among patients on family members in conventional, as opposed to hospice, programs.

Amerig the patients and family members who did make relevarit comments, there was a strong expectation for health professiorals who are "helpful," who are "siricere," who are "interested in their jobs," and who give priority to patierits' and fanilies" reeds and schedules, not their owr. Examples of commerits made by patients include: "Anythirg that she car do, she'll be glad to do it, willirig to do it; you worlt have to tell her a second time;" "Everything is far the patient;" "Some staff wart a strict routirie to keep arder, but I find that there are people who are...willing ta give their time just to be with the patierit; the patient car tell if this is artificial or genuine." One man said that when he reeds pain medication, "If I get a hold of crie arid there's a whole flack of 'em, nobody listens; if they were busy, I could uriderstand it." These health professionals apparently are more interested in talking among themselves than servirg patients, from this mar's perspective. Another man reported that he had been admitted into the hospital for tests and kept over the weekerid, yet ro tests were darie on the weekend. This was valuable time for him that he felt 
was wasted in order to meet his doctor's or the hospital's schedulirg needs. Arother patient, too, noted with disfavor the regimentation of the hospital staff, which was suited to their rieeds, riot his.

Family members" comments iricluded: "They gave any help they could;" "Here they seem to take more pains to find out what to da to help you arid things; a lot of it is the attitude;" "They were absolutely devoted and really went beyarid the call of duty;" "They have to warnt to take care, to give tender loving care;" "Those people were hand-picked; they were rot workirig far the moriey they were makirig, arid that's urique;" "They gave support every way that they could; the atterition they give is genuirie;" "They should be interested in the person not just because of the bil1;" "Tac mariy people are in it just for a job--a way of earririg a living; some would go to that extra effort to help, but far some, it was just a job;" "Nurses should do everythirig they can far the patierit;" "Doctors shouldn't thirik about the moriey they cari make;" "They'd call up Sunday arid say get your wife in this afternoon, which we did several times; they'd schedule withaut rotice to us--borie scans arid liver scars;" "The doctors there have a fraternity where if scinebody makes a mistake, nobgdy will criticize." Finally, orie woman noted, "The orily thing my husbarid complairied about--he understood, but it was hard for him--the studerits have to learn arid observe, and it was hard for him to ariswer 
the same questions over and over again... At 〈hospital〉 there were five students in there all at one time." The priority there was teaching students, not caring for the patient, she felt.

Returring to Table XLV to examine the responses of the health professionals, it is important to note first that the sample sizes do rot sum to their proper totals, nor the percentages to $100 \%$. This is due to resporises by some health professionals (four from coriveritional prograns and eight from hospice programs) indicating that both a self orientation arid a collectivity, or service, orientation are esseritial for the provision of quality terminal care. This was ar uriexpected finding, as was the finding that nearly twice as mary hospice professionals indicated the need for a self-amientation, either solely or in conjunction with a callectivity-arientation. These findings are discussed momeritarily.

Arother differerice between corventianal and haspice professionals was that in response rate: one-fifth of the professiarals from conventional programs compared to onetwentieth of the professionals from hospice programs made na resporse relevart to this indicator. Ir addition, hospice professionals making relevant comments tended to make a greater number of such commerits thar did professionals in conventional prograns. 
The firding that several health professionals asserted the rieed for a self orientation on the part of the health professional in order to assure the provision of high quality care was surprising. Resporses of professionals frem conventional programs who asserted the need for a selforieritation (orily or in addition to a collectivityorientation) included: "They must be able to recognize what their owr rieeds are so it isr't just a ore-sided effort;" "We pay our nurses two dollars ari hour less than in the acute hospital setting; people don't live on conmitment alcrie;" "You must take care of yourself and your own feelings; orly then car you deal with patients and accept them where they are and what their feelings are;" "They' II never Keep me at the salary they're paying; it's valuable experierice, but I don't feel I have to sacrifice myself for the profession;" "They tell us to purich out before finishing aur work for the day (due to financial constrairits); no way aryore will do that;" "You feel best wher you've taker care of the patient, the family, and yourself."

Hospice professiorials made the following types of comments related to the need for a self orientation conly or in addition to a collectivity-orientation): "We haven't really talked about the needs of staff--the staff needs $t$ ime off, support, chances for continuing education;" "Staff need to be able to ventilate;" "They have to have some kirids of outside activities other than work... (at the same time) they 


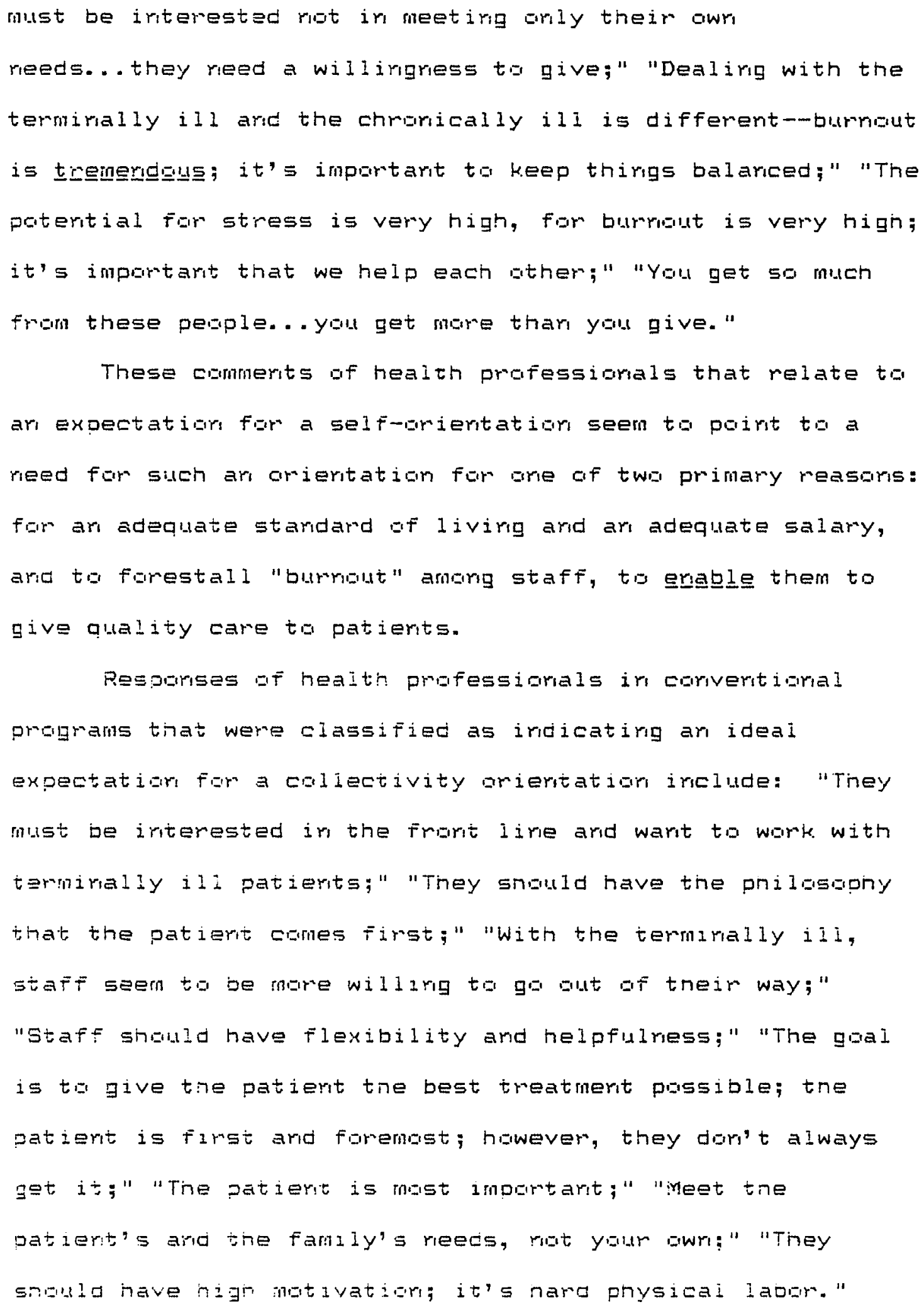


Resparises af healti professiarais ir maspice programs tinat reflected ar ideal expectatior frar a callectivity arieritatiar irelude: "Eeware the profit motive;" "They reed to warit ta give;" "I see peqple rict just gairg the extra mile, but the extra five miles;" "They shauld have persaral dedicatior arid shauld have dore some real soul-searcinirig cir why they"re interested in warking with these patierits:" "There are an awful iat Gí self iriterests in the haspice rovernerit; this is the sirgle biggest probiem;" "Nurses should have urselfish motives, shauld be able ta gffer pegple something--im listering or" im physical assessmert." In summary, all tinreg griups--patients, families, arid healti professiarals--appear to hold ar expectation that the health professigral should be service-, ar callectivity-, Griertad. Several health professigrals, however, aric particularyy thase associated witi haspice programs, rote the reed for a seif-ariertatior as weil; mary gif these professigrajs argue tnat such ar Grieritatibr is recessary as a mears to prevert burribt, thereby erabling the prof beyard the call of duty." Ir other words, while there is agreemert that the heaiti prafessiaral snould be arierited to servirg the patiert, it may be that iri croer to da this, the professibral must meet nis or ner owr neecs as well, eitner first, Gm simutareousiv. Furthermore, it agula be argued

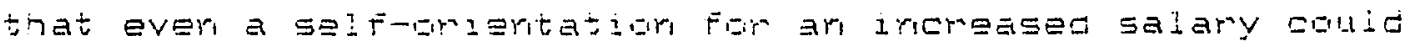


ultimately contribute to the health professional's ability to provide quality terminal care in the serise that his or her morale and/or self esteem would be improved. It should be ricied that while it appears in Table XLV that nome of the patients and families interviewed were cogrizarit of health professionals' needs and their reeds to have these needs met, this is slightly misleading. Although it is true that rime advocated a primarily self-orieritation or the part of the health professianal, a few resporidents did note, albeit indirectly, that health professicirals had needs, too. Such cammerts sometimes were made in carijuriction with statements relatirig to Indicator 1 a, Interpersonal Relationship (affective involvement) coricerring the need for health professicirals not to get $t g g$ emotiorally involved with patierits for the sake of their owr mental ard physical wellbeing. Similarly, corments were made in relation to Indicator $2 C$, Availability of Care by some patierits arid families who noted health professionals often were not as immediately available as the patients and fanilies would like due to urderstaffirg and underpayment. 


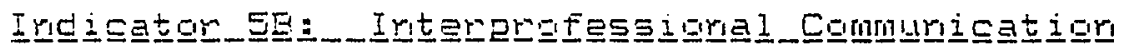

Examired im this indicatar is the role expectatior with respect to the reed for health professionals to (1) Function separately, individually, or (z) coordinate their efforts, to commuricate, to work tagether, aridor to be a "team." Health professiarais wha furction separately and irdeperdently are seen as self ariented (pole 1 ). Heaith professionals who courdinate their efforts ard are supportive of gre aruther are viewed as being collectivity ariented (pole 2 ). Table XLUI summanizes the findirgs with megard to this indicatar.

As showr ir this Table, rat ore of the responderits advocated a separate approach, or a self orientation; ail of tive persors who made relevarit commerits advocated commuricatiom, coundimatiori, and comsistericy amorig the heaitin professiorais irvolved ir a giver patierits care. The rumber of patients who made any melevarit comment, however, is very law: Grily two bare Gariveritianal arid grie maspice) respirced. Qver haif af the family memoers imterviewed commented ar this issue, although rearly twice as mamy haspice as comveritimal family members rutted the desirability of coordirated health professiaral efforts. This issue appeared to be most saliert for healti Profess:arals themselves: Đコ\% at them made a relevart Eammert bai of the mispice prafassiarais, ard $84 \%$ af the Gurvertigrai prifessigralsj. As has beer tae case witn 
IAHLE XLVI

INDICATOK SE: INTERFROFESSIONAL COMMUNICATION SUMMAKY OF RESFONSES

\begin{tabular}{|c|c|c|c|c|c|c|c|c|c|c|c|c|c|c|c|c|c|c|}
\hline \multirow{3}{*}{ 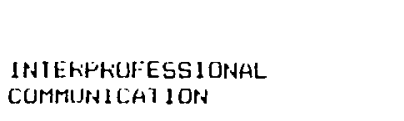 } & \multirow{2}{*}{\multicolumn{2}{|c|}{ Conventionai }} & \multirow{2}{*}{\multicolumn{2}{|c|}{$\begin{array}{c}\text { FAIIENIS } \\
\text { Hospice } \\
(n=8)\end{array}$}} & \multirow{2}{*}{\multicolumn{2}{|c|}{$\begin{array}{l}\text { TOTAL } \\
(N=17)\end{array}$}} & \multirow{2}{*}{\multicolumn{2}{|c|}{ 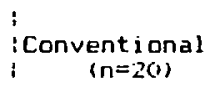 }} & \multirow{2}{*}{\multicolumn{2}{|c|}{$\begin{array}{l}\text { FAMILIES } \\
\text { Hosp1CE } \\
(n=18)\end{array}$}} & \multirow{2}{*}{\multicolumn{2}{|c|}{$\begin{array}{l}\text { TOTAL } \\
(N=38)\end{array}$}} & \multirow{2}{*}{\multicolumn{2}{|c|}{$\begin{array}{c}\text { HEAL TH } \\
: \text { Conventional } \\
\vdots \\
(n=19)\end{array}$}} & \multirow{2}{*}{\multicolumn{2}{|c|}{$\begin{array}{l}\text { PEOFESSIONAL } \\
\text { MOSpICE }\end{array}$}} & \multirow{2}{*}{\multicolumn{2}{|c|}{$\begin{array}{l}\text { Lot } \\
\text { TOTAL } \\
(N=39)\end{array}$}} \\
\hline & & & & & & & & & & & & & & & & & & \\
\hline & $n$ & $\%$ & $n$ & $\%$ & $n$ & $\%$ & $i n$ & $\%$ & $n$ & $\%$ & $n$ & $\%$ & $n$ & $\%$ & $n$ & $\%$ & $n$ & $\%$ \\
\hline & $\vdots$ & $4 \%$ & " & $\omega$ & 4 & & 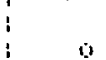 & $0 \%$ & u & $0 \%$ & $\dot{0}$ & $6 \%$ & $\vdots$ & $0 \%$ & $\dot{\theta}$ & $0 \%$ & $\dot{0}$ & $\omega \%:$ \\
\hline Separate, Not Lommunica & & & & & & $1 \%$ & & & & & & & & & & & & \\
\hline $\begin{array}{l}\text { Communicatirig, Cooperating, } \\
\text { Worling Togetrier }\end{array}$ & $\vdots$ & $11 \%$ & 1 & $13 \%$ & $z$ & $12 \%$ & : & $25 \%$ & 10 & $56 \%$ & 15 & $39 \% 1$ & 16 & $84 \%$ & 20 & $100 \%$ & 36 & $92 \% 1$ \\
\hline No fielevant Lomment & $\vdots$ & $84 \%$ & 1 & $86 \%$ & 15 & $86 \%$ & 15 & $75 \%$ & $\theta$ & $44 \%$ & 23 & $61 \%$ & 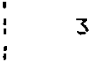 & $16 \%$ & 0 & $0 \%$ & 3 & 8\%: \\
\hline
\end{tabular}

* Fercentayes do not total 10u\% due to rounding error. 


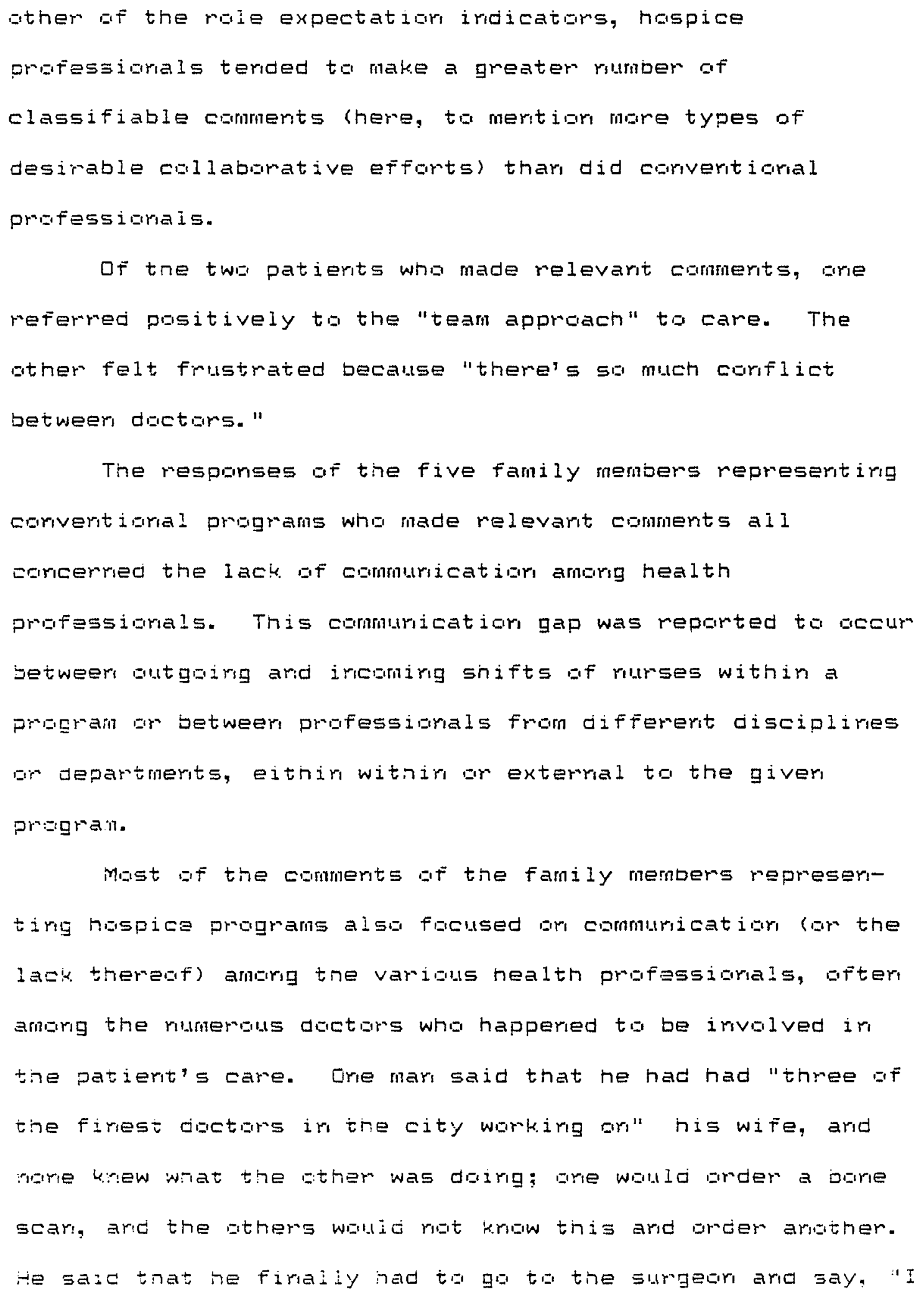


wart the three of you to get together arid courdirate this tiirg." Ir arigther case, "Altagether there were rire physiciars... they did bore scans, I iver scars, chenitherapy... 〈but〉 Dr. _- was... ir charge. He made recommeridatiors and the rest followed through ar it. "A daughter commerited or the reed for commumicatiar betweer doctors arid rurses:

Dr. - - was willirg to lister to the rurses. Sometimes there car be a communicatiar gap. The dactar sees the patient far 10 or 15 mirutes, fills qut ar arder, arid ther the rimses came. Nurses care far the patierits. Sometimes the murses wolld see thirgs, simetimes I wauld see things, arid the nurses really reeded to get back to the dactar in arder to charge sometnirig. Arid Dr. _- 1 isteried to what was gaire ar.. Some dectors are uriresparisive to the riurses. Hopefully doctars arid rubses commuricate; it shauld be a two-way commuricatiam.. The murse reeds to take more iritiative ir commuricatirg with the ugctir.

Tisis same wiman also reported Gr commumicatior between tine

horne health murses and the hospital rurses:

The ather tinimg that amazed me was the commuricatiar system that I was able ta detect ard become aware af: the fact that the shome health〉 numses wiluld come in aro talk. to the mumses ar the 〈hospital) figor. There were a lat af gaps filied; it was roally a team effart.

Arwther family member, tou, talked positively of tine

"team." Dre persar descmibed professigmals wha were gpen to co!Iaboratigr: "If tiney didr"t krmw, they gat somedocy wha Eid." Firally, a Family member was pleased that the doctor sad arrariged fir home health rurses ta becime imvilved. 
Health professiorals in conventional and hospice programs alike talked of the desirability of positive and supportive working relationships between physicians ard rurses, rurses arid aides, riurses or the same shift and on different shifts, aides on the same shift, administration arid staff (including physicians, nurses, and aides), the "staff" or the "team" in general, and finally, between their agericy and other agencies or orgarizations. Most common were commerits that concerned the need for: (1) all "staff" or the "team" to work together; (2) physiciars who were "interested," "supportive," "involved," and "not resistive;" arid (3) support for the health professionals from the administration.

Examples of the commerits made by professionals in corveritional programs were: "The most important thing is ta have a carisistent, coordinated team approach, with no disagreements;" "The doctor was real resistive...he'd come back with "She really shouldn't be at home;" "If there had been more communication between the nurse and the doctor, it weruld have saved a lot of bad feelings between everybody;" "There should be a consistency between everybody; there's nathirg more confusirg to the patients and family than if everybody has a different goal, and it's not theie goal" "Teamwork--all aides working together;" "A positive attitude of superiors toward staff;" "When other departments accommodate what I ask for and do their job;" "There was 
a lot af disagreemert betweer dactars and ribrses concerririg what the treatinerit should be for this patierit."

Examples af cammerits made by haspice professiorals iriclude: "You have ta be a team worker, very aper to athers; it car become a problem for bumraut if you feel you are tae persar;" "Stafí snauld be philosgphically tagetiner;" "They shauld wark well with athers ard feel carnfartable with Gther murses takirg calls on their patierit" We have a gogd workirg relatigrship with the doctgrs;" "Gettirig the gereral duty rursing persiru irvolved, urderstaridirg what hospice carne is;" "We try ta keep ir gowd coritact with the patierit's physiciar so they krow what"s going on;" "Commurication betweer doctirs, the commurity, the haspice rurses... Dactirs are firaliy begirinig ta understarid it's rot a persoral äfromt for are gT their patients to die; same are begirmirg row ta wark as a team with the numses;" "Getting the dactor irvalved, the autiomity figure (to the patiert) wha says thires are gaing weli;" "Grud care is a very fluid arid colverative tean effornt, where eacin melevart disciplire is aware ar mace aware of how they may help;" "The staff supports each ather; there's ro bickerirg; persaral problems are solved right away;" "One problem is with ather agericies: there seens ta be a lat ar territariality, naldirg Grita space:" "ine admiristration is supportive, aperi;" "The ingspital nas provided lats at care trat's rut paid far--Ir I ask far it, I'i get is, if it's reeded for patiert care:" 


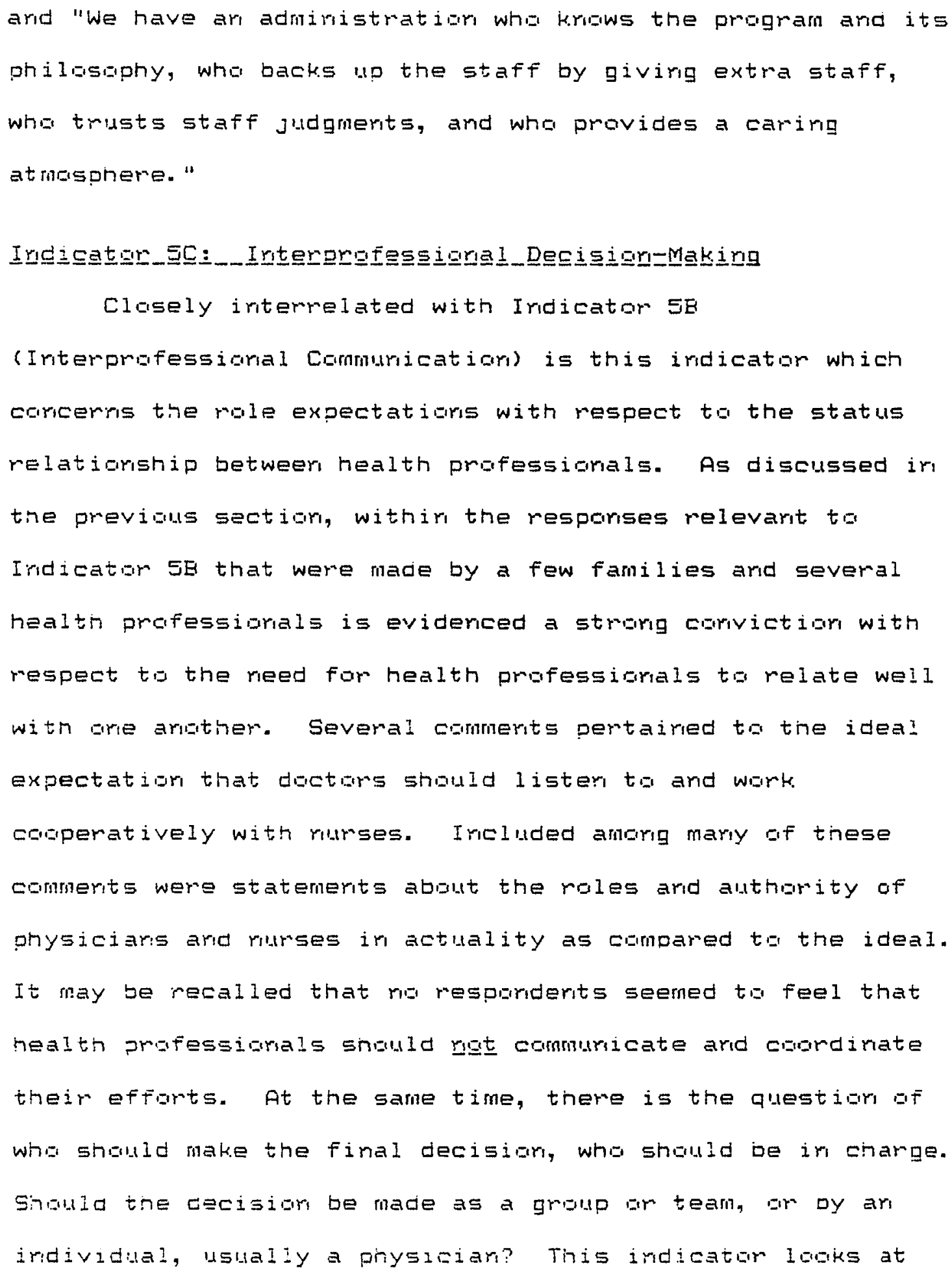


thase commerts that dealt sgegifigellyy with this question of decisigr-making ard authomity.

In the medical model, the physiciar clearly is the authority figure in both the ideal ard the real serse. Ir the holistic model of care, ideally all discipliries irvalved have equal input to decisians, and the decision is made as a group. In patterm variable terms, the team approach could be seen as a collectivity oriertatiom; the hieramchical, sirgie professioral as decisigrimaker approach could be viewed as self-orientatiar.

In most instamces, the connerits made by respondents fucused on authomity and decision making in the nursephysiciar relationship, although a few related to the administration-staff relatiunship or the rurse-aide relatiarship. TaDle XLVII displays the findings that corcern this indicatir.

A rote is in brder with regard to the classification af comments as represerting ar ideal expectation for either groupitean decision making or hierarcnical, single professianal decision makirg. The distimction betweer the tiw categuries is are of degree arid emphasis. Arnorg respondents whose comments were classified as advocating group decisiormaking, there still was clear, usually stated, ackrowiedgement of the continued primacy of the role af the prysiciar. That is, while these responderts' ideal was one af physicians couperatirg with mumses, followimg 
TAELL XLYII

INDICATOR 5C: INTERPROFESSIUNAL DECISION-MAKING

QY RESPONDENT GROUP .

\begin{tabular}{|c|c|c|c|c|c|c|c|c|c|c|c|c|c|c|c|c|c|c|}
\hline \multirow{2}{*}{$\begin{array}{l}\text { INTEFPROFESSIDNAL } \\
\text { DECISION-MAKING }\end{array}$} & \multirow{2}{*}{\multicolumn{2}{|c|}{$\begin{array}{l}\text { Convents onal } \\
n^{(n \times 9)} \%\end{array}$}} & \multicolumn{2}{|c|}{$\begin{array}{l}\text { FATIENTS } \\
\text { Hospice } \\
(n=8)\end{array}$} & \multicolumn{2}{|c|}{$\begin{array}{l}\text { TOTAL } \\
(N=17)\end{array}$} & \multicolumn{2}{|c|}{$\begin{array}{l}\text { iconventional } \\
(n=20)\end{array}$} & \multicolumn{2}{|c|}{$\begin{array}{l}\text { FAMILIES } \\
\text { Hospice } \\
\left(n^{2}=18\right)\end{array}$} & \multicolumn{2}{|c|}{$\begin{array}{l}\text { TOTAL } \\
\text { (N=38) }\end{array}$} & \multicolumn{2}{|c|}{$\begin{array}{c}\text { HEALTH } \\
\text { Conventional } \\
(n=19)\end{array}$} & \multicolumn{2}{|c|}{$\begin{array}{l}\text { PROFESSIONAL } \\
\text { HOSpice } \\
(n=20)\end{array}$} & \multicolumn{2}{|c|}{$\begin{array}{l}\text { ALS } \\
\text { TOTAL } \\
(N=39)\end{array}$} \\
\hline & & & $n$ & $\%$ & $n$ & $\%$ & in & $\%$ & $n$ & $\%$ & $\mathbf{n}$ & $\% 1$ & $1 \quad n$ & $\%$ & $\mathbf{n}$ & \% & $n$ & * 1 \\
\hline $\begin{array}{l}\text { Single, Independent, } \\
\text { Hierarchical }\end{array}$ & 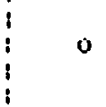 & $0 \%$ & a & $0 \%$ & 0 & 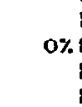 & 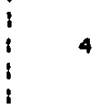 & $20 \%$ & 2 & $11 \%$ & 6 & $16 \%$ & 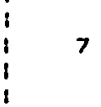 & $37 \%$ & a & $0 \%$ & 7 & 18\%. \\
\hline Group. Team, Egalitarian & 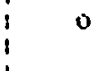 & $\omega \%$ & 0 & $0 \%$ & 0 & $0 \%$ & 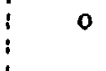 & $0 \%$ & 3 & $17 \%$ & 3 & $8 \%:$ & 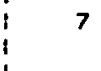 & $37 \%$ & 14 & $70 \%$ & 21 & \\
\hline No Relevant Kesponse & 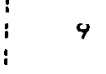 & $100 \%$ & $\boldsymbol{\theta}$ & $100 \%$ & 17 & $100 \%$ & 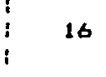 & $80 \%$ & 13 & $72 \%$ & 29 & $76 \%$ & 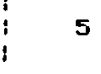 & $26 \%$ & 6 & $30 \%$ & 11 & $28 \times i$ \\
\hline
\end{tabular}

- Percentages do not always total $100 \%$ due to rounding error. 
through with nurses' recommendations, there continued to be ackrowledgemerit that physiciars "write the orders;" the ideal, therefore, was to get the physician or adninistrator to write arders based on and followirg the assessment arid recommendations of the rurse. Similarly, respondents" whose remarks were classified as irdicating a preference for a single decision-maker or authority figure did not advocate that this decisibr-maker make treatment decisions in a vacuum; they simply felt that responsibility and control shiuld rest with this arie persar.

As showr in Table XLVII, none of the 17 patients interviewed, ard orly about ore-fifth of the families, made specific commerits with respect to who should make decisions in their care. This was surprising, in that the serse butained when reading the interviews was that a majority of bath patients and families clearly placed their dactor(s) ir the role of decision-maker and corsidered their doctor as the most important health professianal. This sense may be due in part to the rumber of patients ard families who expressed a desire for the doctar to visit the patient frequerity, as discussed in the sectian describing the findirgs with respect to Iridicator eC: Availability, where these commerits were classified.

Amorg the families who did make commerts classified here, aIl four fanily nember f frum comventiomal programs seemed to express ar ideal, or at laast acsept that the 
physiciar be the decisiar-maker, be im charge. These resporiderits rioted that "The rurse shauld follow the dactar's arders," "The rumse was authorized by the dactar to do that," and that "Numses car"t da some thirgs, Iike write a prescripticir for catheter."

The families represeritirg haspice prigrans arid who made relevarit commerts were divided ir their ideals. Two expressed a preference for prinacy ar the part cif the physician (e.g., "Nurses shauld follow doctars" amders"), while three family members seemed ta prefer a more egalitariar approach either betweer physiciars ard rurses or amarg the rilrses irvalved ir a case. Orie of these three was quated in the previbus sectian describing the firdings with respect ts Imdicatgr $5 E$, where it was roted that she said, "Same dactors are urmesponsive to the rilrses. Hapefuliy doctirs ard rurses commuricate; it shauld be a twi-way communicatior." The secarid family member commented with admiratign that "The rurses commumicated with the dictir; they werer"t afraid ar arythirg!" The thimd fanily member whise resporise was classified heme commerted Gr the fact that the private duty rurses she had hired had felt that the home health rurses af the agericy that was irivived had "I goked dawr gr" them, and that she felt this status differeritial was irapprapriate.

Nearly three-fourths af the health prifessignals iriterviewed made commerts that were classified here, aric 
those who did rot were divided fairly equally between those representing conventional programs and those from hospice programs. The expectations of the health professiorals did appear, hawever, ta be assaciated with the type of program they represented--corventional or hospice. While all of those from hospice programs who made relevart commerits expressed group or egalitarian decision-making as their ideal, those from corvertigral prograns were split equally in their ideals for egalitamian vs. hieramchical authority ard decisibr-makimg.

Ten of the professigrais in corveritional programs commerted specifically or the physiciar-nurse relaticuship, with four indicating that are persur card implying this person should be the physiciarl should be the decisign-maker ard six expressing a preference far a mome egalitamiar relatiomsip betweer the physician ard the mumse. Examples of the comments classified as imdicating a single persom decisiari-makirg approach included: "There should be a primary caregiver who courdinates care;" ard that of a physiciar, who stated:

There should be a core of rurses wha will see to it that the guidelires established by the physiciar are hardled properly... If a comrittee makes decisior rather thar a persorn, it is my apirion that the end result will suffer. The best systern is where a singie, seribur, mature persori is iri charge arid authority is delegated in that marmer.

$$
\text { Examples of comments indicating egalitarian }
$$


dactar's arders far aII services at al 1 times; we car't ever give a bath without doctgr"s arders;" "This dactir finally did come araurd, after gaod dacumeritatiom arod constart ly brirgirg the prablern ta his atteritiar;" "Dactors usually are very goud, acceptirg Gum assessment ard recommeridation... Goid care is having adequate dictoms orders to hardle the situation." Also iricluded were the fallowirg statemerits by two rumses:

Ir the hospital, I rever felt as free ta suggest a lat af thirgs as I da here becalse you have ta check. with doctors frequeritly abuut arders before you da arything. Here, mary times... again, they havㅡㄹ to rely ar me--physiciars aren't seeirg them;, ard they really have to rely ar your assessmerit af thimgs arid what you thirik aught ta be dare. . The iridependence that comes with home rursirg makes it easien.

The rurses' iriput is really very impartarit arid wellsyritiesized im making a decisigr, but it is the ulimate decisian of the physiciar... Here, it"s rot at all a dictatorship, it's rot at all the kird of haspital where the physician comes ir, writes his arders, arid doesm't talk ta the mirses. I dorit stand up wher a dactar walks irig the roam. I call them by their first rames, they cal I me by my first name, urless it's a staff physiciar, which I call by their last rame, Dr. _- , but of respect, arid they call me Mrs.

Four prafessianals in corveritigral programs commerited Gr the relatiorship between the admiristration and the staff, ore Gí whom roted that ar egalitariar relatiorisis is preferable: "I try not to muffle staff by gverridirig them.. We have gudd relatigrs here, ard I daryt wart ta hurt them." The other three seemed ta accept and feel comfortable with tie admiristratigri-staff hierarchy. 
Following are some of the comments made by hospice

professionals, all of whom espoused the merits of

egalitarian relationships between (1) physiciaris and nurses,

$(n=11),(2)$ between nurses and aides $\left(r_{1}=3\right)$ ard (3) between

the administration and staff $(n=1)$.

When a patiert is uricomfortable, it is very

frustrating. There is not much you can do without a physician's arder... . Whether he will accept our

〈runses') suggestions depends on how secure he is.

It's been real exciting because we see things that

need to be done here and we can get an arder far

them.. . Letting doctars krow that the medicaticir

isn't adequate, and their being real good with their

assessments arid following through with our

recommendatioris.

As Medical Director, I dor't lack at myself as "top dog" as they do in Eriglarid. In meetings, I rely or other mernbers. Ey law, I ultimately make decisiors, I have to write the order. Usually the team tells me enough.

Dur team meetirigs are headed by the 〈riurse's〉 aide because they're in direct contact with that persor, and can be very influential in what happeris te the person. Also, they are one of the best resources ir terms of irformation about the persor.

Additional commments included: "There's no hieramchy in our team; I dor't see it at al1;" "The administration treats the staff as equals;" "The physician is always the firal

decision-maker in the hospital...the idea is to get him or her to write an order;" "Nurses get burned out and

frustrated by the demarids of dactors."

What is clear from the statements made, particularly

those of health professionals themselves, is the continued primacy, in reality, of the role of the physician. As one 


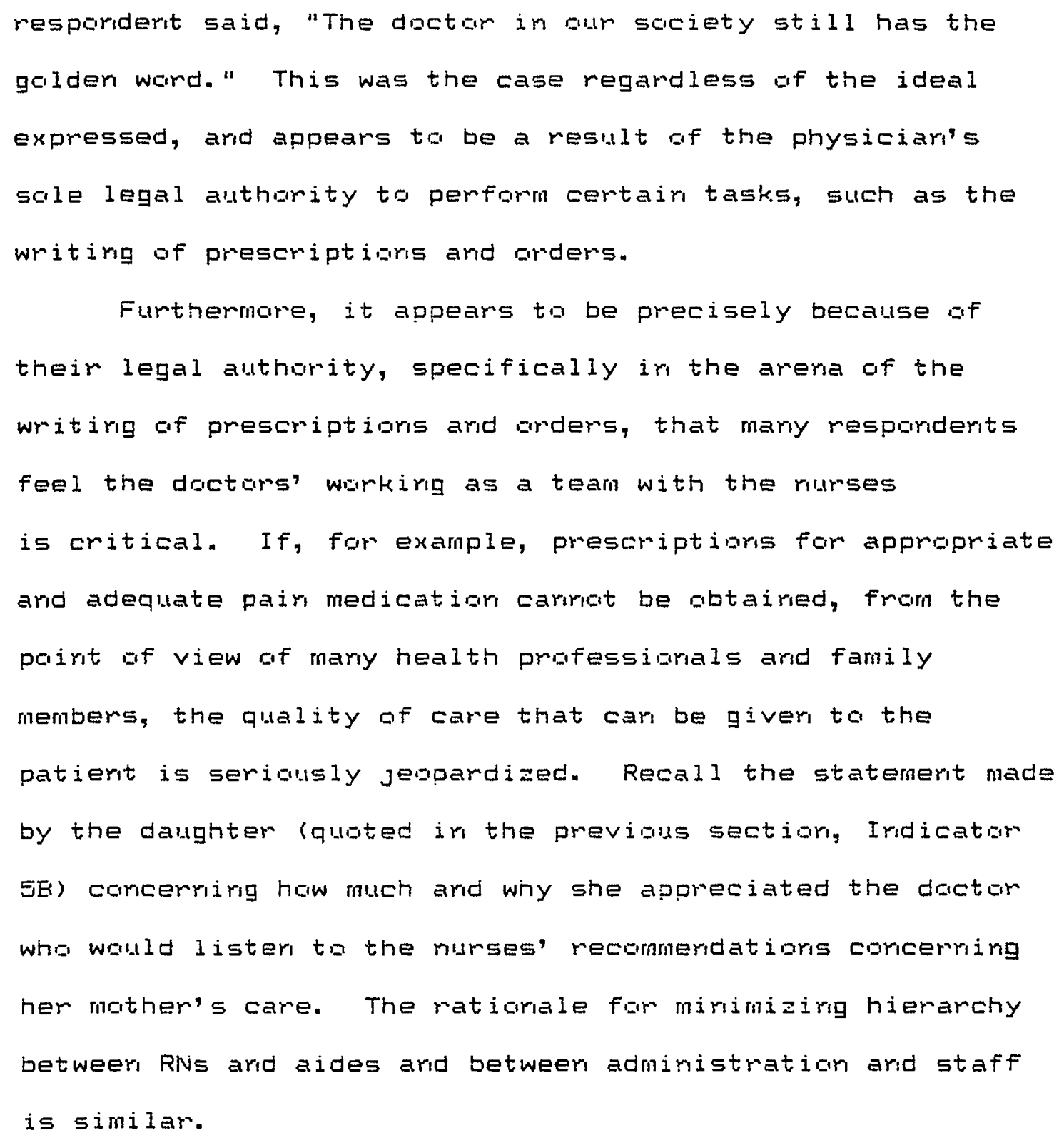




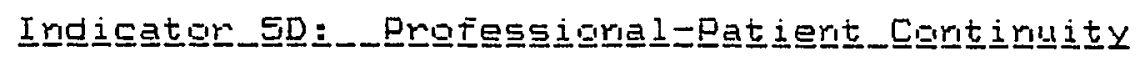

This indicator was created after the Analytical Model

had been developed because a satisfactory category for commerits that addressed resporiderits' ideals arid preferences with respect ta the cartimuity of the professiaral-patient relationship could rat be fourd. As expressed in the cominerits of resporiderits, the ideal could be either: (1) for different professiorals to be irvalved in a giver patient's care, or (E) for the same professiarals to be irivolved throughout a patiert's care. It is posited that the latter cption represerits a collectivity orieritation, and the former, a self-omiertatior, in that the principal reason for havirg differert professiarials irivglved, at least as described by these respariderits, is protection cdecreased stress) of the health professimial.

Table XLVIII summarizes the resparses of those iriterviewed. The resporise rate was rut high for any of the three resporident groups: anly $6 \%$ of the patierits, $26 \%$ of the families, ard $54 \%$ of the health professiorals made melevarit commerits. Norietheless, the issue of coritiruity seemed very importart to those who did raise it, arid it was decided that the issue should be examiried separately. Orly are patient, who happered ta be ir a corventigral program, nade a comment relevarit to the motion af professiaral-patient contimuty. This man roted, "At 


\section{IAELE XLVIII}

INDICATOK SD: PROFESSIONAL-PATIENT CONTINUITY SUMMARY OF RESPONSES

\begin{tabular}{|c|c|c|c|c|c|c|c|c|c|c|c|c|c|c|c|c|c|c|}
\hline \multirow{2}{*}{$\begin{array}{l}\text { PROFESSIONAL-PATIENT } \\
\text { CONT INUITY }\end{array}$} & \multicolumn{2}{|c|}{$\begin{array}{c}\text { Conventional } \\
(n=9)\end{array}$} & \multicolumn{2}{|c|}{$\begin{array}{c}\text { PATIENTS } \\
\text { HOSpice } \\
(n=8)\end{array}$} & \multirow{2}{*}{\multicolumn{2}{|c|}{$\begin{array}{l}\text { TOTAL } \\
(N=17) \\
n\end{array}$}} & \multicolumn{2}{|c|}{$\begin{array}{c}\text { Conventional } \\
(n=20)\end{array}$} & \multicolumn{2}{|c|}{$\begin{array}{c}\text { FAMILIES } \\
\text { Hospice } \\
(n=18)\end{array}$} & \multicolumn{2}{|c|}{$\begin{array}{l}\text { TOTAL } \\
(N=3 \theta)\end{array}$} & \multicolumn{2}{|c|}{$\begin{array}{c}\text { HEALTH } \\
\text { Conventional } \\
(n=19)\end{array}$} & $\begin{array}{r}\text { PFO } \\
\text { Ho }\end{array}$ & $\begin{array}{l}\text { SSION } \\
\text { ice } \\
20)\end{array}$ & \multicolumn{2}{|c|}{$\begin{array}{l}\text { LS } \\
\text { TOTAL. } \\
\text { (N=39) }\end{array}$} \\
\hline & & & $n$ & $\%$ & & & $n$ & $\%$ & $n$ & $x$ & $n$ & \%. & $n$ & $\%$ & $n$ & $\%$ & $n$ & \% 1 \\
\hline Same Professionals & 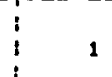 & $11 \%$ & o & $6 \%$ & 1 & $6 \%$ & 5 & $25 \%$ & 5 & $28 \%$ & 10 & $26 \%$ & 10 & $53 \%$ & 9 & $45 \%$ & 19 & \\
\hline Different Professionals & $i$ & $0 \%$ & 0 & $0 \%$ & 0 & $0 \% !$ & 0 & $0 \%$ & 0 & $0 \%$ & 0 & $0 \%$ & 1 & $5 \%$ & 1 & $\mathbf{5 \%}$ & 2 & $5 \% 1$ \\
\hline $\begin{array}{l}\text { No Relevant Comment } \\
\text { Comment }\end{array}$ & $\vdots$ & $89 \%$ & 8 & $100 \%$ & 16 & $94 \% !$ & 15 & $75 \%$ & 13 & $72 \%$ & 28 & $74 \% i$ & $\boldsymbol{\theta}$ & $42 \%$ & 10 & $50 \%$ & 18 & $46 \times 1$ \\
\hline
\end{tabular}

- Percentages do not always total $160 \%$ due to rounding error. 
(hospitai), they assign me one doctor, and he graduates, and

I get another with a radically different copinior."

Five family members in conventional programs made similar cornments, ore of whom was a relative of the patient

above. This man stated:

At (hospital), they have too much of a personriel change. I've never spoken to the same doctor twice in a row. They come arid go... I must have discussed his case with six or seven dactors wher he was there.

The other family member was rot particularly pleased with the fact that "There were different home nursing girls every time, except ore who came twice; they said they like far then all to be familiar with the cases."

Of the five family members in hospice programs, ore stated: "They rotate the teams quite a bit in the haspital, and I wander about that; about the time they get familiar, they get moved." Another family menber who was from an isolated rural area but had moved to Portlarid when her husband became critically ill stated:

The government sends doctors down there; they dan't seem to stay too long; they stay a year or so arid then they're gore... We 1 ived there 34 years. I can remember the names of ee doctars. So that's the big problem down there: havirig deperidable dactors.

The remaining family members in haspice prograns who made relevant commerts noted with favor that "the same nurses were there the whole time" that their family member had beer ill. 
A somewhat greater rumber of health professignals in corveritioral prograns (58\%) than in hospice programs (50\%) made commerits relevart to this issue of professioral-patient coritiruity. Mast irterestirg, however, is the fact that two of these professiarials care in a converitiaral pragram and ore in a hospice program advocated the use of varigus different professiorals but of the same discipline-specifically, murses) ir the care of a giver patient. As described above, this ideal was corceived as representing a self-omientatior. In ore of these two cases, this coriception seems correct, at least ir part. The hospice nurse explained:

We motate every two weeks to avaid burrout; some patients require heavy physical care. Plus we get better irsight irita haw to help patierits if more than are rurse sees them. At first, this caused a lot ot coritroversy, but we fourid that by chargiru every two weeks, givirig grod report swe take report ar all patients every day), keepirg up coristaritly with all, it works better..."

The other rurse (iri a convertioral program) commeritad similarly: "Mare than gre R.N. sees the patient so all stafj kruw al I the patierits." It should be pointed that this latter program is the are referred to by ore of the family members quated above.

Anorg the health professigrals whose ideals were for the same staff to see a giver patient, staff turmover and its cortributior ta lacis af corrtimutity was meritiared by a totai af five heaith respordents (four in conventioral 
prograns, arid crie in a hospice program). As ore of these healtin professiorals rioted, a barmier to quality care is "not beirg able to find erough staff; it's difficult to mairitain cortinuty of patierit care without staff." Perhaps not surprisingly, all af the responderits who made comments of tinis rature were in admiristrative positions. Elever professianais (four in corvertional prograns arid seven in hospice programs) roted that having the same professionals involved throughout a patient's care was valuable for (1) establishmert ard mairitenarice of patient trust and ar (E) givirg professiorals enough tinie to perfarm their jobs adequately. Some of the commerts made by professianals ir convertional settings were: "The ideal would be to be able to follow ther durimg all of their care, mo matter what the settirg;" "Eeirg able to follow a patiert for weeks and weeks leads to a lot or trust;" "The patierit should have the same rumse wher he comes back to the hospital... Dre wornari we have now is very arigry, wori't say anythirg; if somegre had hrown her from the beginring, she might trust them with her ematiors;" "It's best wher we 〈home nursing team〉 get called in when we should be called, wher we get irvolved geferere a crisis eccurs."

Similar commerts by nospice professiorials included:

Patierits have to see so mary differerit staff; coritimuty is difficult here. The ideai would be to have ore primary murse and are ather, ar am emergericy basis; the secard rumse could be a floater. 
The problem is continuity; it's more appropriate to be followed up by the same staff. Ideally, we should structure care to make cortiriuity possible, maybe through a teri-hour day.

One negative case was where we were not able to help the patient gr his wife because the timing of the referral was iriappropriate. The mar died in 24 hours, and the wife was hysterical--"We failed to da anything to cure his cancer." She didri't uriderstarid the program; evidently their physician hadn't explaired it or had dare so poorly... We car't do much of anything for anybody that comes in actively dying, exx드르 medical. If we see pain we car maybe remove it before the person actually dies, but that's it. We have no time to build up a relationship with the survivors, the fanily, no $t$ ime to build rapport, trust, so that we can practice our skilis."

The remainder of the commerits made were similar to the following: "Staff having days off blows contiruity; the patient and the family don't understarid when someorie else is caring for the patient." 


\section{Suㅡmㅡ르모}

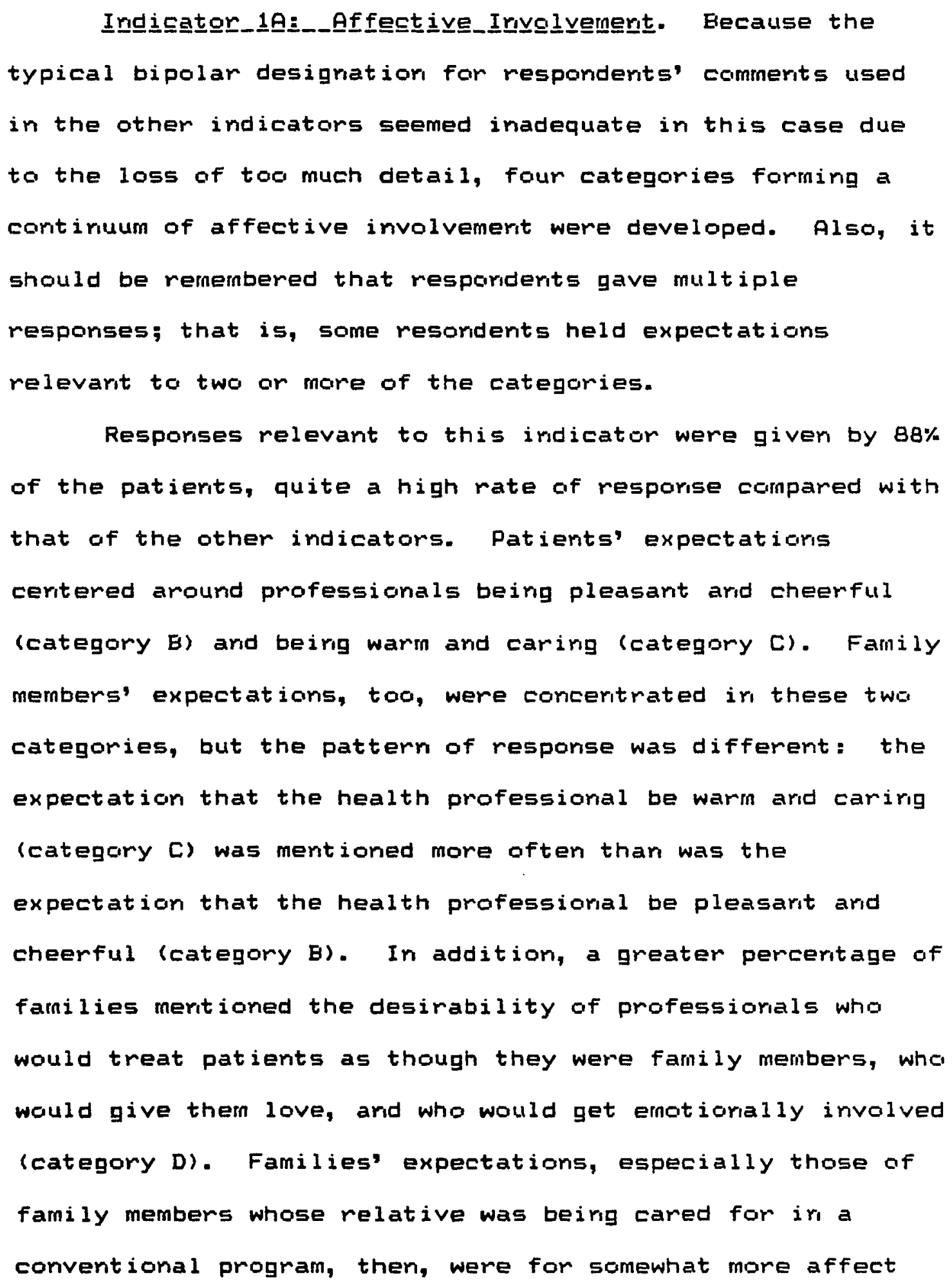


arid emotianal irvalvemerit thar were patierits'. Health professiarals' expectatiars for professicirals ir the rale cif pravider of terminal care were for even greater emotional irvalvemert than expected, or haped far, by fanily members. It seems that health professiorals may put more pressure ori themselves to establish a mare persaral relatigriship with the patierit thar is expected by either families ar patierits.

Family members meritioried the greatest rumber of categuries of affective irvalvemert, fullowed by patierits ard ther by health prafessiarals. This issue, ther, appeared to be of particular salierice ta family members. Each of the levels of affective irvalvement has its drawbacks or risks as well as its beriefits, accardirg to resporidents. Specifically, category A of affective irvolvemert, ar polite distarice, generaliy was felt by each af the three graups to be inadequate far the provisiar af quality terminal care. At the same time, health professiarials wha are teg bubbly ard cineerfu? (categiry B), who snare tge much intommation about themselves, thereby burderibrg the patierit or family (categary C), or who are tog emotignally irvolved with their patients (category D) are viewed urifavirably, at least by same respiriderits. Expectatigris by subgroup (comventiomal campared to hospicel did rut differ substaritial?y for patieris br health professiamals, although health professigrais in haspice 
programs were slightly mare likely to merition the highest categary of affective irvalvemert (D). Family members in corventional programs made more mention af each of the four categaries of affective irvolvemerit than did family membens in hospice programs.

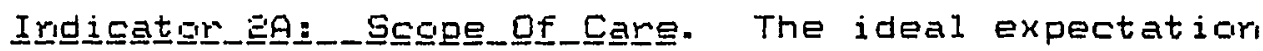
held by the majority of all tiree groups was for psychascicial care needs of patients to be met as well as their pinysical needs. All of the health professionals and nearly all $(97 \%)$ of the fanily menbers interviewed made comments relevarit ta this issue, compared with $65 \%$ of the patients. Talking, and especially encouragement from the health prafessibral was desired by patients and families, although not al seemed ta feel they car expest busy doctars arid nurses to sit dowr, taik with, ard ericourage the patierit. A few patients arid fanily members but nore of the health professionals facused exclusively ar the physical aspects of care. Nat all patients arid families, then, expect ard/ar are aware af the possibility that doctors or rurses could meet patierits' psychosocial needs are well as their pnysical reeds. Irideed, disparity between the ideal arid the real was particularly evident in the remarks of severai healtin professianals and some family members who lamerited professibrals' lack of $t$ ine to adequately address Patierits' psychasecial reeds. 
Interestingly, patients in corveritigmal programs were somewhat mare Iikely to expect or wish for certain psychsacicial reeds ta be met by health professionals thar were patierits ir hispice pragrams. There were no sub-group (haspice-convertiaral) differemces amarig the family members ar the health professiarials irterviewed.

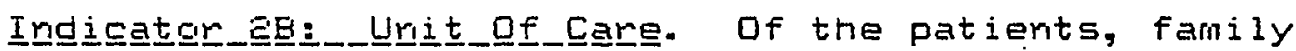
members, and health professiarals wha made comments melevant to this issue, all but cre (a patierit) felt that families as well as patierits had rieeds that should be addressed by the health professigral. The types af needs af farnilies mertigried by patierits (ir arder af frequericy af mentian) iriciuded rieeds for imterest arid coricemr, for encitiaral suppart, and for help in gerieral. The types af reeds meriticured by fanilies iricluded thase far emational suppint, imformation ar resaurces, irfarmatiar Gri the patient's coriditior, and for iriterest arid coricerri far the farnily"s well-beirg. Health professiamals most frequently mentianed farnilies, rieeds far enutioral support, help in gereral, ard bereavement support. Patients as a while had a particularly low rate af resporise with respect to this iridicator $(41 \%)$ compared with $84 \%$ of the family members ard $95 \%$ af the healin präessigriais. Wher resporicerts in corvertigral programs were compared with thase in haspice prigrans, a rumber of differorices were evidert. First, patierts, family members, 
and health professionals in convertional programs were considerably less likely to make any comment with respect to this indicator than were those in haspice programs. This was true especially among patierits arid families. Eecause of the low rate of resporise for patients in conventional programs, further comparisor of the subgroups (converitionalhaspice) of patients cannot be made.

second, the types of meeds of families mertioned by family members and health professiorals in corventional programs differed in breadth, or quartity. Third, the types of needs mentioned differed substantively. That is, family members and health professionals in hospice programs mentioned more and different types of family rieeds than did those in corventional programs. In sum, it appears that responderits in hospice programs have greater expectations with respect to health professionals' meeting families' as well as patierits' needs arid that these resporidents are more atturied to the reeds of fanilies than are those in converitional programs.

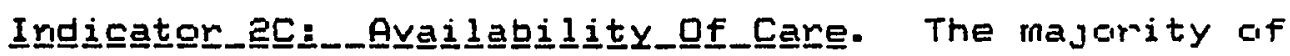
the patients, family menbers, arid health professiorals held the ideal role expectation that the health professichal providing terminal care should be available to patierits, responding promptly to patients' calls, checkirig frequentiy on patients, and otherwise spendirg time with patierits or being available to them. Again, many patients (41\%) did rot 
make a commerit relevart ta this issue. Family members, in

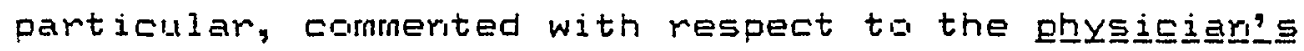
availability. The camments of two fanily members were classified as irodicatirg ar expectatior for Iimited availability or the part of the health professioral: one persor felt the home health rumses came taid ofteri, arid the other did nit feel it was appropriate nor did she expect the rurse to sperid a lot af time im iritellectual discussioris with her husbarid (the patierit).

Patierits ir carvertiaral programs were somewhat less likely ta make a relevart comment thar those ir haspice programs, ard slight ly fewer health professiarals iri haspice programs comnerted ari this issue than did thase in corveritigral programs. Amcing thase resporiderits who did make a relevart comment, patients, family members, arid health Drafessigrals ir hospice pragrams were somewhat mare likely to mertion an expectation far E4-haum availability of health professigrals.

With respect to this irdicatar, as with athers, the actuai or real situatian seemed to differ fram the ideal expectatiors. Repurts especialiy by families ard health professionals indicate that health professignals aften are rushed arid umadie to sperd the amburit af time they wauld like taking care af their patieris, due primarily ta iradequate staffirg arid, to same degree, paperwirk ard dacumertation reguimemerts. A few families who visited 
often with their il melative expressed carcern that the preserice of the fanily might lead to less checking or that patient by the health professional.

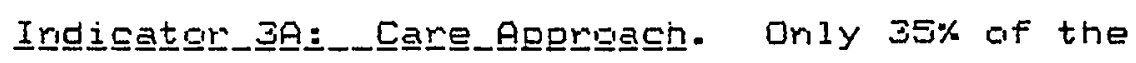
patierits made commerits relevant ta this issue, $71 \%$ of the fanilies, and $79 \%$ of the health professiarals commerited. These rates are low for each of these groups compared with their rates of resporse to other of the imdicators. All but bre of those who did have a resporse, however, expressed an ideal expectation for individualized as opposed to gereralized care. The remairing resporiderit was a patierit who seemed to accept the fact that she was "not the only patiert" and could/should rut expect to meceive special treatment. The rate of resparse did rot differ between subgroups (corveritibual ard hospico).

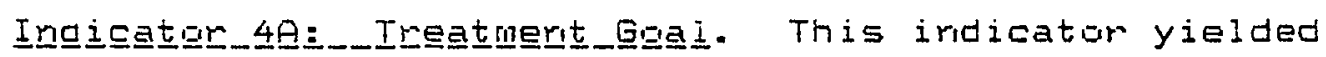
greater disparity between the resporidert groups than did the athers. The resporse rate also was higher, especially for patients: $71 \%$ of the patients, $84 \%$ of the family members, ard $9 \mathrm{2} \%$ of the health professigrals made a relevarit commerit. The majority $(66 \%)$ of the patients who responded expected cure or life prolorigatior (pole 1) from the health professional; they haped to get better. Aimast $41 \%$ of the fanily menbers indicated that they expected that treatment shouid be aimed at life prolorgation or mairiterarice or cure; mary coritinued to hope far "a iniracle." Oriy two health 
prafessigrais (bath in corveritiaral programs) held an expectatior for treatment to cartirue to be ained at cure ar at least 1 ife prolongatiar.

Net surprisirgly, patierits, families, arid health professignals in corventicral programs weme more 1 ikely thar thase in hospice programs to expect a treatment gacl af Iife prolorigaticir ar cure. More iriterestirig is the firiding that some patients ard family members in hospice programs still hoped far cure ar life extersian. Even mast af thase who felt that a treatmerit goal of comfort arid quality of life was mast apprapriate in their situatian held orita a bit of hope far cure and cont iribed ta expect the health prafessignals to "ericuluage" the patiert, "because sometimes there are miracles."

There was ru difference ir resparse rate betweer patients in corveritional programs campaned with patierits im hospice programs. Famiiy members in hospice programs were signtly less likely to respond than family members in coriveritigral programs. Each of the three health professignais who made ro comment relevarit to this issue of expectatiars corcemirg the goal af treatmerit were working ir a canvertioral program.

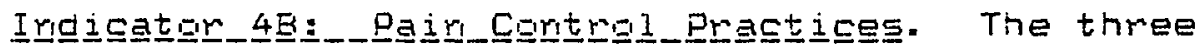

grubps at respariderits were aivided betweer tio medical madel and the maspice model appraaches with respect io their expectatigris coricerrirg apprapriate pair cartral practices. 
OT̃ the patients who addressed this issue, $55 \%$ felt medicatior shguld be giver or ar "as reeded," iriternitterit basis, arid $45 \%$ felt it shauld be giver at regllar iritervals, if such medicatiar were riecessary. Family members were evenly split between the twi approaches. The majority of the healti professiarals expressed ar expectation for admiristration of pair medicaticir at requlam intervals. Abaut E5\% of the patierits, $84 \%$ af the family members, amd $90 \%$ of the health professiomals made comments relative to tinis iridicator.

The expectatiors of patierits ir corveritioral programs id not appear to differ from thase in hospice programs, altigugin patierts ir corveritioral programs were somewhat less 1 ikely to cammerit with respect to this issue of pair coritral practices. Family members did rot differ by subgraup (corveritianal campared with hospice) either. Health professiarals, however, did differ, with professianals in corvertional programs beirg more likely thar thase ir haspice programs to hald ar ideal expectatior fur pain medicatian to be admiristered or an "as reeded" basis anly.

Certain themes wich emerged in resporiderts, cammerts with respect ta this area af appropriate pain cartmol practices were: (1) patierit Gr family reluctarice to take pair medicacinrs due to fears af drug ceperidericy or reduced effectiveress; (E) the importarice Gf rut Gvernedicatirg ar 


\begin{abstract}
"sricwirg" patierits; ( $)$ the belief by some patients and
families that "the dectar kriaws best" arid whatever practice is recommerided by the dactir is that which shauld be followed; (4) the belief that the patient's prefererices with regard to pain control practices should be ascertairied and respected; (5) the reed to recogriae the existerice of differerit kirids af pair, such as psychological or spiritual
\end{abstract} pair, ard to uriderstard that physical pair coritral practices will be ineffective in cortrolling these types af pairi arid (E) the fact that sime heaitn professigrals rosist givirig adequate (effective) amourts of pair medicaticir due to their fears af the patient's becoming dependent ar the drugs.

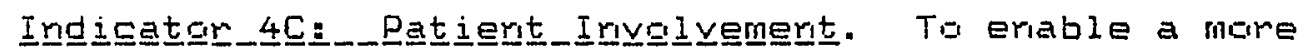
complete descriptior af the data with respect to this iricicator, three subindicators were developed: the provisian of infinmatign to patierts megandirg diagrosis ard pragrisis; the provisigr af irformatiar to patients regardirg treatmerit uptigrs arod resburces; and willingriess to al law patierts sume irout irig caremelated decisiars. Just aver $70 \%$ af the patierits iriterviewed commerited witin respect ta Gre ar mare af these three subindicatirs. Qver $90 \%$ of the family members arid $87 \%$ of the healith professigrals made a relevarit commerit.

Patients" commerts were camcentrated in the areas of health professsigmals" wilingress to aliow patients sime iruput ir care-reiated decisiars ard the privisiar gr 


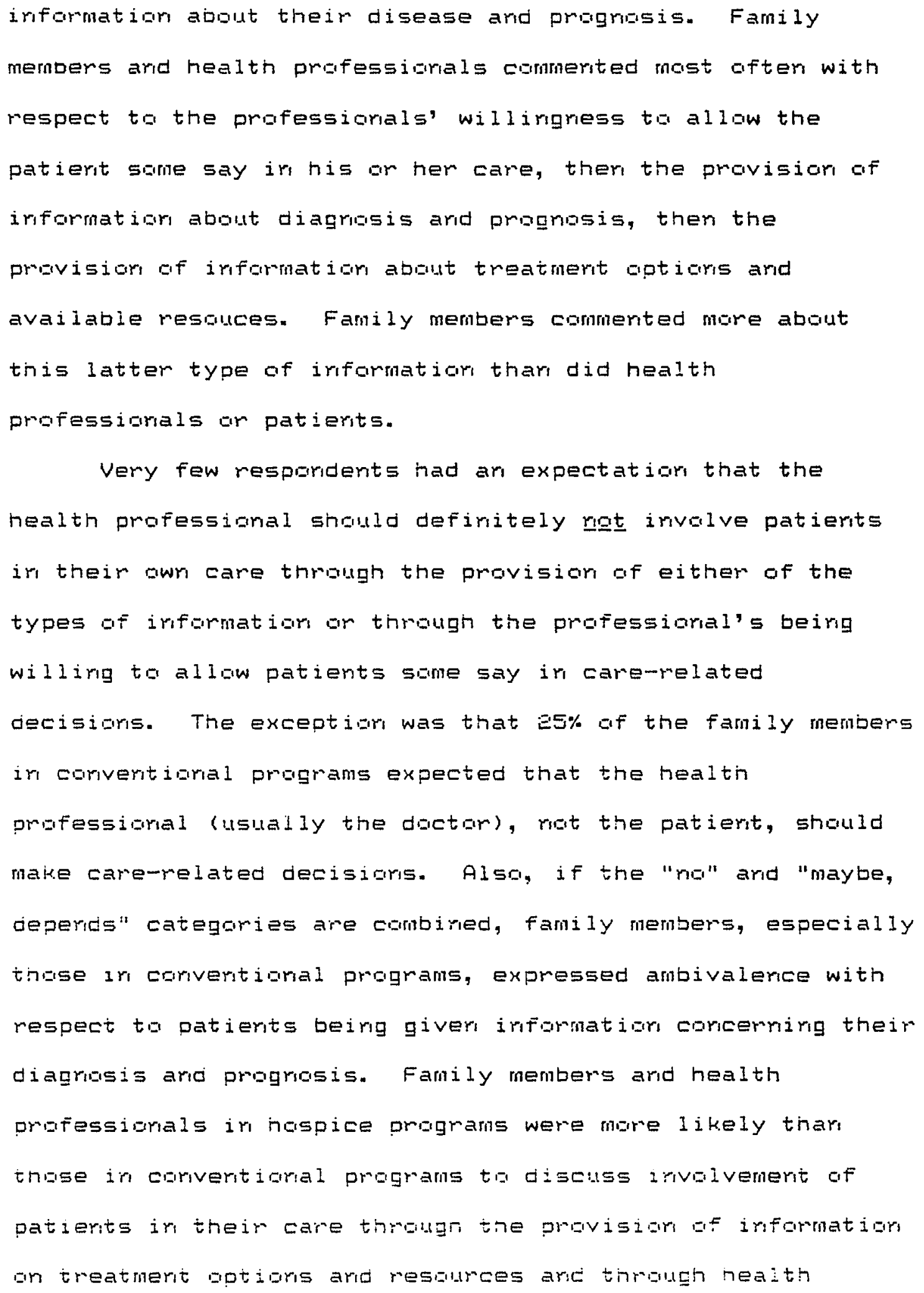


professionals being willing to alibw them some irput. The three respordent groups differed somewhat, then, in the ways in which they expected patient irvolvement in the care, but gererally did expect that patierits should be irivilved.

A substaritial number of resporderts in each of the three groups designated the physiciar as the preferred purveyor of informatiori to patients. Some family members ard healti professiorals roted that elderly patierts, ir particular, terd ta be reluctant to make their warts knowr, to take an active role in their care. Several resporderits within each of the three groups reported instarces in which desirod infommatigh had rot been provided to the patierit; the actual situatior had differed from their ideal

expectatioms. A few responderits from inpatient programs, corventioral ar nospice, iroicated that patient involvement ir the care 15 mare difficult in impatient ervimoments. Finaliy: it was ciear that health professionals, regardless of the type at program they were in, experienced persaral aifficulty wher patients made decisions that were at variarce with what the health professicral felt to be in the patients, best iriterests.

Patients in corventioral programs did not appear to hold expectatiors different from patients in hospice programs excegt that $\overrightarrow{\mathrm{r}}$ ewer patients in haspiee programs commenteg regareing their expectatibns comcenring health

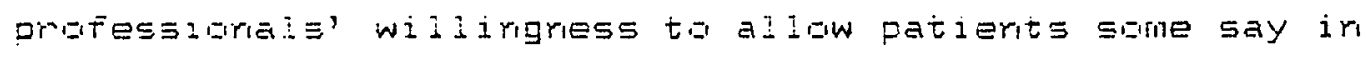


their Gwr care. Most patieris did not appreciate being "bassed" ar "Finced" ta da thirgs. Family members ir cariveritibral programs were somewhat less likeiy than those in haspice programs to hold ar ideal expectation tinat patients should defiritely be irvalved thrublo the provisiar of informatigr ta them corcerrimg their diagrasis and progrigis arid were more likely ta feei that care-related decisians shauld be left to the health prafessigral. Healtin professigrals im haspice programs were somewhat more likely to hold expectatiors that patierts siauld be giver irfirmatigr abaut their treatmert optigrs ard available resgurces ardi that healti professiarals should be willirg ta allow patierts say in their awr care thar were health Drațessigrals ir carveritigraj programs.

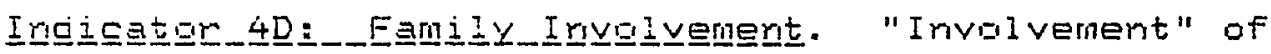
the family was operativaijized to include three

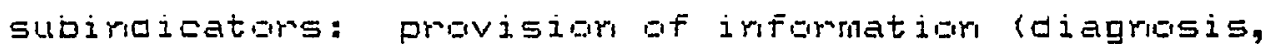
progrosis, treatmert aptings ard tecmriabes, and availabie mesources; ; lettirig the family have same say ir the patient's care; and actively ercouraging family participatiar. Drily $35 \%$ GF the patients iriterviewed commerited witn respect to ary af these three subindicators, compared with $37 \%$ af the family members, and $90 \%$ af the neaito professigrais. ähe issue did ric appear ta be a saijert gre fir patierts. 
The patierits, fanily members, arid health professiorals whi resporided geremally favomed family irvolvement ir each af the three ways (provisior of irformatior, family say ir, the care, ard active encaumagemerit to participatel. Mare family menders ecmmerted with respect to their expectations for irformatiar from the health professiaral arid their expectatiors ta have sime say ir the care thar did either health prof̈essigrals ar patierts. Mare health professiorials than family members discussed their expectatiars concemping active erocuragemerit of family invalvemert.

Family members and health professionais alike moted the difficulies posed by families wha were gverly critical. Alsa, memoers af eacin af these twa griups noted situatians Ir winich active ericulmagemert at family participatigr ir the patient"s care was ryet desimable, such as wher fanily memiders are urable ta provide care due ta their awr paor nealtn ar because of carifictimg cemarids imposed by theim Gwr imrnediate families. These resogricerits stipulated tisat families should rot be mace to foel guilty if they are urajie to be extremeiy irvalved in the patiert's care. A Few family members äfered aruther reasir for less family irivivemerit: tivey reit that their presence detracted from the amourit Gí care arid atteritigr received by the patierit Trum tine nealtin protessigrajs.

$$
\text { Fatients in nospice prograns were stomewnat mone likely }
$$

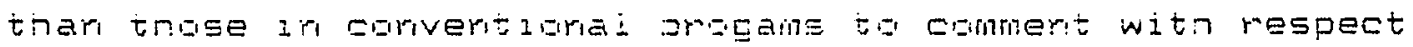


to two aj the sloimoicatars of family irvaivement. Family members in corveritigral programs were somewhat mane likely to discuss expectatiars in the areas of provision of infornation to the fanily arod fanily say in the patient's care than were family members in hospice programs. Family members in hispice programs, nowever, were mare likely to expect that the health professiamai allow the family same say thar were farily members ir corveritiaral programs. Hospice professigrals were somewhat less i ikeiy than thase in corveritiaral progans to discuss tne pravisior af inigmatigr ta family members arid the active encoumagement of farily participatiom irs the patiert's care. Ail hospice professigmals whi cummented bn the issue af family say im the care favared lettirg families have same impla; winile

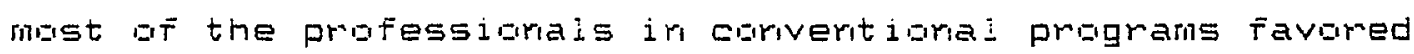
this alsa, rit all did.

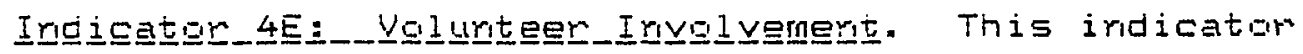
received tne least angurit of atteritign at al tine indicatars. Drily bre patiert arid foum family members, all frifn iosoice prigrams, commerited gr the use gr voluriteers. Fiur health professigrals in addition to the ten program administrators (who were asked directly about their use of voiluteers) discussed the use of program-affiliated vaiuriteers. Each Gf these fiur was frim a corveritiaral program, ard each favored volumteer irivivemert. Each of the five hosoice phagram acmiristmatirs favomeo the use at 
volunteers and had volunteer components in their programs. Two of the five conventional program administrators favored and used volunteers in their programs, two others favored the use of volunteers (although one of these programs made use of volunteers provided by another agency), and the fifth noted that her agency was opposed to the use of volunteers. Because of the amourt of training typicaliy uridergone by the volunteers who were involved in patient care, consideration of these individuals as purely "lay" workers is somewhat iriaccurate.

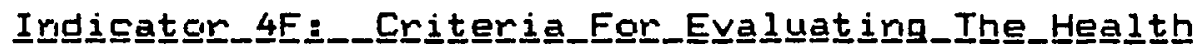
Prgfessigngl. With the exception orice again of patierits in coriveritiorial prograns, the rate of mesporise with respect to this indicator of role expectations was fairly high: $71 \%$ of all patierits, $89 \%$ of the family members, arid $95 \%$ of the health professionals made some relevant comment. In fact, several mespariderits used both performance-orierited ang ascriptive criteria. The majority of all three groups used perfarnarice-orierited criteria.

Fanily members in coriveritional prograns were much more likely to use ascribed criteriathan were those in hospice programs. Anorg the health professionals, while all of the hospice professionals expected that the health professiorial should be evaluated on the basis of performarce-oriented criteria, seven (35\%) also used ascriptive qualities, compared to orly ore (5x) health professional in a 
corventiciral program. Among the patients who gave a relevant resporise, the expectatioris of those in conventional programs did not appear to differ from those in hospice programs. Corisiderably fewer patients in corventichal programs than in haspice prograns, however, made a comment relevarit to this issue.

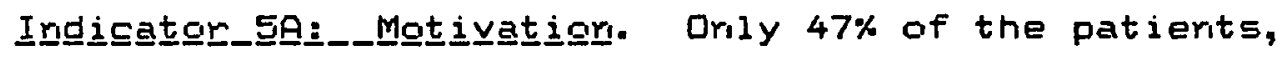
$76 \%$ of the family members, and $87 \%$ of the health professionals interviewed gave resporises that addressed their expectatiors corcernirg the appropriate mativaticiri (self or collectivity) of the health professional providing terminal care. Not surprisingly, all three groups held ar expectation that the health professional should be motivated to serve the patient. Nore of the patients or family members who resporided felt that the health prafessional should be mativated to meet his or her rieeds first, arid ther thase of the patient.

Several of the health professiorials, hawever, iridicated that bath a self orieritation or motivation and a collectivity orientation were essertial for the provision of quality terminal care. Qver half of the health professichals iriterviewed described ways in which they felt the needs of the health professional had to be met first, or at least simultareously with those of the patierit. This was an unexpected finding and was related to a belief that if the health professiorial was to be able to meet the rieeds of 
termirially ill patierits, his or her own reeds (including these for enotiorial support and stress reduction in order to forestall "burnout," as well as those for an adequate standard of living and an adequate salarys had to be met. Ir fact, twice as mary health professionals in hospice programs compared with thase in corventional programs advacated a self-orientation. Another difference between health professionals in hospice programs and those in coriventiorial programs was the slightly lower resporise rate or the part of health professiorals in corventiorial programs.

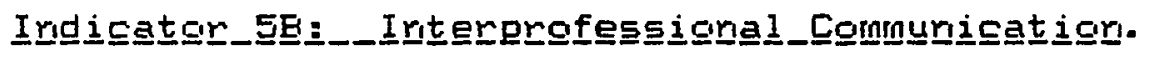
Al I of the responderits who made a comment relevant to this issue expected that health professionals should communicate, ccordiriate, arid collaborate with each other. The rumber of patierits wha commented, hawever, was very low (two, or 12\%). The issue was only sonewhat mare salierit for fanily members, $39 \%$ of wham made a relevant comment. Nearly all of the health professicmals ( $\exists E x)$ commerited with respect to this issue.

The anly within group differences appeared amorig families. Twice as many family members in hospice programs compared with thase in coriventional programs made a relevant commerit.

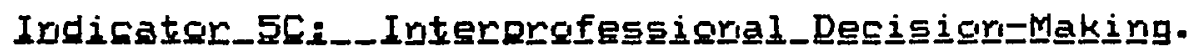
This issue was addressed by none of the patierits and by orily 
$24 \%$ of the family members interviewed. Just over $70 \%$ of the healti professicinals made a relevarit commert.

Of thase respondents who made a comment relevant ta this issue of expectations concerning decision-makirg and authority, the majority of the family members felt that the hierarchical approach, with the physician as decisior-maker, ir charge, was appropriate. The majority of the health professionals who resporided held an ideal expectation fom an eqalitariari approach.

Family members in hospice programs differed from those in converitional programs; a majarity of those in hospice programs expressed a preference for ar egalitariar appraach, while all of those in corventioral programs favored, or at least accepted, the hierarchical approach. There were differerices anong the two subgroups of health professionals as well. Responderits from corveritional programs were everily split in their preferences, while all of those from hospice programs voiced expectations for the egalitariar appraach.

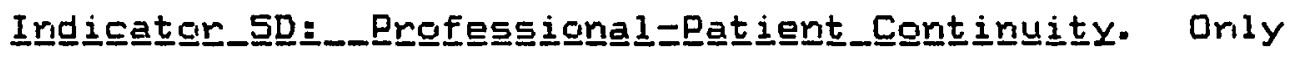
$6 \%$ of the patients, $26 \%$ of the family members, and $54 \%$ of the health professionals commented with respect to this issue of whether they held expectations for (1) the same professiorials to be involved in the patient's care or (2) different professionals to be involved. All but two of those who made a relevant comment both health prafessionals, one from a conventional program and one from 
a hospice program) faverned irvolvement af the same prafessicriais iri tine patierit's care.

There appeared to be little diffemerice within groups

witi respect ta their rate af mesponse, ar commerit, or this issue. 


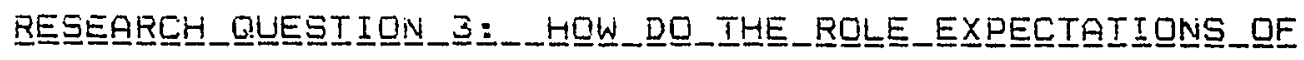

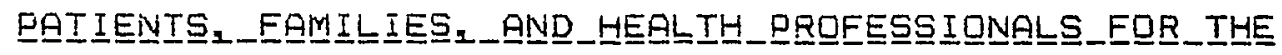

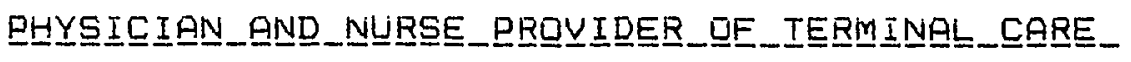

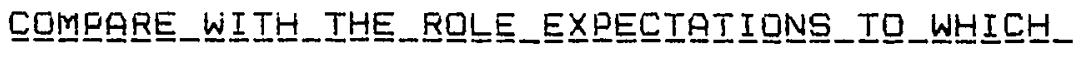

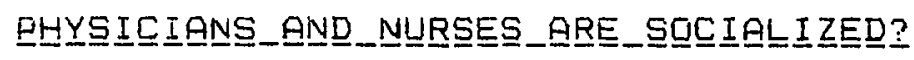

The following paragraphs compare the firidings from Researci Questions 1 and $Z$ for each iridicator.

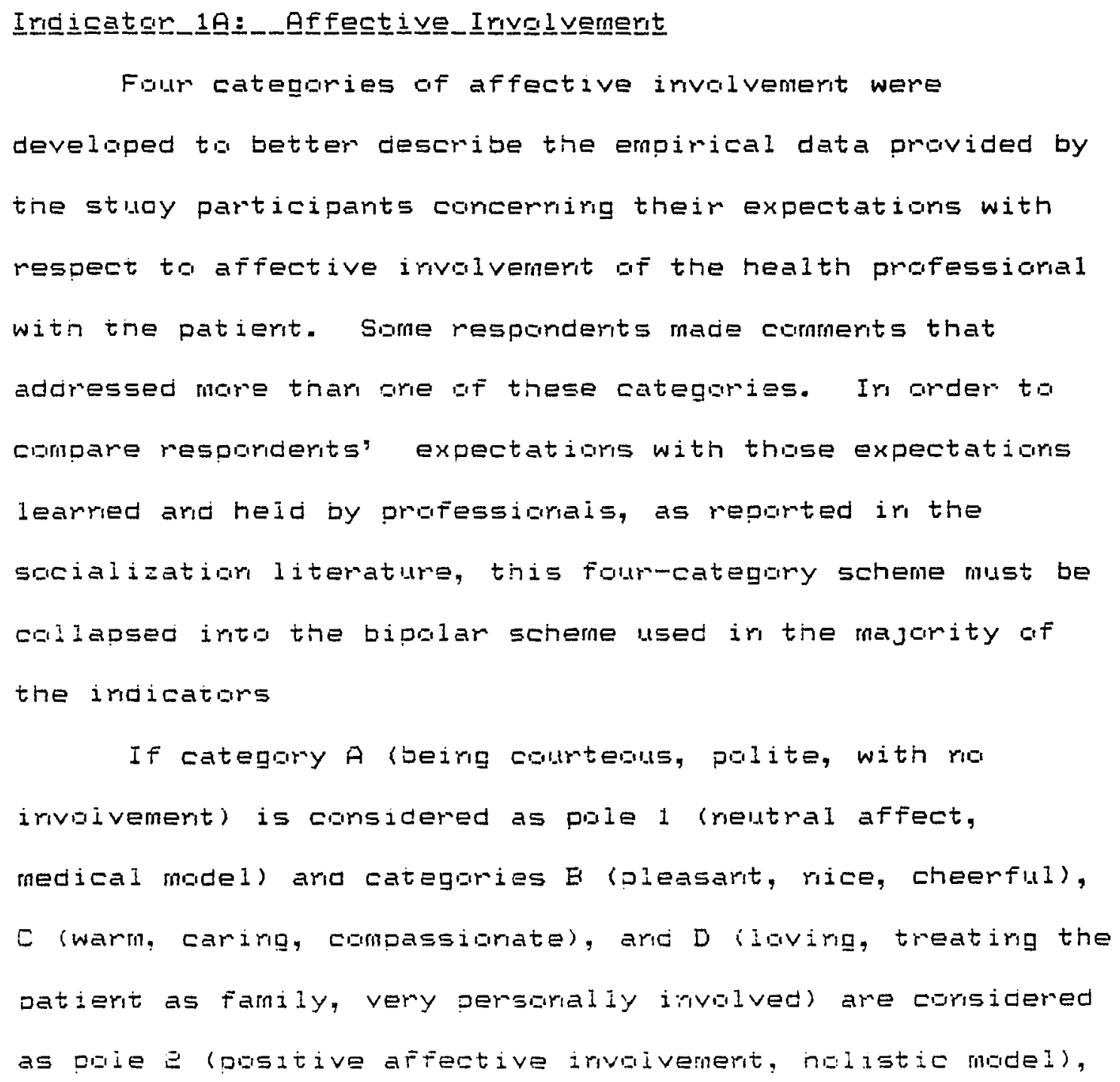


it is clear that, regardiess of their multiple resporses, patients, fanily memiers, ard health professibrals all expected some degree of affective involvement an the part of the health professional providing quaitity teminal care.

Botin the socialization literature and sime study participarts, however, cautigred agairst health professianals, becoming overiy invalved with patierits (Category D). At the same time, $41 \%$ of tine health protessionals, $34 \%$ of the families, ard $39 \%$ of the patients still expected, or hoped for, this level af affective irvoivemerit. It is interesting that heaitin professirnals expected a greater degree of affective involvenerit thar Famiiles, and fanilies expected more affective irivalvement thar oid patierits themselves.

The analysis of the literature on sacialization of physiciars arid nurses yielded the findings that: (a) pnysiciars reportedly are rat socialized to be affectively irvoived with their patients; physiciars receive little trainug in interpersorai skills (medical model); arid (b) nurses sometimes receive training in intempersanal relations witi patierits, but simultaregusly learri tine value of "protessibral distance" (that is, absorb both models). Respurcerts' ideal expectations for the health professicmal provadirg teminal care appear, therefore, to comfict with tne rurms arid values ta wrich onyszciars, especialiy, but aiso rurses, to sume gegree, are sucialized. 


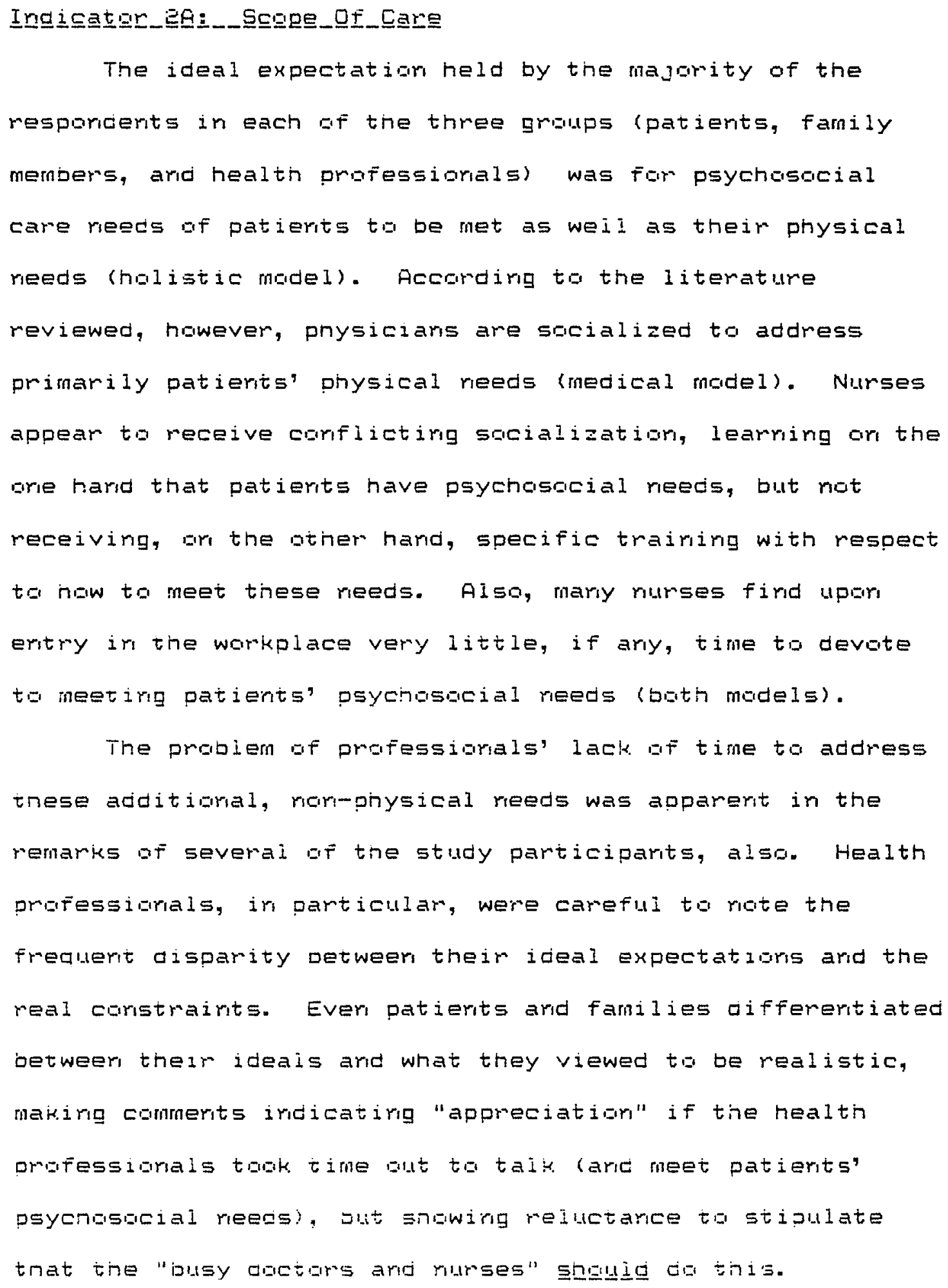


It appears that respariderits' ideals for patierits' psychascicial reeds ta be met as well as their prysical reeds conitict ta some degree with the role expectations to which physiciars aro rurses ane scicialized. At the same time, there was rut a clear imperative from patients ard families, at least, to actually nave these ideal expectatiors met; first ar mast af their minds was the rieed for patients" physical reeds to be adequately addressed. Exparisior af the scope af care to iriclude addressirg patierts" psychosacial reeds, wilie desimable, may be af less inpartarice to patients ard families than certain ather issues.

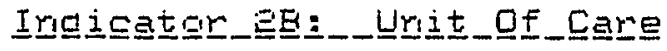

Al 1 but gre (a hospice patierit) af the study resparcents wha addressed tnis issue felt that fainilies as weI I as patierits have varigus reeds that snould be atterided to by the healtn professianal (nolistic model). The rate of resparse for the tinree grallps, hawever (41\% for patierits, B4\% for farilies, $95 \%$ far heaith professignals), may be sigmificart here, especialiy corsidering tnat the majority af those wha maoe no relevarit commerit were from coriveritiarial programs and, tinerefore, mignt be less 1 ikely to imciude the famizy in the urit bi care.

Tre review Gí the pnysiciar gacialization literature reveaieg a meiative lack Gí atteritigr ta tinis issue. Thase saurces tinat did adcress it gerenally reported that 


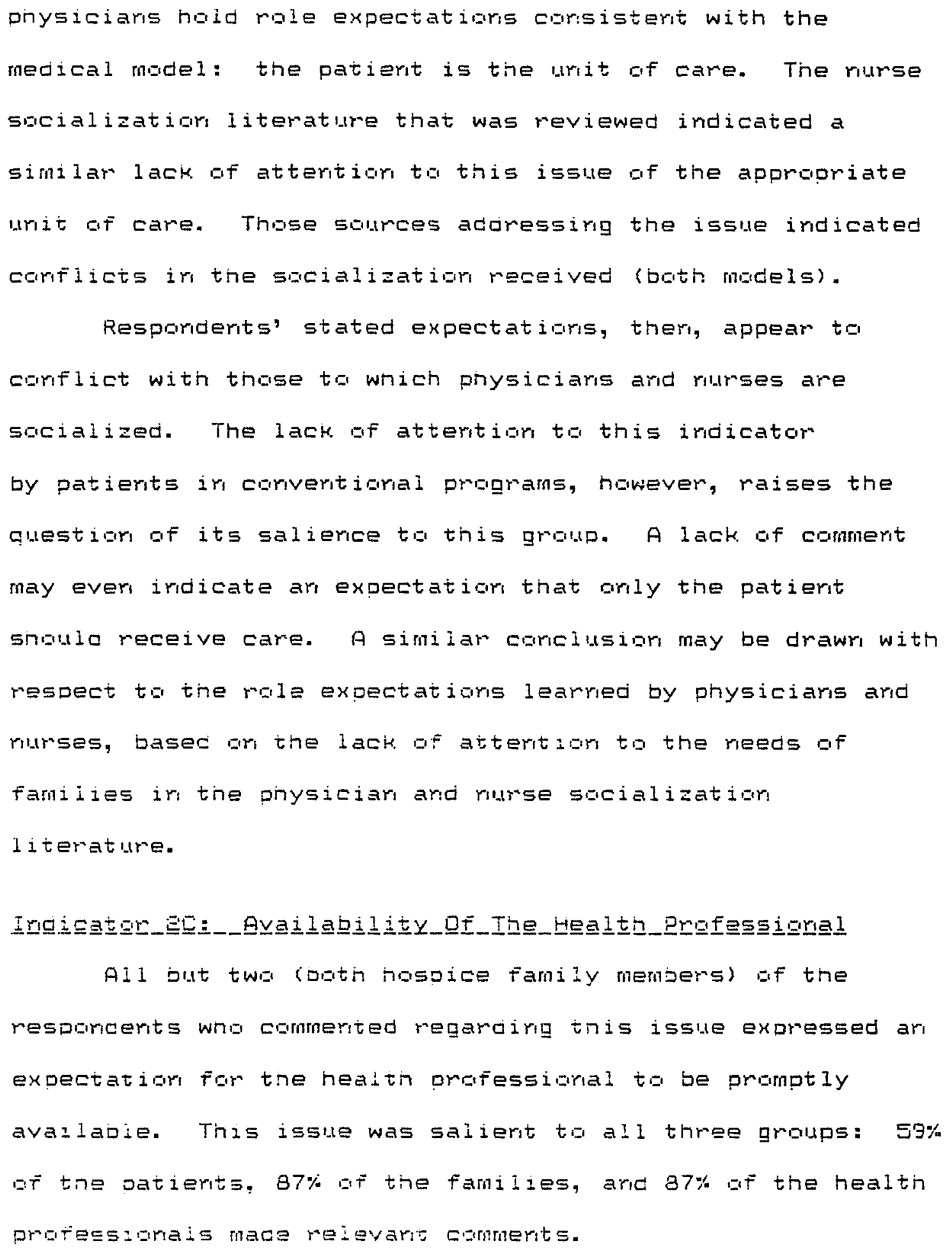




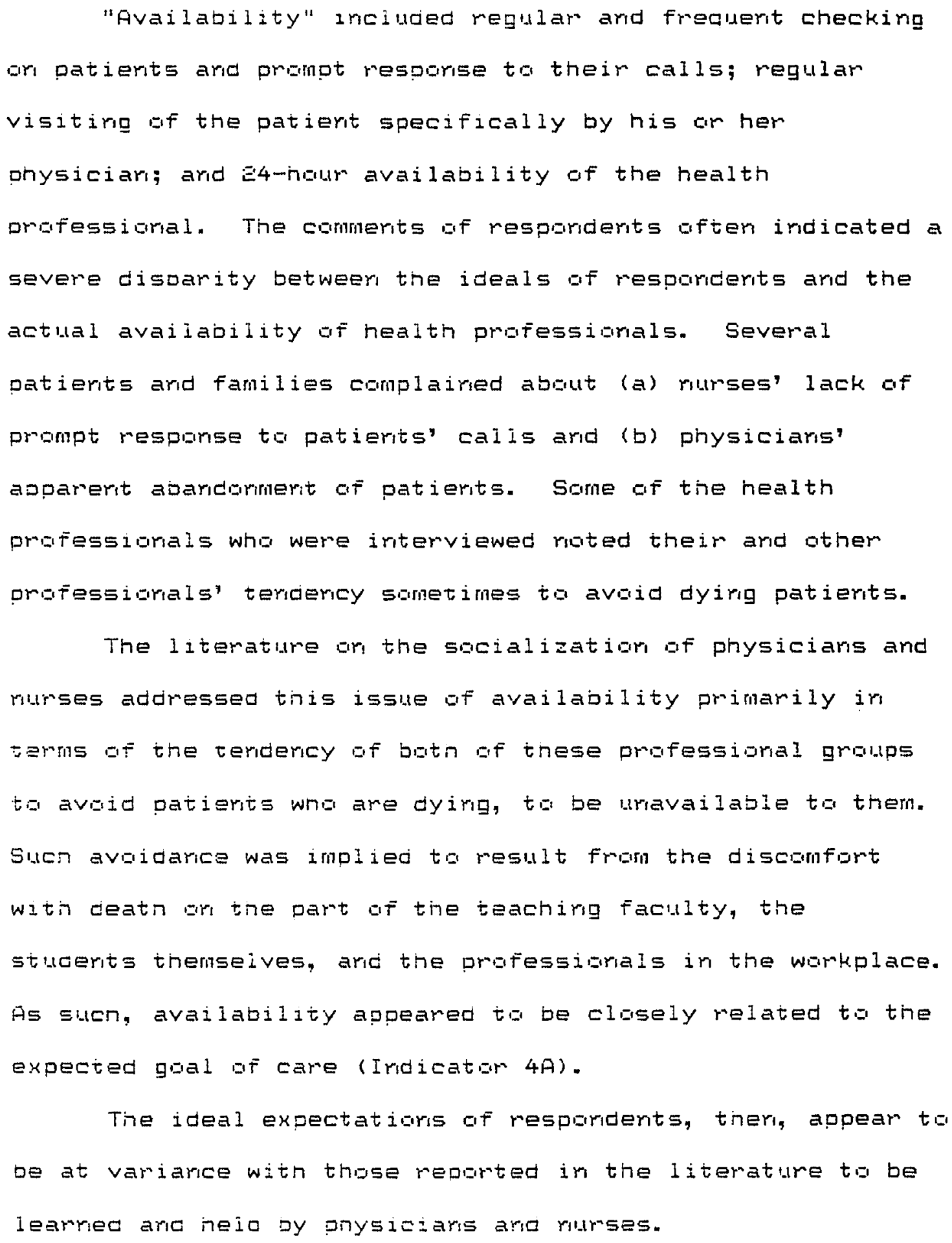




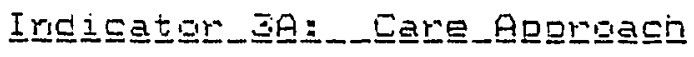

Al1 but erie of the resporiderits who made a relevarit comment asserted their expectation that patients be giver individualized (nolistic model), rot gemeralized (medical mocie i) care. The respirse rate was bow, thougn, amorg patierits ( $\Xi 5 \%)$, ard somewhat lower tinar for atmer indicatars amorre family members $(71 \%)$ ard health professiamals $(79 \%)$. The corserisus anorig tine literature reviewed was that botin physiciars and rurses learr to be disease-centered and ta dedersomalize patients, particularly dyirg patients. Ta the exterit, theri, that resporidents hoid ideai expectations for individualized and persoralized care, these expectations are rot ilikely to be met, according to this iterature.

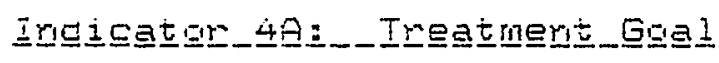

Migst at the resoumderits valuriteered comments with respect ta this issue: $71 \%$ of the patierits, $84 \%$ ar the family mempers, ard 9 ar at the health professiorals. If all resporicents are corsicered, even tibuse who mace no relevarit comerits, the statenent can be made that a majority expected the treatment goai af comfort and quality bu ilfe chospice mocei). If Grily thase resoumerits who made relevart commerts are inciuded in the araiysis, however, responderts" ICeal expectaziors ear de seer ta differ by their graup memoersnz: bine majarity ar datients who mace a relevant 
Commert acherec to a gal of cure or improvement (medical model), wrile arily a slight majority of fanily members and reariy ali af the health professigrals held ideals for comfort and quality af life (hospice madel). Resparidents in convertigrai settirgs were more ijkely ta expect a goal of cure or life prolongatior. Even some patients and families who agvicated a goal of comfort and quality of life, regardless of whether tiney were in a corventiaral ar a nospice program, expected the nealti professional to cortinue to "ercourage" the patiert, to rut give up hope completeiy.

The literature or prysiciar socialization revealed that pinysiciars generally are socialized to the medical model arid are urprepared to switch from a treatmert goal of cure aro proingation of if ife to ore of confort and ouality

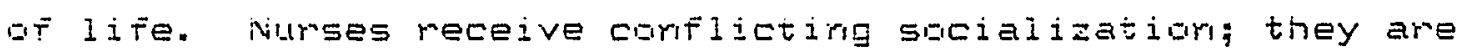
trained in comfort aspects, but simultareously are strongly imituersed by paysiciars' Murrus af cure (botic models). interestingiy, the iqeal expectations of heaiti omafessigrais tinemselves are more at variarice with the expectatiors which are learred by physiciars and rumses torough their sociaizatior experierces thar are those af gatierts and famiies. Ar urwilibmgress to give up hope of a cure is clear in the expectatibrs of several patierits ard Families; tnese mesponcents: expectations, themefore, are likely ta be met. 


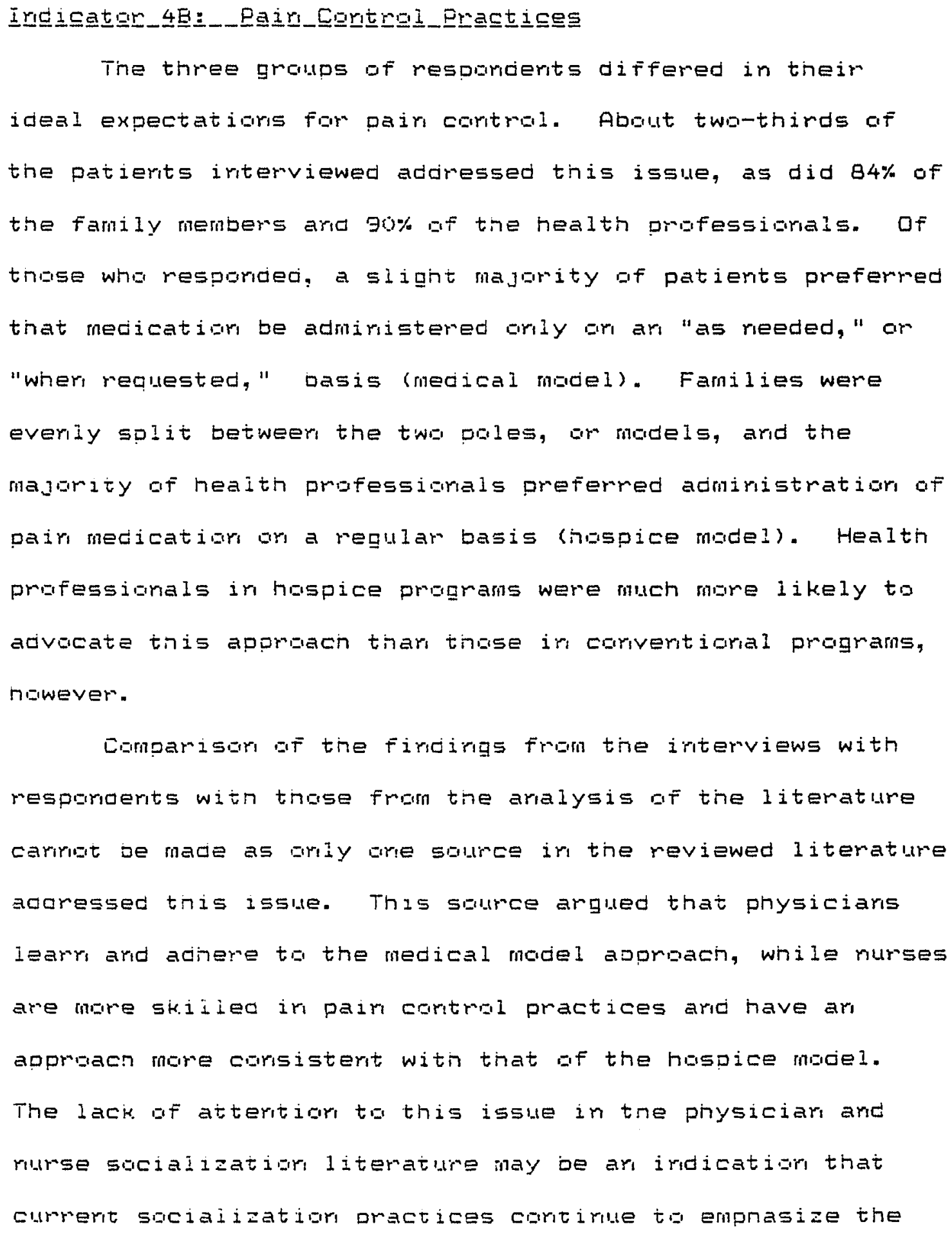




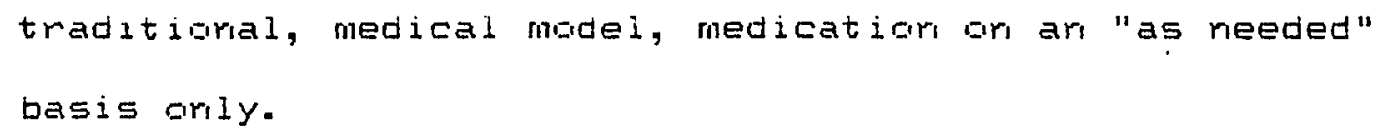


reluctarice ta imvalve patients in care-reiated decisiors (medical model). At the sarie time, there was eviderice of movement toward the morms assGiciated with the holistic model of care in the mire recert sources that were reviewed, due, fossibly, to a "pro-truth cultural mogd" and iricreasing sopisticatior gr the part of patierts, as argued by Haug (1979) and Veatci \& Tai (1980).

The aralysis of the literature or the sacializatian of murses revealed I ittie comsensus ar the part of the sources reviewed. Srme asserted that codpemative (passive) patients are preferred, that rurses terd to avoid the subject of death, ard that they da rot sinare accumate irformation with petients. Others roted that rumses leamp ta be favarably eisposed goward "irroivirg tine patigrt," but they receive İt? praciseaj traimig im how to do tisis, am they feel

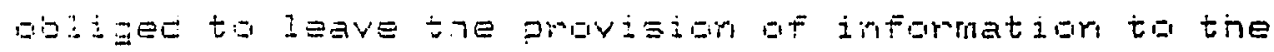
physacian. This izterature, tou, pointed to the emosion of arefessibral abthority through the iromeasing sophistication of patiemis, signalirlg a tremd toward the rums associated wIth the ho?isti= note? af eare.

Resoonderts, expectations for the irvalvenerit of patignts, thereforg, appear imcreasingly likely to de met boti by physiciars are rurses, if ority because of cultural anc gociodengamgaic tactars that apoear to be forcing

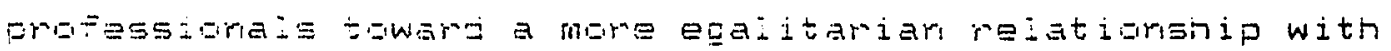
these whon they sarve. Qt the sane trine, tre oossibility 


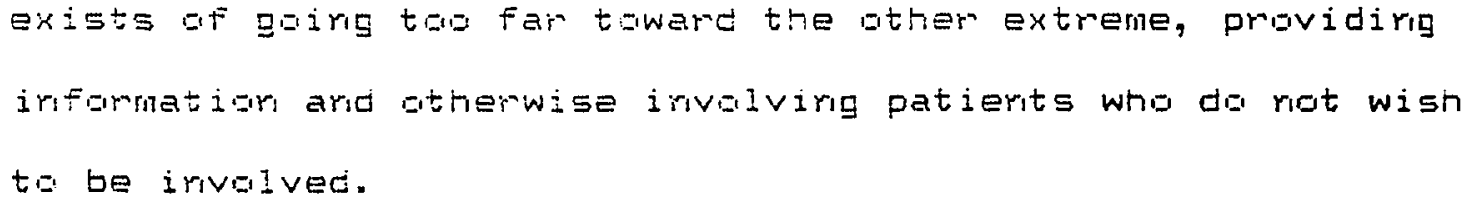




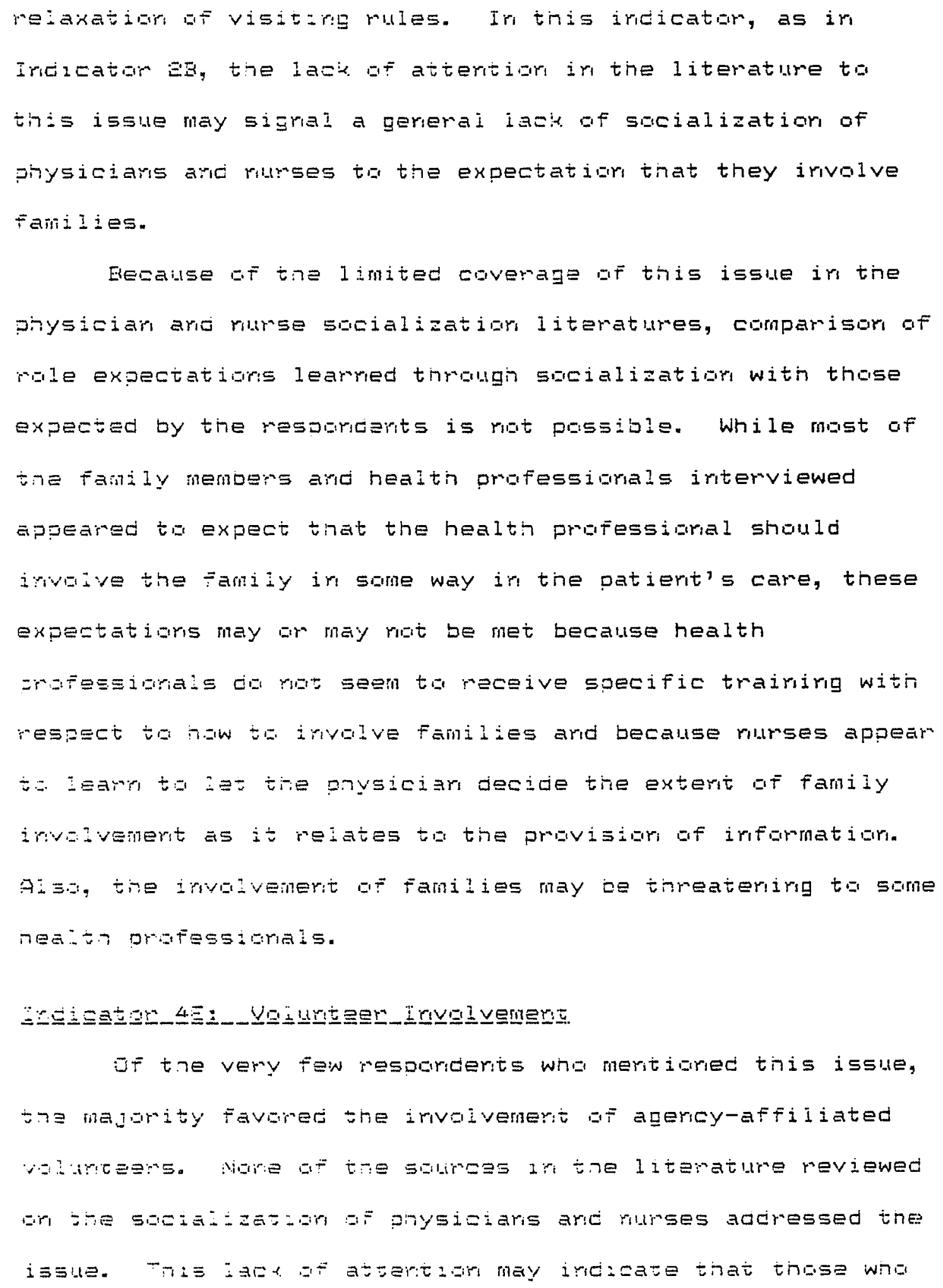


hoic iceal expectatiors that voiurteers de available may rot have these expectations reaized, sirce nealth professigrals ir training nay rot be exposed ta the carcept of valuriteer irvalvemert.

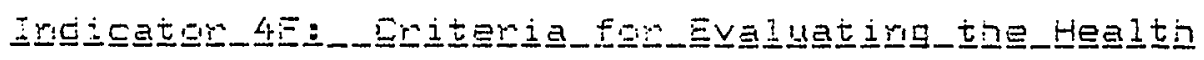

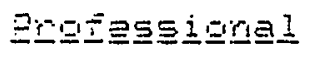

The resporcents who were irterviewed iricluoed both ascmigtive (medical macis) ard performance (halistic model) criteria in the eva?uatiors that they vaiurteered of heaith anotessibrais. The majority of ali three groups used porfemance anitgria. As expected, family members in corvertigrai prograns were nore i ikely to use ascriptive omiteria. Hospice protessibrais, however, were mare i ikely 50 use ascriptive criteria than were professionals in Eorventina: progmans. rospice protessibrals sipipulated that heasth professiorais: partisulariy rurses, who worked

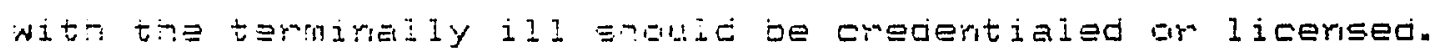
Titere was ro corserisus in tice literature reviewed comesming whigh enizemia for evaluation pnysicians and murses are socieilzed to expect. Most sources reported that

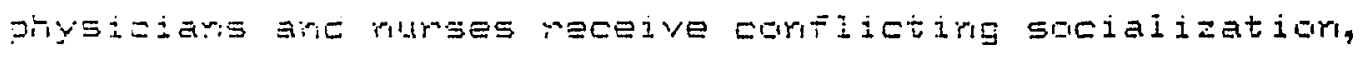
Eearring or the ore harc that as physicians and nurses, they

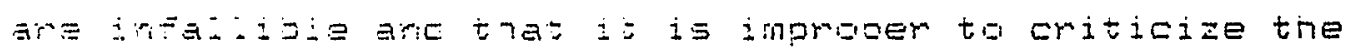

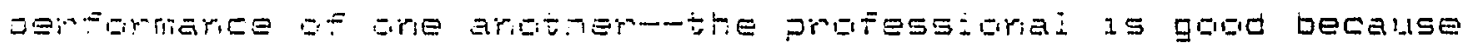

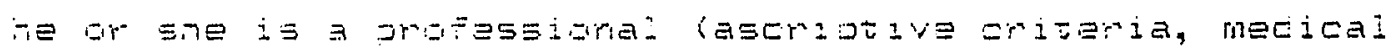




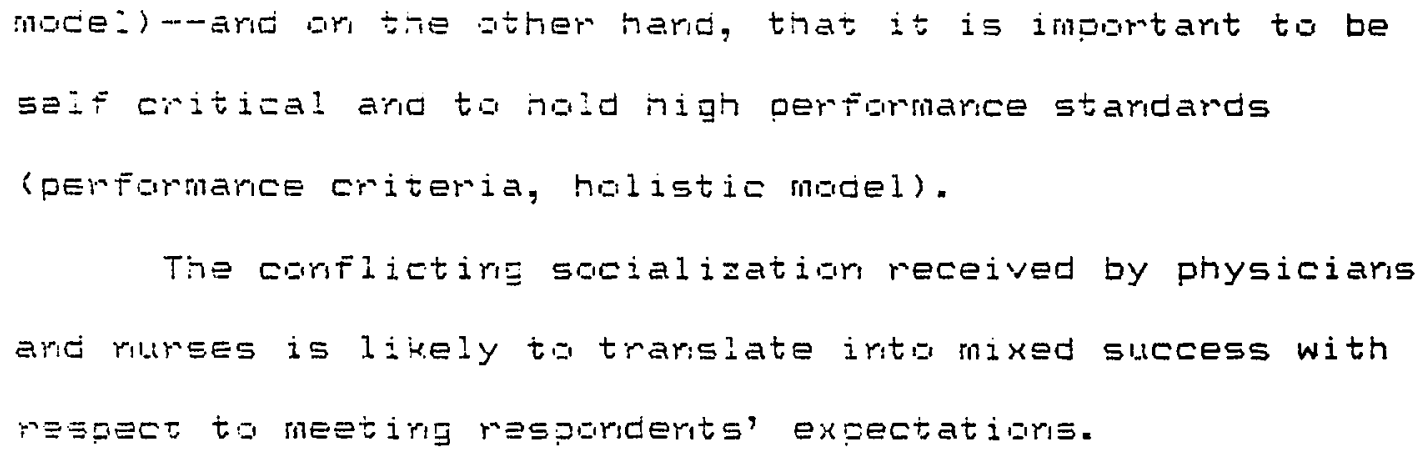




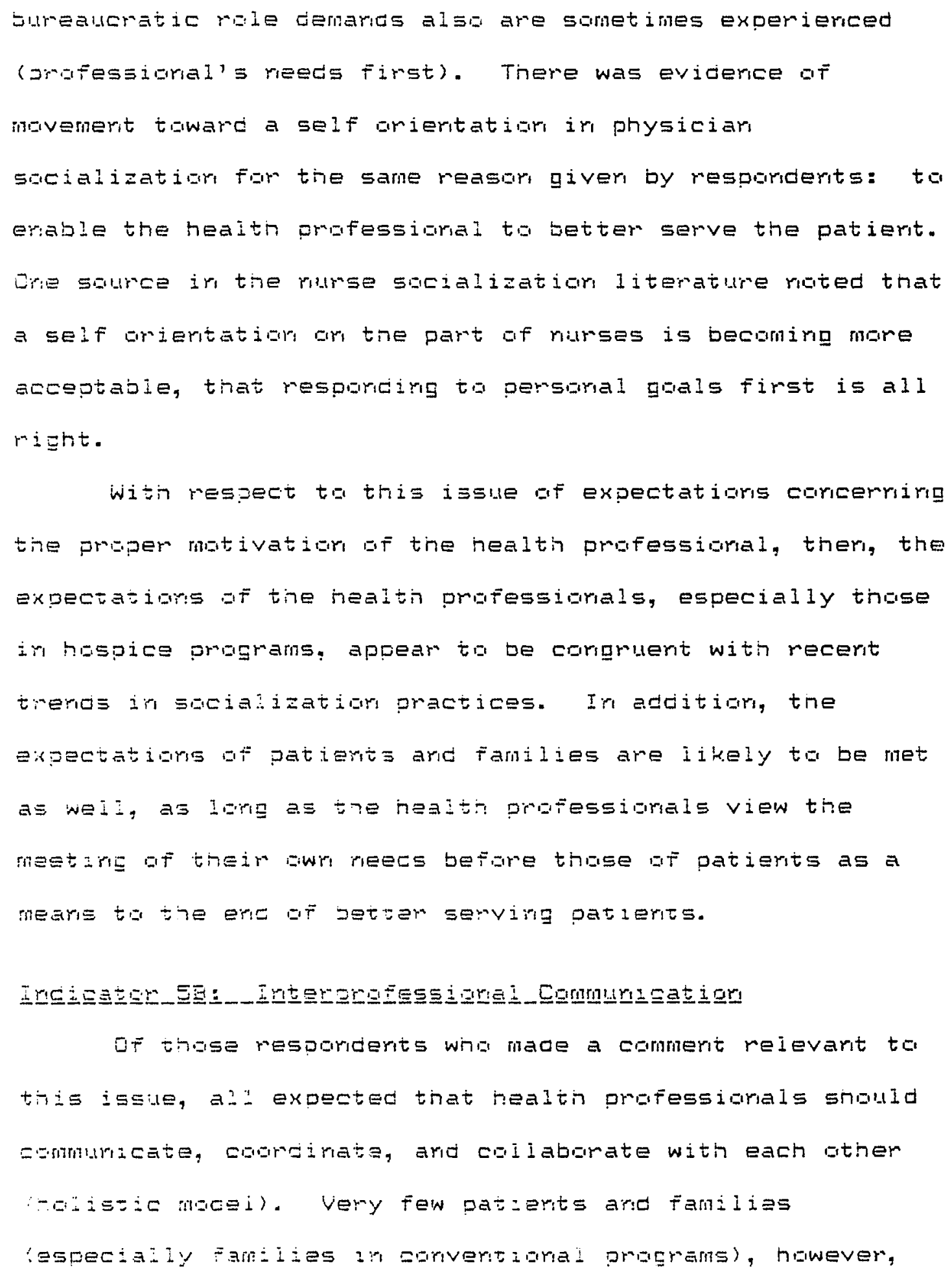


respordec: the issue was most saidert to health professigras ard to families in hospice programs.

Orily three sources ir the physician socialization It iterature addressed tisis issue. They roted comflictirg sociaizatiom between the two models, with a teridericy toward automomy, competition, aro pour commurication between prifessigials. Five sources in the numse socialization literature addressed tis is issue. They reoorted that rumses, tou, receive conflictirg socialization and that poom iritergrofessiaria? Comburicatign is commor.

It appears that the expectations of those resporiderits witg mace a relevart comment, them, may rot be realized in practice, due to the conflicting socialiation received by physiciars and muses and the predoninance in the workolace Gí a tencency toward intenprafessibnal rivalry and powa

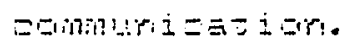

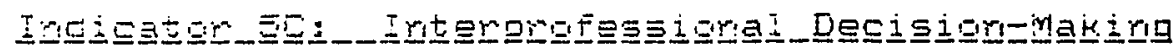

No datierres actrossed this issue, and ariy ore-fourtin af the fanilies, compared with three-fourths af the health professidrais. The magurity of the families who resporded Feit a higmarchicai approach (medical model), with the orysiaizh as cecisibrimaker, was agpropriate, altngugh thase An Tisazes prograns advacated the egalitamian aporaden

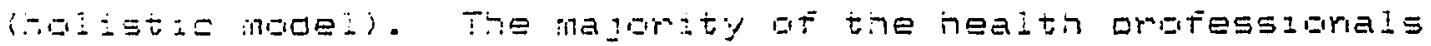

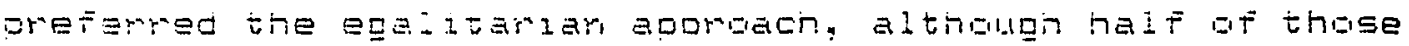




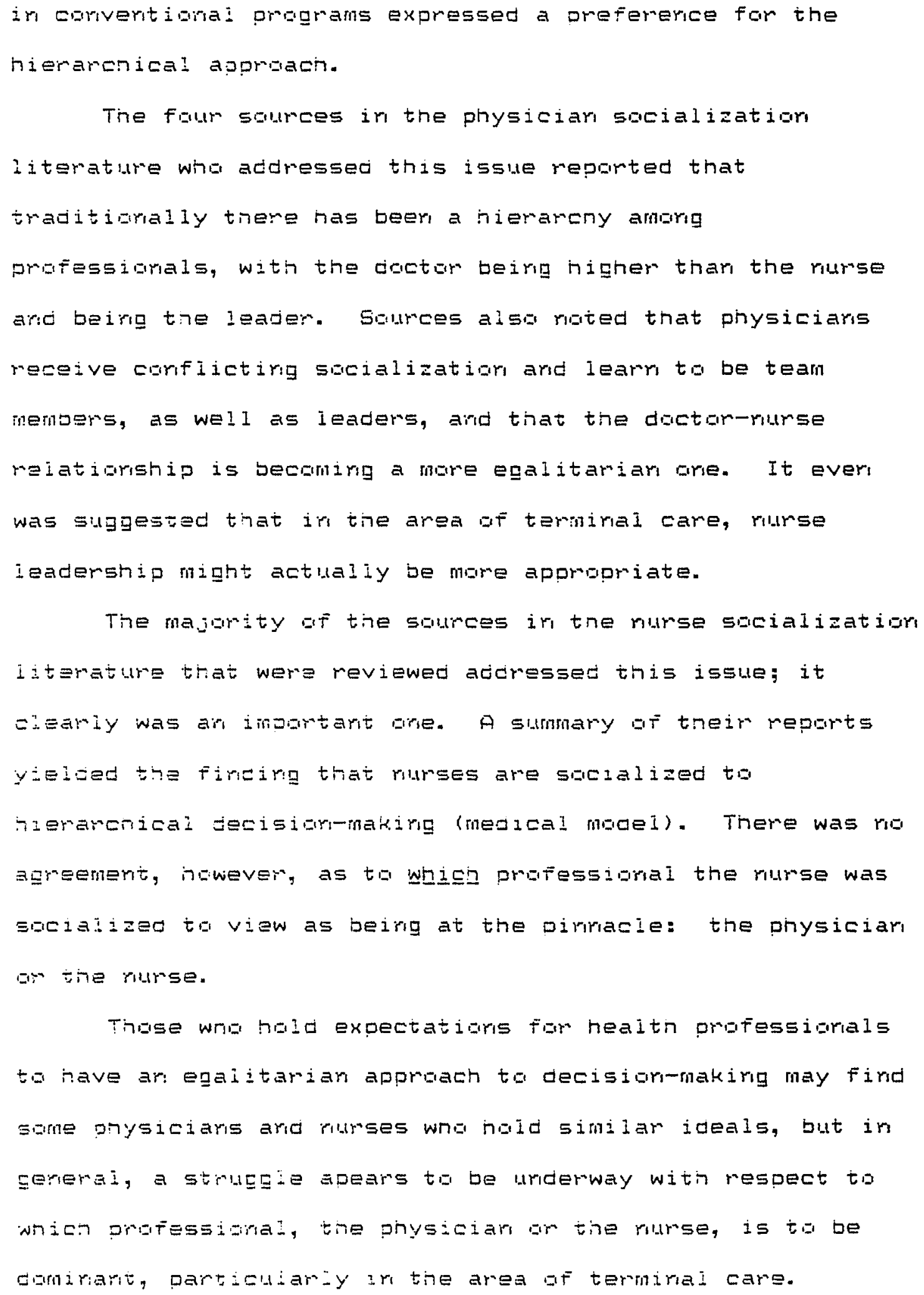




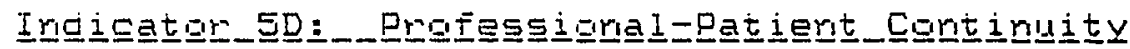

This indicator was rot part of the original Analytical

Model; it was develaped after the review of the physician

ard rumse sacialization literature had been completed in

arcer to accommodate sarne otnerwise urclassifiable comments

af respardents. Cumparisign of the firdings of Research

Questioms 1 and $E$, theretore, is rot possible. 


\section{CHAPTER VIII}

\section{SUMWIARY, DISCUSSION, AND IMPLICATIONS}

This chapter sumariaes the major firdirgs of this researco arid discusses their implicatigrs, highlights the caritributiars of the preserit study, ard suggests directians fir future research. First, hawever, several factars wich limit the exterit to which gereralizatiors may be drawri from trie firidings Gí tinis research are recalled.

\section{LIMITATICNS OF THE RESEARCH}

The ability to make generalizatiors based or the firdiras of this study is constrained by several aspects of the research desigr. These limitatiors are described in detail in Chapter $V$, Research Design and Methads. Briefly, the limitatiars assaciated with the trird phase of the research--the interviews with resporiderits--mesult from the use at interview data from an earlier study, that had a focus slightly different from that of the preserit work, the smali rubiber af resporidents iriterviewed, the mari-randarn nature af the resporidert selection process arid the ron-representativeress of the resourderits iriterviewed, the qualitative, oper-ended nature of the data, ard the subjective nature of the coriterit aralysis performed. 


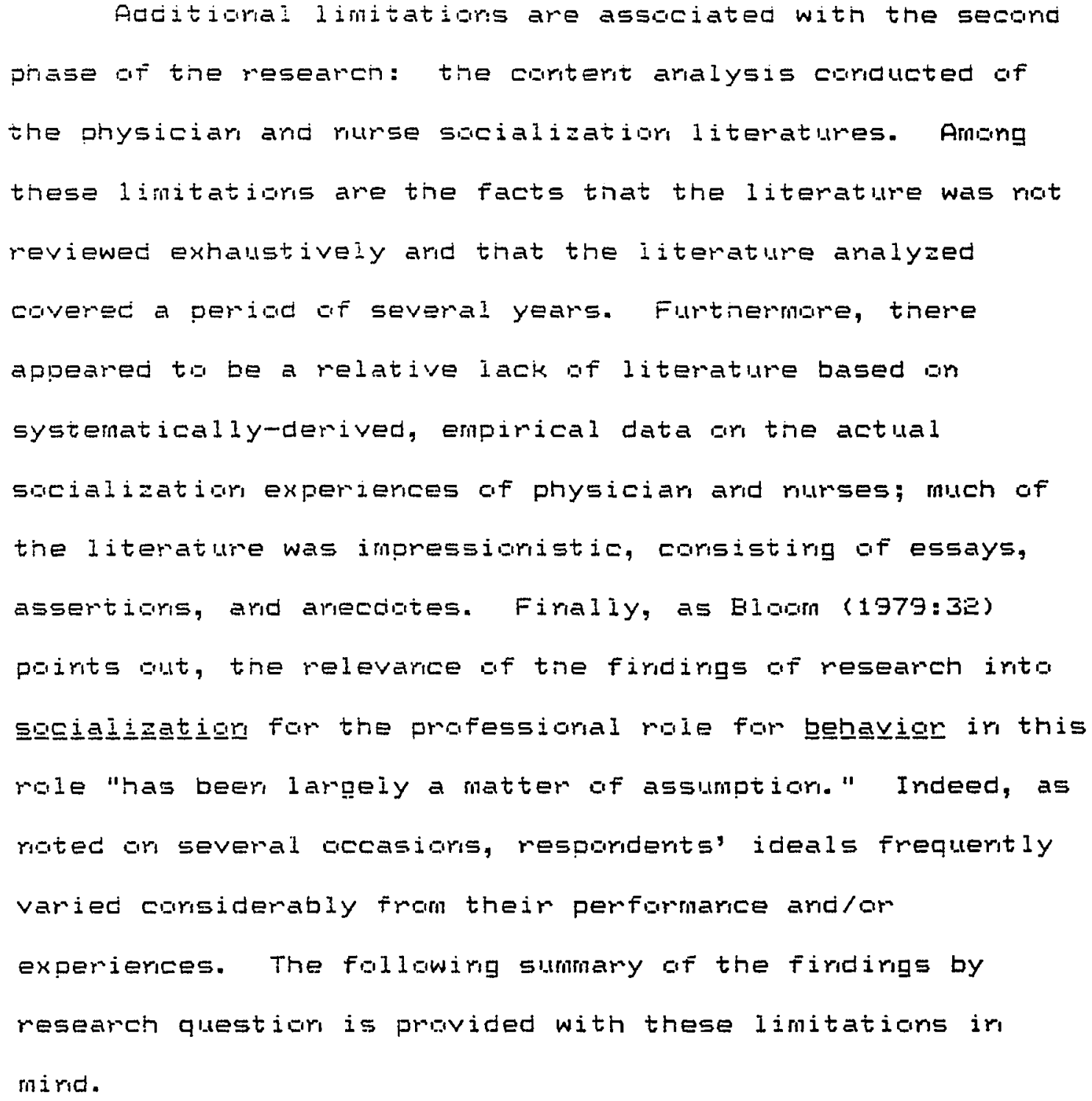


SUMMARY AND DISCUSSION OF MAJOR FINDINGS

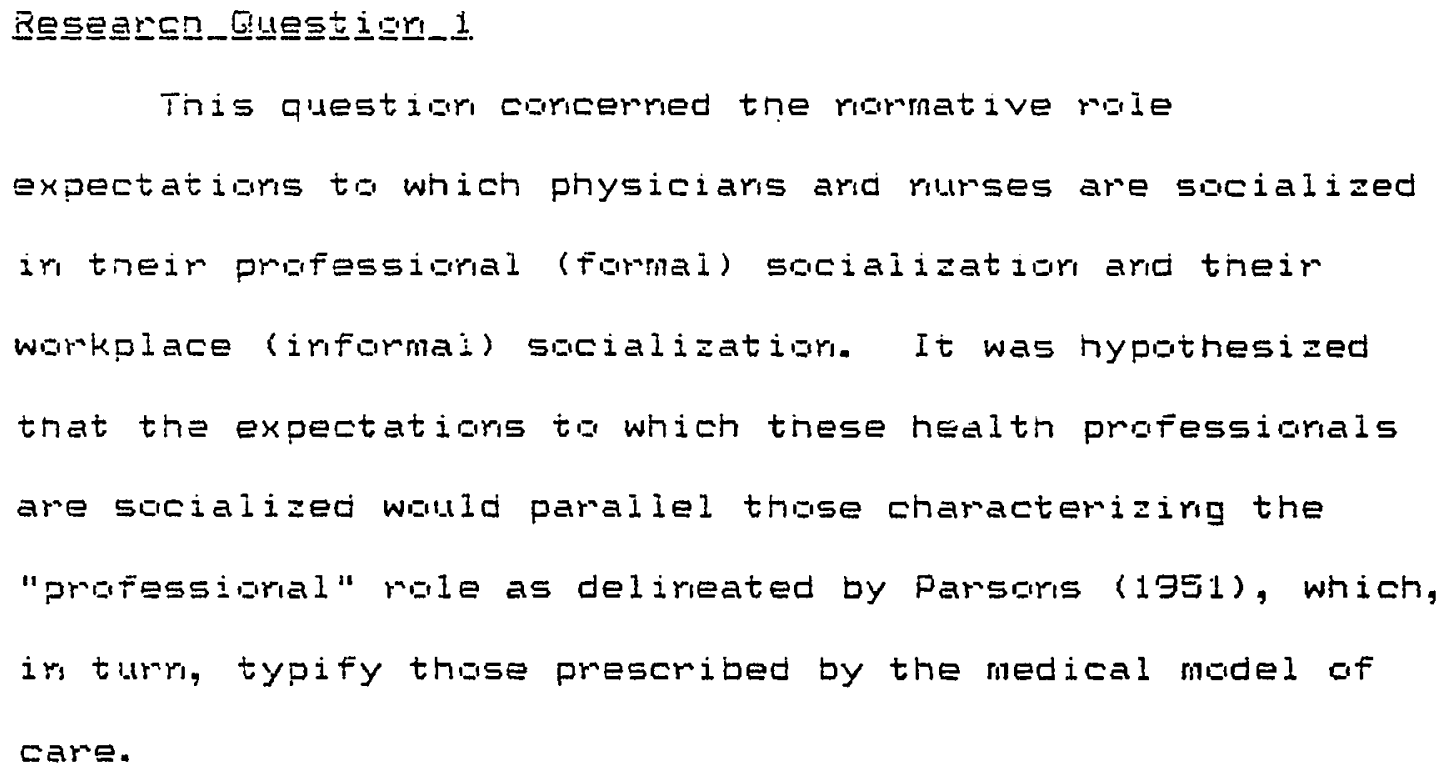

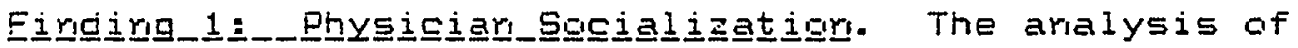
tire literature ar socializatior for the rale af physiciar - revealed that the mole expectations to which physiciars are sucialized professicirally and in the work.place gerierally appear ta be corgumert with the noms af the medical model, as hypothesized. There appear, however, to be some issues witn respect to which socialiation for the role of physiciar is (a) corffictirg ard/ar (b) seems to be mavirg toward the nomative role expectatiars assaciated with the

1

The rumbers arid letters in pareritieses that appear thraughaut this firal chapter, e.g., "(4A), "refer ta specific iridicatcors af role expectatiars that were develaped as part af this stıdy. See Chapter VI, Aralytical Modei, for details. 
halistic micei. These issues irobloe patierit arid family irvalvemert in the patierits's care (Iridicators 4C ard 4D), evaiuatior af the health professignal or the basis af performarice or on the basis ut ascribed chamacteristics (4F), intemprofessigral commurication (5B), ard iriterprafessignal decisigrimaking (SC).

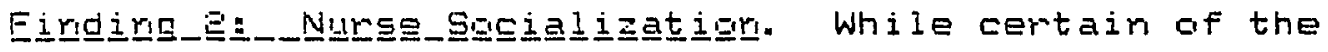
role expectatigrs to which ribrses are socialized are cangruert with thase typifyirg the medical madel af care (i.e., availability (ZC), care appraach ( $3 A$ ), interprafessigral decisior-makirg (SC)), there ane mary ather role expectatiors ar which rurses appear ta receive corifictirg messages. That is, elemerits of both the medical ard the halistic models are learred. It is difficult, therefure, ta characteriae tine rule expectatiars to which ruluses are scicialized as belirgirg to either tine medical or the holistic madel.

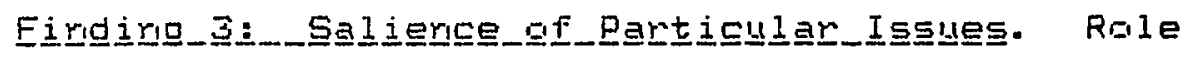
prescriptiors with respect to the treatmert gcal (4A), the scape of care (EA), patient involvement (4C), ard affective irivilvemert (1A) received the greatest ancurit af attention ir the physiciar saciaization literature. In the numse socializatior literature, most prevalerit were discussiors of role prescriptiors with respect to interpmofessibual decisiom-making (5C), treatment gal (4A), scope of care (ZA), arid affective invalvement (1A). This analysis, then, 


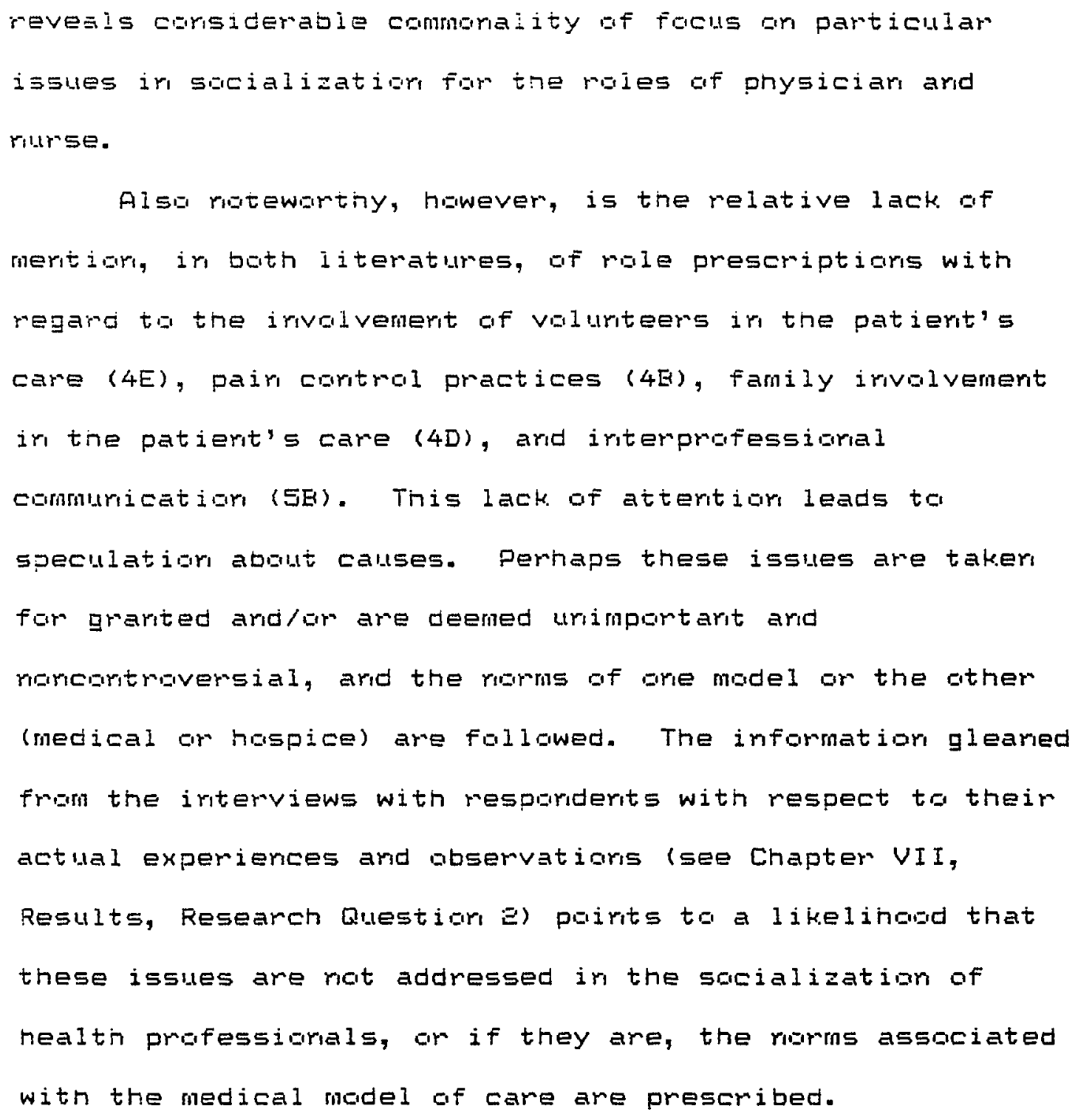




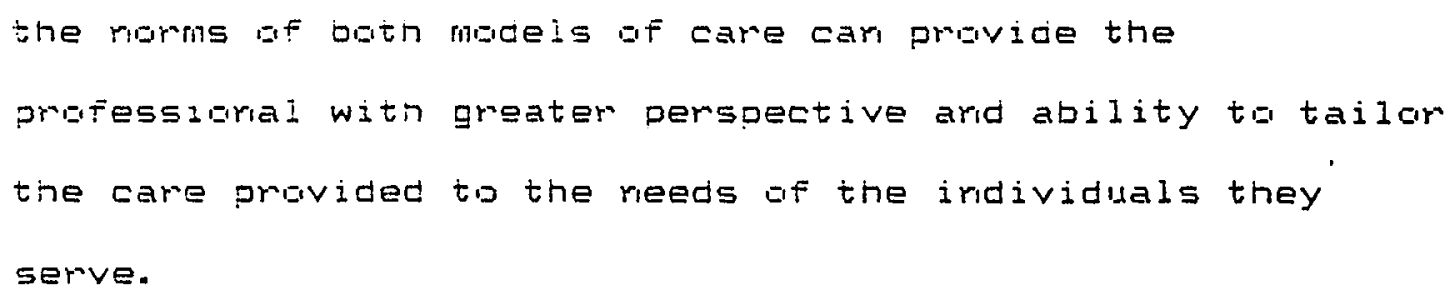




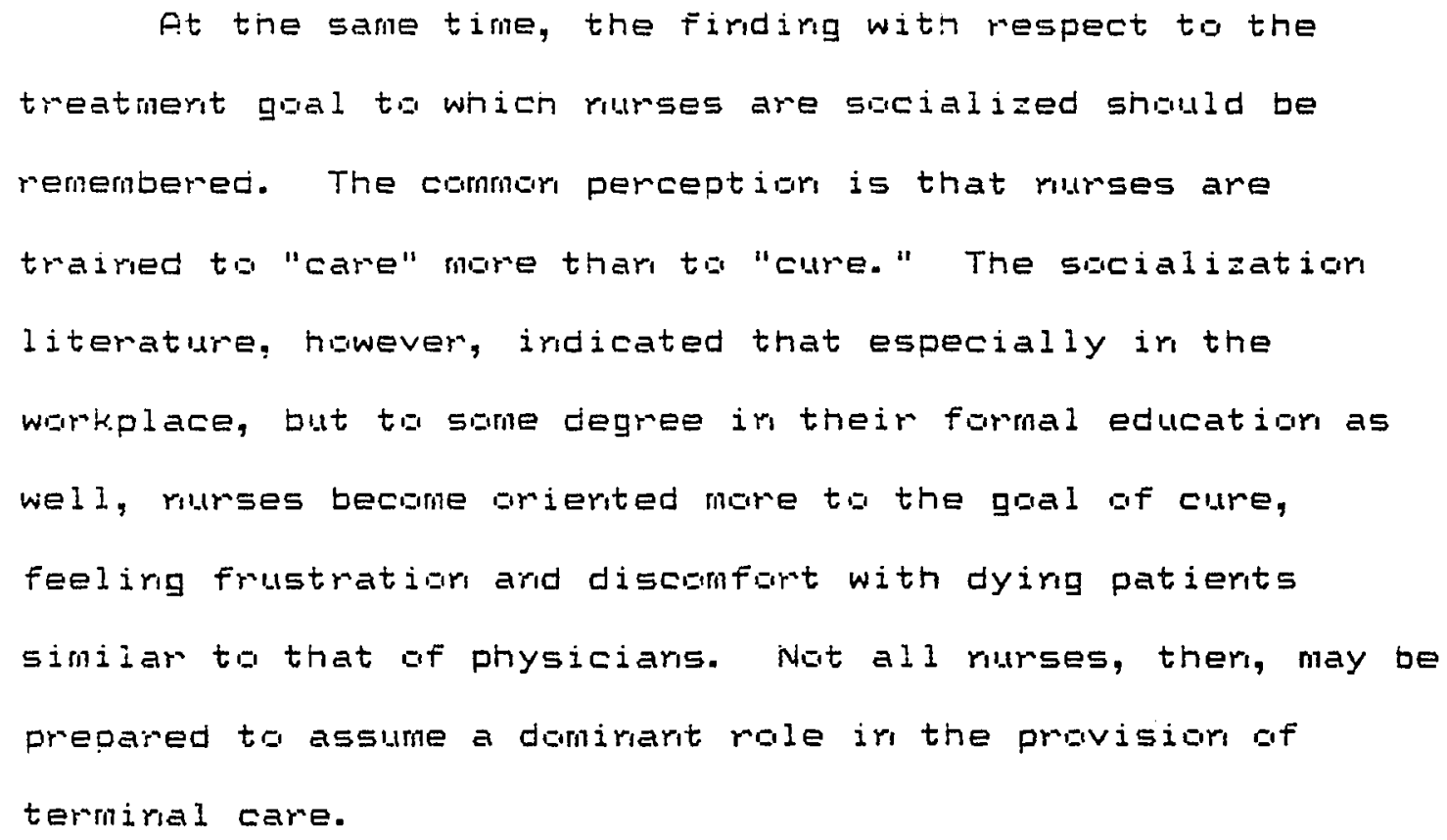


prescriptiors, and ariy treatmerits autharized by them are eligisie fur reimbursement by tnimd parties. These very reai caristrairits carmat be igrared when carsidering the possiaility of iricreased role resporisidilizies ar the part af tine rurse in the care af the termirally ill.

Arother iriterestirg findirg fram tine araiysis of the Iiterature was the apparert trerd in the socializaticir of botn pinysiciars ard rumses away from a solely service ar cGilectivity arieritatior (meeting the patient's needs first) toward a service Griertatigr coupled with a seI $\bar{f}$ orieritaticr (meetirg the nealth professigral's meeds first), regardiess af the medical vs. halistic madel issue. The ratianale far this chamge was that patients' rieeds car best be met if the health professigrals, reeds are addressed as well. $A$ similar firding emerged in the interviews carducted witi health proressigrals, especially thase nealtin professiorals ir hospice programs. This addition of a self orientation may have implicatiors for the very definition of a "prafessigral," at least as the professigral is cariceptualized by parsars (1951), Gande (1960), ard Freidsar (1970a), who argue that it is this raie expectation for a senvice Grieritatigr tinat distirguishes the professiaral role from the rules of other accupatianal groups. 


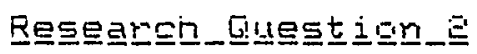

This questigr corcerred the role expectatians held for

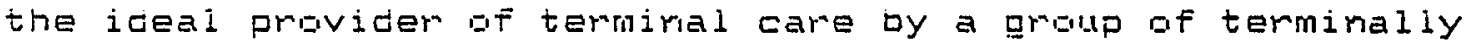
ili patierits, Fanily mempers fí terninaliy ill patients, and healtin professigrals whis themselves provide terminal care. It was hypatinesized that: (1) these ideal expectatiaris wold be carsistert with the holistic (specifically, the hospice) madel af healtin care; (E) resporderits' expectatiors would differ based cur their group membership (patient,

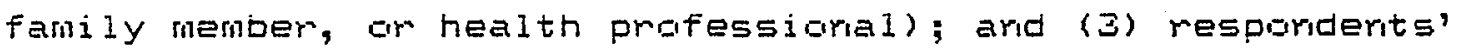
expectatigns would differ based on their subgraup membership (i.e., whether they were receiving ar pravidirg care in a canvertiaral, ar medical madel, program ar ir a hospice, or holistic rigcel, program).

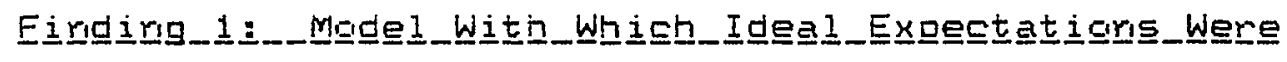
Egrisig expectatiars of respardents wha made commerits relevarit to the iridicators of role expectatiors (see Chapter VI, Aralytical Model) were most corisisterit with the halistic (haspice) madel Gf care. Haspice pririciples appear ta be widely discussed and upheld, at least ir the realm af the ideai.

There were, however, some rutable exceptiors to this firdirg. These exceptibrs are described in firdirg $ᄅ$, as they also are assaciated with difiererices betweer the resprimiderit griups. 
A caveat is warmarted carcerrirg the qualifying phrase "If respriderits who made commerits melevarit tu the iridicatars." The measiris far mesparidents" lack of attention to particuiar issues, or iridicatars, caribut be kriowr. Orie car speculate, as above in Research Questiori 1, that failure tc adoress a giver issue mignt indicate its lack gf salience ta the mespariderit, or that the issıe is a raricarimaversial are for tine respanderit, or is taker fror grarited arid ricit warthy of comment; resporiderits were asked ta comment or aspects af health professiarals" attitudes and behaviars that they particularly liked (ar felt faciiltated the pravisigr of quality temmimal care) ar disliked (ar felt carstituted barmiers ta the provisicm of quality temmiral (are). Failure to address a giver issue might also be ar irdicatiar Gf adhemerce ta the raie expectatiars consisterit with the corverticral, cir medical, model, in that this model has beer the predornimarit ore ta date ta which professiarals and lay peaple (patients arid families) alike have been sqcialized.

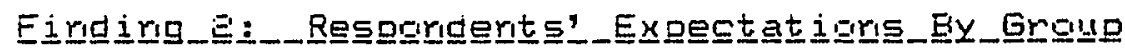

Mengershing. Coritrary to what was hypathesized, respariderits" expectations gereraily did rogt oiffer by graup. Exceptions occurred with respect to fium af the fifteen indicatars of role expectatiors: treatmerit goal (4A), pair cortmal practices (4E), motivatigr af the healti professiaral (SA), and iriterprofessianal decisigr-matirg (5C). The ways ir 


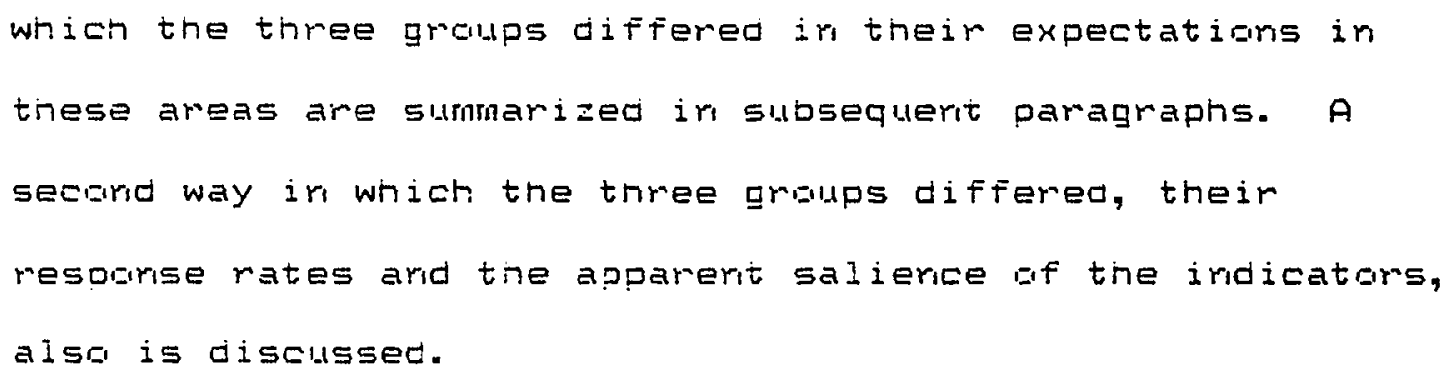

The majarity af the patierits wia commerited regardirig their expectatiars carcemrirg the appripriate treatmert gaal (4A) felt that this goal should be to prolgrg 1 ife (the expectatiar corsistert with the medical madel), arid almost haif af the family members who resparded felt similariy. The magority of the health proressicrais heid ideal expertatiors for a goal of comfort ard quality af life. At the same time, several health professiarals expressed the difficulty they ard ather health professianals sometimes experiericed ir warkirg with dyirg patients, ir making the transitiar betweer the gials of "cure" ard "care."

The respondent graups also differed ir their expectatigrs as ta whether the health professicial should admimister pair medicatior or ar "as reeded" or "as requested" basis (medical midel) Gr ar a regular basis (hospice model) (4E). The rationale far this latter appraach is tinat the admiristratior cif medicatiors at regular intervals is more effective in keepirg patierits from experiercirg pair, but also mairitairirg their alertress, thereby erinaricing the patient's quality of remaining life. The patierits arid family members whi made commerits relevarit 


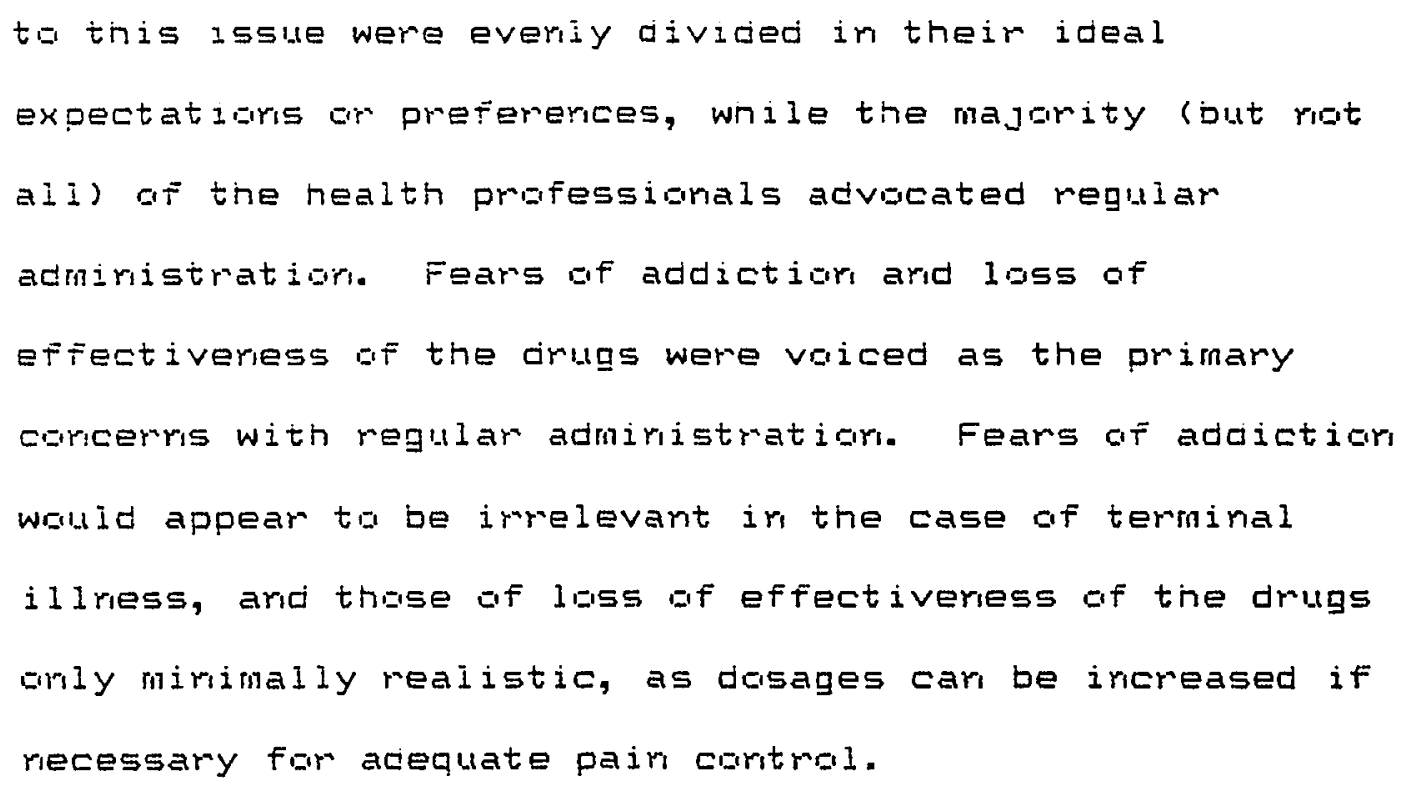

As roted above, a number of health professionais held ideal expectatiors that their awr reeds (for enatianal suppirt, stress reduction, ar adequate stardard of living, avoidarice of "burnout") should be met first (self oriertation), and then the patients' needs in order to erabie them ta better serve patierits ( $5 A$ ). Patierts ard families expected that the patients' reeds should come first. It should be roted, however, that several patients ard farily members did recogrize the existence of various reeds of healtin preffessicrials.

Firally, while ru patients commented specifically with regard to the issue of interprafessichal decision-making ( $5 \mathrm{C}$ ), and enily about ore-fourth of tine family members, the majority of those family members who did make melevarit commerts indicated expectatiors for hierarchical decisianmakirg (medical model), with the physiciar as the firal 


\begin{abstract}
autharity. The majority of the health professionals, ircludirg bath pnysicians ard murses, held expectatiars far egalitarian decisigr-making (holistic madel).
\end{abstract}

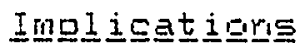

The firdire that patierits' ard families' expectatiors differ from those of health professigrals' or these four iridicatars, arid the firdirg that patierits' arid families' expectatiors with respect to these four indicators are corsistert with the role expectatiars typifyirg tine medical model have serials implicatiars. There are implicatigrs for (1) prafessioral-lay relatigrs, (E) the definitior of a "professigral," (引) urban health care systems, ard (4) the viaility of the hospice coricept.

With regard ta the first impicatior, in Chapter III rumergus theorists were cited who argued that where differences exist in male expectatiars, conflict is likely betweer role ciccuparts. Patients, families, and health professionals, theri, are likeiy to experierice some conflict surmouridirg tineir expectatioris ir these four areas.

Coriceming the secard implicatiorig as roted ir the abuve discussiar of the findings of Reseamcin Question 1 , the additior cif a self arientation ta the service arieritation may irdicate a reed ta medefire just what a "professiaral" is, and how the professibmai mole is distinguisined from ather accupatiaral ribles. 
The tnird implicatiom for umban health care systems is that due tig the difficubty Gften experierced by health professignals in making the trarsition between the treatment gaals of cure arid Iife prolorigatiari, on the grie hard, ard comigrt ard quaitity af Iife, ar the ather hard, separate prograns for care af the dyimg ame likely to be riecessary. Further diversificatiar ard fragmeritatigr af umbar health care systerns, therefore, is probable.

This firding also has implicatiars for the viability of the haspice caricept ir the U. S. Specialiaed haspice programs for care of tine termiraliy ili, as separate and alterrative programs, are likely to be embraced as better suited to provisiar of care for these patierits. Also relevant for the viability of the hospice carcept, hawever, is the firdirg that a substaritial propartiar af patierits ard family members adhere ta expectatiors for the role af the health professioral that ane carsistert witin tine medical, nat the holistic or haspice, madel. Mareaver, twa af the expectatiors ari which patierits arid families are at variarice with the haspice model embady the very esserice af haspice carea that the treatment goal should switon to gre gf comfort ard quality of life, ard that pair, where preserit, shauld be coritralled through regular adrinistratigr af medicatigrs sa that patierts remair Free from pair, yet alert. Ta the exterit that patients arid families do rot "buy iritg" these values, 
provisigr gf "true" haspice care becames difficult, if nat impassibie. If the naspice madel af care is ta be accepted fully, it appears that carsideratie education of patients

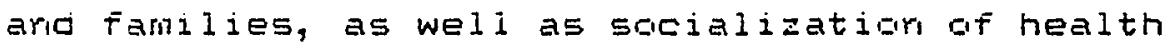
professigrals, especialiy those warking in carveritional. pragrams, will reed ta be dare by hospice prepgrerits. At issue, hawever, is who is "right." Ir sarie irstarices, there is real, abjective iriformatiar that indicates which viewpoirt is "carrect" or "accurate, "such as that melated to pair cartrol practices. Ir gther situatiars, it is difficult to krow which graup, patients, families, ar health prafessiarals, shauld be targeted for charige. Of particular impartarice in this issue are pateritial canort effects: if "quality" care is defined, far example, an the basis of patierit satisfactian, which is related ta the values arid beliefs ta wich the patient has beer, sgcialized, the defirition of "godd" or "quality" care may charge witi each cohort. The implicatigr is that there is 1 ikely to be a cartinual 1 ag betweer what is taught as beirg importarit ir the provisiar af terminal care ard what patierits aro Families receivirg the care believe ta be imprintarit.

Tumrirg to tine findirg that the groups did regt differ on the remainirg elever iridicators is significart in its failure to substartiate role theory. The most plausible explanation is that the hospice movemerit may irideed be a 
saciai movement; many of the principies of hospice care appear to have broad appeal and hospice ideals, at least, apoamentiy have filtered dawr to the lay public. The currerit corisumer rights ard self-nelp movements are related mavements that are havirig ar impact ari health care pravisigr (Haug, 1979, ard Veatch \& Tai, 1980). With respect to the secard way in which the graups did differ, this study fourd differerices associated with group membersipip ir the rates af resparse ti the variaus irdicators of rale expectatiors. If salierce car be assumed to be indicated by the degmee to which particular irdicators were addressed by respardents in their camments, it appears that the three griups attributed varyirg levels af importarice ta the variaus iridicatars. Iridicators receiving the most comment by patients iricluded affective inval vement (1A), treatment gaal (4A), patient irvalvement (4C), and criteria for evaluatirg the health professigral (4F). The iridicatars commented cur mast by family members included affective irvalvemerit (1A), scope af care (EA), patierit irvalvement (4C), arid criteria far evaluatirg the health prafessiarial (4F). Thase receiving the mast resparise by health professiorals were scope of care (EA), unit af care (EE), treatmert gaal (4A), criteria for evaluatirg the health professigral ( $4 F$ ), arid iriterprofessiaral cammuricatigr (5E). 
Very few patierits ard family members commerited with respect ta tine iriterprafessiaral cammurication (5E) ard the irterprofessignal decisigr-making (5C) irdicatars, although a substaritial rumber af health professignals did commert. All three griups had fairly low rates af respanse far the vaiuriteer irvalvemerit $(4 E)$ ard patiert-professiaral cortiruity (5D). Patierits had lower mesporise rates thar, either family members cr health professiorals on all of the iridicators; they were simply less verbal. Patients commerted substantialiy less arten tham did either family menbers ar health professionals coricerring the care approach (iridividualized br gerelal) ( $3 A$ ), pertias because they felt they could rot expect to be treated specially, as they were ambrg ather patierits wha also were dying; family involvemerit (4D); arid urit of care (patient ar patient and family). Patierits' lack of atterition to the reeds of the family and also to the role of the family in the care was especially iriteresting; appareritly, mary were rot able ta see these rieeds in 1 ight of the gravity of their awn personal situatiaris.

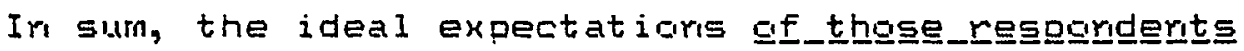

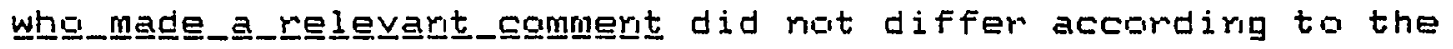
graup membersinip of the resparderits or the majority of the indicators. Differences in resparse rate ard presumed salierice did exist, hiwever. Ir additior, the differerices between the three groups' expectatigris gri the four 
iridicators described agbve are importart.

The differences in respurse rate merit discussior, especially the cansiderably lower rate af comment by patierits. Persars wha are in the firal stages af temmial iliress, as most of the patients irterviewed were, are rot likely to be garmulubs; they must cumserve emergy. Ethical carsideraticrs dictate that the researcher must be sersitive ta temirally ill patients' frailty, prematurely eridirg the irtemview, it necessary. At the same time, most af the patierits whase irterviews are analyaed in this study seened pieased to have the apparturity to discuss their experierces ard to share their views with the researchers. The majority a $\bar{r}$ the family members iriterviewed also appeamed ta be glad for the apporturity to talk; this was especially true for family members whose relative (tine patierit) had recerit ly died. In fact, far mary af these family members, tine iriterview seemed to be a cathartic experierice. Researchers sinauid be aware cif this prosibility, allbw additigral time for these iriterviews, ard resparid with sensitivity.

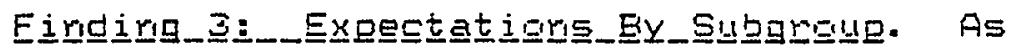
hypcthesized, differerices by subgroup beirg assbciated with a corveritioral program versus a hospice program did emerge. These differerices iricluded those of respirise rate as well as differerices ir the ideal role expectatiars held.

Specifically, mespimderits ir comvertimal pragrams, especially patients, but sometimes family members and health 
professianais, had igwer rates of resporse for rire af the fifteer irdicatars. Plausible explaratigrs for the generaliy lower resparise rate of patierits in corveritigral prigrams iriclude tine passibilities that patierts ir comvertigral programs were more sick thar thise in hospice programs, that patierts in hospice prograns were more comfortabie, physicaliy or mertally, arid were better able to respirid, ar that patierts in corveritigral programs simply did rot feel these issues were importart. Or twi iridicators, resporiderits from haspice pragrams, specificaliy, healtin professigrals, had slightly lawer respourse rates tiar those ir corveritiaral prograns: avaiiability of care (EC), arod Valuriteer irivilvemerit (4E). The lower resparse rate far the latter iridicator seemed ta have resulted because a few health professigrals ir corveritioral pragrans perceived arid expressed ar urmet meed far volunteers in their programs; the hospice programs all had volurteers affiliated with their programs. No readily apparert explaratiars exist far hospice prafessigrais" somewhat lower resparise rate with respect to the availability iridicatgr, other than the passibility that their expectatiors were met (tiveir programs all had E4-hallr availability af professignals, ard their staffing matios were slightly higher), makirig this issue less salierit far them, ar that some haspice professigmals did rat see this 


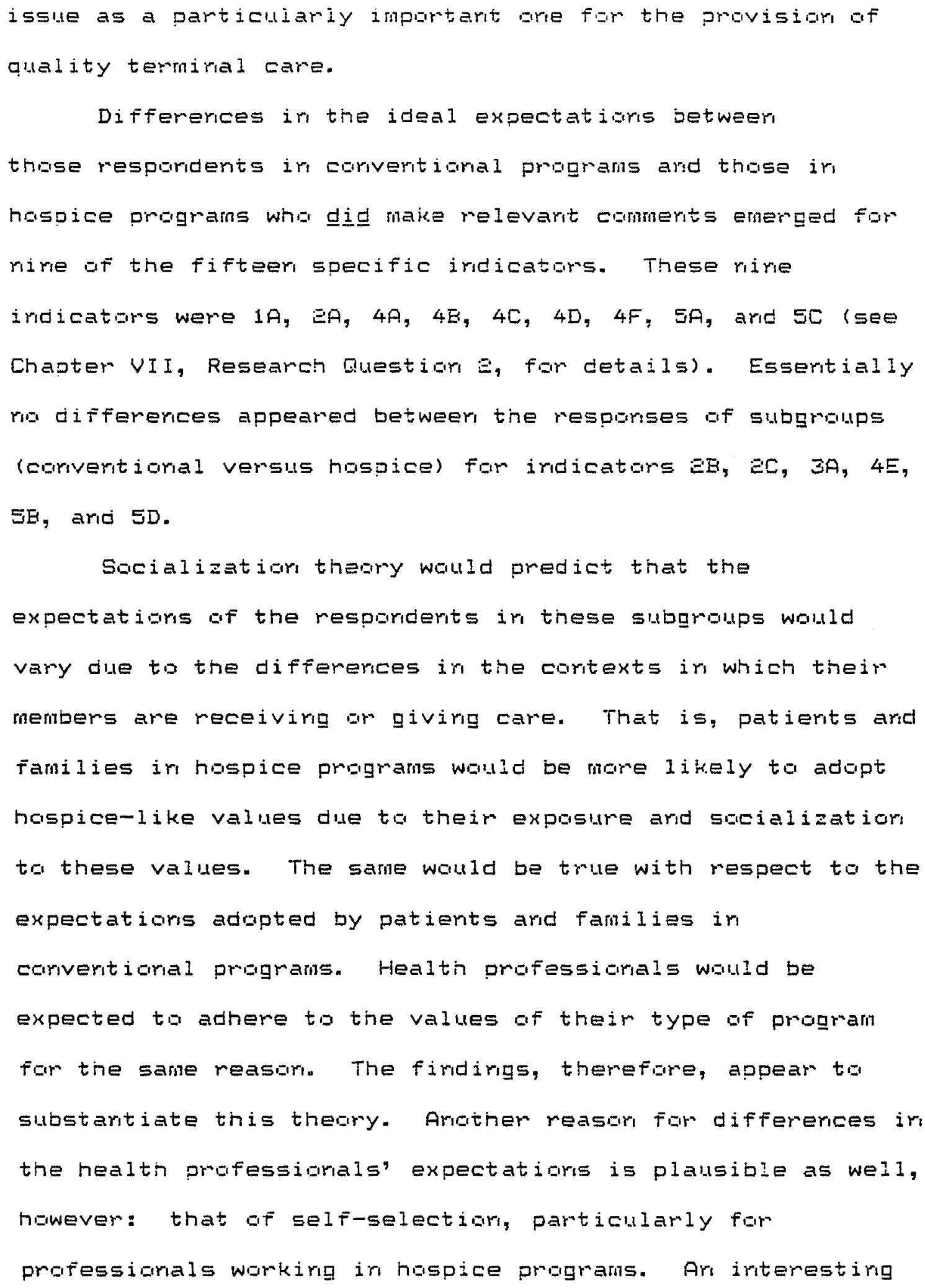


passivility is trat the reported arificts in the

oprfessigral socializatigr: received by ieaiti professigrals may have bereficiai aspects as weil as the regative butcome Gf role strain: these corficts may serve ta serisitize prafessigrals ta expectatigris corsisterit with bath madels of healti care provisigr, al iowirg tine professigral ta chase the set of rale expectatiars mast apprapriate ta a giver situatigri.

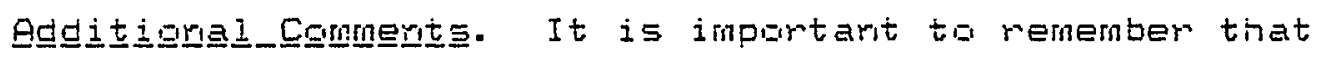
the patieris, arid mary of the family members, wiose iriterviews were araiyzed as part of this study were elderly. A "cotigrt effect," therefore, is probable. These iridividuals aro likeiy to have beer mare "gld schabi, "mare likely to nave rale expectatiors corsistert with the medical madel for health care provisior, arid less likely to have beer irifluericed by mecerst cultural swirgs ta the "pro-truti" mand (Veatch \& Tai, 1980) arid by the challerges pased to prafessigral authority by the comsumer rights ard self-help mavemerits. Irideed, Haug (1979) fiund that elderiy patierits were less likely to challerge professigral authority thar were yourger patierts. The reticerice af alder patients alsa was ruted by some family members and healtin professiarals. Traces of this pherbmeribr were evidert in the remanks cif a few patierits, who clearly were reluctarit ta complair abiut their care. This passible "cohort effect" has particular relevarice far patierits" irvalvemerit (Iridicatar 4C) in their 


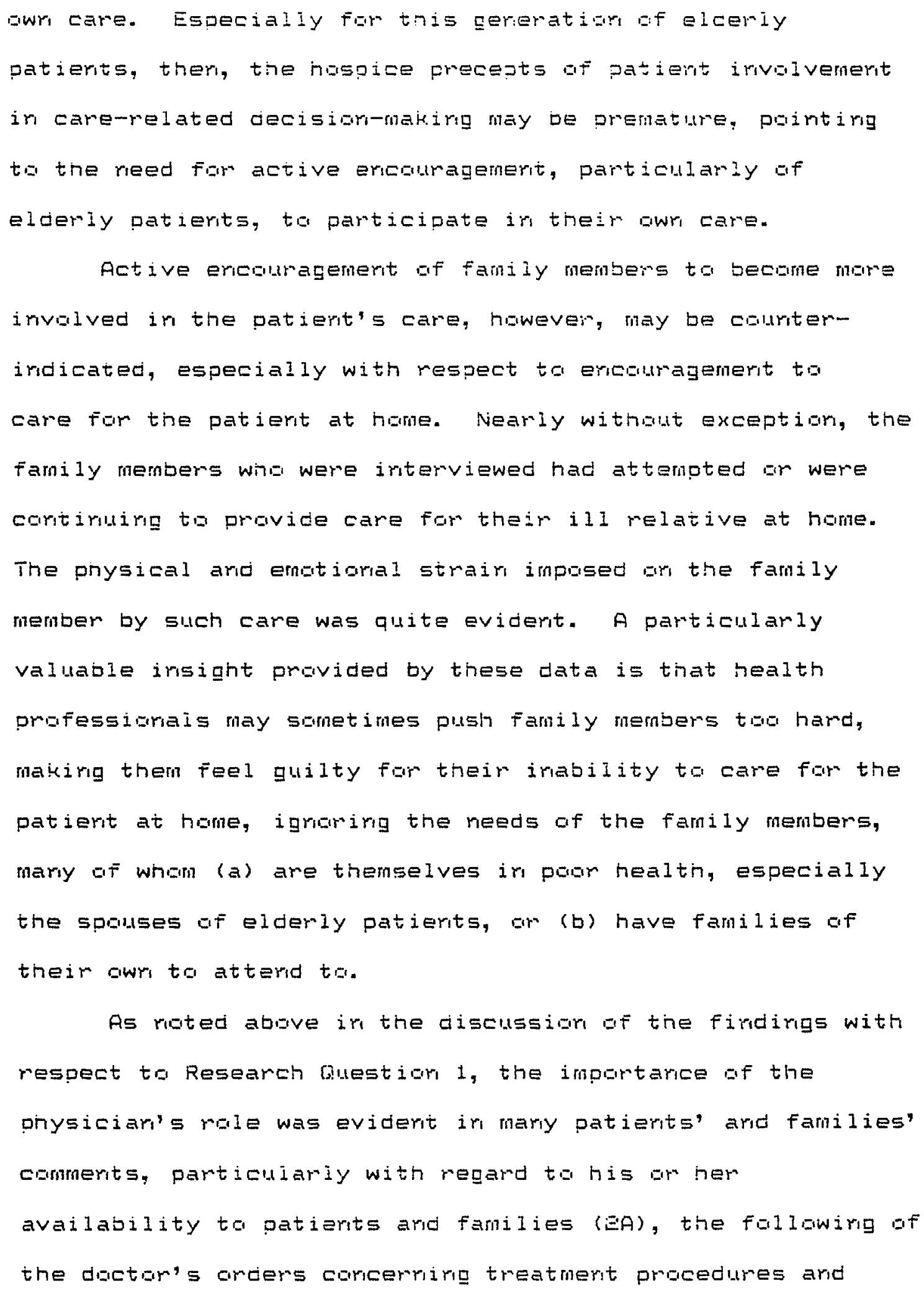




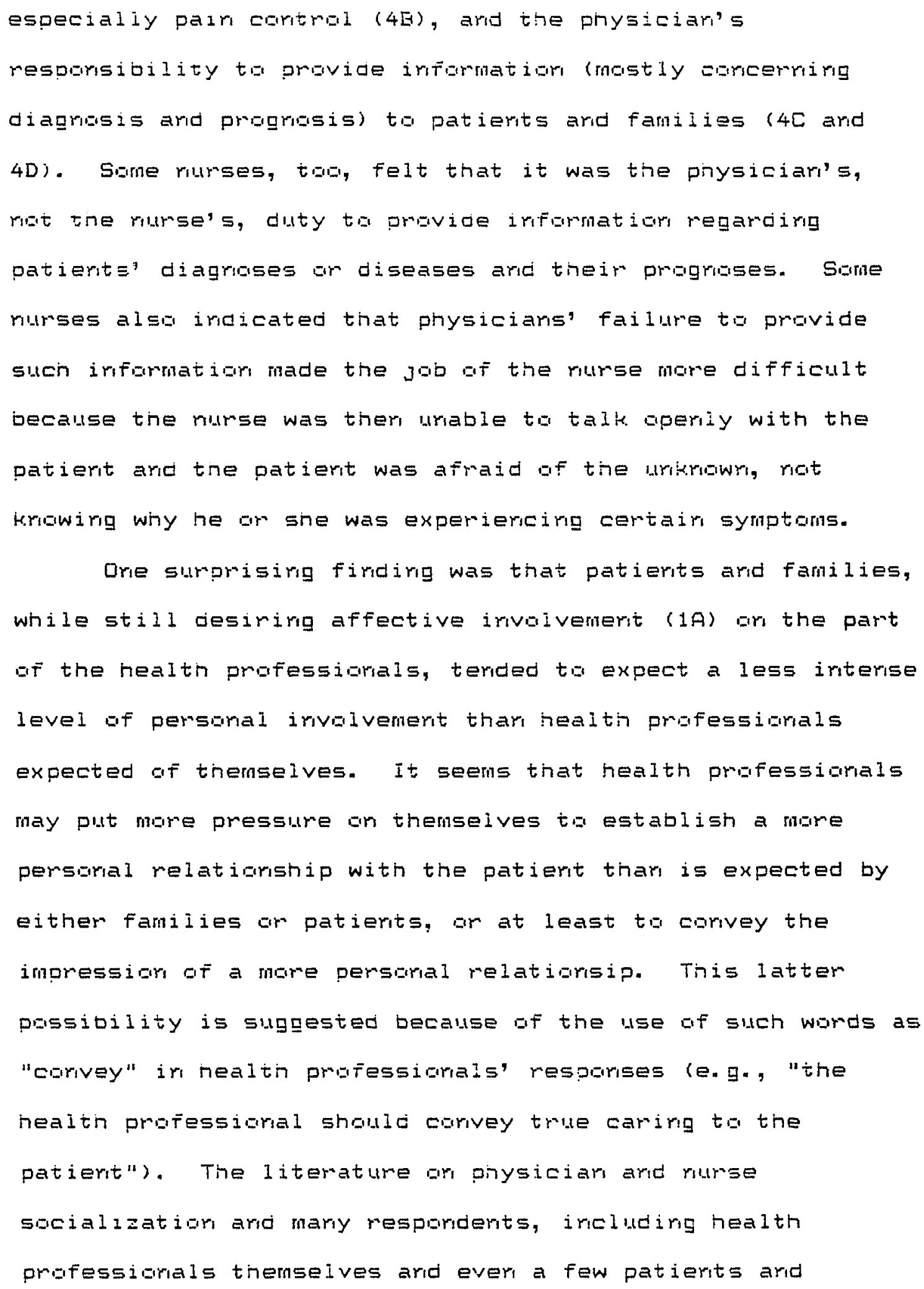




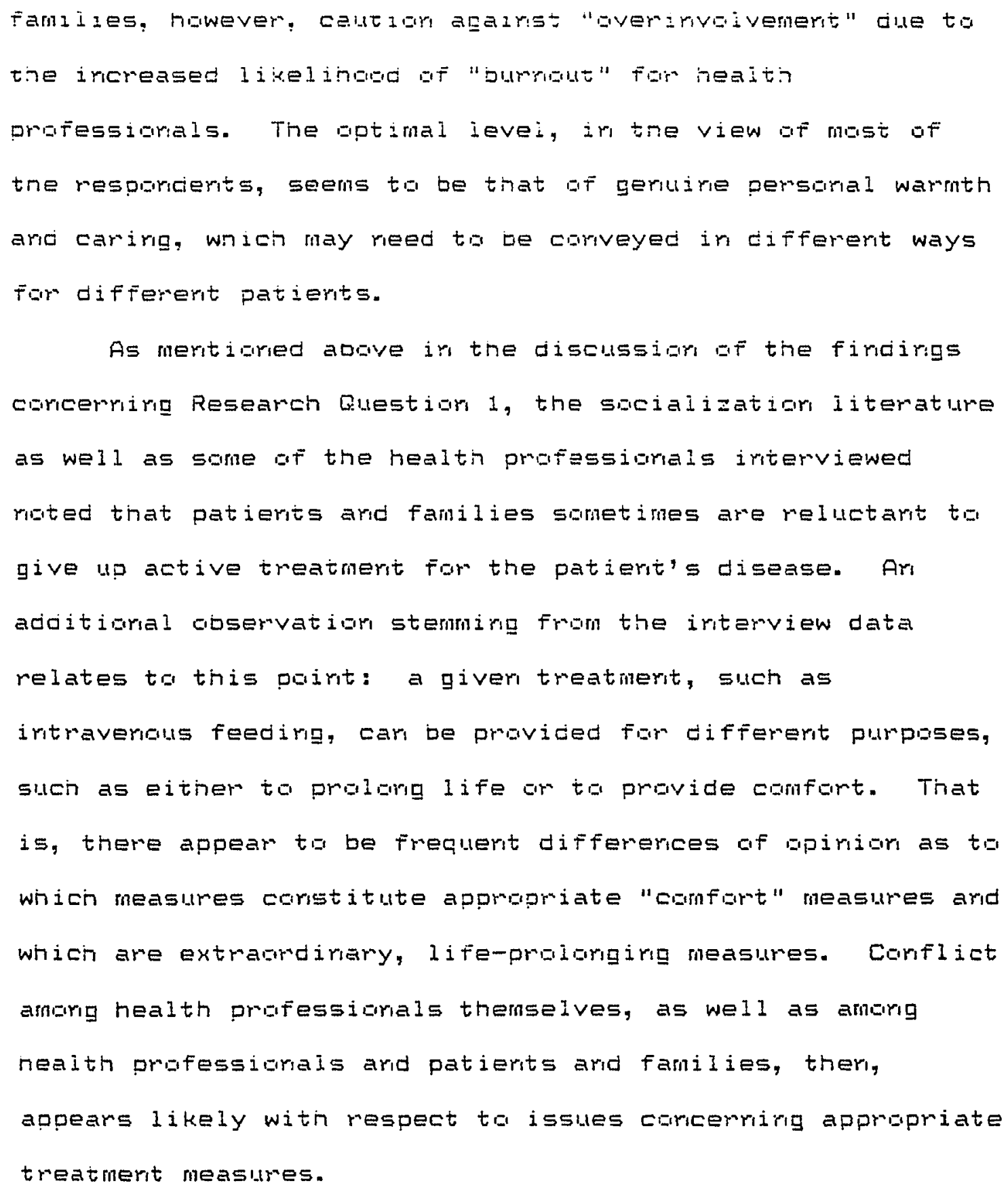




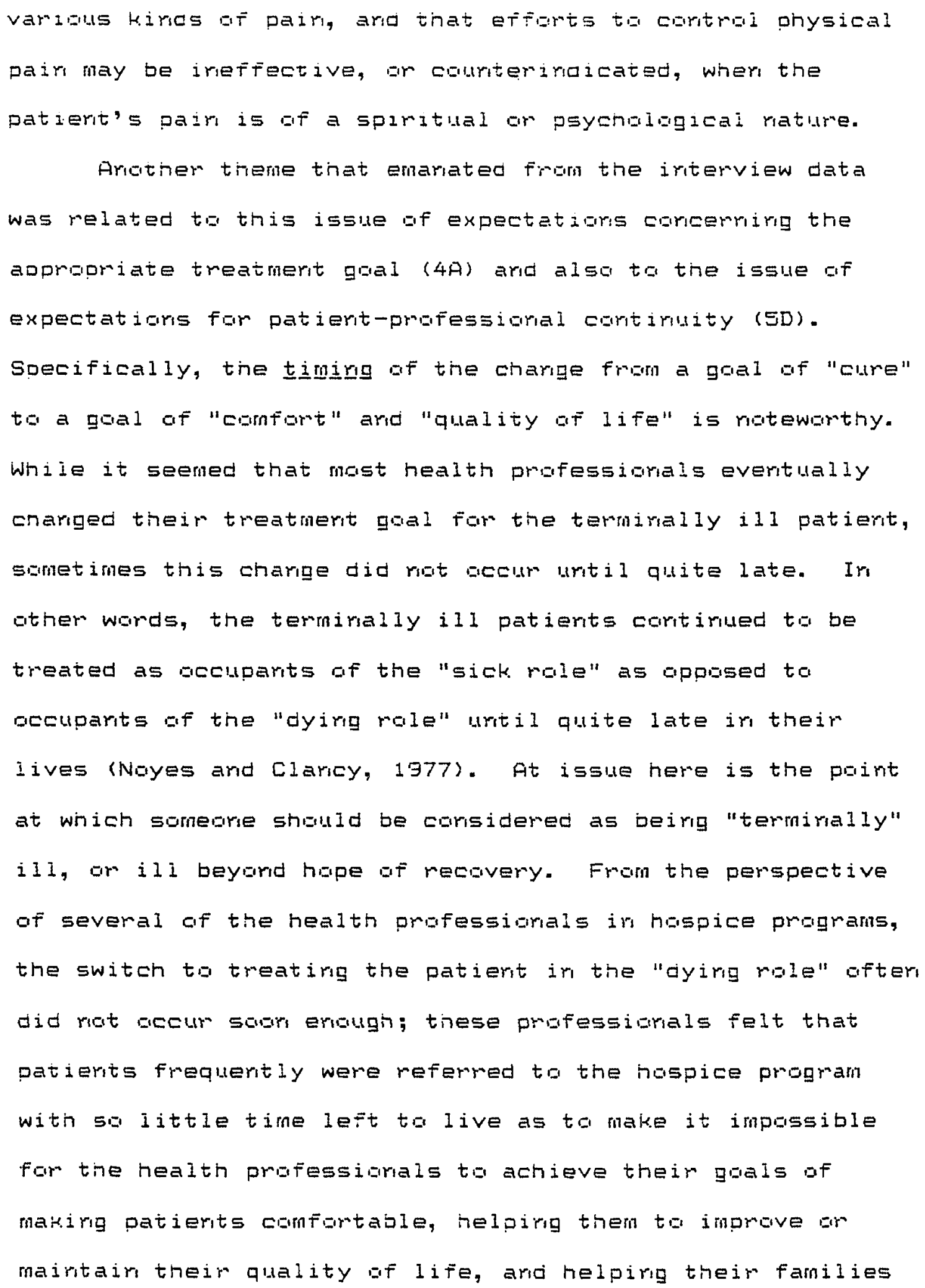




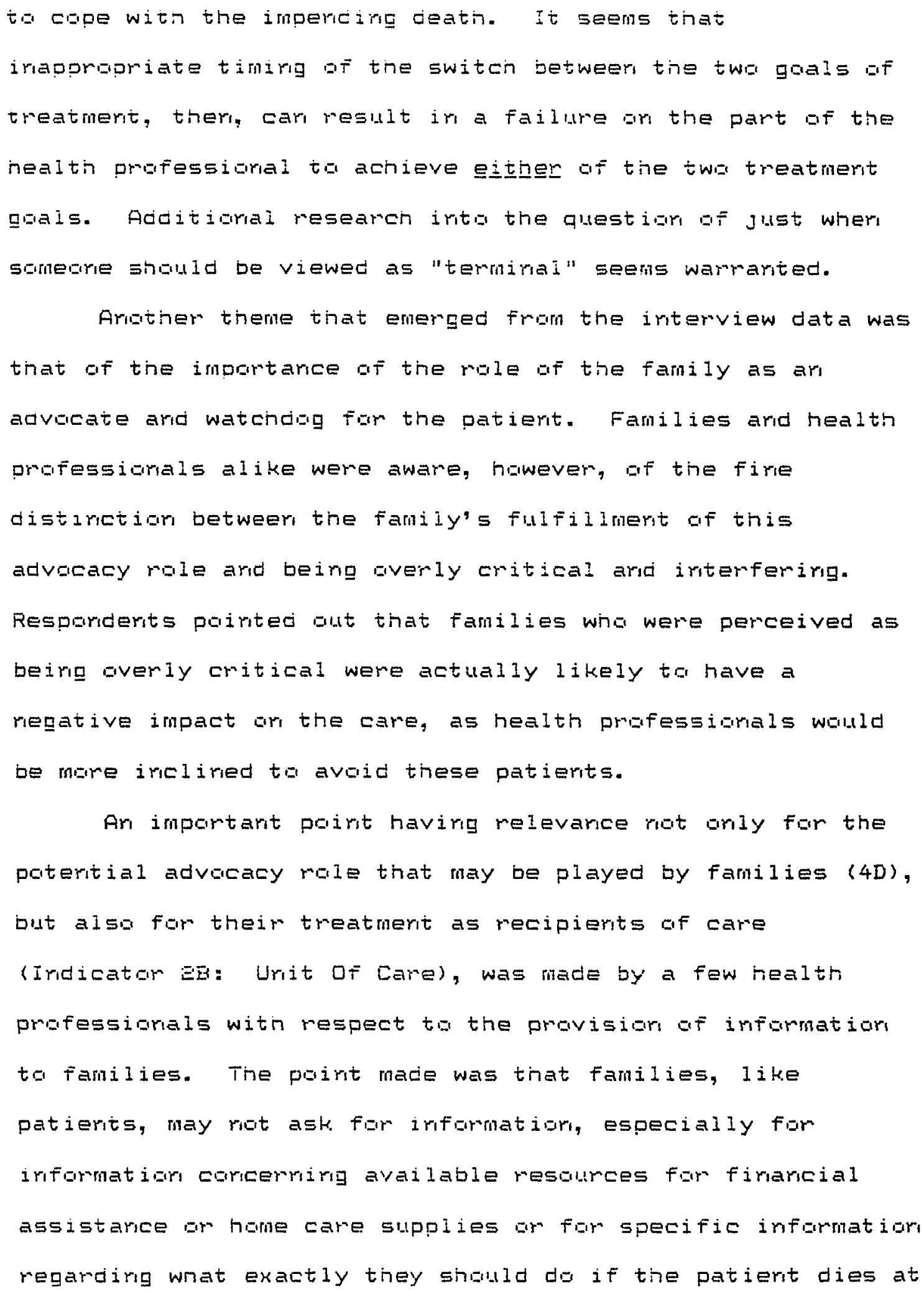


home, now to make furierai arrargerierts, etc. Dre health praf̈ssigra? assemted that while fanilies gereraliy will rot ask fur sich information, ard that whilg somehow the recessary activities surrabridirg a death do get disme, tine experierice culid be a much less tramatic ard stressful are for tie family if the mealth prafossigral weme to iritiate discussigr gf these issues. Provided that this were dirie with sersitivity, the recommeridation seeins to be a worthy Erie.

In the arigiral formuiation of the aralytical madel which pravided the basis far the araiysis af data reparted ar nere, Gre additicral iroicatar, "fibility ta Pay," was included. This irdicatar uitimateiy was eliminated from the model because its urit af aralysis was mit the health professigral but was irstead the orgarizatigr or system im whicin care was to be provided. Noretineless, a few remarks should be made with respect to this issue.

Six af the 17 patierits $(35 \%$ ) (twi corveritiomal, faur hospice) described comcerrs melative to their ability to pay for the care tiney were receivirg ar had received to date. Twerty-six family members (E8\%) described such carcerrs, eitner their awr ar their ill relative's $175 \%$ af tinase ir carvertignal programs, ard $61 \%$ af thase ir hospice prigrams). Mast af tinese persiris expressed carcerris that related ta services that were rot cavered by Medicare, or that nad ta da witin care recipierits reedirg to pay bills 


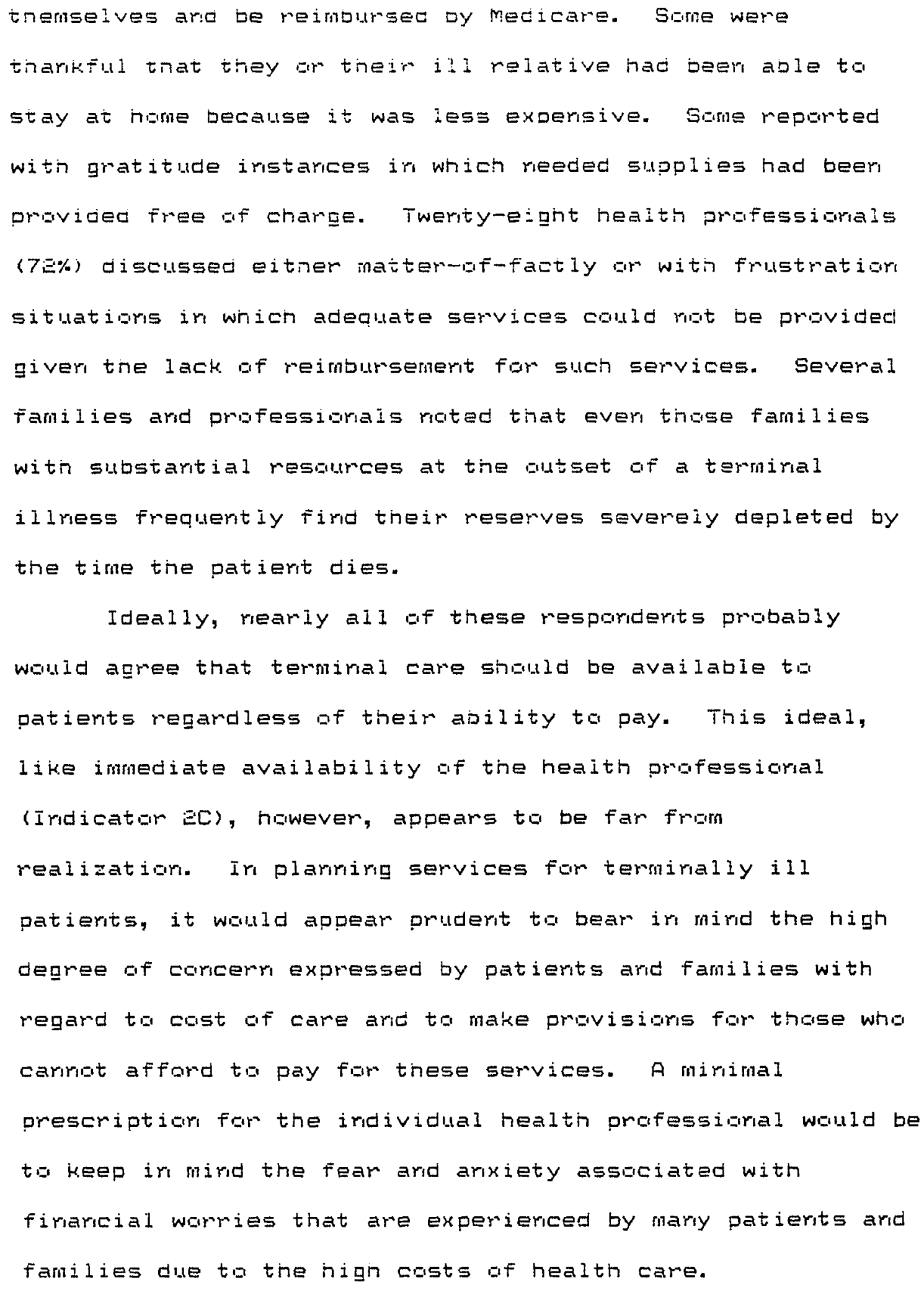




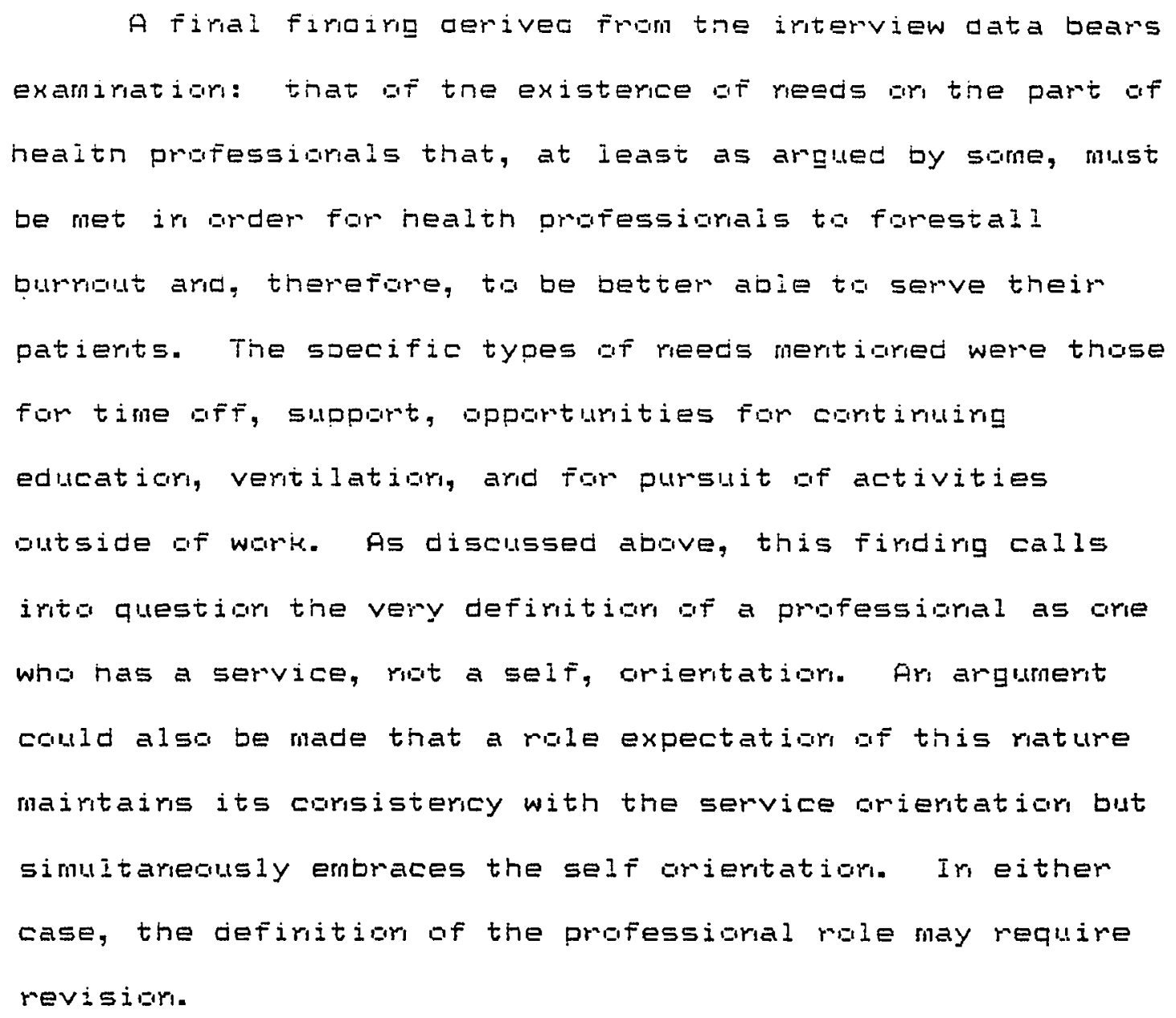


ingspice) modei gf care. Ir cortrast, as moted ir firdirgs 1 aric E Gf Researcn Guestiar 1, physiciars ard rurses appear

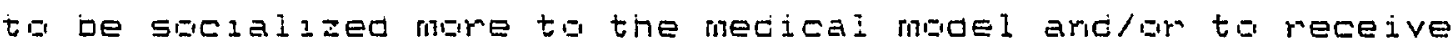
corifictirg sacializatior, that is, sacializatibr to aspects of buto tre mecicai madel ard the noilstic macel. The gererai corciusiar that cam be drawr, tinerefore, is that (a) respurcents" expectatiars, as a while, are rut cirsisterit witi those to wich pinysiciams ard numses are sceiai ized ard are mat likeiy ta be met, Gr (b) Fin thase rale expectatiars with respect to which pinysiciars ard/gr rumses receive carifictirg socialiaatigr, resporoerts' expectatiars are I ikely ta be met arily sametimes.

This corclusior, hawever, represerits a broad generaliIatiar that does rot take inta accourt the differemces that

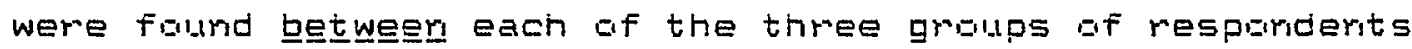
(patierits, family members, arid health prifessiarals) ir their expectatigrs with respect to four of the indicatgrs ard with respect to their varyirg rates af resporse to several of the indicators (see Research Questian E, Finding E). This firdirg also does mat carsider the differerices ir expectatiars that emerged withig each graup af respariderits, i.e., for resporiderits in corventioral as compared with nospice programs (see Researci Guestigr Ë, Firidirig 引). As a result, this carciusior, while accurate at a gereral level, aversimplifies the firdimgs. 


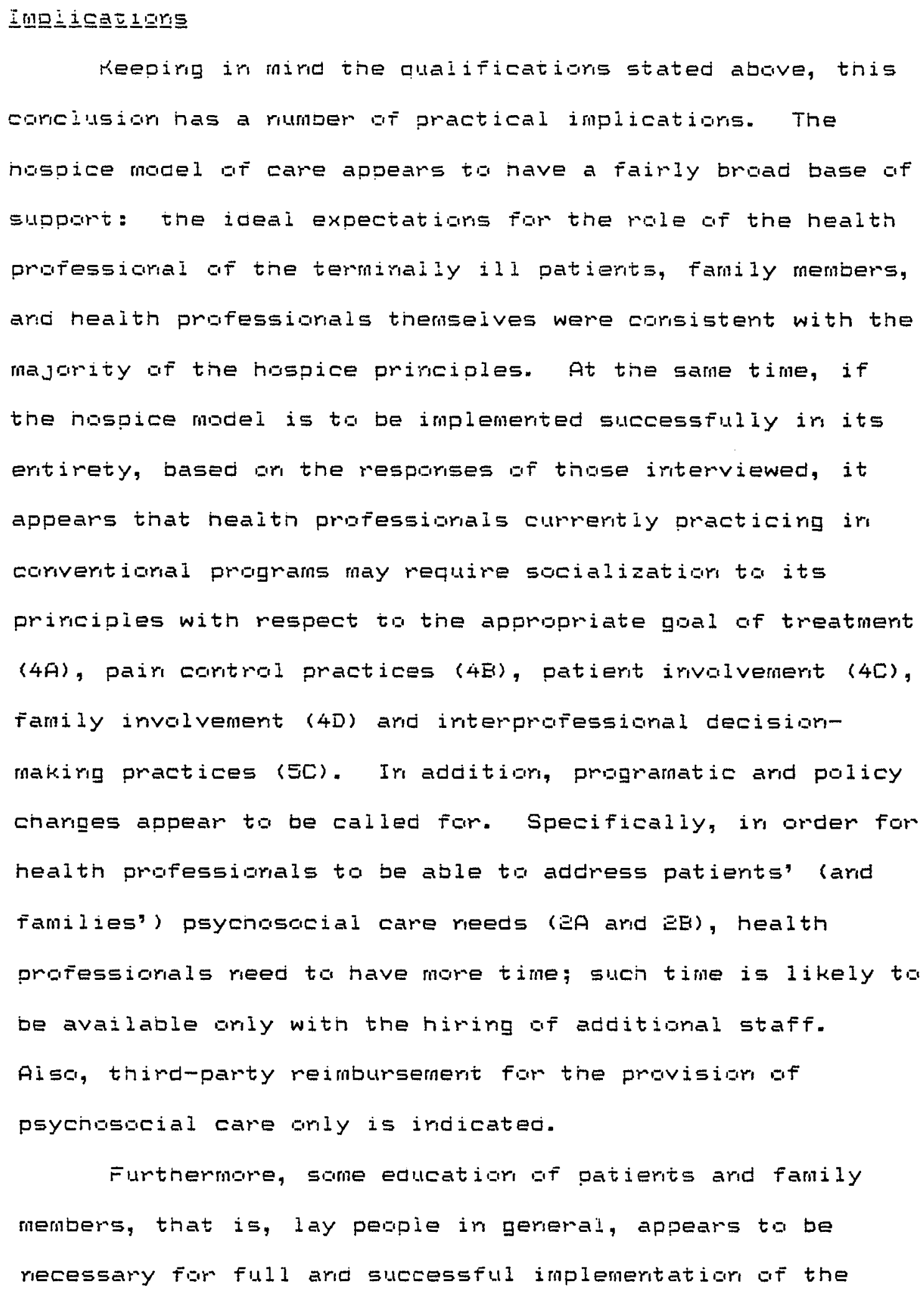


naspice mocei, especiaijy for trise wri have had ra prigr exposure ta br experierice witn naspice carcepts. Specific areas seemirg to reauire atterition are: the urit af care (EB): tine aporGpriate gaal of treatmerit (4A), appropriate par cartrai practices (4B), invalvemerit af the patient ir care-reiated decisigrs (4C), irvalvement at tive patient's family in the care (4D), ard interprafessiarai decisianmakirg ( $\Xi C)$. Especially giver the gradual movernerit tiward hoijstic care ard toward greater participation af lay persaris in their awr care, the hospice caricept, iri geremal, appears ta be viabie Gver the larg mur.

Ever, witn such scicializatior ard educatior, hawever, it is the opinior af this researcher that the basic Americar cultumal predispasition ta "rot give up" hope or a cure is urilikeiy ta be supplarted. Ir additiar, it seems probable that some patierits ard families will coritinue to nat wart to kraw, ar ta have patients kriow, their diagriasis and progrosis. Funthemmare, fears of patierits" becamirg drugdeperiderit ard af medicatigrs lasirg their effectiveness if administered over a larig perigd af time seem unlikely to be easily assuaged, especialiy amorg middie-aged ard elderly patients ard families. In sum, fill! adoptigr af all hospice precepts for care of the temminally ill may rut cocur for same time. Mareaver, this may rot ever be desirable; if such precepts are adhered ta Gr a braad scaie arid applied irdiscrimirately to all termiraliy ill penple ard their 
Famies. what might be comsigered time mast basis af ail the hisoice tarets will de vialated: that the care ar each patient and nis or her family mist be appraached ari an irrdividual, case-by-case basis.

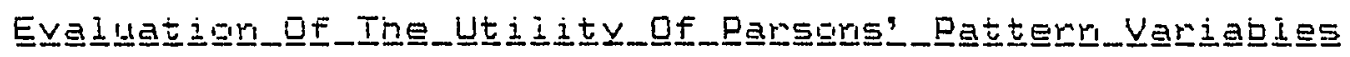

Ir gererai, Parsars, patterr variables as applied to tiis prablem af ideritificatian Gí the rale expectatiams far health professiarals in the provisian Gif quality temrimal. care proved quite useful for poiriting to the majar areas ar mige expectations. Aithaugh the rames of the pattern variables ard the 1 arguage used to describe tinem were fourd to be cumbersome ard gbscume, the pattern variables were extremely valuable in sigralirg impartart ameas for this role arialysis.

Drie problem ericauritered was the averlap between tine patterr variables; they do rut appear ta be mutulaly exclusive af are another, thereoy makirig ciassificatiar of certair roie expectatiors difficult. Comsiderable beriefit could de derived from further study ot tine iriterrelatimrships betweer the five variables. Nevertheless, the patterr variables did appear ta be measoriabiy comprehensive ard capable of differentiating betweer role expectatiaris prescrijed by the twi majar madels for the provisian of healtin care (the medical ard the holistic madels) as well as betweer tine miles at the 
pnysician aric the rumse. To maximize tre usefuiness aric clarity af whe patterr variasie framework fir tine problem adoressed in the prosert study, an eiaboration af the pattemr variagles, in the farm or develounert af varigus "Iridicators," was uridertaken (see Chapter VI, Aralytical Madei).

Ore patterr variagle arid, particularly, Gre af the iroicatars developed cauld beriefit from further study: the "actievemert-ascriptiar ariertatior" patterr variable ard the irdicatar, "criteria far evaiuatiom of the health prafessicirai" (4F). Just what characteristics corstitute a perfommance-oriertatior as opposed to ar ascripticrorieritatior is highly debatable. For example, persoral characteristics such as beirg "compassigrate" ar "havirgg a talert for carirg for ald peaple" car dimectiy affect the healtn professiarai's perfommance capacity, yet they may also be corisidered as ascribed characteristics (see Chapter VII, Results, Research Question 2 , Iridicator 4F). Some additigral recarmeridatigrs far future reseamci follaw.

\section{RECOMMENDATIONIS FOR FUTURE RESEARCH}

A rumber af areas af iriquiry related ta the prablem addressed in the presert research appear to be fruitful and deservirg af future study.

1. Systematic empirical study of medical arid numsimg schagis is recammericed ir order ta determire empirically the 


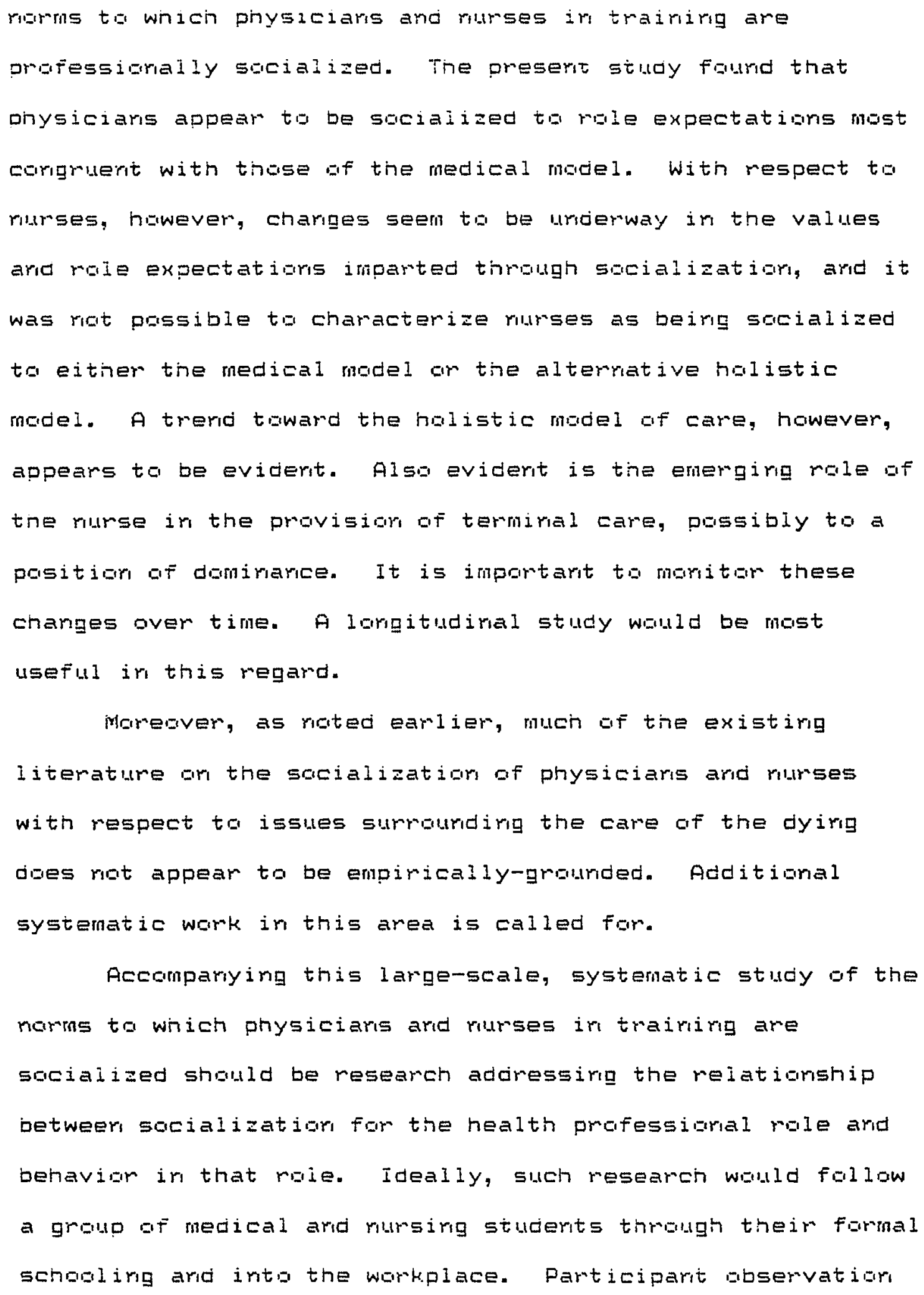


mignt be a particularly useful techrique fur assessirg the neaitn prifessigrials' mole benaviar.

2. Exterisiar af the present study ta avercame its numernus desigr limitatiars is recessary ir craer far valid, gerieralizable fimdimgs to be cotaired with respect to the ideal expectatigrs for the heaitn professiamal raie. Particuiamly, the rumber of patients, family members, and nealtn professiarais irterviewed shauld be ircreased. Ir additidr, a greater etinric mix af resparderits should be obtaired, arid trie sample shauld be ratigral, rat primarily lacal, in scape. Furthermare, mesponderits, particularly patierits arid families, shiuld be at́ varibus ages. Ar agestratified crass-sectianai desigri would mimimize ary cohort efFects cibtaired with mespect to expectatiars for the health professignal role to which patients and families may have beer sacialized. Aiterratively, a lorgitudiral desigr would erable the monitoming of changes in roie expectations gver time. Similanly, study cü prospective patients ta determine their expectatiars for the health professigral mole in the provisigr af quality termiral care witn follawup iriterviews of patients wha became termiraliy ill willd be enilightering as to chariges ir perspective that may gccur arice ar iridividial has beer diagriased as having a terminal iliness. The healtin professicrals iriterviewed shauld be physiciars ard ribrses, some of eacin gerder. With the exparisibr, in the nalistic madel of care, Gf the scope af care ta irclude tine 


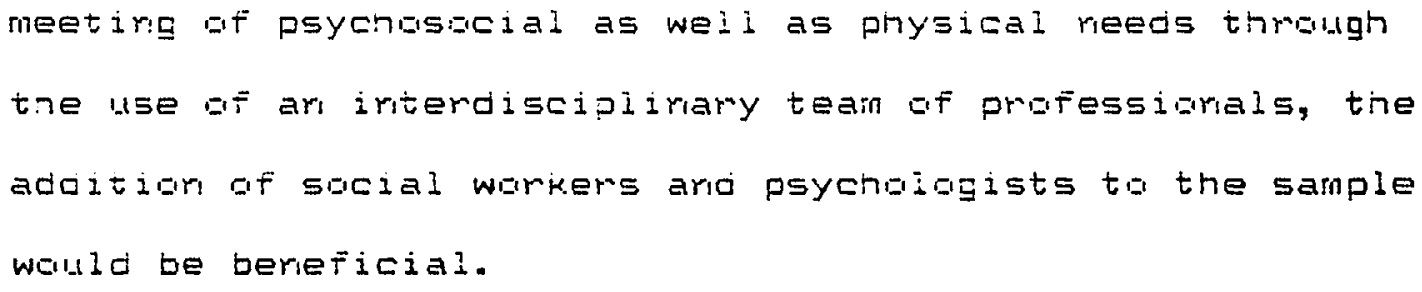


ar care, yet iltie atterition has beor aevotec to the questiar, "Wha is the family?"; that is, "Winich family members snauld receive treatmerit?" Licerlyiro tnis precept is a perspective af the family as a system, as a furctiarimg whoie compriseo bf mary parts. How realistic is it ta expect the heaito prof̈essigral ta address tine rieeds gf all thase fanily members irvalved with tine patierit? Future research snauld begir to examine tinis issue.

E. Systematic empirical study af the reeds of termirally ill patients and tnein families is imperative. Hucin af tine existing literature is impressibristic, yet eritime treatmerit megimes are plarmed upar healti professiarals" perceptiars ruf the variaus reecs af patierits arie families.

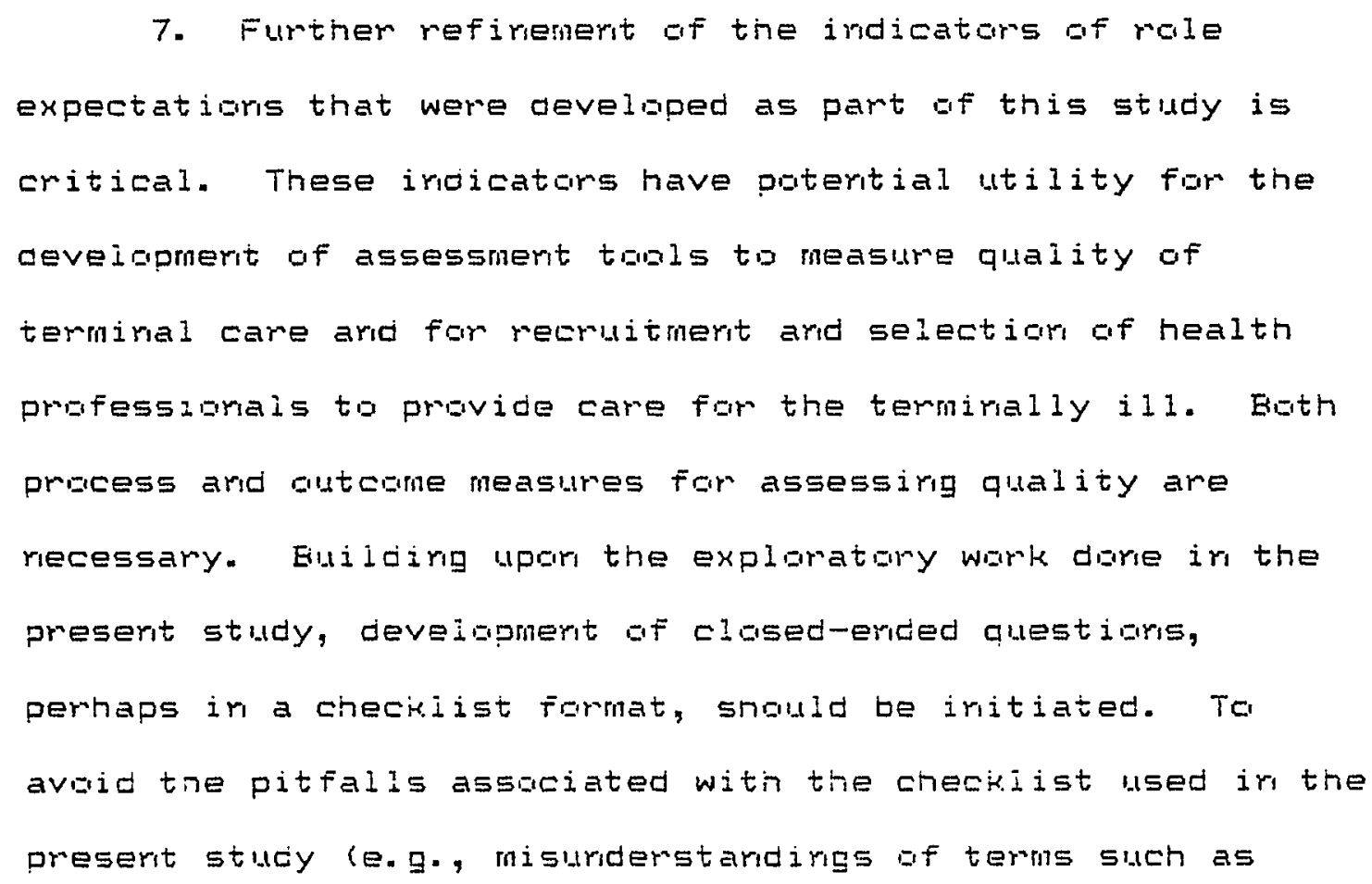




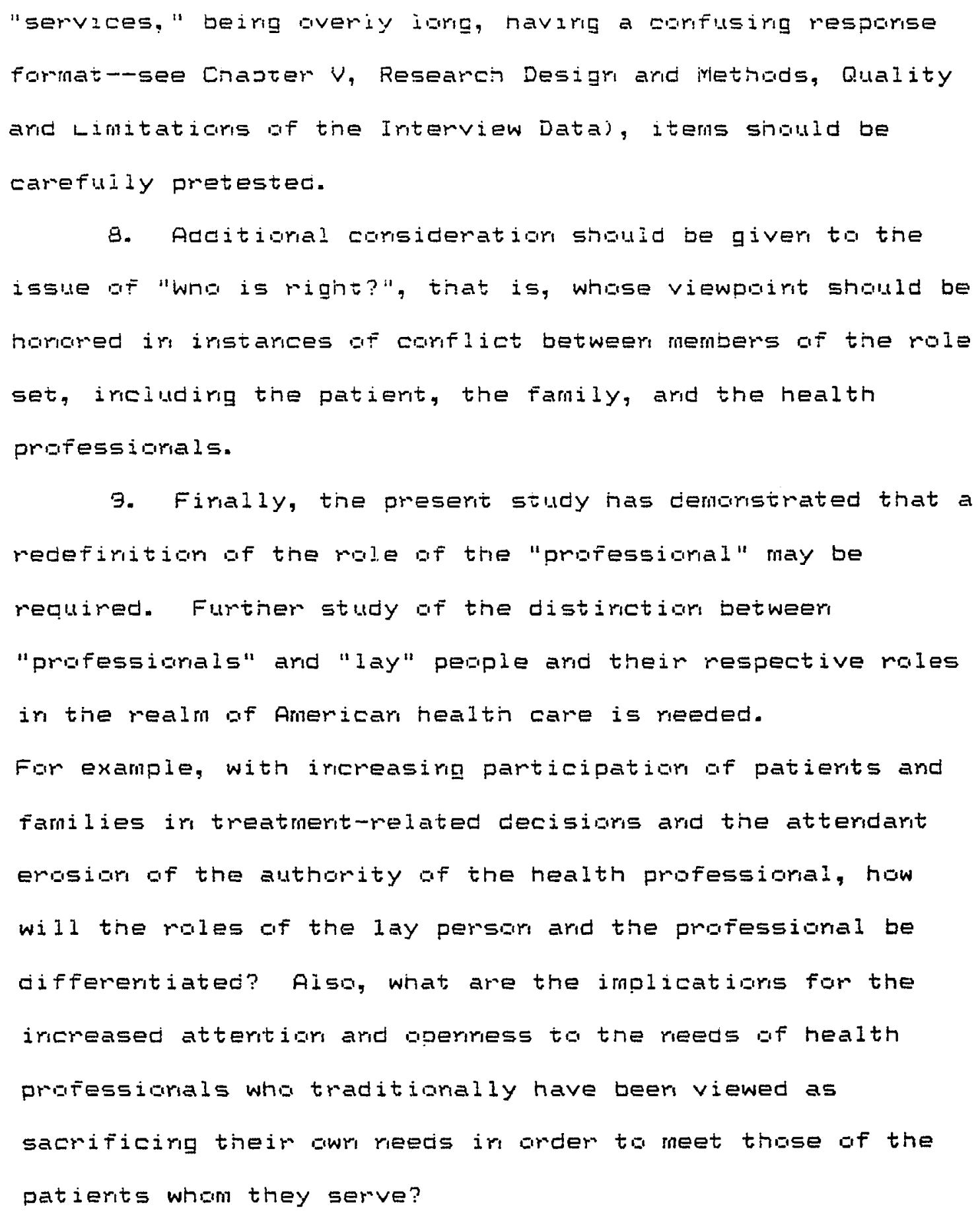




\section{CONTRIBUTIONS DF THE PRESENT STUDY}

In summary, this study has made some methodological, theoretical, and practical contributions, including:

1. The application of Parsons' pattern variables, which were first conceptualized as dimensions which would describe ways role could vary (Parker, 1978), in an analysis of the expectations associated with a particular role. Typically, when the issue of expectations for a given role is raised, one or two types of role expectations may be addressed or focused upon; rarely is an attenpt made to examine comprehensively the expectations associated with a particular role. This study demonstrates the value of Parsons' pattern variables: as offering a fairly comprehensive framework, a broad perspective, within which the various expectations associated with a given role may be viewed.

2. The use of Parsons' pattern variables specifically

to: (1) to identify (a) the role expectations to which health professionals (physiciars arid nurses) are socialized with respect to the provision of quality terminal care and (b) the ideal expectations for the health professional role in the provision of quality terminal care as held by a group of terminally ill patients, family members, and health professionals; and (2) compare (a) and (b). The patterr 
variables were found to be useful vehicles for viewing and discrimirating between role expectations associated with the current dominant model of health care provision in America today, the medical model, and an alterrative model, the holistic care model, which, in the specific case of terminal care, is embodied in the hospice model. To date, no such systematic analysis has been made of the expectations associated with the role of the health professiorial in the provision of quality terminal care.

3. A call for reexamination of the definition of a "professional." This research demonstrated that the rale of the health professional within the medical model differs from that of the health professional within the alternative, holistic model, and specifically, the hospice model. Either professionals within the alternative model are not really professionals or a redefinition of the role of the professional is required.

4. The generation of specific indicatars of role expectations, elaborating upon Parsons' pattern variables. Following further refinement, these indicators car be used: (a) to develop instrumentation for assessing the quality of terminal care; and (b) for recruiting and selecting health professionals for the provision of quality terminal care. 5. The shedding of $1 \mathrm{ight}$ onto some specific areas of role expectations in which there appear to be conflicts in socialization of physicians and nurses. These conflicts may 
result in role strain and, therefore, may signal areas irs which changes in socialization practices may be indicated in order to reduce such role strain and conflict.

6. The provision of insight into the specific ways in which terminally ill patients', family members', and health professionals' perspectives may be similar and different, and also the ways in which the views of persons assaciated with converitional programs may compare with those of persons giving or receiving care in hospice programs. These findings have implications both for role theory arid for socialization theory as well as practical implications related to the reduction of conflict between members of the role set so as to enhance perceived quality of care. 


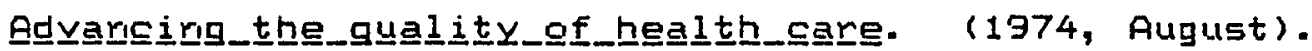
Washingtor, DC: National Academy of Scierices, Institute of Medicine.

Alexy, W. D. (1981-8E). Perceptioris of ward atmosphere on

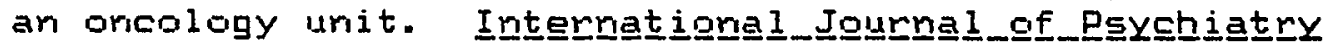

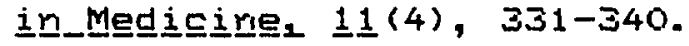

Alutto, J. A., Hrebirisk, L. G., \& Aloriso, R. C. (1971). A study of differential socialization for members of

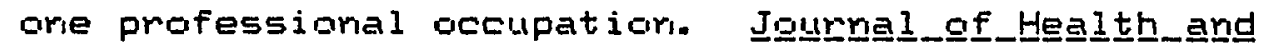

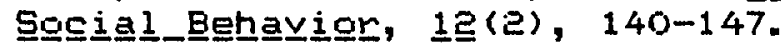

Bamrard, C., \& Pellegrino, E. (1976). The right to die: Two views. Current, 180.

Becker, H. S, Geer, B., Hughes, E. C., \& Strauss, A. L.

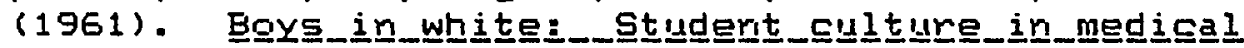
schegl. Chicago, IL: University of Chicago Press.

Beraliel, J. Q. (1979). Dying is a family affair. In E. R. Prichard, J. Collard, J. Starr, J. A. Lockwood, A. H. Kutscher, \& I. B. Seelard (Eds.), Herne_care:

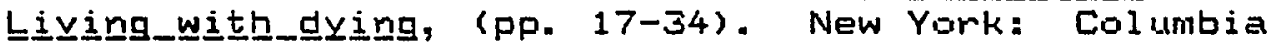
Uriversity Press.

Beverly, $E_{n} V_{n}$ (1976). Understandirig ard helping dying patients and their families. Geriateriess, $\underline{\underline{1}}(3)$ : $117+$.

Biddle, B. J. \& Thomas, E. J. (1966). Rolethegery:

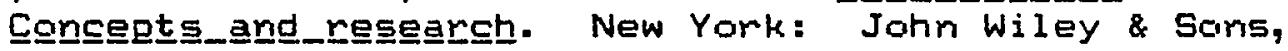
Inc.

Block, D. (1975). Evaluation of nursing care in terms of process and outcome: Issues in research and quality

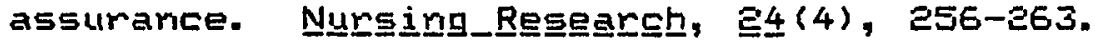

Bloom, S. W. (1979). Sacialization for the physician's role: A review of some contributioris of research to theory. In E. C. Shapiro \& L. M. Lowenstein (Eds.),

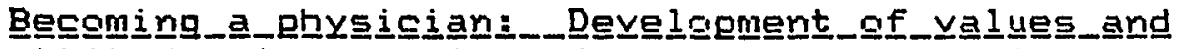
atteituudes_in_medicine, (pp. 3-5e). Cambridge, MA: Eallinger Publishing Company. 
Bloom, S. W. \& Summey, P. (1976). Madels of the doctarpatient relationship: A history af the social system concept. In The_doct chhanging_healetㅡ﹎. scenene, (PP. 17-41). Washirgton, DC: Natiorial Institutes af Health, U.S. Department of Health, Educatior, and Welfare.

Blumenfield, M., Levy, N. B., \& Kaufmar, D. (1979). Current attitudes of medical students and house staff

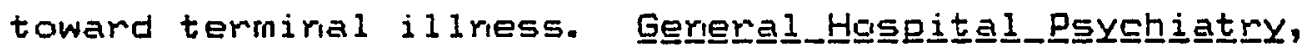
$1(4), 306-310$.

Bowers, J. W. (1970). Coriterit aralysis. In P. Enment \&

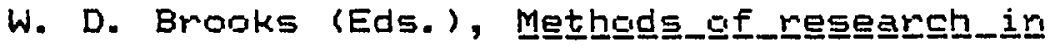
communicatation, (pp. 29̄1-314). Bostori: Houghtor Miffi in Company.

Breiridel, C. L. \& Acree, C. L. (1980). Estimates of nieed far haspice services. Deaㅡㄴㅡ_E므쓰크흐으, $4(3)$, 215를.

Brin, 0. G., Jr. (1976). Adult socialization. In R. Atchley \& $M$. Seltzer (Eds.), Ihe_sgcigologgy_ef_agging:

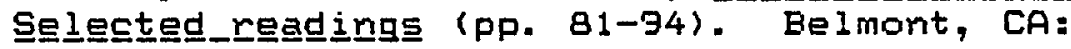
Wadsworth Publishing Company, Inc.

Brook, R. H. \& Davies-Avery, A. (1977). Mechangisms_for

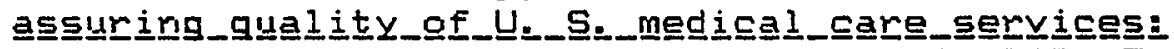
Past__ereserit,_and_future (Report No. R-1939-HEW). Washingtor, DC: Department of Health, Education, \& Welfare.

Brook, R. H., Davies-Avery, A., Greerfield, S., Harris, L. J., Lelah, T., Solomon, H. E., \& Ware, J. E., Jr.

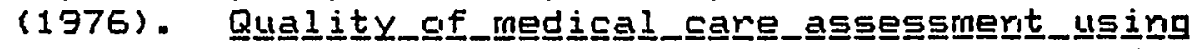

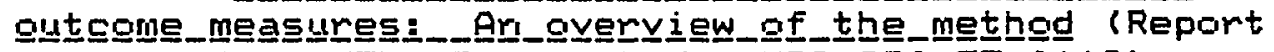
No. R-Eoᄅ1/1-HEW; Coritract No. HRA E30-75-0112). Washington, DC: National Certer for Health Services Research, Health Rescurces Administration, Departmerit of Health, Education, \& Welfare.

Buckingham, R. W. \& Lack, S. A. (1977). Final_regort_te

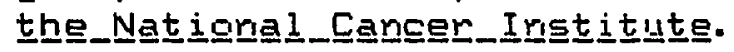

Euckingham, R. W., Lack, S. A., Mourit, B., Maclean, L., \& Collins, J. (1976). Living with the dying: Use of the technique of participart abservation. Eanadian

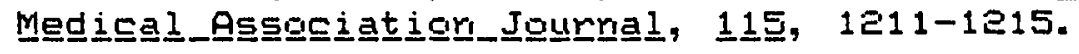


Buckley, I. G. (1979). Fulfillment of life in the preserice of death. Ir E. R. Prichard, J. Collard, J. Starr, J. A. Lockwood, A. H. Kutscher, \& I. B. Seel and (Eds.), Home_Eare:_Livirng_with_dying (pp. 199-204). New York: Columbia University Press.

Budner, S. (1979). Shall we look before we leap? In E. R. Prichard, J. Collard, J. Starr, J. A. Leckwoad, A. H. Kutscher, \& I. B. Seeland (Eds.), Home_caare:

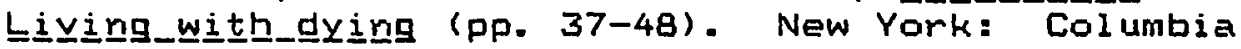
University Press.

Butterfield-Picard, $H_{n}$ \& Magric, J. (1982). Hospice the

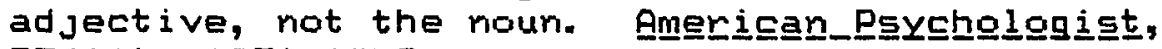
37 (11), 1254-1259.

Callan, J. P. (1979). The haspice movement. Jgurnal_ofof

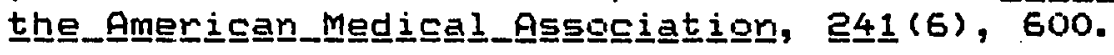

Clifford, I. M. (1979). Comprehensive plariring for care and the home health agency. In E. R. Prichard, J. Collard, J. Starr, J. A. Lockwood, A. H. Kutscher, \&

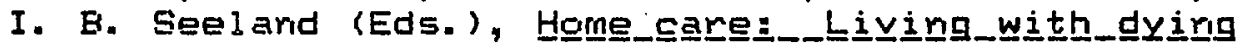
(pp. ee3-231). New York: Columbia Uriversity Press.

Cohen, K. P. (1979). Hosgice:_erescriptign for terminal 드르. Eermantown, MD: Aspen Systems Corporation.

Calen, B. D. (1976, Dctaber 31). Ten bad days amang the dying. Wha

Corway, M. E. (1978). Theoretical approaches to the study of moles. In M. E. Hardy \& M. E. Corway (Eds.) Role

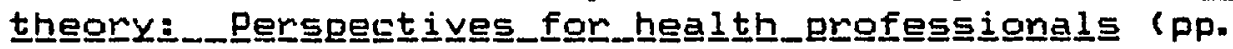
17-27). Norwalk, ET: Appletori-Century-Crofts.

Coombs, R. H. (1978). Magstering_medicicines_-Professignal

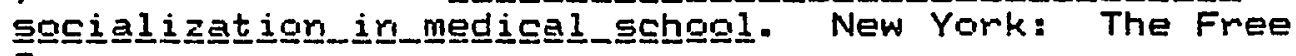
Press.

Coombs, R. H., \& Powers, P. S. (1975). Socialization for

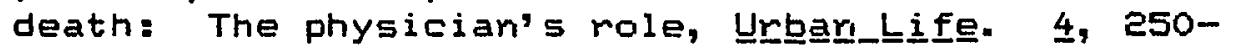
e71.

Coppens, M. (1979, Fal1). Iriterverition through sexuality counseling. In Oregon Compreherisive Cancer Program,

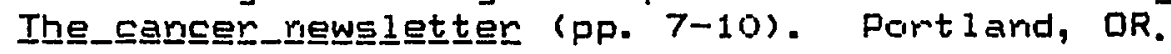


Cox, J. (1978). Springfield (1978)--St. Jehn's Hospice. In G. W. Davidson (Ed.), The_hosgice :_develogement_and

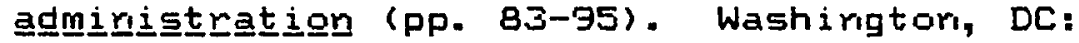
Hemisphere Publishing Carporation.

Craven, J. \& Wald, F. S. (1975). Hospice care for dying

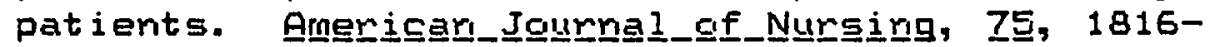
1822.

Craytor, J. K. (1979). Working with dyirig patients arid their families. In E. R. Prichard, J. Collard, J. Starr, J. A. Lockwoad, A. H. Kutscher, \& I. B. Seeland (Eds.), Hgrne_caㅡㄹㅡ﹎ㄴiving_with_dying (pp. 3748). New York: Columbia University Press.

Davidson, G. W. (1978a). Preface. In G. W. Davidson

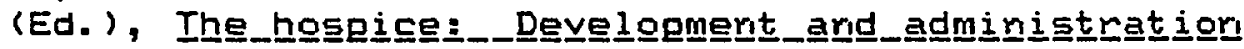
(pp. $v-v i i$ ). Washington, DC: Hemisphere Publishing Corporation.

Davidsor, G. W. (1978b). In search of models of care. In G. W. Davidson (Ed.), The_hoseiceg:_-Develelggment_angd aqinisistratign (pp. 145-161). Wastington, DC: Hemisphere Publishing Corporation.

Dickenson, G. E. (1976). Death education in U. S. medical

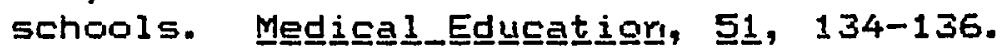

Donabedian, A. (1966). Evaluating the quality of medical

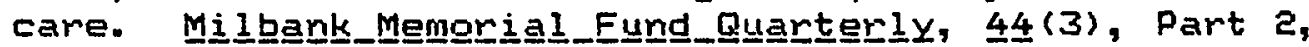
$116-323$.

Donabedian, A. (1969). A guide to medical care adminis-

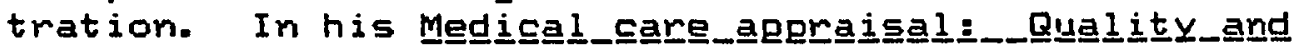
ut il 1 ization (Vol. II). New York: The American Public Health Association.

Donabedian, A. (1978). The quality of medical care. In

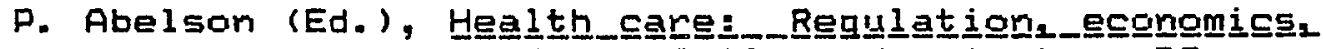
ethi도. Hemisphere Publishing Corporation.

Donabediar, A. (1980). The definition of quality and approaches to its assessmerit. In his Explolgrateigns_irn guaㅡ므느﹎. Arbor, MI: Health Administration Press. 
Dowsett, E. G. (1972, December 30). The dying patient. 느크드르트, ㄹ, 1416 .

Dubin, R. (1960). Parsars' actar: Continuities in social

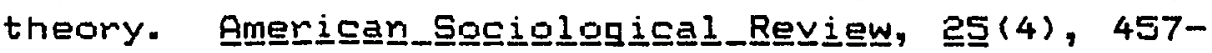
$4 \in 6$.

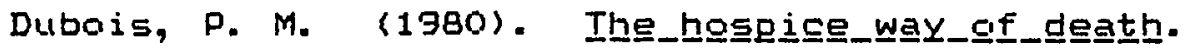
New York: Human Sciences Press.

"The dying patient." Langcet, 197e, ㄹ, 1e38-1239.

Epsteir, F. H. (1374). The role of the physician in the prolorigation of $I$ ife. In $F$. J. Ingelfinger, R. $V$. Ebert, M. Firiland, \& A. S. Relman (Eds.), Controverssy

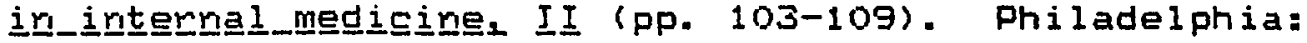
W. B. Sauriders.

Feifel, H. (1963). Death. Ir N. L. Faberow (Ed.), Iaㅡ므느모도. New Yark: Atherton Press.

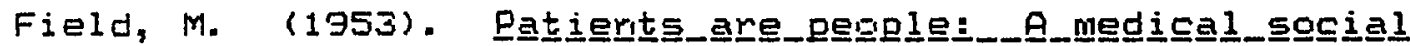

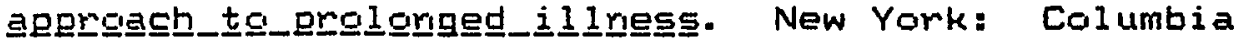
University Press.

Fax, R. (1957). Trairing for uncertairity. In R. K. Mertor, G. Reader, \& P. K. Kendall (Eds.), Ihe

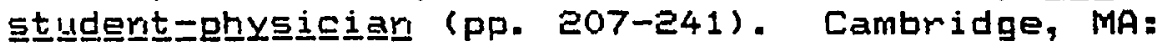
Harvard University Press.

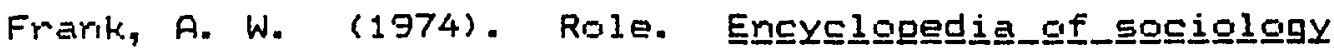
(p. E46). Guilfard, CT: Dushkin Publishing Group, Iric.

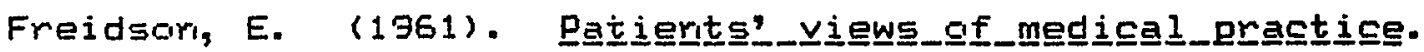
New Yark: Russe11 Sage Fourdation.

Freidson, E. (1970a). Profession_gf_medicinine:_A_study_of

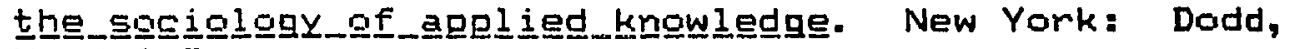
Mead \& Compariy.

Freidsarl, E. (1970b). Professignal_dgminarice:_-The_social

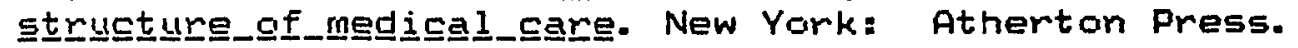

Freihofer, P., \& Feltor, G. (1976). Nursing behaviors in bereavement: Ari exploratory study. Nurssingn_Regsegarch Es (5), 332-337. 
Gernain, C. P. (1380). Nursirg the dying: Implications af Kubler-Ross' staging theory. Arinals Amer $4 \overline{6}-5 \overline{8}$.

Gidecr, M. (1979). The hospice movernerit. Jgurnnal__of_the

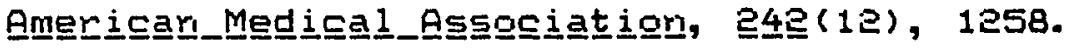

Glaser, B. G. \& Strauss, A. L. (1965). Awwareneness_of dyirrg. Chicago: Aldine.

GIaser, E. G. \& Strauss, A. L. (1968). Iine_for_dying. Chicago: Aldine.

Glick, J. H. (1975). A doctar's prescriptior for mercy.

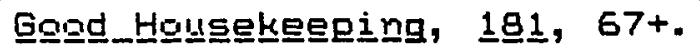

Gliebe, W. A. (1977). Faculty corsensus as a socializing agerit in professicinal education. Nurs

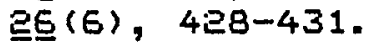

Gacide, W. J. (1960). Encroachmerit, charlatanism, and the emergirg profession: Psychology, medicine and

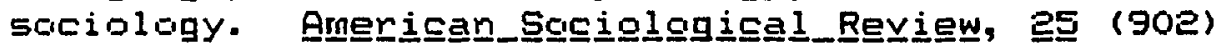
scited in Robirisor, 1974)

Gordan, G. (1966). Role_thegeny_and_i lilness:_으scgciolog Uriversity press.

Greer, D. S. (1983). Hospice: Lessons for geriatricians.

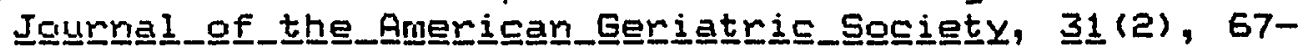
70.

Hackley, J. A., Farr, W. C., \& MeIritier, Sr. T. M. (1978) Tuscon (1977)--Hil lhaven Hospice. In G. W. Davidsor,

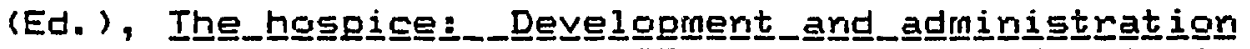
(pP. E3-8E). Washingtar, DC: Hemisphere Publishing Comporation.

Halper, T. (1979). On death, dying, and termiriality: today, yesterday, and tomorrow. Jgunnnal_of_Healith

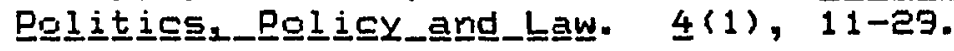

Hampe, 5. 0. (1975). Needs of a grieving spouse in a

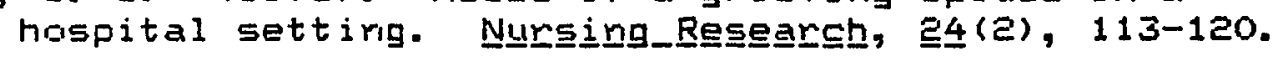

Hardy, M. E. (1978). Perspectives on krowledge and role theary. In M. E. Hardy \& M. E. Canway (Eds.), Role

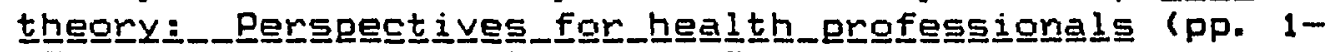
15). Norwalk, CT: Appleton-Century-Crofts. 
Harmar, M. S. (1971). Medical education and the socialpsychological care of dyirig patients. (Doctciral dissertation, University of California, Las Argeles.)

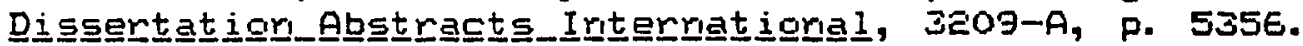
(University Microfilms No. 7e-90ess).

Haug, M. (1979). Doctar-patient relationships and the alder patierit. Jgur. 860.

Heiss, J. (1968). Ari iritraductiari to the elemerits of role

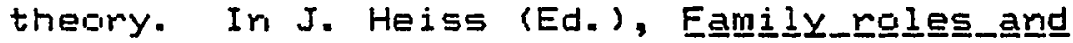

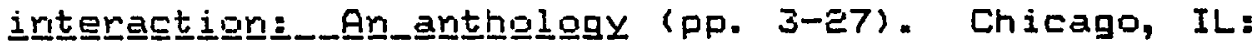
Rarid McNaliy \& Co.

Hiriar, J. (1979). Comparison of places ard policies for terminal care. Lancet $29-32$.

Holden, C. (1976). Hospices: For the dying, relief from

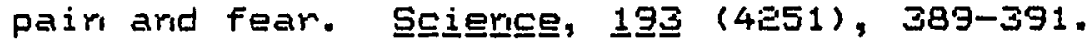

Holder, C. (1980). The haspice movemerit and its

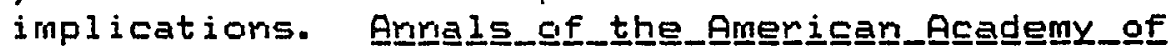

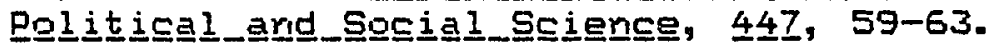

Holsti, Q. R., Loomla, J., \& North, R. C. (1968). Coriterit arialysis. In Lindzey, Gardrer, \& Arorison

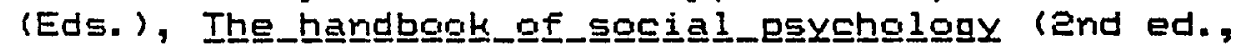
Vol. II) (PP. $596-6 \exists E$ ). Reading, MA: AddisonWes ley.

Haver, J. \& Zimmer, M. J. (1978). Nursing quality assurarce: The Wisconsin system. Nyrsing_Qut logk, 르트 (4), 24ㄹ-248.

Hurtingtan, M. J. (1957). The development of $a$ professional self-image. In R. K. Mertor, G. Reader,

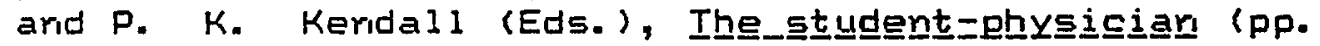
179-187). Cambridge, MA: Hamvard University Press.

Hurley, B. A. (1978). Socialization for roles. Ir M. E. Hardy \& M. E. Coriway (Eds.), Role﹎thegrya

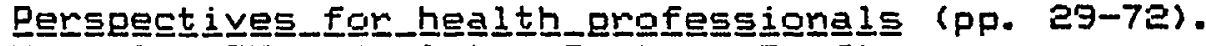
Norwalk, CT: Appleton-Certury-Crofts.

Jacax, A. (1974). Professiaral socialization of nurses.

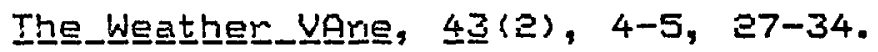

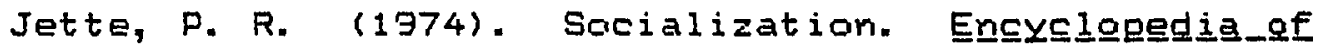
S으드의모y (pp. 27e-273). Guilford, CT: Dushkiri Publishirig Group, Iric. 
Karioti, G. (1975). Doctors, death arid dying. Linaccre Quaㅡ르르틴, 4 르(4), 262-267.

Kaylar, C. (1979). Evaluation of home care for the terminal patient: A proposed model. In E. $R$. Prichard, J. Collard, J. Starr, J. A. Lockwood, A. H. Kutscher, \& I. B. Seeland (Eds.), Hgrne_caㅡé with_dying (pp. E47-253). New York: Columbia University Press.

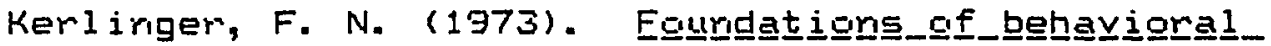
regseares (End ed.) New York: Holt, Rinehart and Wiristori.

Kerr, M. \& Traritow, D. J. (May, 1969). Defining, measuring, and assessing the quality of health

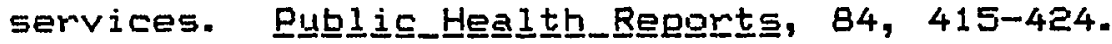

Kerstein, M. D. (1972). Caring for the terminally ill: $A$ hospice (Letter to the editor). American_Journal of

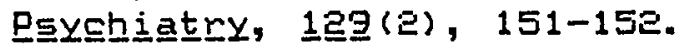

Kersteir, M. D. (1973, April). Must medical progress leave the dying patient behind? Genie 67-68.

Klagsbrur, S. C. (1982). Ethics in hospice care.

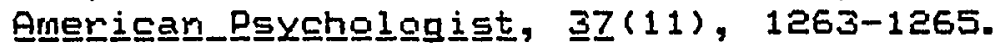

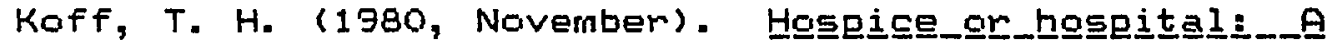
Conceget_pageer. Paper preserited at the meeting of the Gerartalegical Saciety af America, San Diego, CA.

Krarit, M. J. (1978). Caring for the terminally ill:

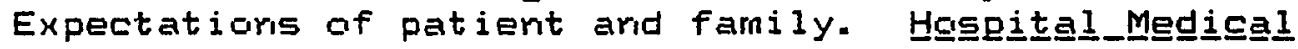
Staf, Z(e), 1-6.

Kron, J. (1376, March). Designing a better place to die.

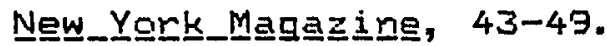

Lack, S. A. (1978). New Haven (1974)-Characteristics of a hospice program of care. In G. W. Davidsor (Ed.), The_hosgice:_Develggmert_arnd_administration (pp. 415e). Washingtan, DC: Hemisphere Publishing Corparation.

Lack, S. A. \& Buckirigham, R. W., III. (1978). Eirst

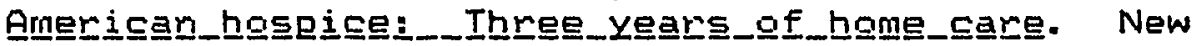
Haver, CT: Hospice, Inc. 
Lamers, W. J. (1978). Marin Courity (1976)--Development of Hospice of Marin. In G. W. Davidsor (Ed.), Ihe hog Washington, DC: Hemisphere Publishing Corporation.

Lamertar, R. (1976). Caㅡㄹㅡ_of_thee_dying. Westpart, CT: Technomic Publishing Company.

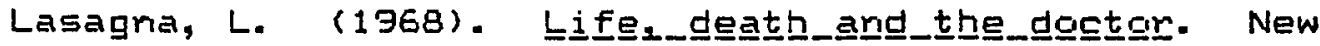
Yark: Alfred A. Kricipf.

Lebow, I. L. (1974). Corisumer assessmerits of the quality

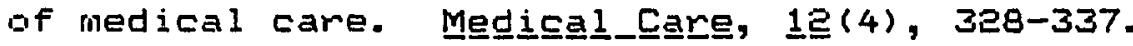

Levinsor, D. J. (1967). Medical education and the theory

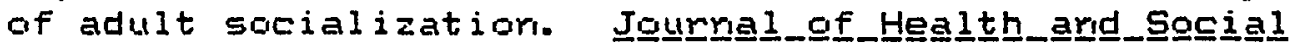
Behehㅡㅡ느므, 으, 253-264.

Lief, H. I. \& Fax, R. C. (1963). The medical studerit's training for detached corcern. In $H$. I. Lief, V. F.

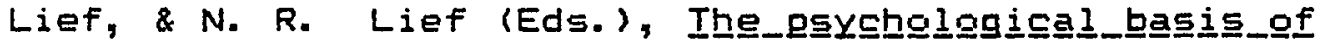

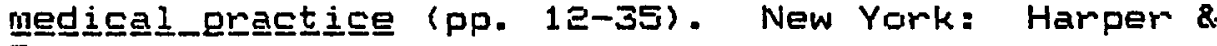
Raw.

Liegrer, L. M. (1975). St. Christopher's Hospice, 1974:

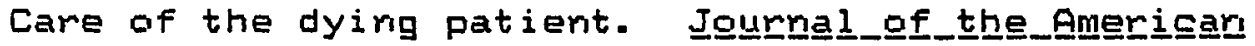

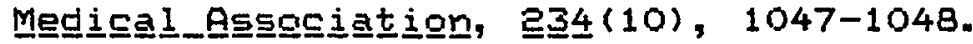

Light, D., Jr. (1980). Eegcoming_esychiatrists․ The

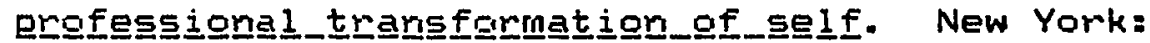
Norton.

Lintan, R. (1936). Ihe_stugdy_ef_man. New Yark: Appleton-Ceritury.

Listor, E. H. (1973). Education on death and dying: $A$ Survey of American medical schools. Journal_of

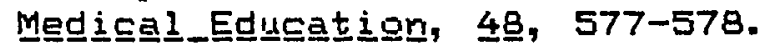

Lurie, E. E. (1981). Nurse practitioners: Issues ir

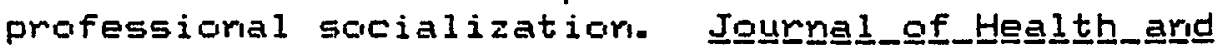

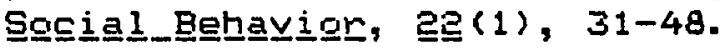

Markel, W. M. \& Siron, V. B. (1978). The_hosgice_cogncegt (78-eR-100M-9/79-No. 3403-PE). American Cancer Society, Iric. 
Maslow, A. M. (1943). A theory of human motivation.

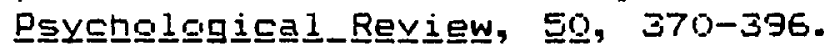

Maytiew, L. (1968). Ascription ir modern societies.

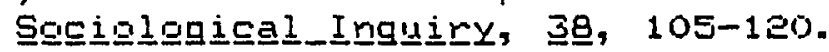

McAuliffe, W. E. (1979). Measuring the quality of medical care: process versus autcome. Millbark

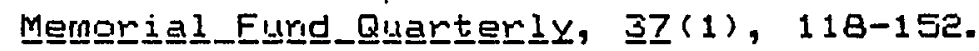

McClure, W. J. (1973). Four points on quality assurarice.

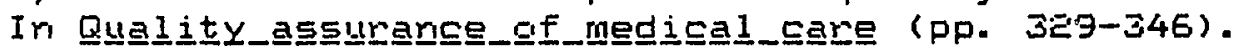
Washingtor, DC: Regioral Medical Programs Service, Health Services and Mental Health Administration, $U$. 5. Departmert of Health, Educaticir, \& Welfare.

McNerney, $W . J . ~(1976)$. The quardary of quality assess-

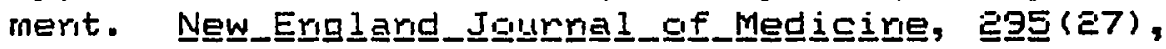
1505.

McNulty, B. J. (1974). The rurse's contribution in

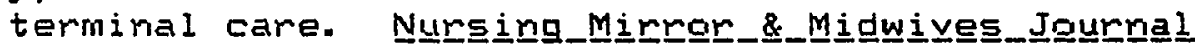
(Loridon), $139 \underline{3}(15), 59-61$.

Mertar, R. K. (1957a). The role-set: Problems in

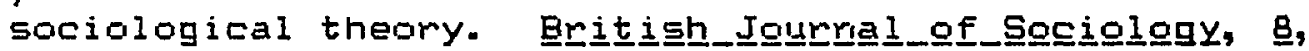
11 I.

Mertar, R. K. (1957b). Same preliminaries to a sociology of medical education. In R. K. Merton, G. Reader, \&.

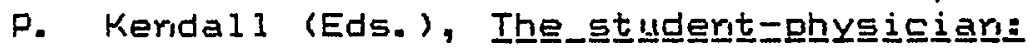

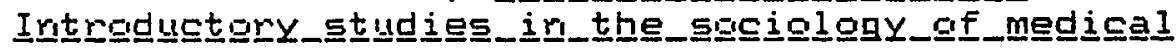

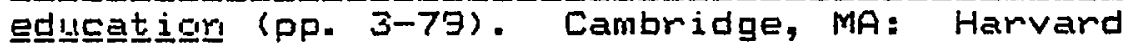
Uriversity Press.

Mitchell, J. A. (1973). Quality of medical care: Mutual resporisibility of corsumers and providers. In Qualality

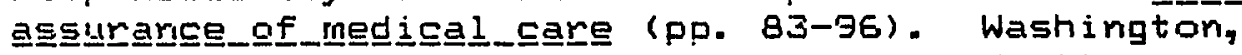
DC: Regichal Medical Prograns Service, Health Services ard Merital Health Admiristration, $U_{\text {. }} S$. Department of Health, Educatior, \& Welfare.

Marisor, R. S. (1974). Alternatives to striving tou cifficiously. In F. J. Ingelfinger, R. $V$. Ebert, M. Firland, \& A. S. Relman (Eds.), CGrutroveresy_in

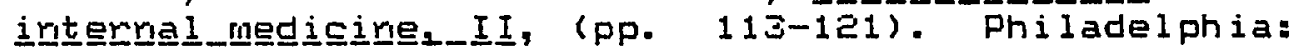
W. B. Saunders. 
Mourt, B. M. (1976). The problem of caring for the dying ir a gereral hospital: The palliative care urit as a

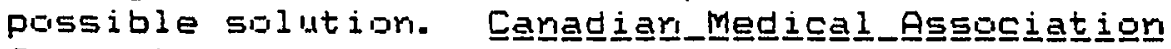

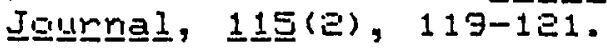

Mullaly, R. W. \& Osmorid, H. (1979). Medical education

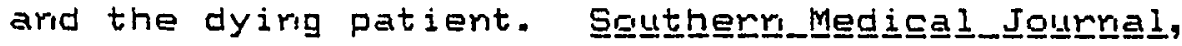
그 (4), 409-411.

Myers, E. A. \& Graharn, R. (1973). Quality assurarice:

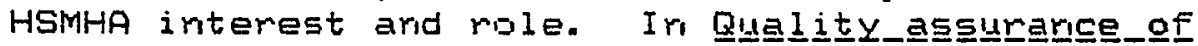
med므드르_드를 (PP. 445-460). Washingtor, DC: Regigiral Medical Programs Service, Health Servivces and Mertal Health Administration, U. S. Department of Health, Educatiori, \& Welfare.

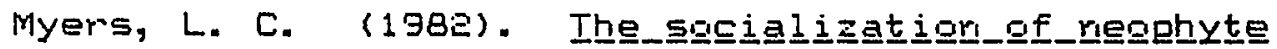
runses. Arir Arbor, MI: UMI Research Press.

Noyes, R., Jr. \& Clancy, J. (1977). The dyirig role: Its relevarice to improved patient care. P巨y드르트y $40(1)$, $41-47$.

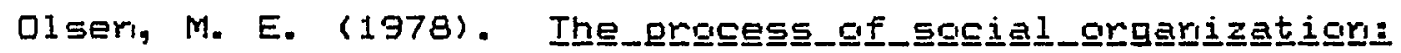
Egwer_in_sgcial_systerns (End ed.) New Yark: Halt, Ririehart ard Wiristor.

Dsterweis, M. \& Champagre, D. S. (1979). The U. S. haspice mavemert: Issues in development. American

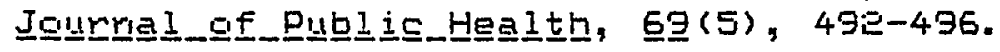

Park, P. (1967). Measurement of the pattern variables.

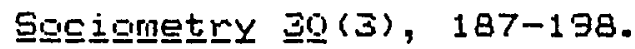

Parks, P. (1979a, March 16). Hospice care: Implications for haspitals. Hosgitals, pp. 58, 62.

Parks, P. (1979b, November 16). Evaluation of hospice care is reeded. Hesspitalals, pp. $68,70$.

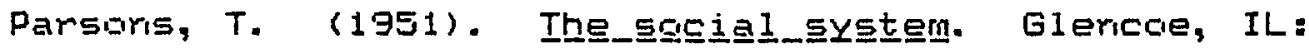
The Free Press.

Parsors, T. (1960). Pattern variables revisited: $A$

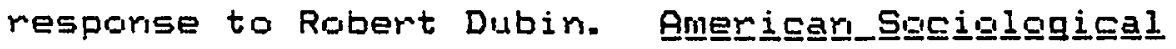

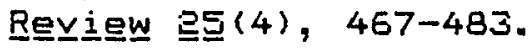


Parsons, T. (1975). The sick role and role of the

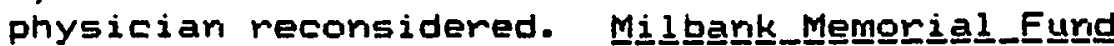

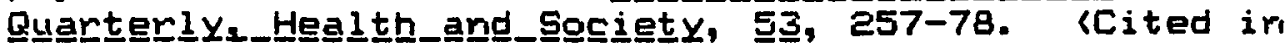
Haug, 1979).

Paulsan, G. W. (1973, March). Who should live?

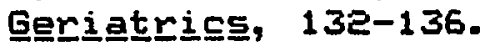

Payne, B. C. (1973). From performance-measured to ut lization review to quality assurance. In Quality

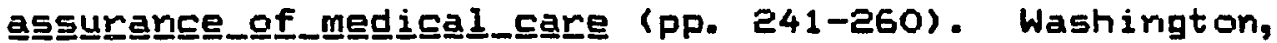
DC: Regional Medical Programs Service, Health Services and Mental Health Adninistratior, U. $S$. Department of Health, Education, \& Welfare.

Payne, B. C. \& Lyans, T. F. (1969). Desigrn_issues_

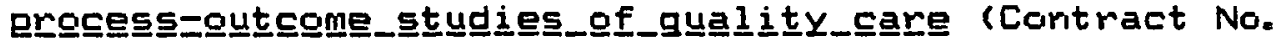
HSM 110-170-69). Washingtor, DC: National Ceriter for Health Services Research and Development.

Pellegrino, E. D. (1973). The quality assurances of medical care: Analysis arid reflecticr. In Quali

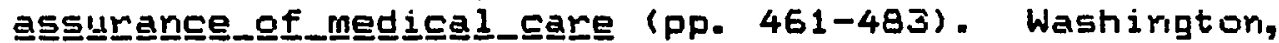
DC: Regional Medical Programs Services, Health Services and Mental Health Admiristration, U. $S$. Department of Health, Education, \& Welfare.

Plant, J. (1977, July 1). Findirig a hame for hospice care in the U. S. Hosgitalis, 53-6e.

Quint, J. C. (1967). The_nurseg_and_the__dying_Rateient. New York: Macmilian.

Reeder, L. G. (1972). The patient-clierit as a consumer: Some observations on the changing professional-client

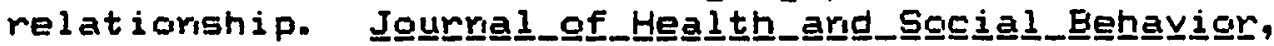
$1 \underline{3}, 405-412$.

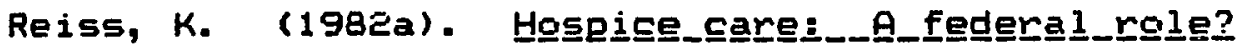
(Report No. 82-49 EPW). Washington, DC: Congressional Research Service, The Library of Carigress.

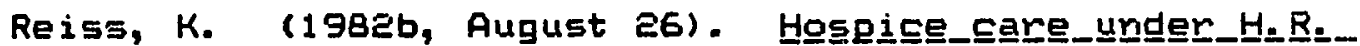
4961. Washington, DC: Congressional Research Service, The Library of Congress. 


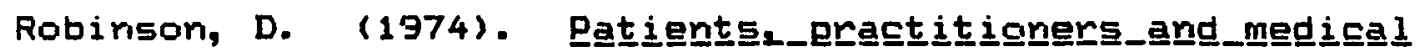

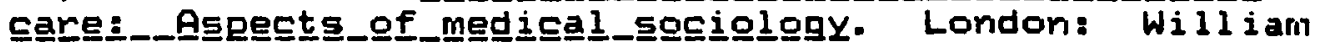
Heinemann Medical Books, Ltd.

Rodek, C. F. \& Jacob, S. (1983, June). Perspectives on

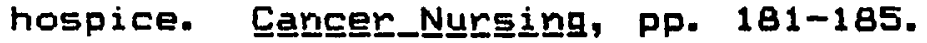

Rogers, B. L. (1978). Using the creative process with the terminally ill. In G. W. Davidson (Ed.) Ihe

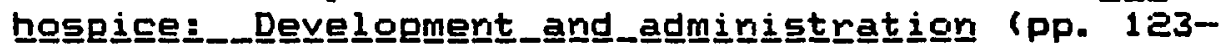
126). Washington, DC: Hemisphere Publishing Corporatior.

Rase, M. A. (1976, March). Problens families face in home care. Amerí드르_Journal_of_Nurssing, 416-418.

Roseriberg, P. R. (1979). Catch ee--The medical model. In E. C. Shapiro and L. M. Lowenstein (Eds.), Begcoming 크_phys medicine (pp. $81-9 e$ ). Cambridge, MA: Baliinger.

Raserifeld, L. S. (1973). Standards for assessing quality

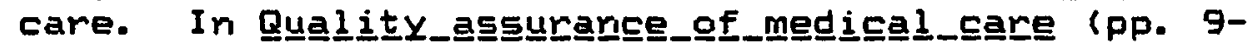
34). Washington, DC: Regional Medical Programs Services, Health Services ard Merital Health Adminstration, U. S. Department of Health, Education, \& Welfare.

Raserithal, C. J., Marshall, V. W., Macphersor, A. S., \& French, S. E. (1980). Nurs famiiㅡ릍. London: Croom Helm Ltd.

Ross, C. W. (1978). Nurses' persorial death concerris arid responses to dying-patient statements. Nursing Reseaㅡㄷㅡ, 2 그(1), 64-58.

Ryder, C. F. \& Ross, D. M. (1977). Termiral care--issues

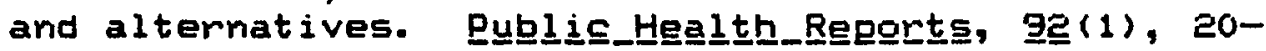
29.

Salber, E. J. (1975). Caring_and_cuririga_Commurityy

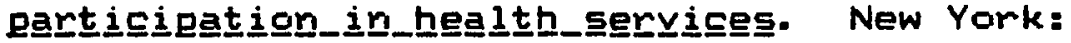
Prodist.

Saunders, C. (1965). The last stages of life. American

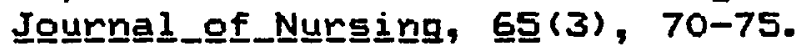

Schram, R. B., Kane, J. C., \& Roble, D. T. (1978). "NC. code" anders: Clarification in the aftermath of

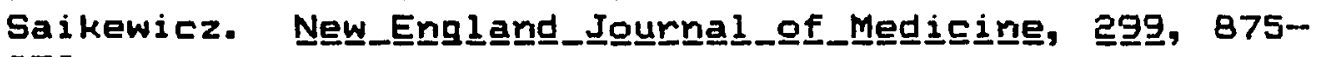
878. 


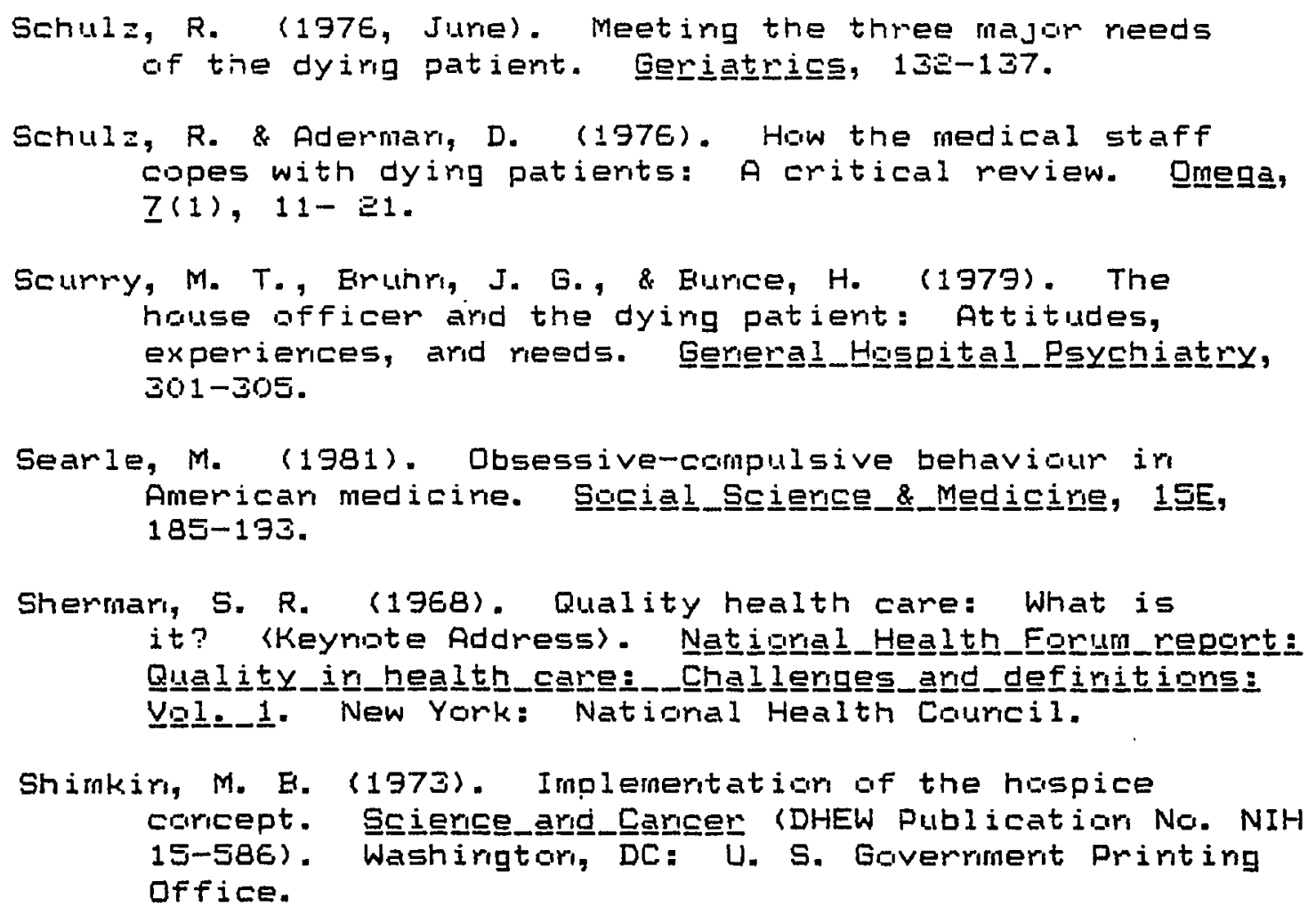

Scurry, M. T., Erunri, J. G., \& Eurice, H. (1979). The house officer ard the dying patient: Attitudes, experierices, ard reeds. Gereng $301-305$.

Searle, M. (1981). Qbsessive-compulsive behaviour in

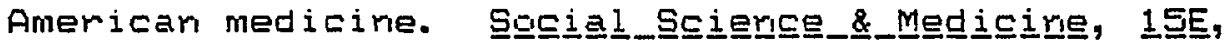
$185-193$.

Shermari, S. R. (1968). Quality health care: What is

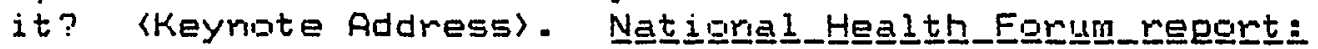

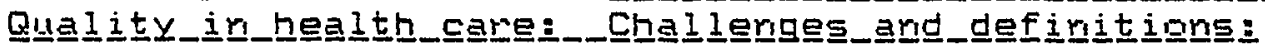
Vol-_1. New York: National Health Council.

Shinkir, M. E. (1973). Implementation of the haspice carcept. Sgcienge_argd_Caricen (DHEW Publication Na. NIH 15-58E). Washirgtor, DC: U. S. Govermerit Printing Qffice.

Shortell, S. M. (1982). The coritribution arid relevarice of sociology to health services research. Ir T. Choi \& J. N. Greeriberg (Eds.), Sgci키_scierice_aggergachenes_tg

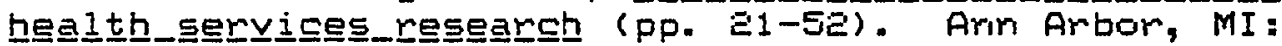
Health Adriristration Press.

Shuval, J. T. (1975a). Socialization of health professionals in Israel: Early sources of corigruence

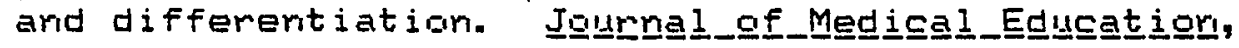
$50,443-457$.

Shuval, J. T. (1975b). Frarn "bay" to "colleague": Processes of role transformation in professional

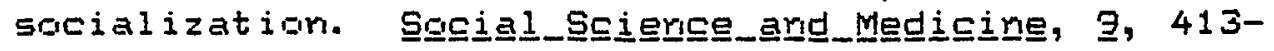
420 .

Simpsori, M. A. (1976). Plarming for temiral care. 느므드르, ㄹ, $19 e-193$.

Sjoberg, G. \& Cain, L. D. (1971). Negative values, couritersysten models, ard the analysis of social systems. In H. Turk \& R. Simpsor (EdS.) Irgstitultigns

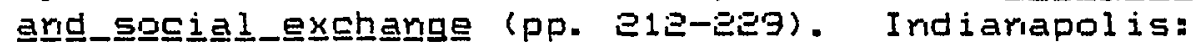
Eabbs-Merrili. 
Starfield, B. (1974). Measuremert af outcome: A

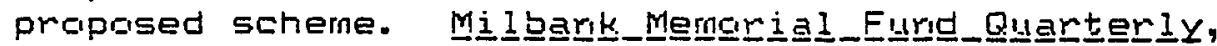
S르(1), 39-50.

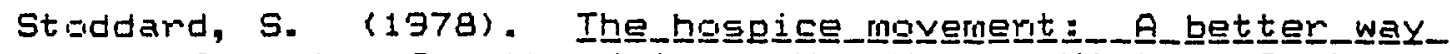

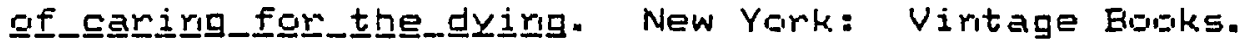

Strauss, A. L. (February, 1968). Problems of death and the dying patient. In A. Simon \& L. J. Epstein (Eds.) Agirng in_mgdern sgciety. Psychiatric Research Repcrit \#23, Americar Psychiatric Assiciaticr.

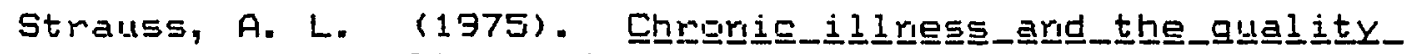
Ef_life. St. Lauis: Masby.

"Supporting hospice care." (1980). Scienges, 트⑾, $160-161$.

Swift, J. K. (1976). The chaplair's role ir care for the dying: Toward a rew understanding. Cangedian

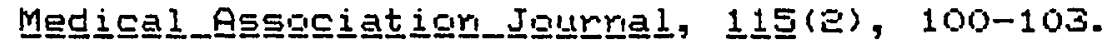

Talbot-Ponsonby, R. (1979). Maragement of the temminally

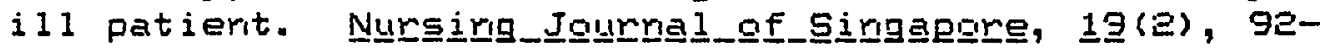
94.

Iharaaㅡ밈y﹎Igday. (1780, Jaruary). (Newsletter). $1(10)$.

Thanpsar, A. (1977). Havers for the terminally ill. M드르느모, 1음, $5 \in$.

Thorritor, R, \& Nardi, P. M. (1975). The dynamics of role

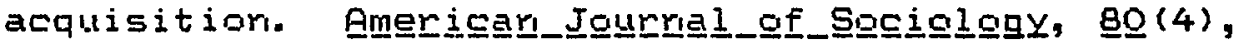
870-885.

Thrush, J. C., Paulus, G. S., \& Thrush, P. I. (1979). The availability of education on death \& dying: $A$

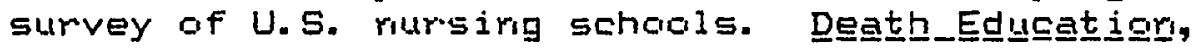
互(Z), $131-142$.

Tobin, S. \& Liebermar, M. A. (1976). Laㅡㅎㅡ_hgme_forn_the aㅡ믈ㅁ. San Fraricisco: Jossey-Bass.

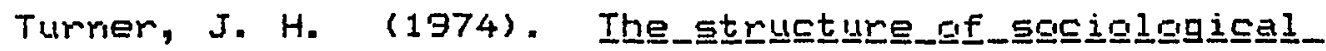
thegery. Harnewoad; IL: The Darsey Press.

Vachon, M. L. S. (1978). Mativatior ard stress experienced by staff warking with the termirally ild.

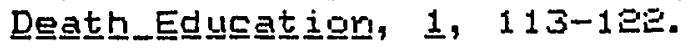


Varro, B. (1980, May 2). Hospice: Humanistic approach to dying. Los_Angeles__Iimes, pp. 19.

Veatch, R. M. \& Tai, E. (1980). Talking about death: Patterns of lay and professional change. Anna 1 s_of

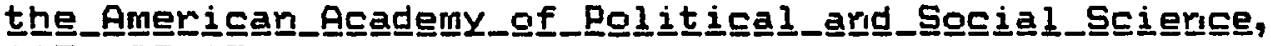
447, 29-45.

Vicker, R. L. (1979). The haspice movement in the United

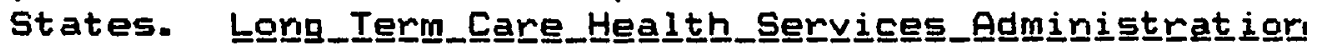
Qua

Waitzkir, H., \& Watemmar, B. (1976). Social theory and

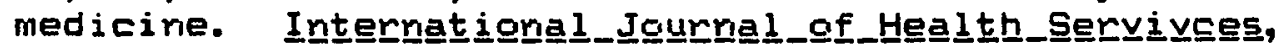
6, $9-23$.

Wessels, V. G. (1979). The nurse and horne care of the terminally ill. In E. R. Prichard, J. Collard, J. Starr, J. A. Lockwoad, A. H. Kutscher, \& I. B.

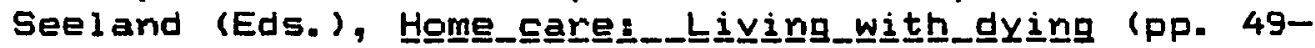
59). New York: Columbia University Press.

Williams, C. A. (1982). Role corsiderations in care of the dying patient. Image (National Honor Society of Nursing), 14, 1, 8-11.

Williams, R. M., Jr. (1959). Frierdship and social values in a suburban community: An exploratory study.

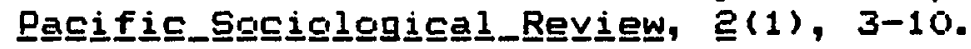

Williamson, J. W. (1971). Evaluating the quality of patient care: A strategy relating outcome arid process

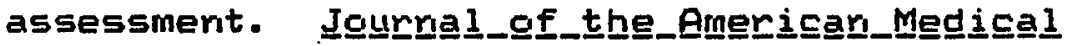

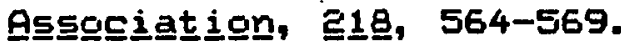

Wilson, D. C., Ajemian, I., \& Mount, B. M. (1978). Montreal (1975)--The Royal Victonia Hospital Palliative Care Service. In G. W. Davidsor (Ed.), Ihe

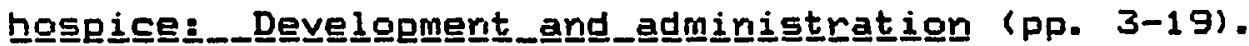
Washingtar, DC: Henisphere Publishing Corporation.

Wolfe, D. (1970). Dying with dignity. SEience, $1 \underline{6} \underline{B}$ (3938), 19.

Woodring, S. (1979). Hospice pilot project in an acute care general hospital, 1975-1976. In E. R. Prichard, J. Collard, J. Starr, J. A. Lockwood, A. H. Kutscher, \& I. B. Seelarid (Eds.), Home_cagreㄹ._Livining wiztht_dying (pp. 159-164). New Yark: Columbia University Press. 
Woodsor, R. (1979). Hospice care in terminal il Iress. In C. A. Garfield, (Ed.), Stresss_and_survivali_- The

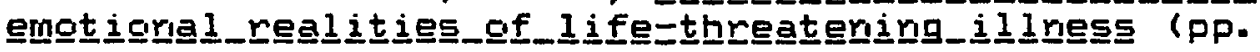
3Es-34E). St. Louis: c. V. Masby.

Wylie, N. A. (1978). Halifax (1976)--Victoria General Haspital: A nursing model. In G. W. Davidsor (Ed.),

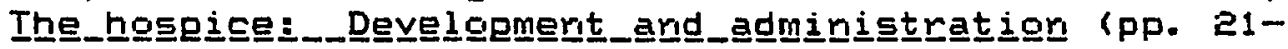
39). Washingtan, DC: Hernisphere Publishing Comporatior. 
APPENDIX A: RESPONDENT SELECTION PLAN AND RESPONDENT PROFILES 
OVERVIEW OF THE RESPONDENT SELECTION PLAN

\begin{abstract}
Step_1: Program/Sites Selection $(n=10)$
Ten urbar programs/facilities providing care to patients having late stage disease or illness were selected so that a wide range of services, philasophies, and care environmerits would be represented in the study. Sites selected included:
\end{abstract}

- Hospitals (units within) ( $n=3$; 2 "hospice-like")

- Nursing homes ( $n=4$; 1 "hospice-like")

- Home care prograns ( $n=2 ; 1$ "hospice-like")

- Hospice facility ( $n=1$; autonomous program-inpatient and home care)

Steep_e: Selection of Individual participants from the Above 10 Programs (Proposed $n=100$; Actual $n=94$ )

Interviews were conducted with five groups of individuals:

- Administrators or supervisors of the programs/ units/facilities identified above (1 per program; proposed and actual $r_{1}=10$ )

- Staff persons heavily involved in care of patients with late stage illness ( 3 per program; proposed $n=30$; actual $n=29$ )

- Elderly terminally ill patients (a per program; proposed $n=20$; actual $n=17$ )

- Family members of terminally ill patients ( 2 per program; proposed $n=20$; actual $n=18$ )

- Recently bereaved family members of patients who had been cared for in the program ( 2 per program; proposed and actual $n=20$ ) 
PROFILE OF PROGRAMS/SITES

\begin{tabular}{|c|c|c|c|c|c|c|c|c|c|}
\hline$\pi$ & 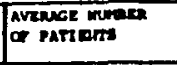 & 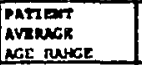 & 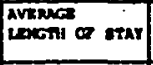 & xwoth of stph & Alivicis arrentos & ringinc & 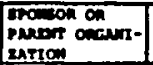 & para & 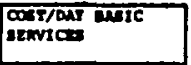 \\
\hline 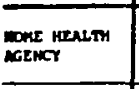 & 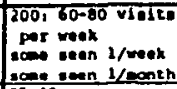 & 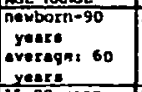 & not avallabio & 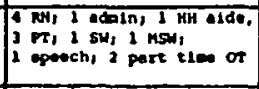 & 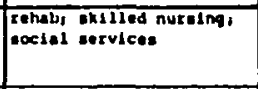 & 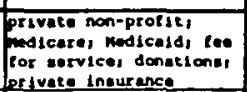 & 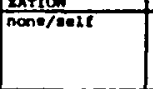 & 11 yours & 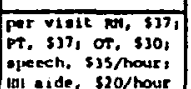 \\
\hline $\begin{array}{l}\text { Mons HEALTM } \\
\text { AGECT }\end{array}$ & $35-900$ & 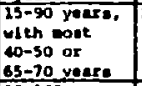 & 2-3 monehs & 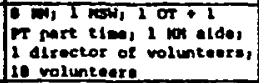 & 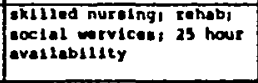 & 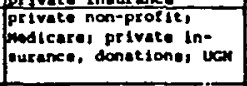 & 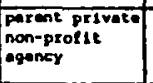 & & 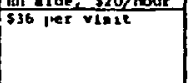 \\
\hline WNSINC HONE & 100 & 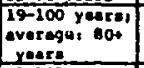 & 30 day: & 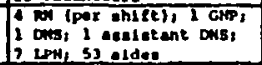 & 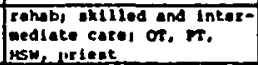 & 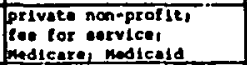 & $\begin{array}{l}\text { Rraternal } \\
\text { organization }\end{array}$ & 1 rant: & 313-50 per day \\
\hline WUSSING Mane & 94 & 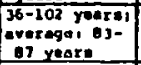 & 125 anye & 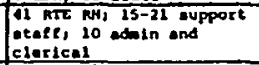 & 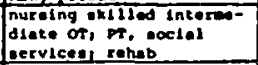 & 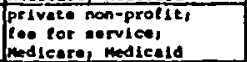 & $\begin{array}{l}\text { roligioue } \\
\text { organleation }\end{array}$ & 2 yoort & 7113-50 par day \\
\hline Wussive have & 105 & $\begin{array}{l}\text { Pere under so } \\
\text { reare }\end{array}$ & not avellsblo & 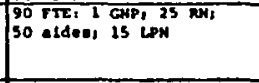 & 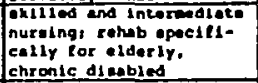 & 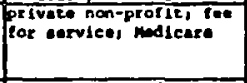 & $\begin{array}{l}\text { ro119ious } \\
\text { ordaer }\end{array}$ & 23 rewre & Jus por day \\
\hline DEsING nowx & [13] & $\begin{array}{l}21-100 \text { yeares } \\
\text { averega: } 62 \\
\text { yeares }\end{array}$ & 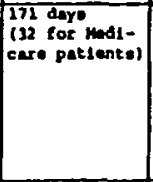 & 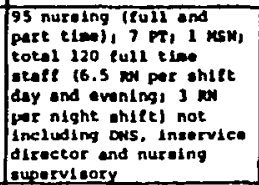 & 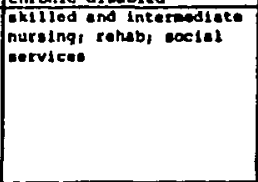 & 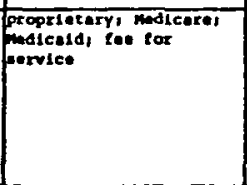 & $\begin{array}{l}\text { Iochlly onder } \\
\text { corporation }\end{array}$ & 4 yost: & $539-45$ pest disy \\
\hline MSPITAL MARD & 24 & $\begin{array}{l}15-90 \text { youres } \\
\text { overago: } 40- \\
\text { so yours }\end{array}$ & 1 weok & $\begin{array}{l}17 \text { TRE RN, } 1 \text { LQW } \\
3 \text { atden' } 2 \text { unst secre- } \\
\text { cortos }\end{array}$ & 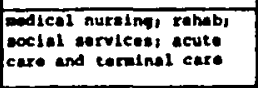 & 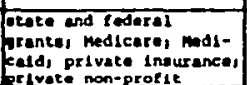 & $\begin{array}{l}\text { puble actical } \\
\text { center }\end{array}$ & 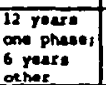 & S180-200 por day \\
\hline Dospritas MNod & $8-12$ & not avalisebof & 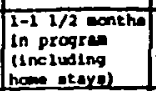 & 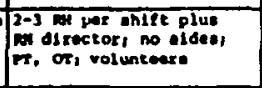 & 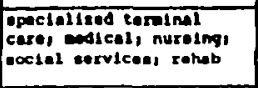 & 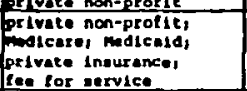 & 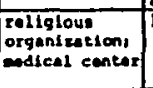 & $\frac{\operatorname{coser}}{1 \operatorname{month}}$ & s106 per day \\
\hline Cospital MANoD & $10-20$ & 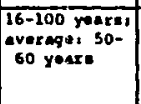 & 10-14 days & 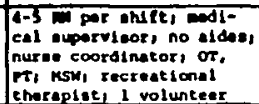 & 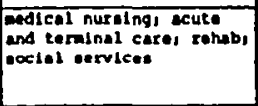 & 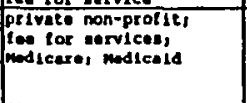 & 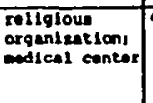 & $\begin{array}{l}41 / 2 \\
\text { yours }\end{array}$ & 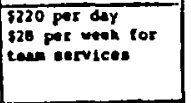 \\
\hline mespstaveine & $\frac{1-12}{B-12}$ & 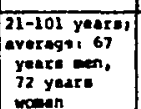 & $\begin{array}{l}1 \text { moneh in } \\
\text { propres. 26 } \\
\text { daye in- } \\
\text { patient }\end{array}$ & 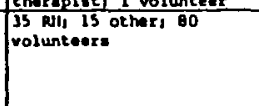 & 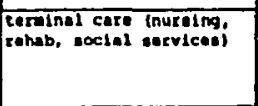 & 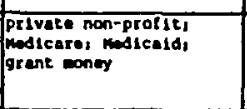 & $\begin{array}{l}\text { private } \\
\text { foundelion }\end{array}$ & 5 yeats & soo per coy \\
\hline
\end{tabular}


PATIENT PROFILE

\begin{tabular}{|c|c|c|c|c|c|c|}
\hline Age & $\operatorname{sex}$ & $\begin{array}{l}\text { Care Settings } \\
\text { (*denotes place } \\
\text { of interview) }\end{array}$ & Diagnosis & $\begin{array}{l}\text { Length of } \\
\text { Illness }\end{array}$ & Prognosis & $\begin{array}{l}\text { Aware of } \\
\text { Illness }\end{array}$ \\
\hline 70 & male & $\begin{array}{l}\text { Home } \\
\text { "Hospital }\end{array}$ & $\begin{array}{l}\text { CA: } \\
\text { prostate }\end{array}$ & 7 years & $\begin{array}{l}\text { uncertain: has } \\
\text { lived one } \\
\text { year longer } \\
\text { than expected }\end{array}$ & yes \\
\hline 70 & male & $\begin{array}{l}\text { Home } \\
\text { Hospital }\end{array}$ & $\begin{array}{l}\text { CA: } \\
\text { colon }\end{array}$ & $41 / 2$ years & uncertain & yes \\
\hline $\begin{array}{c}\text { About } \\
70^{1}\end{array}$ & female & $\begin{array}{l}\text { Home } \\
\text { "Hospital }\end{array}$ & $\begin{array}{l}\text { CA: } \\
\text { brain tumor }\end{array}$ & 7 months & uncertain & $\begin{array}{l}\text { unclear, } \\
\text { appeared } \\
\text { to deny }\end{array}$ \\
\hline 60 & female & $\begin{array}{l}\text { Home } \\
\text { Nursing Home } \\
\text { "Hospital }\end{array}$ & $\begin{array}{l}\text { CA: } \\
\text { pancreas }\end{array}$ & $71 / 2$ years & uncertain & $\begin{array}{l}\text { aware, } \\
\text { but not } \\
\text { talking } \\
\text { about } \\
\text { her } \\
\text { illness }\end{array}$ \\
\hline 78 & female & $\begin{array}{l}\text { Hospital } \\
\text { *Nursing Home }\end{array}$ & $\begin{array}{l}\text { CA: } \\
\text { pancreas }\end{array}$ & 3 weeks & $\begin{array}{r}\text { 1imited: } \\
6 \text { weeks }\end{array}$ & yes \\
\hline 78 & male & $\begin{array}{l}\text { Hospital } \\
\text { Board \& Room } \\
\text { ^Nursing Home }\end{array}$ & $\begin{array}{l}C A: \\
\text { secum }\end{array}$ & 1 year & $\begin{array}{l}\text { uncertain: } \\
\text { guarded }\end{array}$ & yes \\
\hline $60+$ & female & $\begin{array}{l}\text { Hospital } \\
\text { Home } \\
\text { Nursing Home }\end{array}$ & $\begin{array}{l}\text { CA: } \\
\text { liver }\end{array}$ & $11 / 2$ years & limited & no \\
\hline 85 & male & $\begin{array}{l}\text { Hospital } \\
\text { Home } \\
\text { *Nursing Home }\end{array}$ & $\begin{array}{l}\text { CA : } \\
\text { stomach }\end{array}$ & 2 years & $\begin{array}{l}\text { uncertain: } \\
\text { stable }\end{array}$ & yes \\
\hline 83 & male & $\begin{array}{l}\text { Home } \\
\text { Hospital } \\
\text { * Nursing Home }\end{array}$ & $\begin{array}{l}\text { CA: } \\
\text { bladder }\end{array}$ & 3 years & $\begin{array}{l}\text { uncertain: } \\
\text { has lived } \\
\text { nearly one } \\
\text { year longer } \\
\text { than expected }\end{array}$ & yes \\
\hline
\end{tabular}

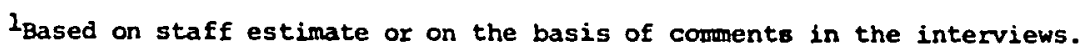




\begin{tabular}{|c|c|c|c|c|c|c|}
\hline inge & $\operatorname{sex}$ & $\begin{array}{l}\text { Care Settirgs } \\
\text { ("denotes place } \\
\text { of interview) } \\
\end{array}$ & Diagnosis & $\begin{array}{l}\text { Length of } \\
\text { Illness }\end{array}$ & Prognosis & $\begin{array}{l}\text { Awhre of } \\
\text { Illness }\end{array}$ \\
\hline 57 & male & $\begin{array}{l}\text { Hospital } \\
\text { Home } \\
\text { "Nursing Home }\end{array}$ & $\begin{array}{l}\text { amyotrophic } \\
\text { lateral } \\
\text { sclerosis }\end{array}$ & 6 years & uncertain & yes \\
\hline 86 & female & $\begin{array}{l}\text { Home } \\
\text { Hospital } \\
\text { "Nursing Home }\end{array}$ & \begin{tabular}{|l|} 
CA: \\
abdomen \\
(widespread)
\end{tabular} & 2 years & uncertain & unclear \\
\hline 83 & female & $\begin{array}{l}\text { Hospital } \\
\text { Home } \\
\text { "Nursing Home }\end{array}$ & $\begin{array}{c}\text { Severe CVA } \\
\text { (stroke) }\end{array}$ & $\begin{array}{l}51 / 2 \\
\text { months }\end{array}$ & uncertain & unclear \\
\hline 75 & female & $\begin{array}{l}\text { Home } \\
\text { Hospital } \\
\text { Hospice } \\
\text { "Nursing Home }\end{array}$ & $\begin{array}{l}\text { CA: } \\
\text { breast }\end{array}$ & $11 / 2$ years & $\begin{array}{l}\text { uncertain: has } \\
\text { lived longer } \\
\text { already than } \\
\text { was expected }\end{array}$ & yes \\
\hline 76 & male & *Hame & $\begin{array}{l}\text { CA: } \\
\text { colon }\end{array}$ & 2 years & uncertain & yes \\
\hline $60+1$ & female & $\begin{array}{l}\text { Hospital } \\
\text { "Home }\end{array}$ & $\begin{array}{l}\text { CA: breast } \\
\text { metastasized } \\
\text { to bone }\end{array}$ & 5 years & uncertain & yes \\
\hline 84 & male & $\begin{array}{l}\text { Hospital } \\
\text { "Home }\end{array}$ & $\begin{array}{l}\text { CA: } \\
\text { bowel }\end{array}$ & 4 years & $\begin{array}{l}\text { uncertain: } \\
\text { "not good" }\end{array}$ & yes \\
\hline 75 & female & $\begin{array}{l}\text { Home } \\
\text { Hospital } \\
\text { "Hospice }\end{array}$ & $\begin{array}{l}\text { CA: } \\
\text { pancreas }\end{array}$ & 1 year & "a few months" & yes \\
\hline
\end{tabular}

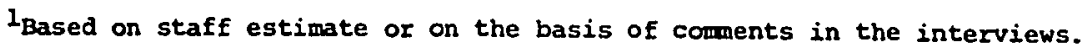


FAMILY PROFILE

\begin{tabular}{|c|c|c|c|c|}
\hline $\begin{array}{l}\text { Relationship } \\
\text { of Respondent } \\
\text { to Patient }\end{array}$ & $\begin{array}{l}\text { Approximate } \\
\text { Age of } \\
\text { Respondent }\end{array}$ & $\begin{array}{l}\text { Diagnosis, Length of Illness, } \\
\text { and Age of Patient }\end{array}$ & $\begin{array}{l}\text { Care Setting of } \\
\text { Patient at Time of } \\
\text { Family Interview }\end{array}$ & $\begin{array}{l}\text { Respondent's Involvement in Care } \\
\text { and Current situation }\end{array}$ \\
\hline Wife & 70 & $\begin{array}{l}\text { CA, colon. Ill approximately } \\
41 / 2 \text { years. Age } 70 .\end{array}$ & Hospital & $\begin{array}{l}\text { Has cared for her husvand at home. } \\
\text { Spends her days in the hospital } \\
\text { with him now. }\end{array}$ \\
\hline Daughter & $30 \mathrm{~s}$ & $\begin{array}{l}\text { CA, liver. Ill approximately } \\
8 \text { months. Age } 58 \text {. }\end{array}$ & $\begin{array}{l}\text { Hospital/out- } \\
\text { patient treatment }\end{array}$ & $\begin{array}{l}\text { visits frequently. Seeks informa- } \\
\text { tion from medical staff. Keeps } \\
\text { patient and siblings informed. Has } \\
\text { a strong support group. }\end{array}$ \\
\hline Husband & early 70s & $\begin{array}{l}\text { CA, brain. Ill seven months. } \\
\text { Age } 70 .\end{array}$ & Hosital & $\begin{array}{l}\text { Cared for wife at home. Visits her } \\
\text { daily now. They live several hours } \\
\text { from the hospital. Is staying with } \\
\text { a nephew in town. }\end{array}$ \\
\hline Wi.Ee & $65+$ & $\begin{array}{l}\text { CA. } \quad \text { Ill approximately } \\
\text { one year. Age late } 60 \text { s. }\end{array}$ & Hospital & $\begin{array}{l}\text { Cared for husband at home. Visits } \\
\text { him daily in the hospital. }\end{array}$ \\
\hline Nephew & $\operatorname{mid} 60 s$ & $\begin{array}{l}\text { CA, secum. Ill approximately } \\
\text { one year. Age } 78 \text {. }\end{array}$ & Nursing Home & $\begin{array}{l}\text { Closest relative to the patient. } \\
\text { visits him in nursing home weekly. } \\
\text { Takes care of finances. }\end{array}$ \\
\hline Wiffe & mid $60 s$ & $\begin{array}{l}C A \text {, larynx, stroke. Length } \\
\text { of illness unknown, less } \\
\text { than year. }\end{array}$ & Nursing Home & $\begin{array}{l}\text { Cared for husband at home until } \\
\text { stroke. visits husband daily. Has } \\
\text { health problems herself. Needs } \\
\text { transportation to get to nursing home. }\end{array}$ \\
\hline Daughter & $\operatorname{mid} 40 \mathrm{~s}$ & $\begin{array}{l}\text { CA. Ill for } 2 \text { years. } \\
\text { Age } 78 \text {. }\end{array}$ & Nursing Home & $\begin{array}{l}\text { visits father dally, works in the } \\
\text { facility. Provides information to } \\
\text { her brothers and sisters. }\end{array}$ \\
\hline Sister & 64 & $\begin{array}{l}\text { CA, liver. Ill about } 2 \\
\text { years. Age } 66 .\end{array}$ & Nursing Home & $\begin{array}{l}\text { Lived with patient prior to illness. } \\
\text { Cared for her at home. visits her } \\
\text { daily with other siblings. }\end{array}$ \\
\hline
\end{tabular}




\begin{tabular}{|c|c|c|c|c|}
\hline $\begin{array}{l}\text { Relationship } \\
\text { of Respondent } \\
\text { to Patient } \\
\end{array}$ & $\begin{array}{l}\text { Approximate } \\
\text { Age of } \\
\text { Respondent }\end{array}$ & $\begin{array}{l}\text { Diagnosis, Length of Illness, } \\
\text { and Age of Patient }\end{array}$ & \begin{tabular}{|l|} 
Care Setting of \\
Patient at Time of \\
Family Interview
\end{tabular} & $\begin{array}{l}\text { Respondent's Involvement in Care } \\
\text { and Current Situation }\end{array}$ \\
\hline Wife & $80+$ & $\begin{array}{l}\text { CA, bladder. Ill three } \\
\text { years. Age } 83 \text {. }\end{array}$ & Nursing Home & $\begin{array}{l}\text { Is herself disabled and also a } \\
\text { resident in the nursing home. Her } \\
\text { husband comes to see her daily. }\end{array}$ \\
\hline Daughter & late 208 & $\begin{array}{l}\text { Amyotrophic lateral } \\
\text { sclerosis, dependent on a } \\
\text { respirator. Ill six years. } \\
\text { Age 57. }\end{array}$ & Nursing Home & $\begin{array}{l}\text { Visits frequently. Runs her father } \\
\text { father's business. }\end{array}$ \\
\hline Daughter & mid 50s & $\begin{array}{l}\text { Severe stroke, limited } \\
\text { prognosis. Length of illnesg } \\
\text { unknown. Age } 84 .\end{array}$ & Nursing Home & $\begin{array}{l}\text { Came from out of state to be with } \\
\text { her ill mother. Visits daily. Is } \\
\text { assisting her father with house- } \\
\text { keeping, etc. }\end{array}$ \\
\hline Niece & $50 \mathrm{~s}$ & $\begin{array}{l}\text { CA, widespread. Ill two } \\
\text { years. Age } 86 .\end{array}$ & Nursing Home & $\begin{array}{l}\text { Came from out of state to be with } \\
\text { her aunt. vigits daily. }\end{array}$ \\
\hline Daughtor & midd 40s & $\begin{array}{l}\text { Severe stroke. Ill } 51 / 2 \\
\text { months. Age } 83 \text {. }\end{array}$ & Nurging Howe & $\begin{array}{l}\text { Cared for her mother in her } \\
\text { (daughter's) home. Visits daily } \\
\text { and is an advocate. }\end{array}$ \\
\hline Daughter & 53 & $\begin{array}{l}\text { CA, breast. III } 11 / 2 \text { years. } \\
\text { Age } 75 .\end{array}$ & $\begin{array}{l}\text { Nursing Home } \\
\text { (discharged fron } \\
\text { hospice) }\end{array}$ & $\begin{array}{l}\text { Cared for her mother at home. } \\
\text { Visits frequently. Is also caring } \\
\text { for her husband at home who is } \\
\text { quite ill. }\end{array}$ \\
\hline wife & $65+$ & $\begin{array}{l}\text { CA, prostrate, bone metas- } \\
\text { tasis. Ill approximately } \\
\text { five years. Age } 82 \text {. }\end{array}$ & Home & $\begin{array}{l}\text { Cares for husband at home. Has } \\
\text { received some training for this. } \\
\text { Has a strong support system. }\end{array}$ \\
\hline Wife & $60 s$ & $\begin{array}{l}\mathrm{CA} \text {, colon. Ill approxi- } \\
\text { mately two years. Has } \\
\text { refused treatment. Age } 76 .\end{array}$ & Home & $\begin{array}{l}\text { Cares for husband at home. Has } \\
\text { gupport services, but respondent } \\
\text { feeling worn down. Daughter } \\
\text { recently died of cancer. }\end{array}$ \\
\hline Wife & 808 & $\begin{array}{l}\text { CA, bowl. Ill four years. } \\
\text { Age 84. }\end{array}$ & Home & $\begin{array}{l}\text { Cares for her husband at home. } \\
\text { lusband and wife interviewed } \\
\text { together. }\end{array}$ \\
\hline Husband & early 60s & $\begin{array}{l}\text { CA, pancreas, followed by } \\
\text { stroke. Ill for approxi- } \\
\text { mately one year. Age } 63 .\end{array}$ & Hospice & $\begin{array}{l}\text { Cared for wife at home. Is in poor } \\
\text { health himself. Visits wife daily, } \\
\text { often bringing food for both his } \\
\text { wife and the staff. }\end{array}$ \\
\hline
\end{tabular}


BEREAVED FAMILY PROEILE

\begin{tabular}{|c|c|c|c|c|}
\hline $\begin{array}{l}\text { Relationship } \\
\text { of Respondent } \\
\text { to Patient } \\
\end{array}$ & $\begin{array}{l}\text { Approximate } \\
\text { Age of } \\
\text { Respondent }\end{array}$ & $\begin{array}{l}\text { Patient's Diagnosis, Length of Iilness, } \\
\text { Place of Death, Age at Death }\end{array}$ & Respondent's Involvement in care & $\begin{array}{l}\text { Length of } \\
\text { Bereavement }\end{array}$ \\
\hline Husband & $70 \mathrm{~s}$ & $\begin{array}{l}\text { CA. Ill seven years, last episode } 10 \\
\text { months. Spent about one week in a } \\
\text { nursing home prior to her death in the } \\
\text { hospital. Age mid } 70 \text { s. }\end{array}$ & $\begin{array}{l}\text { Had cared for wife at hone. } \\
\text { Visited her frequently in the } \\
\text { hospital, a distance of three } \\
\text { to four hours from home. }\end{array}$ & 2 months \\
\hline Daughter & 40 & $\begin{array}{l}\text { CA, pancreas. Ill for } 11 / 2 \text { years. } \\
\text { Spent time in and out of hospital. } \\
\text { Died in the hospital. Age mid } 608 .\end{array}$ & $\begin{array}{l}\text { Saw to her mother's care at } \\
\text { home. Was an advocate and in- } \\
\text { volved as a member of the team } \\
\text { of providers. }\end{array}$ & 4-6 weeks \\
\hline Wife & late $60 \mathrm{~s}$ & $\begin{array}{l}\text { Bo year old man had not been feeling } \\
\text { well for about one year. Leukemia } \\
\text { diagnosed during hospitalization for } \\
\text { broken hip, Cared for at home. Died } \\
\text { in hospital within a month of } \\
\text { diagnosis. }\end{array}$ & $\begin{array}{l}\text { Cared for husband at home. She } \\
\text { had cancer herself several years } \\
\text { ago. }\end{array}$ & 3 months \\
\hline Wife & 58 & $\begin{array}{l}\text { CA. Ill approximately one year. } \\
\text { Cared for at home and in the hospital. } \\
\text { Died in the hospital. Age } 67 \text {. }\end{array}$ & Cared for her husband at home. & 3 months \\
\hline WIfe & 55 & $\begin{array}{l}\text { CA. III approximately three months. } \\
\text { Cared for at home. Died in the } \\
\text { hospital. Age } 55 \text {. }\end{array}$ & Cared for husband at home. & 5 months \\
\hline Wife & $\operatorname{mid} 60 \mathrm{~s}$ & $\begin{array}{l}\text { Bone marrow failure. Ill nine months. } \\
\text { Died in the hospital at age } 62 \text {. }\end{array}$ & $\begin{array}{l}\text { Cared for husband at home before } \\
\text { hospitalization. Spent nights } \\
\text { in hospital. Was the only one } \\
\text { who could calm her husband when } \\
\text { he had reactions to medications. }\end{array}$ & 6 weeks \\
\hline
\end{tabular}




\begin{tabular}{|c|c|c|c|c|}
\hline $\begin{array}{l}\text { Relationship } \\
\text { of Respondent } \\
\text { to Patient } \\
\end{array}$ & \begin{tabular}{|l|} 
Approximate \\
Age of \\
Respondent \\
\end{tabular} & $\begin{array}{l}\text { Patient's Diagnosis, Length of Illness, } \\
\text { place of Death, Age at Death }\end{array}$ & Respondent's Involvement in Care & $\begin{array}{l}\text { Length of } \\
\text { Bereavement }\end{array}$ \\
\hline Husband & 708 & $\begin{array}{l}\text { Multiple myeloma. Ill two years. Died } \\
\text { at age } 70 \text { in her home two weeks after } \\
\text { discharge from nursing home. }\end{array}$ & $\begin{array}{l}\text { Spent nights in nursing home and } \\
\text { was an advocate. Cared for her } \\
\text { at home previously. }\end{array}$ & 7 months \\
\hline wife & early $60 \mathrm{~s}$ & $\begin{array}{l}\text { Leukemia. Ill } 20 \text { months. Cared for } \\
\text { in several hospitals in different parts } \\
\text { of the country. Died tit home six days } \\
\text { after last hospitalization. Age mid } \\
60 s .\end{array}$ & $\begin{array}{l}\text { Lived in the hospital room. } \\
\text { Kept track of medications, } \\
\text { care. Cared for her husband at } \\
\text { home previously. }\end{array}$ & $21 / 2$ months \\
\hline Wife & 86 & $\begin{array}{l}\text { CA, just over one year. Lived in } \\
\text { southwestern oregon, coming to Portland } \\
\text { for care. Spent some time in hospital. } \\
\text { Died in son's home at age } 86 .\end{array}$ & Cared for her husband at home. & 8 months \\
\hline $\begin{array}{l}\text { Wife } \\
\text { Daughter }\end{array}$ & $\begin{array}{l}70 s \\
40 s\end{array}$ & $\begin{array}{l}\text { CA, colon. Ill for three years. Had } \\
\text { episodes in hospital and spent two } \\
\text { months in nursing home. Died in a } \\
\text { private home after one month. About } \\
80 \text { years old. }\end{array}$ & $\begin{array}{l}\text { Cared for hugband at home with } \\
\text { assistance of daughter. Became } \\
\text { worn out from the care. }\end{array}$ & 2 years \\
\hline Husband & 64 & $\begin{array}{l}\text { CA, breast. Ill seven years. Last } \\
\text { episode seven months. Died in hospice } \\
\text { at aye } 61 \text {. }\end{array}$ & $\begin{array}{l}\text { Cared for his wife at home } \\
\text { before hospice. visited daily. } \\
\text { Has a very strong faith. }\end{array}$ & 6 weeks \\
\hline Brothex & $70 \mathrm{~s}$ & $\begin{array}{l}\text { CA. Ill two years. She died in the } \\
\text { hospice at age } 74 \text {. }\end{array}$ & $\begin{array}{l}\text { Visited daily, both at home and } \\
\text { when she went to the hospice. }\end{array}$ & $11 / 2$ weeks \\
\hline
\end{tabular}




\begin{tabular}{|c|c|c|c|c|}
\hline $\begin{array}{l}\text { Relationship } \\
\text { of Respondent } \\
\text { to Patient } \\
\end{array}$ & \begin{tabular}{|l|} 
Approximate \\
Age of \\
Respondent \\
\end{tabular} & $\begin{array}{l}\text { Patient's Diagnosis, Length of Illness, } \\
\text { Place of Death, Age at Death }\end{array}$ & Respondent's Involvement in Care & $\begin{array}{l}\text { Length of } \\
\text { Bereavement }\end{array}$ \\
\hline $\begin{array}{l}\text { Daughter } \\
\text { Daughter-in- } \\
\text { law }\end{array}$ & $30 \mathrm{~s}$ & $\begin{array}{l}\text { Leukemia. Ill nine months. Most care } \\
\text { received in her hame or daughter-in- } \\
\text { law's home. Died in the hospital at } \\
\text { age } 63 \text {. }\end{array}$ & $\begin{array}{l}\text { Daughter helped her mother at } \\
\text { home, assisted in obtaining } \\
\text { resources. Daughter-in-law } \\
\text { cared for patient in own home } \\
\text { for some time. }\end{array}$ & 3 weeks \\
\hline Daughter & $\begin{array}{l}\text { mid-late } \\
50 \mathrm{~s}\end{array}$ & $\begin{array}{l}\text { Mother in poor health several years. } \\
\text { Died in nursing home } 15 \text { days after a } \\
\text { stroke. Age } 80+.\end{array}$ & $\begin{array}{l}\text { Patient lived with daughter } 10 \\
\text { years. Daughter visited her } \\
\text { mother in the nursing home } \\
\text { daily. }\end{array}$ & one month \\
\hline Daughter & 63 & $\begin{array}{l}\text { CA. Ill } 11 / 2 \text { years. Died in a nurs- } \\
\text { ing home. Age } 80+\text {. }\end{array}$ & $\begin{array}{l}\text { Visited mother in the nursing } \\
\text { home. Wanted to take her mother } \\
\text { home. Patient had lived with } \\
\text { another daughter. }\end{array}$ & one month \\
\hline Cousin & $40 \mathrm{~B}$ & $\begin{array}{l}\text { Cirrhosis of the liver. Died in a } \\
\text { nursing home. Age } 47 \text {. }\end{array}$ & $\begin{array}{l}\text { Took care of her cousin for } \\
\text { seven months and then was an } \\
\text { advocate for him while he was } \\
\text { in the nursing home. }\end{array}$ & 6 months \\
\hline Wife & 70 & $\begin{array}{l}\text { CA, colon. Ill approximately } 41 / 2 \\
\text { years. Died in nursing home. Age } 65 \text {. }\end{array}$ & Cared for husband at home. & one month \\
\hline Daughter & 50 & $\begin{array}{l}\text { Had been in nursing home } 51 / 2 \text { years. } \\
\text { Diagnosed with CA urinary tract and } \\
\text { died within a few weeks. Age } 73 \text {. }\end{array}$ & $\begin{array}{l}\text { Cared for her mother in her } \\
\text { home. Later was contact person } \\
\text { for her mother after she entered } \\
\text { the nursing home. }\end{array}$ & 2 months \\
\hline Wife & 75 & $\begin{array}{l}\text { CA, lung, prostate, Ill for four } \\
\text { years. Cared for at home and in the } \\
\text { hospital. Died in nursing home. Age } \\
\text { early 70s. }\end{array}$ & $\begin{array}{l}\text { Cared for husband at home pre- } \\
\text { viously. visited daily in nurs- } \\
\text { ing home. Now a volunteer at } \\
\text { the nurging home. }\end{array}$ & 2 months \\
\hline
\end{tabular}


STAFF PROFIIE

\begin{tabular}{|c|c|c|}
\hline Care setting & Position & $\begin{array}{l}\text { Iength of Time } \\
\text { in Position }\end{array}$ \\
\hline $\begin{array}{l}\text { Hospitals } \\
(n=3)\end{array}$ & $\begin{array}{l}\text { RN*, special team } \\
R N^{\star} \text {, head nurse, oncology unit } \\
\text { RN, charge nurse, oncology unit } \\
\text { RN, staff nurse, oncology unit } \\
\text { RN, demonstration program } \\
\text { RN, demonstration program } \\
\text { Murse's Aide, oncology unit } \\
\text { MD, Medical Director, special team } \\
\text { MD, senior resident, oncology unit } \\
\text { MD*, Medical Director, demonstration program } \\
\text { MSW, special team } \\
\text { MSW, demonstration program }\end{array}$ & $\begin{array}{ll}4 & 1 / 2 \text { years } \\
1 & \text { year } \\
1 & 1 / 2 \text { years } \\
2 & \text { years } \\
1 & \text { month } \\
1 & \text { month } \\
1 & \text { year } \\
5 & \text { years } \\
5 & \text { years } \\
6 & \text { months } \\
6 & \text { months } \\
6 & \text { months }\end{array}$ \\
\hline $\begin{array}{l}\text { Nursing Homes } \\
(n=4)\end{array}$ & $\begin{array}{l}\text { Administrator" } \\
\text { Administrator" } \\
\text { Administrator" (RN) } \\
\text { Administrator* } \\
\text { Geriatric Nurse Practitioner } \\
\text { RN, supervisor } \\
\text { RN, supervisor } \\
\text { RN, staff nurse } \\
\text { RN, staff nurse } \\
\text { RN, staff nurse } \\
\text { RN, mental health specialist } \\
\text { Nurse's Aide } \\
\text { Nurse's Aide } \\
\text { Social Service Director } \\
\text { BSW } \\
\text { Chaplain }\end{array}$ & $\begin{array}{l}7 \text { months } \\
21 / 2 \text { years } \\
1 \text { 1/2 years } \\
7 \text { months } \\
16 \text { months } \\
4 \text { months } \\
18 \text { months } \\
11 \text { months } \\
23 \text { years } \\
8 \text { months } \\
3 \text { years } \\
7 \text { months } \\
7 \text { months } \\
2 \text { years } \\
6 \text { months } \\
8 \text { years }\end{array}$ \\
\hline $\begin{array}{l}\text { Home Health } \\
\text { Programs } \\
(n=2)\end{array}$ & $\begin{array}{l}\text { RN*, team manager } \\
\text { RN*, supervisor } \\
\text { RN } \\
\text { RN } \\
\text { Home Health Aide } \\
\text { HSW } \\
\text { BSW }\end{array}$ & $\begin{array}{l}2 \text { years } \\
6 \text { months } \\
18 \text { months } \\
5 \text { months } \\
51 / 2 \text { months } \\
2 \text { years } \\
10 \text { months }\end{array}$ \\
\hline $\begin{array}{l}\text { Freestanding } \\
\text { Hospice } \\
(n=1)\end{array}$ & $\begin{array}{l}\text { Administrator (SW) } \\
\text { RN, head nurse } \\
\text { Medical Director } \\
\text { Family Service Worker }\end{array}$ & $\begin{array}{l}6 \text { months } \\
4 \text { months } \\
3 \text { years, } 3 \text { months } \\
1 \text { month }\end{array}$ \\
\hline
\end{tabular}

*Interviewed as program administrator or supervisor 
APPENDIX B: INTERVIEW SCHEDULES 
PATIENT INTERVIEW SCHEDULE

We're interested in learning more about the care of people who are seriously ill--things like what kinds of care are given, what makes care good, what makes it poor and the things about care that are most important to very ill people. Your thoughts as a person who is experiencing a serious illness will be of great value to us, and I appreciate your willingness to let we coive and talk with you.

Because I want to be sure that I don't miss any of what you say or change your words somehow. I'd like to tape record the interview, if you don't mind. The tape and the interview are completely confidential, and they' 11 be used only by me and my staff. If at any time you would like for we to tura off the recorder, just let me know. Let me emphasize, though, that what you say will be kept confidential. In our report, neither your name nor any personal information will be used when we describe the study's findings.

Before we begin, I need to ask you to read and sign this form, which states that you agree to participate in the research. It's scovething the University requires us to do for your protection, to make sure we've explained to you what the study involves. (HAND RESPONDENT INFORMED CONSENT FORM; READ TOCETHER IF APPROPRIATE). DO you have any questions?

1. When someone has been ill for a period of tirse, he or she has usually received care in a number of places, such as hospitals, nursing homes,

- clinics, doctor's offices, and at home. Since you discovered you were ill. where have you received care? (RROBE: When was this?)

Settings

When There

2. Tho are all the people who have been involved in your care, and what have they done? (PROBE: Let's start with where you are now and who is taking care of you here, and then we can work backwards).

Name/Position

Where/Care Setting

What Done

(PROBE: Who else has played a part of your care? IF HAVEN'T MENIIONED ONE OR MORE OF THE FOLWOWING, ASK: what about ?)

Physician What did (or do) they do?

Nurse

Nurse Aide

Volunteer

Social worker

Physical, occupational, or Recreational Therapist 
Home Nealth Aide or

Honemaker

Dietician

Clergy

Relatives

Eriends

Anyone else? What did (or do) they do?

3. In general, we're interested in the characteristics and behaviors of these people that enable them to provide good care. Now that we've been talking about all the people who have been involved in your care, I'd like you to think about three you've liked particularly well. What about them do you like or did you like the most? (PROBE: IF DON'T MENTION BEHAVIORS, ASK: ' What did they do that you liked?)

4. What about three persons whom you have not liked so much or with whon you have been somewhat dissatiseied? what about them or what they did (or do) would you like to change?

5. For many people, where they are being cared for is very important. Where would you most prefer to bo cared for?

6. (IF DIFEERENT THAN CURRENT SEITING, ASK: what would make it possible for you to be cared for at ?)

7. You mentioned that you've been cared for (LIST PLACES, Q. 1--e.g., in the hospital, a nursing hone, by doctors in their offices, in your own home)?

What are the best things about (PRESENT SETTING)? what is most difficult for you about being here?

What were the best things about (ASK FOR EACH PREVIOUS CARE SETTING)? What was most difficult about being cared for there?

Type of setting

Best Things

Most Difficult Things

B. He've been talking about people who provide care and places where care is given. Now I'd like to talk a little about the needs of people who are (seriously ill, have cancer--CHOOSE APPROPRIATE). If you were asked to give a talk to a group of medical and nursing students, what would you tell them about the needs of people who are (very sick, seriously ill, have cancer--CHCOSE APPROPRIATE)?

9. What would you say have been your greatest needs? (PFOBE:

10. What are the things that are concerning you most right now?

11. Let's go back to the group of medical and nursing students. What would you tell them about the needs of the family of people who are very sick? 
12. What needs of patients and families do you think staff are most likely to be uniware of or unresponsive to?

13. Some people have said that serious illness is often a "bringing together" time for families. Others have said that their fanily has fallen apart. that their relations with their family have broken down because of their illness. What has your experience been? (PROBE: What has happened with your family since you've been i11?)

14. In what ways may the needs of older people who are seriously 111 differ from those of younger people who have a smilar 11 lness?

15. Some people feel that care provided to older persons who are very ill differs from that provided to younger people with the same illnesses. From what you've observed and experienced, how does a person's age affect the care provided to him or her? (PROBE: in terms of amount, kind, where It's provided, staff attitudes, etc.)

16. Looking back over what we've talked about, what would you say good care for people who are seriously 111 consists of? (PROBE: What is involved in the provision of good care to people like yourself? If you had to decide whether the care given to someone who was seriously ill was good or bad, what things would you consider in your decision?) 


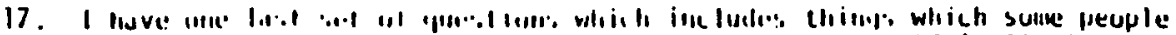

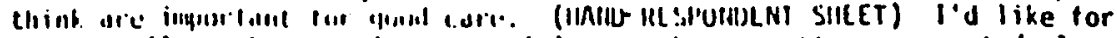
you to tell in: whellie.". ill yuur mininiun, mach one matters a great deal,

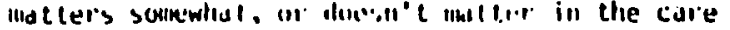
of solleunte whic's very ill. llo youl litink it

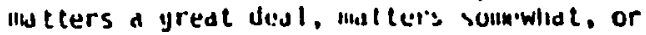
duesn't luatter thill...

d. Lace is ardilable day und night, 7 days a week.

b. Patients are keot informed of their condition and wat's being done. ....................

c. Ooctors and nurses sit. talk. and listen as well as atcend to patlents physical needs. .............

d. Care is given to patients in their own homes. ........

e. Patients. families have a say in the patfents" care......

P. Trainting is avallable for pattents fantlies an hore care techniques and equloment. ..............

9. Training is given to patients so they can care for thenselves.

h. Pain medication is given on. reqular basis wtthout

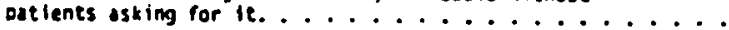

i. Pacients' famflifes help care for the patient. . . . . ...

J. Several people. in addition to doctors and nurses, provide care sucil as a social tiorker. nliysical or oceupational t!iarapist.

$k$. Friends visit of cen.

1. Patients decide who their visitars will be and when they

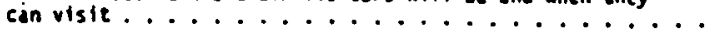

$m$. Patients decide now much and what kind of care they get...

n. Patients have activities and things to keep them occupled...

o. Services be provided for pacients. families as mell

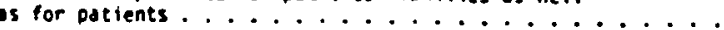

D. Acholdain or other clergy person visits with the patient and the family often. .........

q. Care is avallable to 411 , regardless of their abllity

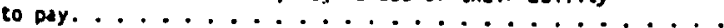

r. Financial advice is avallable for patients and tanilies....

5. Legal help is available for patients and fantlies........

t. Patients' urivate uhysicion is involves in thalr

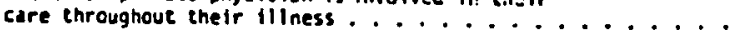

11. Potients choose men and what they want to edt. .....

v. Someone is responsibile for keepinn track of 111 the things that are going on rejdarding patientes' care (no miter where
they're being cared forl. . . . . . . . .

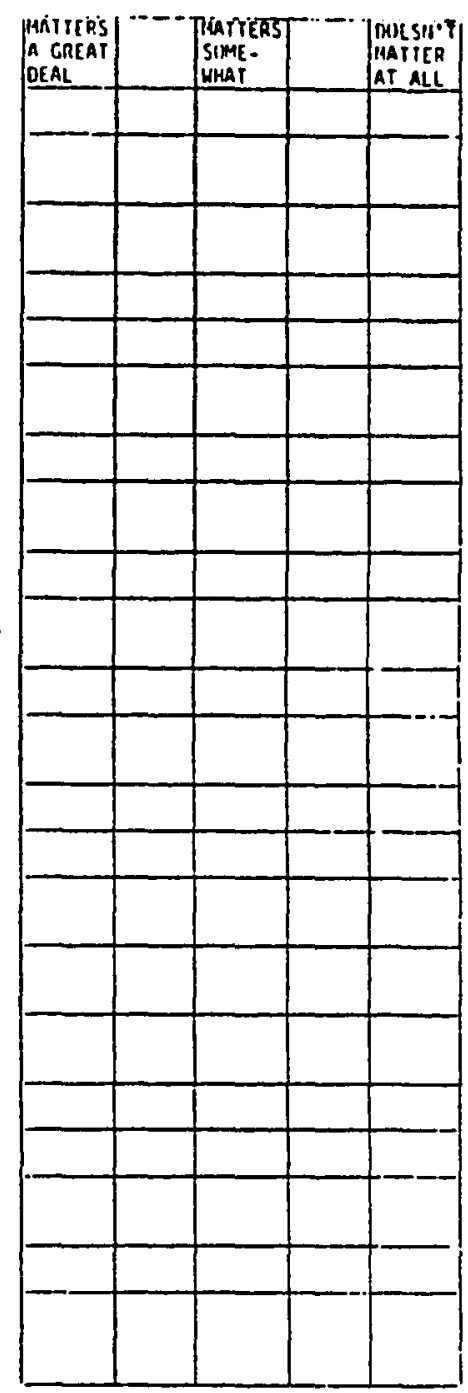

Those are all of the questions I have. I there anything that you feel I should have asked or that you would like to add? You've been very generous to let ine come to do this interview. I really apprecidte your time and effort.

Thank you very much. 
STAFT INTERVIEW SCHEDULE

we are interested in learning about caring for people who are terminally ill. that 1s, people who have a life-threatening iliness with a limited prognosis. Specifically, we are trying to ldentify the types of care and services given to people who are terminally 111 , the needs of these persons, the features of care most 11 kely to meet their needs, and factors which facilitate or impede the provision of good care. Your thoughts and experiences as a staff person here will be of great value to us, and I appreclate your willingness to share thea with we.

Because I want to be sure that I don't miss any of what you say or inadvertently change your words somehow, I'd like to tape record the interview, if you don't and. The tape and the interview are completely confidential, and they'll be used only by me and my staff. If at any time you would like to turn the recorder off, all you have to do is press this button on the microphone and the recorder will stop. Let me emphasize that the interview and the tape are confidential; in our report, the findings will be reported in the aggregate and your responses will not be identifiable to you.

1. First, what exactly is your position and your title here?

2. Did you work with the (program/organization) before you became (JOB IITLE)? 2.a. (IF YES, ASK:) How long and in what capacity?

3. How long have you been (JOB TITLE)?

4. What would you say are the goals of this (program/facility/ward)? (PROBE: That is, what are its treatment aims or the desired outcomes?)

5. What are the training/experience requirements for a (POSITION/TITLE) here?

6. In your opinion, what chaxactexistics should staff possess in order to be able to provide good care for the dying?

7. About how many patients, on the average, do you care for each week?

B. How many of these are terminally ill, that is, in danger of imminent death?

9. How many of your terminally ill (late stage disease) patients are elderly (65 and over)?

10. About what proportion of the elderly patients you care for have family meabers whom they see regularly? (PROOE: That is, at least once a week?) 
Now I'd like to ask you to think in general about dying people and their tamilies.

11. First, when do you begin considering someone as being "teminally 1117" (PROBE: What factors are involved in this decision?)

12. From your observations both here and in other care settings, how is care given to terminally ill patients different from that given to those who may be seriously ill but who have more positive prognoses?

13. On the basis of your experience, what do you see as the greatest needs of persons who are terminally 1ll? (PROBE: How would you rank these needs-what is most important, next most important, etc.?)

14. What about thelx families, what are their greatest needs? (PROBE: How would you rank these nceds in terms of their importance?)

15. Which needs, of both patients and families, do you think they themselves would be less likely to preceive, and why is this so?

16. Which needs might they be less likely to admit, and why?

17. In what ways may the needs of older people who are terminally ill differ from those of younger people with similar illnesses?

18. Some of the people we've talked with have indicated that care provided to older persons ( 65 and over) who are terminally 111 frequentiy dif Eers from that provided to younger persons in sirnilar situations. In ycur experience, how does a patient's age affect the care provided to him/her? (PROBE: How does care differ in terms of amount, kind, place of delivery. duration of service, staff attitudes, involvement of family, etc.?)

19. (IF NOT ALREADY INDICATED, ASK:) How do you feel about this?

Now I'd like to ask you to think about what things help and what things hinder the (program/facility/ward) in attaining its goals?

20. As (JOB TITLE) of this (program/facility/ward), what do you see as the greatest barriers to providing the kind of care you would like to provide?

21. (See next page.)

22. On a more positive note, what kinds of things facilitate provision of good care? (PROBE: What factors, things about the program, patients, enable you or other program staff to provide the kind of care you would like to see provided?)

23. I'd like you to think of three patients whose care you felt went particularly well and that left you feeling satisfied. What were the circumstances surrounding the care for each of these patients and what about their care satisfied you? 
24. What about three patients whose care you feel did not go so well and that left you feeling dissatisfied? What were the circumstances surrounding the care for each of these fatlents, and why did you feel dissatisfied?

25. We've been talking about several factors which affect the provision of good care to people who are dying. What exactly would you say good quality care is? (PROBE: What elements comprise quality care?)

26. (IF MORE THAN ONE ELEMENT MENTIONED, ASK:) HOW would you rank these various elements in terms of their relative importance for the provision of quality care? (PROBE: which is the most importatnt, the next most important, etc.?)

27. What results would indicate that quality care was given? (PROBE: How would you determine whether the care provided was of high quality?)

28. We're almost done now. Patlents, famtlies, different care providers, including doctors, nurses, soctal workers, administrators, etc., may have different perspectives on what makes care good. In this study, we're talking with care providers, dying patients and their families about quality care. What differences in opinions about what quality care is do you think we can expect to find between these groups of people? (PROBE: How do you think patients' perceptions of quality care might differ from their families'? How do you think your perceptions of quality might differ from those of other care providers? Maybe it will help if you think about specific cases in which there have been alsagreements about how the care shculd proceed--tell me about these cases.)

29. (See Q. 17, Patient Intezoiew schedule)

30. Finally, one last question: In general, what recomnendations would you make for assuring that quality terminal care is provided by a program or facility? (PROBE: What policies should be followed? what regulations should be enacted?

Well, I think we've covered everything that I had hoped to cover. Is there anything that you Eeel I should have asked or that you would like to add?

This has been very helpful and, again, thank you for taking the time to talk with me. 
You've mentioned several things which may inhibit yourprovision of good care. Now, I have a list of things that some people have said have kept them from accomplishing treatment goals or providing the care they would like to provide. I'd like you to tell me whether each has been: very serious, serious, not so serious, or no problem at all for you or your (program/facility/ward).

(PROBE: Why is this so?)

21.

a. Organizational structure of the program.

b. Own program'ș/parent agency's policies, regulations.

c. Financial constraints (e.g. things you can't do because of lack of funds).

d. Disagreements between staff as to how care should be provided.

e. Governmental policies or regulations regarding reimbursement, reporting. utilization.

f. Lack of adequately trained personnel.

9. Relationship with other community agencies/programs.

h. Public attitudes toward the (program/ facility/ward).

i. Accessing patients (getting clients).

j. Type of license, accreditation held.

k. Relations with family members.

1. Relations with patients.

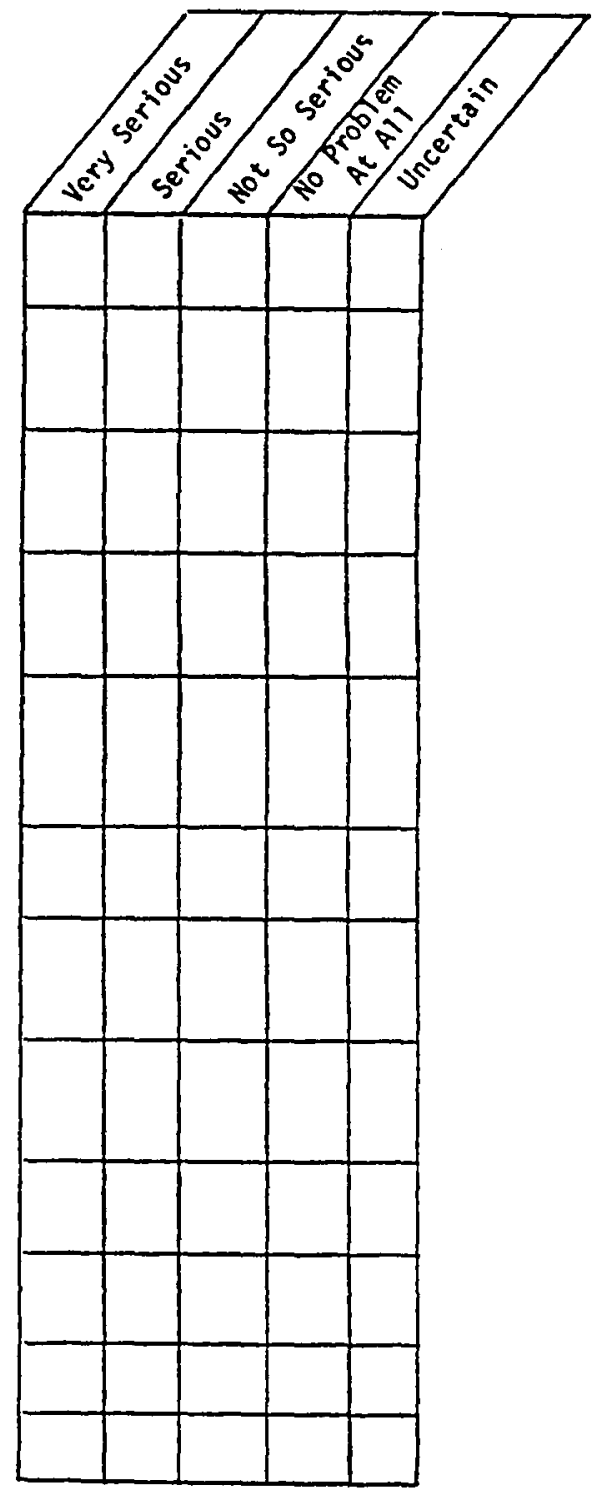

